\begin{abstract}
UNIVERSIDADE DE SÃO PAULO
FACULDADE DE FILOSOFIA, LETRAS E CIÊNCIAS HUMANAS

DEPARTAMENTO DE LETRAS MODERNAS

PROGRAMA DE PÓS-GRADUAÇÃO EM ESTUDOS LINGUÍSTICOS

E LITERÁRIOS EM INGLÊS
\end{abstract}

HELMARA FEBELIANA REAL DE MORAES

O advérbio em fraseologias das áreas da Culinária e do Direito Contratual: um estudo baseado em corpus 


\author{
UNIVERSIDADE DE SÃO PAULO \\ FACULDADE DE FILOSOFIA, LETRAS E CIÊNCIAS HUMANAS \\ DEPARTAMENTO DE LETRAS MODERNAS \\ PROGRAMA DE PÓS-GRADUAÇÃO EM ESTUDOS LINGUÍSTICOS \\ E LITERÁRIOS EM INGLÊS
}

HELMARA FEBELIANA REAL DE MORAES

\title{
O advérbio em fraseologias das áreas da Culinária e do Direito Contratual: um estudo baseado em corpus
}

Tese apresentada ao Programa de Pós-Graduação em Estudos Linguísticos e Literários em Inglês do Departamento de Letras Modernas da Faculdade de Filosofia, Letras e Ciências Humanas da Universidade de São Paulo, para a obtenção do título de Doutora em Letras.

Orientadora: Profa. Dra. Stella Esther Ortweiler Tagnin

São Paulo 
Catalogação na Publicação

Serviço de Biblioteca e Documentação

Faculdade de Filosofia, Letras e Ciências Humanas da Universidade de São Paulo

Moraes, Helmara Febeliana Real de

O advérbio em fraseologias das áreas da culinária e

do direito contratual : um estudo baseado em corpus I

Helmara Febeliana Real de Moraes; orientadora Stella

Esther Ortweiler Tagnin. - Säo Paulo, 2010.

$448 \mathrm{f}$. ; il.

Tese (Doutorado) - Faculdade de Filosofia, Letras e

Ciências Humanas da Universidade de São Paulo.

Departamento de Letras Modernas. Área de concentração: Estudos Linguísticos e Literários em Inglès.

1. Linguística de corpus. 2. Língua inglesa. 3 . Advérbios. 4. Fraseologia. I. Título. II. Tagnin, Stella Esther Ortweiler. 
HELMARA FEBELIANA REAL DE MORAES

O advérbio em fraseologias das áreas da Culinária e do Direito Contratual: um estudo baseado em corpus

Tese apresentada ao Programa de Pós-Graduação em Estudos Linguísticos e Literários em Inglês do Departamento de Letras Modernas da Faculdade de Filosofia, Letras e Ciências Humanas da Universidade de São Paulo, para a obtenção do título de Doutora em Letras.

Aprovada em:

\section{Banca examinadora}

Prof.(a) Dr.(a):

Instituição: Assinatura:

Prof.(a) Dr.(a):

Instituição: Assinatura:

Prof.(a) Dr.(a): Instituição: Assinatura:

Prof.(a) Dr.(a): Instituição: Assinatura:

Prof.(a) Dr.(a): Instituição: Assinatura: 
Em especial ao meu pai e amigo Hélio, o maior colaborador e incentivador para meus estudos e crescimento profissional. A todos aqueles que, de alguma forma, torceram para que este trabalho se concretizasse. 


\section{AGRADECIMENTOS}

Primeiramente a Deus, pela oportunidade e força para alcançar mais um de meus objetivos na vida. Aos meus pais, Hélio e Marlisa, que desde sempre torcem por mim: em suas orações silenciosas ou com palavras que me incentivam para que eu vá adiante. Ao meu irmão, que muito se orgulha de minhas realizações.

Um agradecimento especial à minha orientadora, a Profa. Dra. Stella E. O. Tagnin, que sempre confiou em meu trabalho e direcionou minha pesquisa - com carinho, paciência e comprometimento.

Ao Prof. Dr. Tony Berber Sardinha e à Profa. Dra. Marisa Grigoletto, pelas sugestões e críticas sempre construtivas quando de minha qualificação, fundamentais para o desenvolvimento da tese.

Às amigas Elisa Duarte Teixeira e Luciana Carvalho Fonseca: primeiro por me "emprestarem" seus corpora - material que deu sustentação para esta investigação; segundo, pelas sugestões sempre pontuais e suporte "especializado" - além de tradutoras e pesquisadoras, Luciana é advogada e Elisa uma chef de cozinha internacional!

À amiga Alvamar Lamparelli, pelo interesse em minha pesquisa e pelos dicionários especializados muito úteis para a conclusão de minha investigação.

A todos os amigos do projeto CoMET, muito obrigada pelo apoio, incentivo e crença de que meu trabalho realmente possa contribuir para os avanços de nossas áreas de pesquisa.

Aos meus colegas de trabalho, pela torcida, incentivo e convicção de que eu chegaria lá!

E last but not least, gostaria de agradecer ao amor incondicional de dois seres muito especiais que passaram por minha vida, cuja ausência é ainda mais marcante nos momentos de dificuldade: meus cachorros fofos, Tinki e Nina - o carinho (nem sempre silencioso!) de vocês está guardado em minha memória e no meu coração. 


\section{RESUMO}

MORAES, H. F. R. 0 advérbio em fraseologias das áreas da Culinária e do Direito Contratual: um estudo baseado em corpus. 2010. $448 \mathrm{f}$. Tese (Doutorado) - Faculdade de Filosofia, Letras e Ciências Humanas, Universidade de São Paulo, São Paulo, 2010.

Ao analisar o material hoje disponível sobre os advérbios em inglês e em português observa-se, em especial naqueles baseados em corpus - e aqui referimo-nos mais especificamente às gramáticas -, que o estudo dessa classe gramatical vem ganhando espaço. Além de abordar questões morfológicas, sintáticas, pragmáticas, semânticas e em alguns casos discursivas, essas obras de referência têm procurado conscientizar o consulente sobre a imprecisão dessa classe gramatical, chamando a atenção para seu uso em contexto. Mesmo com esses avanços significativos, no entanto, observa-se que não há dados sobre o uso dos advérbios, mais especificamente aqueles terminados em $-l y$ e -mente, em linguagens especializadas, principalmente no que tange o levantamento de padrões linguísticos que venham a caracterizar essas áreas e tenham, em sua composição, esse grupo de advérbios. Partindo de dois corpora de estudo, um composto de receitas culinárias em inglês e em português e outro de instrumentos contratuais no mesmo par de línguas, levantamos os cinco advérbios terminados em -ly e -mente mais chave em cada tipologia e língua e extraímos os padrões linguísticos em que ocorriam. Considerando a extração e análise dos dados coletados, pudemos comprovar a nossa tese de que esse grupo de advérbios apresenta características próprias e fraseologias típicas da área em que se inserem, ajustando-se a cada contexto de uso. Inclusive, tal fato é evidenciado quando analisamos immediately, advérbio com alto índice de chavicidade e comum às receitas culinárias e contratos em inglês, e imediatamente e juntamente nessas tipologias em português. Descrevemos também todo o processo para o levantamento de formas equivalentes de algumas fraseologias na direção inglês-português, com o objetivo de enfatizar a necessidade de incluir os resultados obtidos em diferentes obras de referência, especialmente em gramáticas e dicionários especializados, o que contribuiria de modo significativo para o trabalho do produtor de textos, principalmente o tradutor.

Palavras-chave: Linguística de Corpus. Advérbios. Padrões linguísticos. Fraseologia. Linguagens especializadas. 


\begin{abstract}
MORAES, H. F. R. The adverb in phraseologies in the areas of Culinary and Contract Law: a corpus-based study. 2010. 448 p. PhD dissertation - Faculdade de Filosofia, Letras e Ciências Humanas, Universidade de São Paulo, São Paulo, 2010.
\end{abstract}

When analyzing the material available nowadays about adverbs in English and in Portuguese we observe, especially in those that are corpus-based - more specifically grammar books -, that the study of this grammatical class has gained ground. Besides covering topics such as morphology, syntax, pragmatics, semantics and sometimes discourse, these reference books have tried to make the reader aware of the lack of precision when referring to this grammatical class, emphasizing its use in context. However, despite these significant advances we observe that adverbs, especially those ending in -ly in English and -mente in Portuguese, are not mentioned as far as specialized languages are concerned, especially when referring to linguistic patterns that may characterize their use in specific areas, in both languages. Based on two study corpora, one with recipes (Culinary) in English and in Portuguese and the other with agreements (Contract Law) in these two languages, we extracted the five adverbs (ending in -ly and -mente) with the highest keyness index in each text typology and language, also identifying the linguistic patterns in which they occurred. Considering the extraction and analysis of the collected data, we could confirm our thesis that these adverbs have their own characteristics and specific phraseologies in the area in which they occur, adjusting to each context of use. This was also observed when we analyzed immediately, an adverb with a high keyness index that was common to both areas of study, i.e., culinary recipes and agreements in English, and imediatamente and juntamente in the same text typologies in Portuguese. We have also described the whole process to extract the equivalent forms of some phraseologies in the English-Portuguese direction, with the objective of emphasizing the need to include the results obtained so far in different reference books, especially grammar books and specialized dictionaries - which would contribute significantly to the job of the text producer, mainly the translator.

Keywords: Corpus Linguistics. Adverbs. Linguistic patterns. Phraseology. Specialized languages. 


\section{LISTA DE FIGURAS}

\begin{tabular}{|c|c|c|}
\hline Fig. & Título & pág. \\
\hline 1 & $\begin{array}{l}10 \text { primeiras linhas de concordância do advérbio slightly do corpus de } \\
\text { receitas culinárias compilado por Teixeira (2008) }\end{array}$ & 83 \\
\hline 2 & Página inicial do BYU-BNC & 114 \\
\hline 3 & Página inicial do COCA & 115 \\
\hline 4 & Detalhes sobre o Banco de Português & 116 \\
\hline 5 & $\begin{array}{l}\text { Pastas criadas para os textos a serem etiquetados - arquivos de texto } \\
\text { em BBC_recs_ }\end{array}$ & 124 \\
\hline 6 & Página inicial do Etiquetador Tree-Tagger & 126 \\
\hline 7 & $\begin{array}{l}\text { Parte etiquetada do arquivo BBC_recs_1a100.txt, agora nomeado } \\
\text { BBC_recs_1_t.txt }\end{array}$ & 127 \\
\hline 8 & $\begin{array}{l}\text { Recorte do corpus de Culinária (português) etiquetado por Teixeira } \\
\text { (2008) }\end{array}$ & 129 \\
\hline 9 & $\begin{array}{l}\text { Tela com instruções para carregar o texto a ser etiquetado no } \\
\text { Portuguese VISL }\end{array}$ & 131 \\
\hline 10 & Trecho etiquetado do texto POACC01.txt (Direito - português) & 132 \\
\hline 11 & O Controller do programa WST, com as três ferramentas disponíveis & 134 \\
\hline 12 & $\begin{array}{l}15 \text { primeiras ocorrências da lista de frequência do corpus de Direito } \\
\text { (inglês) }\end{array}$ & 135 \\
\hline 13 & $\begin{array}{l}\text { Dados estatísticos do corpus de Direito (inglês) e de alguns de seus } \\
\text { textos }\end{array}$ & 136 \\
\hline 14 & $\begin{array}{l}\text { Linhas de concordância para reasonably (corpus de Direito - inglês), } \\
\text { ordenadas pela } 1^{a}, 2^{a} \text { e } 3^{a} \text { palavras à sua direita }\end{array}$ & 137 \\
\hline 15 & $\begin{array}{l}\text { Linhas de concordância para simplesmente (corpus de Direito - } \\
\text { português), ordenadas pela } 1^{\mathrm{a}}, 2^{\mathrm{a}} \text { e } 3^{\mathrm{a}} \text { palavras à sua esquerda }\end{array}$ & 138 \\
\hline 16 & $\begin{array}{l}15 \text { primeiras linhas da lista de colocados para reasonably (corpus de } \\
\text { Direito - inglês) }\end{array}$ & 139 \\
\hline 17 & $\begin{array}{l}5 \text { primeiras linhas do recurso plot para a palavra simplesmente } \\
\text { (corpus de Direito - português) }\end{array}$ & 140 \\
\hline 18 & $\begin{array}{l}\text { Co-ocorrências mais freqüentes para a palavra de busca reasonably } \\
\text { (corpus de Direito - inglês) }\end{array}$ & 140 \\
\hline 19 & $\begin{array}{l}\text { Resultados parciais do recurso clusters para reasonably (corpus de } \\
\text { Direito - inglês) e a janela para ajustes }\end{array}$ & 141 \\
\hline 20 & 25 primeiras palavras-chave do corpus de Direito (português) & 143 \\
\hline
\end{tabular}




\begin{tabular}{|c|l|c|}
\hline 21 & $\begin{array}{l}\text { Resultados do WSConcGram para o advérbio reasonably (Direito - } \\
\text { inglês) }\end{array}$ & 145 \\
\hline 22 & Concgrams para reasonably e request (Direito - inglês) & 146 \\
\hline 23 & 23 primeiras linhas de concordância de finely (Culinária - inglês) & 168 \\
\hline 24 & Algumas concgrams de finely e until & 182 \\
\hline 25 & Alguns resultados de finely chopped no COCA & 270 \\
\hline 26 & $\begin{array}{l}\text { Resultado parcial da busca da palavra partes e de concord }{ }^{*} \text {, como } \\
\text { palavra de contexto }\end{array}$ & 324 \\
\hline 27 & Resultados da busca de expressly provided no BNC & 334 \\
\hline 28 & Linhas de concordância para conforme disposto (BP) & 335 \\
\hline 29 & $\begin{array}{l}\text { O advérbio immediately nas receitas apresentado com a ferramenta } \\
\text { plot do programa WST }\end{array}$ & 339 \\
\hline 30 & $\begin{array}{l}\text { O advérbio immediately nos contratos, apresentado com a ferramenta } \\
\text { plot do programa WST }\end{array}$ & 344 \\
\hline
\end{tabular}




\section{LISTA DE QUADROS}

\begin{tabular}{|c|c|c|}
\hline Qd. & Título & pág. \\
\hline 1 & $\begin{array}{l}\text { Critérios iniciais apresentados pela autora (em forma de tabela) para a } \\
\text { coleta do corpus de receitas culinárias (TEIXEIRA, 2008, p. 209) }\end{array}$ & 104 \\
\hline 2 & $\begin{array}{l}\text { Tipos contratuais que compõem o corpus de estudo no Direito } \\
\text { (Instrumentos Contratuais) }\end{array}$ & 110 \\
\hline 3 & $\begin{array}{l}\text { Descrição do processo de seleção dos arquivos para etiquetagem - } \\
\text { corpus de Culinária (inglês) }\end{array}$ & 123 \\
\hline 4 & $\begin{array}{l}\text { Etiquetas utilizadas no processo de etiquetagem parcial do corpus da } \\
\text { Culinária (inglês) - etiquetador Tree-Tagger }\end{array}$ & 128 \\
\hline 5 & $\begin{array}{l}\text { Etiquetas utilizadas para identificar os advérbios no corpus do Direito } \\
\text { (inglês) - etiquetador CLAWS versão } 7\end{array}$ & 130 \\
\hline 6 & $\begin{array}{l}\text { Etiquetas utilizadas para identificar os advérbios no corpus do Direito } \\
\text { (português) - etiquetador Tree-Tagger }\end{array}$ & 133 \\
\hline 7 & $\begin{array}{l}\text { Advérbios selecionados para análise qualitativa e quantitativa (Direito } \\
\text { e Culinária) }\end{array}$ & 157 \\
\hline 8 & $\begin{array}{l}\text { Algumas fraseologias em inglês e suas formas equivalentes em } \\
\text { português (Culinária) }\end{array}$ & 269 \\
\hline 9 & $\begin{array}{l}\text { Algumas fraseologias em inglês e suas formas equivalentes em } \\
\text { português (Direito) }\end{array}$ & 332 \\
\hline 10 & Dados do advérbio immediately nas receitas e nos contratos & 349 \\
\hline 11 & Dados do advérbio imediatamente nas receitas e nos contratos & 358 \\
\hline 12 & Dados do advérbio juntamente nas receitas e nos contratos & 359 \\
\hline 13 & $\begin{array}{l}\text { Resumo dos padrões e formas equivalentes identificados na Culinária } \\
\text { (receitas) e no Direito (contratos) }\end{array}$ & 366 \\
\hline 14 & $\begin{array}{l}\text { Resultados da busca de unidades identificadas em receitas culinárias } \\
\text { (inglês) em Teixeira e Tagnin (2008) }\end{array}$ & 370 \\
\hline 15 & $\begin{array}{l}\text { Resultados da busca de unidades identificadas em receitas culinárias } \\
\text { (inglês) em Klie (2006) }\end{array}$ & 371 \\
\hline 16 & $\begin{array}{l}\text { Resultados da busca de unidades identificadas em receitas culinárias } \\
\text { (inglês) em Saldanha (2007) }\end{array}$ & 373 \\
\hline 17 & $\begin{array}{l}\text { Resultados da busca de unidades identificadas em contratos (inglês) } \\
\text { em Garner (1999) }\end{array}$ & 375 \\
\hline
\end{tabular}




\section{LISTA DE TABELAS}

\begin{tabular}{|c|c|c|}
\hline Tab. & Título & pág. \\
\hline 1 & $\begin{array}{l}\text { Os cinco advérbios terminados em -ly e -mente mais frequentes em } \\
\text { receitas culinárias levantados no estudo piloto desenvolvido em } 2006\end{array}$ & 18 \\
\hline 2 & $\begin{array}{l}\text { Os cinco advérbios terminados em -ly e -mente mais frequentes em } \\
\text { contratos levantados no estudo piloto desenvolvido em } 2006\end{array}$ & 21 \\
\hline 3 & Corpus de estudo da Culinária (Receitas) & 105 \\
\hline 4 & Corpus de estudo do Direito (Instrumentos Contratuais) & 107 \\
\hline 5 & O Banco de Português (BP) & 117 \\
\hline 6 & Advérbios no corpus do Direito (inglês), a partir das etiquetas & 147 \\
\hline 7 & Advérbios no corpus do Direito (português), a partir das etiquetas & 148 \\
\hline 8 & Advérbios no corpus da Culinária (inglês), a partir das etiquetas & 148 \\
\hline 9 & Advérbios no corpus da Culinária (português), a partir das etiquetas & 148 \\
\hline 10 & $\begin{array}{l}\text { Comparação entre o número total de advérbios em cada corpus e } \\
\text { aqueles terminados em }-l y /- \text { mente }\end{array}$ & 149 \\
\hline 11 & $\begin{array}{l}\text { Porcentagem de advérbios terminados em -ly/-mente nos corpora de } \\
\text { estudo. }\end{array}$ & 150 \\
\hline 12 & $\begin{array}{l}\text { Advérbios terminados em -ly com chavicidade igual ou superior a } 100 \\
\text { - Culinária (inglês) }\end{array}$ & 153 \\
\hline 13 & $\begin{array}{l}\text { Advérbios terminados em -mente com chavicidade igual ou superior a } \\
100 \text { - Culinária (português) }\end{array}$ & 154 \\
\hline 14 & $\begin{array}{l}\text { Advérbios terminados em -ly com chavicidade igual ou superior a } 100 \\
\text { - Direito (inglês) }\end{array}$ & 155 \\
\hline 15 & $\begin{array}{l}\text { Advérbios terminados em -mente com chavicidade igual ou superior a } \\
100 \text { - Direito (português) }\end{array}$ & 156 \\
\hline 16 & $\begin{array}{l}\text { Número total de advérbios terminados em -ly/-mente com } \\
\text { chavicidade acima de } 100 \text { em nossos corpora de estudo }\end{array}$ & 157 \\
\hline
\end{tabular}




\section{SUMÁRIO}

Introdução.

Capítulo I - Fundamentação teórica.

1.10 advérbio em fontes de referência em inglês e em português:

avanços significativos

1.1.1 Obras de referência consultadas para o português: uma análise quanto ao uso dos advérbios.

1.1.2 Obras de referência consultadas para o inglês: uma análise

quanto ao uso dos advérbios. .56

1.2 Linguística de Corpus: um panorama geral............................................74

1.2.1 Linguística de Corpus: teoria, abordagem ou metodologia?......................80

1.2.2 Linguística de Corpus: alguns conceitos.............................................. 81

1.2.3 Corpus-based ou corpus-driven?.................................................. 84

1.3 Linguística de Corpus e convencionalidade..........................................91

Capítulo II - Materiais e métodos......................................................... 102

$2.1 \mathrm{O}$ corpus de estudo da Culinária (Receitas)............................................103

2.2 O corpus de estudo do Direito (Instrumentos Contratuais) .............................106

2.3 Os corpora de referência: British National Corpus e Banco de Português........111

$2.4 \mathrm{O}$ processo de etiquetagem............................................................119

2.4.1 A etiquetagem dos corpora da Culinária (inglês e português)...................121

2.4.2 A etiquetagem dos corpora do Direito (inglês e português) ......................129

2.5 O programa WordSmith Tools: extração e manipulação dos dados...................134

2.6 levantamento dos advérbios em inglês e em português.............................147

2.6.1 Os advérbios terminados em -ly e -mente para análise dos padrões linguísticos 
3.1 Os advérbios na Culinária.

3.1.1 Os advérbios em inglês nas receitas culinárias: algumas considerações.

3.1.2 Os advérbios em português nas receitas culinárias:

algumas considerações

3.1.3 Comparando resultados: os advérbios em receitas culinárias

- inglês e português.

3.1.4 A busca pela forma equivalente em receitas culinárias:

alguns exemplos na direção inglês - português

3.1.5 As fraseologias analisadas em receitas culinárias e suas formas

equivalentes nos corpora de língua geral.

3.2 Os advérbios no Direito

3.2.1 Os advérbios em inglês nos contratos:

algumas considerações

3.2.1.1 O discurso jurídico: breves comentários

3.2.2 Os advérbios em português nos contratos:

algumas considerações

3.2.3 Comparando resultados: os advérbios em contratos

- inglês e português.

3.2.4 A busca pela forma equivalente em contratos: alguns exemplos

na direção inglês - português

3.2.5 As fraseologias analisadas em contratos e suas formas

equivalentes nos corpora de língua geral.

3.3 Os advérbios em receitas culinárias e contratos:

comparações importantes.

3.3.1 Immediately nas receitas culinárias.

3.3.2 Immediately nos contratos.

3.3.3 Immediately nas receitas e nos contratos: comparando as análises.. 349

3.3.4 Imediatamente e juntamente nas receitas culinárias. 351

3.3.5 Imediatamente e juntamente nos contratos. 355

3.3.6 Imediatamente e juntamente nas receitas e nos contratos:

comparando as análises 
3.3.7 Um panorama dos "-lys" e "-mentes" sob a ótica das tipologias 360

3.4 As fraseologias e suas formas equivalentes: breves comentários

3.5 As fraseologias em inglês em dicionários especializados:

são contempladas?

Considerações finais 379

Referências bibliográficas 387

Anexo A - Corpus de Culinária (inglês) e corpus de Culinária (português). 404

Anexo B - Advérbios terminados em -ly: corpus de Culinária.. 410

Anexo C - Advérbios terminados em -mente: corpus de Culinária. .418

Anexo D - Advérbios terminados em -ly: corpus de Direito. .422

Anexo E - Advérbios terminados em -mente: corpus de Direito. 429

Anexo F - 100 primeiras palavras-chave do corpus de Culinária (inglês). .434

Anexo G - 100 primeiras palavras-chave do corpus de Culinária (português).......438

Anexo H - 100 primeiras palavras-chave do corpus de Direito (inglês). .442

Anexo I - 100 primeiras palavras-chave do corpus de Direito (português)...... 446 


\section{Introdução}

Nosso interesse pelos advérbios delineou-se há um bom tempo, no início da década de 90, quando fizemos o Curso de Especialização em Tradução na Universidade de São Paulo, na época subordinado ao Setor de Cursos Extracurriculares da FFLCH (Faculdade de Filosofia, Letras e Ciências Humanas). Para a monografia de final de curso, decidimos estudar essa classe gramatical - tida como difusa e cujo uso é sempre tão difícil de delimitar -, com um olhar voltado para a convencionalidade lingüística, mais especificamente para as colocações adverbiais em língua geral. Fizemos então um levantamento manual dessas unidades, limitando-nos a apenas elencá-las em inglês e em português, sem estabelecer qualquer equivalência entre as línguas. Naquela época, desconhecíamos estudos já desenvolvidos fora do país na área de Linguística de Corpus, como os de John Sinclair (1991), apenas para citar um dos grandes expoentes da área, o que certamente teria facilitado e ampliado nossa pesquisa.

Ao retomarmos nossos estudos em 2000, o interesse pelos advérbios ainda fazia-se presente. Dessa forma, ao iniciarmos nosso Mestrado na Universidade de São Paulo em 2002, resolvemos novamente trabalhar com as colocações adverbiais, agora com o suporte teórico-metodológico da Linguística de Corpus. Valendo-nos das ferramentas então disponíveis, pudemos buscar as formas equivalentes de algumas colocações, inclusive ousando propor a elaboração de um glossário de colocações adverbiais que viesse ao encontro das necessidades do produtor de textos, principalmente do tradutor. Instigava-nos a idéia de que nem todos os advérbios em inglês terminados em -ly seriam necessariamente traduzidos por advérbios com o sufixo tido como sua forma equivalente em português, -mente, ou vice-versa. Apresentamos abaixo uma breve revisão dessa pesquisa, numa tentativa de justificar nosso interesse e relatar os resultados então obtidos.

No primeiro capítulo daquele trabalho, apresentamos a fundamentação teórica de nossa investigação, enfatizando os conceitos de corpus, colocação, coligação, prosódia semântica e lematização. Trabalhamos com colocações adverbiais, ou seja, a associação entre verbos ou adjetivos e advérbios (TAGNIN, 2005 , p. 45), partindo dessa última classe gramatical para desenvolver a pesquisa. 
Primeiramente, fizemos uma análise de como os advérbios eram abordados em algumas gramáticas então disponíveis e não encontramos uma definição que fosse além daquelas já arraigadas na literatura, de modo a esclarecer seu uso. Dentre as obras consultadas, vale destacar duas que apresentaram informações mais pontuais sobre os advérbios, quais sejam, Longman Grammar of Spoken and Written English (BIBER et al., 1999), uma gramática em língua inglesa baseada em corpus, e o capítulo "Considerações sobre a posição dos advérbios", de Rodolfo llari (1996), inserido na Gramática do português falado (CASTILHO, 1996). Nenhuma delas, no entanto, classificou ou sequer mencionou as colocações adverbiais. Fizemos também alguns comentários sobre o processo de tradução dessas colocações que, por serem unidades convencionalizadas em cada língua, podem apresentar problemas de produção. Verificamos que pode haver equivalência semântica sem necessariamente haver equivalência morfossintática entre as unidades.

No capítulo seguinte, apresentamos os resultados de uma pesquisa feita em dicionários monolíngues e bilíngues, considerando-se um pequeno grupo de colocações adverbiais em ambas as línguas. Em linhas gerais, observamos que os dicionários consultados eram ineficazes como fonte de pesquisa para esse padrão linguístico. Quando encontradas, não havia coerência na apresentação das colocações: ora estavam no verbete do verbo ou adjetivo, ora no verbete do advérbio, ora em ambos. Outro problema foi a exemplificação - quando as colocações eram encontradas, raramente havia contexto de uso. Esses resultados corroboraram a necessidade de um levantamento detalhado que, além de apresentar essas unidades de forma sistematizada, fornecesse informações quanto ao seu uso e as contextualizasse em dados autênticos.

No terceiro capítulo, especificamos as fontes de investigação e ferramentas utilizadas, bem como a descrição da metodologia adotada para o levantamento das colocações que seriam analisadas no capítulo seguinte. Desenvolvemos uma análise contrastiva (considerando o inglês como língua de partida) de 48 colocações adverbiais (22 em inglês e 26 formas equivalentes em português) que, selecionadas quantitativa ou qualitativamente, foram agrupadas de acordo com a área temática e suas relações semânticas. É importante ressaltar que, durante esse processo, fizemos várias observações quanto ao uso dos advérbios, deixando clara a abordagem direcionada pelo corpus (corpus-driven approach). 
Concluímos nossa dissertação de Mestrado apresentando a proposta de um glossário bidirecional (inglês-português) de colocações adverbiais, com informações relevantes para o produtor de textos: os aspectos morfossintáticos e pragmáticos mais significativos, exemplificados, outras unidades linguísticas maiores em que a colocação pudesse ser encontrada, e finalmente a sugestão de formas equivalentes pragmaticamente possíveis, que não necessariamente seriam formadas pelas mesmas classes gramaticais da colocação em inglês. Detalhamos a macro e a microestrutura desse glossário, sugerimos um índice remissivo com entrada pelos advérbios e exemplificamos alguns verbetes em ambas as línguas.

Em geral, acreditamos ter atingido os objetivos propostos: demonstrada a ineficácia do material então disponível para a pesquisa de colocações adverbiais, desenvolvemos um estudo baseado em dados autênticos e apresentamos a análise detalhada de um grupo dessas colocações, o que resultou em uma proposta de um dicionário bidirecional que pode contribuir para o trabalho do produtor de textos, principalmente do tradutor. Essa pesquisa, longe de exaurir o tema em questão, instigou-nos a continuar nossos estudos sobre os advérbios.

Em 2006, demos início a nossa pesquisa de Doutorado. Novamente, optamos por trabalhar com os advérbios, mais especificamente aqueles terminados em -ly e -mente - intrigava o questionamento de sua importância na língua. Outra questão era o uso dessa classe gramatical em linguagens especializadas, focando principalmente os padrões linguísticos que poderiam integrar e como deveriam estabelecer-se as formas equivalentes no par de línguas inglês-português. Esses aspectos nortearam nosso interesse e resultaram nas seguintes perguntas: Os advérbios terminados em -ly e -mente comportam-se da mesma forma em língua geral e em linguagens especializadas? Há diferenças entre as linguagens especializadas? Como se dá a equivalência funcional entre as duas línguas estudadas, considerando-se esse grupo de advérbios?

Ao iniciarmos o levantamento para nossa investigação, quando ainda não tínhamos noção das proporções que a pesquisa iria tomar, decidimos trabalhar com cinco grandes áreas: Culinária, Ecoturismo, Hipertensão, Informática e Instrumentos Contratuais - justamente aquelas contempladas nos corpora ${ }^{1}$ que, naquela época,

\footnotetext{
${ }^{1}$ Para a definição de corpus/corpora, vide capítulo I, item 1.2.2.
} 
integravam o projeto CorTec (Corpus Técnico-Científico) $)^{2}$. Como balão de ensaio, elegemos a Culinária (Receitas) e o Direito (Instrumentos Contratuais) para iniciar nossa investigação. Ao manipularmos os dados, no entanto, observamos que o processo investigativo acarretaria um nível de detalhamento que dificilmente conseguiríamos alcançar caso persistíssemos na ideia de trabalhar com as cinco grandes áreas anteriormente cogitadas. Dessa forma, decidimos concentrar-nos na Culinária (Receitas) e no Direito (Instrumentos Contratuais); ou seja, o que de início faria parte de um balão de ensaio passou a ser o foco de nossa pesquisa. E por que essas duas áreas? Nossa escolha deu-se por vários motivos, elencados a seguir.

O interesse pela área da Culinária adveio, inicialmente, de comentários tecidos por nossa colega Elisa Duarte Teixeira, que desde muito vem trabalhando como tradutora e pesquisadora na área. Conhecedora de nossos estudos sobre os advérbios, ela chamou nossa atenção para o fato de que os advérbios terminados em -ly eram uma constante em textos de receitas culinárias, em inglês, ao passo que aqueles terminados em -mente, tidos como sua contrapartida em português, não ocorriam com tanta frequência nessa língua. Instigados pela dúvida sobre como o significado dos advérbios terminados em -ly seria retratado em português, ou seja, quais seriam as formas equivalentes utilizadas nessa língua, uma vez que os advérbios terminados em -mente apresentavam uso menos frequente, decidimos desenvolver um estudo piloto ${ }^{3}$ que nos desse alguma luz sobre o uso desse grupo de advérbios em receitas culinárias.

Para esse estudo, utilizamos os subcorpora de Culinária (receitas) do CorTec, Corpus Técnico-Científico que faz parte do projeto CoMET (Corpus Multilingue para Ensino e Tradução) ${ }^{4}$. Naquela época - tempos depois o corpus intitulado Culinária 2 foi incluído no projeto, com um número significativamente maior de ocorrências -, utilizamos os subcorpora que apresentavam 324.199 ocorrências em inglês e 232.505 em português. A partir desses dados, levantamos os cinco advérbios terminados em -ly e -mente mais frequentes, apresentados na tabela abaixo juntamente com sua frequência relativa nos corpora, em cada mil palavras:

\footnotetext{
${ }^{2}$ Depois do início dessa pesquisa, outros corpora foram acrescentados ao projeto e alguns desses foram atualizados. Disponível em: http://www.fflch.usp.br/dlm/comet.

${ }^{3}$ Esse estudo foi apresentado no VI Encontro de Lingüistica de Corpus realizado na Universidade de São Paulo em 2007. Dele resultou o artigo intitulado "Os advérbios em -ly e -mente: a busca pela equivalência na Culinária e no Direito", publicado em Tagnin e Vale (2008, p. 315-332).

${ }^{4}$ Disponível em: http://www.fflch.usp.br/dlm/comet.
} 
Tabela 1 - Os cinco advérbios terminados em -ly e -mente mais frequentes em receitas culinárias levantados no estudo piloto desenvolvido em 2006

\begin{tabular}{|l|c|c|l|c|c|}
\hline \multicolumn{3}{|c|}{ Receitas culinárias - inglês } & \multicolumn{2}{c|}{ Receitas culinárias - português } \\
\hline advérbio & $\begin{array}{c}\text { Freq. relativa no } \\
\text { corpus (cada mil } \\
\text { palavras) }\end{array}$ & $\begin{array}{c}\mathbf{n}^{\circ} \\
\text { oc. }\end{array}$ & advérbio & $\begin{array}{c}\text { Freq. relativa no } \\
\text { corpus (cada mil } \\
\text { palavras) }\end{array}$ & $\begin{array}{c}\mathbf{n}^{\circ} \\
\text { oc. }\end{array}$ \\
\hline gently & 2 & 648 & aproximadamente & 1 & 240 \\
\hline finely & 1,6 & 538 & levemente & 0,6 & 148 \\
\hline lightly & 1,3 & 445 & imediatamente & 0,5 & 117 \\
\hline freshly & 1,2 & 396 & novamente & 0,4 & 111 \\
\hline gradually & 0,6 & 216 & ligeiramente & 0,4 & 96 \\
\hline Total: & $\mathbf{6 , 9}$ & $\mathbf{2 . 2 4 3}$ & Total: & $\mathbf{3}$ & $\mathbf{7 1 2}$ \\
\hline
\end{tabular}

A primeira coluna apresenta os advérbios em ordem decrescente de frequência, seguida de sua ocorrência em cada mil palavras na segunda coluna e do número total de ocorrências em todo o corpus na terceira ${ }^{5}$. Logo em um primeiro momento, podemos observar a frequência significativamente maior dos advérbios em inglês, com 2.243 ocorrências, comparada às 712 levantadas em português, fato que sinaliza um papel mais incisivo desse grupo de advérbios em receitas culinárias naquela língua. Um olhar mais atento também irá observar que quatro dos cinco advérbios em inglês (gently, finely, lightly e gradually) parecem caracterizar modo pelo menos aparentemente e de forma descontextualizada - o que se pode observar em apenas dois dos cinco advérbios em português, quais sejam levemente e ligeiramente. A partir dessa tabela, surge um primeiro questionamento: se temos dois subcorpora considerados representativos dessa tipologia textual, formados por textos autênticos nas duas línguas, como é representado o significado dos advérbios em inglês - se é que isso ocorre - em português? Será que esse aspecto semântico - e também pragmático - é relevante nessa língua? Se o é, como é veiculado nas receitas culinárias em português? Com o intuito de buscar essa equivalência, nosso primeiro passo foi observar os advérbios em contexto, iniciando com gently e finely, em inglês. A partir das linhas de concordância geradas com a ferramenta Concord do programa WordSmith Tools (versão 3.0$)^{6}$ e considerando a frequência de coocorrência entre as palavras - o que também pode ser observado com o uso da ferramenta acima citada -, chegamos a vários agrupamentos lexicais e associações entre classes gramaticais que variavam entre duas e treze palavras ${ }^{7}$. Dentre eles,

\footnotetext{
${ }^{5}$ Esses resultados foram obtidos usando-se a ferramenta Wordlist do programa WordSmith Tools, versão 3.0. Para mais detalhes sobre o programa, vide o capitulo II desta tese.

${ }^{6}$ Devemos esclarecer que fizemos o download das linhas de concordância geradas pelo concordanciador do projeto CoMET e gravamos em .txt para que pudéssemos manipular os dados com o programa WordSmith Tools.

${ }^{7}$ Para mais detalhes, vide o artigo na íntegra: Moraes (2008).
} 
podemos citar finely chopped, com 352 ocorrências. Com o objetivo de encontrar uma provável forma equivalente para essa colocação em português, iniciamos nossa busca com a tradução de chopped, que definimos por picado. Nossa intuição de falante nativo da língua portuguesa dizia-nos que finamente picado não seria a tradução mais adequada. De fato, o corpus em português apresentou 11 ocorrências de finamente picada, apenas uma de finamente picado e nenhuma ocorrência das formas no plural. Os resultados foram semelhantes quando buscamos picado finamente (e suas variações). Analisando apenas as ocorrências de picado (com as variações no feminino, no plural e também no diminutivo), observamos sua frequente co-ocorrência com o advérbio bem. Resumindo todo o processo investigatório, chegamos à conclusão de que as formas equivalentes mais adequadas para finely chopped seriam (bem) picadinho, bem picado, picado (bem) fino. Como podemos observar, a equivalência semântica deu-se por meio de diferentes recursos, como o uso de um outro advérbio que não apresenta o sufixo -mente e da forma diminutiva do adjetivo, em português.

Finely chopped é apenas um exemplo que descrevemos brevemente dentre outros observados nesse estudo piloto, cujo detalhamento foge ao escopo desta Introdução. No entanto, demonstra a necessidade de olharmos mais atentamente a classe dos advérbios em linguagens especializadas, tanto para a produção de textos nas línguas estudadas quanto para a busca de formas equivalentes no processo tradutório. Relegados a um segundo plano pela Terminologia, justamente por não incluírem um termo em sua composição, esses padrões linguísticos ${ }^{8}$ podem, quando traduzidos de forma inadequada, comprometer a naturalidade e a precisão do texto traduzido. A Culinária, que se constitui uma área técnica per se, não escapa a esses entraves da Tradução.

A visibilidade conquistada por essa área no mundo atual veio agregar-se ao nosso interesse, sendo também um dos motivos pelos quais optamos por trabalhar com ela - a presença marcante da Culinária nos diversos meios de comunicação de massa, como é o caso da televisão e da Internet $^{9}$, nos leva a aspectos mais práticos quanto a sua divulgação em um mundo globalizado. Certamente, o mercado editorial

\footnotetext{
${ }^{8}$ No capítulo I, trataremos a questão dos padrões linguísticos de forma mais detalhada.

${ }^{9}$ Teixeira aponta vários fatores que contribuíram para a ascensão da Culinária e da Gastronomia no Brasil: além da Internet e da televisão, que veicula vasta programação tanto na TV aberta quanto na TV a cabo, temos o aumento do poder aquisitivo da população, fato que indiretamente impulsiona o mercado e a indústria gastronômica, somado ao aumento significativo de cursos de formação profissional na área, inclusive em nível superior (TEIXEIRA, 2008, p. 70).
} 
brasileiro, assim como o mundial, tem acompanhado toda essa inovação e progresso, necessitando, cada vez mais, do trabalho do tradutor, que depara com dificuldades para a tradução de expressões como finely chopped, acima apontada. Os tradutores mais incautos, é importante ressaltar, acabam se preocupando apenas com questões terminológicas (quando o fazem) e não observam como uma dada expressão é utilizada em textos naturalmente produzidos na língua de chegada, o que resulta em uma tradução artificial que não irá cumprir sua função comunicativa.

Concomitante ao interesse pelo uso dos advérbios em receitas culinárias, uma outra área de pesquisa chamou-nos a atenção, primeiramente por ser tida como tão diversa da primeira. A pesquisadora e tradutora de textos jurídicos Luciana Carvalho Fonseca, que também é advogada de formação, desenvolvia sua dissertação de Mestrado na Universidade de São Paulo (CARVALHO FONSECA, 2007), pesquisando binômios em inglês e suas formas equivalentes em português no Direito Contratual, em um estudo baseado em corpus. Ao comentarmos sobre nossas descobertas no campo da Culinária, ela mencionou que, nos contratos, a coocorrência entre advérbios terminados em -ly, formando binômios, era frequente, como é o caso de duly and validly, directly or indirectly ou mesmo wholly or partially. Despertado esse interesse inicial no sentido de identificar o uso dos advérbios terminados em -ly e -mente nessa área de pesquisa (como seriam utilizados em ambas as línguas?), decidimos proceder como fizemos com as receitas culinárias: dando continuidade ao estudo piloto acima exposto, iniciamos uma nova investigação, em Direito Contratual, valendo-nos dos corpora compilados por Luciana Carvalho Fonseca e também disponíveis no projeto CoMET ${ }^{10}$. Em inglês, o corpus continha 192.960 ocorrências e, em português, 186.870 ${ }^{11}$. Apresentamos abaixo os cinco advérbios terminados em -ly e -mente mais frequentes, bem como sua frequência relativa em cada mil palavras e o número absoluto de ocorrências.

\footnotetext{
${ }^{10}$ Os dados levantados nos corpora de Direito Contratual estão parcialmente disponíveis no artigo anteriormente mencionado. A análise do advérbio reasonably, também feita durante esse estudo piloto, está disponível em http://www.nilc.icmc.usp.br/viencontro/anais.htm, como parte da comunicação apresentada no VI Encontro de Lingüística de Corpus realizado na Universidade de São Paulo em 2007.

${ }^{11}$ É importante deixar claro que os corpora de Culinária e de Instrumentos Contratuais utilizados em nosso estudo piloto estavam, naquela época, em construção, hoje apresentando um número maior de ocorrências.
} 
Tabela 2 - Os cinco advérbios terminados em -ly e -mente mais frequentes em contratos levantados no estudo piloto desenvolvido em 2006

\begin{tabular}{|l|c|c|l|c|c|}
\hline \multicolumn{2}{|c|}{ Instrumentos Contratuais - inglês } & \multicolumn{3}{c|}{ Instrumentos Contratuais - português } \\
\hline advérbio & $\begin{array}{c}\text { Freq. relativa no } \\
\text { corpus (cada mil } \\
\text { palavras) }\end{array}$ & $\begin{array}{c}\mathbf{n}^{\circ} \\
\text { oc. }\end{array}$ & \multicolumn{1}{|c|}{ advérbio } & $\begin{array}{c}\text { Freq. relativa no } \\
\text { corpus (cada mil } \\
\text { palavras) }\end{array}$ & $\begin{array}{c}\mathbf{n}^{\circ} \\
\text { oc. }\end{array}$ \\
\hline reasonably & 0,8 & 157 & devidamente & 0,6 & 115 \\
\hline duly & 0,6 & 119 & somente & 0,5 & 92 \\
\hline promptly & 0,5 & 100 & expressamente & 0,4 & 86 \\
\hline immediately & 0,5 & 97 & independentemente & 0,4 & 77 \\
\hline directly & 0,4 & 84 & imediatamente & 0,3 & 73 \\
\hline Total: & $\mathbf{2 , 8}$ & $\mathbf{5 5 7}$ & Total: & $\mathbf{2 , 4}$ & $\mathbf{4 4 3}$ \\
\hline
\end{tabular}

A partir desse levantamento, podemos observar várias diferenças quando comparamos os resultados àqueles obtidos na Culinária. À primeira vista, verificamos que, em número de ocorrências, a diferença entre as línguas não é discrepante - temos 557 ocorrências em inglês e, em português, 443, o que se reflete na frequência a cada mil palavras. Apesar desse balanceamento, no entanto, observamos que apenas um advérbio em inglês, ou seja, immediately, apresenta sua tradução literal em português na tabela acima, fato que sinaliza que o uso dessa classe gramatical é diferente nas línguas estudadas - nem todos os -ly "viram" mente, em português, ou pelo menos não são utilizados com a mesma frequência. Para satisfazer nossa curiosidade inicial, fomos buscar as ocorrências de razoavelmente, tradução literal (e descontextualizada) de reasonably. Surpreendemo-nos com o resultado: apenas uma ocorrência no corpus em português. Partimos para o levantamento dos agrupamentos lexicais e gramaticais de reasonably, numa tentativa de, através do contexto, chegar a uma forma equivalente para essas unidades $e$, consequentemente, para o advérbio em português. Nesse processo, pudemos evidenciar a linguagem extremamente repetitiva do Direito (em ambas as línguas, com destaque para o inglês) e a necessidade de ampliarmos o contexto de uso para verificar até que ponto, em um dado parágrafo, essa repetição ocorria e, de fato, o que essa formulaicidade implicaria para o uso do grupo de advérbios sob análise.

Diante desses resultados, crescia nosso interesse pela classe dos advérbios terminados em -ly e -mente nas receitas e nos contratos. Obviamente, esse interesse não se restringia aos aspectos morfossintáticos. Quando tratamos desse grupo de advérbios, sabemos ser esperada sua co-ocorrência com um verbo ou adjetivo, com função modificadora ou intensificadora, principalmente em se tratando 
das receitas. Mas especificamente com quais itens lexicais e/ou gramaticais isso acontece? Partindo do advérbio, quais fraseologias seriam típicas daquele contexto de uso? E caso uma mesma unidade fosse identificada em duas áreas diferentes, como por exemplo a co-corrência entre dado advérbio e um item lexical (ou gramatical) específico, quais outras semelhanças e diferenças seriam identificadas? Considerando-se suas relações sintagmáticas e paradigmáticas, até que ponto essas fraseologias teriam algo em comum, se é que isso poderia ocorrer? Qual o contexto de uso de fraseologias maiores? E diante dessas fraseologias em inglês, quais seriam as formas pragmaticamente equivalentes em português? Foram esses e vários outros questionamentos que nos levaram a buscar, na literatura então disponível, estudos sobre a classe dos advérbios.

O primeiro artigo pesquisado intitula-se Translations of 'ly' adverbs of degree in an English-Spanish parallel corpus, de Ramón e Labrador (2008). Apesar de o estudo abordar o par de línguas inglês-espanhol, interessou-nos verificar qual a metodologia adotada pelas autoras, como elas conduziram as análises e a quais conclusões chegaram sobre o uso dos advérbios de intensidade em língua geral, enfocando o processo tradutório. Além disso, havia a expectativa quanto aos advérbios terminados em -mente, em espanhol, forma cognata ao sufixo em português. Ramón e Labrador pressupunham haver certa tendência em se traduzir "-lys" por "-mentes", caracterizando o fenômeno conhecido como translationese ${ }^{12}$ o tradutês, em português. É interessante observar que descartaram os advérbios de modo (os mais frequentes nesse grupo de advérbios) e concentraram o estudo naqueles que expressavam intensidade. Segundo as autoras, esse grupo de advérbios não é pragmaticamente equivalente no par de línguas em estudo - os falantes do espanhol preferem outros recursos para expressar intensidade, tais como outros advérbios (que não incluem aqueles terminados em -mente), sintagmas preposicionados e construções com adjetivos. Para a análise, valeram-se de dois pares de corpora: um formado por textos originais em inglês e suas respectivas traduções para o espanhol, e outro com textos originais e traduções,

\footnotetext{
${ }^{12}$ Há vários pesquisadores na área de Estudos da Tradução que abordam esse tema, dentre os quais podemos citar Gellerstam (1986 apud LAVIOSA, 2002, p. 21), Baker (1992, 1995), Laviosa (2002, 2004), Santos (1995) e Hatim e Munday (2004). Em linhas gerais, esse fenômeno ocorre quando o tradutor calca sua opção de tradução no texto original, envolvendo aspectos lexicais e/ou sintáticos da língua de partida que seriam inadequados ou não se aplicariam à língua de chegada, como é o caso dos exemplos citados por Teixeira (2008, p. 129): utilizar "chocolate semi-doce", a invés de "chocolate meio-amargo", como forma equivalente de semi-sweet chocolate, ou mesmo "cebola vermelha" para red onion, quando em português utilizamos "cebola roxa".
} 
ambos em espanhol. Em um primeiro momento, analisaram um pequeno grupo de advérbios terminados em -ly, onde pudemos observar que nem sempre esse advérbio irá associar-se a um verbo ou adjetivo, como é o caso de partly, que apresentou a associação partly because como a mais frequente. Além disso, demonstraram que os advérbios podem co-ocorrer com grupos de verbos semanticamente específicos, como observado com closely, frequentemente encontrado com verbos que indicam percepção visual. Quanto à prosódia semântica, destacaram que deeply apresenta conotação negativa. Esses dados corroboraram nosso interesse em verificar se tais observações seriam pertinentes nas áreas especializadas que tencionávamos estudar.

Ao trabalharem a questão da tradução, Ramón e Labrador compararam quantitativa e qualitativamente as opções utilizadas para traduzir os advérbios terminados em -ly. A opção mais frequente foi a do grupo dos advérbios terminados em -mente, como era esperado. Mesmo não trabalhando com textos traduzidos em nossa pesquisa, os resultados dessa comparação, abaixo listados, nos levaram a questionar se tais fatos seriam relevantes no par de línguas inglês-português:

- um advérbio terminado em -ly pode apresentar como equivalente um advérbio terminado em -mente que não necessariamente é sua forma cognata, como absolutely, traduzido por estrictamente;

- há maior variedade de advérbios terminados em -ly em inglês do que daqueles terminados em -mente, em espanhol;

- há dificuldade de tradução de advérbios que derivam de adjetivos com conotação negativa, como é o caso de badly e awfully, muitas vezes utilizados apenas como intensificadores (awfully sorry).

Chamou-nos a atenção o fato de as pesquisadoras não terem analisado as fraseologias das quais esses advérbios poderiam fazer parte, o que certamente contribuiria para uma análise mais aprofundada dos dados.

Houve também casos de apagamento do advérbio no texto traduzido, o que levou-nos a questionar como seu significado seria veiculado na língua de chegada, se é que isso deveria ocorrer.

Em um terceiro momento, as formas equivalentes propostas na direção inglês (língua de partida) - espanhol (língua de chegada) com advérbios terminados em -mente foram pesquisadas em textos originais em espanhol. Concluiu-se que o uso era realmente inadequado: em excesso para alguns advérbios e pouco utilizado 
quanto a outros, comprovando o tradutês na classe dos advérbios de intensidade terminados em -ly/-mente. Essa terceira parte do estudo ressalta a importância da pesquisa em textos originais, que justamente vem ao encontro do que propomos em nossa investigação.

Outro artigo que trabalha com advérbios no par de línguas inglês-português, dessa feita em linguagem de especialidade, intitula-se Advérbios terminados em -mente (L2) e -ly (L1): um estudo sobre as condições de tradução de manuais de química (CECHIN; CONTINI; FINATTO, 2004). Nessa investigação, as autoras analisaram a presença e principalmente a funcionalidade desse grupo de advérbios em textos de Termodinâmica, propondo uma classificação de acordo com seu uso. Além da grande incidência dessa classe gramatical em seu corpus de estudo, interessava-Ihes reconhecer o seu modus dicendi. Como havíamos também observado em nossa dissertação de Mestrado, as autoras ressaltaram que as gramáticas tradicionais apresentam uma classificação limitada, não abrangendo uma gama de funções semântico-sintáticas que são peculiares a esse grupo de advérbios.

Esse artigo evidencia a necessidade do estudo dos advérbios e de sua categorização para uma melhor definição de seu papel no discurso, independente da área em questão. No caso de linguagem especializada, demonstra que os advérbios possuem características próprias - alguns deles inclusive são típicos daquela área, como é o caso de adiabaticamente, classificado pelas autoras como um advérbio terminológico específico, ou mesmo de eletricamente, considerado um advérbio terminológico amplo. Essa investigação instiga-nos a questionar o uso desse grupo de advérbios (aqueles terminados em -ly e -mente) em um espectro maior, observando-o em outras áreas de especialidade, para que assim possamos descrever o seu uso tanto em inglês quanto em português. É também relevante no sentido de que as traduções utilizadas foram feitas por especialistas da área, que acrescentaram advérbios de restrição no texto e/ou omitiram aqueles que expressavam a opinião do autor, o que dentre outras considerações pode indicar que tal prática é usual na língua de chegada, ou seja, no português. Assim como no artigo anterior, esse estudo também não focou a formação de fraseologias, que considerávamos primordial para a análise do contexto em que os advérbios foram utilizados. 
A importância das fraseologias é apontada por Teixeira (2008), que trabalha com a formação de Unidades de Tradução Especializada (UTEs) em receitas culinárias e comenta sobre a importância dos advérbios nesse processo, apontando fraseologias compostas por essa classe gramatical. Segundo a autora, seu papel é de extrema relevância na Culinária e não pode ser desprezado na análise das receitas. No Direito, Carvalho Fonseca (2007) também deixa clara a importância dos advérbios ao abordar a formação de binômios, fraseologia que desempenha um papel específico nos contratos.

Como podemos observar, há vários pesquisadores que, mesmo focando diferentes aspectos da língua, deparam com a questão do advérbio. Em nossa pesquisa, decidimos partir exatamente dessa classe gramatical, mais precisamente dos advérbios terminados em -ly e -mente, em duas áreas especializadas, com 0 objetivo de trazer alguma luz e contribuir para sua descrição e uso em textos escritos originalmente em inglês e em português, contribuindo para o trabalho do produtor de textos, principalmente do tradutor. Isso posto, estabelecemos duas hipóteses que seriam comprovadas (ou não) ao final do desenvolvimento de nossa pesquisa:

1- A função dos advérbios - ou de fraseologias com advérbios - varia de acordo com o domínio em que ocorre.

2- A tradução dos advérbios pode ser um problema para o tradutor, uma vez que as formas cognatas nem sempre satisfazem suas necessidades.

Para um panorama geral de nossa investigação, apresentamos abaixo uma breve descrição dos capítulos que compõem esta tese.

No primeiro capítulo, delineamos como os advérbios são apresentados em diferentes obras de referência, incluindo gramáticas e dicionários, várias inclusive baseadas em corpus, tanto em inglês quanto em português. Em seguida, apresentamos um panorama sobre Linguística de Corpus e seus conceitos basilares, com o objetivo de fundamentar a investigação que se segue. Concluímos esse capítulo associando a pesquisa baseada e direcionada por corpus à padronização e convencionalidade linguística; como parte da sustentação teórica, 
introduzimos vários padrões que podem ser encontrados no decorrer de nossa investigação.

Iniciamos o segundo capítulo com a apresentação dos corpora utilizados na pesquisa: primeiramente os corpora de estudo na Culinária e no Direito; na sequência, aqueles considerados como corpora de referência. Como a etiquetagem dos dados fez-se necessária em determinado momento, apresentamos também como se deu esse processo nos dois corpora de estudo. Descrevemos a metodologia para o levantamento de dados juntamente com a apresentação do programa WordSmith Tools, versão 5 (SCOTT, 2007), software utilizado para manipular os dados e extrair os padrões a serem analisados. Por fim, apresentamos todo o processo e critérios para a extração dos advérbios terminados em -ly e -mente, a partir dos corpora de estudo.

O terceiro capítulo é dedicado ao levantamento e à análise de nossos dados. De início, fazemos uma análise detalhada dos cinco advérbios selecionados criteriosamente no capítulo anterior a partir do corpus de Culinária (inglês), tecendo comentários sobre todos os padrões linguísticos extraídos de nossos dados. Procedemos da mesma forma com os cinco advérbios selecionados a partir do corpus de Culinária em português. Para finalizar, comparamos os resultados obtidos nas duas línguas. Com o intuito de sugerir algumas formas equivalentes - e baseadas em corpus - dos padrões extraídos em inglês a partir das receitas, apresentamos a metodologia empregada e exemplificamos com várias fraseologias, na direção inglês-português. Em seguida, buscamos essas fraseologias e suas formas equivalentes nos corpora de língua geral, com o objetivo de verificar se realmente são típicas das receitas.

Procedemos da mesma forma com os advérbios selecionados a partir do corpus de instrumentos contratuais, cinco em inglês e cinco em português: analisamos suas ocorrências nas duas línguas, comparamos os resultados, sugerimos formas equivalentes e buscamos essas fraseologias nos corpora de língua geral. Como essa linguagem especializada apresenta inclusive peculiaridades históricas, dedicamos uma seção a comentários sobre o discurso jurídico.

A seguir, comparamos o uso dos advérbios em receitas e contratos, em ambas as línguas. Iniciamos com os advérbios-chave em comum entre as duas tipologias, tanto em inglês quanto em português. Extraímos os padrões, comparamos as análises e apresentamos um panorama dos advérbios terminados 
em -ly e -mente sob a ótica das tipologias investigadas; comparamos também as fraseologias e formas equivalentes identificadas.

Para finalizar esse terceiro capítulo, buscamos as fraseologias em inglês (nas duas tipologias) em obras de referência especializadas (dicionários monolíngues, bilíngues e tesouros), numa tentativa de verificar como são contempladas - caso o sejam - no material impresso hoje disponível para consulta no par de línguas inglêsportuguês. A tese conclui com as considerações finais de nossa pesquisa. 


\section{Capítulo I - Fundamentação teórica}

Para iniciarmos nossa investigação, recapitulamos algumas considerações tecidas em nossa pesquisa de Mestrado (MORAES, 2005) e apresentamos um panorama de como o advérbio é apresentado em outras obras de referência, tais como dicionários e gramáticas, tanto em inglês quanto em português, que podem (ou não) ser baseados em corpus. Em seguida, apresentamos a Linguística de Corpus e alguns de seus conceitos, bem como os padrões linguísticos que podem ser investigados utilizando-se todo o aporte teórico e metodológico desta forma de estudar diversos aspectos da língua.

1.10 advérbio em fontes de referência em inglês e em português: avanços significativos

Conforme relatado em Moraes (2005, p. 25-38), o advérbio é geralmente tratado de forma difusa e superficial nas gramáticas tradicionais em língua portuguesa, chegando em alguns casos a ser ignorado justamente por ser uma categoria que não é claramente definida. A sua imprecisão é inclusive retratada em dicionário, como podemos observar em nota apresentada por Houaiss (2001):

a) os advérbios são uma classe de palavras de difícil definição pela
variedade de comportamentos sintáticos, peculiaridades semânticas,
divergências de funções e classificações duvidosas que abrange;
este dicionário limitou-se a dar-lhe a definição tradicional, por falta
de conclusão definitória entre os gramáticos da língua b) alguns
advérbios podem contrair-se com a preposição que os antecede
[p.ex.: dacolá = de + acolá; dalém = de + além etc.] c) um grande
número de advérbios é formado com o sufixo -mente, que se
pospõe: 1) a um radical de adj. $2 \mathrm{~g}$. (infelizmente, vulgarmente); 2) a
um radical de adj. no fem. (astutamente, belamente,
caprichosamente, secundariamente). (HOUAISS, 2001)

Há ainda aqueles que apresentam a visão tradicional tão frequentemente encontrada, como é o caso de Ferreira (2004), onde temos: 
advérbio

[Do lat. adverbiu.]

Substantivo masculino.

1.E. Ling. Palavra invariável que modifica um verbo, um adjetivo ou outro advérbio, exprimindo circunstância de tempo, lugar, modo, dúvida, etc. [Cf. adverbio, do v. adverbiar.] (FERREIRA, 2004)

O mesmo acontece em dicionários de língua inglesa, como podemos observar na definição apresentada pelo Macmillan (2007):

adverb 'ædv3:(r)b 'æd, v3rb noun [countable] LINGUISTICS a word used for describing a verb, an adjective, another adverb, or a whole sentence. Adverbs in English often consist of an adjective with '-ly' added, for example 'quickly', 'mainly', and 'cheerfully'. ${ }^{13}$ (MACMILLAN, 2007)

$\mathrm{Na}$ sequência, apresentamos um apanhado geral dos achados de Moraes (2005, p. 25-38), quando a autora analisou três obras de referência para o inglês e o mesmo número para o português. Tais dados são importantes para o prosseguimento deste processo investigativo.

No inglês, a autora analisou as seguintes obras:

BIBER, Douglas et al. Longman Grammar of Spoken and Written English. Essex: Longman, 1999.

BOLINGER, Dwight. Degree Words. The Hague/Paris: Mouton, 1972.

QUIRK, Randolph; GREENBAUM, Sidney. A University Grammar of English. London: Longman, 1974 [1973].

Em linhas gerais, observou-se que todas esclarecem diferentes pontos sobre o uso do advérbio, mas apresentam também aspectos que necessitam ser melhor detalhados. A única baseada em corpus, elaborada por Biber et al. (1999), além de apresentar maior rigor científico, define essa classe gramatical de forma mais clara e precisa, com exemplos autênticos. Além de os itens por toda a obra serem elencados de modo a tratar cada tipo de advérbio de forma separada, o que facilita a

13 Neste caso, preferimos apresentar a tradução em nota de rodapé: “advérbio [pronúncia, em inglês] substantivo [contável] Linguística palavra utilizada para descrever um verbo, adjetivo, outro advérbio, ou toda a oração. Os advérbios em inglês frequentemente são formados por um adjetivo acrescido de '-ly', como por exemplo ‘quickly’ (rapidamente), ‘mainly’ (principalmente) e cheerfully’ (animadamente).” (tradução nossa) 
consulta, os autores preocuparam-se em associar cada um deles à tipologia textual em que mais são utilizados.

No português, as obras consultadas foram:

BECHARA, Evanildo. Moderna gramática portuguesa. 37. ed. rev. e aum. Rio de Janeiro: Editora Lucerna, 2001.

CUNHA, Celso; CINTRA, Lindley. Nova gramática do português contemporâneo. Rio de Janeiro: Nova Fronteira, 1985.

ILARI, Rodolfo et al. Considerações sobre a posição dos advérbios. In: CASTILHO, Ataliba Teixeira de (Org.). Gramática do português falado. 3. ed. Campinas: Editora da UNICAMP, 1996. v. 1, p. 65-141.

Segundo Moraes (2005), as duas primeiras apresentam aspectos tradicionalmente encontrados sobre os advérbios em gramáticas, não fazendo referência a contextos de uso ou mesmo à tipologia textual - as questões semânticas e pragmáticas são praticamente ignoradas. Já a obra de llari et al. (1996) apresenta um estudo inusitado. Deixa claro, inclusive, que a língua falada não é tão confusa e desorganizada como se supõe. No entanto, as informações não são claramente apresentadas, principalmente quanto à divisão de tópicos. Para entendê-la, o consulente deve conhecer profundamente a gramática tradicional (MORAES, 2005, p. 38).

Diante desse quadro, decidimos dar continuidade à investigação em outras obras, numa tentativa de encontrar, nelas, dados mais precisos sobre a classe gramatical dos advérbios.

1.1.1 Obras de referência consultadas para o português: uma análise quanto ao uso dos advérbios

A pesquisa iniciou-se por nossa língua materna, ou seja, o português. As obras selecionadas para este estudo foram:

BOMFIM, Eneida. Advérbios. São Paulo: Ática, 1988. 
BORBA, Francisco S. (Org.). Dicionário UNESP do português contemporâneo. São Paulo: UNESP, 2004.

BORBA, Francisco S. Dicionário de usos do Português do Brasil. São Paulo: Ática, 2002.

NEVES, Maria Helena de Moura. Texto e gramática. São Paulo: Contexto, 2006.

NEVES, Maria Helena de Moura. Guia de uso do português: confrontando regras e usos. São Paulo: Editora UNESP, 2003.

NEVES, Maria Helena de Moura. Gramática de usos do português. São Paulo: Editora UNESP, 2000.

Apresentamos abaixo os resultados da análise de cada obra, separadamente, e quando pertinente tecemos alguns comentários relacionados à nossa investigação.

\section{A) Advérbios - Eneida Bomfim}

A primeira obra analisada, Bomfim (1988), deve ser lida e considerada por aqueles que visam estudar os advérbios - a autora demonstra grande preocupação com essa classe gramatical que, segundo ela, advém de longa data. Além disso, esse estudo, que procura focar a questão do advérbio em seus aspectos morfossintáticos, semânticos e pragmáticos, apresenta uma abordagem questionadora e intrigante quando comparada às gramáticas contemporâneas tradicionais produzidas antes ou mesmo depois do lançamento desta obra. Apesar de breve - são 80 páginas no total, Bomfim leva o leitor a questionar a visão tradicional que temos sobre essa classe gramatical e a refletir sobre a linha tênue que separa a classificação de algumas palavras ou expressões, fato observado na falta de consenso entre os gramáticos a esse respeito. Diz a autora:

Um confronto do tratamento dado pelas nossas gramáticas ao advérbio dá a impressão inicial de uniformidade: essa classe de palavras é invariável, modifica o verbo, um adjetivo, outro advérbio ou todo o enunciado e expressa circunstâncias.

Essa aparente concordância não resiste a um exame mais acurado. Basta atentar para a variação, de compêndio para compêndio, dos elementos que integram as listas de exemplos. (BOMFIM, 1988, p. 5) 
Segundo Bomfim (1988, p. 6), não podemos generalizar o conceito de advérbio: os que expressam afirmação, negação ou dúvida, por exemplo, não expressam circunstância, não se referem ao processo verbal, tampouco são intensificadores, como é o caso de realmente e provavelmente. Enfatiza que os mais legítimos representantes da classe dos advérbios são os de modo, dentre eles destacando-se aqueles terminados em -mente. Esse grupo vem sendo alvo de diferentes estudos, como o apresentado por Pottier (POTTIER, 1968 apud BOMFIM, 1988, p. 9), em que o autor sustenta que o advérbio é para o verbo o que o adjetivo é para o substantivo, ou seja, um qualificador. Analisaremos essa questão em nossos dados, mais adiante, uma vez que questionamos essa visão sobre a função do advérbio.

Outro aspecto também apontado é que nem todos os advérbios terminados em -mente são de modo. Esse tipo permeia as diferentes subclasses dos advérbios - alguns não são modificadores e/ou não estão ligados a circunstâncias de qualquer natureza, como é o caso de certamente em Certamente ela virá. Em nosso estudo, verificaremos como se subdividem os advérbios terminados em -mente nas áreas especializadas investigadas.

Observamos também a ênfase aos advérbios que, segundo a autora, expressam a opinião do emissor (subjetividade) - dentre os quais muitos terminados em -mente -, perdendo traços semânticos dos adjetivos que lhes deram origem e enfraquecendo-se a ponto de indicar apenas intensificação positiva ou negativa. Como exemplo, Bomfim (1988, p. 23) cita imensamente em imensamente feliz. Há também casos em que o emissor expressa crítica, como em terrivelmente cruel, incrivelmente pálido. Essa característica na língua geral foi observada por Moraes (2005), tanto em inglês quanto em português; resta verificar se isso também ocorre em linguagens especializadas. Bomfim (1988, p. 24) ressalta, no entanto, que essas observações não podem ser generalizadas, pois há casos em que não há interferência da opinião do emissor, como em psicologicamente débeis e moralmente fracas. Esses advérbios, por sua vez, restringem os adjetivos que os seguem, revelando uma outra característica dos advérbios.

Bomfim (1988) salienta que há autores, como Silva Júnior e Andrade e Macambira, que admitem que o advérbio pode modificar outras classes de palavras além de verbos, adjetivos ou outros advérbios. 
Ao focar os advérbios de tempo e de lugar, Bomfim (1988, p. 27) faz uma análise semântica dos advérbios de tempo, primeiramente enfatizando a questão da posição desses advérbios e a sua incidência sobre outros elementos da frase. Demonstra que há diferenças nesse grupo, como é o caso de ontem, hoje e amanhã, quando comparados a cedo/tarde. Enquanto apenas esses últimos podem ser intensificados por outros advérbios, os primeiros apresentam um ponto de referência no contexto extralinguístico (dêiticos) do mesmo modo que os pronomes, podendo, inclusive, exercer o papel de sujeito da oração, como podemos observar neste exemplo por nós obtido na Web: Eleições autárquicas: Hoje e amanhã são dias de reflexão. ${ }^{14}$ (grifo nosso).

Neste grupo, interessam-nos aqueles terminados em -mente, como é o caso de antigamente, atualmente e futuramente, na medida em que poderão fazer parte de nossos dados.

Ao tratar dos advérbios de lugar, a autora afirma que há um paralelismo entre esses e os advérbios de tempo, sendo os primeiros localizadores espaciais e, os últimos, temporais (BOMFIM, 1988, p. 38). Partindo da análise que apresenta para vários advérbios de lugar, questionamos a afirmação de que aqui, aí, lá, etc. não são passíveis de intensificação. Fica a pergunta: Como explicar bem aqui na frase $A$ pontuação aumenta se você usar o menor número de cliques possível para vencer cada fase. Para jogar basta clicar aqui BEM AQUI [...]. ${ }^{15}$ ?

Na sequência, Bomfim (1988) apresenta e discorda da inclusão dos advérbios como subclasse das preposições, aspecto defendido por alguns estudiosos. Apesar dos pontos de contato entre preposições e advérbios, a autora deixa claro que são classes diferenciadas. Para isso, elenca vários fatores que corroboram sua opinião, dentre os quais destacamos (BOMFIM, 1988, p. 42-47):

- sobre os advérbios podem incidir elementos terciários, como mais, bem, bastante, muito, etc., desde que não haja incompatibilidade semântica. Tal característica não é observada com as preposições, como podemos verificar nos exemplos:

Só vim a conhecê-la bem depois.

\footnotetext{
${ }^{14}$ http://www.maputo.co.mz/por/content/pdf/29233. Acesso em: 4/10/2009.

${ }^{15}$ Exemplo obtido em http://zoomdoggle.com/2009/08/play-roly-poly-eliminator/ e acessado em 4/10/2009. Sem considerar ou analisar a que palavras a expressão bem aqui se referia ao fazermos uma busca com o motor Google (www.google.com.br), obtivemos 551.000 resultados.
} 
*Vim muito de casa, agora. (o asterisco é utilizado pela autora para indicar que a oração não está gramaticalmente correta)

- as preposições estabelecem uma relação de dependência entre dois termos, como podemos observar em alguns sintagmas nominais. Em sino de ouro, por exemplo, a preposição de subordina ouro a sino.

- as preposições levam o pronome pessoal regido para a forma tônica, independente da ocorrência de advérbios no sintagma, como é o caso de perto/longe e antes/depois em expressões como perto de / longe de ou antes de / depois de, seguidos de um ponto de referência. Exemplos: Patrícia, Ana e Cecília têm saudades de mim.; Patrícia sentou-se perto de mim. (grifo nosso).

- apesar de todos os contextos que admitem modificação por advérbio admitirem também modificação por sintagma preposicional, tal fato não significa que advérbio é preposição, como podemos observar no uso do advérbio bem nos exemplos abaixo:

Eles conversaram bem pacificamente.

Eles conversaram bem em paz.

No segundo exemplo, bem refere-se a todo o sintagma que se segue, não apenas à preposição em. ${ }^{16}$

Em linhas gerais, a autora estabelece pontos convergentes e divergentes entre palavras tidas como advérbios e aquelas que, tradicionalmente, são atribuídas a outras classes gramaticais mas, segundo ela, deveriam ser classificadas como advérbios. Fecha a obra ressaltando dois aspectos: o caráter subjetivo de um grande número de advérbios (ligados ao emissor) e a relação com as circunstâncias que envolvem a emissão do enunciado (a questão da função textual). Deixa claro que os advérbios de modo são os únicos que, de fato, se referem ao processo verbal - não ignorando o fato de que nem todos os advérbios terminados em -mente incluem-se nesse grupo.

Vários dos aspectos mencionados por Bomfim (1988) são retomados por Solange Nascimento (2008) no artigo "Os verdadeiros advérbios: modo, tempo e lugar". Nascimento também coloca a problemática de que

\footnotetext{
${ }^{16}$ Todos os exemplos citados neste trecho foram retirados da obra (BOMFIM, 1988, p. 42-47).
} 
[m] uitos elementos pertencentes ao grande grupo denominado "Advérbios" apresentam, em relação a aspectos sintáticos e semânticos, comportamentos tão diferenciados que podem configurar, na verdade, grupos de palavras diferentes, devido a suas diversas naturezas e origens. (NASCIMENTO, 2008, p. 322)

Observando a necessidade de pesquisas mais aprofundadas sobre o assunto, a autora decidiu ater-se apenas ao grupo dos advérbios de modo, tempo e lugar nesse artigo. Para tal, considerou como ponto de partida as obras de Evanildo Bechara (1999), Cunha e Cintra (1997) e Rocha Lima (1998), além do trabalho de Eneida Bomfim (1988), acima comentado. Quanto às gramáticas, observa que o caráter preciso e bem definido geralmente atribuído ao advérbio não se concretiza em seu uso, questionando inclusive se realmente existe uma classe dos advérbios: "Será que esta não comportaria na verdade uma mistura de classes, tendo em vista seus comportamentos diferenciados?" (NASCIMENTO, 2008, p. 326). Outros aspectos também questionados são as noções de modificação e circunstância geralmente atribuídas ao advérbio - nem todas as palavras classificadas como advérbios apresentam esses atributos.

Nascimento (2008) enfoca a questão da subjetividade, apontando para o fato de que um advérbio pode expressar opinião ou dúvida por parte do emissor, como observado em Bomfim (1988). Ressalta que há estudiosos que apresentam os advérbios como modificadores apenas de verbos, sendo os adjetivos, outros advérbios ou mesmo orações inteiras modificados por palavras que deveriam ser classificadas de outra forma.

Em sua análise, a autora classifica como modalizadores a maioria dos advérbios terminados em -mente, que segundo ela denotam a opinião ou dúvida do emissor sobre o enunciado (ou parte dele). Apresenta algumas reflexões sobre os advérbios de tempo e de lugar, embasadas em Bomfim (1988), que fogem ao escopo desta pesquisa, mas que também deixam clara a imprecisão dessa classe gramatical. Em suas considerações finais, menciona três pontos de nosso interesse: nem todo advérbio é circunstancial ou modificador; alguns advérbios terminados em -mente são modalizadores e não modais; e os advérbios de modo e intensidade são os únicos que modificam o verbo, sem necessariamente indicar uma circunstância.

Dentre os vários estudiosos, Nascimento (2008) menciona Neves (2000), cujas considerações sobre os advérbios apresentamos a seguir. 


\section{B) Gramática de usos do português - Maria Helena de Moura Neves}

Logo na apresentação da Gramática de usos do português (NEVES, 2000), a autora faz um comentário que nos instiga a continuar a leitura: a obra objetiva apresentar uma abordagem diferenciada. Segundo ela, essa gramática parte dos itens lexicais e gramaticais da língua, apontando-os em uso e em todos os níveis, desde o sintagma até o texto. Pudemos comprovar tal fato durante nossa investigação - os advérbios são analisados no nível do sintagma, da oração, do enunciado e do discurso.

Analisar os capítulos $O$ advérbio (p. 231-282) e Apêndice do advérbio (p. 283331) em Neves (2000) não foi tarefa fácil, especialmente pelo nível de detalhamento apresentado. Nossa dificuldade inicial foi compreender e assimilar a divisão dos tópicos, o que certamente deve confundir outros consulentes. Colocamos abaixo parte dessa distribuição, elencando apenas as informações apresentadas em sequência numérica (a autora também utiliza letras para subdivisão de alguns tópicos):

1 A forma dos advérbios

2 A natureza do advérbio

2.1 De um ponto de vista morfológico, o advérbio é uma palavra invariável

2.2 De um ponto de vista sintático, ou relacional, o advérbio é uma palavra periférica, isto é, ele funciona como satélite de um núcleo

2.2.1 O advérbio (ou locução adverbial) atua nas diversas camadas do enunciado

2.2.2 Essa atuação em camadas fica muito evidente quando advérbios de diferentes tipos coocorrem

3 As subclasses dos advérbios

3.1 Advérbios modificadores

3.1.1 Advérbios de modo (ou qualificadores)

3.1.2 Advérbios de intensidade (ou intensificadores)

3.1.3 Advérbios modalizadores

3.1.3.1 Epistêmicos ou asseverativos

3.1.3.2 Delimitadores ou circunscritores

3.1.3.3 Deônticos

3.1.3.4 Afetivos ou atitudinais

3.2 Advérbios não-modificadores

3.2.1 Advérbios que operam sobre o valor de verdade da oração

3.2.1.1 Advérbios de afirmação

3.2.1.2 Advérbios de negação 
3.2.2 Advérbios que não operam sobre o valor de verdade da oração

3.2.2.1 Advérbios circunstanciais (de lugar e de tempo)

3.2.2.2 Advérbios de inclusão

3.2.2.3 Advérbios de exclusão

3.2.2.4 Advérbios de verificação

3.2.3 Advérbios que operam conjunção de orações

4 Os advérbios de modo

4.1 Os advérbios de modo constituem a subclasse mais característica dos advérbios $[\ldots]^{17}$

4.2 Em princípio, os advérbios de modo constituem, pois, uma categoria não-fórica, [...]

4.3 Os advérbios de modo constituem uma classe aberta na língua, [...]

4.4 Além disso, podem-se criar indefinidamente locuções adverbiais de modo iniciadas por preposição

5 Os advérbios modalizadores

5.1 Os advérbios modalizadores compõem uma classe ampla de elementos adverbiais [...]

5.2 Subclasses dos advérbios modalizadores

5.2.1 Modalizadores epistêmicos

5.2.1.1 Subclassificação dos modalizadores epistêmicos (asseverativos)

5.2.1.1.1 Asseverativos afirmativos [...]

5.2.1.1.2 Asseverativos negativos [...]

5.2.1.1.3 Asseverativos relativos [...]

5.2.1.2 Observações sobre o modo de emprego dos advérbios asseverativos

5.2.1.2.1 Pela sua natureza, advérbios asseverativos [...]

5.2.1.2.2 O emprego de advérbios asseverativos [...]

5.2.1.2.3 Na conversação, advérbios asseverativos [...]

5.2.2 Modalizadores delimitadores

5.2.2.1 Esses advérbios não garantem nem negam propriamente o valor de verdade [...]

5.2.2.2 De dois modos principais se faz a delimitação adverbial dos enunciados [...]

5.2.2.3 Embora a delimitação sugira principalmente redução de âmbito, [...]

5.2.3 Modalizadores deônticos

5.2.4 Modalizadores afetivos

5.2.4.1 Modalizadores afetivos subjetivos

5.2.4.2 Modalizadores afetivos interpessoais

5.3 Distribuição e posição dos advérbios modalizadores

6 Os advérbios circunstanciais

${ }^{17}$ Como a autora utiliza numeração em alguns parágrafos, apresentamos apenas os comentários iniciais dessas referências. 
6.1 A natureza dos advérbios de lugar e de tempo

6.2 As subclasses dos advérbios circunstanciais

6.2.1 Advérbios de lugar

6.2.1.1 Fóricos

6.2.1.2 Não-fóricos

6.2.2 Advérbios de tempo

6.2.2.1 Fóricos

6.2.2.2 Não-fóricos

6.3 Funções sintático-semânticas dos advérbios circunstanciais

6.3.1 Função argumental (nuclear) [...]

6.3.1.1 Atuam como participantes, ou argumentos, [...]

6.3.1.2 Indicam circunstância relativa a participantes [...]

6.3.2 Função adjuntiva adverbial

6.3.3 Função adjuntiva adnominal

6.3.4 Função juntiva

6.4 O esquema sintático

6.4.1 Não-completáveis, intransitivos ou avalentes

6.4.2 Completáveis ou transitivos

6.5 Traços semânticos dos advérbios de lugar

6.5.1 Situação, ou seja, lugar propriamente dito, o que configura um valor estático

6.5.1.1 Posição absoluta

6.5.1.2 Posição relativa

6.5.2 Percurso

6.5.3 Origem e direção

6.5.3.1 Origem

6.5.3.2 Direção

6.6 A semântica dos advérbios de tempo

6.6.1 A relação tempo entre tempo e aspecto

6.6.2 Traços semânticos e aspectuais dos advérbios de tempo

6.6.2.1 Situação

6.6.2.1.1 Situação absoluta

6.6.2.1.2 Situação relativa

6.6.2.2 Duração

6.6.2.2.1 Período referido a um momento da enunciação (fóricos)

6.6.2.2.2 Período não referido a um momento determinado da enunciação ou do enunciado (não-fóricos)

6.6.2.3 Freqüência 
6.7 Propriedades distribucionais dos circunstanciais de lugar e de tempo

6.7.1 Advérbios que têm a mesma distribuição de um sintagma nominal [...]

6.7.1.1 Fóricos

6.7.1.2 Não-fóricos

6.7.2 Advérbios que têm a mesma distribuição de sintagma preposicionado [...]

6.7.2.1 Fóricos

6.7.2.2 Não-fóricos

7 Os advérbios juntivos anafóricos

7.1 A natureza dos advérbios juntivos adversativos

7.2 O valor semântico dos advérbios juntivos

8 Particularidades das construções com advérbios

8.1 Numa seqüência de advérbios em -mente, pode-se dispensar [...]

8.2 O comparativo de superioridade de BEM e de $M A L$ pode ser [...]

No Apêndice do Advérbio (NEVES, 2000, p. 283-331), a autora trabalha exclusivamente a questão da negação, desde o seu processo até à negação como operação pragmática. Como foge ao escopo desta pesquisa, optamos por não elencar os tópicos desse apêndice, mas a autora apresenta o mesmo nível de detalhamento anteriormente demonstrado.

Outro fato que sobrepuja gramáticas tradicionalmente encontradas no mercado é o número de páginas destinado aos advérbios, classe considerada híbrida pela própria autora. No total, temos cem delas dedicadas exclusivamente ao advérbio per se (p. 231-331), além de um tópico na Parte IV, intitulado As conjunções subordinativas adverbiais (p. 787-929). Considerando-se o olhar criterioso da pesquisadora, salientamos que essa obra é fruto de uma investigação baseada em um corpus escrito de língua portuguesa, conhecido como Corpus de Araraquara, que na época contava com 70 milhões de ocorrências. ${ }^{18}$ Ao utilizar esse material, a autora reforça seu posicionamento de que a interpretação das categorias linguísticas não pode prescindir da investigação de seu comportamento em uma unidade maior, ou seja, o próprio texto em que ocorre, considerada a real unidade de função (NEVES, 2000, p. 15).

\footnotetext{
${ }^{18}$ Esses dados estão armazenados no Centro de Estudos Lexicográficos da UNESP - Campus de Araraquara, tendo sido também utilizados para a elaboração do Dicionário de usos do português (BORBA, 2002), trabalho coordenado por Francisco da Silva Borba e também investigado nesta pesquisa.
} 
Para analisarmos os diversos aspectos apontados por Neves (2000) quanto ao uso dos advérbios, decidimos apresentar, explicar e citar os exemplos da autora, entremeando esses dados com nossos comentários. Acreditamos ser esta a melhor forma de dar ao leitor subsídios para que compreenda nosso posicionamento e a importância desta investigação.

Logo de início, observamos o foco que uma gramática baseada em corpus dá às coligações das quais os advérbios fazem parte. Na p. 232, por exemplo, Neves (2000) apresenta vários padrões morfossintáticos, como é o caso de preposição + substantivo / adjetivo / advérbio (às vezes, em verdade); preposição + substantivo quantificado (de alguma maneira); e preposição + nome/ pronome + preposição + mesmo nome/pronome (de tempo em tempo, de quando em quando). Em nenhum momento (ou mesmo no desenrolar de todo o capítulo), a autora menciona as denominações comumente encontradas em gramáticas tradicionais, como é o caso de locução adverbial de tempo, etc.

Segundo Neves (2000, p. 233), a natureza do advérbio (conceituação) apresenta diferentes pontos de vista:

Em nível de sintagma:

- morfologicamente, o advérbio é uma palavra invariável para o diminutivo. Quando utilizado, a intenção do falante é intensificar o próprio advérbio, como em depressinha e agorinha.

- sintaticamente, o advérbio é uma palavra periférica, funcionando como satélite de um núcleo. Atua nas diversas camadas do enunciado, desde o sintagma até o discurso. A autora elenca outras classes gramaticais sobre as quais também incidem os advérbios. Além daquelas tradicionalmente encontradas em obras de referência, ou seja, verbos, adjetivos (ou sintagmas com valor adjetivo), ou advérbios (ou sintagmas com valor adverbial), Neves (2000, p. 234-235) cita também o numeral, o substantivo, o pronome, e até mesmo a conjunção embora. Exemplos ${ }^{19}$ :

É imperativo de segurança da causa, que todos esposamos, valorizar também a América Latina, com os seus duzentos milhões de habitantes APROXIMADAMENTE, fazê-la adquirir maior relevo. (JK-O)

\footnotetext{
${ }^{19}$ Todos os exemplos foram retirados da obra. Utilizamos a mesma formatação apresentada pela autora: em itálico, a unidade sobre a qual o advérbio (em versalete) incide. As letras ao final do exemplo indicam o texto de onde foi retirado no corpus utilizado para a pesquisa. Para mais detalhes, vide Neves (2000, p. 963-984).
} 
Não diz bobagem. Greve AGORA não vai nada bem. (EN)

$E$ quem sabe se de tudo que pudesse fazer, se entre todas as reações possíveis, não era JUSTAMENTE isto - ceder, pagar. (FP)

Alguns inquéritos solicitados pelo Saps à polícia arrastam-se morosamente sem chegar à apuração policial dos crimes, MUITO embora as autoridades da mais alta hierarquia se empenhem nisso. $(E S P)^{20}$

Em nível de enunciado:

- incide sobre a oração ou proposição (é considerado periférico):

REALMENTE, sentia fome. (ARR)

Em nível de discurso:

- incide sobre todo o enunciado (é considerado periférico):

ENTÃO, mãe, como é que foi a reunião em Palácio? (DZ)

Apesar de interessante, acreditamos ser difícil diferenciar um advérbio que incide sobre uma oração daquele que o faz sobre todo um enunciado.

Neves (2000, p. 236) enfatiza que os advérbios são uma classe heterogênea quanto à função. Apresenta suas subclasses, dividindo-as em dois grandes grupos:

Os advérbios modificadores: afetam o significado do elemento sobre o qual incidem, fazendo uma predicação sobre as propriedades desses elementos, isto é, modificando-os. A autora ainda os subdivide e classifica semanticamente:

- advérbios de modo (ou qualificadores): qualificam uma ação, um processo ou um estado expressos num verbo ou num adjetivo. Ex.: "Tenho uma cabeça que pensa muito DEPRESSA. (AMI)."

Para demonstrar quão tênue são as diferenças nessas subclassificações, comentamos o seguinte exemplo, incluso neste grupo: "Os dedos encarquilhados exibiam pedras ESCANDALOSAMENTE falsas. (CP)" . O advérbio escandalosamente poderia também expressar, além de modo, opinião, ou mesmo ser considerado um intensificador do adjetivo falsas. Portanto, poderia fazer parte desses outros subgrupos. Além disso, consideramos provável que escandalosamente falsas seja uma colocação, isto é, uma associação de palavras cuja co-ocorrência é frequente ${ }^{21}$. Em rápida pesquisa na Web com o buscador Google (12/10/2010), encontramos 446

\footnotetext{
${ }^{20}$ Em um levantamento feito com o buscador Google, em 12/10/2010, obtivemos 681.000 ocorrências de muito embora na Web, o que indica estarmos diante de uma unidade de significado que necessita ser melhor investigada.

${ }^{21}$ Para mais detalhes sobre o que é uma colocação, vide item 1.3 desta tese.
} 
ocorrências de escandalosamente falsa e 318 de escandalosamente falsas, o que evidencia a necessidade de uma investigação mais aprofundada.

- advérbios de intensidade (ou intensificadores): intensificam o conteúdo de um adjetivo, verbo ou advérbio. Ex.: "Acho que, por hoje, você já ouviu BASTANTE. (A)"

Vale observar que há autores que definem os advérbios de intensidade apenas como intensificadores (não como advérbios), como aponta Bomfim (1988), o que demonstra falta de consenso entre os estudiosos.

Nesse item, a autora inclui algumas particularidades sobre o advérbio BEM: além de expressar intensidade, como em bem feliz, pode também expressar verificação de algo comentado anteriormente, representado pela palavra que se segue, como em "Não era BEM isso o que quis dizer. (ARR)".

- advérbios modalizadores: modalizam o conteúdo de uma asserção (em nível oracional). Esse grupo inclui os epistêmicos ou asseverativos, como em "Mas, CERTAMENTE, não era o seu desejo. (A)"; os delimitadores ou circunscritores, "Nós temos barcos capacitados TECNICAMENTE para essas pesquisas. (CB)"; os deônticos, que apresentam uma necessidade, na verdade tida como uma obrigação: "Não que pense em evitar a conversa que, NECESSARIAMENTE, tenho que ter com ele. (A)"; os afetivos ou atitudinais, que refletem o estado de espírito do falante em relação ao conteúdo da asserção: "FRANCAMENTE, comissário, o senhor me deixa confusa. (APA)". Nesse grupo, há unidades que poderiam ser consideradas uma colocação, como é o caso de capacitados tecnicamente no exemplo acima, uma vez que em pesquisa com o buscador Google (7/11/2009), encontramos 9.470 ocorrências dessa associação, apontando para a necessidade de uma investigação mais aprofundada.

O segundo grande grupo é o dos advérbios não-modificadores, aqueles que não afetam o significado do elemento sobre o qual incidem. Neves (2000, p. 238241) subdivide-o em grupos menores, como vemos a seguir:

Aqueles que operam sobre o valor de verdade da oração: os advérbios de afirmação e os de negação. Dentre os exemplos de negação, um instigou-nos a refletir se estávamos (ou não) diante de uma unidade de significado, mais precisamente de uma colocação: utilizando o buscador Google, encontramos 4.650.000 ocorrências de nem sempre na Web (7/11/2009). Neves (2000, p. 238) cita o seguinte exemplo: "Os homens NEM sempre aceitam certas coisas. (ANA)". 
A autora também menciona que alguns advérbios negativos são utilizados para fazer indicação temporal, como em "JAMAIS se deixou abater. (SPI)". Isso reforça a ideia de mobilidade e fluidez entre as classes dos advérbios, evidenciando a dificuldade de se classificar vários deles.

Aqueles que não operam sobre o valor de verdade da oração: advérbios circunstanciais (de lugar e de tempo); de inclusão (inclusão de outros elementos ou inclusão com exclusividade); de exclusão; e de verificação. Segundo Neves (2000, p. 241), os três últimos atuam como focalizadores da parte do enunciado que vem a seguir, como em "O segredo do vosso estilo está JUSTAMENTE na sua sábia simplicidade. (AM-O)".

Aqueles que operam conjunção de orações: Neves (2000, p. 241) os classifica como advérbios juntivos, de valor anafórico e que ocorrem numa oração ou sintagma, indicando contraste (porém, contudo, entretanto, todavia, no entanto) e conclusão (portanto, por conseguinte, então). Ex.: "Muito áspera foi e está sendo a jornada que vivemos a partir de 1964. Os resultados alcançados são, PORÉM, indiscutivelmente, positivos, marcantes mesmo. (ME)". Interessante observar que a própria autora aponta que a gramática tradicional classifica esses advérbios como conjunções utilizadas para introduzir orações adversativas e conclusivas. No entanto, não esclarece porque optou por classificá-los dessa forma, deixando o consulente sem uma justificativa mais adequada.

Antes de apresentarmos os advérbios de modo, foco de nossa pesquisa, um aspecto negativo que observamos nesta gramática é a organização dos dados, uma vez que o consulente tem de avançar e voltar nas páginas durante a leitura para ter uma visão macro do assunto, o que pode confundi-lo. Na p. 239, item 3.2.2.1, por exemplo, Neves apresenta os advérbios circunstanciais (de lugar e de tempo) como parte do grupo de advérbios que não operam sobre o valor de verdade da oração. Esse grupo, por sua vez, faz parte dos advérbios não-modificadores (item 3.2). Na p. 256, os advérbios circunstanciais são novamente mencionados e seus subgrupos, detalhados. Essa "hierarquização" e numeração de itens, em um primeiro momento, demanda que o consulente releia o texto para melhor compreender o aspecto gramatical em sua totalidade. A nosso ver, isso pode desestimular a consulta.

Da p. 241 a 256 (itens 4 e 5), Neves aborda os advérbios de modo e os modalizadores. Segundo ela, os advérbios de modo são a subclasse mais característica dos advérbios - são qualificadores de uma ação, um processo ou 
estado, modificando propriedades de verbos e adjetivos. Ela equipara a função desses advérbios àquela dos adjetivos quantificadores, em relação aos substantivos. Novamente, nos exemplos, encontramos unidades que podemos considerar colocações, como é o caso de frear bruscamente e tratar carinhosamente em:

Um carro era freado BRUSCAMENTE. (BH)

Sempre os negócios de terras, de sítios de seus clientes, lhe excitavam a imaginação e tratava deles CARINHOSAMENTE como se fossem próprios. (BS)

Neste subgrupo, Neves (2000, p. 242) inclui o advérbio assim, um elemento fórico que pode ocorrer incidindo sobre um substantivo, como em "E você creia: jamais acreditei que pudessem existir remorsos ASSIM. (A)". A autora ressalta, ainda, outras ocorrências desse advérbio.

Os advérbios de modo constituem uma classe aberta, uma vez que podemos formá-los acrescentando o sufixo -mente à forma feminina de adjetivos qualificadores. Há também o grupo de adjetivos que podem ser gramaticalizados como advérbios, mesmo sem o acréscimo de -mente, caso da expressão jogar limpo em "Corinthians jogou LIMPO, foi melhor em campo e derrotou o Grêmio. (FSP) (=limpamente, lealmente)." Pode-se também criar locuções adverbiais de modo iniciadas por preposição, como de repente, de supetão, à queima roupa, etc. Ex.: "Agora me comunicavam DE SUPETÃo uma viagem. (MEC)."

A subclasse dos advérbios modalizadores, por sua vez, é composta por uma gama de elementos adverbiais, que basicamente expressam alguma intervenção do falante na definição de validade e do valor do enunciado. Esse falante modaliza o valor de verdade e/ou dever, podendo restringir o domínio, definir a atitude e avaliar a própria formulação linguística. Essa é uma subclasse bastante heterogênea que incide em nível oracional e/ou de enunciado. Ex.: "A equipe anterior REALMENTE não ia bem. (EX)"; "Provavelmente você não gostará da resposta. (CLA)". A seguir, elencamos as subclasses apresentadas pela autora (NEVES, 2000, p. 245-256), que detalhamos por incluírem os advérbios terminados em -mente.

Modalizadores epistêmicos: expressam uma avaliação que passa pelo conhecimento do falante. Eles asseveram, ou melhor, marcam uma adesão do falante ao que ele próprio diz - são advérbios asseverativos e podem expressar uma atitude positiva, negativa ou relativa. 
Os asseverativos afirmativos são utilizados para reforçar que o conteúdo do que se afirma ou se nega é um fato, fora de dúvida. É interessante observar a presença de vários advérbios terminados em -mente, agrupados semanticamente, como é o caso dos que expressam evidência (evidentemente, reconhecidamente); irrefutabilidade (incontestavelmente, indubitavelmente, indiscutivelmente); verdade dos fatos (verdadeiramente, realmente, na realidade). Os advérbios asseverativos se constroem tanto com enunciados afirmativos, como em "EVIDENTEMENTE sabia de muita, muita coisa. (A)", quanto com enunciados negativos: "NATURALMENTE não falta quem diga que imoral mesmo é a miséria. (C-JB)".

Os asseverativos negativos são utilizados para expressar que o conteúdo do que se diz é indubitavelmente não-factual, como em "Não deixaria de ir ao cinema aquela noite, DE JEITO NENHUM. (ANA)". ${ }^{22}$

Os asseverativos relativos reforçam que o conteúdo do que se diz é eventual, como algo que o falante crê ser possível, ou impossível, provável, ou improvável. Ex.: "PRovaVELmente havia um certo exagero no julgamento. (ANA)".

A autora também menciona outros recursos dos quais o falante se vale para expressar o grau de probabilidade do conteúdo de seu enunciado, como o emprego do subjuntivo ou do futuro do pretérito, junto com o advérbio, como podemos observar em "EVENTUALMENTE, poderia testar o conhecimento teórico utilizado. (BF)".

O uso dos advérbios asseverativos é bastante individual e depende do posicionamento do falante diante do enunciado (NEVES, 2000, p. 249). Muitos derivam de adjetivos (daí o grande número daqueles terminados em -mente), reforçando sua função atributiva:

- Se você recorrer à História, verá que as concepções variaram.

- EXATAMENTE. (FIG)

(= Exatamente: Se você recorrer à História, verá que as concepções variaram.)

O próximo subgrupo apresentado (NEVES, 2000, p. 250) é o dos advérbios modalizadores delimitadores. Ao utilizá-los, o falante circunscreve os limites de interpretação do enunciado, ou de um de seus constituintes, delimitando onde buscar a factualidade (ou não) do que é dito, como em "Já disse que quero passear PURA e SIMPLESMENTE, eu e esta donzela puríssima que tenho aqui ao meu lado.

\footnotetext{
${ }^{22}$ Vale lembrar que os exemplos citados são da própria autora (NEVES, 2000). Quando isso não ocorre, apresentamos as devidas referências.
} 
(DM)". Neves cita vários exemplos e detalha o nível em que a circunscrição ou delimitação do enunciado pode ocorrer. Este subgrupo pode também ser utilizado para fixar a validade do enunciado dentro de um domínio do conhecimento, como observamos em "As mulheres são BIOLOGICAMENTE iguais aos homens? (REA)".

Os modalizadores deônticos são utilizados quando o falante apresenta o enunciado como algo que deve necessariamente ocorrer, uma obrigação. Pode ocorrer em nível de oração, como em "OBRIGATORIAMENTE as empresas aplicariam $30 \%$ do Imposto de Renda no Programa de Integração Nacional - PIN. (NOR)", ou sobre um de seus constituintes: "Qualquer análise da evolução do custo de vida está OBRIGATORIAMENTE sujeita à crítica. (ESP)".

Durante toda a leitura, fica evidente o nível de detalhamento apresentado pela autora, principalmente no que concerne o aspecto semântico e textual, de onde parte toda a sua análise. Como podemos observar, vários advérbios estão presentes em subgrupos diferentes - veja o caso de naturalmente - e alguns são mais específicos, como obrigatoriamente no exemplo acima.

Com os modalizadores afetivos o falante exprime reações emotivas, isto é, manifesta-se quanto ao que é afirmado ou negado. Há os modalizadores afetivos subjetivos: "O problema, LAMENTAVELMENTE, vem de muitos anos. (EM)"; "O cerrado é ESPANTOSAMENTE rico em plantas acumuladoras. (TF)", e os interpessoais: "HONESTAMENTE não sei o que faria. (SPI)". Difícil distinguir entre um tipo e outro, ou mesmo a que elemento do enunciado se refere. A nosso ver, na primeira frase lamentavelmente incide sobre a oração. Já espantosamente (segundo exemplo) parece fazer parte da unidade espantosamente rico, o que certamente necessita de uma investigação aprofundada.

Neves (2000, p. 254-256) apresenta também a distribuição e a posição dos modalizadores em relação ao enunciado e aos seus elementos constituintes, como é o caso de sintagmas verbais e adverbiais, por exemplo. Essas observações reforçam a ideia de que o consulente deve ter amplo conhecimento dos aspectos morfossintáticos para acompanhar a descrição apresentada.

No item seguinte (NEVES, 2000, p. 256-272), temos os advérbios circunstanciais (de lugar e de tempo). São categorias dêiticas, que fazem orientação por referência ao falante e ao momento do enunciado (aqui-agora). A relação entre lugar e tempo é muitas vezes confusa, implicando grande transição entre uma categoria e outra. Tanto os advérbios de lugar quanto os de tempo podem subdividir- 
se em fóricos e não-fóricos. Em ambos os aspectos, há uma descrição detalhada e a preocupação da autora em delinear todo o perfil semântico em que esses advérbios são utilizados, através do contexto, o que implica dada situação, sua duração e frequência. Apresenta também suas funções sintático-semânticas, enfatizando traços aspectuais e propriedades distribucionais. No caso dos advérbios de tempo, observamos que há muitos terminados em -mente, como é o caso de anteriormente, atualmente, recentemente etc.

O item 7, intitulado Os advérbios juntivos anafóricos (NEVES, 2000, p. 272281), apresenta os advérbios juntivos (ou conjuntivos) adversativos que, como a conjunção coordenativa mas, marcam uma relação de desigualdade entre o segmento em que ocorrem (enunciado, oração ou sintagma) e outro anterior. Apesar de semelhantes semanticamente, a diferença entre esses advérbios juntivos e a conjunção mas é marcada por duas situações: podem deixar de ocorrer como primeiro elemento da oração ou sintagma, como em "Não havia ninguém. Pôde escutar ENTRETANTO pisadas rápidas se afastando... (ED)"; e podem coocorrer com conjunções coordenativas, como em "Sem chuva fenece. Mas PORÉM resiste. (FR)". 23

Ainda nesse item, a autora apresenta uma série de especificidades sobre o valor semântico desse grupo, o que nos leva a refletir sobre o grau de conhecimento do consulente para compreender a análise proposta. Outra questão que levantamos é: seria possível chegarmos às conclusões apresentadas nessa gramática, partindo de uma pesquisa mais direcionada pelo corpus ? $^{24}$ Mesmo na apresentação e introdução da obra, não fica claro como se desenvolveu o processo investigativo.

Dentre algumas particularidades das construções com advérbios (NEVES, 2000 , p. 281), encontramos o recurso de acrescentar o sufixo apenas ao último advérbio, quando há uma sequência deles: "Olivetto acha que está ocorrendo diminuição do racismo no Brasil, mas que o negro ainda precisa ascender SOCIAL e ECONOMICAMENTE. (FSP)".

Conforme colocado no início da análise desta obra, Neves (2000, p. 316) apresenta um apêndice para tratar exclusivamente da negação. Nele encontramos advérbios terminados em -mente que, apesar de não constituírem palavras de

\footnotetext{
${ }^{23}$ A autora tece comentários mais específicos sobre este grupo, mas foge ao escopo desta pesquisa detalhá-los. Para isso, vide Neves (2000, p. 273).

${ }^{24}$ Para mais detalhes sobre essa abordagem, vide item 1.2.3 desta tese.
} 
negação, conferem certo valor negativo à oração, como é o caso de raramente e dificilmente em: "Foi recebido com surpresa, pois Pantaleão RARAMENTE visitava alguém. (AM)"; "DIFICILMENTE conseguirei resistir. (A)". Outro advérbio chamou-nos a atenção - absolutamente (NEVES, 2000, p. 318), que integra o grupo dos advérbios que reforçam a negação, podendo também fazê-lo em uma afirmação. Ex.: "Mas, o real motivo NÃO foi, ABSOLUTAMENTE, aquele que a princípio imaginei. (A)" (negação); "Eu me senti ABSOLUTAMENTE segura. (ELL)" (afirmação). Com isso, concluímos nossa análise desta obra.

A seguir, apresentamos a análise da segunda obra de Neves considerada para esta pesquisa, intitulada Guia de uso do português: confrontando regras e usos (2003).

C) Guia de uso do português: confrontando regras e usos - Maria Helena de Moura Neves

Como se trata de um guia organizado por verbetes, nossa investigação atevese ao Prefácio, escrito por Francisco Platão Savioli e José Luiz Fiorin (NEVES, 2003, p. 9-12) e à Apresentação redigida pela autora (NEVES, 2003, p. 13-20), únicos momentos em que temos acesso a algumas informações sobre a elaboração da obra, além daquelas mais gerais colocadas na contracapa ${ }^{25}$.

No Prefácio, Savioli e Fiorin tecem vários elogios à obra e comparam-na com as gramáticas tradicionais hoje disponíveis no mercado. Enfatizam a preocupação da autora quanto à dimensão social da linguagem, posto que as situações de comunicação são diversas e cada uma exige um determinado padrão linguístico. Para Savioli e Fiorin, Neves (2003) deixa ao leitor/consulente a opção de escolha, ao confrontar o que é de uso comum entre falantes cultos da língua - o corpus investigado é formado por textos produzidos por literatos, jornalistas, parlamentares,

\footnotetext{
25 "Esta obra dirige-se a qualquer pessoa - estudante, profissional ou simples falante da língua portuguesa - que, em algum momento de desempenho lingüístico, sinta algum tipo de dificuldade na formulação de seu enunciado. Organizada a partir do exame de livros, jornais, revistas e peças teatrais contemporâneos, ela informa como está sendo usada a língua e, quando oportuno, as prescrições que a tradição vem repetindo. Partindo do princípio de que o uso pode contrariar a norma, e o falante tem a liberdade de escolha, o livro lhe dá a conhecer os dois lados da questão: o modo como os manuais normativos dizem que 'deve ser' o uso, e o modo como, realmente, ele "é'."
} 
etc. $^{26}$ - e o que encontramos em gramáticas e compêndios normativos. Cabe ao usuário refletir sobre as formas linguísticas e utilizar aquela que, por diferentes razões, considera a mais conveniente para seu discurso (NEVES, 2003, p. 12).

Esses pesquisadores tecem comentários que refletem claramente as incongruências das gramáticas e compêndios normativos, enfatizando a total despreocupação quanto à definição dos critérios em que se baseiam para determinar se o uso linguístico está ou não correto. Tal fato gera discordâncias e resultados desencontrados, que nada esclarecem o consulente (NEVES, 2003, p. 11).

Na apresentação (NEVES, 2003, p. 13-20), chama-nos a atenção o fato de que a autora não esclarece adequadamente como se deu a seleção das palavras a serem analisadas e inseridas no guia. Em nota de rodapé (NEVES, 2003, p. 13), comenta que os usos apresentados foram embasados na investigação feita no corpus da UNESP de Araraquara, mas não define claramente os critérios utilizados - apenas menciona que é uma pesquisa baseada na ocorrência e, quando necessário, na frequência dessas ocorrências. A partir dessas informações, levantamos algumas questões: Qual a frequência considerada significativa para esse corpus de estudo? A pesquisa privilegiou apenas palavras lexicais para a definição dos verbetes? Quais? Seria $(\mathrm{m})$ a frequência e/ou a simples ocorrência o(s) único(s) critério(s) considerado(s) para o levantamento das palavras a serem analisadas e incluídas na obra? Neves (2003, p. 16-20) apresenta alguns verbetes como exemplos e explica todos os recursos e informações apresentadas, como é o caso da frequência (porcentagem de ocorrência), quando necessário, o que certamente auxilia e facilita a pesquisa por parte do consulente. No entanto, deixa dúvidas quanto aos critérios que alicerçam a elaboração do guia, fato reforçado no comentário abaixo reproduzido:

Em alguns casos, para equilibrar as informações, foi necessária referência a elementos ou construções que não ocorreram no banco de dados de análise, ou seja, no córpus de língua escrita que foi examinado: há indicações, por exemplo, de que a forma "não ocorreu". (NEVES, 2003, p. 17)

\footnotetext{
${ }^{26}$ Na Apresentação, Neves (2003, p. 13-14) comenta, em nota de rodapé, que utilizou para suas análises o corpus disponível no Laboratório de Estudos Lexicográficos da Faculdade de Ciências e Letras da UNESP, Campus de Araraquara, que na época contava com 80 milhões de ocorrências do português escrito contemporâneo do Brasil.
} 
Diante disso, questionamos: Como foi definida a inclusão (ou exclusão) de palavras que não ocorreram no corpus utilizado para a investigação? Quais os critérios de seleção?

Aleatoriamente, decidimos buscar alguns advérbios terminados em -mente, dentre eles aproximadamente e delicadamente, encontrados em língua geral ${ }^{27}$. Para o primeiro advérbio, a autora apresenta a seguinte definição:

\begin{abstract}
aproximadamente
É advérbio que indica aproximação de cálculo. Quando junto a numerais, indica arredondamento, e, por isso, não se liga a numerais muito especificados. - No livro II, Ovídio dedica APROXIMADAMENTE o mesmo número de versos para explicar a forma de reter o afeto conquistado. (PO) U Um mármore permanece sem alteração APROXIMADAMENTE de cinqüenta a cem anos. (NB) Antônio ficou num cubículo de APROXIMADAMENTE três por dois metros, com paredes de cimento. (VEJ) (NEVES, 2003, p. 83)
\end{abstract}

Ao não encontrarmos delicadamente como entrada, buscamos o adjetivo do qual deriva, ou seja, delicado, numa tentativa de encontrar alguma referência ao advérbio. Surpreendemo-nos ao verificar que essa palavra também não consta da obra. Seria delicado uma palavra tão pouco frequente a ponto de não ser incluída? ${ }^{28}$ O que de fato poderia ter se tornado uma fonte de busca na medida em que traria informações que confrontassem o descrito em gramáticas tradicionais e o uso efetivo, deixou-nos mais uma vez na expectativa de uma visão mais prática sobre os advérbios, no caso aqueles terminados em -mente. Nossa intenção era a de confrontar essa descrição, embasada na língua geral, com os dados a serem observados nas linguagens especializadas investigadas em nossa pesquisa.

Apesar de alguns aspectos não serem devidamente esclarecidos, vale ressaltar a forma inovadora como os verbetes são apresentados, fato que nos leva a sugerir a ampliação da obra para que outras palavras de uso corrente também sejam analisadas. Assim que definirmos os advérbios a serem investigados nesta pesquisa, faremos uma busca no guia para verificar se foram abordados como entrada. Em caso afirmativo, interessa-nos observar como a autora os apresenta.

\footnotetext{
${ }^{27} \mathrm{Na}$ Web (buscador Google), encontramos: aproximadamente - 22.000 .000 oc.; delicadamente -2.480 .000 oc. (pesquisa feita em 12/10/2010).

${ }^{28}$ Em rápida pesquisa na $W e b$, encontramos 5.150 .000 oc. com o buscador Google em 12/10/2010.
} 
Para finalizar, passemos a algumas considerações embasadas na terceira obra de Neves, considerada em nossa pesquisa, qual seja, Texto e Gramática (NEVES, 2006).

\section{D) Texto e Gramática - Maria Helena de Moura Neves}

Texto e Gramática (NEVES, 2006) não é um compêndio gramatical onde poderíamos encontrar um capítulo dedicado aos advérbios; apresenta alguns conceitos e posicionamentos da autora considerando-se uma visão funcionalista da linguagem. Nesse caso, interessa-nos o fato de que suas análises são novamente baseadas no Corpus de Araraquara ${ }^{29}$. Decidimos verificar a apresentação e o primeiro capítulo, o que nos ajudou a melhor compreender sua visão nas outras duas obras anteriormente analisadas.

Nessas duas partes da obra (NEVES, 2006, p. 11-34), a autora aborda a visão da língua em uso, cuja avaliação deve ser feita no domínio discursivo, induzindo-nos a uma gramática funcional que prevê a interação verbal como uma atividade estruturada e ao mesmo tempo cooperativa. Segundo a autora, nesse processo há dois sistemas de regras: aquelas que regem a constituição das expressões linguísticas, ou seja, as regras sintáticas, semânticas, morfológicas e pragmáticas, e aquelas que regem o modelo de interação verbal no qual essas expressões são utilizadas - as regras pragmáticas (NEVES, 2006, p. 13).

Em vários momentos, a autora comenta a funcionalidade e o dinamismo da língua, apresentando inclusive um conjunto de assunções funcionalistas atreladas à base das reflexões sobre os usos, bem como ao reconhecimento da existência de processos acomodativos na vida da língua. Dentre essas assunções, destacamos a regularização, a idiomatização e a convencionalização contínuas, uma vez que iremos observar padrões linguísticos geralmente identificados e nomeados por serem recorrentes, idiomáticos ou mesmo convencionais na língua em uso.

Ao tratar da relação entre gramática e cognição, Neves menciona Givón (1991 apud NEVES, 2006, p. 21), que fala de uma correlação icônica entre "empacotamento cognitivo" e "empacotamento gramatical". Apesar de as diversas

\footnotetext{
${ }^{29}$ Disponível em meio digital no Laboratório de Estudos Lexicográficos da Faculdade de Ciências e Letras da UNESP, Campus de Araraquara, conforme já citado.
} 
línguas apresentarem diferenças na codificação estrutural de um mesmo evento, tal fato não implica diferenças profundas no processo cognitivo. A nosso ver, isso quer dizer que faz parte do processo cognitivo observar e recortar a realidade sob um determinado aspecto, o que se reflete nas estruturas então utilizadas pelo falante. Chafe (1987 apud NEVES, 2006, p. 25) ressalta que o importante é a forma como o conteúdo ideacional é "empacotado" e apresentado ao ouvinte - o conteúdo em si fica em um segundo plano. Ao compartilhar a forma como esse conteúdo é "empacotado", a informação flui de forma natural entre os interlocutores, processo que envolve tanto aspectos cognitivos quanto sociais.

Essa associação entre cognição, gramática e texto reforça um aspecto também abordado pela autora, ou seja, o fato de que a língua apresenta zonas de imprecisão e/ou oscilação, "as verdadeiras testemunhas do equilíbrio instável que caracteriza a própria vida da língua, refletindo a sua constante adaptação segundo a força das constantes pressões que se exercem sobre os usos." (NEVES, 2006, p. 16). Tal vaguidade nos limites entre as categorias também é mencionada ao tratar do conceito de protótipo - imprecisão essa também atribuída à classe dos advérbios.

Em todos os tópicos da apresentação e do primeiro capítulo, Neves (2006) menciona a relação entre gramática e texto, chegando inclusive a comentar os rumos da gramática funcional: uma gramática funcional discursiva, que se apresenta como expansão de uma gramática da frase para uma gramática do discurso.

Nas obras de Neves (2000, 2003 e 2006) parcialmente analisadas, pudemos observar sua preocupação com uma análise mais discursiva da gramática, ou seja, a gramática e sua relação com o texto. Além de dar margem a vários outros estudos baseados em corpus, tal ponto de vista corrobora nossa pesquisa, uma vez que iremos trabalhar com duas áreas especializadas que apresentam características textuais próprias e bem definidas, em seus aspectos morfossintáticos, semânticos e pragmáticos, apenas para citar alguns deles.

A seguir, analisaremos a quinta obra considerada para nossa pesquisa, qual seja, o Dicionário de usos do Português do Brasil (BORBA, 2002).

E) Dicionário de usos do Português do Brasil - Francisco S. Borba

Logo na nota do editor (BORBA, 2002, p. v), verificamos a preocupação com o registro do uso efetivo do sistema linguístico (contexto real), num período e local 
determinados. As entradas foram estabelecidas a partir da investigação no Corpus de Araraquara (já mencionado), que registra a língua escrita em prosa no Brasil a partir de 1950. Na época da elaboração desse dicionário, contava com mais de 70 milhões de ocorrências em textos de literatura romanesca, dramática, técnica, oratória e, mais predominantemente, jornalística. Dentre os objetivos estabelecidos pelo autor, destacamos sua ênfase em fazer a ligação entre a sintaxe e a semântica, valorizando as relações gramaticais e as propriedades colocacionais da língua em uso.

O critério estabelecido para registro é o de ocorrência combinado com o de colocação contextual. No verbete, a ordem é determinada pela frequência. O autor menciona que os advérbios de modo com o sufixo -mente, com frequência acima de três, foram incluídos na classe de palavras gramaticais, com tratamento individualizado, assim como todos os outros tipos de advérbio apresentados, junto com o artigo, o numeral, o pronome, a preposição, a conjunção e a interjeição. No grupo das palavras lexicais, elenca apenas os nomes (substantivos), os adjetivos e os verbos. Ao apresentar algumas especificidades do DUP (Dicionário de Usos do Português do Brasil), no entanto, o autor deixa confuso quando os advérbios terminados em -mente constituem entrada. Segundo ele, isso só ocorre quando esse grupo de advérbios apresenta sentido diferente do da palavra original (BORBA, 2002, p. xi).

Em geral, os advérbios são subclassificados pelo valor semântico oracional:

Afirmação (sim), Aproximação (assim), Assunto (ali), Atenuação (porventura), Causa (daí), Comparação (perto), Concessão (apesar), Conclusão (afinal), Conseqüência (assim), Delimitação (porcentualmente), Dúvida (talvez), Exclusão (fora), Finalidade (atrás), Freqüência (sempre), Focalização (aí), Graduação (bem), Inclusão (ademais), Intensidade (assaz), Lugar (aqui), Modalizador (felizmente), Modo (bem), Negação (não), Ordem (aquém), Preço (barato), Quantidade (numerosamente), Retificação (aliás), Situação (lá), de Tempo (hoje). (BORBA, 2002, p. viii)

Essas anotações são incluídas nos respectivos verbetes. É interessante observar como tais subclassificações são diferentes daquelas geralmente encontradas em obras de referência mais tradicionais - elas devem ajudar o consulente a ter uma definição mais precisa do advérbio em questão. No entanto, observamos, no trecho acima citado na apresentação da obra, exemplos que geram 
dúvidas justamente por estarem descontextualizados: daí e assim parecem conter o mesmo sentido; por que atrás é utilizado para exemplificar finalidade?

Afim de verificar a definição atribuída para as palavras adverbial e advérbio, uma vez que a obra propõe uma abordagem diferenciada, fomos aos verbetes:

adverbial Adj [Classificador de nome não-animado] 1 que funciona como advérbio: Usemos agora um adjunto adverbial para exprimir a mesma causa $(\mathrm{PH})$; um parágrafo dedicado às orações adverbiais de modo (PH); Três orações adverbiais subordinadas: uma desenvolvida, uma reduzida infinitiva, uma gerundial (SUC) 2 referente a advérbio: qualificações adjetivas ou adverbiais (FI). (BORBA, 2002, p. 33)

advérbio $\mathrm{Nm}$ [Abstrato de estado] função de palavra invariável que incide sobre o verbo ou sobre a oração para acrecentar-lhes [sic] significação e, sendo intensificador, sobre o adjetivo ou sobre outro advérbio: a dramaticidade aumenta graças ao advérbio incontinenti que nos faz ver a rapidez do ato $(\mathrm{PH})$; o advérbio figura com mais insistência em seus escritos (RB); repeti o mesmo zurro com um advérbio de modo (AID). (BORBA, 2002, p. 33)

Apesar da proposta apresentada, podemos observar que o autor mantém a definição comumente encontrada em outros dicionários e gramáticas tradicionais. Assim que definirmos os advérbios a serem investigados nesta pesquisa, faremos uma busca nesse dicionário (BORBA, 2002) para verificar se constituem (ou não) uma entrada. Em caso afirmativo, observaremos como o autor apresenta cada um desses advérbios.

Ainda na linha dos dicionários baseados em corpus, consultamos outro, também produzido por Francisco S. Borba, intitulado Dicionário UNESP do português contemporâneo (BORBA, 2004), cuja análise apresentamos a seguir.

F) Dicionário UNESP do português contemporâneo - Francisco S. Borba

O principal critério para registro, bem como para a organização interna dos verbetes, é a frequência de ocorrência no Corpus de Araraquara $^{30}$, além de ter ocorrido no Corpus de Referência do Português Contemporâneo, do Centro de Linguística da Universidade de Lisboa. De modo geral, foram extraídos do corpus os itens que tiveram, no mínimo, duas ocorrências em textos diferentes - outros

\footnotetext{
${ }^{30}$ Vide detalhes em obras anteriormente analisadas.
} 
critérios também foram utilizados para certos conjuntos de palavras. Para os advérbios terminados em -mente, por exemplo, determinou-se a ocorrência mínima de três em jornais e revistas atuais quando, segundo o autor, apresentam o valor deduzido de sua estrutura morfológica, caso de distraidamente em "Folheava o jornal distraidamente. [=de modo distraído]" e friamente em "Olhou-me friamente. [= de modo frio]" (grifo nosso). Caso contrário, seguiu-se o critério geral, ou seja, o mínimo de duas ocorrências em textos diferentes (BORBA, 2004, p. viii). ${ }^{31}$

Essa obra demonstra grande atenção para com as palavras gramaticais, além de preocupar-se com a contextualização de seus registros. As palavras são contextualizadas em frases e expressões extraídas de textos do corpus, com condensações e adaptações, quando necessário. O dicionário apoia-se na teoria gramatical escolar que, segundo o autor, foi utilizada para organizar, de forma coerente, os verbetes das palavras lexicais e de forma descritiva as palavras gramaticais, não confundindo, dessa forma, dicionário com gramática, uma vez que apresenta as informações gramaticais topicamente (BORBA, 2004). Apesar de facilitar a consulta, refletimos sobre por que os autores de obras baseadas em corpus, como é o caso dessa, optam por apoiar-se nas teorias gramaticais tradicionais, uma vez que se propõem a adotar uma outra postura de investigação. Seria apenas para facilitar o trabalho do consulente ou por ser mais viável a elaboração embasada em critérios arraigados e previamente estabelecidos? Não nos cabe discutir essa questão no momento, mas gostaríamos de deixá-la como ponto de reflexão para pesquisas futuras.

Novamente, assim que definirmos os advérbios a serem investigados nesta pesquisa, faremos uma busca nesse dicionário (BORBA, 2004) para verificar se constituem (ou não) uma entrada e como são abordados pelo autor.

Com esta última análise, concluímos nossa investigação em língua portuguesa. Pudemos observar que há certa movimentação, por parte dos estudiosos, para que se privilegie a língua em uso. Gostaríamos de salientar que, dentre as várias gramáticas conhecidas e consultadas, a Gramática de usos do português (NEVES, 2000) é a primeira que observamos dar atenção especial à

\footnotetext{
${ }^{31}$ Para mais detalhes, vide introdução da obra (BORBA, 2004). Não fica claro, no entanto, o que o autor quis dizer ao colocar que a ocorrência mínima dos advérbios terminados em -mente deve ser de três "quando tem o valor deduzido de sua estrutura morfológica".
} 
classe dos advérbios, mesmo considerando-se que é confusa para o consulente. Verificamos que os advérbios terminados em -mente distribuem-se em diferentes grupos semânticos, dentre eles os tradicionais advérbios de modo até aqueles de negação. Um aspecto que consideramos necessitar de mais aprofundamento na obra é o morfossintático - teria sido de grande valia a apresentação, por exemplo, dos padrões em que os advérbios mais ocorrem. Em se tratando de tipologias textuais, seria importante apontar em quais tipos determinados advérbios são mais comuns, o que certamente contribuiria para termos uma gramática mais abrangente, com rumos a uma gramática discursiva.

Quanto ao uso dos advérbios, mais especificamente os terminados em -mente, observamos a necessidade de pesquisas mais focadas e detalhadas, especialmente em linguagens especializadas. Com esta pesquisa, procuramos contribuir para algum avanço nesse sentido.

$\mathrm{Na}$ sequência, analisaremos as duas obras selecionadas para a língua inglesa.

1.1.2 Obras de referência consultadas para o inglês: uma análise quanto ao uso dos advérbios

Para o inglês, trabalhamos com duas gramáticas. São elas:

BIBER, Douglas; CONRAD, Susan; LEECH, Geoffrey. Longman student grammar of spoken and written English. Edinburgh/Harlow/Essex: Longman, 2002.

CARTER, Ronald; McCARTHY, Michael. Cambridge grammar of English: a comprehensive guide - spoken and written English grammar usage. Cambridge: Cambridge University Press, 2006.

A primeira, Longman Student Grammar of Spoken and Written English (BIBER; CONRAD; LEECH, 2002), é baseada na Longman Grammar of Spoken and Written English (LGSWE) (BIBER et al., 1999), anteriormente analisada por Moraes (2005). Nessa nova gramática, os autores decidiram simplificar e reorganizar o conteúdo da LGSWE (BIBER et al., 1999), evitando detalhes técnicos sem no 
entanto deixar de abordar seus aspectos mais importantes e apresentar o mesmo rigor científico. Além de trabalhar com exemplos autênticos da língua inglesa - agora com trechos mais simples para facilitar a consulta -, objetiva contrastar o uso da língua escrita e falada. O corpus investigado intitula-se Longman Spoken and Written English Corpus (LSWE Corpus), com um total de aproximadamente 40 milhões de palavras. As análises desenvolvidas embasam-se em quatro principais registros: acadêmico, conversação (transcrições), ficção e jornalístico, que formam um subcorpus de aproximadamente 20 milhões de palavras. Tanto o inglês britânico quanto $O$ inglês americano estão devidamente representados. Nas páginas introdutórias (BIBER; CONRAD; LEECH, 2002, p. 2-11), o consulente tem todas as informações sobre a elaboração da obra.

Em linhas gerais, observamos que os autores objetivam atingir também um público menos acadêmico, voltando-se para as necessidades do professor e do aluno em sala de aula. Inclusive, para acompanhar a gramática, foi elaborado um livro de exercícios que pode ser adquirido separadamente. Além de trazer comentários sobre como o material foi elaborado, apresenta exercícios para todos os capítulos abordados na gramática. Os advérbios e locuções ou adjuntos adverbiais $^{32}$ são contemplados nos capítulos 7 e 11, com exercícios que exigem do estudante maior atenção e raciocínio para sua resolução.

Os autores apresentam explicações de conceitos gramaticais mais básicos, com uma linguagem (e terminologia) simplificada para facilitar a compreensão. É o que ocorre, por exemplo, ao apresentarem a classe dos adjetivos e dos advérbios. No entanto, o consulente deve ter, no mínimo, conhecimentos intermediários da língua inglesa para acompanhar o desenvolvimento dos tópicos.

Para podermos analisar como os autores abordam os advérbios, especialmente aqueles terminados em -ly, verificamos os capítulos e subcapítulos abaixo listados a partir do índice, que a nosso ver refletem a abordagem baseada em corpus:

1- Introduction: a discourse perspective on grammar

1.1- Introduction

1.2- A corpus-based grammar

1.3- More about language variation

\footnotetext{
${ }^{32}$ Em inglês, o termo utilizado foi adverbials. Em português, no entanto, podemos traduzi-lo tanto por locução adverbial (classificação morfológica) quanto por adjunto adverbial (classificação sintática). $\mathrm{O}$ uso de uma ou outra forma irá depender do contexto em que se insere.
} 
1.4- More detail on the LSWE Corpus

1.5- Overview of the book

1.6- Conventions used in the book

2- Words and word classes

2.1- Introduction

2.2- What are words?

2.3- Survey of lexical words

2.4- Survey of function words

2.5- Special classes of words

2.6- Word-class ambiguities

3- Introduction to phrases and clauses

3.1- Introduction

3.2- Phrases and their characteristics

3.3- Types of phrases

3.4- A preview of clause patterns

3.5- Clause elements

7- Adjectives and adverbs

7.1- Introduction

7.2- Characteristics of adjectives

7.3- The formation of adjectives

7.4- The function of adverbs

7.5- The formation of adverbs

7.6- Semantic categories of adjectives

7.7- More about attributive adjectives

7.8- More about predicative adjectives

7.9- Other syntactic roles of adjectives

7.10- Syntactic roles of adverbs

7.11- Semantic categories of adverbs

7.12- Comparative and superlative forms of adjectives

7.13- Comparative and superlative forms of adverbs

7.14- Comparative clauses and other degree complements

11- Adverbials

11.1- Introduction

11.2- The main classes of adverbials

11.3- Syntactic forms of adverbials

11.4- Positions of adverbials

11.5- The relationship between adverbials and other clause elements

11.6- Semantic categories of circumstance adverbials

11.7- Extremely common circumstance adverbials in conversation

11.8- Positions of circumstance adverbials

11.9- Additional semantic categories of circumstance adverbial clauses

11.10- Syntactic forms of adverbial clauses

11.11- Positions of adverbial clauses

11.12- Subordinators with circumstance adverbial clauses

11.13- Semantic categories of stance adverbials

11.14- The most common stance adverbials

11.15- Positions of stance adverbials

11.16- Other discourse functions of stance adverbials

11.17- Semantic categories of linking adverbials

11.18- The most common linking adverbials in conversation and academic prose

11.19- Positions of linking adverbials 
12- Word order choices

12.8- Adverbials in existential clauses ${ }^{33}$

No total, há 62 páginas dedicadas aos advérbios e às locuções ou adjuntos adverbiais (doravante também tratados com o termo adverbials). No entanto, antes de analisar esses aspectos, gostaríamos de tecer alguns comentários sobre os capítulos 1, 2 e 3, acima mencionados.

Toda vez que falamos ou escrevemos, fazemos escolhas - não apenas aquelas sobre o quê dizer, mas também como dizer. Essas opções são influenciadas por uma gama de fatores, tais como o contexto, nosso público-alvo, se estamos utilizando a língua falada ou escrita etc. Essas escolhas originam padrões na gramática de uma dada língua. Para aprendê-la, é importante tomarmos contato com a língua em uso - não apenas com o que é possível, mas também com o que é mais ou menos provável em diferentes situações. Para isso, uma gramática baseada em corpus oferece ao consulente várias vantagens (BIBER; CONRAD; LEECH, 2002, p. 2-3):

- exemplos autênticos (reais);

- variação linguística - o corpus utilizado abrange quatro grandes registros, acima citados;

\footnotetext{
${ }^{33}$ 1- Introdução: uma perspectiva discursiva sobre gramática / 1.1- Introdução / 1.2- Uma gramática baseada em corpus / 1.3- Mais sobre variantes da língua / 1.4- Mais detalhes sobre o Corpus LSWE / 1.5- Visão geral da obra / 1.6- Convenções utilizadas na obra / 2- Palavras e classes de palavras / 2.1- Introdução / 2.2- O que são palavras? / 2.3- Pesquisa sobre palavras lexicais / 2.4- Pesquisa sobre palavras funcionais (gramaticais) / 2.5- Classes especiais de palavras / 2.6- Ambiguidades em classes de palavras / 3- Introdução a sintagmas e orações / 3.1- Introdução / 3.2- Sintagmas e suas características / 3.3- Tipos de sintagmas / 3.4- Uma visão geral de padrões oracionais / 3.5- Elementos da oração / 7- Adjetivos e advérbios / 7.1- Introdução / 7.2Características dos adjetivos / 7.3- A formação dos adjetivos / 7.4- A função dos advérbios / 7.5- A formação dos advérbios / 7.6- Categorias semânticas dos adjetivos / 7.7- Mais sobre adjetivos em posição atributiva / 7.8- Mais sobre adjetivos em posição predicativa / 7.9- Outras funções sintáticas dos adjetivos / 7.10- Funções sintáticas dos advérbios / 7.11- Categorias semânticas dos advérbios / 7.12- Formas comparativa e superlativa dos adjetivos / 7.13- Formas comparativa e superlativa dos advérbios / 7.14- Orações comparativas e outros complementos de grau / 11- Locuções ou adjuntos adverbiais / 11.1- Introdução / 11.2- Classes principais de locuções ou adjuntos adverbiais / 11.3- Formas sintáticas de adjuntos adverbiais / 11.4- Posições de locuções ou adjuntos adverbiais / 11.5- A relação entre locuções ou adjuntos adverbiais e outros elementos da oração / 11.6Categorias semânticas de locuções ou adjuntos adverbiais de circunstância / 11.7- Locuções ou adjuntos adverbiais de circunstância extremamente comuns em conversação / 11.8- Posições de locuções ou adjuntos adverbiais de circunstância / 11.9- Categorias semânticas adicionais de orações adverbiais de circunstância / 11.10- Formas sintáticas de orações adverbiais / 11.12- Partículas de subordinação com orações adverbiais de circunstância / 11.13- Categorias semânticas de locuções ou adjuntos adverbiais modalizadores / 11.14Locuções ou adjuntos adverbiais modalizadores mais comuns / 11.15- Posições de locuções ou adjuntos adverbiais modalizadores / 11.16- Outras funções discursivas de locuções ou adjuntos adverbiais modalizadores / 11.17- Categorias semânticas de locuções ou adjuntos adverbiais de ligação / 11.18- Locuções ou adjuntos adverbiais de ligação mais comuns em conversação e prosa acadêmica / 11.19- Posições de locuções ou adjuntos adverbiais de ligação / 12- Opções de ordem de palavras / 12.8- Locuções ou adjuntos adverbiais em orações que designam existência (tradução nossa - devemos lembrar que todas as traduções desta tese foram feitas pela autora).
} 
- frequência e preferência de uso, também para estruturas alternativas e condições a elas associadas;

- interpretação de frequências, enfatizando as escolhas gramaticais de acordo com o contexto e o discurso;

- padrões léxico-gramaticais.

Os autores preocupam-se em diferenciar as gramáticas descritivas (como é o caso dessa) das prescritivas. Enquanto essas últimas ditam como um falante deve usar a língua, a SGSWE ${ }^{34}$ enfoca a descrição de padrões em uso e as possíveis razões para essa escolha. Como a frequência é um fator importante para delimitar as ocorrências em diferentes registros, dialetos e situações, os autores optaram por apresentá-la de duas formas: ora utilizando termos como frequentemente, raramente, comum ou incomum, ora valendo-se de gráficos em barras (ocorrências por milhão).

No capítulo 2, os advérbios são mencionados no item 2.3.4, no grupo das palavras lexicais, e descritos em seus aspectos morfológico, sintático e semântico. Sintaticamente, classificam-se como modificadores de um adjetivo ou outro advérbio, como em really old e very soon. Em outros casos, podem atuar como adverbials, como em l'll see you again soon. Semanticamente e como modificadores, os advérbios geralmente expressam grau, como é o caso de totally em totally right. A classe dos advérbios (incluindo as locuções adverbiais) atua de forma variada:

- pode modificar uma ação, processo ou estado, expressando noções de tempo, lugar ou modo, como em She learned German quite quickly;

- pode expressar a atitude do falante com relação à informação contida na oração, como em Surely that child's not mine?;

- pode expressar relação com o que foi dito anteriormente, como em lt must be beautiful, though.

Segundo os autores, o uso das classes de palavras lexicais pode auxiliar a descrição dos registros investigados nessa gramática. No caso do advérbio, por exemplo, são mais frequentes na conversação e na ficção (escrita), uma vez que esses dois registros apresentam um maior número de verbos. Os advérbios são tipicamente utilizados para descrever circunstâncias relacionadas a ação, processo

\footnotetext{
${ }^{34}$ Student Grammar of Spoken and Written English. Sugestão de tradução: Gramática escolar do inglês falado e escrito.
} 
e estado expressos por verbos (BIBER; CONRAD; LEECH, 2002, p. 23) - daí sua maior ocorrência nesses dois registros.

As classes de palavras apresentam limites tênues; conforme coloca Neves (2006), há uma força dinâmica por trás do constante desenvolvimento da linguagem, dinamismo esse que é um "componente necessário de qualquer consideração dos componentes linguísticos (sintático-semânticos) vistos no uso real, ou seja, na interação verbal (componente pragmático)" (NEVES, 2006, p. 18). O advérbio, obviamente, faz parte desse dinamismo, e podemos verificar a "vaguidade nos limites entre as categorias prototípicas" (NEVES, 2006, p. 22) das classes de palavras ao observarmos o "empréstimo" feito a partir da classe dos quantificadores, com o uso de all e a little nos exemplos abaixo (BIBER; CONRAD; LEECH, 2002, p. 35):

Don't get all mucky.

It's a little hard for him to understand.

No capítulo 3 (BIBER; CONRAD; LEECH, 2002, p. 37-54), os autores apresentam os sintagmas, os elementos e padrões de orações. Três são os aspectos a serem considerados para a descrição de um sintagma: a estrutura/forma (morfologia); sua função sintática (sintaxe); seu significado (semântica). Para cada palavra lexical, há um tipo de sintagma - os advérbios são os principais elementos dos adverb phrases, ou seja, dos sintagmas adverbiais. Esses sintagmas, juntamente com sintagmas preposicionados e orações subordinadas adverbiais, podem exercer a função de adverbials (locuções ou adjuntos adverbiais). Exemplos: He was an attractive little creature with a sweetly expressive little face. - sweetly exerce o papel de modificador do adjetivo que o segue; She smiled sweetly. - nesse caso, sweetly exerce a função de adverbial em nível oracional.

No item 3.5.5, os autores apresentam mais algumas informações sobre os adverbials (BIBER; CONRAD; LEECH, 2002, p. 50-51). Há aqueles que são obrigatórios, ou seja, são essenciais para completar o significado de um verbo, ou opcionais (a grande maioria), que acrescentam alguma informação ao significado da oração. Exemplos:

I treated her badly, very badly. (obrigatório)

I only bought one today. (opcional) 
O capítulo 7 (BIBER; CONRAD; LEECH, 2002, p. 186-220) é dedicado aos adjetivos e advérbios. Na descrição da formação dos advérbios, observamos que aqueles terminados em -ly merecem destaque, mas essa é uma classe gramatical bastante diversa. Há quatro categorias de advérbios: os advérbios simples (rather, quite), os advérbios compostos (anyway, heretofore), aqueles derivados por sufixação, como é o caso do -ly, e os sintagmas fixos (of course, kind of). Deve-se observar que nem todas as palavras terminadas em -ly são advérbios, como é o caso de weekly e fatherly.

$\mathrm{Na}$ distribuição dos advérbios entre os registros estudados, observamos alta frequência daqueles terminados em -ly em todos eles, destacando-se o acadêmico, que concentra $55 \%$ de seus advérbios nesse grupo. São utilizados com diferentes propósitos: para modalizar o discurso (stance adverbials), expressando a atitude do falante, como é o caso de obviously em Obviously this is an overstatement; para descrever processos ou condições, como em The solubility decreases rapidly as the temperature falls; como modificador, Acclimatization is relatively unimportant; e também para dar ênfase à descrição de um determinado evento, como é o caso de easily e absentmindedly em All three adults giggled easily and at everything, absentmindedly fingering small silver spoons.

No item 7.10, são analisadas as funções sintáticas dos advérbios: aqueles que modificam adjetivos, outros advérbios e também outros elementos da oração, como é o caso de sintagmas nominais (ou parte deles), sintagmas preposicionados, partículas, numerais e unidades de medida. Nesse item, os autores não enfatizam a relação entre advérbios e verbos, que apenas aparecem nos exemplos do trecho que trata dos adverbials, abaixo citados. Essa relação é tratada com mais vagar nos capítulos que se seguem. Exemplos:

'It came as quite a surprise', said one. - o advérbio quite modifica o sintagma nominal a surprise.

It is still not clear whether the approximately 250 people still listed as missing include those whom ex-detainees say were still alive in May. - o advérbio approximately modifica o numeral 250.

Tosi [...] estimates that roughly one-quarter to one-third of the total surface area of four sites in 'prehistoric Turan' was devoted to different craft activities. roughly modifica a expressão one-quarter to one-third. 
Há também casos em que o advérbio pode ocorrer como pós-modificador, como above em: Thus, in the ammonia example above, [...].

Como elementos de uma oração, os advérbios (ou sintagmas adverbiais) são chamados de adverbials, conforme anteriormente comentado. Subdividem-se em adjuntos adverbiais de circunstância, adjuntos adverbiais modalizadores (encontramos advérbios terminados em -ly nesses dois grupos) e adjuntos adverbiais de ligação. Esses últimos correspondem às conjunções da gramática tradicional, uma vez que ligam trechos do discurso, como é o caso de therefore em Most of our rural people do not have radio or television and a large proportion are illiterate. Therefore we had to use approaches that do not depend on the mass media or on literacy.

É interessante observar que os advérbios podem ser usados de forma independente, desconectados de outros elementos do discurso, como em:

A: What you could afford you had.

B: Exactly. Exactly.

E também para perguntar e responder:

A: You can still vote if you lost it.

B: Really?

A: They should have your name on the roster.

A: It's warm, isn't it. By the radiator.

B: Probably.

Semanticamente, os autores apresentam sete categorias principais: advérbios de lugar, de tempo, de modo, de grau, de adição/restrição, modalizadores e de ligação. Além de a maioria dos advérbios poderem ser utilizados tanto com seu significado literal quanto metafórico, eles também podem pertencer a diferentes grupos semânticos - sua definição dependerá do contexto. Em todos os grupos, com exceção dos advérbios de ligação, encontramos os advérbios terminados em -ly. Há também outros significados, além dos grupos acima citados, que podem esporadicamente ser atribuídos a um dado advérbio, como ocorre com symbolically em When there is a funeral, the body is washed symbolically as part of the service., que é utilizado como um advérbio de finalidade.

Ainda no capítulo 7 , encontramos seis padrões gramaticais que funcionam como complemento de advérbios, como por exemplo adverb+enough+to-clause 
(advérbio+enough+oração infinitiva), o que demonstra a preocupação dos autores em identificar a padronização gramatical. Exemplo: At least four people were bitten seriously enough [to be hospitalized].

O capítulo 11 dedica-se ao grupo dos adverbials (locuções ou adjuntos adverbiais), elementos em nível de oração que apresentam três funções principais: expressam circunstância, ou seja, quando e onde uma determinada atividade ocorreu - são as locuções ou adjuntos adverbiais de circunstância; expressam os sentimentos, avaliação ou comentários do falante sobre o que a oração se refere as locuções ou adjuntos adverbiais modalizadores; e ligam uma oração (ou parte dela) a outra - são as locuções ou adjuntos adverbiais de ligação. A nosso ver, a identificação desses elementos não é tarefa fácil, como podemos observar nas características abaixo, que facilmente confundem o aprendiz de língua inglesa:

- podem exercer funções variadas;

- apresentam diferentes papéis semânticos;

- podem exercer diferentes funções sintáticas;

- podem ocorrer em várias posições em uma oração;

- uma única oração pode apresentar vários adverbials;

- a maioria dos adverbials são opcionais.

Nos três grupos acima citados, encontramos adverbials terminados em $-l y$. Os adverbials são uma classe comum nos quatro registros investigados, com maior frequência na ficção. Destacam-se os de circunstância, que se subdividem em obrigatórios e opcionais, como podemos observar nos exemplos abaixo:

We were at the game. (obrigatório)

Writers on style have differed a great deal in their understanding of the subject. (opcionais)

Além dos aspectos semânticos que discutiremos em detalhe por estarem estreitamente relacionados ao escopo de nossa pesquisa, os autores também apresentam a descrição sintática (formas) e a posição dos adverbials em uma oração (BIBER, 2002, p. 358-360).

Semanticamente, as locuções ou adjuntos adverbiais de circunstância subdividem-se nas categorias e subcategorias abaixo elencadas, segundo os autores (BIBER; CONRAD; LEECH, 2002, p. 362): 


\begin{tabular}{|l|l|}
\hline \multicolumn{1}{|c|}{ categoria } & \multicolumn{1}{c|}{ subcategorias } \\
\hline lugar & distância, direção, posição \\
\hline tempo & ponto no tempo, duração, frequência, relação de tempo \\
\hline processo & modo, meio, instrumento, agente \\
\hline contingência & causa/razão, finalidade, concessão, condição, resultado \\
\hline grau & extensão (ampliação, diminuição) \\
\hline adição/restrição & adição, restrição \\
\hline recipiente (beneficiário) & -- \\
\hline
\end{tabular}

Nesse grupo, interessa-nos especialmente a categoria de processo, que agrupa as locuções ou adjuntos adverbiais de modo, foco principal de nossa investigação por apresentar diversos advérbios terminados em -ly. Outro grupo também de nosso interesse é o de grau, que abarca o grupo dos intensificadores (muitos terminados em -ly). Devemos esclarecer, no entanto, que os adverbials terminados em -ly são também encontrados nas demais categorias, e, quando identificados em nossos corpora de estudo, serão analisados.

Quanto à sua distribuição nos quatro registros, os adverbials de lugar, tempo e processo são os mais frequentes. Os de processo, mais especificamente, destacam-se na ficção (BIBER; CONRAD; LEECH, 2002, p. 367).

Do item 11.9 a 11.12 (BIBER; CONRAD; LEECH, 2002, p. 373-382), os autores apresentam uma análise detalhada das locuções ou adjuntos adverbiais de circunstância em nível oracional, exercendo a função de orações subordinadas. Como não apresentam advérbios terminados em -ly, faz-se desnecessário comentar esses dados nesta pesquisa.

O próximo grupo apresentado pelos autores é o das locuções ou adjuntos adverbiais modalizadores, onde também encontramos advérbios terminados em -ly. Esse grupo marca a atitude do falante em relação a uma dada oração ou comentário sobre seu conteúdo. Subdivide-se em três outros grupos: os epistêmicos, os de atitude e os de estilo.

Os epistêmicos apresentam grupos semânticos diversificados. Podem expressar:

- certeza ou dúvida: That sort of gossip should certainly be condemned.

- factualidade: In fact l'm taller than the doors. 
- referência: According to Mr. Kandil, nuclear power was the only clean energy alternative for Egypt.

- limitação: Typically there is a pair of ganglia in each segment of the body.

- perspectiva: In our view it would be a backward step.

- imprecisão: Men were like literally throwing themselves at me.

Já os atitudinais geralmente apresentam a avaliação e/ou expectativa do falante: Hopefully this problem will be solved when the group is thoroughly revised.

No grupo dos adverbials que denotam estilo, chamaram-nos a atenção prováveis colocações, tais como technically speaking e generally speaking, mas isso não é comentado por parte dos autores.

Quanto à ocorrência nos quatro registros investigados, os modalizadores são muito mais frequentes na conversação, destacando-se o grupo dos epistêmicos.

O último grupo analisado é o das locuções ou adjuntos adverbiais de ligação (BIBER; CONRAD; LEECH, 2002, p.389-396). Como operam em nível oracional, fogem ao escopo de nossa investigação.

Em linhas gerais, a SGSWE (BIBER; CONRAD; LEECH, 2002) é uma gramática que apresenta informações diversificadas sobre os advérbios, locuções e adjuntos adverbiais, sempre demonstrando seu uso e registrando sua frequência em quatro importantes registros. Tal fato é de extrema importância ao consulente, que muitas vezes necessita de detalhes como, por exemplo, se determinado advérbio (ou mesmo o grupo semântico ao qual pertence) é ou não utilizado em dada área, como é o caso da escrita acadêmica. Essas considerações contribuem significativamente para maior fluidez na produção de um texto. Devemos também salientar a organização da obra e a subdivisão dos capítulos, que facilitam a consulta. Outra informação sempre enfatizada pelos autores é o fato de a classe dos advérbios ser bastante imprecisa. No entanto, a abordagem é diferenciada: ao comentar o assunto, os autores sempre exemplificam e deixam claro como essa imprecisão pode ocorrer, o que muitas vezes não ocorre em outras obras de referência. Enfim, no que concerne os itens analisados, acreditamos que os autores tenham atingido seus objetivos com essa nova versão da Longman Grammar of Spoken and Written English. No entanto, ainda buscamos mais detalhes sobre a classe dos advérbios e suas nuanças, agora em dois tipos textuais mais específicos que não são abordados pela gramática, quais sejam, receitas culinárias e contratos, conforme detalharemos posteriormente. 
Na segunda obra analisada para o inglês, intitulada Cambridge Grammar of English (CARTER; McCARTHY, 2006), observamos também a preocupação dos autores em localizar o consulente quanto à abordagem adotada para a elaboração da obra. No primeiro capítulo, Introduction to the Cambridge Grammar of English, encontramos noções básicas como o que é gramática, passando por alguns conceitos de Linguística de Corpus, até a organização dos capítulos da obra. É uma gramática descritiva do inglês britânico padrão, com um enfoque discursivo. Quanto ao uso da língua, há grande preocupação em apontar o que é aceitável ou não, e principalmente o que é provável, sempre considerando-se a frequência e o contexto. Essencialmente probabilística, apresenta regras baseadas na observação da língua falada e escrita, enfatizando a relação entre morfossintaxe e outros níveis linguísticos, como é o caso do lexical. A $C G E^{35}$ define-se como corpus informed, o que em linhas gerais significa que utiliza o corpus (vide detalhes logo abaixo) como fonte de informação para o levantamento dos dados apresentados. Os autores dessa obra acreditam que trabalhar com corpus não significa apenas importar dados da língua em uso para a elaboração de uma obra de referência, uma vez que nem sempre essa é a melhor forma para seu aprendizado. Diante de trechos que continham referências culturais, algumas vezes optaram por não selecioná-los ou fizeram modificações para facilitar a compreensão do consulente - o objetivo era que os dados apresentados fossem informados pelo corpus, não direcionados ou controlados por ele (CARTER; McCARTHY, 2006, p. 11-12). Devido a esse posicionamento, observamos que foram utilizadas várias classificações e categorizações geralmente encontradas em gramáticas tradicionais, conforme discutiremos ainda neste capítulo. Muitos dos exemplos foram retirados do Cambridge International Corpus (CIC), com mais de 700 milhões de palavras na época, e de um de seus subcorpora, o CANCODE (Cambridge and Nottingham Corpus of Discourse in English), com cinco milhões de palavras para a língua falada.

Ao descreverem como a gramática foi elaborada, considerando-se tanto dados quantitativos quanto qualitativos, os autores enfatizam a formação de word clusters, ou seja, de agrupamentos com duas ou mais palavras. Segundo eles, essas associações podem diferir entre a língua falada e escrita, e o seu conhecimento certamente emprestará mais fluência ao texto produzido justamente

\footnotetext{
${ }^{35}$ Cambrige Grammar of English.
} 
pelo uso de "blocos linguísticos" que facilitarão a construção do sentido. Com a descoberta de novos padrões linguísticos, torna-se ainda mais tênue a linha divisória entre morfossintaxe e léxico, imposta por uma visão mais tradicional da língua.

Oferecendo uma abordagem mais balanceada entre língua falada e língua escrita, os capítulos da gramática subdividem-se da seguinte forma:

Introduction to the Cambridge Grammar of English

From word to grammar: an $A-Z^{36}$

Spoken language

Introduction to grammar and spoken English

From utterance to discourse

From discourse to social contexts

Grammar and discourse

Grammar across turns and sentences

Grammar and academic English

Word and phrase classes

Introduction to word classes and phrase classes ${ }^{37}$

Nouns

The noun phrase

Nouns and determiners

Pronouns

Verbs

Verb phrase 1: structure of verb phrases

Verb phrase 2: tense and aspect

Types of verb

\section{Adjectives and adverbs}

Adjectives and adjective phrases

Adverbs and adverb phrases

Prepositions and particles

Prepositions and prepositional phrases

Word formation

Word structure and word formation

Sentence and clause patterns

Introduction to sentences and clauses

Verb complementation

Clause types

Clause combination

\section{Adjuncts}

Time

Present time

Past time

Future time

\section{Notions and functions}

\footnotetext{
${ }^{36}$ Aqui são incluídas palavras mais frequentes, geralmente polissêmicas, que apresentam peculiaridades e são reconhecidamente difíceis para o aprendiz da língua inglesa.

${ }^{37}$ As partes em negrito ressaltam onde encontramos os advérbios, foco de nosso estudo.
} 
Modality

Speech acts

Questions

Negation

Condition

Comparison

Information packaging

Word order and focus

The passive

Speech representation

Appendices

Glossary

Index

Passaremos agora à análise dos trechos relacionados a nossa pesquisa, iniciando com o capítulo From word to grammar: an A-Z (Da palavra à gramática: de A a Z), onde encontramos cinco advérbios terminados em -ly:

Especially: apresenta diferenças semânticas e pragmáticas entre especially e specially, enfatizando peculiaridades da língua falada.

Fairly: encontra-se no item dedicado a quite, e suas características estão descritas juntamente com outros advérbios, na estrutura quite, pretty, fairly e rather + adjetivos e advérbios de gradação. Há grande preocupação em se retratar a sutileza das diferenças semânticas (prosódia e campo semânticos) identificadas pelas palavras com que cada advérbio co-ocorre. No caso de fairly, é muito mais frequente na língua falada (registro informal) do que na escrita formal.

Hardly: os autores esclarecem questões semânticas e reforçam que o advérbio é também utilizado para rejeitar ou distanciar o falante de uma determinada ideia, como por exemplo em He could hardly say no to such a request.

Really: o aspecto pragmático é enfatizado, com vasta descrição e exemplificação. Vale ressaltar a observação quanto ao uso de sua forma reduzida, real, na língua falada, como em Why don't you try? It's real easy to work.

Rightly: é apenas utilizado como modalizador: I rightly assumed that I was going to be sacked.

Em geral, há apenas algumas observações mais pontuais quanto ao uso desses advérbios, sem muito acrescentar ao que já temos disponível em gramáticas tradicionais.

$\mathrm{Na}$ sequência, consultamos o subcapítulo Introduction to word classes and phrase classes (Introdução a classes de palavras e classes de sintagmas), em 
busca de mais informações sobre os advérbios. Apesar de tratar de classes de palavras além dos advérbios, decidimos analisar de forma um pouco mais detalhada essa parte da obra em busca de informações que pudessem também contribuir para nossa pesquisa.

No trecho dedicado aos substantivos e sintagmas nominais, nenhuma observação chamou-nos a atenção no sentido de acrescentar algo ao que comumente encontramos em gramáticas tradicionais, mas a leitura é fluente e o texto de fácil compreensão por parte do consulente, o que reflete a preocupação dos autores em beneficiar públicos variados, desde o estudante de língua inglesa ao pesquisador acadêmico. O sistema de remissivas é também claro e eficiente, o que dá ao leitor a opção de consultar apenas dados gerais ou buscar mais detalhes sobre a questão estudada.

Ao tecerem comentários sobre os advérbios, Carter e McCarthy (2006, p. 311) enfatizam que essa é uma classe de palavras que exerce uma vasta gama de funções, indicando tempo, modo, lugar, grau e frequência de um evento, ação ou processo. Nesse momento, o sufixo -ly já é apontado como o principal elemento para a formação de muitos advérbios. Ao descreverem as funções dos sintagmas adverbiais, além daquelas geralmente apontadas pelas gramáticas tradicionais, enfatizam que podem também modificar sintagmas nominais (incluindo pronomes) e sintagmas preposicionados, como podemos observar nos exemplos abaixo:

That was quite a match. (quite modifica o sintagma nominal a match)

It's a chapel but it's almost a cave. (almost modifica o sintagma nominal a cave)

Didn't he manage to speak with nearly everyone there? (nearly modifica o sintagma nominal everyone)

Only someone very stupid would say that. (only modifica o sintagma nominal someone very stupid)

It's really right out in the country. (right modifica o sintagma preposicionado out in the country)

We followed the path right to the end. (right modifica o sintagma preposicionado to the end)

Os advérbios podem também modificar determinantes, especialmente os quantificadores - There's very little chance of that happening -, além de exercerem a 
função de advérbios de ligação, como é o caso de then em Philip got the sack and then we heard Liam was sacked too.

Ao tratarem dos adjetivos e sintagmas adjetivais (CARTER; McCARTHY, 2006, p. 438-451), encontramos vários comentários sobre a função dos advérbios como modificadores (principalmente os de grau), destacando-se os aspectos semântico e pragmático das palavras modificadas. Os autores abordam também várias questões facilmente observáveis quando a investigação envolve o uso de corpus, como por exemplo a posição do determinante em sintagmas como quite $\underline{a}$ tall man e a rather tall man.

Os advérbios e sintagmas adverbiais são considerados a quarta maior classe aberta de palavras, em estreita relação com os adjetivos (CARTER; McCARTHY, 2006, p. 453-460). Como eles, também podem apresentar gradação, sendo modificados por outros advérbios. A formação de um sintagma adverbial é apresentada em detalhes e a função de cada um de seus elementos devidamente explicada: pré-modificadores, pós-modificadores e complementos.

Quanto ao aspecto semântico, encontramos um quadro (CARTER; McCARTHY, 2006, p. 456) que apresenta os principais grupos de sintagmas adverbiais. São eles: modo, lugar, tempo, duração, frequência, grau, foco, modalizador, avaliativo (também chamado de disjuntivo e conjuntivo), ponto de vista (ou perspectiva), de ligação. Embora as categorias frequência e de ligação não apresentem advérbios terminados em -ly em seus exemplos, eles também podem ser encontrados nesses grupos. Alguns advérbios de grau, modalizadores e de foco podem ser utilizados em respostas curtas para expressar atitude ou opinião, principalmente no discurso falado:

\section{A: That's a fair comment, isn't it? \\ $B$ : Absolutely.}

E alguns advérbios são utilizados como marcadores do discurso, como no exemplo abaixo, em que anyway é utilizado para sinalizar o fechamento do diálogo:

A: Sorry. You know what I mean. Sounds like you're gonna post it or something.

B: No.

A: Oh. Anyway, l'll have to go cos l've got to ring Bob. 


\section{B: Right.}

Outro subcapítulo também analisado por conter advérbios e locuções adverbiais é o dos adjuntos (Adjuncts), inserido no capítulo dedicado a sentenças e padrões oracionais (Sentence and clause patterns).

Dentre as gramáticas analisadas, a CGE é a que deixa mais clara a função dos adjuntos em inglês, dedicando todo um subcapítulo ao assunto (CARTER; McCARTHY, 2006, p. 578-596). Sintaticamente, os adjuntos ocupam a quinta posição, colocando-se depois das classes do sujeito, verbo, objeto e complemento. Os adjuntos podem modificar, comentar ou expandir o significado de uma oração quanto ao modo, lugar, tempo, frequência, etc. O sintagma adverbial - ressaltandose os advérbios terminados em -ly, é um dos elementos que formam a classe dos adjuntos. Diante disso, decidimos verificar como a CGE apresenta esse grupo.

Nas análises comentadas, observamos o cuidado de se mostrar a influência da posição do adjunto em relação à oração como um todo, como é o caso de $\underline{U p}$ near the church there was an old tree, onde a antecipação do adjunto up near the church reflete a preocupação do falante em orientar o ouvinte. Inclusive, os autores mencionam também o que é mais frequente em determinados gêneros textuais, como por exemplo colocar o adjunto no meio da oração, entre o verbo auxiliar e o verbo principal, em textos literários (CARTER; McCARTHY, 2006, p. 585-586):

I couldn't stop thinking about the noise of the waterfall. It was a noise that would never stop. It would always be roaring, even now it was, in the middle of the night, all the days and all the nights, shattering itself down the sides of the crevasse.

Em linhas gerais, a obra apresenta uma análise detalhada da posição dos adjuntos, subdividindo-os de acordo com o grupo semântico a que pertencem. Há observações quanto ao uso no discurso falado e na linguagem mais formal, além de diferenças entre determinados gêneros. No entanto, os autores não enfocam a questão da formação de unidades de significado maiores que incluem os advérbios. Seria interessante, por exemplo, se mencionassem que os adjuntos de grau e intensidade, modificadores de verbos na maioria dos casos, podem formar colocações adverbiais.

Outro detalhe positivo que chamou nossa atenção foi a preocupação em contextualizar o leitor nos exemplos utilizados. Como se trata de uma obra 
informada por corpus, as frases podem gerar dúvidas e confundir o consulente, quando retiradas de seu contexto de uso. Exemplo:

[Conservative here refers to the British Conservative Party; disenfranchised means having no power to vote] $]^{38}$

There's such a big Conservative majority we're disenfranchised completely.

Como podemos observar, os autores explicam, entre colchetes, a que se referem algumas das palavras do exemplo.

O papel do contexto é também frequentemente enfatizado - fica claro que um adjunto pode mudar de grupo semântico dependendo de onde se insere, como é o caso de a lot nos exemplos abaixo:

It has changed a lot. (to a great degree) ${ }^{39}$

We plan to go away a lot you see. For weekends and things. (frequently) ${ }^{40}$

Concluindo nossa análise, consideramos a CGE uma gramática inovadora e com uma abordagem bastante clara quanto ao tratamento das classes gramaticais. Com a proposta de ser corpus informed (informada pelo corpus), dá ao consulente a oportunidade de, partindo de uma visão mais tradicionalista e prescritiva da língua, tomar contato com uma abordagem mais probabilística e descritiva. A obra apresenta-se como um momento de transição: em vez de tratar o consulente como se já estivesse familiarizado com o uso e o levantamento de dados em corpus, os autores preferem manter laços com a gramática tradicional e, ao mesmo tempo, introduzir uma nova forma de estudar a língua, abordando a questão do contexto e a formação de alguns padrões linguísticos, com ênfase na análise e no uso de dados autênticos.

Em linhas gerais, através da análise de obras em português e em inglês, focando o uso dos advérbios, pudemos observar que há vários pesquisadores e estudiosos interessados em trabalhar com dados autênticos, através de uma abordagem baseada em corpus, preocupados em descrever a língua e indicar a

\footnotetext{
${ }^{38}$ (Conservative refere-se aqui ao Partido Conservador Britânico; disenfranchised significa não ter poder de voto)

${ }^{39}$ (em grande escala, significativamente)

${ }^{40}$ (frequentemente)
} 
probabilidade de ocorrência em seu contexto de uso. Quanto aos advérbios, observamos uma contribuição bastante significativa para sua descrição, mas há ainda vários aspectos a analisar, como abordaremos nesta pesquisa.

Para concluir, é importante enfatizar que, ao consultar uma obra baseada em corpus, o consulente passa a ter outras opções de pesquisa, além da visão mais tradicionalista que prescreve como a língua deve ser utilizada, comumente apresentada em obras de referência disponíveis no mercado. Na próxima seção, introduziremos os pressupostos teóricos e metodológicos da Linguística de Corpus, considerados para a elaboração das obras acima analisadas, e que fundamentam nosso estudo.

\subsection{Linguística de Corpus: um panorama geral}

Nesta seção, procuraremos apresentar um breve panorama histórico sobre o desenvolvimento da Linguística de Corpus. Segundo Berber Sardinha (2004),

[a] Lingüística de Corpus ocupa-se da coleta e da exploração de corpora, ou conjuntos de dados lingüísticos textuais coletados criteriosamente, com o propósito de servirem para a pesquisa de uma língua ou variedade lingüística. Como tal, dedica-se à exploração da linguagem por meio de evidências empíricas, extraídas por computador. (BERBER SARDINHA, 2004, p. 3).

Nesse trecho, o autor menciona o uso de computador, condição sine qua non para "fazermos" Linguística de Corpus nos dias atuais. No entanto, sabemos que a compilação de corpora, considerando-se o significado encontrado em dicionários de língua geral, qual seja "conjunto de documentos, dados e informações sobre determinada matéria" (FERREIRA, 1986), já era prática comum bem antes (e muito antes) do advento do computador. Indo aos primórdios, na Grécia Antiga temos o Corpus Helenístico, definido por Alexandre, o Grande e, durante a Antiguidade e Idade Média, corpora elaborados a partir da Bíblia (BERBER SARDINHA, 2004, p. 3). Seguindo na linha do tempo e ainda no século XIX, mais precisamente em 1897 , temos o trabalho de Käding, que se valeu de um corpus de 11 milhões de palavras algo comparável aos corpora atuais - para verificar a distribuição e a frequência de letras em alemão (McENERY; WILSON, 2001, p. 3). No século XX, encontramos 
fatos que definitivamente impulsionaram o que hoje consideramos Linguística de Corpus (doravante LC), numa era pré-computador. Naquela época, os dados eram reunidos manualmente, num trabalho árduo e moroso, como é o caso do material compilado por Thorndike, em 1921, que fez um levantamento das palavras mais frequentes da língua inglesa partindo de um corpus de 4,5 milhões de palavras. Em língua portuguesa, podemos citar o trabalho de Said Ali, a Gramática histórica da língua portuguesa, lançada no mesmo ano, que apresenta uma variedade de pesquisas detalhadas em textos escritos de diferentes épocas (VASILÉVSKI, 2007, p. 48). Seguindo esses, houve vários outros trabalhos nos mesmos moldes, principalmente em língua inglesa, mas foi o corpus SEU (Survey of English Language), compilado em 1953 (ainda na era pré-computador), que contribuiu decisivamente para a elaboração dos corpora atuais (BERBER SARDINHA, 2000, p. 325-326).

É importante observar que, naquele período, principalmente entre as décadas de 1930 e 1950, e mais especificamente no mundo anglófono, a Linguística era empirista, ou seja, prevalecia a ideia de que "reflexões sobre a natureza e o funcionamento da língua podem e devem partir das observações de dados concretos", para então chegarmos a generalizações a esse respeito (RAJAGOPALAN, 2007, p. 33). No entanto, manipular grandes quantidades de dados de forma manual não era tarefa fácil ou mesmo confiável. Juntando-se a essa desconfiança, em 1957 Noam Chomsky lança Syntactic Structures, obra que contribuiu definitivamente para a mudança de paradigma na linguística, colocando as teorias racionalistas em evidência. Segundo esse pesquisador, um corpus jamais deveria ser considerado como fonte de investigação para os linguistas. Em linhas gerais, o que deveria ser privilegiado era a competência linguística de um falante tido como ideal, considerando-se seus julgamentos introspectivos. No entanto, e mesmo com o predomínio do racionalismo e do movimento criado por Chomsky que fez surgir termos na literatura da época como "gramática transformacionalgerativa", "teoria padrão", "teoria x-barra", "minimalismo" e "gerativismo" -, a compilação de corpora não foi esquecida: saiu temporariamente de foco mas vários trabalhos continuaram sendo embasados na observação de dados autênticos. Como exemplos, podemos citar as pesquisas no campo da fonética e da aquisição da linguagem. Segundo McEnery e Wilson (2001, p. 14), há várias áreas que não poderiam ser efetivamente estudadas no mundo artificial de estruturas bem 
formadas e falantes/ouvintes idealizados de Chomsky. Nesse "mundo artificial e idealizado", considera-se apenas o conhecimento prévio e internalizado do falante para o estudo da língua, descartando sua realização - mas como fazê-lo em um indivíduo que está na fase de aquisição da linguagem e, portanto, não possui consciência metalinguística? Enfim, é importante deixar claro que, nesse período, apesar da sobrepujança da teoria racionalista, os estudos baseados em corpora continuavam a ser desenvolvidos, como aqueles de Labov, como citam McEnery e Wilson $(2001, \text { p. } 16)^{41}$.

Em linhas gerais, o racionalismo embasa-se na introspecção, no conhecimento prévio e internalizado do falante, considerando a linguagem um sistema de possibilidades. Tal fato opõe-se à forma como o estudo baseado em corpus vê essa mesma linguagem, ou seja, vê-a como um sistema probabilístico, considerando-se o contexto em que é utilizada (observação da língua em uso). Apresentamos abaixo alguns aspectos apontados por McEnery (1997, p. 12) que ressaltam características da pesquisa baseada em corpus, contrapondo-a à teoria racionalista:

- os dados são observáveis e verificáveis por todos que queiram fazê-lo;

- o corpus evidencia quaisquer pontos de vista que tenham sido utilizados para embasar uma dada teoria, o que não ocorre quando os dados são obtidos por meio da introspecção;

- o linguista de corpus observa dados autênticos; já o analista introspectivo valese de dados artificiais, por meio da manipulação do informante;

- a frequência só é computável com os corpora, o que não ocorre via introspecção.

Além de McEnery, Leech (1992) também apresenta alguns contrapontos dessas duas formas de estudar a língua, enfatizando a pesquisa baseada em corpus:

(1) Foco no desempenho linguístico, em vez de na competência;

(2) Foco na descrição linguística, em vez de nos universais linguísticos;

\footnotetext{
${ }^{41}$ Devemos ressaltar que esses autores apresentam, ao longo do primeiro capítulo do livro Corpus Linguistics: an introduction (McENERY; WILSON, 2001, p. 1-27), uma visão bastante abrangente sobre o desenvolvimento histórico da Linguística de Corpus, rica em detalhes e comentários sobre o que vinha à época, ressaltando embates teóricos e metodológicos ocorridos ao longo do século XX, antes e depois da invenção do computador.
} 
(3) Foco em modelos linguísticos, tanto quantitativos quanto qualitativos;

(4) Foco em uma visão mais empirista do que racionalista da pesquisa científica." (LEECH, 1992, p. 107) $)^{42}$

Esses aspectos, como podemos observar, geram muitas discussões e merecem maiores considerações, o que foge ao escopo desse panorama geral. A nosso ver, como colocam vários pesquisadores, dentre eles McEnery $(1997,2001)$ e Fillmore (1992, p. 35), conhecimento prévio (introspecção) e observação da linguagem em uso devem caminhar juntos, numa relação de complementaridade. Para McEnery (1997, p. 16), "A Linguística de Corpus é, e deveria ser, uma síntese de técnicas de introspecção e observação, baseando-se numa mistura de observação artificial e natural."43 Fillmore (1992) também sintetiza essa relação de complementaridade ao dizer:

Não creio que haja qualquer corpus, por maior que seja, que contenha informações sobre todas as áreas do léxico e da gramática da Língua Inglesa que eu queira explorar... [mas] todo corpus que tive a chance de examinar, por menor que fosse, ensinou-me fatos que não poderia sequer imaginar encontrar de outra forma. Minha conclusão é que os dois tipos de linguista necessitam um do outro. (FILLMORE, 1992, p. 35) (4 $^{4}$

Retornando à nossa linha do tempo, a partir da década de 60 o trabalho com corpus tomou força novamente com os computadores mainframe. Desde então, a LC tem se beneficiado dos avanços tecnológicos, com destaque para os anos 80 , com o surgimento dos microcomputadores pessoais e o fortalecimento dessa não tão nova forma de estudar a língua. Nessa década, podemos destacar uma parceria entre o mundo empresarial e o acadêmico: a Universidade de Birmingham (GrãBretanha) e a Editora Collins uniram-se para lançar o projeto COBUILD, marco no desenvolvimento e aplicação de pesquisas baseadas em corpus para fins

\footnotetext{
42 "(1) Focus on linguistic performance, rather than competence. (2) Focus on linguistic description, rather than linguistic universals. (3) Focus on quantitative, as well as qualitative models of language. (4) Focus on a more empiricist, rather than rationalist view of scientific inquiry."

43 "Corpus linguistics is, and should be, a synthesis of introspective and observational techniques, relying on a mix of artificial and natural observation."

44 "I don't think there can be any corpora, however large, that contain information about all of the areas of English lexicon and grammar that I want to explore... [but] every corpus I have had the chance to examine, however small, has taught me facts I couldn't imagine finding out any other way. My conclusion is that the two types of linguists need one another."
} 
comerciais. A partir disso, vários outros centros de pesquisa foram desenvolvidos na Europa, principalmente na Grã-Bretanha (BERBER SARDINHA, 2004, p. 6).

Tognini-Bonelli (2001, p. 47) descreve, em três estágios, o uso de corpora eletrônicos nos estudos linguísticos. Num primeiro momento, os corpora eram vistos apenas como uma ferramenta, uma forma de processar grandes quantidades de dados, algo impossível antes do advento do computador. Em um segundo momento, além de viabilizar a manipulação de grandes quantidades de dados e a consequente observação de novas evidências, esses corpora causaram mudanças na metodologia de pesquisa, acelerando o processo e sistematizando sua aplicação para quantidades de dados cada vez maiores. Na década de 90, atingimos o terceiro estágio, quando a manipulação de grandes corpora, graças aos avanços computacionais, transformou-se em uma revolução teórica e qualitativa, oferecendo insights sobre a língua que abalaram vários dos pressupostos linguísticos bem arraigados na área (TOGNINI-BONELLI, 2001, p. 47-48). Hoje, conforme já comentado, vários pesquisadores vêem a análise baseada no uso de corpora eletrônicos com forma de teoria e dados caminharem juntos, enfatizando-se o aspecto qualitativo (HALLIDAY, 1993, p. 24 apud TOGNINI-BONELLI, 2001, p. 48).

Dentre os vários corpora até hoje compilados em diversas línguas, vale destacar, para o inglês, três que são considerados marcos de referência históricos (BERBER SARDINHA, 2004, p. 8-9): o corpus Brown, por ser o pioneiro; o BNC (British National Corpus), por ser o primeiro a atingir 100 milhões de palavras; e o Bank of English, um corpus monitor, orgânico e em crescente expansão - hoje com aproximadamente 650 milhões de palavras ${ }^{45}$. Para o português brasileiro, podemos citar o Banco de Português, criado no âmbito do grupo de pesquisa Direct na Pontifícia Universidade Católica de São Paulo (PUC/SP), hoje na versão 2 com 750 milhões de palavras de português contemporâneo (falado e escrito); o Lácio-Web, com aproximadamente 10 milhões de palavras de português brasileiro contemporâneo, criado pelo Núcleo Interinstitucional de Linguística Computacional (NILC/USP) (http://www.nilc.icmc.usp.br/lacioweb); e o Corpus Brasileiro, disponível online e gratuitamente ${ }^{46}$, com um bilhão de palavras de português brasileiro

\footnotetext{
${ }^{45}$ Informação disponível em: http://mycobuild.com/about-collins-corpus.aspx

${ }^{46}$ Este projeto vem sendo desenvolvido na Pontifícia Universidade Católica de São Paulo, com apoio da FAPESP, por uma equipe formada pelos pesquisadores Antonio Berber Sardinha, José Lopes Moreira Filho e Eliane Alambert. Para mais detalhes, acessar: http://corpusbrasileiro.pucsp.br
} 
contemporâneo. ${ }^{47}$ Além desses, devemos também citar o projeto CoMET (Corpus Multilíngue para Ensino e Tradução), desenvolvido na Faculdade de Filosofia, Letras e Ciências Humanas da Universidade de São Paulo (FFLCH-USP), que apresenta três subcorpora: o CorTec (Corpus Técnico-Científico), o CoMAprend (Corpus Multilíngue de Aprendizes) e o CorTrad (Corpus de Tradução) ${ }^{48}$.

Berber Sardinha (2004, p. 38) apresenta três paradigmas que têm norteado as pesquisas baseadas em corpus ao longo dos anos, também apontados por Leech (1992, p. 113-120). São eles:

- o paradigma informal, baseado em concordâncias: é o que concentra o maior número de pesquisas, utilizado para a descrição da linguagem com pouco ou nenhum suporte estatístico;

- o paradigma estatístico, baseado em modelos log-linear;

- o paradigma estatístico, fundamentado em Modelos Ocultos de Markov.

Como exemplos do paradigma informal, o que se destaca no desenvolvimento de nossa investigação, Leech (1992, p. 114) cita a pesquisa lexicográfica, qual seja, a de identificar significados e outras características (sintáticas, estilísticas, pragmáticas, culturais, etc.) de um dado item em determinado contexto, e a pesquisa "indutiva" da gramática, que se dá, por exemplo, quando o pesquisador utiliza as linhas de concordância para identificar parâmetros de uso de um determinado item gramatical. Nesse paradigma, é importante ressaltar as habilidades de observação e generalização do pesquisador, visto que o computador apenas organiza e apresenta os dados.

As áreas de pesquisa em LC estão em constante crescimento: vão desde a compilação de corpus e o desenvolvimento de ferramentas computacionais à descrição da linguagem e aplicação de corpora em diferentes áreas. Dentre essas áreas, podemos citar: Lexicografia e Terminologia (elaboração de dicionários e bancos de dados terminológicos); Ensino de Línguas (elaboração de material didático e observação da língua em uso) e Tradução (observação de linguagens especializadas em seus contextos de uso) (TEIXEIRA, 2008, p. 153).

Mesmo diante de tantos avanços na área da Linguística de Corpus, no entanto, ainda hoje não há consenso para sua definição. Se necessário fazê-lo,

\footnotetext{
${ }^{47}$ Para mais detalhes e informações sobre outros corpora de destaque em inglês e em português, vide Berber Sardinha (2004, p. 8-9) e Berber Sardinha e Almeida (2008, p. 26-33).

${ }^{48}$ Mais informações e acesso aos subcorpora em http://www.fflch.usp.br/dlm/comet.
} 
como definir a LC: teoria, metodologia para o estudo da língua, abordagem, ou a junção dessas vertentes? Trataremos desse tema em nosso próximo item.

\subsubsection{Linguística de Corpus: teoria, abordagem ou metodologia?}

A Linguística de Corpus não se refere a um domínio de estudo específico, tão pouco apresenta um objeto de pesquisa delimitado, o que ocorre em áreas como Fonologia, Semântica, Sintaxe e Sociolinguística, apenas para citar alguns exemplos. Segundo Leech (1992, p. 105-106), a LC pode ser vista como uma base metodológica para pesquisa linguística, uma combinação entre técnicas de investigação e diferentes ramos da Linguística, como é o caso daqueles acima citados. Apesar desse cunho metodológico, no entanto, Leech ressalta que a LC vai além de uma metodologia que apresenta diversas ferramentas para investigação: ela gera novo conhecimento, uma nova forma de se pensar sobre a língua. Para ele, a LC deve ser vista como uma nova abordagem filosófica (LEECH, 1992, p. 106). Como aponta Berber Sardinha (2004, p. 36-37), há outros influentes linguistas de corpus que também consideram a LC uma abordagem, como é o caso de Douglas Biber e Michael Hoey. Tognini-Bonelli (2001, p. 1; 49) enfatiza, inclusive, que o papel da LC vai além do metodológico, uma vez que se sustenta e se define como uma disciplina por direito, adquirindo seu próprio domínio. McEnery, Xiao e Tono (2006, p. 7), apesar de concordarem que a LC é um domínio de pesquisa, uma nova empreitada de investigação linguística e abordagem filosófica, se mantém no posicionamento de que a LC é muito mais uma metodologia do que um ramo independente da Linguística. Para eles, deve-se ter uma postura menos rígida e delimitadora, considerando-se a LC uma metodologia que pode ser aplicada a várias áreas e teorias dentro da Linguística. Essa visão é partilhada por alguns pesquisadores no Brasil, dentre os quais podemos citar Rocha e Vasilévski (VASILÉVSKI, 2008, p. 45-46; 63).

Como podemos observar, ainda não há consenso para a definição de LC. Nosso posicionamento, no entanto, corrobora aquele apresentado por Berber Sardinha (2004, p. 36$)$ : a LC não se resume a um conjunto de ferramentas, pois representa muito mais do que um instrumental computacional. Ela trabalha sob uma 
perspectiva empirista, que vê a linguagem como um sistema probabilístico ${ }^{49}$. Partindo das concepções empiristas, em que a LC ancora parte de seu arcabouço teórico, considera-se o que é provável em dado contexto - as ocorrências de dada palavra, em determinada situação (contexto de uso), seguem determinado padrão que se evidencia pela recorrência ${ }^{50}$, que por sua vez será observada e analisada em um corpus eletrônico compilado para fins de investigação. E como bem coloca Teixeira (2008, p. 154), não se trata apenas de ter maior quantidade de dados disponíveis para análise e de ferramentas computacionais para fazê-lo. Sob essa nova perspectiva, pode-se produzir novos conhecimentos e evidenciar novos fenômenos sobre seu objeto de estudo. Essa pesquisadora, inclusive, lembra a comparação que Stubbs (1996, p. 231) faz entre a importância do advento do microscópio para a biologia e do computador para a análise linguística, trazendo nova luz à observação dos fatos (TEIXEIRA, 2008, p. 154). Exemplo disso são as investigações desenvolvidas no campo lexical, como é o caso da colocação entre itens lexicais apontada por Sinclair, um dos maiores expoentes da Linguística de Corpus (BERBER SARDINHA, 2004, p. 36).

Considerando-se todos os posicionamentos apontados, seja a LC tida como disciplina, teoria ou mesmo metodologia de pesquisa, corroboramos a ideia de que o termo abordagem melhor caracteriza e reúne todas essas perspectivas, enfatizando o papel primordial dessa forma de estudar a língua através da análise e exploração da linguagem por meio de evidências empíricas, extraídas por computador. Isso posto, a partir do próximo item passaremos a tratar de aspectos mais pontuais, iniciando com alguns conceitos basilares na área de LC.

\subsubsection{Linguística de Corpus: alguns conceitos}

Dentre os vários conceitos fundamentais em Linguística de Corpus, o primeiro a ser considerado é o que entendemos por corpus. Na literatura disponível, podemos encontrar várias definições que apresentam muitos pontos convergentes e alguns divergentes, e outros que simplesmente se complementam. Como nos

\footnotetext{
${ }^{49}$ É importante lembrar um dos maiores expoentes do empirismo, o pesquisador Michael A. K. Halliday.

${ }^{50}$ Deve-se considerar todo o aparato computacional e estatístico implícito no uso dessa palavra, bem como as ferramentas desenvolvidas para a manipulação de dados em um determinado corpus.
} 
aponta Tognini-Bonelli (2001, p. 52-53), há várias discussões quanto à classificação de dada coletânea ou mesmo quanto à forma de coleta desses dados. Para nossa pesquisa, consideramos a definição apresentada por Sanchez e Cantos, tida como a mais completa por Berber Sardinha (2004, p. 18):

Um conjunto de dados lingüísticos (pertencentes ao uso oral ou escrito da língua, ou a ambos), sistematizados segundo determinados critérios, suficientemente extensos em amplitude e profundidade, de maneira que sejam representativos da totalidade do uso lingüístico ou de algum de seus âmbitos, dispostos de tal modo que possam ser processados por computador, com a finalidade de propiciar resultados vários e úteis para a descrição e análise. (SANCHEZ; CANTOS, 1996, p. 8-9 apud BERBER SARDINHA, 2004, p. 18)

Conforme coloca Berber Sardinha (2004, p. 18-19), essa definição menciona os principais aspectos a serem considerados para a compilação de um corpus: a origem dos dados (o que irá garantir sua autenticidade), o propósito da pesquisa, a seleção criteriosa do material a ser compilado, sua formatação, ou seja, o fato de que deve ser legível por computador, a questão da representatividade e o tamanho um corpus deve ser vasto o suficiente para ser representativo do segmento linguístico que se pretende investigar. Deve-se observar vários critérios para sua compilação, dentre os quais destacamos o modo (falado ou escrito) e o conteúdo (especializado, regional ou dialetal e multilíngue), relevantes para nossa pesquisa. Devemos também considerar a finalidade desse corpus e, com isso, definir a melhor disposição interna dos textos. Segundo Tognini-Bonelli (2001, p. 6-7), pesquisadora que enfoca vários estudos na área da tradução, há três tipos de corpora que se distinguem pela relação entre as línguas que os compõem. São eles:

a) corpus paralelo: formado por textos originais e suas respectivas traduções, apresentados de forma alinhada;

b) corpus de tradução: formado apenas por textos traduzidos, sem os originais;

c) corpus comparável: formado por textos originais nas línguas em estudo, seguindo os mesmos critérios de compilação, tais como ambos serem de linguagem oral ou escrita, pertencerem ao mesmo registro, etc.

Nesta pesquisa, interessa-nos o terceiro tipo (corpus comparável), como será melhor explicitado na descrição dos materiais e métodos utilizados. 
Outro aspecto também importante em estudos baseados em corpus são as linhas de concordância. Considerando-se o número de palavras de dado corpus, que pode variar de pequeno (menos de 80 mil palavras) a grande (igual ou superior a 10 milhões de palavras) (BERBER SARDINHA, 2004, p. 26), pergunta-se: como manipular esses dados, para então poder analisá-los? Disponíveis hoje no mercado (gratuitamente ou através de compra), há vários software que ordenam esse material partindo de uma palavra ou nódulo de busca definido pelo pesquisador, além de ferramentas que acompanham vários corpora disponíveis online, como é o caso do British National Corpus $(\mathrm{BNC})^{51}$ e do CorTec. As linhas de concordância nada mais são do que o resultado dessa busca. Com a maioria dos concordanciadores, caso de uma das ferramentas disponíveis no programa WordSmith Tools ${ }^{52}$ e no AntConc ${ }^{53}$, por exemplo, iremos encontrar essa expressão de busca centralizada e inserida em seu contexto de uso, a partir de todas as ocorrências detectadas no corpus. Apresentamos na figura abaixo algumas linhas geradas para o advérbio slightly, a partir do corpus de receitas culinárias utilizado em nossa pesquisa:

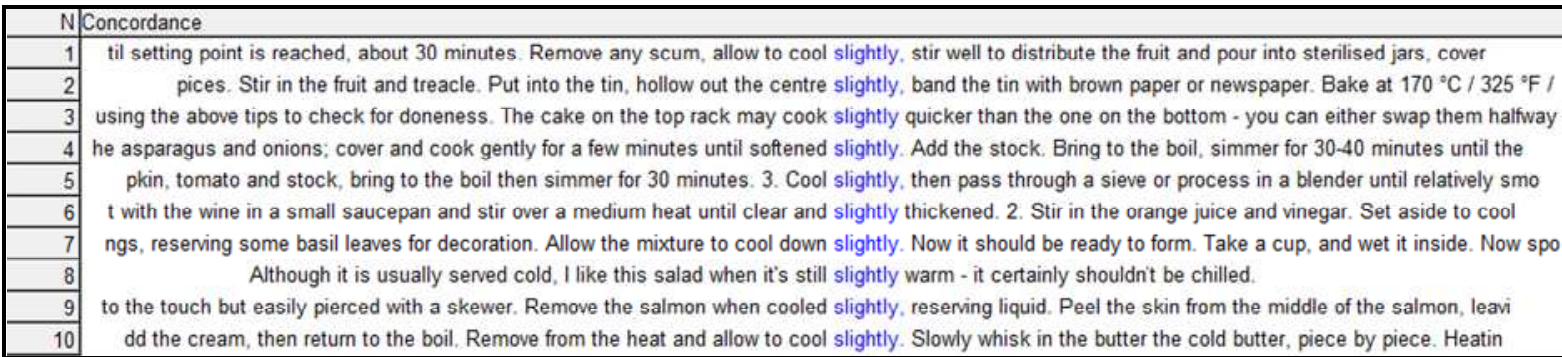

Figura 1 - 10 primeiras linhas de concordância do advérbio slightly do corpus de receitas culinárias compilado por Teixeira (2008)

Para analisar esses dados, o pesquisador deve observar (TOGNINIBONELLI, 2001):

- tanto o eixo horizontal quanto o vertical, analisando todas as linhas;

- a repetição de palavras que co-ocorrem com a palavra de busca (à direita e à esquerda);

- a repetição de padrões lexicais e/ou gramaticais;

\footnotetext{
${ }^{51}$ Consultar o capítulo II para mais detalhes. As linhas de concordância do BNC (British National Corpus) também podem ser geradas em http://www.natcorp.ox.ac.uk/.

${ }^{52}$ Para detalhes sobre o programa, vide Capítulo II, item 2.5.

${ }^{53}$ Esse conjunto de ferramentas não será utilizado nesta pesquisa. Para mais informações, consulte a homepage de seu desenvolvedor, Laurence Anthony, Ph.D.: http://www.antlab.sci.waseda.ac.jp/.
} 
- a repetição em nível semântico e funcional (campo semântico e prosódia semântica).

Em resumo, deve aprender a ler verticalmente e de forma fragmentada, além de enfocar a repetição de itens lexicais e/ou gramaticais. Ao ler horizontalmente, podemos observar a palavra de busca em um trecho de discurso. Já no eixo vertical, observamos ocorrências geradas a partir de vários textos.

Hoey (1997) resume em cinco perguntas os aspectos que devemos considerar ao levantar as linhas de concordância de dada palavra ou expressão de busca:

1- De quais padrões lexicais a palavra faz parte? 2- A palavra associa-se regularmente a outros significados específicos? 3- Em quais estruturas ela ocorre? 4- Há qualquer correlação entre os usos/significados da palavra e as estruturas em que ocorre? 5- A palavra é associada a (alguma posição em qualquer) organização textual? (HOEY, 1997, p. 3) ${ }^{54}$

Juntamente com outros recursos disponibilizados pelo programa WordSmith Tools, tais como as listas de palavras que compõem os corpora e o levantamento das palavras-chave de cada área de estudo, as linhas de concordância são fundamentais para o desenvolvimento de nosso processo investigatório. Essas ferramentas e sua aplicabilidade em nossa pesquisa serão melhor explicitadas no capítulo II.

\subsubsection{Corpus-based ou corpus-driven?}

Segundo vários pesquisadores e teóricos da área, dentre os quais podemos citar Tognini-Bonelli (2001) e McEnery, Xiao e Tono (2006), há duas diferentes formas de trabalharmos com corpus: uma pesquisa pode ser corpus-based, ou seja, baseada em corpus, ou corpus-driven - direcionada pelo corpus. Já deparamos também com o termo corpus-informed (CARTER; McCARTHY, 2006), ou seja, a pesquisa é "informada" pelo corpus. A nosso ver, esse é apenas um outro termo

\footnotetext{
54 "1- What lexical patterns is the word part of? 2- Does the word regularly associate with particular other meanings? 3- What structure(s) does it appear in? 4- Is there any correlation between the word's uses/meanings and the structures in which it participates? 5- Is the word associated with (any position in any) textual organization?"
} 
utilizado para descrever uma pesquisa que segue a primeira vertente, ou seja, um estudo cujos resultados baseiam-se em informações obtidas em corpus.

Tognini-Bonelli (2001, p. 65-83) apresenta uma descrição pormenorizada do que constituem essas duas formas de desenvolver uma investigação em corpus, nomeando também alguns estudiosos que tendem a seguir uma ou outra abordagem.

Em linhas gerais, desenvolver uma investigação baseada em corpus significa utilizá-lo para explicar, ou melhor, esclarecer, atestar e exemplificar teorias e presunções sobre a língua já existentes antes dessa investigação - o corpus seria utilizado para comprovar algum conhecimento prévio do pesquisador. Em um âmbito mais geral, Tognini-Bonelli (2001, p. 65) enfatiza, inclusive, que essas teorias foram formuladas antes da disponibilização dos grandes corpora que hoje temos para consulta. Em uma pesquisa baseada em corpus, o pesquisador:

- usa o corpus para quantificar categorias já existentes - o material é uma ótima fonte de evidências quantitativamente comprovadas; e

- filtra os dados de forma a ajustá-los às teorias consideradas antes de iniciar sua análise.

Esse pesquisador isola e padroniza os dados, além de reduzir o corpus a uma fonte de exemplos. E quando os resultados não se ajustam à teoria, atribui esse "desajuste" à diversidade, variação, ambiguidade e instabilidade da própria língua, certamente refletida no corpus, o que pode levar ao descarte desses dados.

Seguindo essa abordagem, as três principais formas de trabalhar com o corpus são: insulação, padronização e instanciação.

Ao isolar os dados, o pesquisador vale-se de seu conhecimento prévio, da introspecção. Na insulação, a dicotomia competência/desempenho é considerada ao extremo e os insights advindos da investigação fazem parte de apenas uma delas a competência; alguns dados são ou não considerados, de acordo com o julgamento do pesquisador. Os trabalhos desenvolvidos por Aarts e Bod, segundo TogniniBonelli (2001, p. 68-69), seguem essa linha.

Simplificar e padronizar o corpus significa reduzi-lo a um conjunto de categorias pré-estabelecidas, o que ocorre, por exemplo, quando um corpus é anotado (há autores que defendem o uso de corpora crus, como Sinclair) - alguns consideram esse processo um modo de "enriquecê-lo". Essa abordagem, uma outra tentativa de se conciliar conhecimento prévio e evidências obtidas através do 
corpus, inclui linguistas que adotam um posicionamento mais empírico, como é o caso de Leech. A observação dos dados é priorizada, mas deve-se ter em mente que as teorias consideradas são aquelas previamente estabelecidas.

A terceira forma considerada é a chamada de instanciação. Nesse caso, os dados são considerados um sistema de possibilidades abstratas, um conjunto de escolhas paradigmáticas disponíveis em qualquer ponto do texto. Segundo TogniniBonelli (2001, p. 75-76), Halliday é um dos pesquisadores que integram esse segmento. Para ele, o linguista irá interrogar o corpus com vistas a dar um embasamento probabilístico aos parâmetros de um sistema gramatical. Aponta, ainda, que gramática e léxico constituem um mesmo fenômeno que faz parte de um continuum observado sob dois ângulos diferentes.

Para concluir, Tognini-Bonelli resume que

[...] a abordagem baseada em corpus refere-se a um tipo de metodologia em que o comprometimento com os dados em geral não é essencialmente estrito ou sistemático. As distribuições de frequência, ou mesmo a ausência de um determinado padrão, apesar de observadas, podem não ser fatores determinantes na formulação de uma teoria sobre o sistema. Dessa forma, [...] os corpora são tipicamente utilizados para validar - até certo ponto categorias existentes ou para complementar a teoria com uma dimensão probabilística. É típico da abordagem baseada em corpus priorizar a informação advinda de padrões sintáticos sobre os lexicais. As inter-relações sistemáticas entre ambos tendem a passar despercebidas e, consequentemente, não irão determinar as categorias do sistema. (TOGNINI-BONELLI, 2001, p. 81)

$\mathrm{Na}$ abordagem direcionada pelo corpus, o comprometimento do pesquisador é com os dados como um todo - suas observações procuram ser abrangentes com relação às evidências apresentadas. Sua investigação vai além da seleção de exemplos para dar suporte a uma teoria pré-estabelecida ou mesmo de argumentos para validá-la. Nesse caso, os exemplos não são ajustados; a frequência de uso e a recorrência de padrões são elementos-chave para se estabelecer categorias linguísticas. Inclusive, a ausência ou frequência menor do que a esperada também é

\footnotetext{
55 “[...] the corpus-based approach refers to a type of methodology where the commitment to the data as a whole is not ultimately very strict or systematic. Frequency distributions, or the absence of a given pattern, although noted, may not be determining in the formulation of a theoretical statement about the system. In this way, [...] corpora are typically used to validate - but only to a certain extent - existing categories or to supplement the theory with a probabilistic dimension. Typically, the corpus-based approach will prioritise the information yielded by syntactic rather than lexical patterns. The systematic interrelations between the two are likely to go unnoticed and therefore are not allowed to determine the categories of the system."
} 
significativa. A representatividade e a autenticidade do material que compõe o corpus são extremamente importantes para o analista, uma vez que ele será direcionado por esses dados. Com isso, os critérios de compilação do corpus devem ser rigorosamente estabelecidos antes de se iniciar o processo. Ao contrário da pesquisa baseada em corpus, que se caracteriza mais como um processo dedutivo, a pesquisa direcionada pelos dados deve induzir o pesquisador a generalizações sobre a língua. É importante ressaltar, no entanto, que essa "indução" não é pura: certamente, esse pesquisador traz consigo sua inteligência, conhecimento e experiência ao desenvolver suas análises. Essa abordagem vê a língua de forma mais holística: considera o texto inserido em dado contexto, em dada situação e, em um espectro maior, parte de determinada cultura.

Além de analisar as linhas de concordância em seu eixo horizontal, o linguista direcionado pelo corpus irá buscar a repetição de co-ocorrências em seu eixo vertical, o que gera padrões conhecidos como colocações e coligações. Esses padrões tipificam a associação entre léxico e gramática, ponto central dessa abordagem, que a caracterizam como léxico-gramatical. Nessa análise, o pesquisador pode também tirar conclusões sobre a prosódia semântica de sua palavra ou expressão de busca, além de analisar sua preferência semântica ${ }^{56}$.

Segundo Halliday (1991, p. 31-32), a léxico-gramática é um fenômeno unificado, em que léxico e gramática formam um continuum: de um lado as escolhas gramaticais, mais generalizadas e delimitadas; de outro, escolhas que são altamente específicas e, ao mesmo tempo, mais amplas, formadas pelo léxico. Em linhas gerais, léxico e gramática são perspectivas que se completam e explicam diferentes aspectos de um mesmo fenômeno complexo. Outros pesquisadores, como é o caso de Stubbs (1993), também apontam a interdependência entre léxico e gramática. Segundo ele (STUBBS, 1993, p. 16-17), o estudo em corpus demonstra que léxico e gramática são totalmente interdependentes, uma vez que não apenas palavras diferentes apresentam distribuições gramaticais diversas - tal fato pode ocorrer com as diferentes formas (realizações) de uma mesma palavra. É o caso, por exemplo, de consequence e consequences, analisadas por Hoey, que apresentam padrões diferentes pelo fato de se encontrarem no singular e no plural (HOEY, 2003, p. 5-6). Ainda referindo-se a essa interdependência entre léxico e gramática, Stubbs (1993,

\footnotetext{
${ }^{56}$ Esses conceitos serão melhor explicitados na próxima seção.
} 
p. 17-18) elenca algumas conclusões obtidas a partir da análise de linhas de concordância. São elas:

(i) Qualquer estrutura sintática restringe o léxico que nela ocorre; inversamente, qualquer item lexical pode ser especificado considerando-se as estruturas em que ocorre [...].

(ii) Tais restrições não são tipicamente absolutas, mas sim tendências: a gramática é inerentemente probabilística.

(iii) Os falantes nativos não têm intuições confiáveis sobre tais tendências estatísticas. [...] A gramática é 'direcionada pelo corpus' no sentido de que o corpus nos diz quais são os fatos.

(iv) O significado não é constante nas formas flexionadas de um lema. [...]

(v) Cada sentido ou significado de uma palavra tem sua própria gramática: cada significado é associado a um padrão formal distinto. Forma e significado são inseparáveis.

(vi) As palavras são sistematicamente co-selecionadas: o uso normal da língua é selecionar mais de uma palavra de cada vez.

(vii) Uma vez que as escolhas paradigmáticas não são feitas de forma independente da posição na sequência sintagmática, a relação entre os eixos paradigmático e sintagmático deve ser repensada.

(viii) As classes de palavras tradicionais e as unidades sintáticas também devem ser repensadas. ${ }^{57}$ (STUBBS, 1993, p. 17-18)

Além desses, devemos também mencionar Biber, Conrad e Reppen (1998), que dedicam todo um capítulo da obra para a investigação de padrões léxicogramaticais, explicando detalhadamente e exemplificando todo o processo, além de John Sinclair, que já em Corpus, Concordance, Collocation (SINCLAIR, 1991) levanta a questão e, sob a perspectiva léxico-gramatical, analisa a preposição of (SINCLAIR, 1991, p. 81-98). Em Trust the text: language, corpus and discourse (SINCLAIR, 2004), o autor retoma a questão e apresenta um outro termo, qual seja, lexical grammar, para o qual sugerimos gramática lexical como tradução. Segundo Sinclair (2004, p. 164), o termo lexico-grammar não integra os dois tipos de padrão

\footnotetext{
57 “(i) Any syntactic structure restricts the lexis that occurs in it; and conversely any lexical item can be specified in terms of the structures in which it occurs [...].

(ii) Such restrictions are typically not absolute, but clear tendencies: grammar is inherently probabilistic.

(iii) Native speakers have no reliable intuitions about such statistical tendencies. [...] Grammar is 'corpus-driven' in the sense that the corpus tells us what the facts are.

(iv) Meaning is not constant across the inflected forms of a lemma. [...]

(v) Every sense or meaning of a word has its own grammar: each meaning is associated with a distinct formal patterning. Form and meaning are inseparable.

(vi) Words are systematically co-selected: the normal use of language is to select more than one word at a time.

(vii) Since paradigmatic choices are not made independently of position in syntagmatic chain, the relation between paradigmatic and syntagmatic has to be rethought.

(viii) Traditional word-classes and syntactic units also have to be rethought."
} 
que sugere; em linhas gerais, apresenta a gramática com o olhar voltado para a inclusão do léxico em padrões gramaticais, o que não reflete a tentativa de se construir léxico e gramática de forma equilibrada - daí então sua preferência pelo termo lexical grammar (SINCLAIR, 2004, p. 164). Em nossa pesquisa, manteremos o termo léxico-gramática.

Retomando a abordagem direcionada pelo corpus, outra questão também discutida é a lematização. Para Sinclair (1991), por exemplo, lematizar dada palavra é um processo questionável, uma vez que forma e significado caminham juntos. Em linhas gerais, lematizar significa neutralizar as diferentes formas com que uma palavra pode ocorrer e fazer generalizações quanto ao seu uso. No caso de verbos, por exemplo, o lema seria o infinitivo; já nos substantivos, considera-se o masculino singular. Com isso, se o linguista analisar, por exemplo, um verbo em suas diferentes flexões, irá agrupar todas as suas conclusões sob sua forma infinitiva. Tal fato apagaria diferenças observadas entre um verbo conjugado na primeira e terceira pessoas do singular no passado, como é o caso do verbo mentir na colocação mentir descaradamente (MORAES, 2005, p. 144-145). A partir das linhas de concordância, a pesquisadora observou que a colocação raramente ocorria na primeira pessoa do singular, ao passo que era frequente na terceira pessoa. Caso a análise fosse lematizada, essas diferenças não seriam ressaltadas. Além disso, analisar apenas uma forma da palavra no corpus não garante que o resultado seja aplicável a todas as outras formas em que essa palavra venha a ocorrer. Como bem coloca Sinclair (1991),

Há fortes argumentos de que cada forma distinta é potencialmente uma unidade lexical única, e as formas devem ser combinadas em lemas apenas quando seus contextos de uso demonstrarem certa similaridade observável em quantidade e tipo. (SINCLAIR, 1991, p. 8$)^{58}$

A nosso ver, cabe ao pesquisador, considerando os objetivos de sua investigação, estabelecer se é ou não adequado fazer uso da lematização em sua análise. Como coloca Hoey (2005, p. 5), quando várias formas de um mesmo lema compartilham colocados, pode-se estudá-los em conjunto, mas não se pode fazer

\footnotetext{
58 "There is a good case for arguing that each distinct form is potentially a unique lexical unit, and that forms should only be conflated into lemmas when their environments show a certain amount and type of similarity."
} 
generalizações a respeito. Nesta pesquisa, utilizaremos a forma lematizada, representada por letras maiúsculas, quando julgarmos necessário.

Para concluir, gostaríamos de colocar alguns questionamentos apresentados por McEnery, Xiao e Tono (2006, p. 8-12) ao compararem as duas abordagens, cuja distinção consideram confusa e imprecisa. Basicamente, essas questões referem-se aos seguintes aspectos:

$>$ os tipos de corpora utilizados:

Segundo McEnery, Xiao e Tono (2006, p. 9), o linguista direcionado pelo corpus prefere trabalhar com corpora gigantes. Em suas análises, afirma considerar todas as evidências apresentadas pelo corpus. Mas o que dizer dos pontos de corte estabelecidos para desenvolver suas pesquisas, como quando estabelece a frequência mínima da palavra sob análise? Então por que priorizar os corpora gigantes?

o processo de anotação:

Para o linguista direcionado pelos dados, anotar um corpus significa ajustá-lo a teorias pré-existentes; segundo esse linguista, tal processo deve ser evitado. Essa concepção gera a seguinte pergunta: como esse pesquisador irá colocar de lado conhecimentos adquiridos ao longo de sua formação educacional ao analisar os dados?

$>$ focos da pesquisa:

Se os conceitos e teorias pré-existentes não devem ser considerados na pesquisa direcionada pelo corpus, o que dizer do conceito de coligação, que leva em conta a associação entre palavras em nível gramatical? Inclusive, falta precisão em sua definição: há pesquisadores que consideram coligação a associação de um dado item lexical a classes ou categorias gramaticais, enquanto outros consideram também a associação a palavras gramaticais específicas.

o posicionamento do linguista:

Os pesquisadores que se posicionam sob a abordagem baseada em corpus apresentam uma visão menos radical do que aqueles que se intitulam direcionados 
pelo corpus. Inclusive, McEnery, Xiao e Tono (2006, p. 11) ressaltam que, como metodologia $^{59}$, a pesquisa baseada em corpus é aplicável a vários ramos da Linguística.

A nosso ver, é realmente difícil distinguir quando estamos nos baseando nos dados e quando estamos sendo direcionados por eles. Nesta pesquisa, utilizaremos a expressão "baseado em corpus" de uma forma mais geral, incluindo evidências que não cogitávamos encontrar antes do início de nossa investigação.

Nas linhas acima, mencionamos vários termos que retratam o que é típico da língua, ou seja, padrões com os quais frequentemente deparamos, como é o caso de colocação e coligação. Na próxima seção, apresentaremos um apanhado geral sobre convencionalidade, detalhando esses conceitos, e sua relação com a LC.

\subsection{Linguística de Corpus e convencionalidade}

A Linguística de Corpus, ressaltando-se todo o aporte metodológico dessa forma de estudar a língua, vem ao encontro das necessidades daquele pesquisador voltado ao estudo da convencionalidade linguística. Em artigo publicado em 1985, Benson (1985) tece comentários sobre a combinatória lexical de várias palavras, enfatizando o aspecto convencional de algumas colocações que, se tivesse então disponível todos os recursos que o avanço dos estudos em LC hoje apresenta, certamente teria sido mais fácil apontar a colocabilidade entre vários itens lexicais e gramaticais e observar sua recorrência na língua, valendo-se inclusive das linhas de concordância para exemplificação - o artigo elenca as várias colocações levantadas pelo pesquisador, mas não traz exemplos de uso em contexto. Inclusive, não fica claro como chegou a essas colocações - em nenhum momento comenta sobre o uso de corpus. Caso tivesse se valido da LC, certamente chegaria às unidades pelo caminho inverso: através da observação em corpus, identificaria essas colocações e, na sequência, decidiria quais deveriam ou não ser dicionarizadas (uma das questões discutidas no artigo). Um ano depois, Morton Benson, Evelyn Benson e Robert Ilson publicaram o dicionário intitulado The BBI Dictionary of English Word

\footnotetext{
${ }^{59}$ É importante lembrar que McEnery, Xiao e Tono consideram a Linguística de Corpus, em âmbito mais geral, uma metodologia (McEnery, Xiao e Tono, 2006, p. 7-8).
} 
Combinations (BENSON M.; BENSON E.; ILSON, 1986) ${ }^{60}$, que àquela época certamente contribuiu para os estudos da convencionalidade. No entanto, cremos que essa contribuição teria sido mais significativa se a obra tivesse sido baseada em corpus, como observamos em vários outros dicionários lançados posteriormente ${ }^{61}$. Esse é apenas um exemplo de como a LC pode colaborar ou mesmo exercer um papel fundamental em diferentes áreas de estudo, como ocorre com a convencionalidade.

Mas o que entendemos por convencionalidade linguística? Corroboramos a definição apresentada por Tagnin (2005, p. 14), segundo a qual "podemos chamar de convencionalidade o aspecto que caracteriza a forma peculiar de expressão numa dada língua ou comunidade lingüística". Essa convencionalidade pode tanto ligar-se a um fato social - como por exemplo dizer "meus parabéns" ao cumprimentar alguém pelo seu aniversário - quanto ater-se à forma como se apresenta na língua, como quando dizemos mundos e fundos e não universos e profundidades ou mesmo fundos e mundos (TAGNIN, 2005, p. 15).

Linguisticamente, a convencionalidade pode ocorrer em diversos níveis, como o fonético e o morfológico, cujo detalhamento é desnecessário nesta pesquisa; o sintático, que envolve a combinabilidade, ordem e gramaticalidade das palavras que compõem a expressão; o semântico, que trata da relação não motivada entre uma expressão e seu significado, bem como a convencionalização de uma imagem; e o pragmático, que implica a interação entre a situação e a expressão verbal utilizada (TAGNIN, 2005, p. 17-20). Para produzir um discurso natural e fluente, o falante vale-se do que é convencionalmente partilhado em sua comunidade.

As categorias convencionais variam em uma escala que vai daquelas consideradas mais transparentes, como é o caso das colocações, até aquelas tidas como mais opacas, em que conhecer o significado de cada palavra não induz à compreensão do todo. Elencamos abaixo algumas dessas categorias ${ }^{62}$ :

- colocações: upright piano / piano de armário; baking powder / fermento em pó; lie outright / mentir descaradamente;

\footnotetext{
${ }^{60}$ Esse dicionário foi reeditado em 1997 - não observamos o uso de corpus em sua reformulação.

${ }^{61}$ Alguns exemplos: Collins COBUILD English Language Dictionary (1987), o primeiro dicionário monolíngue de língua inglesa baseado em corpus; Oxford Collocations (2002) e Macmillan English Dictionary for Advanced Learners of American English (2002).

${ }^{62}$ As categorias elencadas e todos os exemplos foram retirados de Tagnin (2005). Para mais detalhes, vide a obra na íntegra.
} 
- phrasal verbs: look up, wipe out, do in;

- binômios: heads or tails / cara ou coroa; profit and loss / lucros e perdas; bit by bit / pouco a pouco;

- estruturas agramaticais consagradas: by and large; long time no see; de vez em quando; tanto faz;

- expressões idiomáticas: to beat about the bush / falar com rodeios; to bark up the wrong tree / bater na porta errada; to pour oil on troubled waters / por água na fervura;

- marcadores conversacionais: That's news to me. / Isso é novidade para mim.; Are you following me? / Está me acompanhando?;

- fórmulas situacionais: Cat got your tongue? / O gato comeu sua língua?; Don't jump to conclusions. / Não tire conclusões apressadas.

Sob seus vários aspectos, a convencionalidade e a formulaicidade da língua são temas abordados por vários pesquisadores, dentre os quais podemos mencionar Pawley e Syder (1983); Nattinger e DeCarrico (1992); Celce-Murcia (1995); Prodromou (2003); Tagnin (2005) e Wray (2002, 2008). Alison Wray se destaca no estudo da formulaicidade, que de modo geral é outra forma de referir-se à convencionalidade linguística.

Segundo Wray (2008, p. 3), há opiniões diversas quanto à relação entre formulaicidade e frequência - uma expressão não precisa necessariamente ser frequente para ser formulaica, segundo a autora -, mas com certeza os avanços em LC têm contribuído decisivamente para o estudo de unidades recorrentes formadas por um número variado de palavras. Wray apresenta-nos o termo Morpheme Equivalent Unit (MEU), ou seja, unidade equivalente ao morfema. Segundo a autora (WRAY, 2008, p. 12), essa unidade pode ser definida como

[...] uma palavra ou cadeia de palavras - incompleta ou com "lacunas" onde itens variados podem ser inseridos -, que é processada como um morfema, ou seja, sem a necessidade de se recorrer a qualquer associação de forma-significado que quaisquer de seus elementos venha a conter. (WRAY, 2008, p. 12) ${ }^{63}$

\footnotetext{
63 “[...] a word or word string, whether incomplete or including gaps for inserted variable items, that is processed like a morpheme, that is, without recourse to any form-meaning matching of any sub-parts it may have."
} 
Essas unidades fazem parte do que chama, em um espectro maior, de "sequência formulaica". Enquanto as MEUs tendem a ser frequentes, essas não necessariamente o são. Nessa definição, interessa-nos o fato de que inclui uma sequência de palavras que pode ou não ser completa, abrindo espaço para a inclusão de uma ou mais palavras, e que "funciona" como uma unidade de significado. Além de "sequências formulaicas" cujo significado não pode ser depreendido a partir de suas partes e com as quais possamos deparar durante o levantamento de nossos dados, esta pesquisa visa trabalhar, mais especificamente, com unidades em que o significado das partes é transparente. Além da decodificação, cujo processo pode ficar comprometido quando envolve um falante leigo no assunto - caso de linguagens mais formulaicas como a jurídica -, o problema concentra-se na produção dessas unidades, aspecto que comentaremos na sequência.

É preciso esclarecer que decidimos mencionar Wray (2008) porque ela tece considerações importantes para nossa pesquisa ao mencionar os pressupostos conceptuais nos quais uma MEU se embasa, também importantes para nossa investigação. São eles (WRAY, 2008, p. 12-22):

- o léxico mental é heteromórfico: o material linguístico é armazenado em "pacotes" (bundles) de tamanhos diferentes, que vão desde morfemas a unidades maiores e podem apresentar alguma variação em seus elementos. É certo que nem todas essas unidades são pré-fabricadas - o ser humano tem capacidade para criar novas expressões e/ou manipulá-las da forma que melhor lhe convier;

- o ser humano vale-se dessas unidades de acordo com suas necessidades e motivação (daí a recorrência no uso). A pressão social também o induz a utilizar essas unidades;

- com o uso das MEUs, a comunicação entre falante e ouvinte é facilitada: essas unidades serão privilegiadas quando comparadas ao uso de novas associações. Para atingir seus objetivos, esse falante irá considerar suas próprias necessidades e preferências, mas certamente irá levar em conta as necessidades e expectativas de seu ouvinte.

Wray (2008, p. 21) comenta ainda sobre o uso de "fórmulas opacas", grupo em que inclui os jargões utilizados em linguagens especializadas, e que estão no 
extremo oposto às MEUs tidas como transparentes, também consideradas nesse mesmo grupo. Segundo a autora, essas MEUs mais transparentes, apesar de pertencentes a uma linguagem específica, podem ser um pouco melhor “desempacotadas" e compreendidas pelo ouvinte.

Essas considerações remetem-nos ao princípio idiomático (idiom principle) e ao princípio de livre escolha (open choice principle) colocados por Sinclair (1991). No princípio de livre escolha, o falante restringe-se apenas à gramaticalidade da língua, ou seja, ele é livre para fazer quaisquer associações de palavras, desde que gramaticalmente corretas - ele não embasa necessariamente suas escolhas em aspectos semânticos ou pragmáticos, que certamente restringiriam o uso de uma ou outra palavra, inclusive pelo próprio contexto. O princípio idiomático, por sua vez, é o que geralmente conduz as escolhas do falante. Segundo Sinclair,

[...] [o] falante tem a seu dispor um grande número de sintagmas semi pré-construídos que se constituem em escolhas únicas, apesar de parecerem analisáveis em segmentos. Até certo ponto, isso pode refletir a recorrência de situações semelhantes nas relações humanas, ou ilustrar a tendência natural à lei do menor esforço. Pode também ser em parte motivada pelas exigências do discurso em tempo real. ${ }^{64}$ (SINCLAIR, 1991, p. 110)

Observável na língua geral, entendemos que o princípio idiomático também rege as linguagens especializadas, independente da área a que possamos nos referir. É o que observamos, por exemplo, em receitas culinárias e contratos, permeados de padrões linguísticos que, além de serem típicos dessas áreas, refletem a padronização da própria língua e primam pela "lei do menor esforço", facilitando a comunicação entre os falantes envolvidos em dado discurso. Nesse caso, a dificuldade maior fica para o leigo ou iniciante na área especializada, conforme já comentamos: além da decodificação, a produção desses padrões também revela-se problemática, pelo menos até que o indivíduo se ajuste àquele linguajar.

$\mathrm{Na}$ literatura atual - e aqui ressaltamos a presença de linhas de pesquisa diversas -, encontramos vários termos utilizados para descrever e/ou nomear esses

\footnotetext{
64 " [...] [the] language user has available to him or her a large number of semi-preconstructed phrases that constitute single choices, even though they might appear to be analysabe into segments. To some extent, this may reflect the recurrence of similar situations in human affairs; it may illustrate a natural tendency to economy of effort; or it may be motivated in part by the exigencies of real-time conversation."
} 
diferentes tipos de co-ocorrência ou padronização linguística. Essa heterogeneidade terminológica é comentada por vários pesquisadores, como é o caso de Danielsson (2007, p. 18), que salienta a necessidade de pesquisas futuras nesse sentido.

Para esta investigação, consideramos o conceito de padrão apresentado por Hunston e Francis (2000),

Os padrões de uma palavra podem ser definidos como todas as palavras e estruturas que são frequentemente associadas àquela palavra e que contribuem para o seu significado. Um padrão pode ser identificado quando uma combinação de palavras ocorre com relativa frequência, se depende da escolha de uma dada palavra e se há um significado evidente a ela associado. (HUNSTON; FRANCIS, 2000, p. 37) ${ }^{65}$

Assim como Danielsson (2007), identificaremos os padrões em nossos corpora de estudo baseados na frequência, não restringindo o tamanho ou mesmo a sequencialidade das palavras ou classes gramaticais que compõem as unidades observadas.

Conforme já apontado, não há confluência quanto à terminologia da área, podendo-se observar, inclusive, casos em que um mesmo termo apresenta definições variadas na literatura disponível. Tal fato acaba confundindo o pesquisador, que por sua vez deve deixar claro qual a definição que considera para cada um dos termos utilizados em sua investigação. Em nossa pesquisa, entendemos como colocação uma combinação lexical recorrente e coesa, ou a associação entre o léxico e campos semânticos restritos. Essas recorrências podem ocorrer entre várias classes de palavras, tais como substantivos, verbos, adjetivos e advérbios. Seguindo a terminologia de Hausmann (1985 apud TAGNIN, 1998, p. 4142), Tagnin $(1998,2005)$ apresenta-nos uma tipologia para as colocações, classificando-as em colocações nominais, adjetivas, verbais e adverbiais. Uma vez que nosso foco são os advérbios terminados em -ly e -mente, acabamos por privilegiar as colocações adverbiais, que se dividem em dois grupos: aquelas em que o advérbio modifica o verbo, como em thank profusely (agradecer imensamente); aquelas em que o advérbio modifica o adjetivo, caso de lavishly illustrated (fartamente ilustrado) (TAGNIN, 2005, p. 45).

\footnotetext{
65 "The patterns of a word can be defined as all the words and structures which are regularly associated with the word and which contribute to its meaning. A pattern can be identified if a combination of words occurs relatively frequently, if it is dependent on a particular word choice, and if there is a clear meaning associated with it."
} 
Segundo Cowie (1998, p. 211), o termo colocação foi cunhado por Palmer em 1933, que o definiu como "uma sucessão de duas ou mais palavras que devem ser aprendidas como um todo, e não entendidas a partir das partes que a compõem"66 (PALMER, 1933, p. 5 apud COWIE, 1998, p. 211). Palmer também se preocupou com a subcategorização das colocações, apresentando classificações como colocações verbais, colocações substantivas, colocações adverbiais e colocações preposicionadas $^{67}$ (PALMER, 1933, p. 5 apud COWIE, 1998, p. 211), termos posteriormente retrabalhados por vários outros pesquisadores.

Outro termo também comumente utilizado para referir-se à padronização linguística é coligação. Entendemos como coligação a associação entre itens lexicais e classes gramaticais (BERBER SARDINHA, 2004, p. 40). Podemos citar como exemplo a palavra cases, em inglês, que frequentemente ocorre com a categoria gramatical dos quantificadores, em expressões como in some cases, in many cases, in both cases, etc. (STUBBS, 2001, p. 65).

O terceiro tipo de padrão que gostaríamos de destacar é a prosódia semântica. Conforme já comentado, esse termo refere-se à associação entre itens lexicais e a conotação ou instância avaliativa que uma palavra ou expressão adquire em dado contexto, podendo apresentar-se positiva, negativa ou neutra (BERBER SARDINHA, 2004, p. 40). Como exemplo, podemos citar CAUSE, em inglês, que apresenta prosódia semântica negativa, uma vez que se associa a palavras relacionadas a eventos desagradáveis, tais como problems, death, damage, concern, trouble, cancer e disease. Outro exemplo é PROVIDE (FORNECER seria uma de suas opções de tradução), que ocorre com palavras que denotam coisas desejáveis ou necessárias (information, service(s), support, help, money, protection, food, care) e apresenta prosódia semântica positiva ou neutra (STUBBS, 2001, p. 65). É importante ressaltar que ainda não há consenso entre os autores para a terminologia utilizada. Stubbs (2001), por exemplo, utiliza discourse prosody (prosódia discursiva) para o que Berber Sardinha (2004) define como prosódia semântica. Em artigo publicado em 1997, Hoey (1997, p. 4) define como prosódia semântica o que Stubbs (2001, p. 65) classifica como preferência semântica. Em artigo posterior, Hoey (2003, p. 6) utiliza o termo associação semântica (semantic

\footnotetext{
66 "[...] a succession of two or more words that must be learned as an integral whole, and not pieced together from its component parts."

${ }^{67}$ Verb-collocations, Noun-collocations, Adverb-collocations, Preposition-collocations.
} 
association) para definir a tendência que uma palavra tem de pertencer a um grupo ou classe semântica, cujos elementos podem apresentar-se como seus colocados. O autor coloca, inclusive, que esse fenômeno também é descrito como prosódia semântica e preferência semântica na literatura disponível, além de associação semântica. Nesta pesquisa, adotaremos o termo prosódia semântica segundo a definição apresentada por Berber Sardinha (2004, p. 40) e preferência semântica para o que Stubbs (2001, p. 65) define como a relação entre lemas (ou sua realização em diferentes formas) e um dado grupo de palavras semanticamente relacionadas. Segundo esse autor (Stubbs, 2001, p. 88), preferência semântica refere-se a uma classe de palavras que compartilham determinadas características semânticas, como é o caso de COMETER, que geralmente co-ocorre com palavras semanticamente relacionadas como crime, adultério e suicídio. Não dizemos que um padre "cometeu" um casamento, a não ser que queiramos justamente quebrar a convencionalidade linguística e trazer o aspecto negativo ao contexto, numa avaliação jocosa da situação (MORAES, 2005, p. 24). Outro exemplo é large, frequentemente encontrada com palavras relacionadas a quantidade e tamanho, tais como number(s), scale, part, amounts, quantities e area(s).

Como unidades maiores de significado (extended units of meaning), entendemos os padrões que vão muito além da recorrência entre duas palavras também chamada de core unit (unidade de base), como é o caso de uma colocação adjetiva, por exemplo -, e que pode envolver outras escolhas nos níveis lexical, gramatical e/ou semântico, de forma co-dependente. Essas escolhas "ampliam" a unidade em seu contexto de uso. Tognini-Bonelli (2001, p. 104) e Stubbs (2001, p. 108) comentam os achados de Sinclair (1996b) a partir da colocação naked eye. Stubbs (2001, p. 108) aponta várias co-ocorrências que confirmam as observações de Sinclair, ou seja, de que naked eye é geralmente precedida de the, co-ocorre com verbos modais e verbos lexicais que indicam visão e palavras que expressam dificuldade para enxergar. Eis alguns exemplos:

- just large enough to see with the naked eye

- so small that it couldn't be seen by the naked eye

- bones so tiny that the naked eye has great difficulty in finding them unaided

- can be read, some with the naked eye, others only under magnification

- microscopic hairs, invisible to the naked eye. Each hair is so tiny 
that it can only be seen... (STUBBS, 2001, p. 108)

Como coloca Danielsson (2007, p. 23), observamos que quanto maior a unidade, maior sua especificidade num contexto de uso, fato que certamente iremos investigar em nossa pesquisa.

Outro termo também importante é "unidade de significado funcionalmente equivalente" (functionally equivalent unit of meaning), que utilizamos para tratar a questão da equivalência no par de línguas inglês-português. No artigo intitulado Welcoming children, pets and guests: towards functional equivalence in the languages of 'Agriturismo' and 'Farmhouse Holidays', Tognini-Bonelli e Manca (2004) apresentam um estudo sobre como chegaram a unidades funcionalmente equivalentes entre o inglês e o italiano, nas áreas mencionadas no título. A partir da tradução prima facie dos colocados da palavra welcome, ou seja, children, pets e guests, que por sua vez integravam unidades maiores de significado, chegaram a essa equivalência funcional. Nesse processo, foi também primordial a análise do contexto de cada um desses elementos. As autoras apontam, inclusive, que ter o equivalente prima facie de uma palavra em ambas as línguas não implica, considerando-se o contexto de uso e o fato de que integra uma unidade maior, que elas sejam correspondentes. Foi exatamente o que ocorreu nesse estudo, que apresentou 324 ocorrências de welcome no corpus em inglês e apenas 4 de benvenuto no corpus em italiano. Além de questões léxico-gramaticais, há também aspectos semânticos, pragmáticos, culturais e até mesmo ideológicos a serem considerados no processo tradutório. Daí a necessidade de se buscar unidades que realmente "funcionem" em ambas as línguas. Segundo as autoras,

A evidência em corpus oferece-nos uma forma privilegiada de começar a análise, uma vez que permite examinar simultaneamente as dimensões sintagmática e paradigmática do significado. Tentamos demonstrar que a equivalência funcional só pode ser identificada através da comparação de possíveis ETs [Equivalentes Tradutórios] quando observamos sua padronização sintagmática juntamente com as associações paradigmáticas nas duas línguas. (TOGNINI-BONELLI; MANCA, 2004, p. 311)

\footnotetext{
68 "Corpus evidence gives us a privileged start by allowing us to examine simultaneously the syntagmatic and paradigmatic dimensions of meaning. We have tried to show that functional equivalence can only be identified by the comparison of possible TEs [Translation Equivalents] in the presence of their syntagmatic patterning and their paradigmatic associations in the two languages."
} 
Michael Hoey (2005) também trata da questão da padronização linguística sob outra perspectiva, ou seja, a do priming lexical. A nosso ver, essa teoria vem ao encontro de nossa pesquisa: a partir de uma palavra, gramaticalmente tida como pertencente à classe dos advérbios, decidimos observar seu entorno e verificar suas "preferências", ou seja, as co-ocorrências que privilegia ao ser utilizada. Um corpus seria, a nosso ver, uma forma adequada para reunir esses primings de vários indivíduos e assim observar a língua em uso. Segundo Hoey (2005, p. 13), toda palavra "prima" por alguma co-ocorrência:

- na co-ocorrência com determinadas palavras, estamos diante de seus colocados;

- em um determinado campo semântico, temos suas associações semânticas;

- ao associar-se a funções pragmáticas específicas, temos suas associações pragmáticas;

- ao ocorrer em determinadas posições ou funções gramaticais, temos suas coligações (a sua não ocorrência em determinadas associações também deve ser observada);

- quando representa diferentes classes gramaticais, estamos diante de suas categorias gramaticais.

Hoey (2005, p. 13) coloca as associações da palavra também em nível discursivo:

- quando apresenta determinadas relações de coesão em um discurso, temos suas colocações textuais;

- quando apresenta relações semânticas específicas, suas associações semânticas textuais;

- quando é utilizada em trechos específicos do discurso, suas coligações textuais.

O autor enfatiza, ainda, que não se deve fazer generalizações quando tratamos dos co-hipônimos e sinônimos, bem como das palavras consideradas polissêmicas, uma vez que podem apresentar colocações, coligações e associações semânticas próprias (HOEY, 2005, p. 13). 
Diante dessas considerações de nível teórico, partimos do léxico em geral e voltamos nosso olhar para as linguagens especializadas. Nesse processo, observamos que as palavras tendem a se ajustar a novos contextos, estabelecendo novas (e diferentes) associações ao serem utilizadas em determinada tipologia textual. Mesmo palavras que apresentam associações diversas em língua geral, como é o caso do verbo amass citado por Hanks (2008, p. 222), podem apresentar restrições quando utilizadas em um contexto mais específico. Segundo o autor (HANKS, 2008), amass é utilizada para denotar a quantidade de uma infinidade de coisas, podendo ocorrer com palavras como land, wealth, debts, information, ideas, flowers, an army, etc. No entanto, apresenta uso mais restrito quando ocorre com o substantivo goals. Essa co-ocorrência - amass goals - é encontrada apenas em comentários esportivos, e geralmente em frases que trazem um número cardinal ou expressão de quantidade, como é o caso de enough. Quando usada, significa que um indivíduo somou um determinado número de gols em sua carreira como jogador de um determinado esporte, por exemplo. Em nossa pesquisa, procuraremos observar se essa adequação, ou melhor, restrição de uso, ocorre com os advérbios.

Para concluir, e retomando a questão dos termos utilizados nesta pesquisa, gostaríamos de salientar que, durante a análise de nossos dados, utilizamos alguns deles de forma mais generalizada para referirmo-nos à associação entre palavras e/ou classes gramaticais - obviamente aqueles que permitem fazê-lo. Decidimos proceder dessa forma para evitar a repetição exagerada de alguns desses termos ao longo do texto. Considerando-se a frequência de co-ocorrência, utilizamos: padrões linguísticos, associação, co-ocorrência (lexical), colocação, unidade, fraseologia, fraseologismo, unidade maior de significado (quando tratamos de unidades com três ou mais palavras que podem incluir classes gramaticais), coligação (mais especificamente para nos referirmos à associação entre itens lexicais e classes gramaticais), associações lexicais, clusters, bundles, agrupamentos, etc.

No próximo capítulo, apresentamos os corpora, as ferramentas e a metodologia utilizados para o levantamento e posterior análise de nossos dados. 


\section{Capítulo II - Materiais e métodos}

Para iniciar este capítulo, esclareceremos primeiramente o que entendemos por corpus de estudo e corpus de referência, para em seguida detalharmos os corpora utilizados em nossa investigação.

Segundo Berber Sardinha (2004, p. 21), as nomenclaturas corpus de estudo e corpus de referência referem-se à finalidade a que se destinam. O primeiro é o corpus que se pretende descrever, ou seja, é aquele que será investigado; o segundo é utilizado para fins de contraste com o primeiro, ou seja, os dados encontrados em um corpus de estudo serão comparados àqueles que fazem parte desse corpus maior (o de referência), com o objetivo de se observar suas peculiaridades. Berber Sardinha salienta que o corpus de referência não deve conter o corpus de estudo, apontando duas razões para isso: a primeira refere-se aos valores absolutos, uma vez que a soma das freqüências tende a obscurecer aquelas mais salientes no corpus de estudo, o que não evidenciaria as palavras-chave de forma adequada. A segunda refere-se às freqüências relativas, uma vez que a soma das porcentagens de ocorrência de um item no corpus de estudo e no de referência pouco alteraria a sua probabilidade de ser considerada uma palavra-chave, caso geralmente observado em palavras com poucas ocorrências no corpus de estudo. Outro fato importante é a composição desse corpus de referência, uma vez que ela influenciará os tipos de palavras que podem se tornar chave em uma pesquisa ${ }^{69}$. Dessa forma, um corpus de referência geral, que inclua vários gêneros, é considerado a escolha não-marcada para o levantamento de palavras-chave de um corpus de estudo. Uma última questão é o tamanho, que influencia a quantidade de palavras-chave obtidas: recomenda-se que um corpus de referência seja pelo menos cinco vezes maior do que o corpus de estudo (BERBER SARDINHA, 2004, p. 100-102).

Os corpora de estudo definidos para esta pesquisa - um de Culinária e outro de Direito Contratual - foram criteriosamente compilados pelas pesquisadoras Elisa Duarte Teixeira e Luciana Carvalho Fonseca, em sua tese de Doutorado e dissertação de Mestrado, respectivamente. Teixeira (2008) trabalhou com a

\footnotetext{
${ }^{69}$ Tal fato será melhor esclarecido em 2.5, quando explicitarmos as ferramentas disponíveis no software WordSmith Tools (SCOTT, 2007).
} 
Culinária, enfocando o tipo textual: receitas; Carvalho Fonseca (2007) compilou um corpus na área do Direito, mais especificamente de Instrumentos Contratuais. Como corpora de referência, utilizaremos o British National Corpus (BNC) para o inglês e o Banco de Português (BP) para o português. A seguir, apresentaremos uma descrição desses quatro corpora.

\section{1 o corpus de estudo da Culinária (Receitas)}

No planejamento para a compilação de seu corpus de estudo, Teixeira (2008, p. 206-209) deixa claro que sua intenção não é fazer Terminologia, ou seja, buscar termos, conceitos e definições na área da Culinária, mas sim identificar e registrar Unidades de Tradução Especializadas - Teixeira trabalha na interface Linguística de Corpus/Tradução -, que refletem a padronização em textos técnicos ${ }^{70}$. Os objetivos da pesquisa devem ser considerados desde sua fase inicial, ou seja, desde antes da coleta do material a ser investigado. Nesse caso, a autora optou por trabalhar com receitas culinárias por constituírem o tipo textual mais representativo e de maior circulação na área técnica em questão. Como um de nossos objetivos é também trabalhar com a padronização linguística, com foco no uso dos advérbios, decidimos utilizar esse material já compilado como nosso corpus de estudo, gentilmente cedido pela autora. Os critérios e metas abaixo descritos foram inicialmente considerados para a coleta:

\begin{tabular}{|l|l|}
\hline \multicolumn{1}{|c|}{ Critérios } & \multicolumn{1}{c|}{ Metas } \\
\hline língua & $\begin{array}{l}\text { bilíngue (português brasileiro e inglês, especialmente as variantes } \\
\text { americana e britânica) }\end{array}$ \\
\hline organização interna & comparável (textos originalmente escritos em português e em inglês) \\
\hline tamanho & médio-grande (cerca de 1 milhão de palavras em cada língua) \\
\hline meio & $\begin{array}{l}\text { textos escritos (escritos para serem lidos), preferencialmente } \\
\text { provenientes de livros ou sites confiáveis de culinária }\end{array}$ \\
\hline gênero & $\begin{array}{l}\text { culinária caseira / semi-profissional: pratos doces e salgados, de } \\
\text { todas as categorias (sobremesas, salgadinhos, saladas, sanduíches, } \\
\text { massas, carnes, etc.) - evitar receitas nomeadamente "regionais", } \\
\text { "internacionais" e de bebidas }\end{array}$ \\
\hline
\end{tabular}

\footnotetext{
${ }^{70}$ Para mais detalhes, vide a tese na íntegra. Disponível em: http://www.teses.usp.br/teses/disponiveis/8/8147/ tde-16022009-141747
} 


\begin{tabular}{|l|l|}
\hline autoria & $\begin{array}{l}\text { a mais variada possível; coletar somente receitas, no caso de sites, } \\
\text { que se supõe serem escritas por falantes nativos e terem passado } \\
\text { por algum trabalho de revisão / edição (caso sejam enviadas por } \\
\text { internautas, por exemplo) }\end{array}$ \\
\hline tipologia textual & $\begin{array}{l}\text { receitas caseiras/semi-profissionais, de preferência as que têm a } \\
\text { lista de ingredientes separada do modo de preparo }\end{array}$ \\
\hline data de publicação & $\begin{array}{l}\text { se for possível identificar a data de publicação, coletar receitas } \\
\text { escritas após a década de 1990 (após a intensificação da } \\
\text { globalização na Culinária) }\end{array}$ \\
\hline nível de codificação & $\begin{array}{l}\text { se possível, colocar cabeçalho em todos os textos e identificar as } \\
\text { partes da receita (título, comentários iniciais, lista de ingredientes, } \\
\text { modo de fazer e categorizações) com etiquetas; etiquetagem } \\
\text { morfossintática a ser feita posteriormente }\end{array}$ \\
\hline
\end{tabular}

Quadro 1 - Critérios iniciais apresentados pela autora (em forma de tabela) para a coleta do corpus de receitas culinárias (TEIXEIRA, 2008, p. 209)

Em sua maioria, os dados foram coletados de modo automático na Internet, utilizando-se o offline browser WinHTTrack Website Copier 3.30; os textos foram limpos e salvos em .txt para que assim pudessem ser manuseados com o software WordSmith Tools, uma das ferramentas utilizadas pela autora (TEIXEIRA, 2008, p. 209-211).

$\mathrm{O}$ anexo A desta tese apresenta dois quadros baseados naqueles compilados por Teixeira (2008, p. 366-368), que detalham informações sobre os corpora formados por textos em inglês e em português, na área da Culinária (tipologia das receitas). A compilação desse material demonstra a amplitude e a importância da pesquisa desenvolvida por Teixeira (2008) e, principalmente, o alto grau de confiabilidade nos dados utilizados para nossa investigação.

Segundo Teixeira (2008, p. 214), o corpus em inglês totaliza 1.578 .125 ocorrências (tokens), 14.619 formas (types) e uma razão forma/ocorrência (type/token ratio) de 0,93. Em português, são 1.581.260 ocorrências (tokens), 13.443 formas (types) e uma razão forma/ocorrência (type/token ratio) de 0,85 (TEIXEIRA, 2008 , p. 217). No entanto, gostaríamos de comentar que, ao manusearmos os corpora com a versão 5.0 do programa WordSmith Tools (SCOTT, 2007) - Teixeira trabalhou com uma versão anterior, a 3.0 (TEIXEIRA, 2008, p. 362) - observamos algumas diferenças nos números apresentados que, no entanto, não comprometem nossa investigação e permitem que continuemos a utilizar os dados da tese de Teixeira (2008) como referência. Os números que encontramos ao manusear os corpora com a versão 5 do programa WordSmith Tools são: 
Tabela 3 - Corpus de estudo da Culinária (Receitas)

\begin{tabular}{|l|c|c|c|}
\hline \multicolumn{1}{|c|}{ Corpus } & $\begin{array}{c}\text { no. de ocorrências } \\
\text { (tokens) }\end{array}$ & $\begin{array}{c}\text { no. de formas } \\
\text { (types) }\end{array}$ & $\begin{array}{c}\text { razão forma/ocorrências } \\
\text { (type/token ratio) }\end{array}$ \\
\hline Inglês (geral) & 1.716 .496 & 13.880 & 0,93 \\
\hline Português (geral) & 1.590 .969 & 13.765 & 0,93 \\
\hline
\end{tabular}

A título de exemplificação e para referência durante a pesquisa, apresentamos abaixo duas receitas com etiquetas utilizadas para identificar suas partes. Essas etiquetas foram criadas e classificadas por Tagnin e Teixeira como pragmáticas ou discursivas (TAGNIN; TEIXEIRA, 2004, p. 329). São elas:

- $<$ titRec $>$ título da receita <titRec $>$

- <coment> comentários do autor da receita, como "ótima para os dias quentes de verão" <coment>

- <ingr> lista de ingredientes <ingr>

- <modFaz> descrição dos procedimentos da receita <modFaz>

- <class> informações dadas pela receita quanto ao rendimento, tipo de prato, valor nutricional, tempo de preparo, custo, etc. <class>

Abaixo, as receitas (inglês e português) obtidas em nosso corpus de estudo:

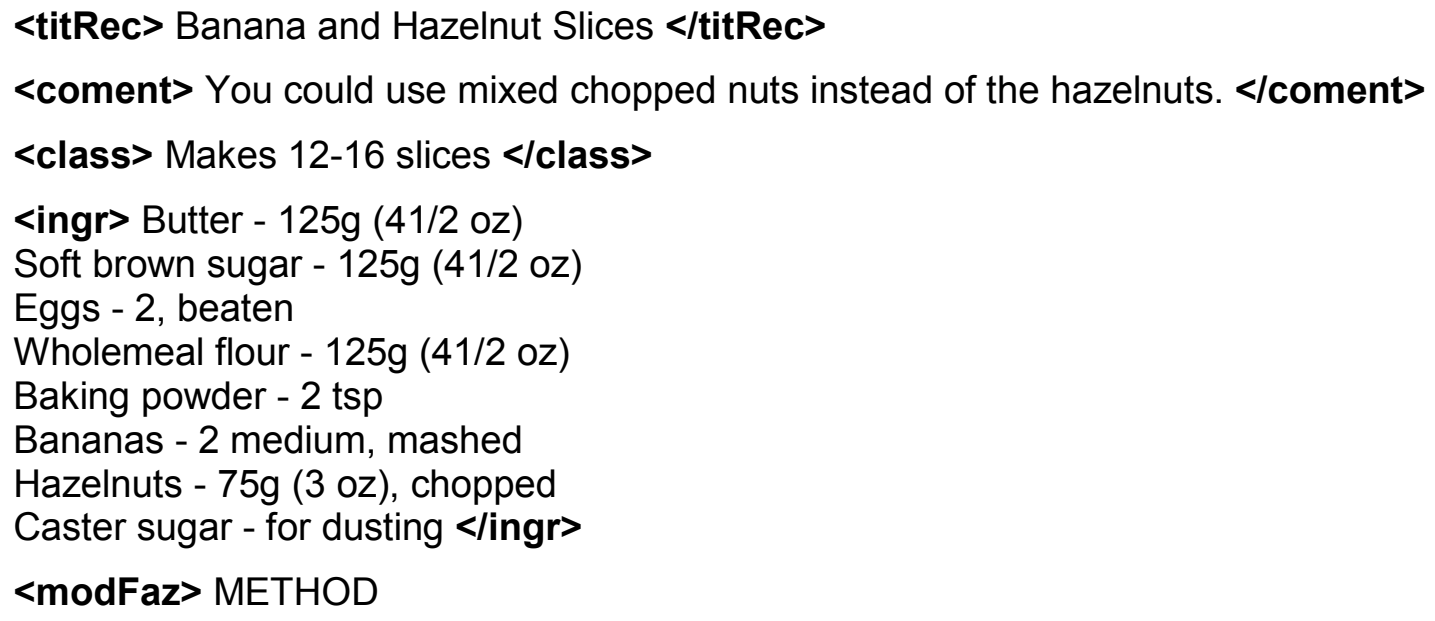
the eggs gradually along with the flour.

2. Add the baking powder, then the bananas and nuts. Fold well until thoroughly mixed.

3. Spread the mixture into a greased $20 \mathrm{~cm}$ (8 inch) square shallow tin. Bake in the oven for 20-25 minutes until golden.

4. Leave in the tin for about 3 minutes then cut into slices (about 12-16) and transfer to a wire rack to cool. Dust with caster sugar. </modFaz> 


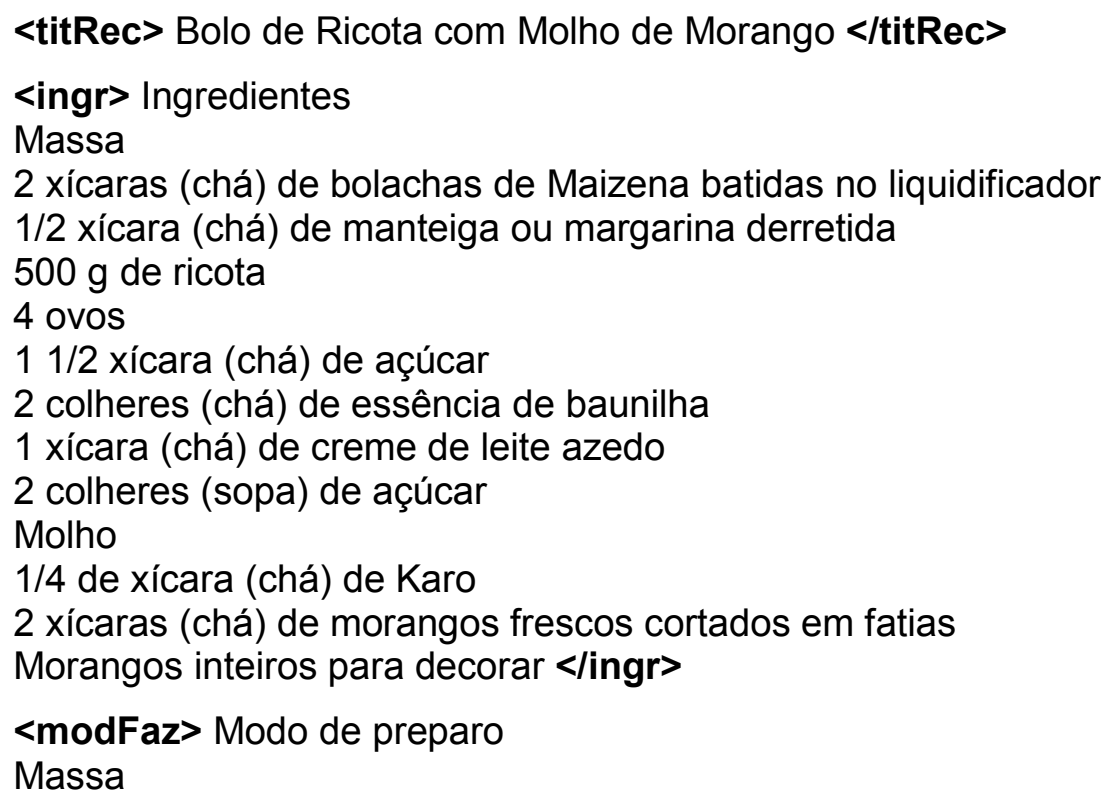
forma redonda e aperte bem no fundo e nos lados. Numa tigela, bata a ricota até obter um creme, junte os ovos, o açúcar e 1 colher (chá) de baunilha. Continue batendo até que o creme fique leve e espumoso. Espalhe sobre a mistura de bolacha e leve ao forno durante aproximadamente 25 minutos. Reserve. Numa tigela misture o creme de leite azedo, o açúcar e a baunilha restante e espalhe cuidadosamente sobre o bolo morno. Leve à geladeira por pelo menos 3 horas.

Molho

Coloque o Karo numa panela, leve ao fogo e deixe levantar fervura. Junte o morango e cozinhe por mais 1 minuto. Deixe esfriar e sirva com as fatias de bolo. Decore com morangos.

Obs: para azedar o creme de leite, basta misturá-lo com 1 colher (sopa) de suco de limão e deixar repousar um pouco. $</$ modFaz $>^{71}$

\subsection{O corpus de estudo do Direito (Instrumentos Contratuais)}

Quando de sua elaboração, a autora visava, em linhas gerais,

estudar os binômios que ocorrem em contratos de common law à luz da Lingüística de Corpus, procurando dar subsídios que auxiliem os tradutores de textos jurídicos a chegar a uma tradução natural, ou seja, para que traduzam linguagem jurídica por linguagem jurídica. (CARVALHO FONSECA, 2007, resumo)

\footnotetext{
${ }^{71}$ Os sinais de maior $(>)$ e menor $(<)$ são utilizados para delimitar o conteúdo da etiqueta e viabilizar a análise por meio de software específicos, como é o caso do WordSmith Tools. Além desses sinais, utiliza-se a barra (/) para indicar o fechamento da etiqueta utilizada.
} 
Para isso, Carvalho Fonseca compilou um corpus comparável de Instrumentos Contratuais - assunto: Direito Contratual, composto por textos originais em inglês e em português, apresentado brevemente na tabela abaixo.

Tabela 4 - Corpus de estudo do Direito (Instrumentos Contratuais)

\begin{tabular}{|l|c|c|c|c|}
\hline \multicolumn{1}{|c|}{ Corpus } & $\begin{array}{c}\text { no. de } \\
\text { textos }\end{array}$ & $\begin{array}{c}\text { no. de } \\
\text { ocorrências } \\
\text { (tokens) }\end{array}$ & $\begin{array}{c}\text { no. de formas } \\
\text { (types) }\end{array}$ & $\begin{array}{c}\text { razão forma/ } \\
\text { ocorrência } \\
\text { (type/token } \\
\text { ratio) }\end{array}$ \\
\hline $\begin{array}{l}\text { Direito (Instrumentos } \\
\text { Contratuais) - Inglês }\end{array}$ & $\begin{array}{c}140 \\
(28 \text { tipos) }\end{array}$ & 648.648 & 10.243 & $1,58 \%$ \\
\hline $\begin{array}{l}\text { Direito (Instrumentos } \\
\text { Contratuais) - Português }\end{array}$ & $\begin{array}{c}140 \\
(28 \text { tipos) }\end{array}$ & 279.923 & 11.465 & $4,10 \%$ \\
\hline
\end{tabular}

Em uma análise inicial, é evidente a grande diferença no número de ocorrências entre o corpus de inglês e o de português. Quanto a isso, a autora (CARVALHO FONSECA, 2007) esclarece que a extensão dos instrumentos contratuais em inglês deve-se ao sistema jurídico utilizado nos Estados Unidos, no qual, em regra, não se adotam normas subsidiárias de aplicação geral como no sistema jurídico brasileiro. No sistema da common law, "há uma tentativa de prever o maior número de situações possível com base na jurisprudência que, ao contrário de leis e códigos, normalmente é esparsa" (CARVALHO FONSECA, 2007, p. 77) - é um sistema casuístico. Já o sistema brasileiro, que é de origem romano-germânica, funda-se sobre princípios estabelecidos pela legislação, conservando certas vantagens de simplicidade e clareza.

Segundo Carvalho Fonseca (2007, p. 72-73), as relações jurídicas são mais dinâmicas e intensas nos Estados Unidos, o que se reflete na maior disponibilidade de instrumentos contratuais na Web em inglês do que em português. Tal fato colaborou para que a pesquisadora encontrasse dificuldades em coletar dados e balancear seu corpus de estudo, o que foi contornado com a revisão dos critérios estabelecidos. Em um primeiro momento, Carvalho Fonseca tinha como objetivo compilar um corpus de tamanho médio a médio-grande (BERBER SARDINHA, 2004, p. 26), com um total de 1 milhão de palavras distribuídas em aproximadamente 260 documentos. Durante o levantamento, no entanto, observou que o corpus em inglês

\footnotetext{
${ }^{72}$ Segundo Berber Sardinha (2004, p. 95), as opções de tradução são: tokens = número de itens (ou ocorrências); types $=$ número de formas (ou vocábulos). Para type/token ratio, adotamos razão forma/ocorrência .
} 
crescia rapidamente à medida em que os documentos eram coletados, o que não ocorria em português - mesmo com um número significativamente maior de documentos nessa língua, o número de palavras permanecia baixo (CARVALHO FONSECA, 2007, p. 66-68). Dessa forma, a autora decidiu revisitar esses critérios e optou por balancear seu corpus de estudo pelo número de textos e tipologia textual, que são idênticos - 140 textos, com 28 diferentes tipos de contrato em cada língua portanto, cinco textos para cada tipo. Esse número foi estabelecido aleatoriamente, mas diversas vezes a autora teve que recorrer a contratos impressos por não encontrar número suficiente disponível na $W e b$, sua primeira fonte de busca (CARVALHO FONSECA, 2007, p. 71) ${ }^{73}$.

Ao retomarmos a tabela acima e considerando-se os diferentes tamanhos dos subcorpora estudados, outro fato que nos chama a atenção é o número de formas (types). Mesmo com a discrepância observada (o número de ocorrências em inglês é mais do que o dobro daquele apresentado em português), o número de formas (types) manteve-se relativamente estável, com 10.243 palavras diferentes em inglês e 11.465 em português, o que corrobora a afirmação de que os subcorpora estão balanceados. Para melhor entendimento, o número de formas (types) difere do número de ocorrências (tokens) no sentido de que o primeiro refere-se aos vocábulos distintos que ocorrem em dado corpus, enquanto o segundo registra o total de ocorrências, independente da repetição desses vocábulos. Exemplificamos com a frase: "Enquanto minha mãe lavava a louça, minha tia arrumava a mesa.", que possui 11 ocorrências - Enquanto(1) minha(2) mãe(3) lavava(4) a(5) louça(6), minha(7) tia(8) arrumava(9) a(10) mesa(11). - e 9 formas: Enquanto(1) minha(2) mãe(3) lavava(4) a(5) louça(6), minha tia(7) arrumava(8) a mesa(9). Observe-se que os vocábulos minha e a aparecem duas vezes e são registrados apenas uma vez, ou seja, referem-se a uma única forma. Em um corpus, esse índice é interessante para observarmos se há um grande número de palavras repetidas ou se ele é lexicalmente mais denso. Obviamente, há que se considerar o tamanho de cada corpus: quanto maior, mais chances de repetição, o que se refletirá na razão forma/ocorrência (type/token ratio), obtida pela divisão do total de formas pelo total de ocorrências. No programa WordSmith Tools - ferramenta Wordlist (SCOTT, 2007), esse valor é transformado em porcentagem, dividindo-se o total de formas

\footnotetext{
${ }^{73}$ Para mais detalhes sobre o processo de compilação, vide a dissertação na íntegra (CARVALHO FONSECA, 2007). Disponível em http://www.teses.usp.br/teses/disponiveis/8/8147/tde-06112007-110242
} 
pelo total de ocorrências divididos por cem. No exemplo acima teríamos, então, $9 \div$ $(11 \div 100)=81.81 \%$. A razão forma/ocorrência indica a riqueza lexical de um texto: quanto maior, mais palavras distintas o texto contém. Já um número menor indica mais repetições de uma mesma palavra, o que pode indicar um texto menos rico ou variado, em termos de vocabulário (BERBER SARDINHA, 2004, p. 94).

Nos dados acima apresentados, observamos que há uma grande diferença entre os subcorpora em estudo: o de inglês é pouco mais de duas vezes maior que o de português, o que certamente influenciará a razão forma/ocorrência (type/token ratio), sensível à extensão do corpus. Diante disso, optamos por observar também a razão forma/ocorrência padronizada (standardized type/token ratio), que faz o cálculo dessa razão em intervalos regulares (por partes do texto) e depois tira a média dos valores forma/ocorrência entre os vários trechos (BERBER SARDINHA, 2004, p. 95). A partir desses dados, podemos tecer comentários mais específicos e comparar a riqueza vocabular entre as duas línguas em nosso corpus de estudo. Em inglês, a razão forma/ocorrência padronizada é de 30,69\%, enquanto em português temos $37,03 \%$. Dessa forma, podemos nos certificar de que, mesmo sendo o subcorpus de português lexicalmente mais rico que o de inglês, essa diferença não é tão alarmante quanto aquela observada na razão forma/ocorrência apresentada no quadro acima (inglês $=1,58 \%$; português $=4,10 \%$ ).

Quanto à tipologia textual, a autora primeiramente definiu que trabalharia com contratos, sendo os tipos definidos de acordo com o material disponível na Web. Inclusive, alguns foram eliminados (como é o caso de hedging e swap, existentes em ambos os sistemas jurídicos) por serem encontrados em abundância em uma língua e não na outra. Abaixo, os 28 tipos contratuais definidos e as respectivas abreviaturas utilizadas para nomear os arquivos, de cinco em cinco com a numeração 01 a 05 ao final de cada abreviatura, gravados individualmente em .txt para viabilizar o manuseio com o software WordSmith Tools (SCOTT, 2007).

\begin{tabular}{|c|l|}
\hline Abreviatura & \multicolumn{1}{c|}{ Tipo contratual } \\
\hline ACC & Acordo de acionistas \\
\hline ADJ & Procuração ad judicia e serviços de consultoria jurídica \\
\hline BAN & Contrato de prestação de serviços bancários \\
\hline CCC & Contrato de cartão de crédito \\
\hline CCV & Contrato de compra e venda \\
\hline CMP & Contrato de compromisso e transação \\
\hline CPC & Contrato de compromisso de compra \\
\hline
\end{tabular}




\begin{tabular}{|c|l|}
\hline CSO & Contrato social \\
\hline CSS & Contrato de cessão \\
\hline DEP & Contrato de depósito \\
\hline DOA & Contrato de doação \\
\hline EMP & Contrato de empréstimo \\
\hline FOR & Contrato de fornecimento \\
\hline FQA & Contrato de franquia \\
\hline GAR & Contrato de garantia real e pessoal \\
\hline GRP & Contrato de garantia de produto \\
\hline LIC & Contrato de licença de uso de software \\
\hline LOC & Contrato de locação de bem imóvel \\
\hline LOM & Contrato de loçção de bem móvel \\
\hline MED & Contrato de assistência médica \\
\hline PSC & Contrato de prestação de serviços de consultoria \\
\hline PSP & Contrato de prestação de serviços profissionais \\
\hline PST & Contrato de prestação de serviços de tradução e interpretação \\
\hline PUB & Contrato para publicação de obra \\
\hline REP & Contrato de representação comercial \\
\hline SGV & Contrato de seguro de vida \\
\hline SIG & Contrato de sigilo \\
\hline TRA & Contrato de trabalho \\
\hline Quadro 2 - Tipos contratuais que compõem o corpus de estudo no Direito (Instrumentos Contratuais) \\
\multicolumn{2}{|l}{} \\
\hline
\end{tabular}

Essas abreviaturas foram utilizadas para os arquivos nas duas línguas - 0 que os diferenciou foi a sigla PO (Português Original) para o português e IO (Inglês Original) para o inglês, colocadas antes da abreviatura de cada tipo de contrato. Dessa forma POACC01, por exemplo, significa Português Original (língua) Acordo de Acionistas (tipo contratual) texto 01. Apresentamos abaixo dois exemplos do tipo Procuração ad judicia e serviços de consultoria jurídica, em inglês e em português:

\section{POWER OF ATTORNEY}

KNOW ALL MEN BY THESE PRESENTS: [individual], hereinafter referred to as PRINCIPAL, in the County of State of __ do(es) appoint [individual] his (her) true and lawful attorney. In principal's name, and for principal's use and benefit, said attorney is authorized hereby; (1) To demand, sue for, collect, and receive all money, debts, accounts, legacies, bequests, interest, dividends, annuities, and demands as are now or shall hereafter become due, payable, or belonging to principal, and take all lawful means, for the recovery thereof and to compromise the same and give discharges for the same; (2) To buy and sell land, make contracts of every kind relative to land, any interest therein or the possession thereof, and to take possession and exercise control over the use thereof; (3) To buy, sell, mortgage, hypothecate, assign, transfer, and in any manner deal with goods, wares and merchandise, choses in action, certificates or shares of capital stock, and other property in possession or in action, and to make, do, and transact all and every kind of business of whatever nature; (4) To execute, acknowledge, and deliver contracts of sale, escrow instructions, deeds, leases including leases for minerals and hydrocarbon substances and assignments of leases, covenants, agreements and assignments of 
agreements, mortgages and assignments of mortgages, conveyances in trust, to secure indebtedness or other obligations, and assign the beneficial interest thereunder, subordinations of liens or encumbrances, bills of lading, receipts, evidences of debt, releases, bonds, notes, bills, requests to reconvey deeds of trust, partial or full judgments, satisfactions of mortgages, and other debts, and other written instruments of whatever kind and nature, all upon such terms and conditions as said attorney shall approve. Giving and granting to said attorney full power and authority to do all and every act and thing whatsoever requisite and necessary to be done relative to any of the foregoing as fully to all intents and purposes as principal might or could do if personally present. All that said attorney shall lawfully do or cause to be done under the authority of this power of attorney is expressly approved. Dated: /s/

\section{PROCURAÇÃO \\ OUTORGANTE: \\ OUTORGADO(S): Dr. \\ número \\ sob 0 n \\ OAB/DF sob o $\mathrm{n}^{\circ}$ \\ OAB/DF sob o $n^{\circ}$ \\ $\mathrm{OAB} / \mathrm{DF}$ sob o $\mathrm{n}^{\circ}$ \\ $\mathrm{OAB} / \mathrm{DF}$ sob o $\mathrm{n}^{\circ}$ \\ $O \mathrm{n}^{\circ}$ - Ed. Dr. Dr. , Dr. Dr. e os estagiários e brasileiro casado, advogado, inscrito na OAB-DF sob o brasileiro, casado, advogado, inscrito na OAB/DF brasileiro, divorciado, advogado, inscrito na brasileiro, solteiro, advogado inscrito na brasileiro, solteiro, advogado inscrito na , brasileiro, solteiro, inscrito na brasileiro, solteiro, inscrito na OAB/DF sob ambos com escritório profissional situado na SEP/Norte - - Bloco CEP , Brasília -DF.}

PODERES: Os da cláusula "ad judicia et extra", para representar o outorgante perante qualquer juízo, Instância ou Tribunal, dando amplos poderes para desistir, renunciar direitos, transigir, firmar compromissos ou acordo, receber e dar quitação, levantar quantias depositadas em juízo, depósitos judiciais e administrativos, desentranhar títulos e documentos, receber os autos em definitivo, requerer expedição de alvarás, substabelecer com ou sem reservas e especialmente para no processo $n^{\circ}$

Brasília - DF, de de 2004.

Outorgante

Passemos agora aos corpora de referência, essenciais para a identificação dos advérbios tidos como palavras-chave nos corpora de estudo, assunto que será abordado ainda neste capítulo.

\subsection{Os corpora de referência: British National Corpus e Banco de Português}

O British National Corpus, também conhecido como BNC, é um corpus fechado de língua geral em inglês e foi definido como corpus de referência para essa língua em nossa pesquisa. Utilizamos a lista de palavras desse corpus 
disponibilizada por Mike Scott (http://www.lexically.net/wordsmith) para chegarmos às palavras-chave (vide item 2.5, onde explicamos como obtê-las) e a interface desenvolvida por Mark Davies, abaixo explicitada, para consulta durante nossa investigação, quando necessário.

O BNC é denominado fechado porque não permite a inserção de novos textos, e tradicional porque foi compilado para a investigação linguística seguindo determinados critérios em sua elaboração, cujo detalhamento foge ao escopo deste trabalho $^{74}$.

Em linhas gerais, o BNC é um corpus sincrônico de 100 milhões de palavras de inglês contemporâneo britânico, tanto falado quanto escrito. É formado por 4.124 textos, subdivididos em um corpus falado (915 textos transcritos, cujo número de palavras representa $10 \%$ do BNC) e um corpus escrito (3.209 textos, que compõem os outros $90 \%$ ). Os textos escritos foram selecionados de acordo com três critérios independentes: o domínio, o período e o meio de publicação. O domínio refere-se à tipologia dos textos: $75 \%$ do material é formado por textos informativos de diversas áreas, tais como ciências aplicadas, artes, crenças e opiniões, comércio e finanças, lazer, ciências puras e naturais, ciências sociais e conhecimentos gerais. Os outros $25 \%$ são formados por textos criativos, tais como obras literárias. O período referese à data de publicação dos textos. Nesse corpus, evitou-se incluir textos anteriores a 1975, com algumas exceções a poucas obras literárias datadas a partir de 1964, cuja inclusão deve-se à popularidade dos textos. O meio de publicação indica onde o texto foi publicado: livros (60\%); periódicos, incluindo-se jornais (25\%); fontes diversas, tais como folhetos de propaganda (5 a 10\%); materiais não publicados, caso de cartas, diários, etc. (5 a 10\%); e textos escritos para serem falados, como por exemplo discursos políticos e peças teatrais (menos de $5 \%$ ). O corpus falado é formado por transcrições de conversas espontâneas e de gravações feitas em diferentes contextos: palestras, noticiários, reuniões de negócios, discursos políticos, entrevistas, comentários esportivos etc.

O BNC foi disponibilizado para a comunidade lingüística em 1995; parte desse corpus pode ser acessada gratuitamente em http://sara.natcorp.ox.ac.uk, gerando um número máximo de 50 linhas de concordância. Apesar da limitação dos resultados, o buscador apresenta o número de ocorrências da palavra em todo o

\footnotetext{
${ }^{74}$ Para mais detalhes, acesse: http://sara.natcorp.ox.ac.uk
} 
corpus, retornando as concordâncias no limite acima mencionado. Outra opção é a aquisição do BNC Sampler, um CD-ROM formado por 184 textos (2 milhões de palavras), seguindo os mesmos critérios para a compilação do BNC. Esse recurso é interessante para aqueles que preferem trabalhar desconectados ou mesmo que não têm fácil acesso à Internet. É também uma opção para pesquisadores que não possuem espaço suficiente no disco rígido para a instalação do corpus integral, também disponível para aquisição. ${ }^{75}$

Em 2004, o professor e pesquisador Mark Davies, da Brigham Young University (Utah, Estados Unidos da América) criou uma interface com o BNC na qual é possível gerar linhas de concordância que acessam o corpus na íntegra, ou seja, as 100 milhões de palavras. Intitula-se BYU-BNC: The British National Corpus (doravante BYU-BNC) e está disponível em http://corpus.byu.edu/bnc. Nesse mesmo endereço eletrônico, pode-se também obter a lista de palavras de todo o corpus, mediante compra. Quando tomamos contato com o BYU-BNC, já havíamos baixado essa lista a partir do Website de Mike Scott, acima citado, onde também encontramos várias versões do programa WordSmith Tools, desenvolvidas pelo pesquisador.

Com a interface BYU-BNC, podemos fazer várias buscas: palavras, sintagmas, formas lematizadas e pesquisas mais complexas. Pode-se também buscar colocados ou refinar a pesquisa usando informações quanto ao registro. Esses são apenas alguns dos recursos disponíveis - para mais detalhes, visite o Website acima.

\footnotetext{
${ }^{75}$ As informações para compra estão disponíveis no website já mencionado.
} 


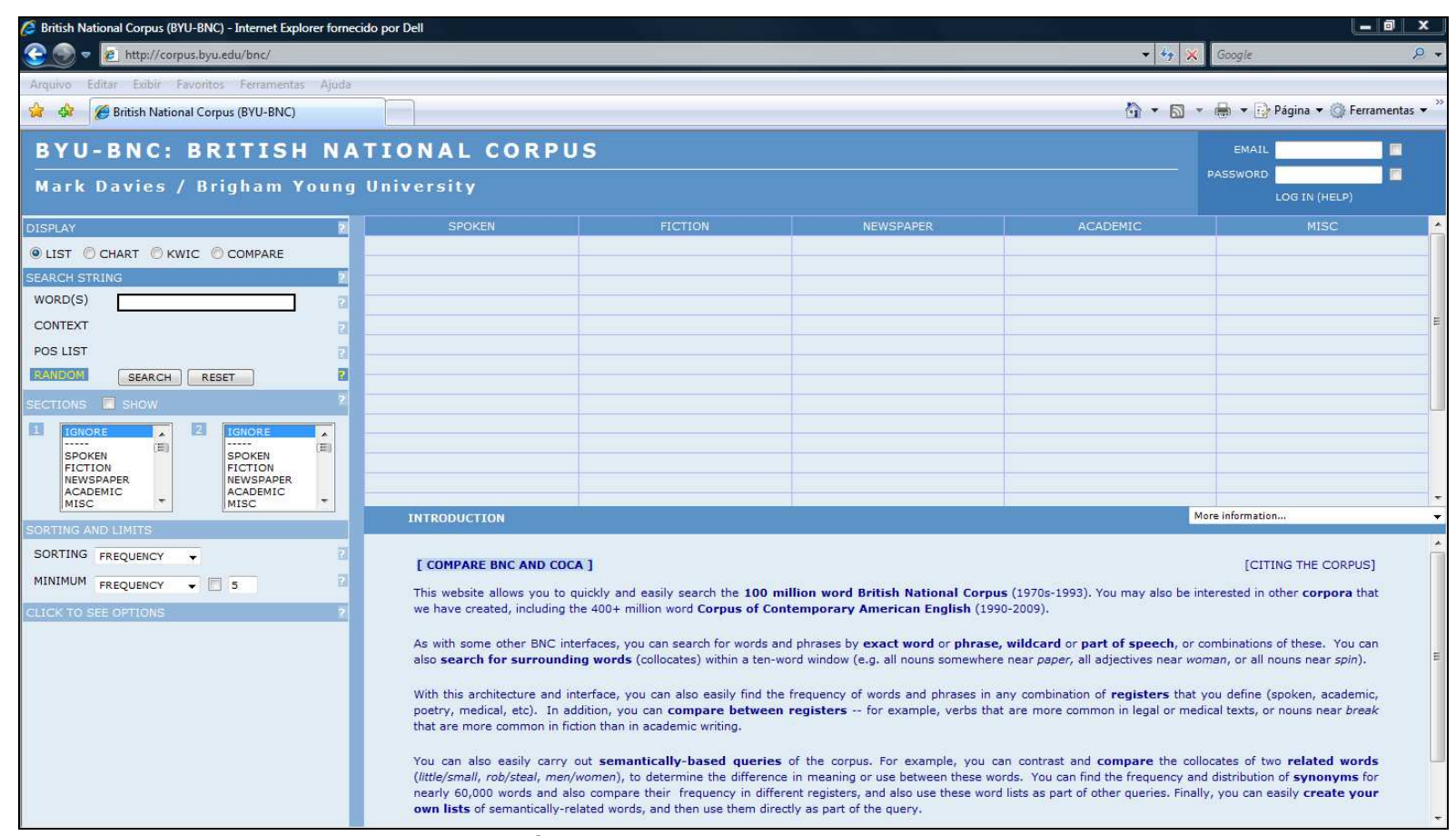

Figura 2 - Página inicial do BYU-BNC

O professor Mark Davies também desenvolveu o COCA - Corpus of Contemporary American English, um corpus de aproximadamente 410 milhões de palavras em inglês americano, disponibilizado em 2008. Atualmente, é o maior corpus de língua inglesa com acesso gratuito, e o único suficientemente grande e balanceado na variante americana. É um corpus anotado e foi etiquetado com o etiquetador $\mathrm{CLAWS}^{76}$, assim como o BNC. O acesso ao corpus é gratuito e pode ser obtido em http://www.americancorpus.org ou http://corpus.byu.edu/coca. É composto de língua falada e escrita, e apresenta diferentes registros: ficção, revistas populares, jornais e textos acadêmicos, sendo atualizado a cada 6-9 meses. O material inclui 20 milhões de palavras a cada ano, de 1990 a 2010. Além dos recursos disponíveis para a interface BYU-BNC, podemos também comparar a palavra de busca em diferentes períodos de tempo, obviamente limitados à abrangência do corpus, ou seja, de 1990 a 2010.

Conforme já comentado, o BNC foi definido como nosso corpus de referência; o COCA será uma segunda opção para verificarmos dados mais atualizados e será utilizado quando necessário, feitas as devidas observações. Vale ressaltar que, além de uma excelente fonte de investigação, ele apresenta inúmeros recursos que certamente viabilizam várias pesquisas em língua inglesa.

\footnotetext{
76 Também utilizado por Carvalho Fonseca (2007), conforme mencionado neste capítulo. Para mais detalhes, acesse http://www.comp.lancs.ac.uk/ucrel/claws/.
} 


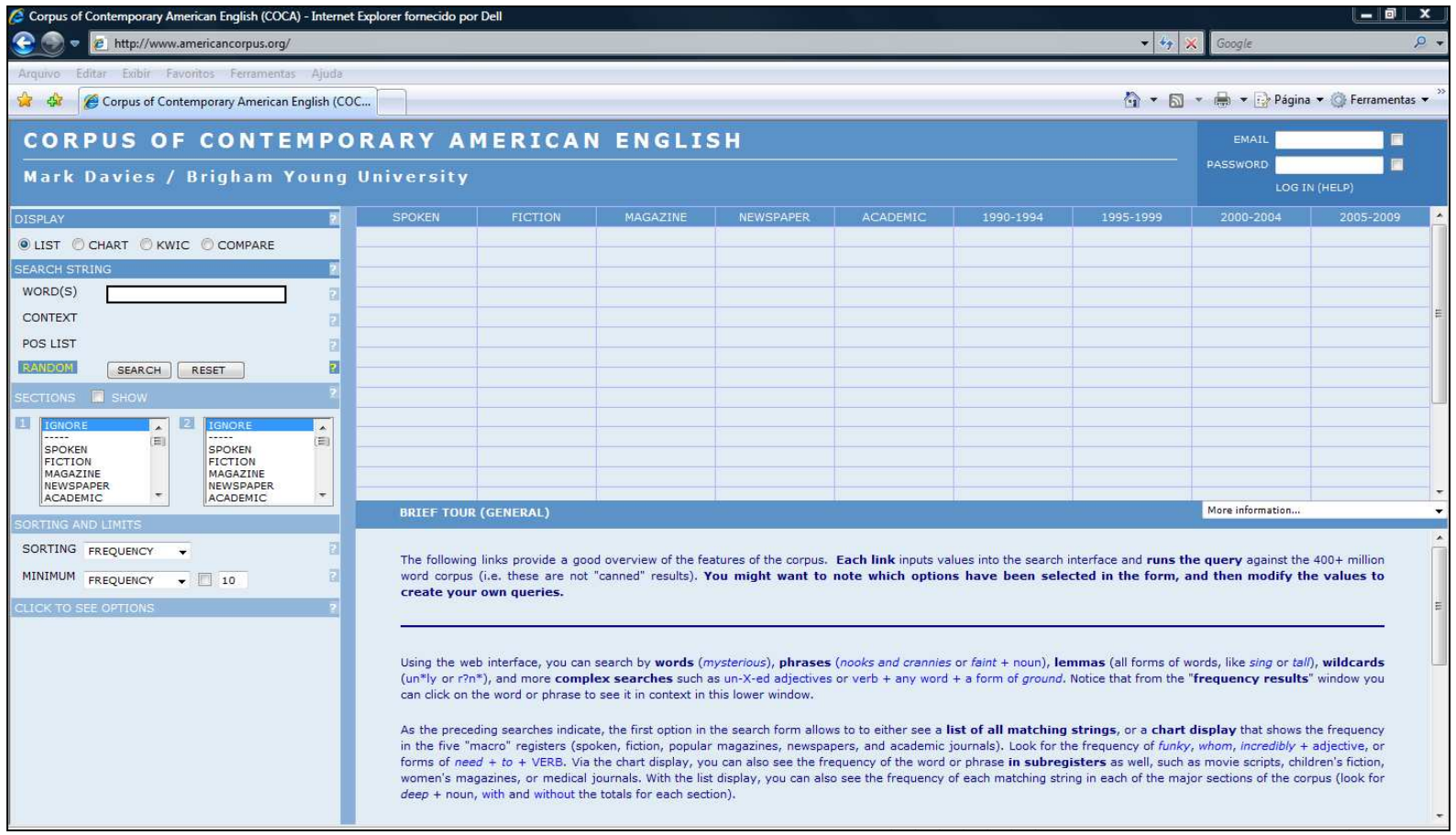

Figura 3 - Página inicial do COCA

Para a língua portuguesa (variante brasileira), utilizaremos o Banco de Português, que hoje conta com aproximadamente 700 milhões de palavras. Na figura abaixo, um recorte mais preciso sobre os números que compõem o corpus total, gerados com o programa WordSmith Tools (doravante WST): 


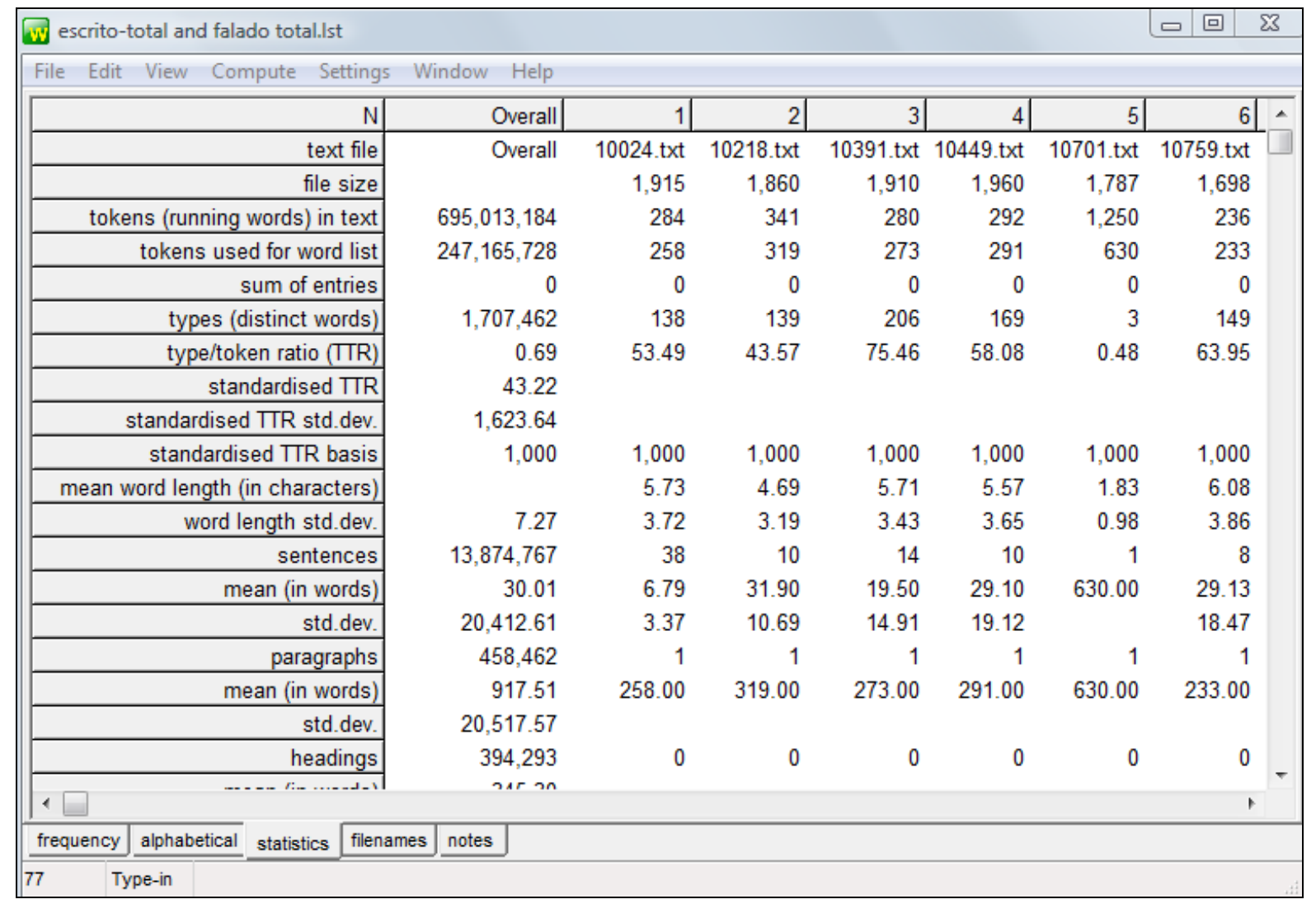

Figura 4 - Detalhes sobre o Banco de Português

Em maio de 2009, solicitamos ao Prof. Dr. Tony Berber Sardinha (PUC-SP) acesso ao Banco de Português na íntegra ${ }^{77}$. Mediante assinatura de uma licença de uso, pudemos utilizar o corpus e dar sequência à nossa pesquisa. Além de todos os arquivos de texto, tivemos também acesso às listas de palavras, consultadas para levantarmos a versão mais atualizada dos registros e gêneros que compõem o corpus, bem como seus respectivos números. Há outras obras de referência que apresentam os dados, mas já estão desatualizadas, como é o caso de Berber Sardinha (2003b, 2004). Ao abrirmos as pastas com as listas de palavras, observamos que cada uma delas está gravada em três arquivos de programas diferentes, o que facilita o manuseio do pesquisador, dependendo dos objetivos de sua investigação. São eles: a lista de palavras gerada com o WST; a lista de palavras salva em arquivo de texto (.txt); a lista de palavras exportada para uma planilha em Excel $^{78}$. Baseados nesses dados, compilamos a tabela abaixo:

\footnotetext{
${ }^{77}$ A versão mais atualizada do Banco de Português na época.

${ }^{78}$ Microsoft® Office Excel 2003 (11.8316.8221) SP 3

Parte do Produto Microsoft Office Profissional Edição 2003

Copyright (C) 1985 - 2003 Microsoft Corporation. Todos os direitos reservados.
} 
Tabela 5 - O Banco de Português (BP)

\begin{tabular}{|c|c|c|c|}
\hline & Arquivo (o título apresenta o registro ou gênero) & Ocorrências (tokens) & Formas (types) \\
\hline \multirow{10}{*}{ Escrito } & Acadêmico/artigo & 262.691 .824 & 1.108 .650 \\
\hline & Culinária/receitas & 469.799 & 6.506 \\
\hline & Jornalístico/crônica & 144.638 & 18.078 \\
\hline & Jornalístico/educação & 2.828 .993 & 52.907 \\
\hline & Jornalístico/jornal & 230.934 .272 & 583.439 \\
\hline & Legal/legislação & 229.785 & 12.042 \\
\hline & Literatura/contos & 57.742 & 7.973 \\
\hline & Literatura/variado & 1.553 .187 & 73.301 \\
\hline & Médico/bula & 156.789 & 9.353 \\
\hline & Negócios/carta & 32.728 & 5.466 \\
\hline \multirow{7}{*}{ Falado } & debate político & 22.043 & 2.985 \\
\hline & entrevista & 3.416 .944 & 58.167 \\
\hline & narração futebol & 75.372 & 3.879 \\
\hline & negócios & 5.369 & 1.068 \\
\hline & pronunciamento & 1.800 .360 & 32.830 \\
\hline & variado (entrevistas, aulas) & 3.424 .654 & 56.095 \\
\hline & Total: & 695.887 .293 & \\
\hline
\end{tabular}


Como podemos observar, o número total de ocorrências (tokens) apresenta pequena diferença quanto ao número apresentado na figura 4. Isso provavelmente deve-se ao fato de arquivos terem sido acrescentados depois que a lista do corpus total foi gerada. Para efeitos de nossa pesquisa, utilizaremos os dados apresentados na figura $4^{79}$.

A origem do Banco de Português data da década de 90, e tem como referência o 'Banco de Textos', uma coleção de documentos que fazia parte do projeto DIRECT (Development of International Research for English, Commerce and Technology - Desenvolvimento de Pesquisa Internacional para Inglês, Comércio e Tecnologia) do Programa de Pós-Graduação em Linguística Aplicada da Pontifícia Universidade Católica de São Paulo (PUC-SP). Essa coleção era basicamente composta de textos na área de negócios, tais como relatórios anuais e cartas. Esse material foi coletado em língua inglesa, mas posteriormente o banco em língua portuguesa começou a ser compilado. Outro aspecto também relevante é que os pesquisadores do CEPRIL (Centro de Pesquisa, Recursos e Informação em Linguagem) da mesma universidade faziam, desde a década de 80 , grande uso de computadores, ferramenta essencial para a compilação de dados ${ }^{80}$ que, como podemos observar, advém de longa data. Em 2000, o Banco de Português (doravante BP) contava com aproximadamente 120 milhões de palavras (BERBER SARDINHA, 2004, p. 159) e em 2003 esse número já havia quase que dobrado, alcançando cerca de 230 milhões (BERBER SARDINHA, 2003b). O BP é um corpus de língua geral do português brasileiro, orgânico (permite crescimento ou diminuição, podendo também ser chamado de aberto) e considerado oportunístico, uma vez que o material é acrescentado à medida que se torna disponível. Por essa razão, não é um corpus balanceado; contém textos completos, escritos e falados (transcrições), não tendo definido um rol de tipos de textos, ou variedades linguísticas, em sua composição. É resultado da compilação de vários (diferentes e independentes) corpora menores, podendo ser entendido como um corpus de corpora: comporta vários anos do jornal Folha de S. Paulo; na seção de fala, inclui transcrições de diversos projetos; em negócios, inclui dados do projeto DIRECT. É também importante enfatizar a contribuição dos estudantes do programa de pós-

\footnotetext{
${ }^{79}$ Consequentemente, utilizaremos essa lista de palavras para gerarmos nossa lista de palavras-chave, conforme explicitado no item 2.6.1.

${ }^{80}$ Como foge ao escopo de nossa pesquisa dar mais detalhes sobre o histórico do Banco de Português, para mais detalhes vide Berber Sardinha (2003b).
} 
graduação em Linguística Aplicada da PUC-SP, que forneceram (e continuam fornecendo) material compilado durante suas pesquisas para o crescimento do BP.

Em linhas gerais, o BP tem quatro papéis (BERBER SARDINHA, 2003b):

- é um repositório de corpora menores, que podem ser analisados de forma independente;

- pode ser considerado um corpus de referência, como é o caso nesta pesquisa;

- pode ser utilizado para análise linguística, como por exemplo por meio de linhas de concordância;

- é uma fonte de conhecimentos sobre a língua portuguesa, no sentido de que pode ser utilizado para o desenvolvimento de software, como é o caso de corretores ortográficos.

Devemos também observar que o BP é um corpus cru (não apresenta quaisquer tipos de etiquetas), não anotado e não lematizado. Caso necessário, o usuário pode obter mais informações sobre cada arquivo no índice do BP, um banco de dados em perl com acesso restrito na Web em http://www2.lael.pucsp.br/ corpora/bp.

Concluímos assim a descrição do material considerado para o desenvolvimento desta pesquisa e, na sequência, trataremos do processo de etiquetagem de nossos corpora de estudo.

\section{$2.4 \mathrm{O}$ processo de etiquetagem}

Em linhas gerais, etiquetar um corpus significa acrescentar informações de natureza variada aos textos crus, de acordo com os critérios e objetivos estabelecidos para a pesquisa. Segundo Teixeira,

Entende-se por etiquetagem (ou anotação ${ }^{81}$ ) a inserção automática, semi-automática ou manual de qualquer tipo de informação em um corpus de estudo, com vistas a facilitar sua análise lingüística. A informação acrescentada é em geral codificada de modo a permitir sua fácil identificação, seja pelo pesquisador, seja pelos programas computacionais empregados nas análises. (TEIXEIRA, 2007, p. 117)

\footnotetext{
81 A autora coloca, em nota de rodapé: "A anotação de um corpus compreende também a colocação de cabeçalhos."
} 
Conforme observado em vários autores (TEIXEIRA, 2007; HUNSTON, 2002; BOWKER e PEARSON, 2002; BERBER SARDINHA, 2004), podemos resumir os tipos mais comuns de etiquetagem em:

- Morfossintática (part of speech ou POS tagging): indica a classe gramatical de cada uma das palavras do corpus (artigo, substantivo, verbo, etc.);

- Sintática (parsing): apresenta a análise da sintaxe das frases (sintagma nominal, sintagma verbal, etc.);

- Semântica: classifica as palavras de conteúdo lexical de acordo com suas características semânticas. Pode ser usada, por exemplo, para indicar o campo semântico a que as palavras pertencem (margarida $=$ flor; cachorro $=$ animal, etc.);

- Discursiva: aponta elementos discursivos de um texto (referentes anafóricos, marcadores discursivos, etc.). (TEIXEIRA, 2007, p. 118-119)

Dentre essas, a mais amplamente utilizada é a morfossintática, e as etiquetas utilizadas irão depender do etiquetador utilizado (cada um possui um inventário próprio de etiquetas). Em geral, essas informações são fornecidas pelo seu desenvolvedor, como é o caso dos etiquetadores disponíveis online ${ }^{82}$. É importante enfatizar que a porcentagem de acertos nesse tipo de etiquetagem (automática) é alta, ficando em torno de 97\% (BERBER SARDINHA, 2004, p. 156), o que eleva seu grau de confiabilidade.

Para este estudo, utilizaremos justamente a etiquetagem morfossintática, e como o processo foi desenvolvido de forma diferente em cada um dos corpora estudados, as etiquetas utilizadas serão explicitadas a seu tempo.

As razões para se etiquetar um corpus são inúmeras. Bowker e Pearson (2002, p. 88) esclarecem que por meio da etiquetagem todas as informações implícitas do discurso tornam-se explícitas e acessíveis, o que acontece, por exemplo, quando definimos a classe gramatical a que uma dada palavra em contexto pertence. Um corpus morfossintaticamente etiquetado permite assim a análise de uma classe gramatical específica, como é o caso dos advérbios, facilitando inclusive a busca por unidades maiores de significado.

\footnotetext{
82 Como exemplo podemos citar o projeto VISL (Visual Interactive Syntax Learning), disponível em http://visl.sdu.dk/visl/pt/info/portsymbol.html. O pesquisador tem acesso a várias informações e ferramentas para investigação lingüística, incluindo aquelas para etiquetagem.
} 
Apesar de trabalharmos essencialmente com os corpora de estudo crus, manuseamos também as versões etiquetadas para o levantamento de alguns dados - daí a importância desta seção em nossa pesquisa. Como bem coloca Hunston, "Conforme os corpora são mais e mais explorados para propósitos além de simplesmente 'olhar a língua' [...], parece óbvio que uma mistura de textos crus e anotados seja sempre necessária." (HUNSTON, 2002, p. 94) ${ }^{83}$

Conforme acima explicitado, a etiquetagem dos corpora utilizados neste estudo deu-se de diferentes formas. Ao desenvolverem suas pesquisas, Teixeira (2008) e Carvalho Fonseca (2007) não necessitaram etiquetar seus respectivos corpora nas duas línguas (inglês e português). Dessa forma, utilizamos aqueles disponíveis (e gentilmente cedidos pelas pesquisadoras) e etiquetamos o necessário para o levantamento de nossos dados.

A seguir, apresentamos os detalhes sobre a etiquetagem de todo o material utilizado.

\subsubsection{A etiquetagem dos corpora da Culinária (inglês e português)}

Considerando-se o tamanho mínimo de um corpus de estudo especializado em inglês sugerido por Berber Sardinha (2004, p. 99) - 91.161 palavras - e para que possamos comprovar que os advérbios terminados em -ly são a maioria dessa classe gramatical em receitas culinárias, decidimos etiquetar $10 \%$ de cada uma das seis pastas criadas por Teixeira (2008), contendo arquivos de texto, com vistas a contemplar todas as fontes de busca utilizadas na compilação do corpus de Culinária (inglês) ${ }^{84}$. Com esse procedimento, objetivamos manter, da melhor forma possível, a imparcialidade e o balanceamento dos resultados obtidos, tomando como adequada a porcentagem estabelecida (10\%) para a questão abordada (BERBER SARDINHA, 2004, p. 29).

A primeira pasta que teve $10 \%$ do seu total etiquetado foi BBC_recs. Como nessa pasta as receitas estão numeradas separadamente em arquivos de texto, nomeadas de 1 a 5.180 - observamos também que se encontram em ordem

\footnotetext{
83 “As corpora are exploited more and more for purposes other than simply 'looking at language' [...], it seems obvious that a mixture of plain text and annotation will always be needed."

${ }^{84}$ Considerando-se os objetivos de sua pesquisa, Teixeira (2008) etiquetou apenas o corpus em português.
} 
alfabética pelo título da receita -, decidimos coletar as cem primeiras em cada mil, até completarmos o total de 518 receitas. Dessa forma, chegamos a seis arquivos em txt, compilando as receitas de acordo com a numeração: de 1 a 100, de 1.000 a 1.100 , de 2.000 a 2.100 , de 3.000 a 3.100 , de 4.000 a 4.100 , de 5.000 a 5.018 . Abrimos cada arquivo, cortamos e colamos as receitas em um único novo documento, agora uma embaixo da outra, para agrupá-las e facilitar o processo de etiquetagem. Procuramos coletar os $10 \%$ dos seis subcorpora de modo que representassem o conteúdo de suas respectivas pastas. Em geral, adotamos o procedimento descrito para o subcorpus BBC_recs, adequando-o ao número de arquivos de cada pasta. No quadro abaixo, apresentamos um resumo desse processo. 


\begin{tabular}{|c|c|c|c|}
\hline subcorpus & no. total arquivos & $\begin{array}{l}\text { no. arquivos } \\
\text { selecionados }\end{array}$ & descrição dos arquivos selecionados para etiquetagem \\
\hline BBC_recs & 5.180 & 518 & 1 a $100 ; 1.000$ a $1.100 ; 2.000$ a $2.100 ; 3.000$ a $3.100 ; 4.000$ a $4.100 ; 5.000$ a 5.018 \\
\hline Espec_IO & 39 & 4 & a primeira receita em cada 10 \\
\hline fishSoup & 181 & 19 & a primeira receita em cada 10 e a última \\
\hline HelenIOB & 2.133 & 218 & $\begin{array}{l}\text { Este subcorpus apresenta } 13 \text { pastas. Coletamos } 10 \% \text { de cada uma, arredondando os } \\
\text { valores para o número acima. Descrevemos abaixo o nome da pasta, o número de } \\
\text { arquivos total/número de arquivos coletados para etiquetagem - uma em cada 10: } \\
\text { BAKING 1: } 296 / 30 \\
\text { CONFEC 1: 50/5 } \\
\text { DESSER 1: } 299 / 30 \\
\text { DRINKS 1: } 96 / 10 \\
\text { FISHRE 1: } 190 / 19 \\
\text { MEATRE 1: } 339 / 34 \\
\text { PRESER 1: } 114 / 12 \\
\text { SALADS 1: } 99 / 10 \\
\text { SAUCES 1: } 71 / 8 \\
\text { SOUPSR 1: } 175 / 18 \\
\text { STARTE 1: } 187 / 19 \\
\text { VEGGIE 1: } 101 / 11 \\
\text { VEGREV 1: } 116 / 12 \text { (neste caso, iniciamos a contagem na } 3^{a} \text { receita) }\end{array}$ \\
\hline Palc_IOA & 110 & 11 & a primeira receita em cada 10 e a última \\
\hline Palc_IOB & 110 & 11 & a primeira receita em cada 10 e a última \\
\hline TOTAL & 7753 & 781 & \\
\hline
\end{tabular}

Quadro 3 - Descrição do processo de seleção dos arquivos para etiquetagem - corpus de Culinária (inglês) 
De acordo com o agrupamento de receitas apresentado na coluna "descrição dos arquivos selecionados para etiquetagem", esse material foi arquivado em pastas com o mesmo nome de cada subcorpus, acrescentando-se o sinal _ (underscore). Cada pasta continha, portanto, apenas as receitas selecionadas para etiquetagem. Para BBC_recs, criamos a pasta BBC_recs_, onde salvamos em seis arquivos de texto as 518 receitas a serem etiquetadas. Para Espec_IO_, fishSoup_, Palc_IOA_e Palc_IOB_, apenas um único arquivo de texto foi gerado em cada pasta. Já HelenIOB_apresenta 13 arquivos de texto, o equivalente ao número de pastas. Depois desse levantamento, geramos uma lista de palavras com o programa WordSmith Tools (SCOTT, 2007) para verificarmos o número total de palavras do corpus de Culinária (inglês) a serem etiquetadas - 147.124, bem acima do mínimo especificado por Berber Sardinha (2004, p. 99) para um corpus especializado (91.161).

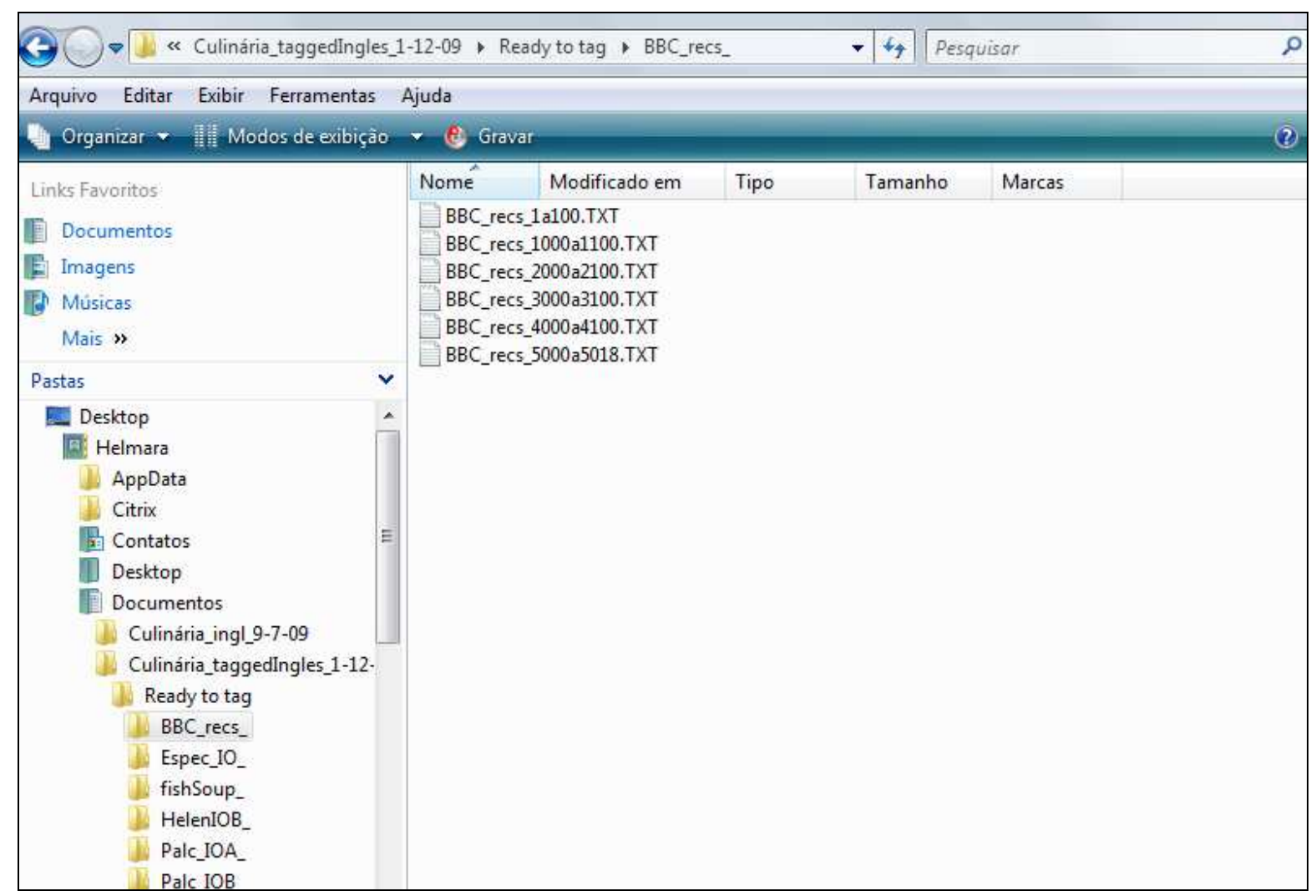

Figura 5 - Pastas criadas para os textos a serem etiquetados - arquivos de texto em BBC_recs_

Definidos os arquivos, passamos para o processo de etiquetagem, feito com o etiquetador Tree-Tagger, ferramenta disponibilizada pelo Prof. Dr. Tony Berber 
Sardinha, da Pontifícia Universidade Católica de São Paulo (PUC-SP) ${ }^{85}$. Na tela inicial (vide figura abaixo), há um link para algumas informações sobre o etiquetador. Em linhas gerais, o Tree-Tagger é uma ferramenta que pode ser utilizada para anotar um texto com informações morfossintáticas e apresenta também o lema de cada ocorrência. Foi desenvolvido no projeto TC (Textual Corpora and tools for their exploration) do Instituto de Lingüística Computacional da Universidade de Stuttgart e pode ser utilizado para os seguintes idiomas: alemão, inglês, francês, italiano, espanhol, búlgaro, russo, grego, português, chinês e francês antigo.

Para etiquetar as receitas, procedemos da mesma forma como feito para o corpus de Direito (português) ${ }^{86}$ : cada um dos 23 arquivos foi carregado individualmente. De posse de um código automaticamente enviado, digitamo-lo no campo correspondente no formulário (tela inicial do etiquetador) e selecionamos a língua para etiquetagem (inglês).

\footnotetext{
${ }^{85}$ No momento da etiquetagem, a ferramenta não estava disponível no site do CEPRIL (PUC-SP), ao contrário de quando etiquetamos o corpus de Direito (português). Nesse caso, acessamos a mesma ferramenta disponibilizada em http://corpuslg.org/tools

${ }^{86}$ Como utilizamos os dados da área do Direito em nossa qualificação, devemos esclarecer que esse corpus foi etiquetado primeiro. Desse modo, informações sobre o etiquetador Tree-Tagger estão distribuídas entre esta e a próxima seção.
} 


\section{Etiquetador Tree-Tagger \\ PUC/SP, LAEL, CEPRIL, GELC}

\section{Para que serve \\ Colocar etiquetas morfossintáticas em cada palavra de um corpus, por meio do etiquetador Tree-Tagger. \\ Como usar \\ - Faça envio (upload) do corpus que pretende usar. \\ - Escolha a lingua. \\ - De posse do código do corpus enviado, digite no espaço correspondente do formulário abaixo e clique Fazer.}

Lingua: Inglês -

Código do corpus (seis digitos):

Fazer Limpar

(c) cgi, sh, html Tony Berber Sardinha, 2003-2007

Figura 6 - Página inicial do Etiquetador Tree-Tagger

Seguidos os procedimentos acima, clicamos uma única vez em "fazer" e o texto etiquetado é exibido na tela em alguns segundos. Para o manuseio, devemos copiá-lo e salvá-lo em .txt. A figura abaixo apresenta parte de um dos resultados, já salvos em arquivo de texto: 


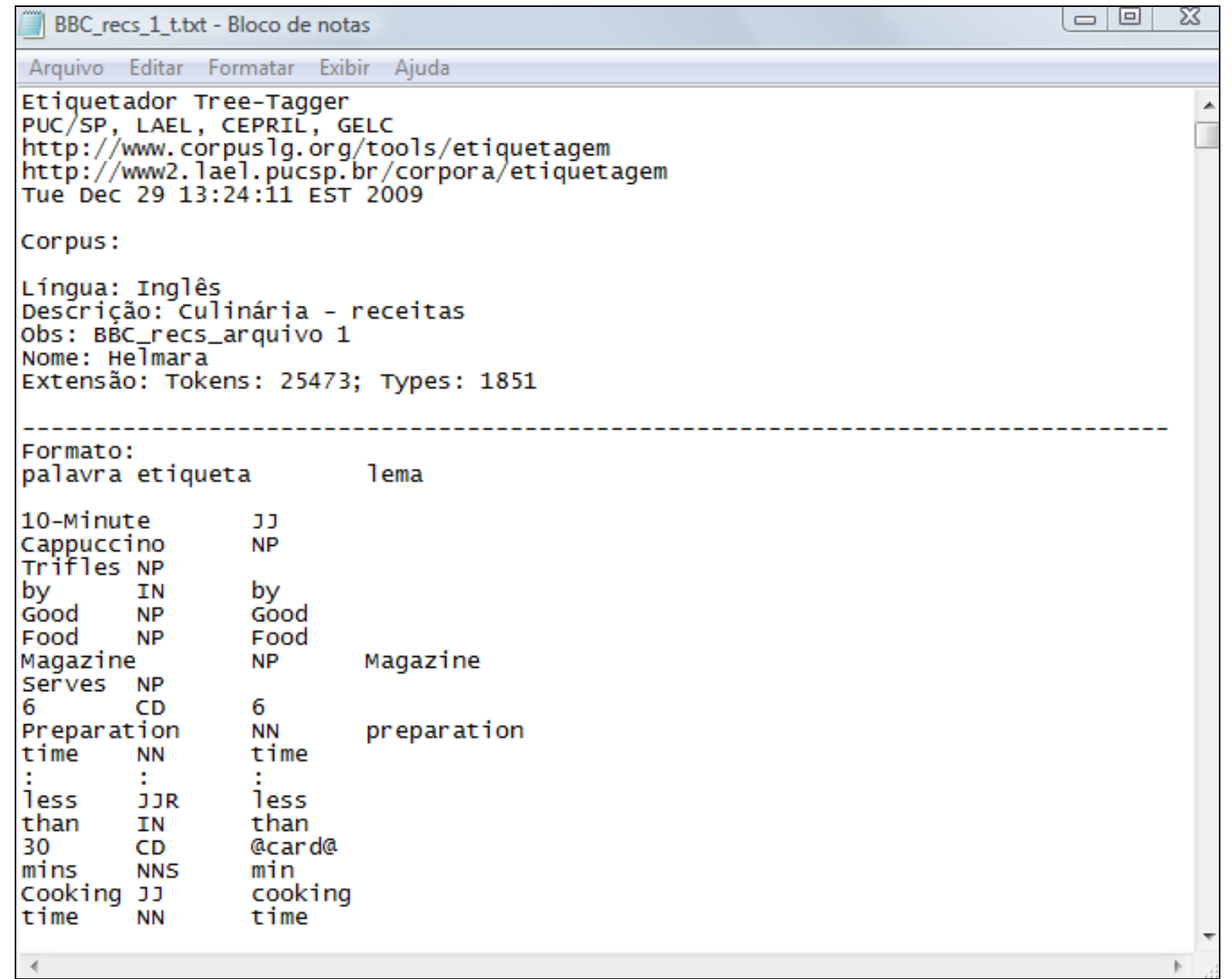

Figura 7 - Parte etiquetada do arquivo BBC_recs_1a100.txt, agora nomeado BBC_recs_1_t.txt

Dessa forma, etiquetamos os 23 arquivos de texto compilados a partir do corpus de Culinária (inglês) a serem também utilizados para o estudo dos advérbios terminados em -ly nesta pesquisa.

No caso da língua inglesa, as etiquetas utilizadas são 36 (SANTORINI, 1991):

\begin{tabular}{|c|l|}
\hline Etiqueta & \multicolumn{1}{|c|}{ Descrição } \\
\hline CC & Coordinating conjunction \\
\hline CD & Cardinal number \\
\hline DT & Determiner \\
\hline EX & Existential there \\
\hline FW & Foreign word \\
\hline IN & Preposition or subordinating conjunction \\
\hline JJ & Adjective \\
\hline JJR & Adjective, comparative \\
\hline JJS & Adjective, superlative \\
\hline
\end{tabular}




\begin{tabular}{|c|c|}
\hline LS & List item marker \\
\hline MD & Modal \\
\hline NN & Noun, singular or mass \\
\hline NNS & Noun, plural \\
\hline NP & Proper noun, singular \\
\hline NPS & Proper noun, plural \\
\hline PDT & Predeterminer \\
\hline POS & Possessive ending \\
\hline PP & Personal pronoun \\
\hline PP\$ & Possessive pronoun \\
\hline RB & Adverb \\
\hline RBR & Adverb, comparative \\
\hline RBS & Adverb, superlative \\
\hline $\mathrm{RP}$ & Particle \\
\hline SYM & Symbol \\
\hline TO & to \\
\hline $\mathrm{UH}$ & Interjection \\
\hline VB & Verb, base form \\
\hline VBD & Verb, past tense \\
\hline VBG & Verb, gerund or present participle \\
\hline VBN & Verb, past participle \\
\hline VBP & Verb, non- $3^{\text {rd }}$ person singular present \\
\hline VBZ & Verb, $3^{\text {rd }}$ person singular present \\
\hline WDT & Wh-determiner \\
\hline WP & Wh-pronoun \\
\hline WP\$ & Possessive wh-pronoun \\
\hline WRB & Wh-adverb \\
\hline
\end{tabular}

Quadro 4 - Etiquetas utilizadas no processo de etiquetagem parcial do corpus da Culinária (inglês) - etiquetador Tree-Tagger

Para o português, utilizamos a versão etiquetada cedida por Teixeira (2008). Inicialmente etiquetada com o Tree-Tagger, a pesquisadora fez vários ajustes nos resultados para viabilizar sua pesquisa. Todas as receitas etiquetadas em português foram salvas em um único arquivo de texto, que totalizou 11,5 Mb. A figura abaixo exemplifica como os resultados se apresentaram: 
COUSCOUS/prop DE/prp COLIFLOR/prop INGREDIENTES/prop (/punc 4/num Por??es/n )/punc 1/n $\mathrm{m} / \mathrm{prp}$ pele/n, /punc em/prp cubinhos/n 10/num g/n de/prp a??car/n mascavo/adj um/art fi e/adv possa/v ser/v cortado/adj em/prp cubos/n ,/punc depois/adv de/prp gelado/adj ./p io/n ./punc Ao/prp 1ado/n ,/punc am?ndoas/n ./punc Cubos/n de/prp ma??/n ,/punc em/prp procedimento/n no/prp preparo/n dos/prp camar?es/n )/punc $2 /$ num cenouras/n m?dias/adj de/prp salsinha/n crespa/adj picada/adj ?leo/n extravirgem/adj de/prp oliva/n para/prp minutos/n em/prp fogo/n baixo/adj. /punc coloque/v o/art caldo/n e/conj cozinhe/v por/ prop ,/punc SC/prop FANTASIA/n DE/prp VITELA/prop COM/prop PIMENT?O/prop E/COnj ALICE/ cada/pron fatia/n de/prp vitela/n com/prp 1/num filet/n de/prp alice/n ,/punc $1 /$ num az ENTES/prop (/punc 4/num Por??es/n )/punc SALADA/n 8/num folhas/n de/prp alface/n carva c batedor $/ \mathrm{n}$ de/prp arame/n )/punc ./punc MONTAGEM/prop Aque?a/v o/art vinagrete/n e/co $\mathrm{p}$ ?/n pequeno/adj de/prp alface/n 1ollo/adj (/punc roxa/adj crespa/adj )/punc 1/num p?/ $\mathrm{rp} \mathrm{sal/n./punc} \mathrm{Reserve/v} \mathrm{./punc} \mathrm{Fa?a/v} \mathrm{o/art} \mathrm{mesmo/n} \mathrm{com/prp} \mathrm{os/art} \mathrm{300/num} \mathrm{gramas/n}$ $\mathrm{p}$ queijo/n parmigiano/adj ralado/adj 15/num g/n de/prp alho/n picado/adj $60 / \mathrm{num} \mathrm{ml} / \mathrm{n} \mathrm{d}$ onj nervos/n ./punc Tempere/v com/prp sal/n e/conj pimenta-do-reino/n ./punc Numa/prp 10/prp chef/n Mauro/prop Jr/prop./punc, / punc do/prp restaurante/n Terra/prop da/prp $\mathrm{r} / \mathrm{prp} 15 / \mathrm{num}$ minutos/n em/prp uma/art vasilha/n e/conj depois/adv esprema/v fortemente nc adicione/v o/art leite/n de/prp coco/n que/conj estava/v reservado/adj e/conj ferva a-do-reino/n mo?da/adj na/prp hora/n a/art gosto/n $1 /$ num $\mathrm{x}$ ?cara/n de/prp manteiga/n ge fatiados/adj bem/adv finos/adj 6/num peda?os/n de/prp cogumelo/n cortados/adj em/prp $\mathrm{f}$ secos/adj e/conj bata/v no/prp liquidificador/n at?/prp virar/v um/art p?/n fino/adj. e/n c?trico/adj e/conj deixe/v marinar/v. /punc FINALIZA??o/prop Recheie/v a/art carne adj $20 / \mathrm{num} \mathrm{g} / \mathrm{n}$ de/prp cebolinha/n verde/adj finamente/adv picada/adj $1 / \mathrm{num}$ flor $/ \mathrm{n}$ de/p e/prp $1 \mathrm{im}$ ?o/n ,/punc o/art coentro/n, /punc a/art cebolinha/n verde/adj, /punc a/art $f$ on os/art ingredientes/n num/prp pi ? o/ $\mathrm{n}$. /punc coloque/v tudo/pron dentro/adv de/prp ou/conj ?gua/n 1/num 1/2/num colher/n (/punc sopa/n )/punc de/prp arroz/n de/prp gr?o/ $\mathrm{ua} / \mathrm{n}$ salgada/adj. /punc cozinhe/v em/prp fogo/n baixo/adj por/prp cerca/adv de/prp 12/ rop cordon/prop Bleu/prop, , punc $\mathrm{Fr}$ an?a/prop PATO/n NO/prop A?A?/prop INGREDIENTES/pro punc nir?/n , punc tudo/pron temperado/adj com/prp sal/n e/conj puxado/v na/prp mantej . /punc Junte/v ao/prp molho/n o/art creme/n de/prp leite/n e/conj o/art bacon/n ./punc n 100/num $\mathrm{ml} / \mathrm{n}$ de/prp fumet/n de/prp peixe/n (/punc Numa/prp panela/n , /punc coloque/v n os/art lados/n. /punc Deglace/prop com/prp champagne/n e/conj flambe/v com/prp u?squ opos/n de/prp vinho/n branco/adj seco/adj,/punc 3/num $\mathrm{ramos} / \mathrm{n}$ de/prp alecrim/n ,/punc $\mathrm{g} / \mathrm{n}$ de/prp a?afr?o/n italiano/adj 400/num g/n de/prp polenta/n italiana/adj bergamasca punc caso/n necess?rio/adj, /punc adicione/v mais/adv caldo/n ./punc Leve/v ao/prp fo o/prop ,/punc RJ/prop LOMBO/prop DE/prp SALM?O/prop MARINADO/prop EM/prp C?TRICOS/prop

Figura 8 - Recorte do corpus de Culinária (português) etiquetado por Teixeira (2008)

No entanto, não foi possível manusear esse arquivo na íntegra com a versão 5 do programa WordSmith Tools (SCOTT, 2007). Tentamos gerar uma lista de palavras e linhas de concordância, mas não houve sucesso. Diante disso e considerando-se que trabalhar com o corpus etiquetado não é o principal foco de nossa pesquisa, decidimos fazer um recorte de 1,3 $\mathrm{Mb}$ nesse arquivo - valor que corresponde a aproximadamente $10 \%$ do total etiquetado. Como consideramos essa porcentagem para etiquetarmos o corpus de Culinária em inglês, cremos que tal fato não comprometerá a análise que pretendemos desenvolver, em ambas as línguas. Esse arquivo menor foi salvo separadamente e nomeado CulináriaP 1,3MB_tagged.txt. A partir dele, conseguimos manusear os dados.

\subsubsection{A etiquetagem dos corpora do Direito (inglês e português)}

Conforme anteriormente colocado, nosso corpus de estudo na área do Direito foi compilado por Carvalho Fonseca (2007), quando da elaboração de sua 
dissertação de Mestrado. Com vistas à busca de binômios em inglês, língua de partida para o desenvolvimento da pesquisa, a autora etiquetou apenas o corpus nessa língua. Dessa forma, tivemos que etiquetar sua contrapartida, ou seja, o corpus em português.

Para o inglês, todo o processo foi feito por meio eletrônico. A pesquisadora enviou o corpus para a Unit for Computer Research on English Language (UCREL) da University of Lancaster e os textos foram etiquetados automaticamente, com o etiquetador CLAWS (the Constituent Likelihood Automatic Word-tagging System), versão 7. Segundo Carvalho Fonseca (2007, p. 83), essa foi a versão mais adequada e indicada para sua pesquisa ${ }^{87}$.

O conjunto CLAWS 7 é composto por 137 etiquetas com um alto grau de detalhamento ${ }^{88}$, dentre as quais mencionamos aquelas utilizadas para os advérbios:

\begin{tabular}{|l|l|}
\hline \multicolumn{1}{|c|}{ Etiqueta } & \multicolumn{1}{c|}{ Descrição } \\
\hline RA & adverb, after nominal head (e.g. else, galore) \\
\hline REX & adverb introducing appositional constructions (namely, e.g.) \\
\hline RG & degree adverb (very, so, too) \\
\hline RGQ & wh- degree adverb (how) \\
\hline RGQV & wh-ever degree adverb (however) \\
\hline RGR & comparative degree adverb (more, less) \\
\hline RGT & superlative degree adverb (most, least) \\
\hline RL & locative adverb (e.g. alongside, forward) \\
\hline RP & prep. adverb, particle (e.g about, in) \\
\hline RPK & prep. adv., catenative (about in be about to) \\
\hline RR & general adverb \\
\hline RRQ & wh- general adverb (where, when, why, how) \\
\hline RRQV & wh-ever general adverb (wherever, whenever) \\
\hline RRR & comparative general adverb (e.g. better, longer) \\
\hline RRT & superlative general adverb (e.g. best, longest) \\
\hline RT & quasi-nominal adverb of time (e.g. now, tomorrow) \\
\hline Quadro 5 - Etiquetas utilizadas para identificar os advérbios no corpus do Direito \\
(ingless) - etiquetador CLAWs versão 7
\end{tabular}

Para o português, acabamos por etiquetar o corpus duas vezes. Na primeira, depois de concluído todo o processo, verificamos que o nível de detalhamento das etiquetas era desnecessário para nossa pesquisa, uma vez que os resultados apresentavam também informações sintáticas que não seriam aqui utilizadas e

\footnotetext{
${ }^{87}$ A autora indica o Website http://www.comp.lancs.ac.uk/ucrel/claws/ para mais informações.

${ }^{88}$ Para a lista completa das etiquetas, vide Carvalho Fonseca (2007, p. 84-86).
} 
dificultariam a investigação. Em todo o caso, apresentaremos, em linhas gerais, como se deu o processo.

O primeiro etiquetador utilizado foi o do projeto VISL (Visual Interactive Syntax Learning $)^{89}$.

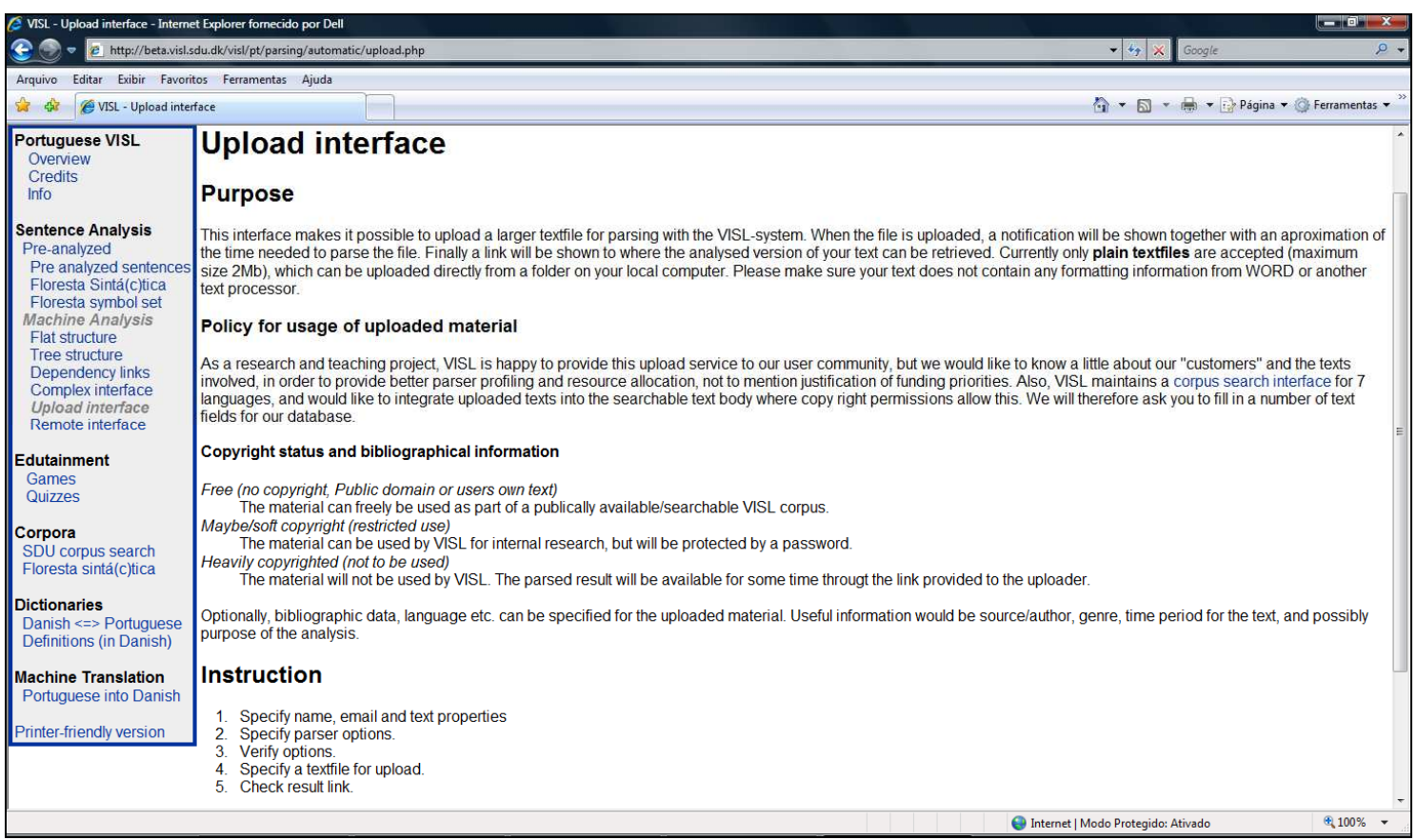

Figura 9 - Tela com instruções para carregar o texto a ser etiquetado no Portuguese VISL

Selecionamos a opção upload interface, que permite carregar cada arquivo individualmente e enviá-lo para etiquetagem. Dependendo do tamanho do texto, que deve estar em .txt, o processo pode levar alguns minutos e os resultados são disponibilizados em um link na própria tela em uso. Um aviso de que o texto etiquetado já está disponível também é enviado por e-mail, juntamente com o link. Dessa forma, etiquetamos os 140 textos do corpus (português) entre os meses de fevereiro e julho de 2008.

Para manipular esses dados, utilizamos o programa WordSmith Tools v. 5 (SCOTT, 2007). Logo no início, e mesmo antes de nos valermos das etiquetas, fizemos alguns testes buscando advérbios e tivemos certa dificuldade para trabalhar com os resultados. Apresentamos abaixo um pequeno trecho etiquetado do texto POACC01.txt:

\footnotetext{
${ }^{89}$ Disponível em http://beta.visl.sdu.dk/visl/pt/parsing/automatic/upload.php.
} 


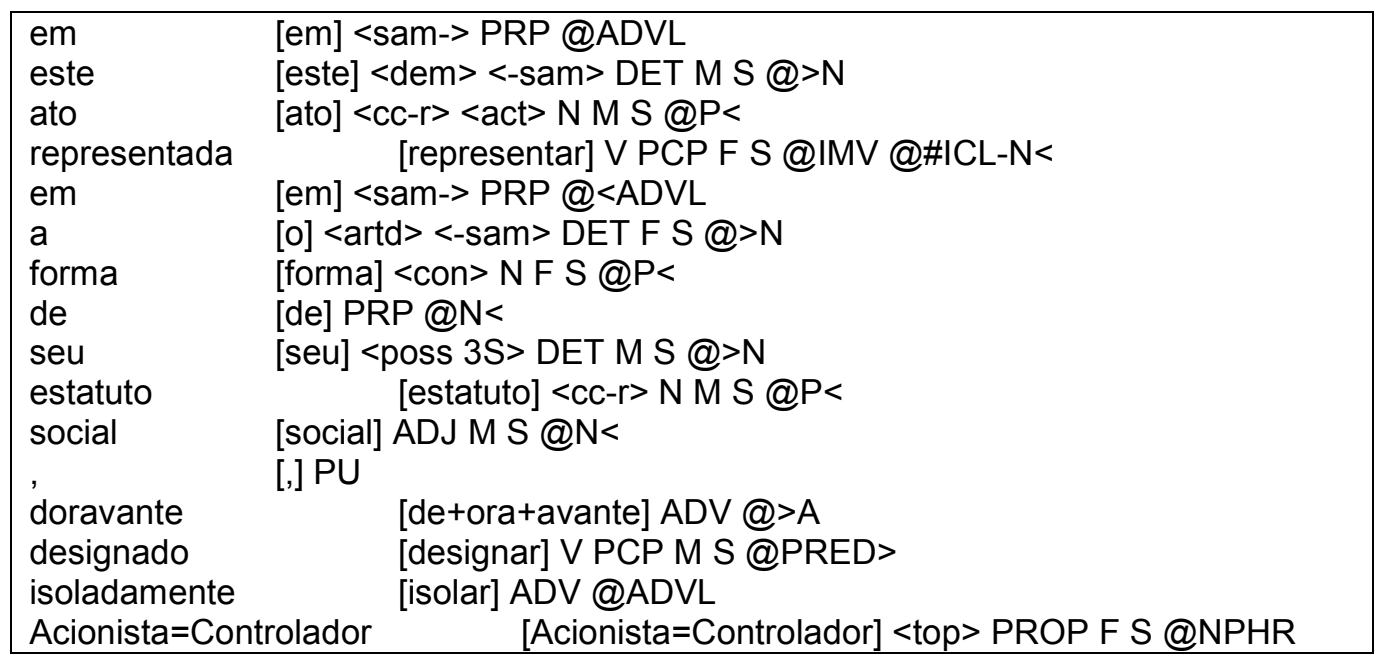

Figura 10 - Trecho etiquetado do texto POACC01.txt (Direito - português)

Apesar de não utilizados para esta pesquisa, decidimos manter todos os textos etiquetados com a ferramenta do projeto VISL, uma vez que poderão ser utilizados futuramente em outras pesquisas.

No segundo processo de etiquetagem, ainda no segundo semestre de 2008 , utilizamos o Etiquetador Tree-Tagger, na época disponível no site do CEPRIL (PUCSP) - http://www2.lael.pucsp.br/corpora/etiquetagem/index.html.

Conforme apresentado na figura 7 da seção anterior, o etiquetador apresenta os resultados em três colunas: a primeira, com a palavra etiquetada; a segunda, com a etiqueta morfossintática; e a terceira, com o lema da ocorrência (palavra) investigada. O exemplo abaixo é do texto POBAN01.txt, parte do corpus de Direito (português):

\begin{tabular}{|l|l|l|}
\hline \multicolumn{1}{|c|}{ palavra } & \multicolumn{1}{c|}{ etiqueta } & \multicolumn{1}{c|}{ lema } \\
\hline Não & ADV & não \\
\hline deixe & V & deixar \\
\hline que & CONJSUB & que \\
\hline outras & ADJ & outro \\
\hline pessoas & NOM & pessoa \\
\hline conheçam & V & conhecer \\
\hline ou & CONJ & ou \\
\hline vejam & V & ver \\
\hline o & DET & o \\
\hline seu & ADJ & seu \\
\hline Código & NOM & código \\
\hline Secreto & NOM & secreto \\
\hline enquanto & CONJ & enquanto \\
\hline digitá-lo & V & \\
\hline
\end{tabular}


Quanto às etiquetas, totalizam onze para o português. São elas ${ }^{90}$ :

\begin{tabular}{|l|l|}
\hline \multicolumn{2}{|c|}{ Pablo Gamallo TAGSET - 11 tags simples } \\
\hline Adjetivo & ADJ \\
\hline Advérbio & ADV \\
\hline Determinante & DET \\
\hline Número Cardinal/Ordinal & CARD \\
\hline Nome Comum/Próprio & NOM \\
\hline Pronome & P \\
\hline Preposição & PREP \\
\hline Verbo & V \\
\hline Interjeição & $\mathrm{I}$ \\
\hline Separadores dentro da oração & VIRG \\
\hline Separadores de orações & SENT \\
\hline
\end{tabular}

Quadro 6 - Etiquetas utilizadas para identificar os advérbios no corpus do Direito (português) - etiquetador Tree-Tagger

Há também combinações de etiquetas, como em PREP+DET (do, das, etc.) e $\mathrm{V}+\mathrm{P}$ (levou-me, disse-Ihe, etc.).

Para etiquetar os 140 textos, agrupamo-los de cinco em cinco em um único arquivo no formato .txt, de acordo com suas respectivas tipologias, seguindo a nomenclatura desenvolvida por Carvalho Fonseca (2007). Dessa forma, obtivemos 28 arquivos que foram carregados individualmente e enviados para etiquetagem. É importante enfatizar que, ao carregarmos o texto a ser etiquetado, temos a opção de fornecer algumas informações que serão automaticamente colocadas em forma de cabeçalho e farão parte dos resultados. Exemplo:

Etiquetador Tree-Tagger
PUC/SP, LAEL, CEPRIL
http://www2.lael.pucsp.br/corpora/etiquetagem
Thu Nov 13 23:31:04 BRST 2008
Corpus:
Língua: Português
Descrição: Direito - Instrumentos contratuais
Obs: POAAC01-05 (5 primeiros textos do corpus total)
Nome: Helmara
Extensão: Tokens: 49305 ; Types: 3341

Todos os resultados foram colocados em uma única pasta, para facilitar seu manuseio com o software WordSmith Tools versão 5 (SCOTT, 2007). Na próxima seção, descreveremos os principais recursos e ferramentas desse programa.

\footnotetext{
${ }^{90}$ Essas etiquetas foram desenvolvidas por Pablo Gamallo Otero e estão disponíveis no site do pesquisador: http://gramatica.usc.es/ gamallo/index.html, opção Linguistic Tools.
} 
Para manipularmos grandes quantidades de dados, necessitamos utilizar ferramentas especialmente desenvolvidas para pesquisa lingüística. Nesta investigação, selecionamos o programa WordSmith Tools (WST) versão 5 (SCOTT, 2007), desenvolvido por Mike Scott ${ }^{91}$.

O WST apresenta-nos uma série de recursos que acessamos por meio da página principal, chamada de Controller. Quando aberta, ela fica no canto esquerdo superior da tela, podendo ser maximizada caso o usuário assim o deseje.

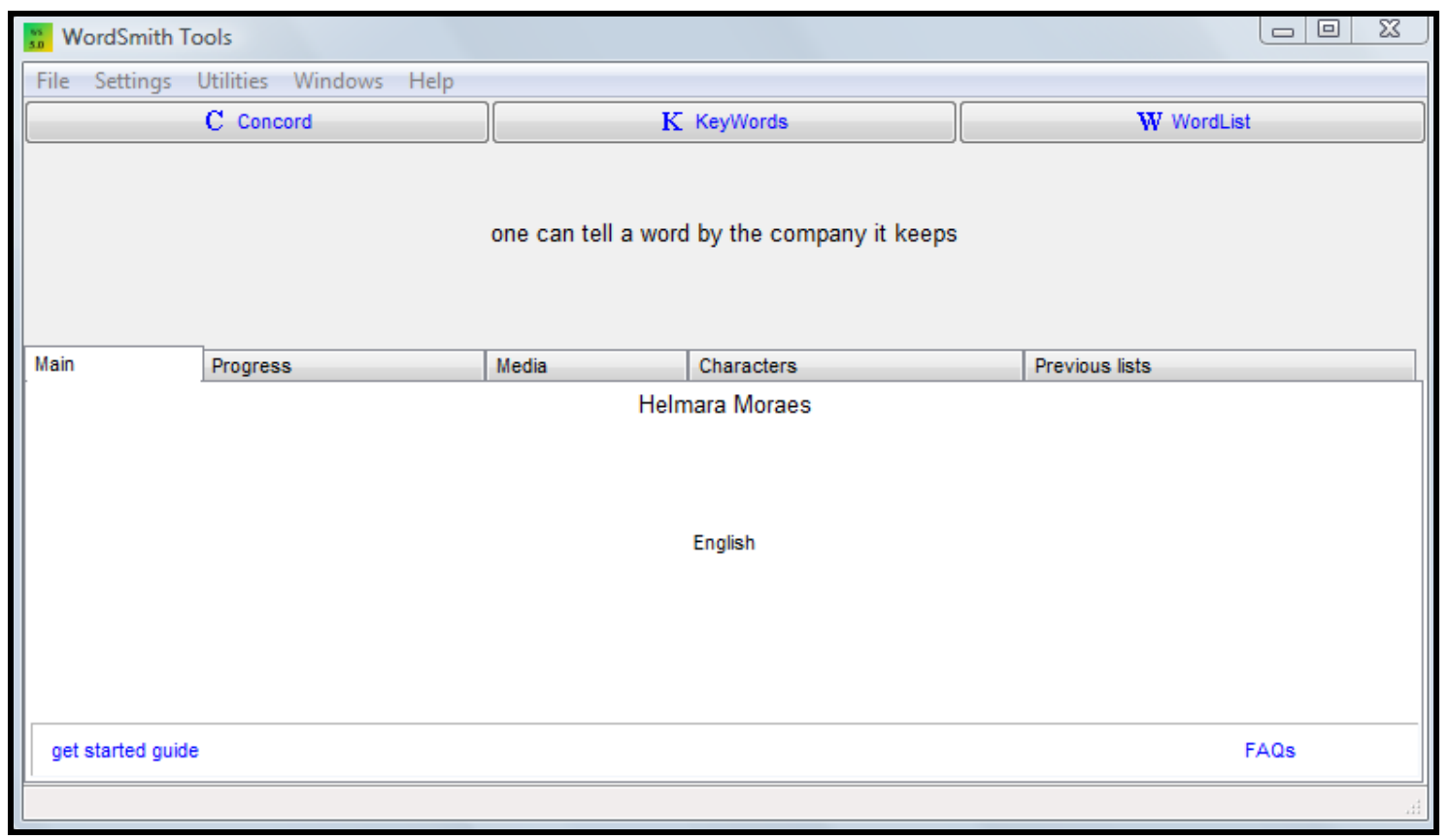

Figura 11 - O Controller do programa WST, com as três ferramentas disponíveis

As três ferramentas disponíveis são: Concord, KeyWords e WordList. Quanto aos utilitários, o programa apresenta onze ${ }^{92}$, alguns novos nesta versão. Dentre eles, destacamos o WSConcGram.

A seguir, apresentaremos alguns detalhes de cada ferramenta, exemplificando, quando possível, com os dados de nossa pesquisa.

\footnotetext{
91 Disponível em http://www.lexically.net/wordsmith. O pesquisador pode tanto utilizar a versão demo - é gratuita e apresenta resultados mais limitados -, quanto comprar o programa completo no próprio Website. Como será esta nossa principal ferramenta de investigação, optamos pela aquisição, feita em 20/08/2008.

${ }_{92}$ Para detalhes sobre cada um deles, acesse o manual disponível no próprio programa ou consulte-o via online em http://www.lexically.net/downloads/version5/HTML/index.html
} 
A primeira ferramenta que utilizamos foi a WordList, que gera 3 listas de palavras a partir do corpus selecionado:

Freqüência: apresenta todas as palavras do corpus, em ordem decrescente de freqüência, com detalhes sobre a porcentagem correspondente de cada uma no corpus e o número de textos em que foi encontrada.

\begin{tabular}{|c|c|c|c|c|c|c|c|c|c|}
\hline W. WordList & & & & & & & & \begin{tabular}{ll|l}
$口$ & 回 \\
\end{tabular} & $\Sigma 3$ \\
\hline File Edit & View Co & apute $\mathrm{Se}$ & ttings Win & dow Help & & & & & \\
\hline $\mathrm{N}$ & & & Wor & \begin{tabular}{l|l|} 
d & Freq. \\
\end{tabular} & $\%$ & Texts & $\%$ & emmas||Set & 1 \\
\hline 1 & & & $\mathrm{TH}$ & $E 44,846$ & 6.91 & 140 & 100.00 & & $\square$ \\
\hline 2 & & & $\mathrm{O}$ & F 27,987 & 4.31 & 140 & 100.00 & & \\
\hline 3 & & & $\mathrm{~T}$ & O 22,283 & 3.44 & 140 & 100.00 & & \\
\hline 4 & & & AN & D 20,965 & 3.23 & 140 & 100.00 & & \\
\hline 5 & & & $\mathrm{O}$ & R 19,341 & 2.98 & 139 & 99.29 & & \\
\hline 6 & & & & $\# 16,867$ & 2.60 & 140 & 100.00 & & \\
\hline 7 & & & | & N 12,489 & 1.93 & 140 & 100.00 & & \\
\hline 8 & & & AN & $Y \quad 11,025$ & 1.70 & 139 & 99.29 & & \\
\hline 9 & & & SHAL & L $\quad 8,787$ & 1.35 & 134 & 95.71 & & \\
\hline 10 & & & & A $\quad 8,510$ & 1.31 & 139 & 99.29 & & \\
\hline 11 & & & $B$ & Y $\quad 8,038$ & 1.24 & 140 & 100.00 & & \\
\hline 12 & & & $\mathrm{~B}$ & E $\quad 7,809$ & 1.20 & 140 & 100.00 & & \\
\hline 13 & & & GREEMEN & T $\quad 6,116$ & 0.94 & 134 & 95.71 & & \\
\hline 14 & & & THI & S 6,042 & 0.93 & 139 & 99.29 & & \\
\hline 15 & & & $\mathrm{FO}$ & 6,027 & 0.93 & 140 & 100.00 & & - \\
\hline frequency & alphabetical & statistics & filenames & notes & & & & & \\
\hline $10,243 \quad$ Тур & pe-in 2,67 & & & & & & & & \\
\hline
\end{tabular}

Figura 12 - 15 primeiras ocorrências da lista de frequência do corpus de Direito (inglês)

Alfabética: apresenta todas as ocorrências do corpus em ordem alfabética. Pode, inclusive, ser ordenada de forma reversa, ou seja, da última para a primeira letra da palavra. Nesse caso, por exemplo, é possível agrupar todos os advérbios terminados em -ly/-mente.

Estatística: apresenta informações estatísticas tanto do corpus como um todo quanto de cada arquivo. Dentre elas, podemos destacar: o número de ocorrências (tokens), o número de formas (types), a razão forma/ocorrência (type/token ratio) e a razão forma/ocorrência padronizada (standardized type/token ratio). Na figura abaixo, apresentamos um recorte da lista do corpus de Direito (inglês). 


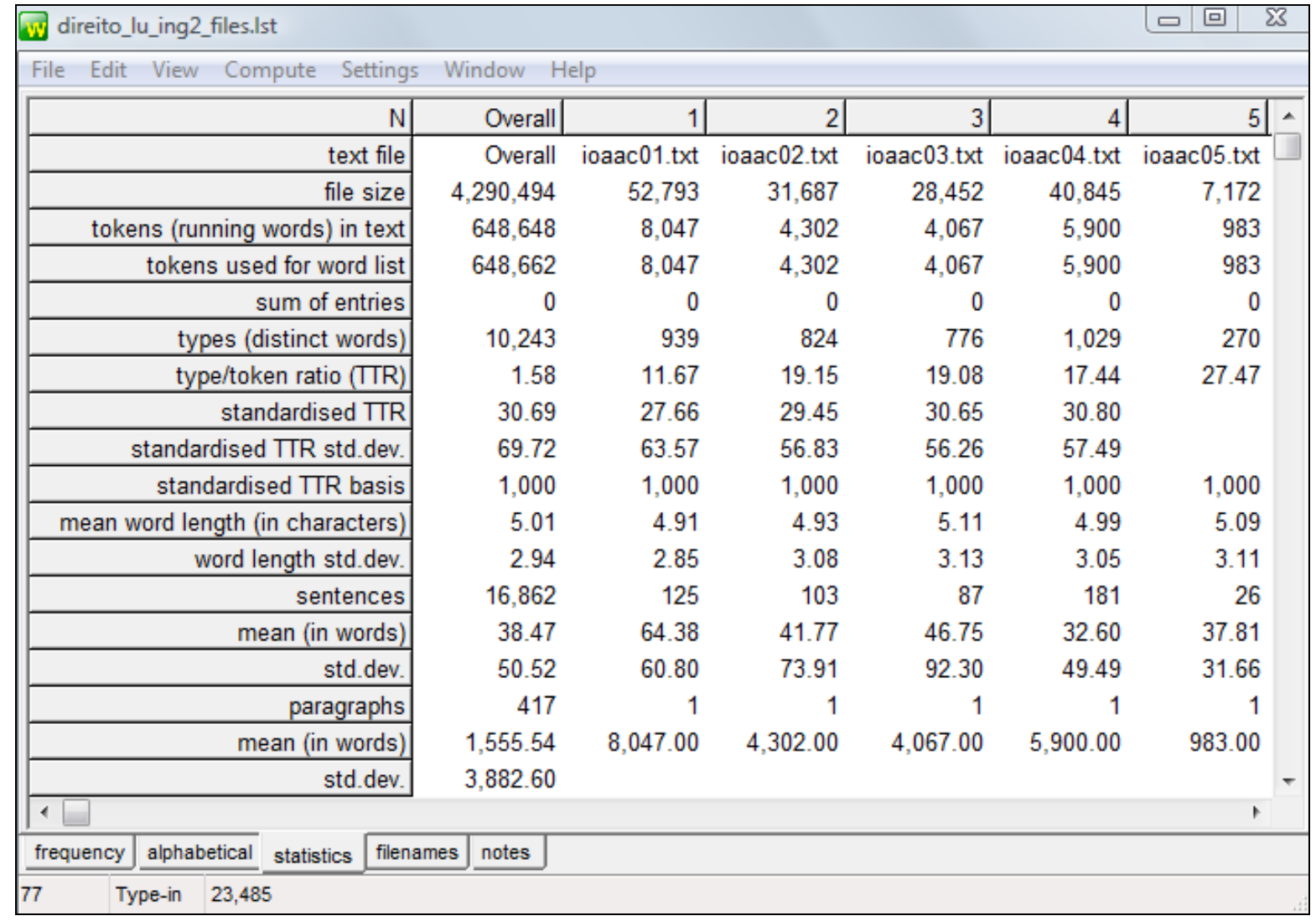

Figura 13 - Dados estatísticos do corpus de Direito (inglês) e de alguns de seus textos

Dentre seus vários usos, a ferramenta WordList permite:

- verificar o tipo de vocabulário do corpus, ao se observar a lista de freqüência;

- identificar os agrupamentos lexicais (clusters) mais comuns;

- gerar as linhas de concordância de uma ou mais palavras da lista, o que possibilita comparar a frequência de uma dada palavra em diferentes arquivos (esse número pode ser observado em plot, recurso que explicaremos na sequência);

- verificar a densidade lexical dos textos, que pode ser medida pela razão forma/ocorrência geral ou padronizada, dependendo dos objetivos da pesquisa.

As listas de freqüência também são importantes para utilizarmos a ferramenta KeyWords, pois são necessárias para encontrarmos as palavras-chave de um dado corpus de estudo. É importante enfatizar que todos os arquivos a serem utilizados para gerar uma lista de palavras devem estar em arquivo de texto (.txt).

A segunda ferramenta que utilizamos foi Concord. Definida uma palavra (também chamada de nódulo) ou expressão de busca, a ferramenta irá buscar todas 
as suas ocorrências no corpus em estudo, apresentando-a no contexto em que ocorreu. Esse contexto é apresentado em uma linha, mas pode ser ampliado ou, se for o caso, o pesquisador pode clicar na palavra e visualizá-la em seu texto de origem. As linhas de concordância são colocadas uma embaixo da outra, apresentando todas as ocorrências em que a palavra ou expressão de busca foi localizada. Observando essas linhas, o pesquisador pode ver, conjuntamente, vários exemplos contextualizados de seu uso, o que facilita a visualização de padrões em que a palavra possa ocorrer. Pode inclusive manipular esses dados ordenando as ocorrências à direita ou à esquerda dessa palavra ou expressão, colocando-as em ordem alfabética. Vejamos os exemplos nas figuras abaixo:

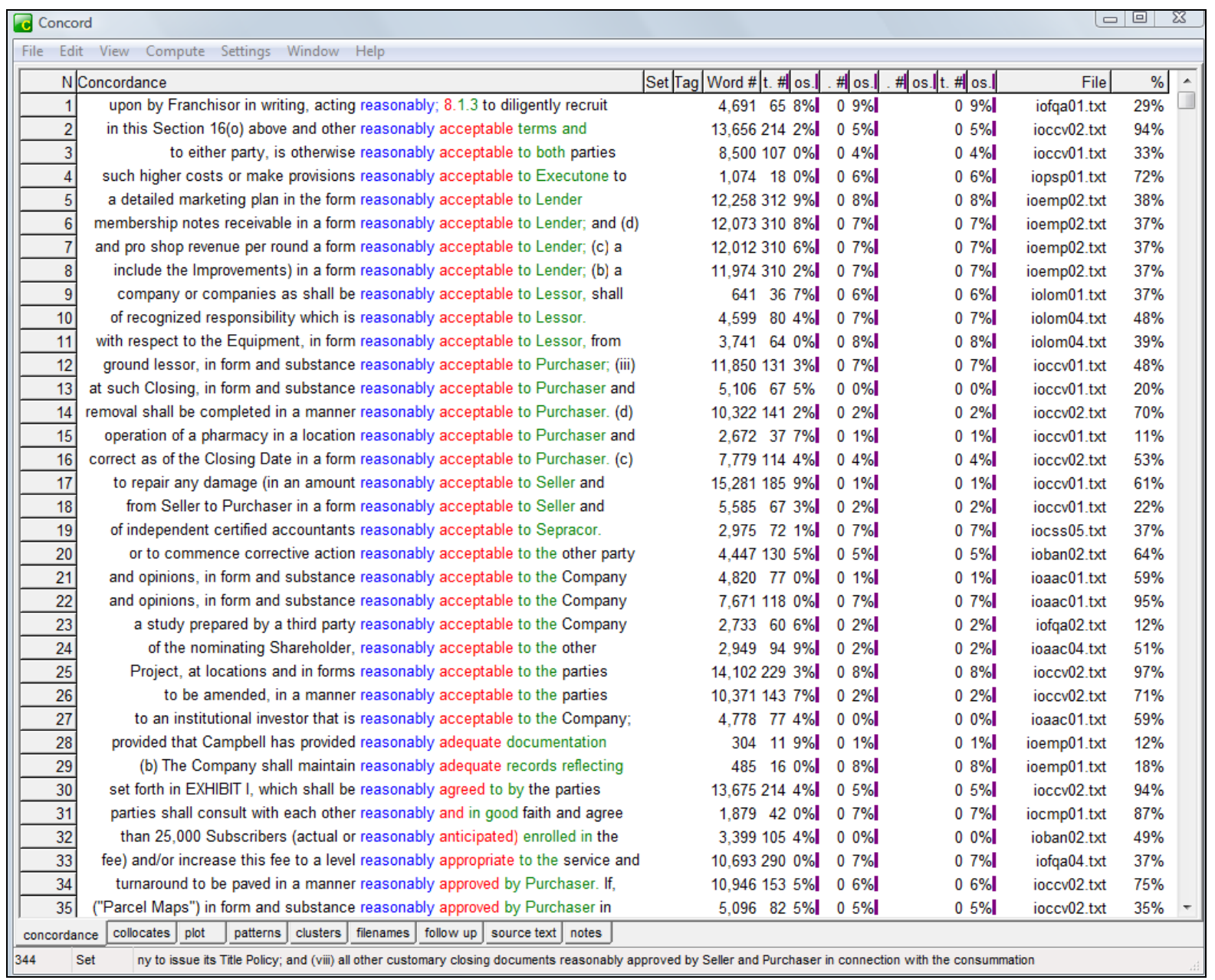

Figura 14 - Linhas de concordância para reasonably (corpus de Direito - inglês), ordenadas pela $1^{\mathrm{a}}, 2^{\mathrm{a}}$ e $3^{\mathrm{a}}$ palavras à sua direita 


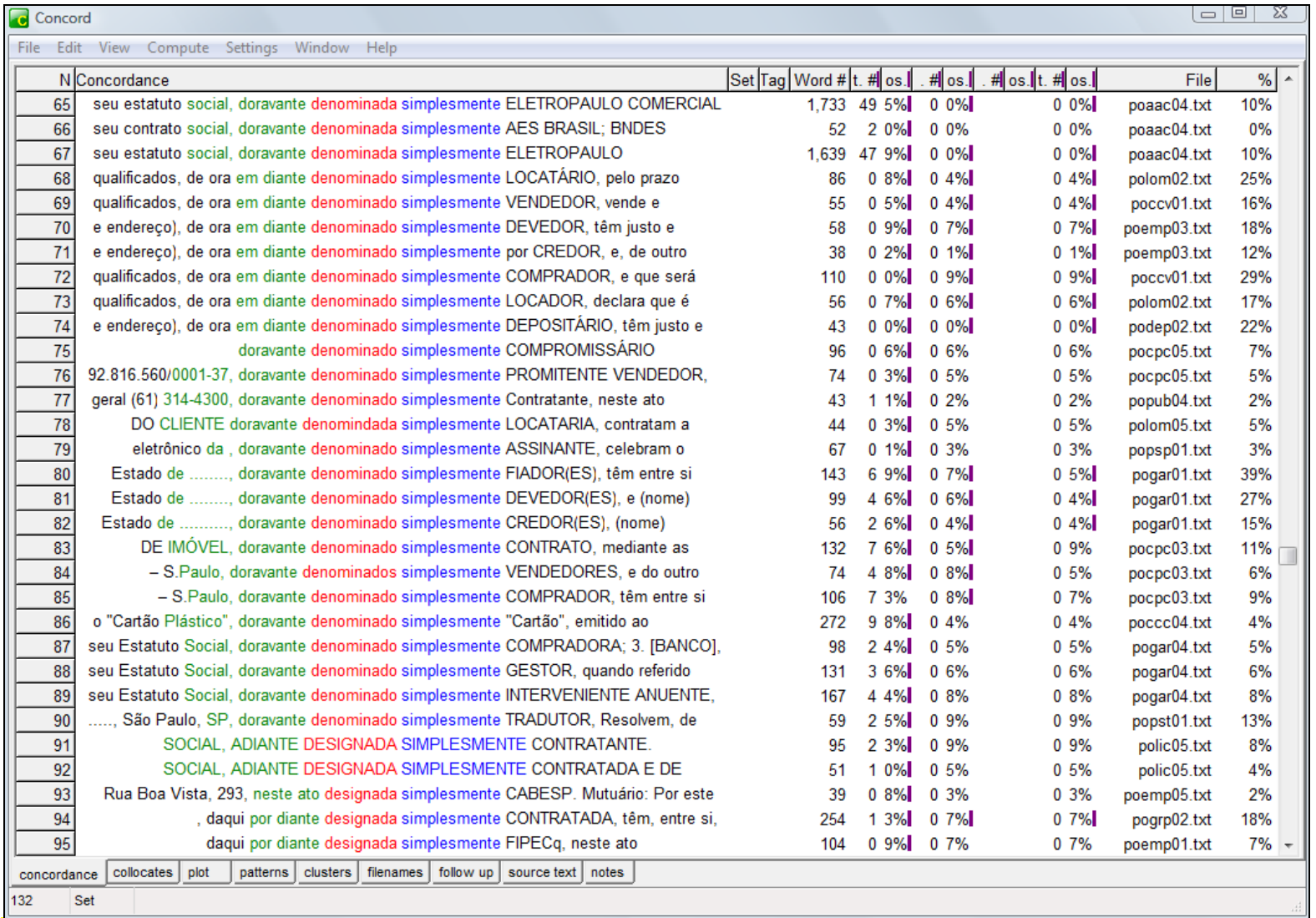

Figura 15 - Linhas de concordância para simplesmente (corpus de Direito - português), ordenadas pela $1^{\mathrm{a}}, 2^{\mathrm{a}}$ e $3^{\mathrm{a}}$ palavras à sua esquerda

Outro recurso dessa ferramenta é o collocates, que apresenta uma lista de colocados (palavras que co-ocorrem com a expressão de busca) com 5 palavras à direita e 5 à esquerda como default. Na figura abaixo, reasonably (corpus de Direito - inglês) é nossa palavra de busca e aparece na posição centre, com o número de ocorrências na primeira linha. Os números em vermelho ressaltam as co-ocorrências mais freqüentes, como é o caso de may (em 75 co-ocorrências, 49 estão na primeira posição à esquerda) ou necessary (em 35 co-ocorrências, 29 estão na primeira posição à direita), por exemplo. 


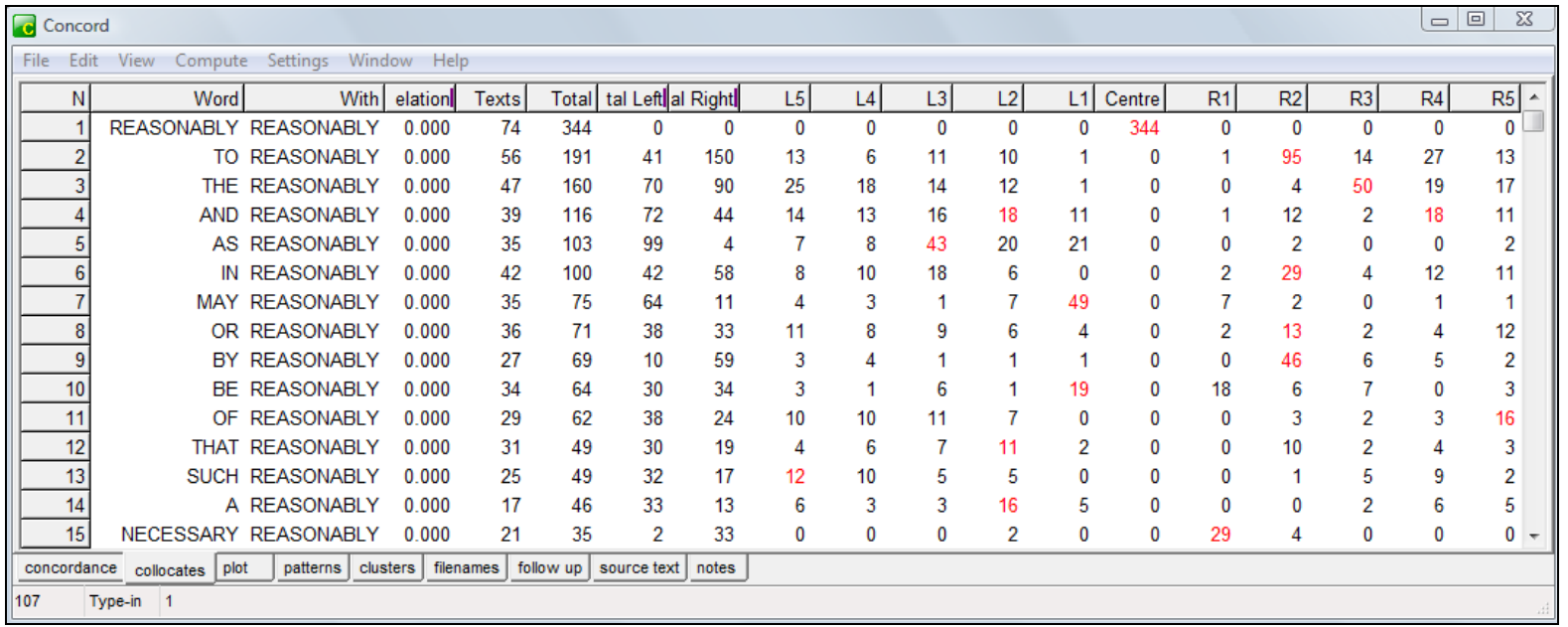

Figura 16 - 15 primeiras linhas da lista de colocados para reasonably (corpus de Direito - inglês)

O plot é outro recurso que mostra onde a palavra de busca ocorre em cada arquivo. Desse modo, podemos visualizar a parte do texto em que mais ocorre. Da esquerda para a direita na figura abaixo, o plot apresenta:

1- o arquivo em que a palavra foi encontrada;

2- o número de palavras daquele arquivo;

3- o número de ocorrências da palavra de busca (hits);

4- o número de ocorrências dessa palavra de busca em cada mil palavras;

5- o valor estatístico da dispersão da palavra de busca naquele texto, que se relaciona à uniformidade (ou não) dessa distribuição - esse valor dá suporte matemático ao gráfico e facilita a comparação. Os resultados de 0.9 a 1 sugerem uma dispersão bastante uniforme, sendo o extremo oposto observado em 0 e 0.1 ;

6- um "gráfico" que mostra onde a palavra de busca é identificada em cada arquivo.

No exemplo abaixo, observamos que em POACC04 (arquivo do corpus de Direito - português) há uma grande concentração de simplesmente no início desse texto. 


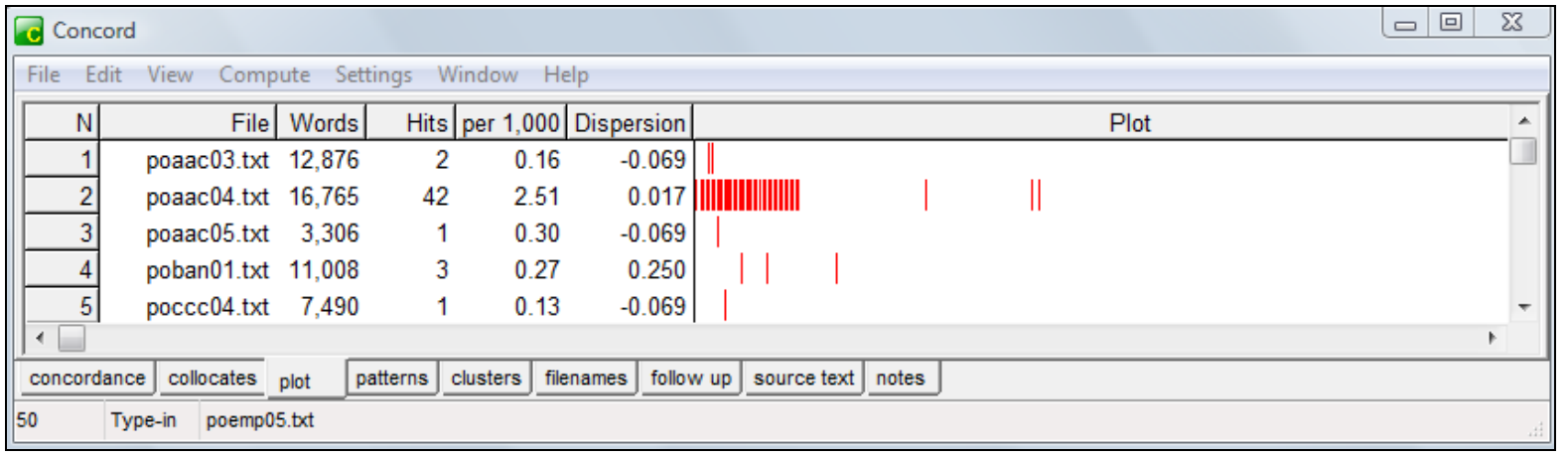

Figura 17 - 5 primeiras linhas do recurso plot para a palavra simplesmente (corpus de Direito - português)

Dentre os nove recursos disponíveis na ferramenta Concord, quais sejam concordance, collocates, plot, patterns, clusters, filenames, follow up, source text, notes, vale ainda salientar mais dois: patterns e clusters.

O recurso patterns ressalta as co-ocorrências mais freqüentes para a palavra de busca, dispondo-as em ordem decrescente de freqüência na posição em que ocorrem (à direita ou à esquerda do nódulo), o que possibilita a visualização de padrões lexicais ou gramaticais. No exemplo abaixo, as palavras que mais coocorrem com reasonably são may à esquerda e request à direita (corpus de Direito inglês). A segunda mais freqüente à direita é necessary, e assim sucessivamente.

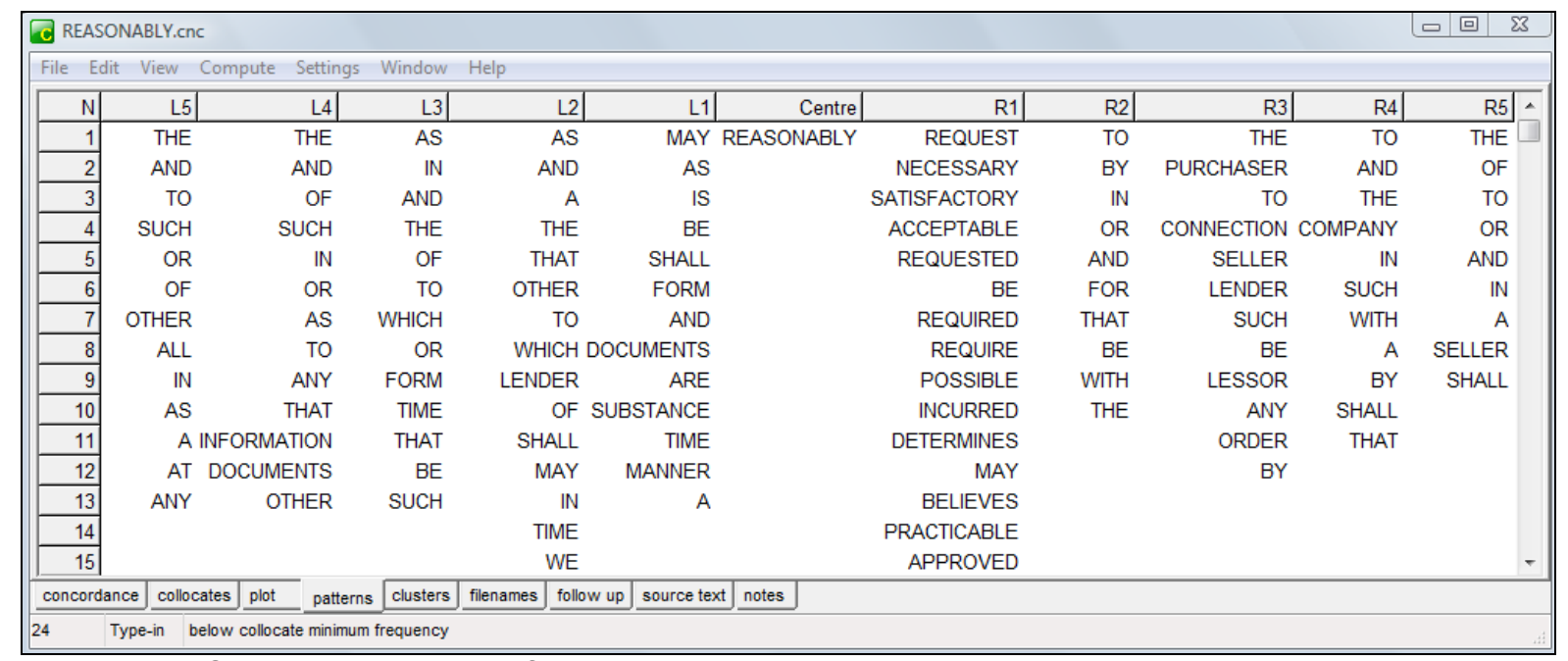

Figura 18 - Co-ocorrências mais freqüentes para a palavra de busca reasonably (corpus de Direito - inglês)

Clusters é um recurso que muito auxilia o pesquisador em busca de padrões linguísticos, especialmente quando trabalhamos com um grande número de concordâncias, uma vez que contabiliza o número de ocorrências de dada associação. Esses agrupamentos lexicais são computados automaticamente, mas é 
possível alterar o default de acordo com os objetivos do usuário. Para esta pesquisa, por exemplo, estabelecemos uma variação de 2 a 6 palavras, com um horizonte de 5 para cada lado e uma freqüência mínima de 5 ocorrências. Esses números poderão ser ajustados de acordo com cada investigação. Para esses ajustes, clicamos em compute $\rightarrow$ clusters e abre-se a janela cluster settings. Além dessa janela, a figura abaixo mostra os vinte clusters mais freqüentes de reasonably. Na coluna related, podemos observar outras unidades maiores em que um determinado cluster ocorreu, bem como seu número de ocorrências.

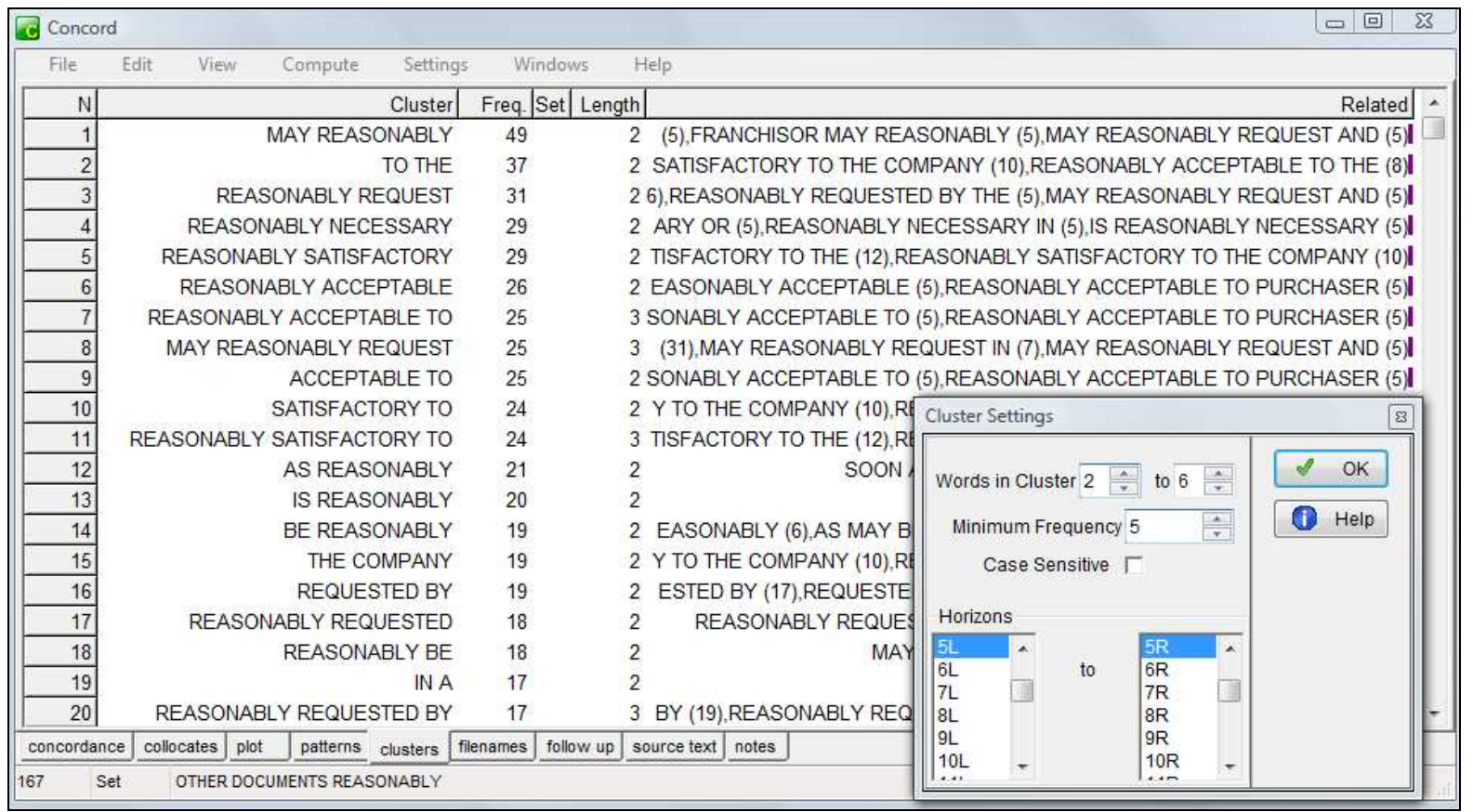

Figura 19 - Resultados parciais do recurso clusters para reasonably (corpus de Direito - inglês) e a janela para ajustes

A terceira e última ferramenta que gostaríamos de mencionar é KeyWords, utilizada para identificar as palavras-chave em um ou mais textos. Dentre seus vários usos, ela ajuda o pesquisador a identificar a tipologia textual, uma vez que as palavras-chave dessa tipologia ficam evidentes na comparação que o programa faz entre duas listas de palavras, previamente geradas com a ferramenta WordList. O resultado desse contraste é uma lista de palavras-chave cuja frequência é estatisticamente diferente nos corpora comparados, ou seja, no corpus de estudo e no de referência.

$\mathrm{Na}$ presente pesquisa, compararemos as listas dos corpora de estudo Direito e Culinária -, com aquelas de nossos corpora de referência, com o objetivo de verificar em quais posições se encontram os advérbios terminados em -ly e 
-mente, se é que serão listados como palavras-chave. Devemos lembrar que cada um desses domínios apresenta duas listas, uma em inglês e outra em português.

No total, foram geradas quatro listas de palavras-chave, duas em inglês e duas em português. Para gerarmos a lista de palavras-chave do corpus de Direito (português), por exemplo, primeiramente foi extraída uma lista de palavras com a ferramenta WordList, tanto para esse corpus quanto para o corpus de referência, o Banco de Português. Em Keywords, fizemos alguns ajustes no item Settings e estabelecemos três como freqüência mínima (este é o default) e um número máximo de 2.000 resultados (o default é 500), para que pudéssemos verificar, em um horizonte maior, a presença de advérbios terminados em -mente. Em seguida, selecionamos as listas extraídas com a ferramenta WordList, clicamos em make a keyword list now e a lista de palavras-chave foi gerada.

A figura abaixo mostra as primeiras 25 palavras que são "mais chave" em nosso corpus de estudo do Direito (português). É interessante observar, por exemplo, a diferença na porcentagem de ocorrência das palavras cláusula e contrato entre o corpus de estudo e o de referência: enquanto representam 0,54\% e 0,72\% do corpus de estudo, respectivamente, não apresentam quaisquer valores na coluna que se refere à porcentagem de ocorrência no corpus de referência. Essa constatação indica que cláusula e contrato são palavras típicas do corpus de estudo, ou seja, da área do Direito. Devemos observar que as palavras na figura estão listadas em ordem decrescente de chavicidade (keyness), não de frequência. 


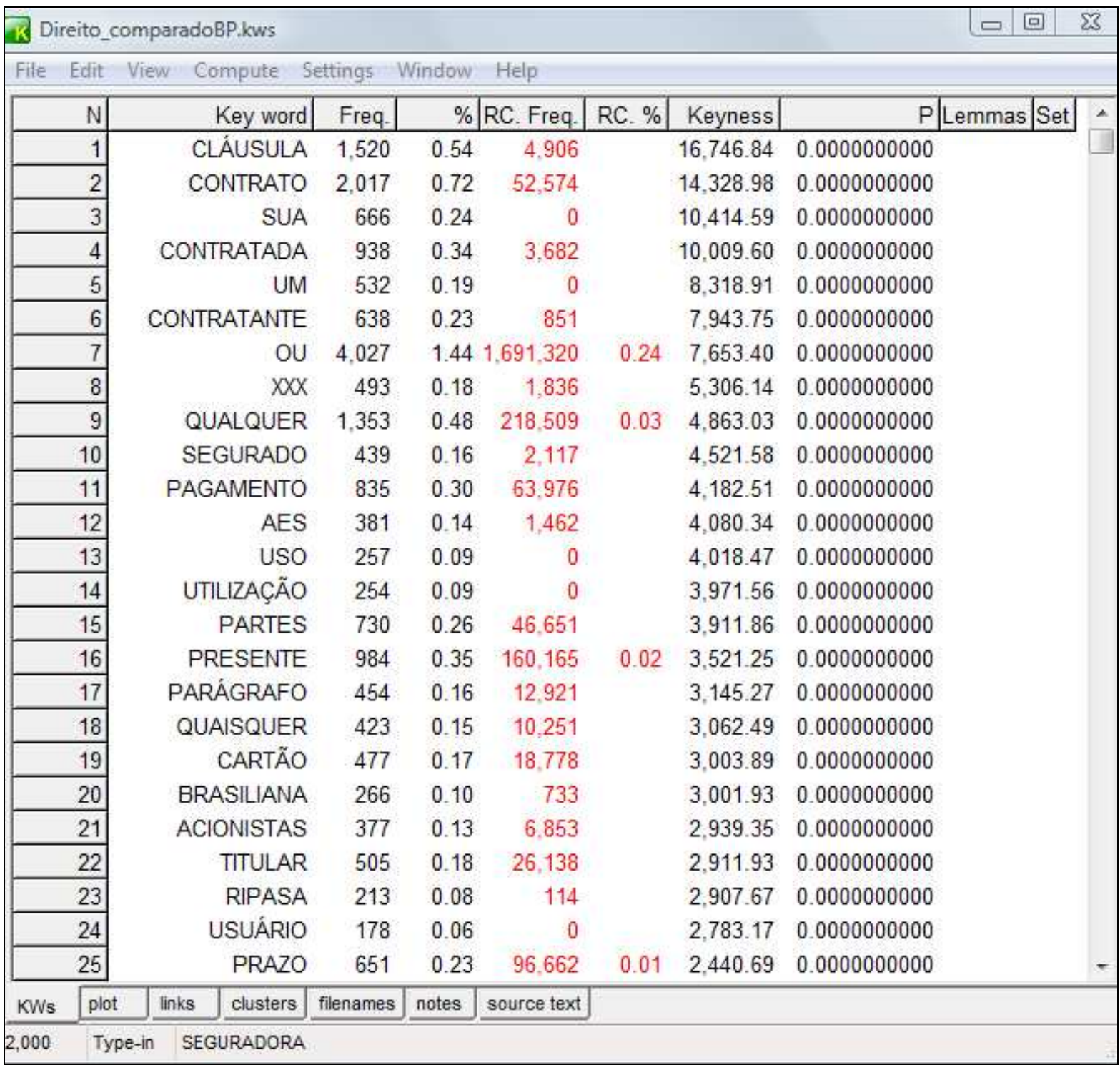

Figura 20 - 25 primeiras palavras-chave do corpus de Direito (português)

As sete colunas que podemos observar, da esquerda para a direita, apresentam as seguintes informações (por coluna):

1- as palavras-chave do corpus de estudo por ordem decrescente de chavicidade (keyness);

2- a freqüência dessas palavras no corpus de estudo;

3- a porcentagem que essa freqüência representa com relação ao corpus de estudo total;

4- a freqüência dessas palavras no corpus de referência;

5- a porcentagem que essa freqüência representa com relação ao corpus de referência total;

6- a chavicidade, ou seja, o resultado da estatística de comparação (neste estudo, utilizamos o log likelihood); 
7- o $p$, valor de significância estatística atingido pelo resultado da chavicidade, ou seja, a probabilidade de aquela palavra ter sido erroneamente identificada como chave pelo cálculo estatístico. (TEIXEIRA, 2008, p. 173)

Dentre os utilitários disponíveis no programa, em algum momento utilizamos o WSConcGram. Com ele, o pesquisador consegue verificar associações de palavras, consecutivas ou não - o que o distingue do recurso clusters, anteriormente apresentado -, que talvez revelem padrões lingüísticos. Para utilizá-lo, o usuário deve, primeiramente, gerar uma lista de palavras indexada com a ferramenta Wordlist, acima descrita. Ao invés de clicar em make a wordlist now, deve-se clicar em make/add to index.

O programa irá gerar três listas: uma com a extensão *.tokens, outra com a extensão *.types, e uma terceira com *.stats. Depois de salvas, essas listas serão automaticamente utilizadas pela ferramenta. Na figura abaixo, apresentamos os resultados gerados para o advérbio reasonably: 


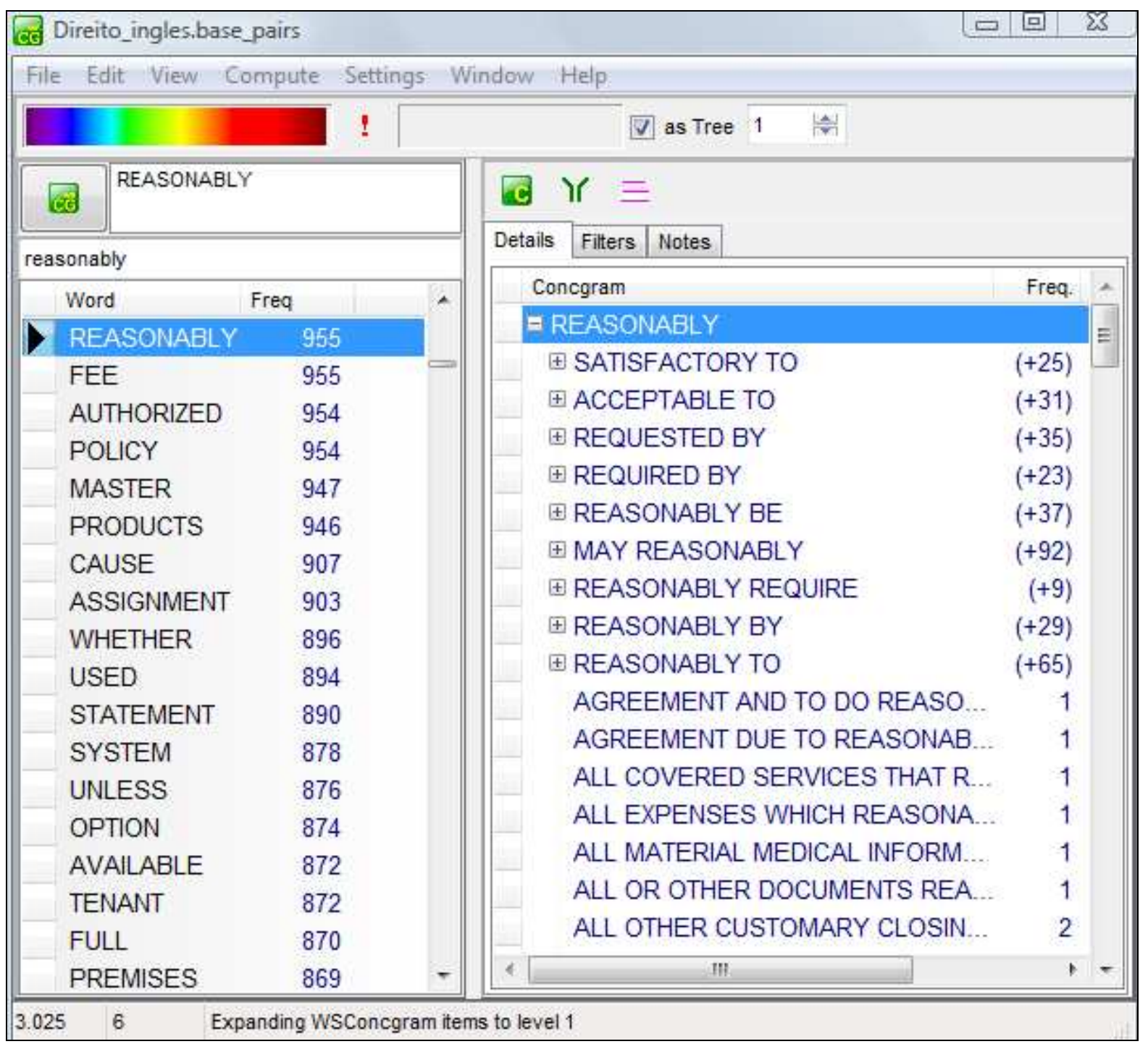

Figura 21 - Resultados do WSConcGram para o advérbio reasonably (Direito - inglês)

As concgrams, ou seja, as associações entre palavras (consecutivas ou não), são listadas na janela à direita. Clicando no sinal de + (mais), abrimos todas as ocorrências em que a associação apresentada ocorreu. Na coluna freq. (frequência), podemos visualizar quantas vezes a unidade foi encontrada. No caso de reasonably to, por exemplo, temos 65 outras associações das quais faz parte, e que podem também apresentar mais ocorrências cada uma. Para verificar a associação em contexto, basta clicar duas vezes sobre ela e somos direcionados às linhas de concordância.

Como podemos observar, o WSConcGram é bastante útil para identificarmos padrões linguísticos. Podemos, inclusive, verificar como uma dada palavra associase a outra. No exemplo abaixo, selecionamos reasonably e request - pode-se 
trabalhar com duas ou mais palavras em uma mesma busca - para gerarmos as concgrams dessa provável associação:

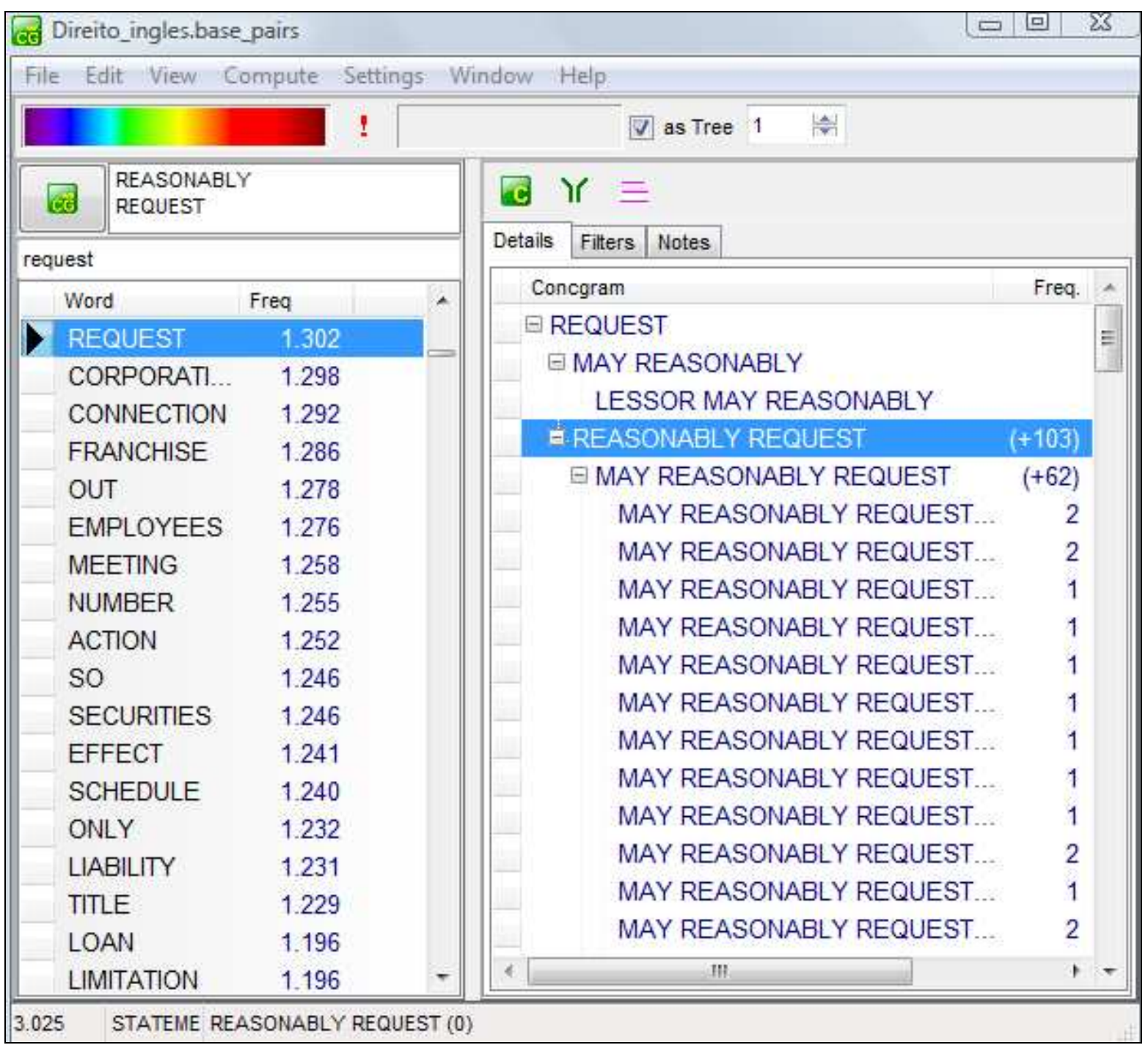

Figura 22 - Concgrams para reasonably e request (Direito - inglês)

No quadro à direita, a ferramenta elenca todas as associações em que as palavras reasonably e request foram encontradas.

Nesta seção, esperamos ter apresentado um panorama geral do programa WordSmith Tools v. 5 (SCOTT, 2007), mais especificamente das ferramentas que serão utilizadas para o levantamento de dados em nosso estudo. 
2.6 O levantamento dos advérbios em inglês e em português

Para justificarmos uma pesquisa que enfocasse os advérbios terminados em -ly (inglês) e -mente (português) necessitávamos, além de consultar outras pesquisas que já apontavam a presença marcante desses advérbios, como é o caso de Moraes (2005) em língua geral e de Teixeira (2008) na área da Culinária (receitas), verificar a frequência de advérbios em geral em nossos corpora de estudo e, a partir dela, identificar quantos seriam terminados em -ly e -mente. Para isso, valemo-nos das versões etiquetadas de nosso material, quais sejam os corpora integralmente etiquetados na área do Direito e os $10 \%$ em cada língua na Culinária.

Primeiramente, fizemos o levantamento das ocorrências de todas as etiquetas utilizadas para descrever um advérbio em cada um dos quatro corpora. Os resultados são:

Tabela 6 - Advérbios no corpus do Direito (inglês), a partir das etiquetas

\begin{tabular}{|l|c|c|c|c|}
\hline \multicolumn{5}{|c|}{ Direito (inglês) } \\
\hline \multicolumn{1}{|c|}{ etiqueta: descrição } & freq. & $\%$ & textos & $\%$ \\
\hline RA: adverb, after nominal head (e.g. else, galore) & 162 & 0,01 & 52 & 37,14 \\
\hline $\begin{array}{l}\text { REX: adverb introducing appositional constructions } \\
\text { (namely, e.g.) }\end{array}$ & 75 & & 24 & 17,14 \\
\hline RG: degree adverb (very, so, too) & 324 & 0,02 & 93 & 66,43 \\
\hline RGQ: wh- degree adverb (how) & 2 & & 2 & 1,43 \\
\hline RGQV: wh-ever degree adverb (however) & 7 & & 7 & 5,00 \\
\hline RGR: comparative degree adverb (more, less) & 84 & & 40 & 28,57 \\
\hline RGT: superlative degree adverb (most, least) & 25 & & 18 & 12,86 \\
\hline RL: locative adverb (e.g. alongside, forward) & 859 & 0,07 & 123 & 87,86 \\
\hline RP: prep. adverb, particle (e.g about, in) & 716 & 0,06 & 112 & 80,00 \\
\hline RPK: prep. adv., catenative (about in be about to) & 2 & & 1 & 0,71 \\
\hline RR: general adverb & 13.984 & 1,08 & 140 & 100,00 \\
\hline RRQ: wh- general adverb (where, when, why, how) & 318 & 0,02 & 101 & 72,14 \\
\hline RRQV: wh-ever general adverb (wherever, whenever) & 68 & & 39 & 27,86 \\
\hline RRR: comparative general adverb (e.g. better, longer) & 349 & 0,03 & 100 & 71,43 \\
\hline RRT: superlative general adverb (e.g. best, longest) & 10 & & 8 & 5,71 \\
\hline RT: quasi-nominal adverb of time (e.g. now, tomorrow) & 904 & 0,07 & 122 & 87,14 \\
\hline Total de etiquetas: & $\mathbf{1 7 . 8 8 9}$ & & & \\
\hline
\end{tabular}


Tabela 7 - Advérbios no corpus do Direito (português), a partir das etiquetas

\begin{tabular}{|l|c|c|c|c|}
\hline \multicolumn{5}{|c|}{ Direito (português) } \\
\hline \multicolumn{1}{|c|}{ etiqueta: descrição } & freq. & $\%$ & textos & $\%$ \\
\hline ADV: advérbio & 7.350 & 0,83 & $\mathbf{2 8}^{\mathbf{9 3}^{3}}$ & $\mathbf{1 0 0 , 0 0}$ \\
\hline Total de etiquetas & $\mathbf{7 . 3 5 0}$ & & & \\
\hline
\end{tabular}

Tabela 8 - Advérbios no corpus da Culinária (inglês), a partir das etiquetas

\begin{tabular}{|l|c|c|c|c|}
\hline \multicolumn{5}{|c|}{ Culinária (inglês) } \\
\hline \multicolumn{1}{|c|}{ etiqueta: descrição } & freq. & $\%$ & do corptos & $\%$ \\
\hline RB: adverb & 5.295 & 1,06 & $\mathbf{2 3}$ & $\mathbf{1 0 0 , 0 0}$ \\
\hline RBR: adverb, comparative & 63 & 0,01 & 16 & 69,57 \\
\hline RBS: adverb, superlative & 15 & & 11 & 47,83 \\
\hline WRB: wh-adverb & 203 & 0,04 & 22 & 95,65 \\
\hline Total de etiquetas & $\mathbf{5 . 5 7 6}$ & & & \\
\hline
\end{tabular}

Tabela 9 - Advérbios no corpus da Culinária (português), a partir das etiquetas

\begin{tabular}{|c|c|c|c|c|}
\hline \multicolumn{5}{|c|}{ Culinária (português) (10\% do corpus total) } \\
\hline etiqueta: descrição & freq. & $\%$ & textos & $\%$ \\
\hline ADV: advérbio & 3.163 & $1,00 \%$ & $1^{94}$ & $100 \%$ \\
\hline Total de etiquetas & 3.163 & & & \\
\hline
\end{tabular}

Considerando-se que os etiquetadores utilizados são confiáveis e que a taxa de acerto dos melhores etiquetadores atualmente disponíveis fica em torno de $97 \%$ (BERBER SARDINHA, 2004, p. 156), podemos totalizar as ocorrências de advérbios nos dados analisados conforme segue:

Direito (inglês): 17.889 (corpus integral)

Direito (português): 7.350 (corpus integral)

Culinária (inglês): 5.576 (10\% do corpus)

Culinária (português): 3.163 (10\% do corpus)

Levantamos também o número de advérbios terminados em -ly e -mente em cada um dos corpora. Para isso, geramos a lista de palavras com a ferramenta Wordlist, utilizando os corpora crus. Preferimos não utilizar o material etiquetado

\footnotetext{
${ }^{93}$ Vale lembrar que todos os 140 textos que compõem o corpus foram agrupados em 28 arquivos de texto.

${ }^{94}$ Neste caso, todas as receitas etiquetadas estão em um único arquivo - daí o registro de apenas um texto, com $100 \%$.
} 
nesta fase, pois além de não o termos na íntegra para a Culinária (inglês), optamos por coletar esses advérbios a partir das listas de palavras e elencá-los com suas respectivas frequências em uma planilha em Excel, iniciando assim a observação de nossos dados. Nesse momento, eliminamos aquelas palavras que, no caso do inglês, terminavam em -ly mas não derivavam de um adjetivo ou mesmo geraram dúvidas quanto à sua classificação gramatical (ora advérbio, ora adjetivo, dependendo do contexto). É o caso de only (494 oc.) e monthly (162 oc.) no corpus do Direito. As listas completas com todos os advérbios encontrados e as ocorrências descartadas estão em: Anexo B e Anexo C para a Culinária; Anexo D e Anexo E para o Direito - em inglês e português, respectivamente.

$\mathrm{Na}$ tabela abaixo, apresentamos uma comparação entre o número de advérbios encontrados nos dados etiquetados e aqueles terminados em -ly e -mente (derivados de adjetivos):

Tabela 10 - Comparação entre o número total de advérbios em cada corpus e aqueles terminados em -ly /-mente

\begin{tabular}{|c|c|c|c|}
\hline corpus & advs - total & advs -ly /-mente & $\begin{array}{c}\% \text { considerando-se } \\
\text { o valor total }\end{array}$ \\
\hline Direito (inglês) & 17.889 & 4.929 & $27,55 \%$ \\
\hline Direito (português) & 7.350 & 2.212 & $30,09 \%$ \\
\hline Culinária (inglês) ${ }^{95}$ & 5.576 & 4.214 & $75,57 \%$ \\
\hline Culinária (português) & 3.163 & 550 & $17,38 \%$ \\
\hline
\end{tabular}

Como podemos observar, a porcentagem de advérbios terminados em -ly e -mente é bastante significativa nas duas áreas estudadas. No Direito, que apresenta dados levantados em $100 \%$ dos corpora, há um equilíbrio entre as línguas: 27,55\% dos advérbios terminam em -ly para o inglês e 30,09\% terminam em -mente para o português. Na Culinária, a presença dos advérbios terminados em -ly para o inglês é maciça: corresponde a $75,57 \%$ de todos os advérbios etiquetados. Já em português, no entanto, não é, comparativamente, tão significativa: $17,38 \%$ dos advérbios etiquetados terminam em -mente.

\footnotetext{
${ }^{95}$ Vale lembrar que tanto os números em Culinária (inglês) quanto em Culinária (português) referem-se apenas aos $10 \%$ do material que foi etiquetado.
} 
Diante desses dados, um estudo desse grupo de advérbios, em geral (mas não necessariamente) tidos como advérbios de modo, contribuiria de forma significativa para a definição de seu papel nas tipologias textuais investigadas.

Considerando-se esses dados, decidimos também verificar qual a frequência desses advérbios no número total de ocorrências dos corpora, no sentido de observar a relevância dessa classe gramatical nas áreas estudadas. $\mathrm{Na}$ tabela abaixo, apresentamos o número de tokens (ocorrências) e de types (formas) dos quatro corpora, os números referentes aos advérbios terminados em -ly e -mente e a porcentagem que representam em cada corpus. Os dados apresentados referemse aos quatro corpora na íntegra.

Tabela 11 - Porcentagem de advérbios terminados em -ly/-mente nos corpora de estudo.

\begin{tabular}{|l|c|c|c|c|c|}
\hline \multicolumn{1}{|c|}{ corpus } & $\begin{array}{c}\text { tokens } \\
\text { (oc.) } \\
\text { total }\end{array}$ & $\begin{array}{c}\text { types } \\
\text { (formas) } \\
\text { total }\end{array}$ & $\begin{array}{c}\text { tokens (oc.) } \\
\text { advs: -ly ou } \\
- \text { mente }\end{array}$ & $\begin{array}{c}\text { types (formas) } \\
\text { advs: -ly ou } \\
- \text {-mente }\end{array}$ & $\begin{array}{c}\text { \% de advs } \\
\text { (oc.) no } \\
\text { corpus }\end{array}$ \\
\hline $\begin{array}{l}\text { Direito } \\
\text { (inglês) }\end{array}$ & 648.648 & 10.243 & 4.929 & 261 & $0,75 \%$ \\
\hline $\begin{array}{l}\text { Direito } \\
\text { (português) }\end{array}$ & 279.923 & 11.465 & 2.212 & 193 & $0,79 \%$ \\
\hline $\begin{array}{l}\text { Culinária } \\
\text { (inglês) }\end{array}$ & 1.716 .496 & 13.880 & 22.762 & 326 & $1,32 \%$ \\
\hline $\begin{array}{l}\text { Culinária } \\
\text { (português) }\end{array}$ & 1.590 .969 & 13.765 & 7.276 & 145 & $0,45 \%$ \\
\hline
\end{tabular}

*Os cálculos da coluna 6 baseiam-se no número de ocorrências.

$\mathrm{Na}$ primeira coluna, identificamos os corpora. Na segunda, apresentamos o número total de ocorrências em cada corpus e, na terceira, o número de formas encontradas. As duas colunas seguintes referem-se aos advérbios terminados em -ly e -mente, levantados a partir da planilha em Excel que elaboramos anteriormente: na quarta, o número total de ocorrências e, na quinta, o total de formas desses advérbios em cada corpus. A última coluna apresenta a porcentagem que os advérbios terminados em -ly e -mente representam nos corpora em sua totalidade. Novamente, evidenciamos o equilíbrio entre as línguas no Direito, o que definitivamente não ocorre na área da Culinária.

As porcentagens acima descritas também evidenciam o número de ocorrências de advérbios em cada mil palavras. Segundo Rocha (2007, p. 221), podemos verificar o número de ocorrências do item investigado em cada mil 
palavras do corpus, processo chamado de normalização das frequências. Esse recurso é amplamente utilizado em Linguística de Corpus, tornando a comparação mais clara. Muitas vezes, fica difícil comparar mentalmente grandes quantidades de dados que, em números absolutos, são tão diferentes, conforme observado em nossos corpora de estudo. Dessa forma, decidimos utilizar a normalização das frequências para verificar o número de ocorrências de advérbios em cada mil palavras, nos quatro corpora. Aplicamos a fórmula sugerida pelo pesquisador (ROCHA, 2007, p. 197-205) e chegamos aos resultados abaixo descritos.

Fórmula:

no. de ocorrências do item em estudo / no. de ocorrências do corpus total $\times 1.000=$ no. do item em estudo a cada mil palavras no corpus

No caso do Direito (inglês), temos: 4.929 / 648.648 x $1.000=7,59$.

Para Direito (português): 2.212 / 279.923 x $1.000=7,90$.

Esses números indicam que, em cada mil palavras no corpus de Direito (inglês), 7,59 são advérbios terminados em -ly. Já em Direito (português), temos 7,9 advérbios terminados em -mente em cada mil palavras. Se quisermos chegar à porcentagem que esses resultados representam no corpus como um todo, devemos dividir esses números por 10. Chegaríamos assim aos resultados acima apresentados, ou seja, os advérbios terminados em -ly constituem $0,75 \%$ do corpus Direito (inglês) e aqueles terminados em -mente representam $0,79 \%$ do corpus Direito (português).

Ao aplicarmos a fórmula aos corpora de Culinária, temos:

Culinária (inglês): 22.762 / 1.716.496 x $1.000=13,26$

Culinária (português): $7.276 / 1.590 .969 \times 1.000=4,57$

Nesse caso, os números indicam que, em cada mil palavras no corpus de Culinária (inglês), 13,26 delas são advérbios terminados em -ly. Em Culinária (português), a proporção é de 4,57 advérbios terminados em -mente em cada mil palavras. Para obter a porcentagem, devemos proceder como feito acima, chegando a $1,32 \%$ de advérbios terminados em -ly em Culinária (inglês) e 0,45\% de advérbios terminados em -mente em Culinária (português).

O leitor deve perguntar-se por que fizemos esses cálculos para chegar a uma porcentagem que já havia sido obtida anteriormente. Apenas transformamos os números em porcentagem para demonstrar outra forma de chegarmos a esses valores. Caso encontre dificuldades para dimensionar as porcentagens devido ao 
tamanho dos corpora, a normalização das frequências facilita a análise do pesquisador. É mais esclarecedor dizermos, por exemplo, que em cada mil palavras do corpus de Culinária (inglês) aproximadamente 13 delas são advérbios terminados em -ly do que $1,32 \%$ do corpus é formado por esse grupo de advérbios. Podemos também comparar melhor a frequência dessas ocorrências entre os corpora, que no Direito é muito mais balanceada entre as línguas, chegando a praticamente oito ocorrências em cada mil palavras. Na Culinária, no entanto, fica evidente que isso não ocorre, pois o número de ocorrências em inglês é quase três vezes maior do que em português. Se estamos diante de corpora comparáveis e que possuem um número bastante próximo de ocorrências, o questionamento é inevitável: como os advérbios terminados em -ly são traduzidos para o português em receitas culinárias, uma vez que a frequência de advérbios terminados em -mente, tidos como a contrapartida em português, é muito menor? Outra questão refere-se às áreas propriamente ditas: por que no Direito as ocorrências estão mais balanceadas entre as línguas do que na Culinária? Esses tópicos serão discutidos no capítulo III, quando analisarmos a busca pelas formas equivalentes.

2.6.1 Os advérbios terminados em -ly e -mente para análise dos padrões linguísticos

Considerando-se o número de advérbios terminados em -ly e -mente obtidos na etapa anterior, quais sejam 27.691 em inglês (soma das ocorrências no Direito e na Culinária) e 9.488 em português (idem), seria difícil realizarmos a tarefa de analisar, em detalhes, todos os dados levantados. Para selecionarmos as ocorrências mais relevantes, decidimos gerar as listas de palavras-chave nas duas áreas ${ }^{96} \mathrm{e}$, a partir delas, levantar as ocorrências dos advérbios terminados em -ly e -mente. Para consulta, as 100 primeiras palavras-chave de cada corpus encontramse em anexo (Culinária: Anexos F e G; Direito: Anexos H e I, em inglês e português em ambas as áreas, respectivamente).

Partindo das listas de palavras-chave, obtivemos os resultados abaixo descritos.

\footnotetext{
${ }^{96}$ Para saber como se deve gerar uma lista de palavras-chave com o programa WST, vide item 2.5.
} 
Culinária (inglês): os advérbios terminados em -ly abaixo listados apresentaram chavicidade igual ou superior a 100 - resultado da comparação entre as listas de frequência do corpus de estudo e do corpus de referência (BNC).

\section{Observações:}

$\mathbf{N}=$

Pal.-chave $=$

Freq. $\mathrm{CE}=$

$\% \mathrm{CE}=$

Freq. $\mathbf{C R}=$

$\% \mathrm{CR}=$

posição do advérbio na lista de palavras-chave, em ordem decrescente de chavicidade

advérbio (palavra-chave) a que os dados se referem

frequência do advérbio no corpus de estudo

porcentagem que representa a frequência do advérbio no corpus de estudo, considerado em sua totalidade

frequência do advérbio no corpus de referência

porcentagem que representa a frequência do advérbio no corpus de referência, considerado em sua totalidade

Chav. $=$

índice de chavicidade do advérbio, em ordem decrescente

$\mathbf{P}=$ valor de $\mathrm{P}$

Tabela 12 - Advérbios terminados em -ly com chavicidade igual ou superior a 100 - Culinária (inglês)

\begin{tabular}{|c|l|c|c|c|c|c|c|}
\hline $\mathbf{N}$ & \multicolumn{1}{|c|}{ Pal.-chave } & Freq. CE & \% CE & Freq. CR & \% CR & Chav. & P \\
\hline 39 & FINELY & 3261 & 0,19 & 684 & & $22.978,30$ & $0.0^{*}$ \\
\hline 40 & FRESHLY & 3248 & 0,19 & 670 & & $22.925,95$ & \\
\hline 82 & GENTLY & 2543 & 0,15 & 3.775 & & $12.349,63$ & \\
\hline 119 & LIGHTLY & 1634 & 0,10 & 1.885 & & $8.527,96$ & \\
\hline 207 & THINLY & 701 & 0,04 & 410 & & $4.266,69$ & \\
\hline 297 & ROUGHLY & 750 & 0,04 & 2.293 & & $2.795,16$ & \\
\hline 446 & COARSELY & 230 & 0,01 & 55 & & $1.597,57$ & \\
\hline 450 & THOROUGHLY & 494 & 0,03 & 2.046 & & $1.595,11$ & \\
\hline 478 & EVENLY & 335 & 0,02 & 708 & & $1.446,12$ & \\
\hline 500 & SLIGHTLY & 803 & 0,05 & 8.598 & & $1.355,07$ & \\
\hline 549 & GRADUALLY & 501 & 0,03 & 3.592 & & $1.165,18$ & \\
\hline 550 & CAREFULLY & 663 & 0,04 & 6.816 & & $1.160,62$ & \\
\hline 680 & IMMEDIATELY & 686 & 0,04 & 10.147 & 0.01 & 826,91 & \\
\hline 685 & OCCASIONALLY & 423 & 0,02 & 3.871 & & 817,79 & \\
\hline 753 & APPROXIMATELY & 332 & 0,02 & 2.829 & & 679,57 & \\
\hline 783 & CONTINUOUSLY & 198 & 0,01 & 883 & & 615,13 & \\
\hline 852 & PREFERABLY & 170 & & 776 & & 521,60 & \\
\hline 890 & GENEROUSLY & 134 & & 442 & & 482,78 & \\
\hline 1000 & SLOWLY & 405 & 0,02 & 7.409 & & 369,59 & \\
\hline 1,098 & HORIZONTALLY & 82 & & 257 & & 302,26 & \\
\hline 1,147 & THICKLY & 86 & & 376 & & 269,99 & \\
\hline 1,172 & TIGHTLY & 152 & & 1.624 & & 256,97 & \\
\hline 1,235 & DIAGONALLY & 59 & & 163 & & 229,55 & \\
\hline 1,280 & NICELY & 104 & & 927 & & 205,40 & \\
\hline 1,358 & LOOSELY & 80 & & 625 & & 174,91 & \\
\hline 1,474 & CONSTANTLY & 160 & & 2.994 & & 141,24 & \\
\hline 1,492 & COMPLETELY & 308 & 0,02 & 8.339 & & 137,41 & \\
\hline 1,593 & VIGOROUSLY & 68 & & 721 & & 115,76 & \\
\hline
\end{tabular}

* $\mathrm{O}$ valor de $\mathrm{P}$, para todas as formas, é 0.0000000000 . Para uma melhor distribuição das colunas, decidimos colocar esta informação separadamente.

Total de ocorrências (tokens): 18.610

Total de formas (types): 28 
Culinária (português): os advérbios terminados em -mente abaixo listados apresentaram chavicidade igual ou superior a 100 - resultado da comparação entre as listas de frequência do corpus de estudo e do corpus de referência (BP).

\section{Observações:}

$\mathbf{N}=$

Pal.-chave $=$

posição do advérbio na lista de palavras-chave, em ordem decrescente de chavicidade

Freq. $\mathrm{CE}=$ advérbio (palavra-chave) a que os dados se referem

$\% \mathrm{CE}=$ frequência do advérbio no corpus de estudo

porcentagem que representa a frequência do advérbio no corpus de estudo, considerado em sua totalidade

Freq. $\mathrm{CR}=$

$\% \mathrm{CR}=$

frequência do advérbio no corpus de referência

porcentagem que representa a frequência do advérbio no corpus de referência, considerado em sua totalidade

Chav. $=$

$\mathbf{P}=$

índice de chavicidade do advérbio, em ordem decrescente

valor de $\mathrm{P}$

Tabela 13 - Advérbios terminados em -mente com chavicidade igual ou superior a 100 - Culinária (português)

\begin{tabular}{|c|l|c|c|c|c|c|c|}
\hline $\mathbf{N}$ & \multicolumn{1}{|c|}{ Pal.-chave } & Freq. CE & \% CE & Freq. CR & \% CR & Chav. & P \\
\hline 213 & LEVEMENTE & 943 & 0,06 & 6.672 & & $5.797,89$ & $0.0^{*}$ \\
\hline 245 & DELICADAMENTE & 513 & 0,03 & 583 & & $4.727,93$ & \\
\hline 297 & GROSSEIRAMENTE & 410 & 0,03 & 648 & & $3.577,50$ & \\
\hline 374 & FINAMENTE & 337 & 0,02 & 779 & & $2.735,66$ & \\
\hline 389 & LIGEIRAMENTE & 495 & 0,03 & 5.863 & & $2.570,21$ & \\
\hline 421 & NOVAMENTE & 851 & 0,05 & 38.822 & & $2.306,53$ & \\
\hline 526 & APROXIMADAMENTE & 802 & 0,05 & 57.433 & & $1.551,99$ & \\
\hline 719 & CUIDADOSAMENTE & 207 & 0,01 & 3.836 & & 901,83 & \\
\hline 732 & IMEDIATAMENTE & 416 & 0,03 & 27.396 & & 863,22 & \\
\hline 873 & RAPIDAMENTE & 347 & 0,02 & 27.127 & & 621,39 & \\
\hline 1,061 & LENTAMENTE & 135 & & 5.128 & & 410,00 & \\
\hline 1,202 & VIGOROSAMENTE & 57 & & 649 & & 300,15 & \\
\hline 1,283 & COMPLETAMENTE & 213 & 0,01 & 24.112 & & 258,65 & \\
\hline 1,301 & JUNTAMENTE & 195 & 0,01 & 21.086 & & 250,06 & \\
\hline 1,48 & ALTERNADAMENTE & 44 & & 849 & & 188,38 & \\
\hline 1,629 & UNIFORMEMENTE & 48 & & 1.773 & & 148,20 & \\
\hline 1,751 & SEPARADAMENTE & 79 & & 6.887 & & 127,60 & \\
\hline
\end{tabular}

* $\mathrm{O}$ valor de $\mathrm{P}$, para todas as formas, é 0.0000000000 . Para uma melhor distribuição das colunas, decidimos colocar esta informação separadamente.

Total de ocorrências (tokens): 6.092

Total de formas (types): 17 
Direito (inglês): os advérbios terminados em -ly abaixo listados apresentaram chavicidade igual ou superior a 100 - resultado da comparação entre as listas de frequência do corpus de estudo e do corpus de referência (BNC).

\section{Observações:}

$\mathbf{N}=$

Pal.-chave $=$

Freq. $\mathrm{CE}=$

$\% \mathrm{CE}=$

posição do advérbio na lista de palavras-chave, em ordem decrescente de chavicidade

advérbio (palavra-chave) a que os dados se referem

frequência do advérbio no corpus de estudo

porcentagem que representa a frequência do advérbio no corpus de estudo, considerado em sua totalidade

Freq. $\mathrm{CR}=$

$\% \mathrm{CR}=$

frequência do advérbio no corpus de referência

porcentagem que representa a frequência do advérbio no corpus de referência, considerado em sua totalidade

Chav. $=$

índice de chavicidade do advérbio, em ordem decrescente

$\mathbf{P}=$

valor de $\mathrm{P}$

Tabela 14 - Advérbios terminados em -ly com chavicidade igual ou superior a 100 - Direito (inglês)

\begin{tabular}{|c|l|c|c|c|c|c|c|}
\hline $\mathbf{N}$ & \multicolumn{1}{|c|}{ Pal.-chave } & Freq. CE & \% CE & Freq. CR & \% CR & Chav. & P \\
\hline 146 & PROMPTLY & 275 & 0,04 & 948 & & $1.480,30$ & $0.0^{*}$ \\
\hline 163 & REASONABLY & 344 & 0,05 & 3.027 & & $1.284,59$ & \\
\hline 189 & EXPRESSLY & 198 & 0,03 & 600 & & $1.109,19$ & \\
\hline 216 & DULY & 206 & 0,03 & 961 & & $1.000,87$ & \\
\hline 252 & COLLECTIVELY & 155 & 0,02 & 538 & & 832,5 & \\
\hline 372 & IMMEDIATELY & 330 & 0,05 & 10.147 & 0,01 & 526,2 & \\
\hline 382 & SOLELY & 151 & 0,02 & 1.640 & & 507,36 & \\
\hline 427 & SUBSTANTIALLY & 141 & 0,02 & 1.708 & & 446,55 & \\
\hline 484 & UNREASONABLY & 73 & 0,01 & 271 & & 383,64 & \\
\hline 490 & INDIRECTLY & 107 & 0,02 & 1.039 & & 380,79 & \\
\hline 511 & MATERIALLY & 66 & 0,01 & 224 & & 357,01 & \\
\hline 608 & MUTUALLY & 76 & 0,01 & 628 & & 292,28 & \\
\hline 707 & VALIDLY & 37 & & 82 & & 226,45 & \\
\hline 737 & SPECIFICALLY & 126 & 0,02 & 3.724 & & 208,74 & \\
\hline 761 & DIRECTLY & 192 & 0,03 & 8.612 & & 198,27 & \\
\hline 797 & IRREVOCABLY & 35 & & 132 & & 182,98 & \\
\hline 881 & FULLY & 175 & 0,03 & 8.812 & & 153,16 & \\
\hline 911 & DILIGENTLY & 28 & & 106 & & 146,2 & \\
\hline 973 & ADVERSELY & 39 & & 417 & & 132,12 & \\
\hline 1.051 & LEGALLY & 53 & & 1.133 & & 115,84 & \\
\hline 1.088 & CONCURRENTLY & 26 & & 178 & & 108,7 & \\
\hline 1.102 & JOINTLY & 50 & & 1.124 & & 105,08 & \\
\hline 1.120 & LAWFULLY & 24 & & 154 & & 103,1 & \\
\hline 1.128 & BENEFICIALLY & 19 & & 67 & & 101,53 & \\
\hline 0
\end{tabular}

* O valor de $P$, para todas as formas, é 0.0000000000 . Para uma melhor distribuição das colunas, decidimos colocar esta informação separadamente.

Total de ocorrências (tokens): 2.926

Total de formas (types): 24 
Direito (português): Os advérbios terminados em -mente abaixo listados apresentaram chavicidade igual ou superior a 100 - resultado da comparação entre as listas de frequência do corpus de estudo e do corpus de referência (BP).

\section{Observações:}

$\mathbf{N}=$

Pal.-chave $=$

Freq. $\mathrm{CE}=$

$\% \mathrm{CE}=$

posição do advérbio na lista de palavras-chave, em ordem decrescente de chavicidade

advérbio (palavra-chave) a que os dados se referem

frequência do advérbio no corpus de estudo

porcentagem que representa a frequência do advérbio no corpus de estudo, considerado em sua totalidade

Freq. $\mathrm{CR}=$

$\% \mathrm{CR}=$

frequência do advérbio no corpus de referência

porcentagem que representa a frequência do advérbio no corpus de referência, considerado em sua totalidade

Chav. $=$

índice de chavicidade do advérbio, em ordem decrescente

$\mathbf{P}=$

valor de $\mathrm{P}$

Tabela 15 - Advérbios terminados em -mente com chavicidade igual ou superior a 100 - Direito (português)

\begin{tabular}{|c|l|c|c|c|c|c|c|}
\hline $\mathbf{N}$ & \multicolumn{1}{|c|}{ Pal.-chave } & Freq. CE & \% CE & Freq. CR & \% CR & Chav. & P \\
\hline 98 & EXPRESSAMENTE & 120 & 0,04 & 1.867 & & 971,52 & $0.0^{*}$ \\
\hline 119 & DEVIDAMENTE & 154 & 0,06 & 10.070 & & 818,11 & \\
\hline 265 & SIMPLESMENTE & 132 & 0,05 & 31.599 & & 378,58 & \\
\hline 297 & AUTOMATICAMENTE & 72 & 0,03 & 6.473 & & 338,35 & \\
\hline 319 & INDEPENDENTEMENTE & 104 & 0,04 & 23.220 & & 311,38 & \\
\hline 344 & IMEDIATAMENTE & 104 & 0,04 & 27.396 & & 280,41 & \\
\hline 465 & EXCLUSIVAMENTE & 83 & 0,03 & 25.741 & & 199,86 & \\
\hline 494 & JUDICIALMENTE & 33 & 0,01 & 1.737 & & 189,15 & \\
\hline 495 & MENSALMENTE & 46 & 0,02 & 5.684 & & 188,29 & \\
\hline 556 & INDIRETAMENTE & 50 & 0,02 & 9.041 & & 169,02 & \\
\hline 589 & MONETARIAMENTE & 19 & & 282 & & 155,54 & \\
\hline 605 & INTEGRALMENTE & 40 & 0,01 & 5.841 & & 151,14 & \\
\hline 632 & JUNTAMENTE & 63 & 0,02 & 21.086 & & 143,35 & \\
\hline 726 & PREVIAMENTE & 58 & 0,02 & 21.486 & & 121,89 & \\
\hline 737 & OBRIGATORIAMENTE & 30 & 0,01 & 3.939 & & 119,35 & \\
\hline
\end{tabular}

* O valor de $\mathrm{P}$, para todas as formas, é 0.0000000000 . Para uma melhor distribuição das colunas, decidimos colocar esta informação separadamente.

Total de ocorrências (tokens): 1.108

Total de formas (types): 15 
Em resumo, os advérbios-chave terminados em -ly e -mente de nossos corpora de estudo com chavicidade acima de 100 totalizam:

Tabela 16 - Número total de advérbios terminados em -ly/-mente com chavicidade acima de 100 em nossos corpora de estudo

\begin{tabular}{|l|c|c|}
\hline \multicolumn{1}{|c|}{ corpus } & ocorrências (tokens) & formas (types) \\
\hline Culinária (inglês) & 18.610 & 28 \\
\hline Culinária (português) & 6.092 & 17 \\
\hline Direito (inglês) & 2.926 & 24 \\
\hline Direito (português) & 1.108 & 15 \\
\hline
\end{tabular}

Desses, selecionamos os cinco primeiros, com maior índice de chavicidade. Como nosso objetivo é fazer uma análise qualitativa e detalhada de cada advérbio, acreditamos que analisar o grupo abaixo descrito seja suficiente - a análise de uma lista exaustiva ultrapassaria o escopo deste trabalho. Os advérbios selecionados são:

\begin{tabular}{|l|l|l|l|}
\hline Culinária (inglês) & Culinária (português) & Direito (inglês) & Direito (português) \\
\hline finely & levemente & promptly & expressamente \\
\hline freshly & delicadamente & reasonably & devidamente \\
\hline gently & grosseiramente & expressly & simplesmente \\
\hline lightly & finamente & duly & automaticamente \\
\hline thinly & ligeiramente & collectively & independentemente \\
\hline
\end{tabular}

Quadro 7 - Advérbios selecionados para análise qualitativa e quantitativa (Direito e Culinária)

No próximo capítulo, apresentaremos o levantamento de dados e a análise de cada um dos advérbios acima listados, além de compararmos os resultados obtidos. 


\section{Capítulo III - Análise de dados}

Neste capítulo, nosso objetivo é levantar os dados e analisar, detalhadamente, os advérbios listados ao final do capítulo anterior em todos os seus aspectos, destacando-se o sintático, o semântico e o morfológico. Definidos esses advérbios como palavras-chave em nossos corpora de estudo e antes de desenvolvermos uma investigação mais minuciosa, decidimos consultar três obras de cunho dicionarístico, em português, já analisadas na fundamentação teórica (vide capítulo I). Uma vez que são descritas como baseadas em corpus, interessa-nos saber como nelas são abordados os advérbios, partindo da suposição de que deveriam ser considerados como verbetes. Para isso, decidimos trabalhar com uma amostra um pouco maior, quais sejam, os dez primeiros advérbios com maior índice de chavicidade em cada área de estudo. São eles: levemente, delicadamente, grosseiramente, finamente, ligeiramente, novamente, aproximadamente, cuidadosamente, imediatamente e rapidamente, na Culinária; expressamente, devidamente, simplesmente, automaticamente, independentemente, imediatamente, exclusivamente, judicialmente, mensalmente e indiretamente, no Direito. As obras consultadas são:

- BORBA, Francisco S. Dicionário de usos do Português do Brasil. São Paulo: Ática, 2002.

- BORBA, Francisco S. (Org.). Dicionário UNESP do português contemporâneo. São Paulo: UNESP, 2004.

- NEVES, Maria Helena de Moura. Guia de uso do português: confrontando regras e usos. São Paulo: Editora UNESP, 2003.

Borba (2002) apresenta, como verbetes, todos os dez advérbios da área da Culinária (receitas). Para aqueles do Direito (contratos), no entanto, não encontramos entrada para dois deles, quais sejam devidamente e indiretamente, nem mesmo como subverbetes em devido e indireto, respectivamente. É interessante observar a importância que o autor dá ao contexto (BORBA, 2002, p. VI), enfatizando inclusive que os dicionários de língua não devem apresentar as 
palavras como unidades de sentido isoladas, mas sim combinadas com outras palavras e estruturas.

Ao consultarmos o total de dezenove advérbios terminados em -mente das duas áreas (ambas apresentam o advérbio imediatamente em comum), observamos que vários apresentam mais de uma acepção, como é o caso de levemente (Culinária) e simplesmente (Direito); quando pertinente, o autor apresenta as diferentes subclassificações de um único advérbio, como em levemente, finamente, simplesmente e independentemente:

levemente $A d v \star$ [Modo] 1 suavemente: Depois, veio até mim, pousou levemente as mãos sobre meus ombros e tentou explicar (A); Mattos sentiu os dedos de Alice deslizando levemente pelo seu rosto (AGO); « [Intensidade] 2 um pouco: Sei que, colocado nesses termos, o assunto parece levemente paranóico (FSP); Esta apenas sorria, numa boca de lábios levemente arrebitados (ASV)

finamente $A d v$ [Modo] 1 bem; excelentemente: Bugre, finamente orientado por Carlos Alberto, seguiu a linha do vento (FSP); As Peixotos eram duas solteironas finamente educadas (JM) 2 agudamente: Caiá assobiou finamente (ARR) 3 elegantemente: os cabelos [...] se desenhavam finamente nas faces (GAT)

simplesmente $A d v \star$ [Exclusão] 1 apenas; somente: $O$ que the falta - e que me seja permitido desde logo precisá-lo - é coragem. Simplesmente isso: coragem (A); Minha querida, sou simplesmente um homem que busca o prazer (FAN) [Modo] 2 de modo simples, humildemente: morrerei simplesmente (AL); Não tinha respeito humano e ao deitar-se, fazia simplesmente e sem a ostentação de

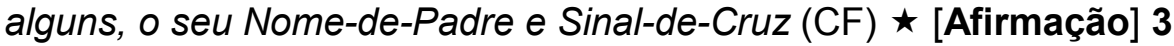
sem dúvida; certamente: Se eu não tivesse a certeza, simplesmente não a teria chamado (DM); tudo quanto é filosofia hoje eu mando simplesmente à merda (DM) $\star$ [Intensidade] 4 incrivelmente: $A$ idéia de que ele aprisionava o chamado Verbo Divino era-Ihe simplesmente deliciosa (ASS); Qual o atraso que vamos levar? Ele respondia logo: quatro horas, seis horas, mais de oito horas. Era simplesmente fabuloso de incompetência! (CF)

independentemente $A d v \star$ [Concessão] [Compl: de+nome] 1 mesmo levando em conta: A privatização é hoje um fenômeno universal, independentemente de ideologia política liberal, socialdemocrata ou pós-comunista (FSP); O risco empresarial existe, independentemente do risco inerente à política de financiamento da empresa (ANI); houve um concurso entre arquitetos somente para a solução das fachadas dos novos edifícios ali programados, independentemente das plantas, dos programas, das técnicas construtivas (AQT) [Compl: de+oração] 2 mesmo levando em conta o fato de: Assim, se vinha uma carta para o Sebastião da Silva, ele a entregava na rua Joaquim Zeferino $n .^{\circ} 101$, independentemente de estar ou não corretamente endereçada (ACT); Contrariamente à 
prosa popular, a poesia tende a perdurar, independentemente de ter sido registrada e publicada (LIP) $\mathbf{3}$ mesmo com exclusão: Positivamente não é bonito. Mas, independentemente dos traços, tem algo que atrai $(\mathrm{CH}) \star$ [Modo] 4 isoladamente: Alguns deles objetaram que as fibras radiadas da membrana basilar não podem vibrar independentemente (ACL) $\mathbf{5}$ separadamente: $\mathrm{Em}$ determinados casos, pode haver dois ou mais pares de genes que se segregam independentemente e que determinam um só caráter (GEN)

Em todos os casos, observamos a preocupação em subclassificar os advérbios e apresentar as diferentes acepções. Nas próprias acepções, ou o autor utiliza um outro advérbio terminado em -mente ou uma palavra ou expressão equivalente, como podemos verificar nos verbetes acima descritos. Utiliza também a expressão "de modo", seguida do adjetivo a que se refere o advérbio. Todas as acepções apresentam pelo menos um exemplo, o que corrobora o posicionamento do autor, ou seja, de que as palavras não devem ser dicionarizadas como unidades de sentido isoladas, mas que se deve dar atenção especial às relações que elas mantêm em dado contexto.

Apesar de a inclusão de advérbios terminados em -mente - geralmente tidos como derivados de adjetivos e por isso, em geral, não serem elencados com entradas em um dicionário de língua geral - significar um grande avanço em termos de dicionarização dessa classe gramatical, observamos ainda a necessidade de um maior enfoque em linguagens especializadas. Seria interessante, por exemplo, ter disponível uma obra que trouxesse o tipo textual em que dado advérbio é mais frequente, ou mesmo detalhes sobre a parte do texto em que é mais utilizado. Em Borba (2002), considerando-se o grupo de advérbios consultados, a acepção mais voltada para uma área técnica que encontramos foi para judicialmente, o que acreditamos dever-se ao caráter delimitativo do próprio advérbio.

Consultamos também outra obra de Borba, o Dicionário UNESP do português contemporâneo (2004), com o objetivo de verificarmos como ele aí aborda o mesmo grupo de advérbios. Conforme já mencionado no capítulo I, tanto para a seleção das palavras incluídas na obra quanto para a organização interna dos verbetes o principal critério foi a frequência. Quanto aos advérbios, não tiveram anotadas suas subclasses, o que foi feito para outras classes gramaticais (nesta obra, o autor considera os advérbios uma classe gramatical), como é o caso dos artigos (definidos e indefinidos), dos numerais (cardinais, ordinais, multiplicativos e fracionários), dos 
pronomes (pessoais, de tratamento, demonstrativos, possessivos, relativos, interrogativos e indefinidos) e das conjunções que, além de coordenativas e subordinativas, foram ainda subclassificadas de forma mais específica ${ }^{97}$. Todos os dez advérbios em português na área da Culinária foram encontrados. Já no Direito, não localizamos devidamente e indiretamente, nem mesmo nas entradas de devido e indireto, como ocorreu na obra anteriormente analisada. A nosso ver, a subclassificação dos advérbios faz-se necessária, como observado em Borba (2002). Para o consulente, principalmente para o produtor de textos (mais especificamente o tradutor), é importante saber se determinado advérbio é mais utilizado para modalizar ou para intensificar um outro elemento do sintagma, por exemplo. Apenas a título ilustrativo, apresentamos as entradas dos advérbios levemente, delicadamente, expressamente e simplesmente:

LEVEMENTE le've'mente Adv 1 de leve; suavemente: Tocou levemente em seu ombro. 2 um pouco: Sentia-se levemente irritado.

DELICADAMENTE de.li.ca'da-men te Adv 1 de modo delicado; com delicadeza: Delicadamente contou-Ihe a verdade. 2 com leveza; levemente: Acariciou delicadamente seus cabelos. 3 cortesmente: $A$ secretária atendeu-o delicadamente.

EXPRESSAMENTE ex.pres'sa'men.te Adv 1 somente; exclusivamente; unicamente: $O$ corpo docente decidirá todas as questões que não tenham sido expressamente reservadas à competência de um órgão particular. 2 especialmente; especificamente: Viajou expressamente para o batizado da neta. 3 de maneira explícita ou categórica: Proibiu-o expressamente de aproximar-se da moça.

SIMPLESMENTE simples mente Adv 1 apenas; somente: O chefe não aparecia, simplesmente comandava. 2 de modo simples; de modo humilde: Vestia-se simplesmente, sem luxos. 3 sem dúvida; certamente: Um negócio mal administrado vai simplesmente fechar. 4 muito; incrivelmente: Simplesmente lamentável a foto da capa.

Apesar de o autor se propor a trabalhar com língua geral - fato devidamente exposto na introdução da obra - observamos que, mesmo não tendo feito qualquer menção ou referência à área da Culinária, os verbetes de finamente e grosseiramente apresentam exemplos relacionados, o que indica maior frequência de uso nesses contextos. No caso de finamente, inclusive, logo na primeira acepção o exemplo apresenta indícios de fazer parte de um texto ou receita culinária:

\footnotetext{
${ }^{97}$ Vide Borba (2004, p. IX) para mais detalhes.
} 
FINAMENTE fi.na.mente Adv 1 em tiras finas: Escolha algum peixe branco e fatie finamente. 2 com fineza(2); com finura(2); educadamente: meninas finamente criadas. $3 \mathrm{com}$ requinte; bem; excelentemente: Eram bordados finamente lavrados 4 elegantemente: Finamente vestida, ela posou para o fotógrafo.

GROSSEIRAMENTE gros sei.ra'mente Adv 1 com grosseria: responder grosseiramente. 2 sem sutileza; sem requinte: uma figura de detalhes grosseiramente exagerados. 3 de modo primário, elementar: O repórter errou grosseiramente no tom da cobertura. 4 sem delicadeza; toscamente: Picou o espinafre grosseiramente. $\mathbf{5}$ de modo geral, sem precisão; genericamente: Grosseiramente, isso significa uma taxa de $37 \%$ ao ano. 6 com falta de decoro: termos grosseiramente pornográficos.

Por fim, consultamos Neves (2003). Devemos deixar claro, no entanto, que a autora não visa apresentar uma obra de caráter abrangente, mas sim as palavras de uso significativamente frequente no português contemporâneo. Segundo Neves (2003, p. 14), dessa forma o consulente terá a possibilidade de confrontar a normapadrão (prescritiva) e a situação real de uso desse grupo de palavras, fazendo assim suas próprias escolhas linguísticas. Na apresentação, a autora já deixa claro que a obra não é um glossário ou dicionário - busca apenas oferecer informações sobre as acepções que auxiliem o consulente em sua pesquisa (NEVES, 2003, p. 16).

Entre os dezenove advérbios consultados, o único encontrado foi aproximadamente, como entrada de verbete. Dentre os demais, apenas juntamente foi mencionado no verbete da palavra junto, como podemos observar logo abaixo. Os outros dezessete advérbios não foram mencionados em quaisquer outros verbetes, nem mesmo nos adjetivos dos quais derivam (por sufixação).

\section{aproximadamente}

É advérbio que indica aproximação de cálculo. Quando junto a numerais, indica arredondamento, e, por isso, não se liga a numerais muito especificados. - No livro II, Ovídio dedica APROXIMADAMENTE o mesmo número de versos para explicar a forma de reter o afeto conquistado. (PO) Um mármore permanece sem alteração APROXIMADAMENTE de cinqüenta a cem anos. (NB) Antônio ficou num cubículo de APROXIMADAMENTE três por dois metros, com paredes de cimento. (VEJ)

junto

1. Como adjetivo, concorda com o substantivo que acompanha. Significa "reunido". Sabia que ele ia responder que eram as duas coisas JUNTAS. (INQ) 
2. Como advérbio, não varia. Significa "juntamente", "ao lado", "ao mesmo tempo". \Que desperdício, riam-se, eu ria JUNTO, mas tinha medo. (ASA) $)^{98}$

Apesar do grande avanço observado na apresentação dos advérbios terminados em -mente como entradas em alguns dicionários - mais especificamente naqueles baseados em corpus - verificamos que as informações apresentadas ainda não são suficientes para o uso da palavra em determinados contextos, principalmente no que tange as linguagens especializadas. Para o tradutor, por exemplo, é necessário delimitar o tipo de advérbio, em que contextos é mais utilizado e, principalmente, com quais outras palavras e estruturas ele mais se associa ou co-ocorre, formando colocações e unidades maiores de significado. Certamente, essas informações facilitariam o trabalho do produtor de textos, principalmente daquele que não pertence à área em questão - caso de um tradutor que não necessariamente é um chef de cozinha, mas tem em mãos um livro com receitas culinárias para traduzir.

Feitas essas considerações, passaremos à investigação em nossos corpora de estudo. Em linhas gerais, procuraremos observar e identificar padrões linguísticos dos quais cada advérbio faz parte, e para tal utilizaremos o programa WordSmith Tools. A priori, faremos uso do recurso Concord para gerar linhas de concordância as demais ferramentas e utilitários serão identificados à medida em que forem necessários para a investigação. Conforme já descrito no capítulo anterior, vale lembrar que na análise dos agrupamentos lexicais (clusters), utilizaremos a variação de 2 a 6, com um horizonte de cinco para cada lado, como default. No entanto, esses números podem ser ajustados de acordo com cada investigação. Ainda na ferramenta Concord, outro recurso que será bastante utilizado é o resort, que apresenta as concordâncias em ordem alfabética e de acordo com a sequência estabelecida pelo pesquisador quanto aos elementos à esquerda e à direita da palavra ou expressão de busca.

Apresentamos a seguir os resultados desse levantamento nos corpora Culinária (inglês), Culinária (português), Direito (inglês), Direito (português), na

\footnotetext{
${ }^{98}$ A palavra junto apresenta ainda um terceiro item, mais longo, cuja apresentação foge ao escopo desta pesquisa.
} 
versão não-etiquetada (corpora crus). Os advérbios, distribuídos em ordem decrescente de chavicidade, são:

Culinária: finely, freshly, gently, lightly e thinly (inglês); levemente, delicadamente, grosseiramente, finamente e ligeiramente (português).

Direito: promptly, reasonably, expressly, duly e collectively (inglês); expressamente, devidamente, simplesmente, automaticamente e independentemente (português).

Cada um será introduzido por um pequeno quadro, com as seguintes informações, lendo-se da esquerda para a direita:

- $N$ : posição do advérbio na lista de palavras-chave, em ordem decrescente de chavicidade;

- adv-chave: advérbio a que os dados se referem;

- freq. CE: frequência do advérbio no corpus de estudo;

- \% CE: porcentagem que representa a frequência do advérbio no corpus de estudo, considerado em sua totalidade;

- freq. CR: frequência do advérbio no corpus de referência;

- \% CR: porcentagem que representa a frequência do advérbio no corpus de referência, considerado em sua totalidade;

- chav.: índice de chavicidade do advérbio, em ordem decrescente.

Nessa lista, consideramos também a possibilidade de incluir o número de textos em que cada advérbio foi encontrado, tanto no corpus de estudo (CE) quanto no corpus de referência (CR), o que refletiria seu uso em textos diversos e corroboraria a ideia de que é bastante utilizado na área. No entanto, ao fazermos o levantamento no corpus de Culinária (inglês) e no BNC, lembramo-nos de que nem todos os arquivos da Culinária equivalem a uma única receita, pois isso não era necessário para a pesquisa conduzida por Teixeira (2008), compiladora do material. Esses números não refletiriam, portanto, a dispersão dos advérbios em cada texto. Nos corpora do Direito, no entanto, Carvalho Fonseca (2007) salvou cada contrato em um arquivo de texto diferente. Decidimos então levantar as informações em todos os corpora, apresentá-las logo abaixo do quadro introdutório para cada advérbio, e comentar quando relevante. As informações em dispersão nos arquivos revelam o número total de arquivos em que a palavra de busca foi localizada, também representado pela porcentagem que se segue. Esses dados foram observados tanto no corpus de estudo quanto no corpus de referência para que o 
consulente possa comparar a dispersão dessa palavra e verificar quão pertinente aquele advérbio é, no caso desta investigação, para a área em questão. Como exemplo, citamos o advérbio promptly, o mais frequente no corpus de Direito, encontrado em 70 textos (50\%) do CE, ou seja, em metade do número de textos do corpus em inglês. Já no CR, apesar de ser encontrado em 592 textos, esse número representa $14,6 \%$ do total do corpus, revelando uma dispersão bem menos significativa.

Numa tentativa de melhor situar o leitor quanto à frequência da palavra em estudo por todo o corpus, calculamos a normalização das frequências, que apresenta o número de vezes em que essa palavra ocorre em cada mil palavras do corpus em questão, que tanto pode ser o de estudo quanto o de referência. Tomando como exemplo o advérbio finely, o mais frequente no corpus de Culinária em inglês, observamos que ele ocorre 1,89 vezes em cada mil palavras, número bastante significativo quando comparado a sua frequência no $C R$, considerada inexpressiva. Isso revela que finely é característico da tipologia das receitas em Culinária. Para esses cálculos, vale lembrar o tamanho dos corpora utilizados em nossa pesquisa:

\begin{tabular}{|c|c|}
\hline \multicolumn{2}{|c|}{ Corpora de referência } \\
\hline BNC & 99.465 .296 \\
\hline BP & 695.013 .184 \\
\hline
\end{tabular}

\begin{tabular}{|c|c|c|}
\hline \multicolumn{3}{|c|}{ Corpora de estudo } \\
\hline & Culinária - receitas & Direito - contratos \\
\hline inglês & 1.716 .496 & 648.648 \\
\hline português & 1.590 .969 & 279.923 \\
\hline
\end{tabular}

Para descrever os padrões linguísticos levantados, utilizaremos o sinal de mais $(+)$ para indicar que uma palavra, classe gramatical ou categoria semântica está logo após a anterior, e os parênteses para demonstrar que uma palavra (ou classe gramatical) pode ou não fazer parte daquele padrão. Na sequência e entre parênteses, colocaremos o número de ocorrências. Exemplo: $N U M+(A D J)+$ garlic cloves, finely $+v_{p p}(97)$. Nesse caso, temos um NUMERAL seguido ou não de 
ADJETIVO, que por sua vez é seguido da colocação garlic cloves, da vírgula, e em seguida do advérbio finely com um VERBO NO PARTICÍPIO PASSADO. Outro recurso também utilizado será a / (barra), que serve para indicar que uma ou outra palavra ocorreu em um determinado padrão. Exemplo: lower/reduce the heat and simmer gently - nesse caso, a barra indica que temos ocorrências com lower the heat and simmer gently e reduce the heat and simmer gently. ${ }^{99}$ Para facilitar a descrição de associações morfossintáticas e outras unidades de referência, as abreviações abaixo poderão ser utilizadas:

\begin{tabular}{|l|l|l|l|}
\hline ADJ $=$ & adjetivo & $\mathrm{SN}=$ & sintagma nominal \\
\hline ADV $=$ & advérbio & $\mathrm{SP}=$ & sintagma preposicionado \\
\hline ART $=$ & artigo & SUBST $=$ & substantivo \\
\hline ART DEF $=$ & artigo definido & $\mathrm{SV}=$ & sintagma verbal \\
\hline COMPL $=$ & complemento & UNID MED $=$ & unidade de medida \\
\hline NUM $=$ & numeral & UNID TEMP $=$ & unidade de tempo \\
\hline PR $=$ & pronome & $\mathrm{V}=$ & verbo \\
\hline SA $=$ & sintagma adjetival & $\mathrm{V}_{\mathrm{pp}}=$ & verbo no particípio passado \\
\hline
\end{tabular}

Visamos também apresentar padrões incluindo categorias semânticas, colocadas entre colchetes e em versalete, que serão estabelecidas no decorrer das análises ${ }^{100}$. Podemos citar como exemplo a unidade "garnish with [HERB] = enfeite/decore/ guarneça com [ERVA]", apresentada por Teixeira e Tagnin (2008, p. 47). Nesse caso, temos a fraseologia garnish with (decore com) seguida de algum tipo de erva, como parsley (salsinha).

Na próxima seção, apresentamos os resultados de nossas análises na área da Culinária.

\footnotetext{
${ }^{99}$ Ao apresentarmos trechos de alguma receita, a barra também será utilizada para indicar quebra de linha, caso necessário.

${ }^{100}$ Essas categorias foram estabelecidas pela pesquisadora a partir de consulta feita ao projeto FrameNet, desenvolvido na Universidade da Califórnia, Berkeley, com pesquisadores por todo o mundo. Em linhas gerais, esse projeto apresenta um recurso lexical online, baseado em frames semânticos resultantes da investigação em corpus. Para mais detalhes, acesse: http://framenet.icsi.berkeley.edu .
} 
3.1 Os advérbios ${ }^{101}$ na Culinária

A) Os advérbios nas receitas culinárias em inglês

Os advérbios selecionados para análise são: finely, freshly, gently, lightly e thinly. Na sequência, apresentamos os resultados obtidos.

- FINELY

\begin{tabular}{|c|c|c|c|c|c|c|}
\hline$N$ & adv-chave & freq. CE & $\%$ CE & freq. CR & $\%$ CR & chav. \\
\hline 39 & finely & 3.261 & 0,19 & 684 & & $22.978,30$ \\
\hline
\end{tabular}

Dispersão nos arquivos:

CE: $1.962(25,31 \%)$

CR: $339(8,36 \%)$

Normalização das frequências:

CE: 1,89 ocorrência em cada mil palavras

CR: resultado inexpressivo $(0,0068$ ocorrência em cada mil palavras)

Finely é o advérbio terminado em -ly com maior índice de chavicidade e portanto o primeiro a ser investigado. Sua frequência no corpus de estudo, quando comparada ao corpus de referência, é bastante significativa - ele representa 0,19\% do total do corpus. Observamos também que é bem distribuído nos arquivos, mesmo considerando-se que pode haver várias receitas em cada um deles. Consultando a Wordlist, verificamos que finely se encontra em 1.962 dos arquivos (25,31\% do corpus total), enquanto no corpus de referência concentra-se em apenas 339 arquivos $(8,36 \%)$ - observa-se uma grande disparidade entre as porcentagens.

Nosso primeiro passo para analisar as ocorrências foi gerar as linhas de concordância, como podemos verificar na figura abaixo.

\footnotetext{
${ }^{101}$ A partir deste ponto, utilizaremos apenas a palavra advérbio para nos referirmos aos advérbios terminados em -ly e -mente identificados para análise. Faremos a distinção com relação aos demais advérbios de cada língua quando necessário.
} 


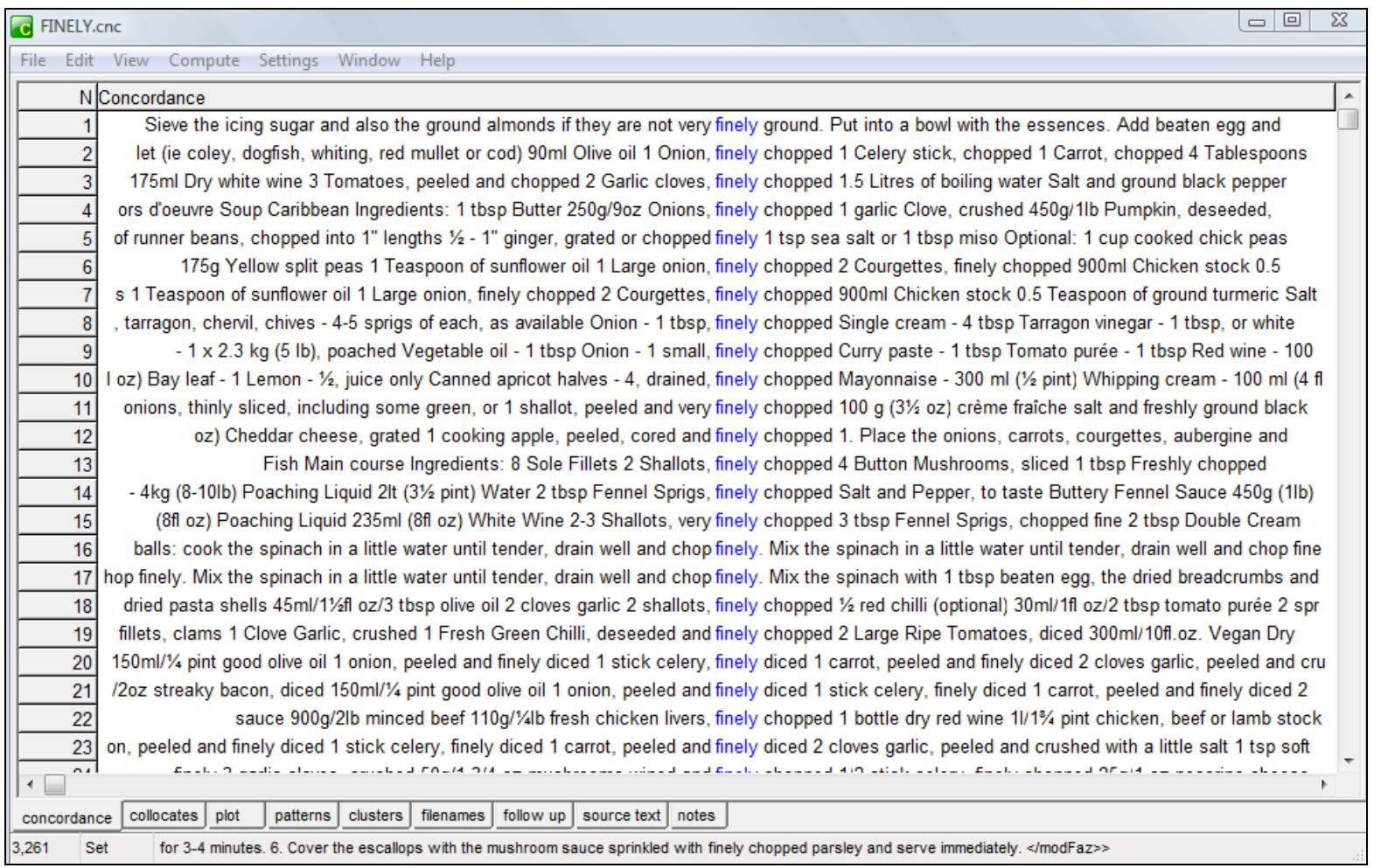

Figura 23 - 23 primeiras linhas de concordância de finely (Culinária - inglês)

Apenas nessas 23 primeiras linhas, já podemos observar algumas associações com duas palavras, tais como finely chopped, finely diced e chop finely. Devido ao grande número de ocorrências (3.261), decidimos iniciar a análise verificando os clusters (agrupamentos lexicais). Inicialmente, levantamos 261 prováveis clusters, ou mesmo associações que indicavam fazer parte de agrupamentos maiores, em um documento de Excel. Devido à quantidade significativa de clusters, decidimos agrupá-los pelo número de palavras em cada provável unidade, inclusive para podermos observá-los morfológica e semanticamente e estabelecer as correlações entre essas associações. Os números abaixo são o resultado de uma primeira análise, quando eliminamos agrupamentos como chopped 1 2; fry the; 2 lime; e 1 tbsp, por exemplo, que são irrelevantes para nossa pesquisa. Os resultados dessa filtragem inicial são:

- 24 clusters com 2 palavras ${ }^{102}$;

- 109 clusters com 3 palavras;

- 82 clusters com 4 palavras;

- 31 clusters com 5 palavras;

\footnotetext{
${ }^{102}$ Nesse caso, o programa apresenta 948 clusters com duas palavras. 24 é o resultado de nossa análise inicial, quando buscamos unidades de sentido completo.
} 
- 15 clusters com 6 palavras.

A partir deles, iniciamos uma análise minuciosa e o levantamento dos padrões com o advérbio finely. Esses padrões tanto poderiam formar-se com vocábulos específicos, como é o caso de peeled and finely chopped (184 oc.), quanto com a associação entre vocábulos e classes gramaticais, como em peeled and finely $+v_{p p}$ (295 oc.), que inclusive inclui as ocorrências do primeiro agrupamento lexical. Dessa forma, poderíamos também melhor visualizar o inverso, ou seja, quando uma unidade menor está incluída em outra maior, como é o caso de finely chopped (2.134 oc.) na unidade acima. Essas e outras ocorrências serão melhor analisadas e exemplificadas no decorrer desta investigação.

Esses clusters foram também observados nas linhas de concordância, principalmente aqueles que apresentavam em sua composição palavras que aparentemente não formavam uma unidade de sentido completo, como é o caso de the finely chopped - associação entre um item gramatical (o artigo definido the) e a colocação finely chopped. Para isso, valemo-nos do recurso resort. Em uma investigação mais contextualizada, poderíamos verificar, por exemplo, se essa associação fazia ou não parte de uma unidade maior, provavelmente incluindo outras classes gramaticais. Durante essa fase, ocorreu-nos agrupar os clusters ou por apresentarem determinada associação lexical em comum ou pela repetição de alguma associação gramatical, como ocorre no exemplo acima, que reúne diferentes verbos no particípio passado. À medida em que analisávamos os clusters, fomos fazendo algumas observações iniciais, abaixo relatadas.

Nas linhas de concordância, percebemos o uso da pontuação, não identificada pelo programa quando os clusters são formados, mas que se apresenta como característica das receitas culinárias. Na lista de ingredientes de uma receita, por exemplo, é comum termos o uso da vírgula ou hífen logo depois de um dado ingrediente, seguido do modo como esse ingrediente deve ser utilizado. Exemplo: garlic - NUM + cloves, + finely + $\mathrm{V}_{\mathrm{pp}}$. Esclarecendo: o substantivo garlic é seguido de hífen, depois, de um numeral associado à palavra cloves, que por sua vez é seguida de vírgula. Depois da vírgula, temos o advérbio finely seguido de um verbo no particípio passado. Uma outra associação semelhante é NUM + (ADJ) + garlic cloves, + finely $+\mathrm{v}_{\mathrm{pp}}$.

Chamou-nos também a atenção o grande número de substantivos que pertencem a um mesmo campo semântico, ou seja, dos temperos e condimentos, e 
que co-ocorrem com o advérbio finely, como é o caso de garlic (clove), onion, shallot, coriander, parsley, thyme, celery, ginger, basil, chives, pepper, rosemary, chilli, etc. ${ }^{103}$ - as respectivas frequências serão apresentadas a posteriori nesta análise. Observamos também o uso de algumas frutas, como é o caso do limão (lemon) e da laranja (orange), que podem ser utilizados como tempero, ao menos nessas ocorrências próximas ao advérbio finely. Alguns exemplos:

tbsp garlic, finely chopped / 2 tsp fresh ginger, finely chopped

2 1/2 cups fresh green coriander, finely chopped

1 small onion, chopped / 1/4 preserved lemon, finely chopped

Uma palavra gramatical que se sobressai é o artigo definido the, utilizado para fazer referência a um item já mencionado na lista de ingredientes. Em todos os casos (não necessariamente a primeira palavra à sua esquerda), o artigo é precedido de verbo no imperativo, forma característica dessa tipologia textual, sendo add (23) e place (6) os mais frequentes.

Foram 45 ocorrências de the finely, seguido de verbo e substantivo:

- the finely chopped seguido de: basil leaves (2), celery, chilli, garlic (3), ginger, mint, mushrooms, onion (5), onions (2), parsley, peppers, shallot (3), shallots (2), suet, white chocolate, zest of the orange;

- the finely diced seguido de: chilli (2), salmon, shallot, vegetables;

- the finely grated rind (5);

- the finely minced liver;

- the finely shredded leeks;

- the finely sliced seguido de: banana, red chilli, onion (2), onions;

- the finely snipped chives. ${ }^{104}$

Constatamos também que os verbos na forma imperativa utilizados com finely (antes ou depois dele) estão sempre no Modo de Fazer, não na Lista de Ingredientes. Já o particípio passado é utilizado em ambas as partes da receita (Lista de Ingredientes e Modo de Fazer), mas concentram-se praticamente na Lista de Ingredientes.

\footnotetext{
${ }^{103} \mathrm{Na}$ sequência: alho (dente), cebola, echalota, coentro, salsinha, tomilho, aipo, gengibre, manjericão, cebolinha francesa, pimenta, alecrim, pimenta (pepper e chilli podem ser traduzidas por pimenta).

${ }^{104} \mathrm{Em}$ todos os dados levantados, os agrupamentos ou palavras que não apresentam a frequência entre parênteses ocorreram uma única vez.
} 
Prosseguindo nossa investigação e observando a repetição de algumas palavras ou classes gramaticais, decidimos agrupá-las sob uma unidade comum, ou seja, utilizamos a unidade formada pelo menor número de palavras para encabeçar a lista desses agrupamentos. Abaixo, os resultados obtidos, seguidos de comentários.

\section{$>0$ advérbio finely e o verbo chop}

A colocação mais frequente é finely chopped, com 2.134 ocorrências. Dessas, 2.055 encontram-se na Lista de Ingredientes das receitas. As outras 79 ocorrências (3,7\% do total) foram registradas no Modo de Fazer ou em algum comentário ao final da receita. Partindo dessa colocação, identificamos as associações abaixo descritas.

\begin{tabular}{|l|l|}
\hline \multicolumn{2}{|l|}{ [INGREDIENTE], finely chopped (304): } \\
\hline parsley, finely chopped (38) & ginger, finely chopped (27) \\
\hline leaves, finely chopped (24) & coriander, finely chopped (17) \\
\hline chives, finely chopped (13) & root ginger, finely chopped (12) \\
\hline pepper, finely chopped (11) & celery, finely chopped (11) \\
\hline tomatoes, finely chopped (11) & fresh coriander, finely chopped (11) \\
\hline fresh parsley, finely chopped (10) & mushrooms, finely chopped (9) \\
\hline flatleaf parsley, finely chopped (8) & fresh root ginger, finely chopped (8) \\
\hline leek, finely chopped (8) & thyme, finely chopped (7) \\
\hline chocolate, finely chopped (7) & bacon, finely chopped (7) \\
\hline basil leaves, finely chopped (6) & fresh mint, finely chopped (6) \\
\hline carrot, finely chopped (6) & rosemary, finely chopped (6) \\
\hline stick(s) celery, finely chopped (6) & basil, finely chopped (5) \\
\hline fresh basil leaves, finely chopped (5) & green pepper, finely chopped (5) \\
\hline fresh ginger, finely chopped (5) & fresh chives, finely chopped (5) \\
\hline leeks, finely chopped (5) & nuts, finely chopped (5) \\
\hline
\end{tabular}

Quanto ao número de palavras em cada unidade acima, temos:

- 3 palavras: 18 unidades;

- 4 palavras: 10 unidades;

- 5 palavras: 2 unidades. 


\begin{tabular}{|l|l|}
\hline \multicolumn{2}{|l|}{ finely chopped + [INGREDIENTE] (204): } \\
\hline finely chopped onion (31) & finely chopped parsley (27) \\
\hline finely chopped celery (19) & finely chopped onions (14) \\
\hline finely chopped fresh parsley (13) & finely chopped shallots (11) \\
\hline finely chopped mushrooms (11) & finely chopped carrot (10) \\
\hline finely chopped spring onions (9) & finely chopped carrots (9) \\
\hline finely chopped chives (8) & finely chopped egg (6) \\
\hline finely chopped lemon (6) & finely chopped fresh ginger (5) \\
\hline finely chopped fresh chives (5) & finely chopped fresh breadcrumbs (5) \\
\hline finely chopped fresh mint (5) & finely chopped green pepper (5) \\
\hline finely chopped fresh rosemary (5) & \\
\hline
\end{tabular}

Quanto ao número de palavras em cada unidade, temos:

- 3 palavras: 11 unidades;

- 4 palavras: 8 unidades.

Abaixo, apresentamos uma sequência de co-occorrências de finely chopped precedida de um outro verbo, unidos pela conjunção and. Na verdade, são 337 ocorrências de $\mathrm{v}_{\mathrm{pp}}+$ and finely chopped. Dentre essas, destacam-se:

\begin{tabular}{|l|l|}
\hline \multicolumn{2}{|l|}{ [INGREDIENTE] + peeled and finely chopped (184) $\mathbf{~}^{\mathbf{1 0 5}}:$} \\
\hline onion, peeled and finely chopped (50) & ginger, peeled and finely chopped (27) \\
\hline garlic clove, peeled and finely chopped (21) & cloves, peeled and finely chopped (19) \\
\hline garlic cloves, peeled and finely chopped (17) & garlic, peeled and finely chopped (16) \\
\hline shallot, peeled and finely chopped (13) & small onion, peeled and finely chopped (12) \\
\hline root ginger, peeled and finely chopped (12) & shallots, peeled and finely chopped (10) \\
\hline fresh ginger, peeled and finely chopped (10) & onions, peeled and finely chopped (7) \\
\hline red onion, peeled and finely chopped (6) & medium onion,peeled and finely chopped (6) \\
\hline large onion, peeled and finely chopped (6) & \\
\hline
\end{tabular}

\footnotetext{
${ }^{105} \mathrm{Se}$ somarmos todas as ocorrências que estão entre parênteses nas unidades que encabeçam as listas apresentadas na sequência, o número total pode ser menor ou ultrapassar aquele colocado ao lado dessas unidades. Isso deve-se a um de dois fatores: as unidades listadas podem incluir outras, como é o caso de red onion, peeled and finely chopped (6 palavras) que inclui onion, peeled and finely chopped (5 palavras); ou ao fato de que unidades com frequência menor do que 5 (valor estabelecido como corte) não são mencionadas.
} 
Quanto ao número de palavras em cada unidade, temos:

- 5 palavras: 7 unidades;

- 6 palavras: 8 unidades.

Nesse grupo, todos os ingredientes são utilizados como tempero.

\begin{tabular}{|l|l|}
\hline \multicolumn{2}{|l|}{ [INGREDIENTE] + seeded and finely chopped (36): } \\
\hline chilli, seeded and finely chopped (19) & chillies, seeded and finely chopped (6) \\
\hline red chilli, seeded and finely chopped (5) & green chilli, seeded and finely chopped (5) \\
\hline
\end{tabular}

[INGREDIENTE] + deseeded and finely chopped (23):

chilli, deseeded and finely chopped (14)

red chilli, deseeded and finely chopped (8)

[INGREDIENTE] + de-seeded and finely chopped (44):

\begin{tabular}{|l|l}
\hline chilli, de-seeded and finely chopped (27) & chillies, de-seeded and finely chopped (5)
\end{tabular}

Outras ocorrências de verbo no particípio passado seguido de and finely chopped são: drained and finely chopped (9); cored and finely chopped (6); trimmed and finely chopped (5); skinned and finely chopped (5). Alguns exemplos:

For the Sauce: 2 anchovy fillets, drained and finely chopped

Cooking apples - $450 \mathrm{~g}(1 \mathrm{lb})$, peeled, cored and finely chopped

For the relish: 1 orange, cut into 4 slices 2 spring onions, trimmed and finely chopped

For the salsa: 1/2 small pineapple, skinned and finely chopped

Nos quadros acima, observamos a grande frequência de chilli seguida de (de)(-)seeded and finely chopped, formando unidades maiores com 5 palavras. Interessante observar que seeded, deseeded e de-seeded equivalem, em português, a uma única tradução, ou seja, sem sementes, que inclusive não apresenta verbo em sua formação. Verificamos também a co-ocorrência com a categoria semântica [INGREDIENTES], com destaque para os temperos. Nesse grupo, temos a formação de unidades que variam de 3 a 5 palavras: 
onion(s):

\begin{tabular}{|l|l|}
\hline onion, finely chopped (214): & onions, finely chopped (77) \\
\hline 1 onion, finely chopped (41) & spring onions, finely chopped (49) \\
\hline red onion, finely chopped (39) & \\
\hline small onion, finely chopped (32) & \\
\hline medium onion, finely chopped (26) & \\
\hline 1 large onion, finely chopped (18) & \\
\hline spring onion, finely chopped (11) & \\
\hline small red onion, finely chopped (8) & \\
\hline
\end{tabular}

Ainda com onion, mas não como primeira palavra antes de finely chopped, encontramos: onion - 1 large, finely chopped (12) e onions - 2 large, finely chopped (3); onion - 1 medium, finely chopped (27) e onions - NUM + medium, finely chopped (10); onion - 1 small, finely chopped (36).

garlic (+ clove(s)) ou apenas cloves - observe-se que a colocação pode estar antes ou depois do ingrediente, sendo a segunda opção a mais frequente:

\begin{tabular}{|l|l|}
\hline cloves, finely chopped (81) & garlic, finely chopped (81) \\
\hline garlic cloves, finely chopped (70) & garlic clove, finely chopped (50) \\
\hline finely chopped garlic (46) & clove garlic, finely chopped (23) \\
\hline finely chopped garlic cloves (9) & \\
\hline
\end{tabular}

Nos dados acima, o leitor deve observar que as ocorrências cloves, finely chopped (81) estão inclusas naquelas da linha logo abaixo, ou seja garlic cloves, finely chopped (70). Decidimos apresentar a primeira unidade porque ela demonstra que garlic não necessariamente ocorre como primeira palavra à esquerda de cloves. É o que observamos em cinco das ocorrências restantes, onde temos Garlic - + NUM + cloves, finely chopped, como em Garlic - 3 cloves, finely chopped.

\section{chilli(es):}

\begin{tabular}{|l|l|}
\hline chilli, finely chopped (51) & red chilli, finely chopped (39) \\
\hline chillies, finely chopped (15) & green chillies, finely chopped (8) \\
\hline green chilli, finely chopped (5) & \\
\hline
\end{tabular}


shallot(s):

\begin{tabular}{|l|l|}
\hline shallots, finely chopped (53) & shallot, finely chopped (48) \\
\hline small shallot, finely chopped (5) & \\
\hline
\end{tabular}

Muito menos frequente quando comparada com finely chopped (2.134 oc.), encontramos a colocação chopped finely (44), com o advérbio posposto ao verbo. Exemplo: 2 large stalks celery, chopped finely e 1 green chilli, chopped finely.

Além de finely chopped e chopped finely, o advérbio associa-se também ao verbo chop, na forma imperativa, formando as colocações finely chop e chop finely. Essas ocorrências geralmente encontram-se no Modo de Fazer das receitas. São elas: finely chop (87), finely chop + [INGREDIENTE] (59) ${ }^{106}$; chop finely (29), drain + $([$ INGREDIENTE] $)+($ well) and chop finely (8). Exemplo: Drain the spinach well and chop finely.

Quanto a associações entre o advérbio finely, o verbo chop e outras classes gramaticais, uma ocorrência significativa foi until finely chopped (16). Com ela, observamos a co-ocorrência de palavras que se referem ao processamento de alimentos, como blend (4), blitz (3), process (3), processor (2), pulse e whizz (2), formando unidades maiores de significado, como é o caso de blend until finely chopped em: Place the fish in a food processor and blend until finely chopped.

Outro agrupamento que nos chamou a atenção foi NUM + tbsp finely chopped, com 126 ocorrências, justamente por apresentar uma unidade de medida (tbsp = tablespoon $\rightarrow$ colher de sopa) bastante frequente e que co-ocorre com o advérbio finely. Exemplos: Fresh parsley - 1 tbsp, finely chopped; 3 tbsp finely chopped green coriander.

Em resumo, as co-ocorrências entre finely e chop apresentam as seguintes características:

- a anteposição do advérbio é muito mais frequente: são 2.134 ocorrências de finely chopped para 44 de chopped finely. Na forma imperativa do verbo, a anteposição também se sobressai: são 87 ocorrências de finely chop comparadas a 29 de chop finely. Importante destacar que a colocação finely chopped representa $65,44 \%$ das 3.261 ocorrências do advérbio finely, enquanto chopped finely equivale a apenas $1,35 \%$;

\footnotetext{
${ }^{106}$ Os ingredientes geralmente encontrados são: chocolate, tomatoes, shallots, etc.
} 
- as ocorrências de finely chopped estão, em sua grande maioria, na lista de ingredientes;

- o padrão [INGREDIENTE], finely chopped é o mais frequente. Nessas ocorrências, sobressaem-se os temperos e condimentos, dentre os quais podemos citar onion(s), (garlic) clove(s), chilli(es) e shallot(s);

- destaca-se a formação de unidades de 4 palavras, onde temos chopped precedido de um outro verbo no particípio passado, ou seja, $\mathrm{v}_{\mathrm{pp}}+$ and + finely + chopped, que são: peeled and finely chopped, seeded and finely chopped, deseeded and finely chopped e de-seeded and finely chopped. Essas colocações, por sua vez, integram unidades maiores;

- em termos de co-ocorrência com palavras gramaticais, destaca-se a associação de finely chopped com until, formando until finely chopped.

\section{$>0$ advérbio finely e o verbo slice}

A colocação mais frequente é finely sliced, com 347 ocorrências (10,64\% do total de ocorrências do advérbio finely), encontrada nos agrupamentos abaixo descritos.

\begin{tabular}{|l|l|}
\hline \multicolumn{2}{|l|}{ [INGREDIENTE], finely sliced (347): } \\
\hline onions, finely sliced (35) & onion, finely sliced (31) \\
\hline spring onions, finely sliced (24) & red onion, finely sliced (14) \\
\hline chilli, finely sliced (13) & shallots, finely sliced (12) \\
\hline red chilli, finely sliced (9) & leek, finely sliced (7) \\
\hline fennel, finely sliced (7) & mushrooms, finely sliced (6) \\
\hline garlic, finely sliced (6) & cabbage, finely sliced (5) \\
\hline
\end{tabular}

Quanto ao número de palavras em cada unidade, temos:

- 3 palavras: 9 unidades;

- 4 palavras: 3 unidades.

Nessas unidades, chamou-nos a atenção a co-ocorrência entre finely sliced e cabbage, primeira verdura a apresentar frequência acima de 5 nos dados até então analisados. 
$\mathrm{V}_{\mathrm{pp}}+(\mathrm{COMPL})+$ and finely sliced $(76)$ :

1 carrot, cut in half lengthways and finely sliced

1/2 cucumber, quartered lengthways and finely sliced

peeled and finely sliced (42):

2 red Asian shallots or 1/2 red onion, peeled and finely sliced

seeded and finely sliced (10):

1/2 red onion, peeled and finely sliced 1 large red chilli, seeded and finely sliced

de-seeded/deseeded and finely sliced (9):

1 red chilli, deseeded and finely sliced 6 mint leaves, shredded

trimmed and finely sliced (9): 1 fennel bulb, trimmed and finely sliced

cored and finely sliced (5): 4 red skinned apples cored and finely sliced

Identificamos algumas unidades maiores que incluem peeled and finely sliced. São elas: onion peeled and finely sliced (11); red onion peeled and finely sliced (8).

Com menor frequência, encontramos também sliced finely (30), presente nas unidades: onions sliced finely (7); shallots sliced finely (5).

$\mathrm{Na}$ forma imperativa (sempre no Modo de Fazer das receitas), slice associase a finely em 24 ocorrências, como em: Peel and finely slice the shallots. Foi encontrada apenas uma ocorrência de slice finely.

Uma última co-ocorrência encontrada foi finely sliced into (5), seguida de sintagma nominal: rounds (2), rings, half-rings, strips. Exemplo: 6 shallots, finely sliced into rounds and soaked in $250 \mathrm{ml} / 9 \mathrm{fl}$ oz good quality red wine.

\section{0 advérbio finely e o verbo dice}

A colocação mais frequente é finely diced, com 272 ocorrências (8,34\% do total de ocorrências do advérbio finely), que integra os agrupamentos abaixo.

\begin{tabular}{|l|l|}
\hline [INGREDIENTE], finely diced (272): \\
\hline onion, finely diced (22) & celery, finely diced (10) \\
\hline shallots, finely diced (10) & tomato, finely diced (8) \\
\hline shallot, finely diced (8) & chillies, finely diced (6) \\
\hline chilli, finely diced (6) & onions, finely diced (6) \\
\hline stick(s) celery, finely diced (5) & \\
\hline
\end{tabular}


Com exceção de stick(s) celery, finely diced, todas as outras co-ocorrências são formadas por três palavras.

[INGREDIENTE], + $\mathrm{v}_{\mathrm{pp}}+$ and finely diced (72)

[INGREDIENTE], peeled and finely diced (49):

onion, peeled and finely diced (19)

red onion, peeled and finely diced (12)

carrots, peeled and finely diced (6)

potato, peeled and finely diced (6)

sweet potato, peeled and finely diced (5)

[INGREDIENTE], + deseeded and finely diced (8):ripe tomatoes, deseeded and finely diced

[INGREDIENTE], + de-seeded and finely diced (8): cucumber, de-seeded and finely diced

[INGREDIENTE], + seeded and finely diced (4) ${ }^{107}$ : green pepper, seeded and finely diced

As ocorrências de diced finely (35) foram bem menos frequentes. Exemplo: 1 ripe mango, peeled, stoned and diced finely. Com o verbo no imperativo (finely dice), foram apenas 6 ocorrências. Exemplo: Cut half the tomatoes into small chunks and finely dice the rest.

\section{$>$ advérbio finely e o verbo grate}

\section{finely grated (206):}

finely grated zest (38), seguido de of (13):

Fold in the flour, baking powder and finely grated zest of one lime.

parmesan, finely grated (23)

finely grated rind (16), seguido de of (12):

Lemon or Orange Pudding: Add the finely grated rind of 1 lemon or orange to the basic mixture.

cheese, finely grated (16)

parmesan cheese, finely grated (9)

finely grated parmesan (9):

Scatter parsley over the top, sprinkle with finely grated parmesan if desired, and serve, straight from the dish.

\footnotetext{
${ }^{107}$ Apesar de haver apenas 4 ocorrências, decidimos incluir essa unidade devido à equivalência de significado entre seeded, deseeded e de-seeded.
} 
finely grated lemon rind (2) / zest (7):

Replace vanilla essence with 1/2 teaspoon lemon essence and 1-2 teaspoons finely grated lemon rind.

ginger, finely grated (8)

finely grated zest only (7):

Ingredients $55 \mathrm{~g} / 2 \mathrm{oz}$ caster sugar 1/2 lemon, finely grated zest only 3 tbsp lemon juice

finely grated orange zest (6):

Decorate the cheesecake with finely grated orange zest and orange segments.

finely grated parmesan cheese (6)

orange, finely grated (6)

root ginger, finely grated (5)

lemon, finely grated (5)

Finely grated representa $6,32 \%$ do número total de ocorrências do advérbio finely. Essa colocação ocorre tanto antes quanto depois do ingrediente, sendo a primeira posição a mais frequente. São 72 ocorrências para [INGREDIENTE], finely grated e 105 ocorrências para finely grated [INGREDIENTE]. Em geral, esses ingredientes são uma fruta cítrica (laranja ou limão), gengibre ou queijo. É também frequente a co-ocorrência com zest (aquela raspinha bem fina ou a casca em tirinhas de um ingrediente utilizado para dar mais sabor ao prato).

Unidades maiores: [INGREDIENTE] + peeled and finely grated (16); ginger peeled and finely grated (5). Exemplos: 1lb carrots, peeled and finely grated; 2 tbsp fresh ginger, peeled and finely grated.

Grated finely (8) também foi encontrada, mas com frequência bem menor. Exemplo: 1/2 oz fresh parmesan, grated finely.

Na forma imperativa do verbo, finely grate (14), temos: Finely grate in a little lemon zest - the amount you add is up to you.

\section{$>0$ advérbio finely e o verbo shred}

Novamente, a unidade mais frequente foi com o verbo no particípio passado são 65 ocorrências de finely shredded. As unidades maiores mais frequentes revelam que essa colocação geralmente ocorre com verduras, ou seja, folhas, como podemos observar em cabbage finely shredded (11); lettuce finely shredded (6); leaves finely shredded (5), formando o padrão [INGREDIENTE] finely shredded. O 
verbo também ocorre antes do advérbio, mas a frequência é bem menor - são apenas 9 com shredded finely. No imperativo, temos finely shred (8) e somente duas ocorrências com shred finely. Exemplos: Roll the leaves up tightly, a few at a time, and finely shred them into strips $5 \mathrm{~mm}$ wide; Wash the lettuce leaves, dry and shred finely.

\section{$>\mathrm{O}$ advérbio finely associado a outros verbos}

Neste subitem, apresentamos as co-ocorrências de finely com outros verbos que, apesar de apresentarem menor frequência, também são significativas e podem ser classificadas como colocações. São elas:

- finely ground (24), sendo almonds finely ground (6) a unidade maior mais frequente: 1 cup unblanched almonds, finely ground.

- finely minced (15): Use a sharp knife to chop the salmon until it is finely minced.

- finely crushed (9): $20 z$ cracker crumbs (cream crackers or saltines), finely crushed.

- finely snipped (5): Top with finely snipped chives.

\section{$>$ Outras associações do advérbio finely}

Observamos também que finely é frequentemente modificado por outro advérbio, ou seja, very. Foram encontradas 222 ocorrências de very finely, a maioria das quais com chopped. Abaixo os agrupamentos identificados e alguns exemplos:

[INGREDIENTE] (+ $\mathrm{v}_{\mathrm{pp}}$ +and) very finely chopped (89):

onion, very finely chopped (10)

peeled and very finely chopped (6): 1 small onion, peeled and very finely chopped

chilli, very finely chopped (6): For the sauce: 1/4 red chilli, very finely chopped

red onion, very finely chopped (5)

garlic cloves, very finely chopped (5)

[INGREDIENTE] chopped very finely (26): 12 oz closed cup of mushrooms, chopped very finely

As unidades abaixo apresentam very finely seguido de outros verbos, formando colocações anteriormente apresentadas sem o advérbio very: 
- very finely diced (26): 1 ball of mozzarella cheese, very finely diced;

- very finely sliced (24): 1/2 red pepper, de-seeded and very finely sliced;

- very finely grated (6): If you were to make cheese scones, you would add 1 3/4 cups very finely grated mature cheddar cheese, [...].

Outras unidades encontradas são:

- as finely as possible (10): Chop all the vegetables as finely as possible without totally crushing them.

- Rub in the butter finely (8), que inclusive é uma oração: Sift the flour and salt into a bowl. Rub in the butter finely. Add the sugar. Add the milk all at once.

Em linhas gerais, observamos que finely co-ocorre com verbos que pertencem a um mesmo campo semântico, ou seja, "cortar", em diferentes formas, como é o caso de dice (cortar em cubos), slice (cortar em fatias, fatiar) e shred (cortar em tiras).

Terminada a análise, decidimos verificar quais outros dados poderíamos levantar com o utilitário Concgram, novo recurso do programa WST com o qual ainda estamos nos familiarizando. Ao observarmos os resultados, chamaram-nos a atenção as ocorrências com a palavra until. Enquanto nas linhas de concordância obtivemos 23 ocorrências de until finely, o Concgram apresenta-nos 68 casos em que essas duas palavras co-ocorrem (com until não necessariamente antes ou logo após o advérbio), formando agrupamentos descontínuos. Mesmo necessitando de uma análise detalhada, esses dados reforçam a ideia de que a co-ocorrência entre uma palavra de conteúdo, ou seja, o advérbio finely, e uma palavra de classe gramatical, no caso until, pode revelar unidades maiores de significado, bem como relações semânticas entre as palavras que ocorrem em um trecho do discurso. 


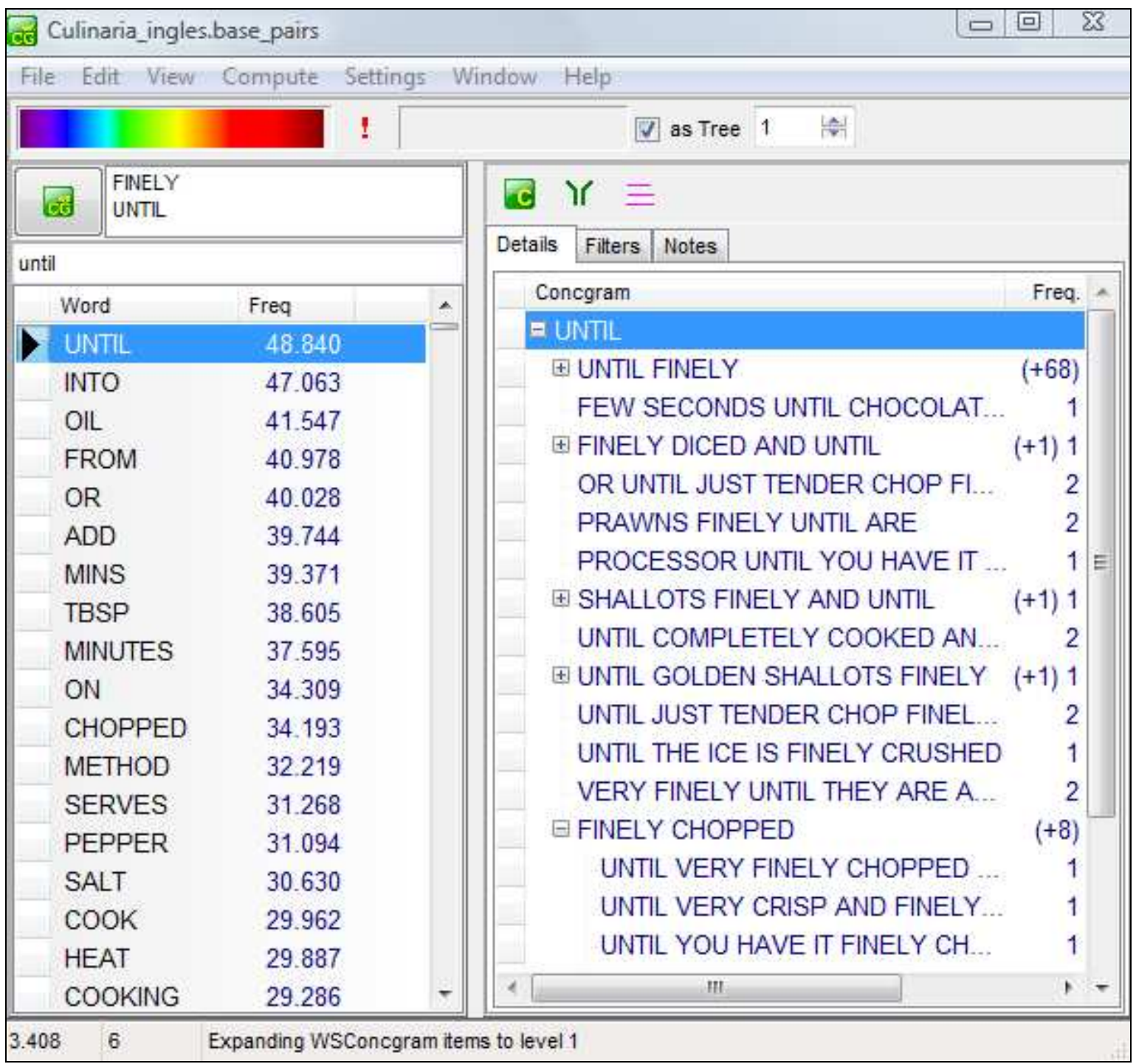

Figura 24 - Algumas concgrams de finely e until

Apresentamos abaixo alguns exemplos das ocorrências identificadas à direita na figura acima, que apontam a relação semântica entre finely e until:

Use a sharp knife to chop the salmon until it is finely minced.

In a blender, blend together the chickpeas, flour and baking powder until chickpeas are finely ground.

Add the Buck's Fizz and liquidise until the ice is finely crushed.

Chop the prawns very finely until they are almost a paste.

Analisando apenas esses exemplos, podemos observar que a palavra until introduz o resultado de um processo, que por sua vez inclui o advérbio finely. Tal fato também foi verificado nas 23 ocorrências de until finely, mas através das 
concgrams pudemos observar que isso é mais frequente do que o observado naquelas linhas de concordância.

Concluída a análise de finely, passamos ao próximo advérbio da lista. Ao final do levantamento em cada área e língua, faremos algumas considerações a partir dessas observações.

- FRESHLY

\begin{tabular}{|c|c|c|c|c|c|c|}
\hline$N$ & adv-chave & freq. CE & $\%$ CE & freq. CR & $\%$ CR & chav. \\
\hline 40 & freshly & 3.248 & 0,19 & 670 & & $22.925,95$ \\
\hline
\end{tabular}

Dispersão nos arquivos:

CE: $2.546(32,84 \%)$

CR: $329(8,12 \%)$

Normalização das frequências:

CE: 1,89 ocorrência em cada mil palavras

CR: resultado inexpressivo $(0,0067$ ocorrência em cada mil palavras)

Como podemos observar nos dados acima, freshly é muito mais bem distribuído no corpus de estudo. Mesmo cientes de que cada arquivo contém várias receitas, podemos verificar que o advérbio encontra-se em $32,84 \%$ deles. No corpus de referência, isso já não ocorre - são apenas $8,12 \%$ dos arquivos que contém o advérbio freshly. Quanto às ocorrências em cada mil palavras, os números já revelam que o advérbio é muito frequente no corpus de estudo, com frequência totalmente inexpressiva no corpus de referência.

Partindo para a análise dos clusters de freshly, considerando-se a variação entre 2 e 7 palavras, observamos novamente que as unidades de duas palavras encabeçam a lista. Como essas unidades estão presentes em todas as outras associações maiores, agrupamos essas co-ocorrências, tendo a unidade de duas palavras como ponto comum. A primeira delas é freshly ground, cujas ocorrências (2.824) representam $86,94 \%$ daquelas computadas para o advérbio freshly, ou seja, 3.248 . 


\section{O advérbio freshly e o verbo grind}

\begin{tabular}{|l|l|}
\hline \multicolumn{2}{|l|}{ freshly ground + [INGREDIENTE] Ou [INGREDIENTE] freshly ground (2.824): } \\
\hline freshly ground black pepper (2.447) & salt and freshly ground black pepper (1.667) \\
\hline freshly ground pepper (254) & salt and freshly ground pepper (190) \\
\hline freshly ground black pepper to taste (163) & sea salt and freshly ground black pepper (121) \\
\hline freshly ground white pepper (49) & $\begin{array}{l}\text { season with salt and freshly ground black } \\
\text { pepper (32) }\end{array}$ \\
\hline freshly ground black pepper to serve (29) & salt and freshly ground white pepper (22) \\
\hline freshly ground pepper to taste (14) & black pepper, freshly ground (12) \\
\hline white pepper, freshly ground (10) & salt and freshly ground pepper to taste (10) \\
\hline
\end{tabular}

Antes de comentarmos esses dados, é importante lembrar que as unidades maiores incluem as menores, e portanto a somatória de todos os números entre parênteses depois de cada unidade não equivale ao número total de ocorrências. Exemplificando: 1.667 das 2.447 ocorrências de freshly ground black pepper estão computadas nas ocorrências de salt and freshly ground black pepper, ou seja, $68,12 \%$ das ocorrências de freshly ground black pepper são precedidas de salt and.

No quadro acima, observamos que a colocação freshly ground é significativamente frequente. Mais saliente ainda, e também pelo número de palavras que compõem o agrupamento, ou seja, quatro, é a unidade freshly ground black pepper, com 2.447 ocorrências, que representam $86,65 \%$ do número total de ocorrências de freshly ground e, respectivamente, $75,33 \%$ das ocorrências de freshly. Além disso, é notório que o verbo, modificado pelo advérbio, ocorre praticamente apenas com o substantivo pepper, independente de ser pepper, white pepper ou black pepper. O único outro substantivo encontrado foi nutmeg (freshly ground nutmeg), com quatro co-ocorrências. Com isso, podemos ressaltar o padrão salt and freshly ground [PIMENTA $]^{108}$.

Em termos de organização textual, freshly ground [INGREDIENTE] é mais frequente ao final da lista de ingredientes, com algumas ocorrências no Modo de Fazer de uma dada receita.

Dentre as unidades maiores, ressaltamos freshly ground black pepper to taste (163); salt and freshly ground black pepper to taste (148) e season with salt and

\footnotetext{
${ }^{108}$ Devido ao grande número de co-ocorrências com diferentes tipos de pimenta, decidimos delimitar melhor essas ocorrências estabelecendo a categoria semântica [PIMENTA] em nossa pesquisa.
} 
freshly ground black pepper (32). Exemplo: Drizzle with olive oil and season with salt and freshly ground black pepper.

Todas as ocorrências de season with salt and freshly ground black pepper estão no Modo de Fazer, muito provavelmente devido à presença do verbo season na forma imperativa.

$\mathrm{Na}$ lista de clusters, encontramos vários agrupamentos que, a nosso ver, não compõem uma unidade de significado - apenas colocam em sequência os ingredientes de uma dada receita. Fomos inclusive verificar a disposição desses ingredientes e confirmamos a observação de que eles estão em linhas separadas, como no exemplo abaixo:

Ingredients

4-5 pepperdew peppers, chopped

2 spring onions, chopped

2 tbsp olive oil

handful herbs, chopped

$120 \mathrm{ml} / 4 \mathrm{fl}$ oz chicken stock

$1 / 2$ smoked sausage, diced

4-5 tbsp double cream

$55 \mathrm{~g} / 2 \mathrm{oz}$ butter

salt

freshly ground black pepper

1 packet vacuum packed rice, preheated

(grifo nosso)

Isso não ocorre, no entanto, quando temos a conjunção and entre salt e freshly ground black pepper. Daí termos incluído salt and freshly ground black pepper no quadro acima, onde listamos as associações que consideramos unidades de significado:

Ingredients

For the cakes:

4 chicken fillets

2 bird's-eye red chillies, chopped

1 tsp peeled and finely grated galangal

1 tsp finely chopped lemongrass

2 spring onions, finely chopped

$15 \mathrm{~g} / 1 / 2$ oz coriander, including stalks, chopped

1 lime, zest of half and juice

2 tbsp vegetable oil

salt and freshly ground black pepper

(grifo nosso) 
Em geral, observamos que freshly ground black pepper é um ingrediente mencionado no grupo dos temperos, como é o caso de salt, vinegar e lemon juice.

Quanto às unidades de medida utilizadas com a colocação freshly ground, a mais frequente é tsp (56) (tsp = teaspoon $\rightarrow$ colher de chá), sempre seguida de freshly ground (black) (white) pepper. Foram também encontradas 7 ocorrências da forma por extenso, ou seja, teaspoon, com os mesmos colocados. Outras ocorrências são some freshly ground black pepper (6) e plenty of freshly ground black pepper (6). Exemplos:

$1 / 2$ tsp freshly ground white pepper

Taste the hot dressing for salt and add some freshly ground black pepper.

Sprinkle over the sundried tomatoes and season with plenty of freshly ground black pepper.

Nas linhas de concordância, observamos que a maior parte das ocorrências com some e plenty of deu-se no Modo de Fazer, não na Lista de Ingredientes, como observamos em outras co-ocorrências.

Além de pepper, nenhum outro ingrediente apresentou mais de cinco coocorrências com freshly ground.

\section{O advérbio freshly e o verbo grate}

A unidade que encabeça a lista de associações entre freshly e grate é freshly grated. Suas 248 ocorrências representam 7,63\% do número total de ocorrências do advérbio freshly. Como vemos abaixo, há co-ocorrências bastante específicas com alguns ingredientes, justamente pela carga semântica do verbo.

\section{freshly grated [INGREDIENTE] ou [INGREDIENTE] freshly grated (248):}

freshly grated nutmeg (83): Add a good sprinkle of freshly grated nutmeg, season, then simmer for 2 minutes.

freshly grated parmesan (68)

$(\mathrm{NUM})+(\mathrm{tbsp})+$ freshly grated parmesan cheese (38): Garnish: 4 baby aubergines 4 cherry tomatoes $15 \mathrm{~g} / 1 / 2$ oz freshly grated parmesan cheese

parmesan cheese (,) (-) freshly grated (19) 
NUM + tbsp freshly grated parmesan (cheese) (18): 4 eggs, beaten 6 tbsp freshly grated Parmesan cheese salt freshly ground black pepper

$\mathrm{NUM}+$ tsp freshly grated nutmeg (14): Cheshire cheese - 50g (2 oz), grated English mustard - 1 tsp Freshly grated nutmeg Double cream - $150 \mathrm{ml}$ (5 fl oz), whipped

(UNID MED) + parmesan (,) (-) freshly grated (8): 2 large eggs, lightly beaten 100g / 31/2 oz parmesan, freshly grated

freshly grated horseradish (6)

freshly grated ginger (6)

Os dois ingredientes que mais co-ocorrem com a colocação são nutmeg e cheese, mais especificamente o tipo parmesão, que em várias ocorrências é identificado apenas por parmesan. Vale lembrar que as 38 ocorrências de (NUM) + (tbsp) + freshly grated parmesan cheese incluem a colocação freshly grated parmesan (68). Quanto à pontuação, observamos que às vezes o substantivo - no caso (parmesan) cheese - ou é seguido de vírgula, ou de travessão, ou de nenhuma marcação quando anteposto a freshly grated. No caso das unidades de medida, é mais frequente a co-ocorrência de tsp (teaspoon $\rightarrow$ colher de chá) com nutmeg e tbsp (tablespoon $\rightarrow$ colher de sopa) ou mesmo oz (ounce $\rightarrow$ onça) com (parmesan) cheese, o que se justifica pelo tipo de ingrediente. Duas outras co-ocorrências bem menos frequentes são com os substantivos horseradish e ginger, alimentos também utilizados na forma ralada - assim como o queijo (parmesão) e a noz-moscada, conferem um sabor mais acentuado ao prato.

\section{O advérbio freshly e o verbo chop}

\section{freshly chopped [INGREDIENTE] (132):}

freshly chopped parsley (32): Serve hot, garnished with freshly chopped parsley.

freshly chopped chives (14)

freshly chopped mint (11)

NUM + tbsp freshly chopped parsley (11): 1 tbsp freshly chopped parsley

freshly chopped flat leaf parsley (9):

10 anchovies, drained and cut in half lengthways 2 tbsp freshly chopped flat leaf parsley

(NUM + tbsp) freshly chopped coriander (8): To garnish: $30 \mathrm{~g}$ (loz) toasted cashew nuts $30 \mathrm{~g}$ (loz) olives $3 \mathrm{tbsp}$ freshly chopped coriander 
freshly chopped herbs (7): To serve, fold the freshly chopped herbs into the squash and top with the marinated seared beef.

parsley (,) (-) freshly chopped (5): 2 tbsp parsley, freshly chopped

A primeira observação é a co-ocorrência bem menos frequente entre o advérbio freshly e o verbo chopped (132), quando comparada àquela entre finely e chopped (2.134). Interessante também é observar o grupo de ingredientes que coocorrem tanto com finely chopped quanto com freshly chopped. Em várias receitas, prefere-se que esses ingredientes em comum, ou seja, ervas, sejam preparados na hora, como é o caso de parsley, mint, chives e coriander. Apesar de não apresentarem o mínimo de cinco ocorrências, identificamos outros ingredientes associados a freshly chopped. São eles: rosemary, dill, oregano, thyme, pertencentes ao campo semântico das ervas, formando o padrão freshly chopped [ERVAS]. Exemplo: 2 tsp. freshly chopped oregano; 2 tsp. freshly chopped thyme.

Em geral, freshly chopped é encontrada na Lista de Ingredientes, com 89,40\% das ocorrências (118) nessa parte da receita - as outras 14 estão no Modo de Fazer. O advérbio não foi encontrado posposto ao verbo - ao analisar as linhas de concordância, o pesquisador deve verificar a que se refere a palavra em estudo, uma vez que as palavras são dispostas em sequência (a quebra de linha é ignorada), o que não ocorre em uma receita. Nesse caso, foram encontradas 26 ocorrências de chopped freshly. Em nenhuma delas, no entanto, o advérbio referiase a esse verbo, mas sim a um outro verbo na sequência, como podemos observar em 2 tbsp coriander, freshly chopped / freshly cooked rice, to serve.

\section{0 advérbio freshly e o verbo mill}

\section{freshly milled + [PIMENTA] (37):}

freshly milled black pepper (34): Sea salt - 1/2 tsp Freshly milled black pepper salt and freshly milled black pepper (24): Now add the hot stock to the rice, along with some salt and freshly milled black pepper.

Como o verbo mill pertence ao mesmo campo semântico de grind, não é surpresa observarmos a grande co-ocorrência com black pepper. Das 37 ocorrências de freshly milled, 34 são freshly milled black pepper (91,89\% do total). 
Inclusive, a co-ocorrência com salt, formando a unidade salt and freshly milled black pepper, também se repete.

As três ocorrências restantes para completar as 37 acima são de freshly milled pepper.

\section{O advérbio freshly e o verbo squeeze}

freshly squeezed + [INGREDIENTE] (18): Try to use the freshly squeezed juices - you will get a much better flavour.

freshly squeezed lemon (10) / orange (4) (juice): 2 tsp freshly squeezed lemon juice; 9fl oz freshly squeezed orange juice

Considerando-se o significado do verbo squeeze, era esperada a coocorrência com os ingredientes lemon e orange, formando unidades de significado. Dentre as ocorrências de freshly squeezed lemon (10), oito são seguidas de juice. As ocorrências que faltam para completar o total de 18 de freshly squeezed são com lime e juice(s). Exemplo: The diners season the dish themselves with sauce and freshly squeezed lime juice.

\section{0 advérbio freshly e outros verbos}

Com um número menor de ocorrências, identificamos as colocações freshly cooked (13) e freshly made (12). Alguns exemplos:

Simmer gently for 2 minutes and serve immediately with freshly cooked pasta.

[...] serve garnished with coriander sprigs and with the freshly cooked rice.

The sauce keeps for a few days in the fridge, but is best if eaten when freshly made.

Em linhas gerais, podemos observar que o advérbio freshly apresenta padrões semelhantes ao advérbio anteriormente analisado, ou seja, finely. Nesse caso, destacam-se também a anteposição do advérbio (com relação ao verbo no particípio passado, com função adjetiva) e a significativa ocorrência das colocações na Lista de Ingredientes. Quanto às fraseologias propriamente ditas, vale ressaltar: freshly ground [INGREDIENTE]; salt and freshly ground [PIMENTA]; freshly ground black 
pepper; freshly grated [INGREDIENTE]; freshly grated nutmeg; freshly grated parmesan; freshly grated parsley; freshly milled [PIMENTA]; freshly milled back pepper; freshly squeezed [INGREDIENTE].

- GENTLY

\begin{tabular}{|c|c|c|c|c|c|c|}
\hline$N$ & adv-chave & freq. CE & $\%$ CE & freq. CR & $\%$ CR & chav. \\
\hline 82 & gently & 2.543 & 0,15 & 3.775 & & $12.349,63$ \\
\hline
\end{tabular}

Dispersão nos arquivos:

CE: $1.945(25,09 \%)$

CR: $979(24,15 \%)$

Normalização das frequências:

CE: 1,48 ocorrência em cada mil palavras

CR: resultado inexpressivo $(0,037$ ocorrência em cada mil palavras)

Como já apontado anteriormente, há arquivos no corpus de Culinária que contém mais de uma receita. Dessa forma, devemos considerar, nos dados acima, que o advérbio gently ocorre em $25,09 \%$ dos 7.753 arquivos que compõem o CE em sua totalidade. No CR, gently também apresenta boa dispersão, ou seja, ocorre em $24,15 \%$ dos arquivos. Devemos lembrar, no entanto, que o CR (BNC) é formado por 4.124 textos (vide capítulo II para mais detalhes), pouco mais da metade de arquivos que temos no CE. Como não temos acesso aos textos do BNC, a não ser por meio das linhas de concordância ${ }^{109}$, torna-se difícil a comparação desses dados. Dessa forma, preferimos analisar os resultados obtidos com a normalização de frequências, que deixa clara a presença marcante do advérbio no CE.

Ao observarmos as linhas de concordância, logo em um primeiro momento já percebemos que o advérbio gently ocorre, em sua grande maioria, no Modo de Fazer. Das 2.543 ocorrências desse advérbio, encontramos apenas duas na Lista de Ingredientes, e ainda assim utilizadas na orientação do preparo de algum ingrediente:

\footnotetext{
${ }^{109}$ Essas linhas podem ser acessadas em http://corpus.byu.edu/bnc. Devemos lembrar que o BNC também está disponível para compra, mas cremos que a normalização de frequências, nesse caso, é suficiente para demonstrar a frequência da palavra nesse corpus.
} 
Ingredients / 15 ripe cherry tomatoes / 1 cup peas (gently braised for 15 minutes in extra virgin olive oil, anchovies and salt)

$20 z$ butter, gently melted / 175g/6oz farmhouse cheddar, grated

Adotamos o mesmo procedimento descrito para os dois advérbios anteriormente analisados: fomos verificar os clusters entre duas e seis palavras, analisando cada grupo separadamente - começamos com agrupamentos de apenas duas palavras, depois de três, e assim por diante. Percebemos que, como gently ocorre no Modo de Fazer, a formação de unidades de significado estendidas ${ }^{110}$ é mais propícia do que no caso dos advérbios finely e freshly. Partindo das unidades com duas palavras, chegamos aos resultados abaixo apresentados.

\section{O advérbio gently e o verbo simmer}

A co-ocorrência mais frequente é com o advérbio posposto ao verbo, na forma imperativa. São 434 ocorrências de simmer gently, distribuídas nas unidades abaixo.

\section{simmer gently (434)}

simmer gently for (about) + UNID TEMP (347): Bring to the boil and simmer gently for at least an hour until thickened and dark red.

simmer gently for + NUM + minute(s) (249): Lower the heat and simmer gently for 30 minutes.

simmer gently for about + minute(s) / hour(s) (33): Cover the pan and simmer gently for about 5 minutes or until the shells open.

simmer gently for + NUM + hour(s) (22): Cover tightly and simmer gently for 11 / 2 hours.

simmer gently for a few minutes (18): Pour in the cream and add the brie, simmer gently for a few minutes, until the cheese has melted.

\footnotetext{
${ }^{110}$ Tognini-Bonelli (2001) as intitula extended units of meaning.
} 


\section{[APLICAR CALOR] and simmer gently for + UNID TEMP (246):}

lower/reduce the heat and simmer gently for + UNID TEMP (62):

Lower the heat and simmer gently for 30 minutes.

Add the chilli flakes and seasoning, then reduce the heat and simmer gently for 10-15 minutes.

bring to the boil and simmer gently for + UNID TEMP (23):

3. Add the vegetable stock, milk, potatoes and mushrooms. 4. Bring to the boil and simmer gently for 20 minutes.

bring to the boil (,) then lower/reduce the heat and simmer gently for + UNID TEMP (18):

Bring to the boil, then lower the heat and simmer gently for 5 minutes.

Pour the vegetable stock into the pan, bring to the boil, then reduce the heat and simmer gently for 8-10 minutes or until the mushrooms are tender.

bring to the boil, cover and simmer gently for + UNID TEMP (11):

Bring to the boil, cover and simmer gently for approximately one hour or cook in an oven.

cover the (steaming) pan and simmer gently for + UNID TEMP (8):

Cover the steaming pan and simmer gently for 13-25 minutes.

turn/reduce the heat to low and simmer gently for + UNID TEMP (5):

Cover the pan, reduce the heat to low and simmer gently for 25-30 minutes.

cover and simmer gently (53): Cover and simmer gently until meat is tender, about 1 hour.

cover and simmer gently for (about)+ UNID TEMP (47):

Cover and simmer gently for about 40 minutes, then strain.

Add the mussels, cover and simmer gently for 3 minutes, shaking them occasionally.

simmer gently until +([INGREDIENTE]) + [RESULTADO] (46):

Continue to simmer gently until the cheese starts to melt.

Put the blackberries and half the water in a large saucepan and simmer gently until soft.

cover and simmer gently until + [INGREDIENTE] + [PROPÓSITO] (5):

Cover and simmer gently until the fruit is soft and pulpy.

allow to simmer gently (for + UNID TEMP) (7): Tip all of the ingredients into a pan, bring to the boil and allow to simmer gently for about 20 minutes.

simmer gently over a moderate/low heat for + UNID TEMP (6): Bring the mixture to the boil and simmer gently over a low heat for about 5 minutes.

A primeira observação é que a colocação simmer gently encontra-se em unidades de tamanhos variados. Procuramos agrupar as ocorrências acima seguindo uma certa lógica: primeiramente, colocamos todas as unidades que continham simmer gently for + UNID TEMP. Na sequência, fomos observar as unidades que se formavam à esquerda da colocação. Chegamos assim ao segundo 
grupo, encabeçado por [APLICAR CALOR] and simmer gently for + UNID TEMP. Na sequência, apresentamos outros quatro grupos, destacando-se as colocações cover and simmer gently for (about) + UNID TEMP, simmer gently until +([INGREDIENTE]) + [RESULTADO] e allow to simmer gently (for + UNID TEMP).

Outras observações:

- A unidade simmer gently for + NUM + minute(s) apresenta os numerais na forma arábica e, em alguns casos, por extenso. Foram encontradas apenas duas ocorrências de minute (singular).

- Há várias linhas de concordância que apresentam a sequência bring to the boil, reduce/lower the heat, cover and simmer gently for + UNID TEMP, com algumas variações que impedem a formação de um padrão fixo. Eis alguns exemplos:

bring to the boil then reduce the heat, cover and simmer gently for 35-40 minutes until the quail are tender.

Bring back to the boil, lower the heat, cover and simmer gently for half an hour.

Bring to the boil, lower heat, cover and simmer gently for 1 hour.

Bring to the boil, reduce the heat to very low, partially cover and simmer gently for 30 minutes, stirring frequently to prevent it burning.

\section{gently simmering water (32)}

$(a)+(A D J)+($ sauce)pan of gently simmering water (27): Cook the tortellini in a large pan of gently simmering water until al dente, then drain and season with nutmeg.

over (a) (small/large) (sauce)pan of gently simmering water (24): Melt the chocolate in a small heatproof bowl over a small pan of gently simmering water.

Interessante observar que gently simmering water, na grande frequência de co-ocorrência com pan, tem chocolate como o ingrediente mais frequente na mesma linha de concordância. Ainda nesse grupo, identificamos 21 ocorrências de over a/the pan of gently simmering water, frequentemente precedidas do substantivo bowl e do verbo place: Place the chocolate and water in a bowl over a pan of gently simmering water and leave to melt slowly. Essa instrução refere-se ao modo de preparo do chocolate nessas receitas.

Apesar da frequência bem menos significativa, verificamos a anteposição do advérbio gently ao verbo simmer, formando a colocação gently simmer (30). A partir dela, observamos a formação das seguintes unidades: 
gently simmer (30):

gently simmer for + UNID TEMP (19): Next, lower the heat to its minimum setting and let the curd gently simmer for 1 further minute, continuing to whisk.

bring to (the) boil (and) (then) gently simmer for + UNID TEMP (7):

Bring to the boil and gently simmer for 20 minutes.

Bring to the boil and then gently simmer for four to five minutes, before placing in the blender.

Bring to boil and then gently simmer for 1 hour, skimming the surface periodically to remove scum.

Gently simmer é precedida da conjunção and em 17 ocorrências, o que indica a sequência das instruções de uma receita. Em 4 delas, temos a co-ocorrência da unidade reduce/lower the heat. Exemplo: Add the beetroot to the pan, reduce the heat and gently simmer for 15-16 minutes.

\section{$>0$ advérbio gently e o verbo cook}

A colocação mais frequente é cook gently (229). A partir dela, observamos a formação dos padrões abaixo descritos. Neste grupo, liderado pelo segundo verbo que mais co-ocorre com o advérbio gently, já podemos notar certa padronização da tipologia das receitas culinárias. Novamente, observamos a co-ocorrência frequente com palavras gramaticais como and, for, until e over. Na verdade, o que varia nessas unidades com gently é o verbo utilizado.

\section{cook gently (229)}

([ADICIONAR INGREDIENTE]) + and cook gently (for + UNID TEMP) (157):

Add the shallots and garlic and cook gently for a couple of minutes.

Pour in the batter and cook gently until the underneath is brown.

add + [INGREDIENTE] + and cook gently (for/until) (72):

Add the whole spices and cook gently for one minute until they begin to smell aromatic.

Add several fresh basil leaves and cook gently for about 10 minutes.

[...] then add the onion, carrot and ham strips and cook gently until just turning brown.

Destacam-se os ingredientes: flour (6), garlic (12) e onion(s) (12):

Add the flour and cook gently for 1 minute, stirring.

Melt the butter in a large pan, add the garlic and cook gently for one minute.

Heat the oil over a medium heat, add the onion and cook gently for 2-4 minutes. 
(and) cook gently until + [RESULTADo], que pode também ser uma oração reduzida (42):

Whisk the egg yolk into the milk, cook gently until it thickens slightly.

Place in a saucepan and cook gently until thickened.

cook gently until + soft (4) / softened (2) / tender (4) / thickened (2):

Melt butter, add onions, cook gently until soft, do not brown.

Put all these ingredients into a pan and cook gently until tender.

cover and cook gently (for + UNID TEMP) / (until) (22):

Heat the oil, add the onion, celery, leek, carrot and swede, cover and cook gently for 10 minutes.

Heat the butter in a saucepan, add the onions, cover and cook gently until softened, shaking the pan occasionally to prevent browning.

(and) cook gently, stirring (+ UNID TEMP/[MODO]) (,) for + UNID TEMP/until [RESULTADO] (19):

Add the onion and cook gently, stirring for a few minutes until softened.

Cover and cook gently, stirring occasionally, for 10 minutes.

Add the onions and cook gently, stirring frequently, until very soft, but not coloured.

lower/reduce/return to (the) heat and cook gently for + UNID TEMP / until [RESULTADO] (10):

Reduce heat and cook gently for 10 minutes.

Lower the heat and cook gently until the sugar has dissolved.

Return to the heat and cook gently, stirring constantly, until the sauce thickens.

cook gently for a few minutes (8):

Add the asparagus and onions; cover and cook gently for a few minutes until softened slightly.

cook gently over a moderate/medium/(fairly) low heat (5):

[...] add a teaspoon of water to the butter and cook gently over a fairly low heat until the whites of the eggs are just cooked.

[...] add the onions, garlic and ginger and cook gently over a moderate heat until just softened.

A colocação gently cook foi identificada em 38 ocorrências, demonstrando novamente que a posposição do advérbio (229 ocorrências) é mais frequente. Com ela, observamos padrões anteriormente identificados com cook gently, como é o caso de (and) gently cook (for + UNID TEMP) (21). Entre os ingredientes, destaca-se onion(s), com 11 ocorrências. Exemplos:

Stir in the oil, cover and gently cook for three minutes.

Heat until it is foaming then add the onion and gently cook for about 5 minutes until beginning to soften.

To make the stuffing, gently cook the onions in oil until soft and translucent. 
O verbo cook foi encontrado no particípio presente em 8 ocorrências, precedido de continue em 6 delas, formando a unidade continue cooking gently: Add the apples and pears and continue cooking gently for 15-20 minutes.

\section{$>0$ advérbio gently e os verbos heat e reheat}

Heat gently é a colocação mais frequente, com 220 ocorrências. Novamente, encontramos padrões muito parecidos com os analisados para as colocações simmer gently e cook gently.

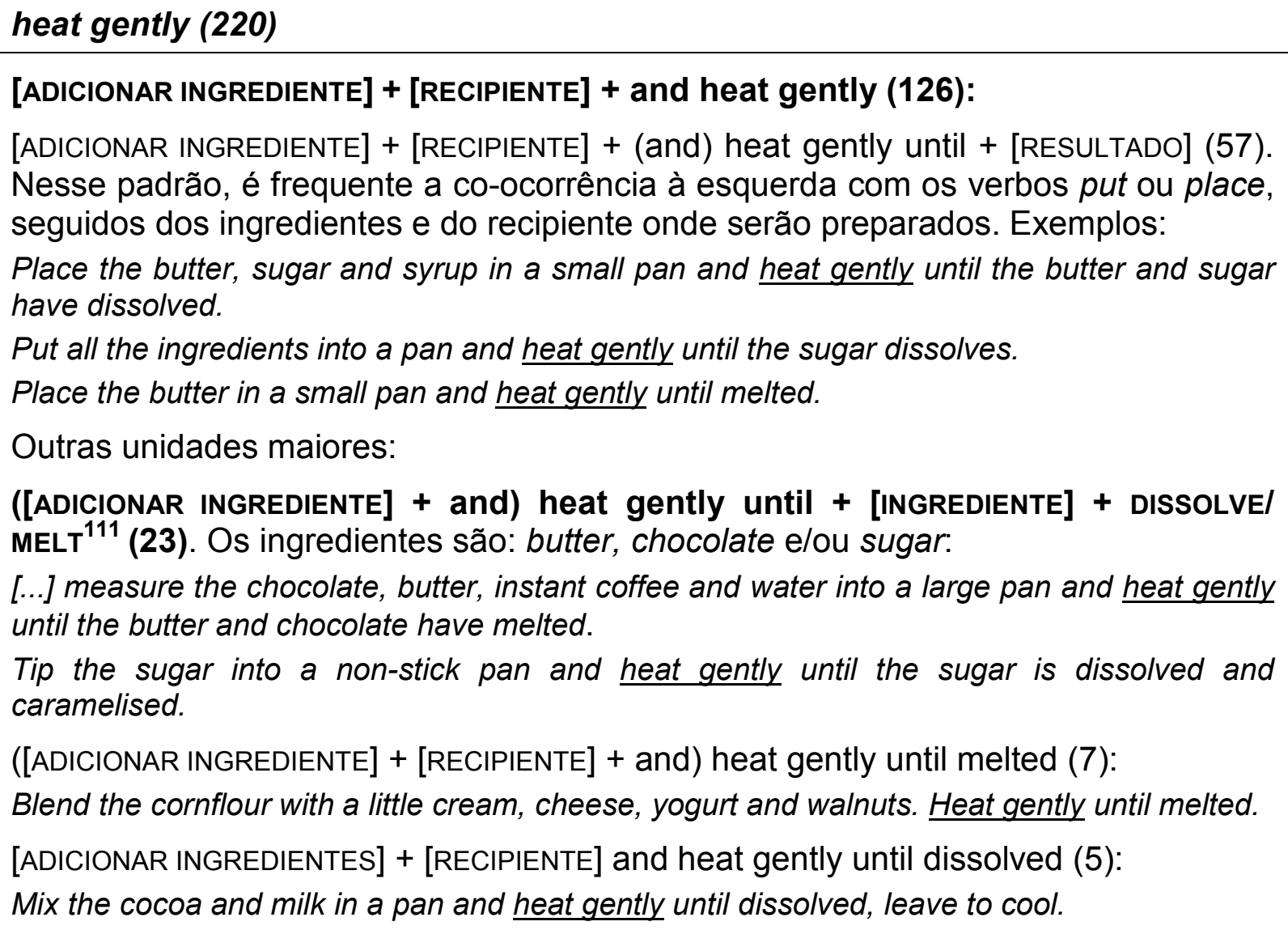

Outras unidades maiores:

([ADICIONAR INGREDIENTE] + and) heat gently until + [INGREDIENTE] + DISSOLVE/ MELT $^{111}$ (23). Os ingredientes são: butter, chocolate e/ou sugar:

[...] measure the chocolate, butter, instant coffee and water into a large pan and heat gently until the butter and chocolate have melted.

Tip the sugar into a non-stick pan and heat gently until the sugar is dissolved and caramelised.

([ADICIONAR INGREDIENTE] + [RECIPIENTE] + and) heat gently until melted (7):

Blend the cornflour with a little cream, cheese, yogurt and walnuts. Heat gently until melted.

[ADICIONAR INGREDIENTES] + [RECIPIENTE] and heat gently until dissolved (5):

Mix the cocoa and milk in a pan and heat gently until dissolved, leave to cool.

([ADICIONAR INGREDIENTE]) (+ and) heat gently for + UNID TEMP (53):

Stir in the sweet potato, beans and seasoning and heat gently for 10-15 minutes, adding extra water if necessary.

Add the flour then pour in the milk, nutmeg and egg, whisking continuously. Heat gently for a few minutes.

\footnotetext{
${ }^{111} \mathrm{O}$ uso de palavras em versalete indica que elas estão lematizadas. No caso de verbos, em inglês, essa forma é representada pelo infinitivo sem a partícula to e inclui todas as flexões que o verbo apresenta nos dados investigados.
} 
([ADICIONAR INGREDIENTE] + and) heat gently for a few minutes (13):

Season with salt and pepper and heat gently for a few minutes.

([ADICIONAR INGREDIENTE] +[RECIPIENTE] and) heat gently(,) stirring (47):

([ADICIONAR INGREDIENTE] + [RECIPIENTE] + and) heat gently, stirring ([MODO]) (,) (until) [RESULTADO] (27):

Heat gently, stirring, but do not boil otherwise it will curdle.

Return to the pan and add the cream, nutmeg and seasoning and heat gently, stirring, until blended.

To make the sauce, put the chocolate into a pan and heat gently, stirring occasionally, until the chocolate melts.

([ADICIONAR INGREDIENTE] + [RECIPIENTE] + and) heat gently(,) stirring(, ) until (all) (the) sugar dissolves/has dissolved (11):

Place all the ingredients in a large saucepan and heat gently, stirring until sugar dissolves.

Heat gently, stirring, until the sugar has dissolved, then bring to the boil.

([ADICIONAR INGREDIENTE]) (+ and) heat gently to + [PROPÓSITO] (10):

Stir in the liqueur and cream. Heat gently to reduce slightly.

Heat gently to dissolve the sugar.

heat through gently (10): Stir in the ricotta and heat through gently for another minute.

Com o verbo heat, observamos que a anteposição do advérbio não é tão significativamente menor - são 113 ocorrências de gently heat, em oposição a 220 de heat gently, incluídas em unidades maiores bastante semelhantes àquelas já levantadas com heat gently:

-[ADICIONAR INGREDIENTE] + [RECIPIENTE] + and gently heat (until) [RESULTADO] (21):

Put the remaining ingredients in a pan and gently heat until boiling.

-gently heat + [INGREDIENTE], destacando-se: the oil (17), the sugar (14), the butter (11), the cream (7), the oil and butter (6) e the milk (5). Exemplos:

In a small frying pan, gently heat the oil for the salmon.

In a medium saucepan gently heat the sugar until melted.

Gently heat the butter, sugar and maple syrup in a pan, stirring continuously

Meanwhile gently heat the cream and bay leaf together, but do not boil.

Meanwhile, to make the pilaff, gently heat the oil and butter in a medium saucepan.

Gently heat the milk and most of the chocolate until the chocolate has melted.

O verbo reheat também é frequente com gently. São 47 ocorrências de reheat gently e 8 de and reheat gently without boiling, frequentemente precedida do verbo 
add ou stir + [INGREDIENTE]. A anteposição do advérbio, formando a colocação gently reheat, foi identificada em 7 ocorrências. Exemplos:

Reheat gently for a minute or two until just warmed through.

Liquidise, add the cream and parsley and reheat gently without boiling.

Return to a clean saucepan, stir in the cream and reheat gently.

Gently reheat the custard and serve the hot crumble with custard poured over.

\section{0 advérbio gently e o verbo melt}

Foram observadas 189 ocorrências de gently melt, agrupadas nas unidades abaixo:

\section{gently melt (189)}

gently melt + [INGREDIENTE] (186) - dentre os ingredientes, destacam-se:

- the butter (150):

In a medium saucepan, gently melt the butter.

- the sugar (19):

In a small pan, gently melt the sugar for the chutney.

- the butter and + [INGREDIENTE] (6), destacando-se oil: Gently melt the butter and oil in a large pan and sauté.

gently melt the butter in + [RECIPIENTE] (123):

gently melt the butter in a pan/saucepan (39):

For the gravy, gently melt the butter in a pan and sweat the onion for a few minutes to soften.

gently melt the butter in a (non-stick) (frying) (large/medium/small) pan/saucepan and sauté + [INGREDIENTE] (30):

Meanwhile, gently melt the butter in a non-stick frying pan and saute the mushrooms for 2-3 minutes to soften.

gently melt the butter in a (non-stick) frying pan (20):

Gently melt the butter in a non-stick frying pan and fry the croissant

gently melt the butter in a medium (non-stick) pan/saucepan (19):

Gently melt the butter in a medium pan and fry the apples with the sugar

gently melt the butter in a large pan/saucepan (11):

Gently melt the butter in a large pan and fry the apples for 4-5 minutes to soften.

gently melt the butter in a small (non-stick) (frying) pan/saucepan (11):

Gently melt the butter in a small non-stick frying pan and scatter the potato in, spreading it out evenly. 
gently melt the butter in a (non-stick frying) pan and fry + [INGREDIENTE] (10):

Gently melt the butter in a pan and fry the mushrooms, spinach, garlic and nutmeg for a few minutes, to soften.

gently melt the butter in a sauté pan (6):

For the spinach, gently melt the butter in a sauté pan and add the spinach

gently melt the butter in a large (non-stick) frying pan (5):

Gently melt the butter in a large non-stick frying pan, until foaming.

To make + [INGREDIENTE] ${ }^{112}$, gently melt the butter in + [RECIPIENTE] (16):

To make the chive butter, gently melt the butter in a pan and whisk in the grated cheese.

gently melt the sugar in a small/medium (non-stick) (frying) pan/saucepan (15):

Gently melt the sugar in a medium frying pan until golden.

gently melt the sugar in a small pan/saucepan over a low heat until caramelised (11): Gently melt the sugar in a small saucepan over a low heat until caramelised.

To make + [INGREDIENTE], gently melt the sugar in + [RECIPIENTE] (9):

To make spun sugar, gently melt the sugar in a small pan over a low heat until caramelised.

For + [INGREDIENTE], gently melt the butter in + [RECIPIENTE] (8):

For the gravy, gently melt the butter in a pan and sweat the onion for a few minutes to soften.

Meanwhile, gently melt the butter in + [RECIPIENTE] (6):

Meanwhile, gently melt the butter in a small pan and add the cream and orange juice.

Além da significativa co-ocorrência com os substantivos butter e sugar, podemos observar a formação de unidades até o nível oracional, como é o caso de Gently melt the butter in a large saucepan. Tanto à esquerda quanto à direita da colocação, pode haver repetição em nível lexical e sintático, como verificado em To make the sauce, gently melt the butter in a pan e demais exemplos acima. É evidente que o advérbio exerce maior influência sobre o verbo, mas fica clara a relação semântica entre todos os elementos da oração. Nesse caso, cremos que o uso desse advérbio (e não de outro) está extremamente ligado ao ingrediente a que o verbo se refere, formando assim uma unidade de significado maior.

Foram encontradas apenas quatro ocorrências com a posposição do advérbio, ou seja, melt gently (4): Add the butter to the pan and allow to melt gently.

\footnotetext{
112 O campo semântico [INGREDIENTE], nesse quadro, pode ser uma guarnição, como é o caso de arroz, um molho, ou qualquer outro alimento preparado que será utilizado para o resultado final do prato.
} 


\section{0 advérbio gently e o verbo fry}

A anteposição do advérbio é mais frequente - são 152 ocorrências de gently fry comparadas às 68 de fry gently. Abaixo, as unidades encontradas para ambas as colocações.

\section{gently fry (152)}

([APLICAR CALOR] + [INGREDIENTE] + ([RECIPIENTE]) + and) gently fry + [INGREDIENTE] + (for + UNID TEMP/until [RESULTADO]) (104) - dentre os ingredientes, destacam-se: (the) onion(s) (43): Heat the oil and gently fry the onion, celery and carrot until soft. the onion(s) and (the) garlic (12): Heat the oil in a large saucepan and gently fry the onion and garlic for a few minutes to soften.

the garlic (9): Gently fry the garlic for one minute and then add the rice.

the chicken (5): Heat the oil in a large frying pan and gently fry the chicken with the onion until lightly browned on all sides.

([ADICIONAR INGREDIENTE]) (+ and) gently fry for + UNID TEMP (40):

Add the onion and garlic, then gently fry for a few minutes until softened.

heat the oil in a (large/medium) (non-stick) (frying) pan/saucepan and gently fry + [INGREDIENTE] (32): Heat the oil in a medium saucepan and gently fry the cabbage for one to two minutes.

heat the oil and gently fry + [INGREDIENTE] (12): Heat the oil and gently fry the button mushrooms.

Gently fry for + NUM + minutes (on) each side, tossing to turn (15):

Gently fry for 1-2 minutes each side, tossing to turn.

Gently fry for + NUM + minutes (on) each side (or) until crisp (10):

Gently fry for 3-4 minutes each side until crisp and golden.

Gently fry for 3-4 minutes (on) each side until crisp, golden and cooked through (8):

Gently fry for 3-4 minutes each side until crisp, golden and cooked through.

melt (half) (the) butter (or margerine) in + [RECIPIENTE] + and gently fry + [INGREDIENTE] + for + UNID TEMP / until [RESULTADO] (9):

Melt half the butter in a large saucepan and gently fry the onion for about 5 minutes until soft but not brown.

add/put + [INGREDIENTE] + and gently fry until [RESULTADO] (5): Add the sausages and gently fry until they are about three quarters cooked and golden brown.

Além dos ingredientes garlic e onion, utilizados como tempero, outro que se sobressai é chicken. Assim como nas colocações anteriores, gently fry também apresenta unidades que contém orações ou sintagmas relacionados a tempo e 
resultados do preparo, introduzidos por for e until. Nos padrões Gently fry for + NUM + minutes (on) each side, tossing to turn e Gently fry for + NUM + minutes (on) each side (or) until crisp observamos que o tempo mencionado é sempre curto, sempre menor de cinco minutos. Novamente, observamos várias unidades em nível oracional.

A colocação fry gently apresenta 68 ocorrências, repetindo alguns dos padrões colocacionais de gently fry. Interessante observar, no entanto, que à medida em que gently fry apresenta 104 ocorrências seguidas de ingredientes que deverão ser fritos, fry gently não apresenta nenhuma ocorrência com essa formação. Em sua grande maioria, a colocação ou é seguida por for + UNID TEMP, ou por until + [RESULTADO]. Nesses casos, os ingredientes são citados antes da colocação, como em Add the mushrooms and fry gently for three minutes.

\section{fry gently (68)}

([ADICIONAR INGREDIENTE]) + and) fry gently for + UNID TEMP (37):

When hot add the onion and fry gently for approximately 10 minutes or until golden.

add + [INGREDIENTE] + and fry gently for + UNID TEMP (25):

Add the carrot, onion and garlic, and fry gently for about 5 minutes.

Nessa unidade, destacam-se as ocorrências de onion(s) (10):

Heat the oil in a saucepan, add the onion and fry gently for about 5 minutes until soft and lightly coloured.

(and) fry gently until + [RESULTADO] (16):

Add the onion and pepper and fry gently until soft.

add the bacon and fry gently until it has rendered its fat and is very crisp.

fry + [INGREDIENTE] + gently in (the) butter (13). Nesse caso, o verbo e o advérbio estão separados pelo ingrediente:

In a saucepan fry vegetables gently in butter for 7-10 minutes.

For the filling, fry the onion and garlic gently in the butter until tender, without browning.

fry gently in + [INGREDIENTE] (6), com destaque para butter (4):

Toss in the flour and fry gently in the butter with the onions.

\section{$>0$ advérbio gently e o verbo fold}

A co-ocorrência mais frequente é gently fold, com 96 ocorrências. Dessas, 93 são seguidas das preposições in ou into, essa última precedida de ingredientes, formando as fraseologias gently fold in e gently fold [INGREDIENTE] into. Fold gently 
seguida de into também foi encontrada, mas com apenas 6 ocorrências. Exemplo: Whisk the egg whites until stiff and fold gently and thoroughly into the mixture. Apresentamos abaixo os agrupamentos mais frequentes de gently fold, seguido de in ou into ${ }^{113}$ :

\section{gently fold in /gently fold [INGREDIENTE] into (93)}

(and) gently fold in (53) $\rightarrow$ (and) gently fold in + [INGREDIENTE] (49). Destacam-se os ingredientes: egg whites (4) e flour (8):

Remove from heat and gently fold in the egg whites.

Using a large metal spoon, gently fold in the flour.

gently fold + [INGREDIENTE] into [MISTURA] (32). Destaca-se o ingrediente (egg) white(s) (13):

Gently fold the whites into the chocolate mixture using a large metal spoon.

gently fold into + [MISTURA] (5):

In a separate bowl, whisk the egg whites until stiff, then gently fold into the raspberry mixture.

Observamos que as fraseologias gently fold in / gently fold [INGREDIENTE] into geralmente co-ocorrem com ingredientes que devem ser delicada e gradativamente acrescentados em uma receita, caso de egg (whites) e flour.

\section{$>0$ advérbio gently e o verbo stir}

Na lista de colocações com duas palavras, a próxima é gently stir, com 38 ocorrências. A posposição do advérbio é igualmente frequente: são 37 ocorrências de stir gently. Abaixo, os agrupamentos encontrados:

\section{gently stir (38)}

gently stir in + [INGREDIENTE] (21):

Remove the pan from the heat and gently stir in the cheese, with the remaining butter and seasoning.

(and) gently stir into + [MISTURA] (6):

Sift the flour, ginger and cinnamon together into another bowl and gently stir into the creamed mixture.

\footnotetext{
${ }^{113}$ Fold in e fold into são phrasal verbs.
} 
Há duas ocorrências em que gently stir não é seguido da preposição in. São elas: To make the salsa, gently stir together all the ingredients in a large bowl and allow to stand for ten minutes before serving.; Gently stir together the raspberries and light brown soft sugar in a 1.2 litre (2 pint) oven-proof dish. A diferença não é apenas morfossintática, mas também semântica. Quando temos gently stir in seguido de algum ingrediente, deve-se acrescentar esse ingrediente mexendo delicadamente. Quando temos gently stir together seguido de ingrediente(s), a instrução é apenas mexer delicadamente um ou mais ingredientes que já foram acrescentados anteriormente. A co-ocorrência de gently stir com a preposição into indica acrescentar ingrediente(s) a uma [MISTURA], mexendo delicadamente.

Apresentamos abaixo os padrões encontrados com a posposição do advérbio, ou seja, com a colocação stir gently:

\section{stir gently (37)}

([ADICIONAR INGREDIENTE] + and) stir gently for + UNID TEMP (8):

Add the fish sauce and the monkfish to the coconut milk mixture and stir gently for just a few seconds.

add + [INGREDIENTE] + and stir gently (for + UNID TEMP) (8):

Add the mango pieces and stir gently for 1 minute to warm the mango.

stir gently to + [RESULTADO] (6):

Place all the ingredients into a large bowl and stir gently to combine.

Stir gently to mix the vegetables through the rice.

Como podemos observar nos padrões levantados, a anteposição ou posposição do advérbio implica diferentes agrupamentos. No caso de stir gently, os ingredientes já foram citados antes da colocação (como objeto do verbo anterior) e, com isso, não são mencionados novamente. Tal fato não ocorre com gently stir. Compare:

Remove the pan from the heat and gently stir the roasted butternut squash into the risotto with the parmesan, the remaining butter and seasoning to taste.

Gently stir in the cream and coriander and cook for a further 2 minutes.

Add the onions, salt and pepper, bay leaves and thyme leaves, stir gently, reduce the heat, cover and cook for 30 minutes, stirring every five minutes.

Remove the pan from the heat and add the hazelnuts and chocolate chips. Stir gently until the chocolate has completely melted. 
Uma outra associação que pode ser feita por engano caso o pesquisador não analise as linhas de concordância atentamente é gently stirring. Ao levantarmos os clusters de gently, encontramos 84 ocorrências dessa possível colocação. No entanto, ao analisarmos as linhas de concordância, pudemos observar que o advérbio referia-se a um verbo anterior, como é o caso de heat. Na formação dos clusters feita pelo programa WST, conforme já mencionado, a pontuação não é considerada - na maioria das ocorrências, havia uma vírgula entre gently e stirring. Isso sem considerarmos os casos em que não havia pontuação, mas que deveria ter sido utilizada. Exemplo: Pour in the milk and heat gently stirring frequently to make a white sauce. Esse engano não ocorre se o advérbio vier depois do verbo - foram identificadas 9 ocorrências de stirring gently: Cook, uncovered, for another 2-3 minutes, stirring gently as you do so.

\section{$>0$ advérbio gently e outros verbos: fraseologias com menos de 30 oc.}

- gently sauté (28) / sauté gently (6):

- heat/melt (+ [INGREDIENTE] + in + [RECIPIENTE]) and gently sauté + [INGREDIENTE] (20). Nos últimos ingredientes, destacam-se onion(s) (8) e shallots (4):

Melt the butter in a frying pan and gently sauté the onion.

Heat the olive oil in a large pan and gently sauté the potato and leeks for a few minutes, to soften.

- gently bring (24):

- gently bring (+ [MISTURA/INGREDIENTE]) to a simmer / to simmering point (9):

In a small frying pan, gently bring the red wine, soy, ketchup, honey and sesame oil to a simmer.

Pour in the water and gently bring to simmering point.

- (and) gently bring (up) to the boil (7):

Break the chocolate into the pan and gently bring to the boil, stirring occasionally, until melted.

- gently warm (20) / warm gently (7):

- gently warm + [INGREDIENTE] (13): Gently warm the jam and brush it over the strawberries to glaze.

- warm gently: Warm gently and serve on a bed of rice with a side salad. 
- gently warm through (6): In a small saucepan, gently warm through the orange quarters for 1-2 minutes.

- boil gently (17):

- boil gently for + UNID TEMP (7): Add the remaining ingredients and boil gently for 1-2 hours.

- boil gently until [RESULTADO] (6): Boil gently until the liquor is reduced by half.

- sizzle gently (19):

- Heat a pan one-third filled with vegetable oil, for deep-frying, until a breadcrumb will sizzle gently in it. (16)

Nesse caso, tomamos o cuidado de verificar se havia duplicidade de receitas. Mas de fato tratava-se de 16 arquivos diferentes, o que mais uma vez reflete a padronização dessa tipologia textual.

- (and) gently press (down) ([INGREDIENTE]) (15) / press gently (5) / press down gently (5):

Gently press the nuts into the dough, then roll it up.

Fold the bottom half of each piece over the top half and gently press down.

The fish is ready when you press gently and the cod flakes begin to separate.

Place the puff pastry on top, press down gently round the edges and score the middle.

- (and) poach gently (for + UNID TEMP) (14) / gently poach [INGREDIENTE] (for + UNID TEMP) (6):

Add the pear halves, and poach gently for 10-12 minutes.

Gently poach the salmon in wine for 5 minutes.

- (and) toss gently (12) / gently toss ([INGREDIENTE]) (10):

Add the salad dressing and toss gently.

With rubber spatula, gently toss vegetables to coat well with dressing.

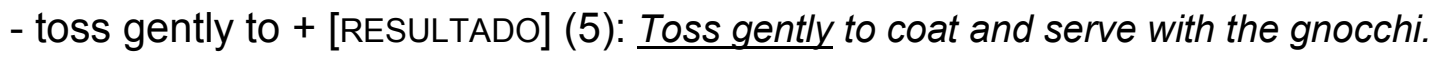

- mix gently (11) / gently mix together (5)

Add to the salad and mix gently with a rubber spatula.

Meanwhile place all the salad ingredients in a large bowl and gently mix together.

- gently remove (10): Cut the tomatoes in half horizontally and gently remove the seeds. 
- bubble gently (for + UNID TEMP) (9): Bring carefully to the boil and allow to bubble gently for just a couple of minutes.

- allow/allowing to bubble gently (5): Add the honey and allow to bubble gently.

- gently sweat (8): Cover the pan and gently sweat the vegetables for about 5 minutes, or until soft but not coloured.

- gently roll (7): Gently roll and hold in place using a toothpick.

- gently ease (7): If using a jar, leave the pastry to set on a baking sheet, then gently ease out the jar.

- knead gently (6) / gently knead (the) (dough) (5):

Turn out, knead gently and shape into a round loaf.

On a lightly floured surface, gently knead the dough until it is nearly smooth.

- gently whisk (in) (6):

Stir in the lemon curd and gently whisk in the single cream.

Gently whisk the cream in a large bowl and place in the fridge [...].

- gently pour (in) (5):

Gently pour in the champagne and stir.

Gently pour the sauce over the remaining egg whites [...].

- gently reduce (5): Pass through a fine-meshed sieve and return to saucepan and gently reduce to half the volume.

- gently soften [INGREDIENTE] (5): Heat a drizzle of olive oil in a frying pan and gently soften the onions, garlic, ginger and chillies.

- gently stew (5): Combine the peppers with the olive oil, salt and pepper in a saucepan, and gently stew for ten minutes, without browning.

\section{Outras associações do advérbio gently}

Observamos que gently pode também ser modificado por outro advérbio, no caso, very. Foram encontradas 87 ocorrências de very gently nos agrupamentos abaixo identificados: 
very gently (87) $\rightarrow \mathrm{V}+$ very gently (65):

simmer very gently (26); simmer very gently for + UNID TEMP (17); cover and simmer very gently for + UNID TEMP (5): Add the bouquet garni, cover and simmer very gently for 2 hours.

cook very gently (12)

cook very gently for + UNID TEMP (6): Cook very gently for another 30 minutes, stirring occasionally.

heat very gently (11): Heat very gently with a good pinch of salt and freshly ground pepper.

V + very gently until [RESULTADO] (10): Boil very gently until the marmalade is as dark as you like it.

Durante a análise das linhas de concordância do advérbio gently, observamos a presença de vários phrasal verbs, tais como fold in, fold into e whisk in. Além desses, temos padrões formados com a preposição for, que introduz uma unidade de tempo, e com a conjunção until, que apresenta o resultado de algum processo. As fraseologias [APLICAR CALOR] and simmer gently for + UNID TEMP (246) e [ADICIONAR INGREDIENTE] + [RECIPIENTE] + (and) heat gently until + [RESULTADO] (57) são exemplos dessas ocorrências.

A palavra funcional then também é significativa em agrupamentos maiores, indicando novo passo no preparo das receitas. São 81 ocorrências à esquerda de gently, sendo 38 delas imediatamente antes do advérbio, e 40 à direita (não necessariamente como primeira palavra nessa posição). Exemplos:

Bring to the boil and then gently simmer for four to five minutes, before placing in the blender.

Stir in the melted butter and then gently mix in the corn kernels.

Drain off any excess oil, then gently flake the salmon.

Place the water and butter in a pan and heat gently until melted then bring to the boil.

Em linhas gerais, observamos que o advérbio gently apresenta associações que basicamente fazem parte de dois campos semânticos: verbos que implicam o uso de fogo para o preparo do alimento, como é o caso de simmer, cook, heat, melt e fry, e verbos que indicam (acrescentar) e mexer delicadamente, como fold (in) e stir (in). Quanto à associação com palavras gramaticais, novamente encontramos 
aquelas acima mencionadas, também presentes nos advérbios anteriormente analisados.

- LIGHTLY

\begin{tabular}{|c|c|c|c|c|c|c|}
\hline$N$ & adv-chave & freq. $C E$ & $\%$ CE & freq. CR & $\%$ CR & chav. \\
\hline 119 & lightly & 1.634 & 0,10 & 1.885 & & $8.527,96$ \\
\hline
\end{tabular}

Dispersão nos arquivos:

CE: $1.181(15,23 \%)$

CR: $764(18,85 \%)$

Normalização das frequências:

CE: 0,95 ocorrência em cada mil palavras

CR: resultado inexpressivo $(0,018$ ocorrência em cada mil palavras)

Com a normalização das frequências, podemos observar que lightly é um advérbio significativamente presente em receitas culinárias - há praticamente uma ocorrência em cada mil palavras.

Ao organizarmos em ordem alfabética as ocorrências à direita de lightly, a primeira observação foi a co-ocorrência com vários verbos no particípio passado, utilizados com função adjetiva, o que diferencia esse advérbio daqueles analisados anteriormente, cujas co-ocorrências eram, em sua grande maioria, com verbos no imperativo.

Nesta análise, utilizaremos a mesma metodologia, ou seja, partiremos de agrupamentos com duas palavras para chegarmos às unidades maiores.

\section{O advérbio lightly e o verbo flour}

A colocação lightly floured é a unidade mais frequente entre as associações do advérbio lightly, com 183 ocorrências. A partir dela, observamos várias unidades maiores, abaixo elencadas. 


\section{lightly floured (183)}

(a) lightly floured surface (133):

Transfer to a lightly floured surface and knead until it is smooth and elastic.

[ALTERAR FORMA] + (ADV + [MASSA]) on a lightly floured surface (69):

roll out ([MASSA]) on a lightly floured surface (28):

Roll out pastry on a lightly floured surface into a $28 \mathrm{~cm}$ (11 inch) square then cut in half.

roll out (thinly) ([MASSA]) on a lightly floured surface to + [FORMA] (11):

Roll out on a lightly floured surface to a circle slightly larger that the pan.

roll out ([MASSA]) on a lightly floured surface and use to + [PROPÓSITO] (10):

Roll out on a lightly floured surface and use to line an $18 \mathrm{~cm}$ (7 inch) flan dish.

Roll out the pastry on a lightly floured surface and use to cover the pie, trimming the edges neatly and making a steam hole in the centre.

[ALTERAR FORMA] + on a lightly floured surface until [RESULTADO] (8):

Knead on a lightly floured surface until smooth.

knead (lightly) on a lightly floured surface (7):

Knead lightly on a lightly floured surface and roll out to about $0.5 \mathrm{~cm}(1 / 4$ inch) thickness.

on a lightly floured surface(,) roll out + [MASSA] (7):

On a lightly floured surface, roll out the pastry very thinly and cut out eight $12 \mathrm{~cm}$ (5 inch) circles.

[CAUSAR MOVIMENTO] + [MASSA] onto a lightly floured surface (36) ${ }^{114}$ :

Tip out the mixture onto a lightly floured surface and knead together.

turn ([MASSA]) (out) onto a lightly floured surface (31):

Deflate the dough and turn it out onto a lightly floured surface.

turn ([MASSA]) (out) onto a lightly floured surface and knead (16):

Turn the mixture out onto a lightly floured surface and knead a few times, just to form a smooth dough.

turn out ([MASSA])/turn + [MASSA] + out on to a lightly floured surface (and) (22):

Turn out the dough on to a lightly floured surface and gently knock back.

Turn the dough out on to a lightly floured surface, knock back and knead in the sultanas and currants.

turn out ([MASSA]) / turn + [MASSA] + out on to a lightly floured surface and knead (9):

Turn out on to a lightly floured surface and knead for 5 minutes until smooth and elastic.

Turn the dough out on to a lightly floured surface and knead well, then roll out and cut into strips

\footnotetext{
${ }^{114}$ Ao analisarmos esse padrão, observamos a formação de um agrupamento com várias orações que descrevem praticamente todo o Modo de Fazer de scones (tipo de pãozinho) variados, em receitas diferentes. São 10 ocorrências de Mix to a soft, but not sticky, dough with a knife. 2. Turn onto a lightly floured surface. Knead quickly until smooth. Roll out to about $1 \mathrm{~cm}(1 / 2$ inch) thick. Cut into 7 or 8 rounds with a $6.5 \mathrm{~cm}(21 / 2$ inch) biscuit cutter. Decidimos não incluir no quadro acima por ir além do enfoque desta análise, ou seja, o advérbio lightly.
} 


\section{(a) lightly floured board (18):}

Knock back, on a lightly floured board, and roll into even lengths, a few feet long.

Turn out onto a lightly floured board (9)

\section{[CAUSAR MOVIMENTO] + [MASSA] on a lightly floured work surface (10):}

Put the dough on a lightly floured work surface and knead for 10-15 minutes until smooth and elastic.

Identificamos também a co-ocorrência de lightly com o verbo no imperativo, bem menos frequente - são 14 ocorrências de lightly flour. Em sete delas, faz parte da unidade grease and lightly flour + [RECIPIENTE] (7): Grease and lightly flour pans required by your recipe.

\section{0 advérbio lightly e o verbo brown}

A associação ao verbo no particípio passado, exercendo função adjetiva, é a mais frequente. São 121 ocorrências de lightly browned encontradas nas unidades abaixo:

\section{lightly browned (121)}

[APLICAR CALOR] ([INGREDIENTE]) (for + UNID TEMP or) until lightly browned (74). Na categoria [APLICAR CALOR], geralmente encontramos os verbos heat, fry, sauté, cook e bake:

In a large saucepan, heat oil and sauté onions until lightly browned.

Increase the heat and fry for 3 minutes on each side, until lightly browned.

Add the fish and cook for a further 3 minutes or until lightly browned on all sides.

Bake for 15 to 20 minutes or until lightly browned.

ADJ + and lightly browned (19):

Remove the foil and bake the gratin until the potatoes are tender and lightly browned.

[APLICAR CALOR] until ([INGREDIENTE] is/are) + soft and lightly browned (9). Geralmente co-ocorre com onion, shallot e garlic:

Fry over a medium-high heat until the shallots are soft and lightly browned.

UNID TEMP(,) until lightly browned (18):

Fry the oxtail pieces and the vegetables in the fat for a few minutes until lightly browned.

[APLICAR CALOR] ([INGREDIENTE]) until lightly browned on all sides (6):

Heat the oil in a large frying pan and gently fry the chicken with the onion until lightly browned on all sides. 
Identificamos apenas 4 ocorrências com o verbo no imperativo, como em Lightly brown the duck, about 3-4 minutes per side, and remove to a bowl., e 12 ocorrências com o adjetivo brown: When the mushrooms are lightly brown, add the garlic and cook for one more minute. Além dessas, registramos também 6 ocorrências de brown lightly, sendo brown classificado como verbo em todas elas. Exemplo: When hot, put in the onion and brown lightly.

\section{O advérbio lightly e o verbo beat}

Em praticamente todas as 116 ocorrências da colocação mais frequente, lightly beaten (verbo no particípio passado) refere-se a egg(s), egg yolk(s) e/ou egg white(s). As unidades encontradas contendo essa colocação são:

\section{lightly beaten (116)}

$\mathrm{NUM}+(\mathrm{ADJ})+$ egg(s), lightly beaten (66), geralmente na lista de ingredientes: Ingredients $1 \mathrm{egg}$, lightly beaten $55 \mathrm{~g} / 2 \mathrm{oz}$ plain flour a little milk to taste 2 slices ham 4 large eggs, lightly beaten 1 tsp vanilla essence $325 \mathrm{~g} / 12 \mathrm{oz}$ caster sugar

lightly beaten egg(s) (white) (16):

Egg wash with lightly beaten egg and sprinkle with the remaining sugar.

brush ([INGREDIENTE]) + with (very) lightly beaten egg (white) (6):

Brush the petals with very lightly beaten egg white, then sprinkle with caster sugar.

eggs - NUM, lightly beaten (11):

Eggs - 2, lightly beaten Plain flour - 350g (12 oz) Baking powder - 1 tbsp

Foram encontradas 24 ocorrências com o verbo no imperativo, sempre no Modo de Fazer. Em todos os casos, a colocação lightly beat refere-se a egg(s), egg yolk(s) elou egg white(s). Exemplos:

Meanwhile, lightly beat the egg yolks with the icing sugar.

Lightly beat the egg with the egg whites and add to the bowl.

Bem menos frequente, identificamos 9 ocorrências de beaten lightly (geralmente na Lista de Ingredientes), que apresenta o mesmo tipo de associação semântica de lighlty beaten, como podemos observar em 1 large whole egg, beaten lightly / 2 large egg whites, beaten lightly. 


\section{$\mathrm{O}$ advérbio lightly e o verbo oil}

Apesar de a colocação lightly oiled (verbo no passado/particípio passado) ser a mais frequente (62 ocorrências), encontramos também lightly oil (verbo no imperativo), com 25 ocorrências. Nessa associação, era esperado que todas as ocorrências de lightly oil estivessem no Modo de Fazer, o que de fato ocorreu. É interessante observar, no entanto, que isso também ocorreu em praticamente todos as ocorrências de lighly oiled, casos em que oiled é utilizada com função adjetiva e refere-se ao substantivo que se segue. Exemplos:

Lightly oil a frying pan and preheat over a medium heat.

Place in a lightly oiled bowl, cover with lightly oiled clear film and leave to rise, in a warm place, for 11/2-2 hours, or until doubled in bulk.

Além de lightly oil + (or butter) + [RECIPIENTE] (23), nenhum outro padrão foi identificado para a colocação com o verbo no imperativo. Apresentamos abaixo as unidades maiores em que lightly oiled foi identificada:

\section{lightly oiled (62)}

(a) lightly oiled [RECIPIENTE] (50). Os recipientes mais comuns são (ADJ) pan (12), bowl (11), baking sheet(s) (4), baking tray (3) e baking dish (2):

Place the twisted strips onto lightly oiled baking sheets, spacing them evenly apart.

cover with lightly oiled clear film and leave to rise (10):

Place in a lightly oiled bowl, cover with lightly oiled clear film and leave to rise, in a warm place, for 1 hour, or until doubled in bulk.

Place in a lightly oiled bowl, cover with lightly oiled clear film and leave to rise, [TEMPERATURA], for + UNID TEMP, or until (nearly) doubled in bulk/size (6):

Place in a lightly oiled bowl, cover with lightly oiled clear film and leave to rise, at room temperature, for about 2 hours, or until doubled in bulk.

\section{O advérbio lightly e o verbo grease}

Nesse caso, a associação mais frequente é com o verbo no imperativo, formando a colocação lightly grease (56). Em 52 ocorrências temos lightly grease + [RECIPIENTE], categoria em que se destaca baking sheet(s) (13): Lightly grease a baking sheet, or use a sheet of greaseproof paper. 
A colocação lightly greased + [RECIPIENTE] apresenta 38 ocorrências, destacando-se novamente baking sheet(s) (10) na categoria semântica: Season the goats cheese with salt and pepper and place on a lightly greased baking sheet with a little honey.

Outras unidades maiores:

- $\quad$ [CAUSAR MOVIMENTO] + on a lightly greased + [RECIPIENTE] (7): Wash sweet potatoes, slice lengthwise and place on a lightly greased baking sheet.

- [CAUSAR MOVIMENTO] + into a lightly greased + [RECIPIENTE] (7):

Place the circles into a lightly greased tin and sprinkle the top with the demerara sugar.

É frequente a ocorrência dos verbos place, put e pour na categoria [CAUSAR MOVIMENTO].

\section{O advérbio lightly e o verbo knead}

A colocação knead lightly apresenta 42 ocorrências e faz parte das seguintes unidades:

\section{knead lightly (42)}

[CAUSAR MOVIMENTO] + [INGREDIENTE] ([LOCAL]) and knead lightly (16). Na primeira categoria semântica, destaca-se o verbo turn (12):

Turn the mixture onto a lightly floured surface and knead lightly to form a smooth dough.

Turn the dough onto a floured surface and knead lightly. (5)

knead lightly on + [LOCAL] (7). Na categoria semântica, temos (lightly) floured surface (6) e floured board.

Knead lightly on a floured surface and roll out.

knead lightly until smooth (5):

Mix all ingredients into a soft dough and knead lightly until smooth.

Em 7 ocorrências, observamos que a categoria [INGREDIENTE] pode estar entre o verbo e o advérbio: $\underline{\text { Knead }}$ the dough lightly, then form into a ball, cover with a damp tea towel and leave to rest for 30 minutes before rolling out. Também em 7 ocorrências, registramos a anteposição do advérbio: Rub in the butter and lightly knead the mixture until it forms a soft dough. 


\section{O advérbio lightly e o verbo whip}

A colocação mais frequente é lightly whipped, com 45 ocorrências. Descrevemos abaixo as unidades maiores das quais ela faz parte.

\section{lightly whipped (45):}

UNID MED + double cream, lightly whipped (22). Todas as oc. estão na Lista de Ingredientes: $5 f l$ oz double cream, lightly whipped

lightly whipped cream (12): Pipe the lightly whipped cream onto the chocolate mousse. [ADICIONAR INGREDIENTE] + (the) lightly whipped (double) cream (8). Todas as oc. estão no Modo de Fazer: Place in a large bowl and fold in the lightly whipped cream.

lightly whip (15): Meanwhile, to make the filling, place the cream in a bowl and lightly whip.

lightly whip the cream (10): For filling two, lightly whip the cream with the malted milk powder until it forms soft peaks.

Em todas as ocorrências, lightly whipped e lightly whip referiam-se a cream ou double cream.

\section{O advérbio lightly e o verbo salt}

Novamente, a associação mais frequente é com o verbo no particípio passado (função adjetiva), formando a colocação lightly salted, com 37 ocorrências. Outras unidades encontradas são:

\section{lightly salted (37):}

lightly salted water (21):

Slice the leeks and boil them in lightly salted water for 10 minutes until really soft.

lightly salted boiling water (12):

Cook the pasta shells in plenty of lightly salted boiling water until al dente.

[APLICAR CALOR] [INGREDIENTE] + in/into a (large) pan of lightly salted (boiling) water (11):

Cook the potatoes in a pan of lightly salted boiling water until tender.

[APLICAR CALOR] + ([INGREDIENTE]) + in lightly salted (boiling) water (9):

Boil the potatoes in lightly salted water for about 15 minutes until just tender.

bring + [RECIPIENTE] + (of) lightly salted water to a boil (6): 
Bring a large pot of lightly salted water to a boil.

In a medium saucepan over high heat, bring 2-1/2 cups lightly salted water to a boil.

lightly salt + [INGREDIENTE] (7):

Meanwhile, lightly salt the fish and let stand for 10 minutes, then rinse with water and lower into soup

\section{$>0$ advérbio lightly e o verbo season}

Nesta associação, não há co-ocorrências com o verbo no particípio passado, devido ao significado do próprio verbo. Foram identificadas 34 ocorrências de season lightly, que também fazem parte dos agrupamentos abaixo descritos.

\section{season lightly (34)}

season lightly with + [TEMPERO] (18):

Drizzle a little oil and lime juice over the whole dish and season lightly with black pepper.

(sv) (and) season lightly with salt and pepper (9):

[...] brush with a little oil and season lightly with salt and pepper.

SV + and season lightly (12): Wash and dry the trout fillets and season lightly.

lightly season ([INGREDIENTE]) (8):

Lightly season the beef with salt and pepper.

\section{O advérbio lightly e o verbo crush}

Nesse caso, a formação mais frequente é com o verbo no particípio passado (função adjetiva), resultando na colocação lightly crushed, com 32 ocorrências. Abaixo, apresentamos as unidades encontradas.

\section{lightly crushed (32):}

[INGREDIENTE], lightly crushed (26). Na categoria [INGREDIENTE], destacam-se coriander seeds (5) e juniper berries (4): 1/4 tsp coriander seeds, lightly crushed / 4 juniper berries, lightly crushed

lightly crush $(11) \rightarrow$ lightly crush + [INGREDIENTE] (8): Lightly crush the potatoes with the back of a fork.

crush lightly (6): Remove the cumin from the pan and crush lightly with a pestle and mortar. 
Praticamente todas as ocorrências de lightly crushed estão na Lista de Ingredientes da receita. Já lightly crush e crush lightly encontram-se no Modo de Fazer.

\section{$>0$ advérbio lightly e o adjetivo golden}

Golden é o adjetivo mais frequente a co-ocorrer com lightly, formando a colocação lightly golden (32). Destaca-se a associação com a palavra gramatical until, formando as unidades:

- [APLICAR CALOR] ([INGREDIENTE]) ([LOCAL]) (for + UNID TEMP) until lightly golden (brown) (13): Pour in the mixture and bake in the preheated oven for 30 minutes or until lightly golden brown and springy to the touch.

- until + ADJ + and lightly golden (8):

Place under the grill until bubbly and lightly golden.

\section{$>$ Os advérbios lightly e very}

O único advérbio que se associa a lightly, na tipologia das receitas culinárias, é very. Foram identificadas 37 ocorrências de very lightly, que podem integrar outras unidades. A associação mais frequente é knead (+ [MASSA]) very lightly (10):

Turn on to a floured work surface and knead very lightly.

Knead the pastry very lightly, then wrap and chill in the fridge for about 30 minutes.

As demais associações não apresentam frequência acima de cinco, número estabelecido como corte nesta pesquisa. No entanto, todos os verbos e adjetivos aos quais very lightly se associa estão analisados nesta investigação, formando unidades com lightly. Abaixo, alguns exemplos:

Brush the petals with very lightly beaten egg white, then sprinkle with caster sugar. In a heavy-bottomed frying pan, fry the mushrooms in the butter very lightly, until just soft.

Heat the two tablespoons of butter in a saucepan and, when melted, add the onion and garlic and fry until very lightly golden. 


\section{$>0$ advérbio lightly em fraseologias com menos de 30 oc.}

Apresentamos abaixo todas as ocorrências de lightly associadas a outra palavra lexical, além de unidades maiores em que essa colocação pode ser encontrada.

- lightly toasted (29): 1 tbsp flaked almonds, lightly toasted

- [APLICAR CALOR] ([INGREDIENTE]) (for + UNID TEMP) until lightly toasted (5):

Fry gently for a few minutes until lightly toasted.

Essa colocação pode ser encontrada tanto na Lista de Ingredientes (logo após o ingrediente a que se refere) quanto no Modo de Fazer, como é o caso da coocorrência acima mencionada com until.

- lightly toast (11): Cut the brioche in half and lightly toast on one side in a dry pan.

- lightly coloured (24): Uncover the terrine and cook for a further 15 minutes, until it is lightly coloured on top.

- [APLICAR CALOR] ([INGREDIENTE]) (for + UNID TEMP) until (ADJ + and) lightly coloured (18): Stir in the sausages and fry until lightly coloured.

- sprinkle lightly (21) / lightly sprinkle (5):

Sprinkle lightly with caster sugar.

Lay vegetable mixture the length of fillet and lightly sprinkle seasoning mixture on fillet.

- (and) sprinkle lightly with + [INGREDIENTE] (21): Sprinkle lightly with curry powder.

- and sprinkle lightly with salt (7): Immediately brush with butter and sprinkle lightly with salt.

- drain (on kitchen paper) and sprinkle lightly with salt (5).

- lightly butter (21). Essa colocação é geralmente seguida da categoria semântica [INGREDIENTE] OU [RECIPIENTE]:

Using a pastry brush lightly butter the apples and then sprinkle lightly with sugar.

Lightly butter a cake tin.

- lightly buttered ([RECIPIENTE] / [INGREDIENTE]) (13). Em praticamente todas as ocorrências, buttered exerce função adjetiva:

Spoon the mushroom mixture into six lightly buttered ramekin dishes.

Serve with lightly buttered bread and a good mature Cheddar cheese. 
- lightly cooked (20). Em geral, essa colocação co-ocorre com vegetais, como em: Add 225g (8 oz) lightly cooked and drained broccoli florets to the sauce with the macaroni.

Interessante mencionar o agrupamento Note: 'At risk' groups such as pregnant women, babies and elderly sick are advised not to eat lightly cooked eggs because of the risk of salmonella poisoning., que apresenta 4 ocorrências e contém a colocação lightly cooked. É uma unidade maior de significado que reflete a padronização na tipologia das receitas culinárias.

- until (+ SV) soft and lightly + ADJ (17). Nesse caso, observamos que o advérbio, fazendo parte de uma unidade maior, modifica o adjetivo na sequência: browned (9), coloured (5), caramelized (2) e golden. Exemplos:

First make the peanut sauce: sweat the onion and the garlic in the oil until soft and lightly browned.

Add the remaining butter to the pan and fry the shallots over a moderate heat about 5 minutes, or until they are soft and lightly coloured.

- lightly fry ([INGREDIENTE]) (15) / fry lightly ([MEIO]) (6):

Melt the butter in a large frying pan and lightly fry the vegetables for 10 minutes.

Stir in the massale and turmeric and lightly fry.

Cut the bread into triangles, and fry lightly in the oil.

- melt + the butter + [RECIPIENTE] + and lightly fry [INGREDIENTE] (for+UNID TEMP) (5):

Melt the butter in a large frying pan and lightly fry the vegetables for 10 minutes.

- lightly fried ([INGREDIENTE]) (8). Predomina a função adjetiva de fried:

Add 110g (4 oz) chopped and lightly fried bacon to the sauce with the macaroni. Follow the recipe above but add $225 \mathrm{~g}(8 \mathrm{oz})$ lightly fried sliced button mushrooms to the sauce.

- lightly brush (14) / brush lightly (7):

- lightly brush (+ [INGREDIENTE]) + with [INGREDIENTE] (13):

Lightly brush the courgette slices with oil and season.

- brush lightly with + [INGREDIENTE] (6):

Brush lightly with beaten egg white.

- lightly whisk (14). Refere-se a egg(s), egg yolk(s) e egg white(s) em todas as ocorrências. 
- lightly whisk the egg(s) (9):

Then lightly whisk the eggs and extra yolk together in a large bowl.

- lightly whisked (9). Em praticamente todos os casos, refere-se a eggs. A maior parte das ocorrências está na lista de ingredientes: Egg white - 1, lightly whisked.

- SV + lightly with a fork (14). Apesar de o advérbio referir-se ao verbo que integra o SV, decidimos mencionar este agrupamento para enfatizar a relação semântica entre seus elementos - verbo, advérbio e instrumento (fork). Os verbos mais utilizados são press, prick e crush. Exemplos:

Sprinkle this mixture over the apples. Press down lightly with a fork.

Prick the top lightly with a fork and cook for 15-20 minutes, turning once, until golden brown.

When they are cooked, crush them lightly with a fork.

- lightly coat ([INGREDIENTE]) (in/with [MEIO]) (12): Lightly coat the fish fillets in the dry spice mixture.

- press down lightly (12); press down lightly with + [INSTRUMENTO] (6): Press down lightly with palm of hand then smooth the top with a knife.

- lightly set (11). Em várias ocorrências, refere-se a egg(s):

Simmer gently until the eggs are lightly set and loosen them with a knife before turning out.

- [APLICAR CALOR] + until lightly set (5): Bake at $190^{\circ} \mathrm{C} / 375^{\circ} \mathrm{F} / \mathrm{Gas} 5$ for about 40 minutes, until lightly set.

- lightly dust (10) / dust lightly (9):

- dust lightly with + [INGREDIENTE] (9). Na categoria semântica, o ingrediente mais

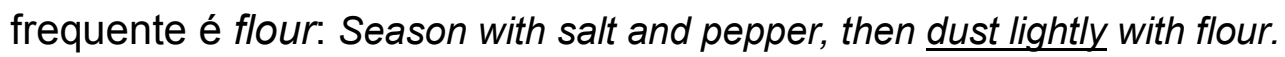

- lightly dust with + [INGREDIENTE] (6): Top with a few whole strawberries and lightly dust with icing sugar.

- lightly dusted with + [INGREDIENTE] (6): On a board, lightly dusted with flour, roll out the dough.

- lightly mix (9) / mix lightly (5):

Lightly mix and serve with the freshly grated cheese.

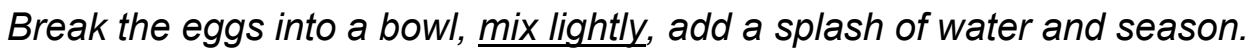


- press lightly (9):

- press lightly to + [PROPÓSITO] (5): Cover with the pastry lid, press lightly to seal the edges.

- lightly pressed (8) / pressed lightly (5):

- will spring/spring(s) back when lightly pressed (6): Cover with greased clingfilm and leave to rise for about 1 hour, or until the dough has doubled in size and will spring back when lightly pressed.

- (spring back) when pressed lightly (5): When the cakes are cooked (the tops should spring back when pressed lightly), prick the tops with a fork.

- lightly smoked (9). Em oito dessas ocorrências, a colocação lightly smoked referese a (raw) salmon: For the salmon: 4 lightly smoked salmon fillets

- toss lightly (8) / lightly toss (6):

Pour the mushroom sauce over the cooked pasta and toss lightly.

Add the apple rings, and lightly toss, to coat.

- lightly fold in [INGREDIENTE] (6):

Lightly fold in the flour, salt and baking powder.

- lightly roasted (7): Stir and fry briefly until lightly roasted.

- lightly spread [INGREDIENTE] (with + [INGREDIENTE/MISTURA]) (5): Toast the bread slices on one side and lightly spread the untoasted side with low fat spread.

- lightly stir (in/into) (5): Lightly stir in the onion mixture and top with the remaining cheese.

- lightly mash (5): Lightly mash the potatoes with the cream.

- $\quad$ AAPLICAR CALOR] ([INGREDIENTE]) (for + UNID TEMP) untill/till + ([INGREDIENTE]) (is/are) softened and lightly + [RESULTADO] (5):

Continue to fry for 4-5 minutes, till the celery and pepper are also softened and lightly tinged brown at the edges

Sauté for a few minutes until softened and lightly coloured.

Em linhas gerais, lightly apresenta características quanto à co-ocorrência que Ihe são mais peculiares: a maior parte das colocações é formada pela associação desse advérbio a um verbo no particípio passado, com função adjetiva, como é o caso de lightly floured, lightly browned, lightly beaten, lightly oiled e lightly greased. 
Há também verbos na forma imperativa, mas com frequência bem menor. Sobressaise também a associação com adjetivos, como é o caso de golden e brown, o que não observamos com os outros advérbios até agora analisados.

- THINLY

\begin{tabular}{|c|c|c|c|c|c|c|}
\hline$N$ & adv-chave & freq. CE & $\%$ CE & freq. CR & $\%$ CR & chav. \\
\hline 207 & thinly & 701 & 0,04 & 410 & & $4.266,69$ \\
\hline
\end{tabular}

Dispersão nos arquivos:

CE: $553(7,13 \%)$

CR: $266(6,56 \%)$

Normalização das frequências:

CE: 0,40 ocorrência em cada mil palavras

CR: resultado inexpressivo (0,0041 ocorrência em cada mil palavras)

O primeiro fato que salta aos olhos ao analisarmos o quadro acima é a diferença de frequência entre o quarto e o quinto advérbios, ou seja, entre lightly (1.634) e thinly (701). É importante lembrar, no entanto, que os advérbios estão elencados em ordem de chavicidade, não de frequência. Quanto à dispersão nos arquivos, apesar das considerações já feitas anteriormente, observamos que thinly ocorre no CE de forma mais significativa do que no CR. Na normalização de frequências, é evidente a presença do advérbio em várias receitas.

A colocação mais frequente, com um número bastante significativo de ocorrências, é thinly sliced (400). Apresentamos abaixo os padrões encontrados. 


\section{0 advérbio thinly e o verbo slice}

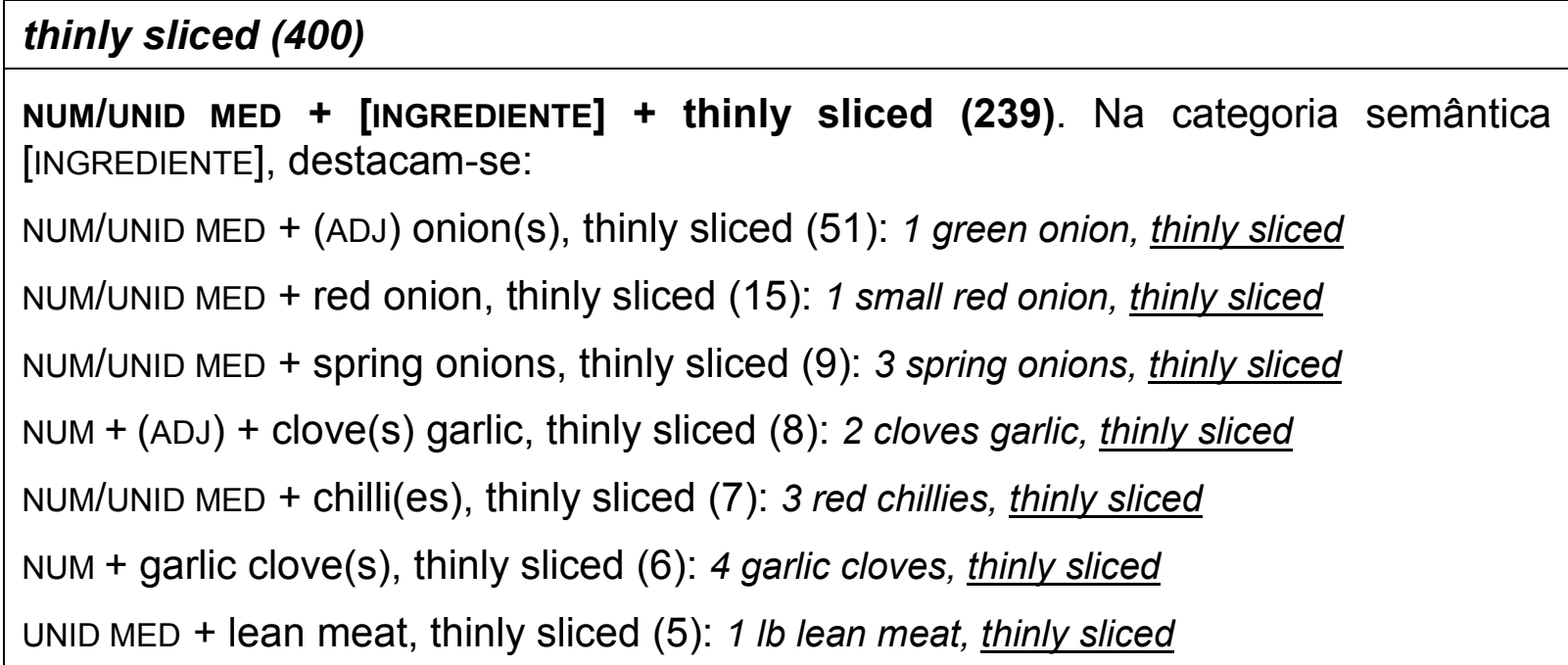

thinly sliced + [INGREDIENTE] (43): Add the peas and the thinly sliced lettuce. A maior parte das ocorrências está no Modo de Fazer.

SV + with thinly sliced + [INGREDIENTE] (5). Todas as ocorrências encontram-se no Modo de Fazer:

Accompany with thinly sliced brown bread and butter.

A ocorrência do advérbio posposto a sliced também é frequente, mas de forma menos significativa, como podemos observar abaixo: 


\section{sliced thinly (94)}

$\mathrm{V}_{\mathrm{pp}}+$ and sliced thinly (25): 1 fresh pineapple, peeled, cored and sliced thinly

NUM/UNID MED + [INGREDIENTE], peeled and sliced thinly (12). As ocorrências estão todas na lista de ingredientes: 2 medium carrots, peeled and sliced thinly

NUM/UNID MED + [INGREDIENTE], sliced thinly. Na categoria [INGREDIENTE], destacamse: onion(s) (13), garlic cloves (6), shallots (5) e chilli(es) (5): 6 large shallots, sliced thinly / 1 red finger chilli, sliced thinly into rings

Com o verbo na forma imperativa, encontramos as seguintes unidades:

thinly slice (54): Roll the omelettes up, leave to cool then thinly slice.

thinly slice + [INGREDIENTE] (47). As ocorrências estão no Modo de Fazer: Thinly slice the baguette and arrange the slices on a baking sheet.

$\mathrm{V}+([$ INGREDIENTE]) + and thinly slice ([INGREDIENTE]) (17): Wash and thinly slice the leeks.

peel and thinly slice + [INGREDIENTE] (5):

To make the dauphinois, peel and thinly slice the potatoes and place in a pan with the milk and cream.

Registramos também 15 ocorrências de (and) slice thinly (observe-se que o verbo está antes do advérbio), todas no Modo de Fazer. Exemplo: Wash the celery and slice thinly.

\section{$>0$ advérbio thinly e outras associações}

- very thinly (45). Em todas as ocorrências, very é o único advérbio que se associa a thinly. Ex: You must cut the chicken across very thinly in order to have two escalopes out of each breast.

Geralmente, essa unidade co-ocorre com sliced, na Lista de Ingredientes, como podemos verificar abaixo:

- [INGREDIENTE] + (V + and) very thinly sliced (21): half a beef rump steak, very thinly sliced

- [INGREDIENTE] + peeled and very thinly sliced (6): 1 small baking potato, peeled and very thinly sliced

- sliced very thinly (5): $55 \mathrm{~g} / 2 \mathrm{oz}$ salmon fillet, sliced very thinly 
- [CORTAR] + [INGREDIENTE] + as thinly as possible (12):

Slice the cucumber as thinly as possible so that the slices are transparent.

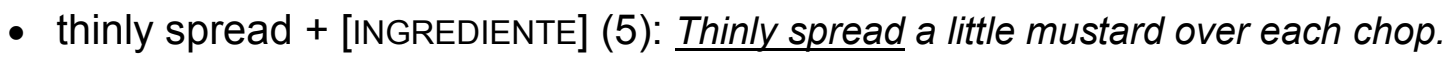

Observamos também que thinly é precedido de palavras funcionais, como é o caso de then (6), co-ocorrência que necessita de mais palavras para formar uma unidade de significado. Exemplos: Roll up to make a swiss roll then thinly shred to create noodles.

Em resumo, thinly apresenta usos semelhantes aos advérbios anteriormente analisados, considerado o significado das palavras às quais se refere; associa-se com maior frequência a sliced, formando a colocação thinly sliced. Uma unidade que nos chamou a atenção por estar associada a outras classes gramaticais além de verbos e adjetivos foi [CORTAR] + [INGREDIENTE] + as thinly as possible.

3.1.1 Os advérbios em inglês nas receitas culinárias: algumas considerações

Diante dos dados coletados, podemos observar que, na área da Culinária mais especificamente na tipologia das receitas, os advérbios terminados em -ly apresentam uso significativamente semelhante. Vale lembrar que esse grupo de advérbios representa $75,57 \%$ dos advérbios identificados no material etiquetado a partir de nosso corpus de estudo em inglês ${ }^{115}$.

Os cinco advérbios analisados, quais sejam finely (3.261), freshly (3.248), gently (2.543), lightly (1.634) e thinly (701) totalizam 11.387 ocorrências e representam $50 \%$ das 22.762 ocorrências de advérbios terminados em -ly identificadas no corpus de Culinária (inglês) total. Observamos que todos eles se associam a verbos, tanto na forma imperativa quanto no particípio passado, exercendo função adjetiva, e a alguns adjetivos. Nesse sentido, há uma padronização quanto ao uso de advérbios nessa tipologia textual, ou seja, são utilizados para modalizar verbos, preferencialmente no particípio passado (com função adjetiva), na Lista de Ingredientes, e no imperativo, no Modo de Fazer. É o

\footnotetext{
${ }^{115}$ Para mais detalhes, vide capítulo II, item 2.6.
} 
caso, por exemplo, de gently, significativamente mais frequente no Modo de Fazer e de finely, com frequência acentuada na Lista de Ingredientes.

Observamos que, nas co-ocorrências de cada advérbio, delineia-se certa preferência semântica que é sustentada pela associação desse advérbio a um outro elemento, geralmente um verbo. A partir disso, amplia-se a relação semântica com os outros componentes da frase ou sintagma. Podemos exemplificar essa reflexão com o advérbio finely, que geralmente co-ocorre com substantivos no campo dos temperos (garlic, onion, shallots, parsley, etc.) quando associado ao verbo chop. Outro advérbio digno de nota é freshly, com 2.447 ocorrências de freshly ground black pepper. Freshly apresenta estreita relação com a colocação black pepper, ingrediente que deve ser moído na hora para acentuar o sabor. O mesmo ocorre nas colocações freshly grated nutmeg e freshly grated parmesan.

Elencamos abaixo as características observadas nas receitas culinárias (inglês), a partir da análise dos advérbios com maior índice de chavicidade em nosso corpus de estudo (finely, freshly, gently, lightly e thinly):

- Em termos de padronização, há uma subdivisão: quando os advérbios ocorrem na Lista de Ingredientes, no particípio passado, observamos que são basicamente regidos pelos seguintes padrões:

- (NUM/UNID MED) + [INGREDIENTE] + (NUM/UNID MED), $\left(\mathrm{V}_{\mathrm{pp}}+\right.$ and $)+A D V+\mathrm{V}_{\mathrm{pp}}: 2 \mathrm{oz}$ squid, cleaned and thinly sliced; orange, finely grated.

- ADV + $\mathrm{V}_{\mathrm{pp}}$ [INGREDIENTE]: freshly ground black pepper.

- No Modo de Fazer: Nesse caso, há maior variação, uma vez que o sentido do verbo rege o padrão formado. As categorias semânticas utilizadas são: [INGREDIENTE], [PIMENTA], [APLICAR CALOR], [RESULTADO], [ADICIONAR INGREDIENTE], [MODO], [RECIPIENTE], [PROPÓSITO], [MISTURA], [ALTERAR FORMA], [MASSA], [FORMA], [CAUSAR MOVIMENTO], [TEMPERATURA], [LOCAL], [TEMPERO], [INSTRUMENTO] $\mathrm{e}$ [CORTAR]. Dentre os padrões, é difícil estabelecer um único que possa representar essa parte das receitas, mas, além das categorias semânticas, compartilham outros elementos como unidade de tempo e unidade de medida. Vale destacar as fraseologias abaixo, que apresentam pontos em comum: 
[APLICAR CALOR] and simmer gently for + UNID TEMP

$([A P L I C A R$ CALOR] + [INGREDIENTE] + ([RECIPIENTE] $)+$ and) gently fry [INGREDIENTE] (for + UNID TEMP/until [RESULTADO])

[APLICAR CALOR] + [INGREDIENTE] + (for + UNID TEMP or) until lightly browned [APLICAR CALOR] + [INGREDIENTE] in/into a (large) pan of lightly salted (boiling) water [APLICAR CALOR] + [INGREDIENTE] + ([LOCAL]) + (for + UNID TEMP) until lighlty golden (brown)

[APLICAR CALOR] + [INGREDIENTE] + ([LOCAL]) + (for + UNID TEMP) until lighlty toasted [APLICAR CALOR] + [INGREDIENTE] + ([LOCAL]) + (for + UNID TEMP) until lighlty coloured

([ADICIONAR INGREDIENTE]) and cook gently (for + UNID TEMP)

[ADICIONAR INGREDIENTE] + [RECIPIENTE] + and heat gently

([ADICIONAR INGREDIENTE] + and) heat gently until [INGREDIENTE] DISSOLVE/MELT

([ADICIONAR INGREDIENTE]) (and) heat gently for + UNID TEMP

([ADICIONAR INGREDIENTE]) (and) heat gently to + [PROPÓSITO]

([ADICIONAR INGREDIENTE]) + and) fry gently for + UNID TEMP/until [RESULTADO]

([ADICIONAR INGREDIENTE]) + and) stir gently for + UNID TEMP

[CAUSAR MOVIMENTO] + [MASSA] onto a lightly floured surface

[CAUSAR MOVIMENTO] + [INGREDIENTE] + [LOCAL] and knead lightly

[ALTERAR FORMA] + (ADV + [MASSA]) on a lightly floured surface

turn out ([MASSA]/turn + [MASSA] out on to a lightly floured surface

simmer gently until ([INGREDIENTE)] + [RESULTADO]

(and) cook gently until [RESULTADO]

stir gently to [RESULTADO]

until (SV) soft and lightly + ADJ

to make [INGREDIENTE], gently melt the butter in [RECIPIENTE]

lightly grease [RECIPIENTE]

[CORTAR] + [INGREDIENTE] as thinly as possible

$\rightarrow$ padrão comum a todos os advérbios no Modo de Fazer:

ADV + V + [INGREDIENTE]: gently melt [INGREDIENTE]; gently fry [INGREDIENTE], etc.

- Apenas o advérbio very foi identificado em co-ocorrência com os advérbios analisados, sendo utilizado como intensificador: Warm the punch very gently, stirring occasionally until the sugar has dissolved.

- Como em outros textos instrucionais, quando tínhamos um verbo transitivo em colocação com o advérbio, as receitas apresentaram seu objeto subentendido, que pode ter sido, inclusive, mencionado em um período anterior. Exemplos: Turn the dough onto a floured surface and knead lightly.; Add the eggs, a little at a 
time, to form a firm dough. Knead lightly, then turn out on to a lightly floured surface.

- As palavras gramaticais são essenciais para a formação de vários padrões, dentre as quais destacamos for, sempre utilizada para introduzir uma unidade de tempo; until, para introduzir a categoria semântica [RESULTADO]; to, para introduzir a categoria semântica [PROPÓsıTO]. Além dessas, observamos o uso de then, utilizada para indicar o próximo passo na elaboração do prato (em nível oracional), e and, com a mesma função, em nível sintagmático.

Em linhas gerais, podemos dizer que os advérbios se revelaram de suma importância para o estabelecimento de fraseologias nas receitas culinárias em inglês, tanto em nível morfossintático quanto semântico. O significado de cada advérbio contribui para a compreensão do padrão, modificando principalmente verbos nas formas imperativa e particípio passado, em diferentes partes da receita, que irão influenciar os resultados do preparo de um prato. Há grande diferença em dizer que um ingrediente deve ser sliced (fatiado) ou finely sliced, ou entre dizer season (temperar) e lightly season. Diante da análise apresentada, podemos dizer que o papel do advérbio vai muito além de modificar verbos e adjetivos nessa tipologia textual, podendo inclusive afetar o resultado final da receita.

B) Os advérbios nas receitas culinárias em português

Nesta etapa, analisaremos os cinco primeiros advérbios em português, na tipologia das receitas culinárias, por ordem decrescente de chavicidade. São eles: levemente, delicadamente, grosseiramente, finamente e ligeiramente.

O primeiro fato que nos chama a atenção é a frequência dos advérbios terminados em -mente ser bem menor do que aquela da forma tida como sua contrapartida em inglês, ou seja, os advérbios terminados em -ly. Mesmo trabalhando com corpora equilibrados, a frequência desses advérbios em cada língua é significativamente diferente. Enquanto em inglês temos 22.762 advérbios terminados em $-l y$, em português temos 7.276 terminados em -mente, fato que necessita de maior atenção por parte dos profissionais que trabalham com essa 
tipologia textual, principalmente do tradutor desse par de línguas. Ao traduzir esses advérbios, deve-se observar como seu sentido é veiculado na língua de chegada, não simplesmente supor que todos os -ly "viram" -mente, caso da tradução na direção inglês - português. Apresentamos abaixo dados mais específicos sobre os advérbios:

\begin{tabular}{|l|l|}
\hline \multicolumn{1}{|c|}{ Culinária - inglês } & \multicolumn{1}{c|}{ Culinária - português } \\
\hline $\begin{array}{l}\text { Total de ocorrências (tokens): } 22.762 \\
\text { Total de formas (types): } 326\end{array}$ & $\begin{array}{l}\text { Total de ocorrências (tokens): } 7.276 \\
\text { Total de formas (types): } 145\end{array}$ \\
\hline
\end{tabular}

Apesar de a variação dos advérbios ser proporcionalmente maior em português (diferentes formas), interessa-nos também o fato de que a frequência em inglês é mais de três vezes maior do que aquela em português. Depois de concluirmos as análises dos advérbios abaixo, faremos outras considerações a respeito.

\section{- LEVEMENTE}

\begin{tabular}{|c|c|c|c|c|c|c|}
\hline$N$ & adv-chave & freq. CE & $\%$ CE & freq. CR & $\%$ CR & chav. \\
\hline 213 & levemente & 943 & 0,06 & 6.672 & & $5.797,89$ \\
\hline
\end{tabular}

Dispersão nos arquivos:

CE: $745(10,75 \%)$

CR: $3.577(2,86 \%)$

Normalização das frequências:

CE: 0,59 ocorrência em cada mil palavras

CR: resultado inexpressivo (0,0095 ocorrência em cada mil palavras)

Ao observarmos os dados acima, mesmo considerando-se que pode haver várias receitas em cada um dos arquivos do $C E$, podemos dizer que nele a dispersão de levemente é muito maior do que no $\mathrm{CR}$, ou seja, no Banco de Português. Quanto à normalização das frequências, levemente ocorre praticamente a cada duas mil palavras no CE, apresentando resultados inexpressivos no CR. 
A partir das linhas de concordância, verificamos que levemente ocorre, em geral, no Modo de Fazer, mas pode também ser encontrado na Lista de Ingredientes. Observamos que os verbos ficar e estar funcionam como auxiliares em várias associações. Considerando-se a forma lematizada ${ }^{116}$, são 86 ocorrências de FICAR levemente e 29 ocorrências de ESTAR levemente, ambas seguidas de um outro verbo no particípio passado, com função adjetiva, na maioria das ocorrências. Exemplos: Cozinhe, sem parar de mexer, por 2 minutos, ou até o molho ficar levemente encorpado. / Refogue em fogo baixo até que as cebolas estejam levemente douradas.

Descrevemos abaixo os agrupamentos levantados; no caso do português, depois de selecionar e listar as prováveis unidades (clusters) em uma planilha de Excel, tivemos que buscar primeiramente pela raiz do verbo ou adjetivo, já que essa língua apresenta desinências que não são encontradas em inglês. Exemplo: para o verbo bater, buscamos bat, que identificaria bata, bate, batendo, batido, etc. No caso do adjetivo utilizamos, por exemplo, cremos para encontrar cremoso, cremosa, cremosos, cremosas.

\section{0 advérbio levemente e o verbo bater}

Nessa associação, a co-ocorrência mais frequente é com o verbo no imperativo, ou seja, bata levemente, com 69 ocorrências. O verbo também pode exercer função adjetiva, sendo utilizado nas formas batido(s) e batida(s). As unidades encontradas são:

\section{bata levemente (69)}

bata levemente + [INGREDIENTE] (47):

Bata levemente os filés de frango e tempere com sal e pimenta-do-reino.

bata levemente os ovos (14):

Bata levemente os ovos e adicione a salsa e a água.

bata levemente o ovo (9):

Em uma tigela bata levemente o ovo, acrescente a essência de baunilha e o leite.

\footnotetext{
${ }^{116}$ A forma lematizada é representada pelo uso do versalete para a forma infinitiva do verbo e do masculino singular no caso dos adjetivos. Isso indica que o verbo pode apresentar qualquer flexão e que o adjetivo pode estar tanto no masculino quanto no feminino, no singular ou no plural.
} 
coloque + [INGREDIENTE] em [RECIPIENTE] e bata levemente (9):

Coloque as gemas em uma tigela e bata levemente.

bata levemente o ovo com a água e o sal (7):

Bata levemente o ovo com a água e o sal. Reserve.

bata levemente as gemas (7):

Bata levemente as gemas e misture ao leite restante.

bata levemente a(s) clara(s) (5):

Bata levemente as claras com 1 colher (sopa) de água.

Em uma/outra tigela (,) bata levemente (6):

Em uma tigela, bata levemente as gemas com 1 lata de leite e o leite condensado.

Bata levemente o ovo com a água e o sal e adicione à mistura de farinha. (5).

Além dessa, encontramos várias orações iguais (e na sequência) em receitas diferentes, todas referindo-se a quiches e tortinhas. Abaixo, o trecho em sua totalidade:

Prepare a massa colocando a farinha de trigo em um mármore e abrindo um buraco no meio. Coloque no centro da farinha a manteiga gelada cortada em cubos. Misture com a ponta dos dedos até a massa ligar. Bata levemente o ovo com a água e o sal e adicione à mistura de farinha. Ligue a massa. Deixe descansar por 20 minutos.

batendo levemente (5):

Prepare a massa batendo levemente a clara com o amido de milho.

[ADICIONAR INGREDIENTE] + o(s) ovo(s) levemente batido(s) (15):

Coloque a carne em uma tigela e acrescente os ovos levemente batidos.

(NUM) + ovos levemente batidos (15):

Acrescentar os ovos levemente batidos, a cerveja e misturar bem a massa.

(NUM) + ovo levemente batido (14):

Passe o peixe no trigo, no ovo levemente batido e na mistura de queijo ralado grosso e fino.

[INGREDIENTE] + levemente batida(s) (9):

Misturar as gemas levemente batidas, deixando apenas levantar fervura sem para de mexer.

Como podemos observar, a colocação bata levemente é seguida de [INGREDIENTE] em 47 ocorrências. No entanto, há 18 casos em que o verbo BATER não é seguido de [INGREDIENTE], que fica subentendido na estrutura, como já observado em inglês. Exemplo: Misture o creme de leite aos ovos e bata levemente, acrescente o refogado de cogumelos. Apesar da grande frequência de co-ocorrência com ovos (e suas partes), observamos também que a colocação associa-se a aves e carnes, como é o caso da co-ocorrência com filé(s), escalopes e peito de frango. Nesse caso, o sentido do verbo é diferente daquele utilizado na co-ocorrência com ovos. Exemplos: 
Bata levemente o peito de frango e corte em cubos de $2 \times 2 \mathrm{~cm}$.

Bata levemente os filés de linguado entre dois sacos plásticos para que fiquem mais finos e maiores.

\section{$>0$ advérbio levemente e o verbo dourar}

$\mathrm{Na}$ forma verbal, encontramos dourar, dourarem, doure e dourem. A associação é também frequente no particípio passado - dourado(s) e dourada(s) -, exercendo função adjetiva. O campo semântico [APLICAR CALOR] precede as colocações abaixo, nem sempre imediatamente à sua esquerda.

dourar levemente (55): Mexa e deixe dourar levemente.

até dourar levemente (28): Fure com um garfo e leve ao forno até dourar levemente.

[APLICAR CALOR] + UNID TEMP + ou até dourar levemente (11): Despeje a massa e leve ao forno por 30 minutos, ou até dourar levemente.

[APLICAR CALOR] + mexendo de vez em quando, até dourar levemente (7):

Acrescente a carne moída e frite por 5 minutos, mexendo de vez quando, ou até dourar levemente.

[APLICAR CALOR] + para dourar levemente (5):

Misturar 1 colher de açúcar ao coco e levar ao fogo numa frigideira para dourar levemente, mexendo sempre para não queimar.

[APLICAR CALOR] + para/até dourarem levemente (5):

Coloque as fatias de baguete e leve-as ao forno para dourarem levemente.

doure levemente (15): Enquanto isso, aqueça o restante do azeite numa frigideira e doure levemente $o$ alho.

(para) (que) dourem levemente (10): Leve ao fogo para que dourem levemente.

levemente DOURADO (78):

levemente dourada (29): A superfície deve ficar levemente dourada.

até + [INGREDIENTE] + ficar levemente dourada (13):

Leve ao forno por 45 minutos, ou até a massa ficar levemente dourada e o recheio um pouco firme.

Asse por cerca de $+\mathrm{NUM}+$ minutos ou até o recheio firmar e a torta estar levemente dourada. (6): Asse por cerca de 30 minutos ou até o recheio firmar e a torta estar levemente dourada.

levemente douradas (8):

Leve ao forno quente por alguns minutos para que elas fiquem levemente douradas. 
levemente dourado (26):

Refogue em fogo baixo até que os pimentões estejam macios e o alho levemente dourado.

ficar levemente dourado (13):

Cozinhe por 2 minutos, ou até a massa coagular e o fundo ficar levemente dourado.

até (+ [INGREDIENTE]) ficar levemente dourado (9):

Leve ao fogo e refogue, mexendo de vez em quando, até o bacalhau ficar levemente dourado.

levemente dourados (15):

Frite os discos de massa na gordura bem quente até estarem levemente dourados.

(até) ficarem levemente dourados (7): Leve ao forno por 30 minutos, ou até os biscoitos ficarem levemente dourados.

No caso da associação entre levemente e DOURADO, decidimos separar as formas masculina e feminina para que o leitor saiba qual delas é a mais utilizada, o que ocasionou também separarmos as unidades maiores das quais essas formas fazem parte, como acima exposto. Interessante observar, no entanto, que os verbos ficar e estar são os que mais co-ocorrem com DOURADO. FICAR foi encontrado em 39 ocorrências e ESTAR em 22 ocorrências. Como um padrão geral para a co-ocorrência entre levemente e DOURADO, podemos estabelecer: [APLICAR CALOR] até/para que ([INGREDIENTE]) FICAR/ESTAR levemente DOURADO.

\section{$>0$ advérbio levemente e o verbo salgar}

Além das associações com o verbo salgar, no imperativo, é também significativa a co-ocorrência com o adjetivo salgada, como podemos observar nas unidades abaixo descritas:

\section{salgue levemente (30):}

Repita esta operação por cerca de 15 minutos, salque levemente e coloque um pouco de pimenta-do-reino.

coloque + ([RECIPIENTE]) + (bastante/abundante) água para ferver e salgue levemente (18): Coloque bastante água para ferver e salgue levemente.

(em/com) (bastante/abundante) água (fervente) levemente salgada (23). A colocação é precedida das categorias [APLICAR CALOR] + [INGREDIENTE] em praticamente todas as ocorrências, à sua esquerda:

Cozinhe as alcachofras em água levemente salgada. 


\section{O advérbio levemente em fraseologias com menos de 30 oc.}

- deixe esfriar levemente (26):

- retire ([INGREDIENTE]) + [RECIPIENTE] (,) (e) deixe esfriar levemente (12): Retire os filés da panela e deixe esfriar levemente.

- deixe esfriar levemente e + SV (8): Deixe esfriar levemente e despeje sobre o creme de baunilha.

- levemente encorpado (21): Cozinhe, sem parar de mexer, até obter um molho levemente encorpado.

- até obter um creme/molho/purê levemente encorpado (11): Cozinhe em fogo baixo, sem parar de mexer, até obter um creme levemente encorpado.

- até ficar levemente encorpado (7): Leve ao forno de microondas, na potência máxima, por 8 minutos, ou até ficar levemente encorpado.

- levemente encorpada (12): Cozinhe, mexendo de vez em quando, até obter uma preparação cremosa e levemente encorpada.

- calda levemente encorpada (10): Tampe a panela, reduza o fogo e cozinhe, mexendo de vez em quando, por 15 minutos, ou até o salsão ficar macio e com uma calda levemente encorpada.

- até obter uma calda levemente encorpada (8): Leve ao fogo e cozinhe, mexendo de vez em quando, até obter uma calda levemente encorpada.

- levemente untada (18):

- levemente untada com + [INGREDIENTE] (10): Despeje em uma fôrma refratária baixa, levemente untada com manteiga.

- [RECIPIENTE] + levemente untada (13). Os recipientes mais frequentes são: assadeira (5), fôrma (4) e frigideira (3): Coloque em uma assadeira levemente untada com óleo e com a ponta dos dedos faça algumas cavidades na massa.

- unte levemente + ([RECIPIENTE]) com + [INGREDIENTE] (11): Unte levemente uma panela larga com o óleo.

- levemente untado (12): Coloque a massa trabalhada na tigela e vire-a para que o outro lado fique levemente untado.

- levemente untado com + SUBST (9): Recheie as cebolas com a mistura preparada e 
coloque-as num refratário levemente untado com azeite.

- misture levemente (16): Coloque o molho sobre os filés e misture levemente.

- misturando levemente (8): Acrescente os ingredientes secos alternando, aos poucos, com o leite de coco e o leite, misturando levemente com uma espátula até ficar homogêneo.

- [ADICIONAR INGREDIENTE] + e misture levemente (6): Coloque o iogurte e misture levemente.

- tempere levemente com sal e pimenta(-do-reino) (9): Disponha um filé de peixe na metade de cada quadrado e tempere levemente com sal e pimenta-do-reino moída.

- pressionando levemente (10): Com o auxílio da esteira, enrole a alga, pressionando levemente para fixar bem o conteúdo.

- pressione levemente (6): Divida as batatas sobre os filés e pressione levemente com as mãos para dar forma.

- levemente enfarinhada(s) (11): Em seguida, abra a massa com um cilindro numa superfície plana levemente enfarinhada.

- em uma/numa superfície levemente enfarinhada (5): Abra a massa com uma espessura de $4 \mathrm{~mm}$ em uma superfície levemente enfarinhada e com um cortador de biscoitos, corte os biscoitinhos. Em todos os casos, a fraseologia co-ocorre com o ingrediente massa.

- enfarinhe levemente (6): Com papel manteiga, unte as laterais com manteiga e enfarinhe levemente.

- [APLICAR CALOR] (até) corar levemente (8): Polvilhe com o queijo parmesão, leve ao forno e asse até corar levemente.

- toste levemente + ([INGREDIENTE]) (8): Toste levemente as fatias de pão no forno.

- esprema levemente (8): Corte os tomates ao meio e esprema levemente para eliminar as sementes.

- esprema levemente para retirar as sementes (6). Em todas as ocorrências, a unidade refere-se a tomates: Corte os tomates ao meio no sentido horizontal e esprema levemente para retirar as sementes. 
- COZINHAR levemente (8), com as seguintes realizações: cozinhar (4), cozinharem, cozinhe (3), sempre como primeira palavra à esquerda do advérbio: Deixe cozinhar levemente, acerte o sal, retire do fogo e reserve.

- levemente cozIDO (12), com as seguintes realizações: cozido (6), cozidos, cozida, cozidas (4): Cubra com papel-alumínio e leve ao forno médio por 4 horas, ou até ficar levemente cozido.

- seque levemente (7): Escorra o cordeiro da marinada, seque levemente e tempere com sal e pimenta-de-reino.

- seque (+ [INGREDIENTE]) levemente com papel absorvente (4): Escorra-o bem e seque levemente com papel absorvente.

- aperte levemente (7): Coloque sobre um pano e aperte levemente para eliminar o excesso de umidade.

- apertando levemente (6): Dobre as bordas para dentro, apertando levemente.

- levemente amassados (7). Encontrada no Modo de Fazer, essa unidade geralmente refere-se a dentes de alho, colocação posicionada à sua esquerda: Numa frigideira coloque a manteiga e os dentes de alho que deverão ser cortados ao meio e levemente amassados.

- amasse levemente (6): Amasse levemente os dois tipos de carne acrescentando a água gelada.

- engrossar levemente (7): Cozinhe em fogo baixo para engrossar levemente.

- até (+[INGREDIENTE]) + engrossar levemente (5): Cozinhe até engrossar levemente e acrescente os grãos de pimenta rosa.

- até/para que (+ [INGREDIENTE]) + engrosse levemente (6): Ferva por 2 minutos ou até que a mistura engrosse levemente, mexendo sempre.

- frite levemente (6): Adicione o arroz, frite levemente e coloque o vinho. Encontramos também 4 ocorrências de fritar levemente: Temperar com sal e fritar levemente de ambos os lados no óleo quente.

- leve ao forno (bem quente) para gratinar levemente (6): Salpique com noz moscada e leve ao forno bem quente para gratinar levemente os sanduíches. 
- mexa levemente (5): Misture a maionese já acrescida do iogurte e mexa levemente. Encontramos também 4 ocorrências de mexendo levemente: Escorra a massa, junte-a ao molho de azeitonas, mexendo levemente.

- (UNID TEMP) + para aquecer levemente (5): Antes de servir, leve ao forno bem quente por 3 minutos para aquecer levemente os tomates.

- aqueça levemente (5): Corte os pães ao meio e aqueça levemente no forno.

- muito levemente (5). Nesse caso, é importante ressaltar que muito foi o único advérbio a co-ocorrer com levemente: Doure levemente em abundante óleo quente, escorra e amasse muito levemente as fatias entre folhas de papel absorvente.

Abaixo, ocorrências com adjetivos diversos, destacando-se as duas últimas colocações:

- sabor levemente + ADJ (7): O contraste do sabor levemente amargo da endívia com o patê dá um toque especial a esta entrada.

- molho levemente + ADJ (6): Cozinhe, sem parar de mexer, até obter um molho levemente encorpado.

- levemente CREMOSo (10), com cremoso (6) e cremosa (4): Asse por 25 minutos ou até ficar bem dourado por fora e levemente cremoso no centro.

- levemente picante (5): De sabor levemente picante, fica ótima no tempero de saladas, principalmente as preparadas com lombo ou peru defumado ou chester.

Conforme já apontado, o verbo FICAR aparece em várias associações onde temos o advérbio levemente. Abaixo alguns agrupamentos que se repetem com frequência, formando unidades com verbos e adjetivos já mencionadas anteriormente:

- até ficar levemente + ADJ / $\vee_{p p}(24)$ : Deixe o sorvete em temperatura ambiente até ficar levemente amolecido.

- ou até ficar levemente $+v_{p p}(14)$ : $A$ seguir, junte o arroz e frite por 2 minutos, ou até ficar levemente tostado.

- até ficarem levemente + ADJ / $\mathrm{V}_{\mathrm{pp}}(11)$ : Aqueça o azeite restante em uma frigideira antiaderente, acrescente os legumes e o sal e salteie até ficarem levemente crocantes.

- ou até ficarem levemente + ADJ / $\mathrm{V}_{\mathrm{pp}}(5)$ : Assim que ferver, adicione as maçãs e cozinhe por 5 minutos, ou até ficarem levemente macias. 
Observamos que o advérbio levemente é seguido das preposições com e para, introduzindo categorias semânticas:

- levemente com [INSTRUMENTO] (70): Divida as batatas sobre os filés e pressione levemente com as mãos para dar forma.

- levemente para [PROPÓsito] (25): Misture e adicione metade da manteiga, amasse levemente para incorporar e regue com o vinho.

Em linhas gerais, levemente já começa a delinear as características do uso dos advérbios na tipologia das receitas culinárias. Interessante ressaltar, por exemplo, a frequente co-ocorrência com os verbos FICAR e ESTAR, compondo unidades maiores. Outra observação importante é a co-ocorrência marcante com dado verbo e ingrediente, como é o caso de BATER levemente o(s) ovo(s), destacando-se a forma imperativa do verbo. O verbo BATER apresentou, semanticamente, dois usos distintos: BATER os filés (muito menos frequente) e BATER os ovos. No primeiro caso, bate-se no ingrediente com um instrumento ou para que o tempero penetre ou para que o ingrediente fique mais fino; já no segundo, utilizase um instrumento para misturar os ingredientes.

Como em outros textos instrucionais, quando tínhamos um verbo transitivo em colocação com o advérbio, as receitas apresentaram seu objeto subentendido, que pode ter sido, inclusive, mencionado em um período anterior. Tal fato também ocorreu nas receitas em inglês. Exemplos:

Corte os tomates ao meio e esprema levemente [os tomates] para eliminar as sementes.

Prepare o recheio, misturando o creme de leite aos ovos e bata levemente [a mistura], tempere com sal e pimenta-do-reino.

Como em inglês, observamos o uso frequente de verbos no particípio passado, com função adjetiva, caso das colocações levemente DoURADO (78), levemente BATIDO (39) e levemente salgada (29). 
- DELICADAMENTE

\begin{tabular}{|c|c|c|c|c|c|c|}
\hline$N$ & adv-chave & freq. CE & $\%$ CE & freq. CR & $\%$ CR & chav. \\
\hline 245 & delicadamente & 513 & 0,03 & 583 & & $4.727,93$ \\
\hline
\end{tabular}

Dispersão nos arquivos:

CE: $439(6,33 \%)$

CR: $522(0,42 \%)$

Normalização das frequências:

CE: 0,32 ocorrência em cada mil palavras

CR: resultado inexpressivo $(0,00083$ ocorrência em cada mil palavras)

Guardadas as devidas proporções, podemos observar nos dados acima que delicadamente é significativamente mais frequente no CE. Mesmo com alto índice de chavicidade, chama-nos a atenção o número de ocorrências com relação ao advérbio anteriormente analisado: enquanto levemente apresenta 943 ocorrências, delicadamente tem 513 - a frequência caiu quase pela metade. Utilizaremos a lematização para apresentar alguns padrões, destrinçando aqueles mais recorrentes quando necessário. Apresentamos abaixo as associações encontradas.

\section{0 advérbio delicadamente e o verbo misturar}

\section{MISTURAR delicadamente (212)}

misture delicadamente (154). Nessa colocação, observamos a frequente coocorrência com claras (de ovos).

[ADICIONAR INGREDIENTE] + e misture delicadamente (78). Os verbos mais frequentes na categoria semântica são adicione, despeje, junte, incorpore e coloque:

Desligue o aparelho, adicione as claras e misture delicadamente.

Despeje o vinho sobre as frutas e misture delicadamente.

Junte o fermento, as uvas passas e misture delicadamente.

Incorpore o queijo e misture delicadamente.

misture delicadamente até [RESULTADO] (16): Adicione as gemas e 1 colher (sopa) de água e misture delicadamente até obter uma massa lisa.

$\mathrm{V}+$ as claras em neve e misture delicadamente (11): Acrescente as claras em neve e misture delicadamente.

misture delicadamente com + [INSTRUMENTO]/[INGREDIENTE] (9): Peneire a farinha por cima e misture delicadamente com uma colher de pau. 
misture delicadamente ao(s) + [INGREDIENTE] (9): Escorra as batatas com uma escumadeira e misture delicadamente aos ovos.

misture delicadamente até ficar homogêneo (5): Junte as claras batidas em neve e misture delicadamente até ficar homogêneo.

Misture delicadamente e reserve (5). Nesse caso, a unidade é uma oração.

misture delicadamente e sirva (5): Acrescente as ervilhas e a salsinha, misture delicadamente e sirva em seguida.

$\mathrm{V}+$ as claras em neve e misture delicadamente até a massa ficar homogênea (4): Junte as claras em neve e misture delicadamente até a massa ficar homogênea.

misturando delicadamente (43): Cozinhe misturando delicadamente para que a farinha doure.

misturando delicadamente com + [INSTRUMENTO] (7): Desligue a batedeira e acrescente 1/3 da farinha de trigo, misturando delicadamente com uma colher de pau ou espátula.

(as claras) em neve, misturando delicadamente (5): Retire e acrescente as claras em neve, misturando delicadamente.

(e) misturar delicadamente (10): Levar as claras ao ponto de neve firme e misturar delicadamente à massa, com movimentos de baixo para cima.

\section{$>0$ advérbio delicadamente e o verbo mexer}

MEXER delicadamente (137)

mexa delicadamente (78):

[ADICIONAR INGREDIENTE] + e mexa delicadamente (50). A categoria semântica é formada por verbos como acrescente, despeje, junte, misture e incorpore. É frequente a co-ocorrência de incorpore com claras em neve:

Acrescente as frutas e mexa delicadamente.

Despeje sobre os biscoitos e mexa delicadamente com uma colher, até obter mistura homogênea.

Em seguida, incorpore a clara batida em neve e mexa delicadamente.

(e) mexa delicadamente até [RESULTADO] (15): Por fim, misture o restante do merengue e mexa delicadamente até a massa ficar homogênea.

[ADICIONAR INGREDIENTE] + a(s) clara(s) (batida(s)) em neve e mexa delicadamente (11): Junte as claras batidas em neve e mexa delicadamente até ficar homogêneo.

mexa delicadamente até ficar homogêneo (6): Misture a amora e o merengue e mexa delicadamente até ficar homogêneo.

mexendo delicadamente (57). É comum o uso dessa colocação entre vírgulas ou ao final de uma frase:

Bata as claras em ponto de neve e adicione ao chocolate, mexendo delicadamente.

Deixe cozinhar, mexendo delicadamente, até a mistura secar.

mexendo delicadamente até [RESULTADO] (11): Juntar o queijo ralado e levar ao fogo brando, mexendo delicadamente até formar um creme. 
$\mathrm{V}+$ as claras (batidas) em neve, mexendo delicadamente (7): Despeje sobre a tapioca e incorpore as claras batidas em neve, mexendo delicadamente.

\section{O advérbio delicadamente e o verbo incorporar}

incorpore delicadamente + ([INGREDIENTE]) (à/ao + [MISTURA]) (22). O ingrediente mais frequente é claras (12): Incorpore delicadamente as claras ao creme de chocolate e distribua nas forminhas.

incorpore delicadamente as claras (batidas) em (ponto de) neve (10): Acrescente a gema, misture bem e, em seguida, incorpore delicadamente as claras batidas em ponto de neve firme.

\section{$>0$ advérbio delicadamente e outros verbos}

- acrescente delicadamente (12):

- (e) acrescente delicadamente à + [MISTURA] (6): Bata as claras em neve e acrescente delicadamente à mistura de queijos.

- (e) adicione delicadamente + ([INGREDIENTE]) (6): Retire o suspiro da batedeira e adicione delicadamente o leite de coco.

\section{$>0$ advérbio delicadamente e palavras gramaticais}

O advérbio delicadamente é seguido de palavras gramaticais que introduzem categorias semânticas, como podemos observar abaixo:

- delicadamente até [RESULTADO] (40): Misture delicadamente até obter uma massa lisa.

- delicadamente com + [INSTRUMENTO] (33): Peneire a farinha por cima e misture delicadamente com uma colher de pau.

- delicadamente para + [PROPÓsıTO] (12): Cozinhe misturando delicadamente para que a farinha doure.

- delicadamente por + UNID TEMP (5): Acrescente o creme de limão e mexa delicadamente por 1 minuto, ou até obter um creme homogêneo.

Quanto a advérbios, identificamos 5 ocorrências em que delicadamente é precedido de muito: Acrescente os camarões refogados e misture muito delicadamente. 
Em linhas gerais, observamos que delicadamente associa-se com maior frequência a verbos, destacando-se as unidades MISTURAR delicadamente, MEXER delicadamente e INCORPORAR delicadamente. Interessante também enfatizar a coocorrência com palavras gramaticais, como acima mencionado.

- GROSSEIRAMENTE

\begin{tabular}{|c|c|c|c|c|c|c|}
\hline$N$ & adv-chave & freq. CE & $\%$ CE & freq. CR & $\%$ CR & chav. \\
\hline 297 & grosseiramente & 410 & 0,03 & 648 & & $3.577,50$ \\
\hline
\end{tabular}

Dispersão nos arquivos:

CE: $369(5,32 \%)$

CR: $587(0,47 \%)$

Normalização das frequências:

CE: 0,25 ocorrência em cada mil palavras

CR: resultado inexpressivo (0,00093 ocorrência em cada mil palavras)

Como os dados apontam, o advérbio grosseiramente é muito mais frequente no CE, apresentando inclusive melhor dispersão entre os arquivos. Em um primeiro momento, observamos a presença de unidades maiores nas linhas de concordância. Decidimos então levantar os agrupamentos de 2 a 12 palavras - o máximo permitido pelo programa, considerando-se que delimitamos 5 como frequência mínima, com 5 palavras para cada lado da palavra de busca. As unidades encontradas estão abaixo descritas.

\section{O advérbio grosseiramente e o verbo picar}

PICAR grosseiramente (119)

(e) pique grosseiramente + ([INGREDIENTE]) (73). A colocação é seguida de ingrediente em 52 oc.:

Pique grosseiramente as folhas de gelatina e coloque em uma tigela.

Descasque a cebola, lave-a e pique grosseiramente.

pique + [INGREDIENTE] + grosseiramente (43): Pique os tomates grosseiramente e coloque no liquidificador. 
PICADO grosseiramente (108):

([INGREDIENTE]) + picadas grosseiramente (36): Se não encontrar pinoli, substitua por castanhas do Pará descascadas e picadas grosseiramente.

([INGREDIENTE]) + picado grosseiramente (28): Apague o fogo e acrescente o salmão picado grosseiramente.

([INGREDIENTE]) + picada grosseiramente (23): Monte a salada em taças, começando com a alface picada grosseiramente e alternado os ingredientes.

([INGREDIENTE]) + picados grosseiramente (21): Deixe reduzir e acrescente os tomates secos picados grosseiramente.

nozes picadas grosseiramente (15). Essa colocação ocorre tanto na lista de ingredientes como no Modo de Fazer:

2 colheres (sopa) de nozes picadas grosseiramente

Junte o refogado de alho-poró e as nozes picadas grosseiramente.

cebola + (ADJ) + picada grosseiramente (11):

Doure em fogo baixo e acrescente a cebola picada grosseiramente.

Ingredientes: 8 fatias de bacon 6 batatas médias 1 cebola média picada grosseiramente

grosseiramente PICADO (30):

[INGREDIENTE] + grosseiramente picadas (21), com destaque para nozes $\rightarrow$ nozes grosseiramente picadas (12): Ingredientes 6 maçãs verdes 3 xíc. (chá) de nozes grosseiramente picadas

[INGREDIENTE] + grosseiramente picado (6): Cobrir com fatias de tomates pelados, anchovas cortadas e alho grosseiramente picado.

Pudemos observar que as formas do verbo picar no particípio passado, ou seja, picado(s) e picada(s) ocorrem tanto na Lista de Ingredientes quanto no Modo de Fazer. Interessante também enfatizar a frequente co-ocorrência com os ingredientes nozes (12) e cebola (11).

\section{O advérbio grosseiramente e o verbo moer}

\section{moída grosseiramente (59):}

[PIMENTA] + moída grosseiramente a gosto (35): 1 xícara (chá) de manjericão picado sal e pimenta-do-reino preta moída grosseiramente a gosto

(e) pimenta-do-reino moída grosseiramente (25): Acerte o sal e junte o tomilho e a pimenta-do-reino moída grosseiramente.

sal e pimenta-do-reino preta moída grosseiramente a gosto (18): 2 colheres (sopa) de alcaparras em conserva sal e pimenta-do-reino preta moída grosseiramente a gosto

pimenta-do-reino moída grosseiramente a gosto (14): 1 ovo 1 xícara (chá) de farinha de rosca para empanar sal e pimenta-do-reino moída grosseiramente a gosto 
pimenta-do-reino branca moída grosseiramente (a gosto) (5): 8 fatias de mussarela sal e pimenta-do-reino branca moída grosseiramente a gosto folhas de manjericão para decorar

[INGREDIENTE] + grosseiramente moídas (7). Os ingredientes são amêndoas (4) e nozes (3): Adicione os ovos, o sal e as amêndoas grosseiramente moídas, misturando bem, até obter um creme homogêneo.

Novamente, observamos que a forma no particípio passado é mais frequente na Lista de Ingredientes, mas ocorre também no Modo de Fazer, como podemos observar em alguns exemplos acima. A recorrência com o ingrediente pimenta é significativamente frequente (35), donde decorre o uso da forma feminina (moída).

\section{O advérbio grosseiramente e outras associações}

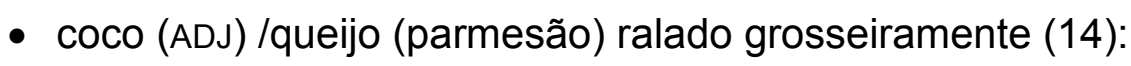

Ingredientes: 1 coco grande ralado grosseiramente 2 xícaras (chá) de açúcar 1/2 xícara (chá) de queijo parmesão ralado grosseiramente sal e pimenta-do-reino a gosto

- $\mathrm{V}+$ [INGREDIENTE] + grosseiramente com as mãos (11). Destacam-se as ocorrências com o verbo PICAR e com abra a massa:

Pique o pão grosseiramente com as mãos e coloque numa tigela.

Em seguida, abra a massa grosseiramente com as mãos e espalhe as frutas cristalizadas.

- desfie grosseiramente (7). A colocação é utilizada para referir-se a bacalhau e frango: Lave bem o bacalhau, desfie grosseiramente eliminando a pele e as espinhas.

- triture grosseiramente + [INGREDIENTE] (7): Triture grosseiramente as bolachas em um processador ou liquidificador.

- [INGREDIENTE] + trituradas grosseiramente (5), destacando-se o ingrediente nozes: 1 xícara de nozes trituradas grosseiramente 1 e 1/2 xícara de farinha de trigo.

- rasgue grosseiramente + [INGREDIENTE] (5). O ingrediente é algum tipo de folha em praticamente todas as ocorrências: Rasque grosseiramente as folhas de alface e coloque em uma saladeira funda.

- abra a massa grosseiramente com as mãos (5): Sove por 5 minutos, ou até ficar lisa. Abra a massa grosseiramente com as mãos e espalhe o recheio.

- quebre grosseiramente os grãos de pimenta (5): Pré-aqueça o forno em temperatura alta. Quebre grosseiramente os grãos de pimenta-do-reino. 
Em linhas gerais, destacam-se as associações de grosseiramente aos verbos PICAR e MOER, bem como a co-ocorrência com os ingredientes cebola, nozes e pimenta, formando unidades de significado maiores, conforme apontado acima.

- FINAMENTE

\begin{tabular}{|c|c|c|c|c|c|c|}
\hline$N$ & adv-chave & freq. CE & $\%$ CE & freq. CR & $\%$ CR & chav. \\
\hline 374 & finamente & 337 & 0,02 & 779 & & $2.735,66$ \\
\hline
\end{tabular}

Dispersão nos arquivos:

CE: $296(4,27 \%)$

CR: $566(0,45 \%)$

Normalização das frequências:

CE: 0,21 ocorrência em cada mil palavras

CR: resultado inexpressivo ( 0,0011 ocorrência em cada mil palavras)

Como no caso dos advérbios anteriormente analisados, tanto a dispersão nos arquivos quanto a ocorrência de finamente em cada mil palavras é maior e mais significativa no $\mathrm{CE}$ do que no $\mathrm{CR}$. Considerado por alguns tradutores mais desavisados como a única forma equivalente do advérbio finely, em inglês, finamente não necessariamente cumprirá essa função, fato que já começa a delinear-se nos dados analisados em português. A questão da tradução, ou a busca de forma(s) equivalente(s), será discutida na seção 3.1.4.

\section{O advérbio finamente e o verbo picar}

PICAR (+ [INGREDIENTE]) finamente (130)

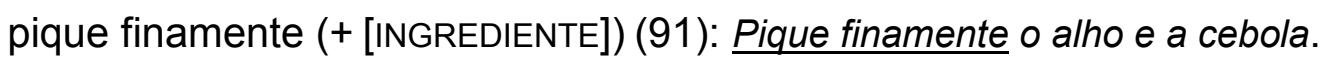

pique finamente + [INGREDIENTE] (74). Dentre os ingredientes, destacam-se: cebola(s) (21), dentes de alho (8), chocolate (7) e tomates (5): Enquanto as lentilhas cozinham, pique finamente a cebola restante, o alho e os tomates.

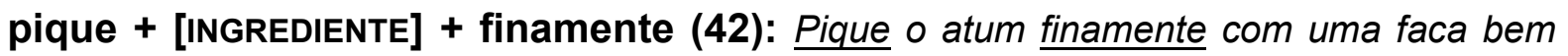
afiada.

separe (somente) as folhas e pique-as finamente (10). Em todos os casos, as folhas referiam-se a diferentes tipos de ervas: Lave as ervas, seque-as, separe somente as folhas e pique-as finamente. 
[INGREDIENTE] PICADO finamente (58):

Praticamente todas as ocorrências estão na Lista de Ingredientes. PICADO apresenta-se nas seguintes formas: picada (25), picado (14), picadas (11), picados (8). Destacam-se os ingredientes cebola e dente de alho:

cebola (+ ADJ) + picada finamente (15): 1 cebola graúda picada finamente 3 colheres (sopa) de coentro picado

dente de alho picado finamente (5): 2 colheres de sopa de cebola picada 1 dente de alho picado finamente

[INGREDIENTE] finamente PICADO (27):

(UNID MED) + [INGREDIENTE] + finamente picada (19). Destacam-se os ingredientes cebolinha (5) e cebola (5): 1/2 cebola branca finamente picada

[INGREDIENTE] finamente picados (5): Acrescente a cenoura ralada e os shiitake finamente picados, misture tudo juntamente com a maisena os ovos e acrescente ao recheio.

\section{0 advérbio finamente e o verbo fatiar}

\section{FATIAR finamente (44)}

fatie finamente + ([INGREDIENTE]) (34): Fatie finamente os shiitake, os cogumelos paris e os funghi reidratados.

fatie + [INGREDIENTE] + finamente (7): Fatie a carne finamente e arrume em uma travessa.

[INGREDIENTE] FATIADO finamente (29):

FATIADO realiza-se nas seguintes formas: fatiada (12), fatiadas (9), fatiado (5), fatiados (3). Dentre os ingredientes, destacam-se cebola (6) e cebolinha (5): Vongoles abafados e cebolinha fatiada finamente

Como unidade estendida de significado, encontramos PICAR/FATIAR + [INGREDIENTE] + finamente com + [INSTRUMENTO] (7): Pique o atum finamente com uma faca bem afiada.

Nos dados analisados, destacam-se as colocações formadas com os verbos picar e fatiar, nas formas imperativa (Modo de Fazer) e particípio passado (Lista de Ingredientes, em sua maioria), co-ocorrendo especialmente com o grupo semântico dos temperos (cebola, dente de alho e cebolinha). 
- LIGEIRAMENTE

\begin{tabular}{|c|c|c|c|c|c|c|}
\hline$N$ & adv-chave & freq. CE & $\%$ CE & freq. CR & $\%$ CR & chav. \\
\hline 389 & ligeiramente & 495 & 0,03 & 5.863 & & $2.570,21$ \\
\hline
\end{tabular}

Dispersão nos arquivos:

CE: $321(4,63 \%)$

CR: $4.014(3,20 \%)$

Normalização das frequências:

CE: 0,31 ocorrência em cada mil palavras

CR: resultado inexpressivo (0,0084 ocorrência em cada mil palavras)

A dispersão no CR e no CE é semelhante, mas vale lembrar que os arquivos não equivalem a um único texto, em ambos os casos. É mais significativo, portanto, observarmos a ocorrência de ligeiramente em cada mil palavras, mais expressiva no CE. Descrevemos abaixo os padrões encontrados.

\section{- 0 advérbio ligeiramente e o verbo dourar}

\section{DOURAR ligeiramente (66):}

dourar ligeiramente (42): Junte a carne, o tomilho, o orégano e refogue até a carne dourar ligeiramente.

[APLICAR CALOR] + ([INGREDIENTE]) (+ UNID TEMP Ou) até dourar ligeiramente (24): Espalhe sobre o bolo e asse por 5 minutos ou até dourar ligeiramente.

doure ligeiramente ([INGREDIENTE]) (16): Doure ligeiramente os legumes e o alho.

$([$ APLICAR CALOR] $+([$ INGREDIENTE] $)+([$ MEIO $])(+$ UNID TEMP) (até/para) que) dourem ligeiramente (6): Frite os filés de frango em azeite até que dourem ligeiramente.

deixe dourar ligeiramente (5): Assim que soltar perfume, acrescente os pinoli e deixe dourar ligeiramente.

ligeiramente DOURADO (39):

DOURADO realiza-se nas seguintes formas: dourada (14), dourados (10), douradas (9), dourado (6): Adicione a cebola e refogue até ficar ligeiramente dourada.

(até) ficar ligeiramente dourada (7): Com um garfo, fure a massa e leve ao forno por 5 minutos, ou até ficar ligeiramente dourada. 


\section{0 advérbio ligeiramente e o verbo bater}

BATER ([INGREDIENTE]) ligeiramente (56):

bata ligeiramente + ([INGREDIENTE]) (41). Nos ingredientes, destaca-se ovos (17): Bata ligeiramente os ovos numa tigela com um garfo.

Bata ligeiramente os ovos para o recheio e acrescente o creme de leite (5). A unidade é uma frase completa. Todas foram encontradas em receitas diferentes.

[INGREDIENTE] ligeiramente BATIDO (78):

$(\mathrm{NUM}+)$ ovos ligeiramente batidos (40). Praticamente todas as oc. estão na Lista de Ingredientes: 5 fatias de pão de forma esmigalhadas / 2 ovos ligeiramente batidos

$(\mathrm{NUM}+)$ ovo ligeiramente batido (18): praticamente todas as oc. estão na Lista de Ingredientes: 1 colher (chá) de sal 1 ovo ligeiramente batido

gemas ligeiramente batidas (11): Adicione as gemas ligeiramente batidas e o adoçante, misturando sem parar.

\section{$>0$ advérbio ligeiramente e outras associações}

- FICAR ligeiramente $+\mathrm{V}_{\mathrm{pp}} / \mathrm{ADJ}$ (33), detacando-se ficar (forma infinitiva), com 18 ocorrências: Coloque o creme em ramekins individuais e asse em banho-maria por aproximadamente 1 hora, ou até ficar ligeiramente firme.

- $\mathrm{v}(+\mathrm{SN})+$ ligeiramente com + [INSTRUMENTO/INGREDIENTE] (28): Em seguida, bata a carne ligeiramente com um batedor. I Regar ligeiramente com molho de tomates e polvilhar com queijo ralado.

- (até) ([MISTURA LÍQUIDA]) engrossar ligeiramente (17): Transfira a mistura para uma bacia grande e deixe esfriar até a mistura engrossar ligeiramente.

- ESTAR ligeiramente $+\mathrm{V}_{\mathrm{pp}} / \mathrm{ADJ}$ (14), com destaque para estejam (5): Cozinhe as peras por aproximadamente 25 minutos, ou até que estejam ligeiramente firmes no centro quando espetadas com uma faca.

- frite ligeiramente (12): Acrescente o arroz, frite ligeiramente e coloque o vinho branco.

- superfície (ADJ) + ligeiramente enfarinhada (6): Com um rolo de macarrão, abra a massa sobre uma superfície ligeiramente enfarinhada. 
- Pincelar/Untar (+ [instrumento]) + ligeiramente com óleo (5): Pincele-a ligeiramente com óleo e reduza a chama para média.

- sobrepondo-as ligeiramente (5). O pronome as refere-se a fatias, em todas as ocorrências: Coloque as fatias sobre o pudim sobrepondo-as ligeiramente.

- aqueça ligeiramente [INGREDIENTE] (5): Aqueça ligeiramente os pães e abra-os ao meio.

- [MISTURA LíQUIDA] (ficar) ligeiramente espesso (5): Numa panela, junte todos os ingredientes e cozinhe em fogo médio, mexendo sempre, por cerca de 5 minutos ou até obter um molho ligeiramente espesso.

- deixe (+ [INGREDIENTE]) esfriar ligeiramente (5): Deixe o arroz esfriar ligeiramente e acrescente a mussarela, o presunto, a ervilha e a salsinha.

Em linhas gerais, destacam-se as associações entre ligeiramente e os verbos dourar e bater, com destaque para as formas infinitiva, imperativa e particípio passado. A partir dessas colocações, observamos a formação de unidades maiores, como é o caso de ovos ligeiramente batidos.

3.1.2 Os advérbios em português nas receitas culinárias: algumas considerações

A partir dos dados levantados, observamos que o uso dos advérbios terminados em -mente em receitas culinárias não é tão significativo como os resultados observados em inglês. Enquanto 17,38\% dos advérbios etiquetados no corpus em português terminam em -mente, em inglês essa porcentagem chega a $75,57 \%$. Como esse levantamento foi feito da mesma forma em ambos os corpora, ou seja, em $10 \%$ de cada um deles (em inglês e em português), esses dados já apontam que o uso dessa classe gramatical é diferente nas línguas estudadas, o que será melhor discutido no item 3.1.3.

Quanto aos advérbios em português, podemos observar, a partir da análise de levemente, delicadamente, grosseiramente, finamente e ligeiramente, que a função dessa classe gramatical na tipologia das receitas culinárias é bastante 
específica: associadas a uma ou mais palavras, elas modalizam seu significado e formam unidades coesas, ou seja, fraseologias. As palavras às quais se associam mais diretamente são verbos ou adjetivos, mas seu uso também atrela-se ao substantivo, ou seja, ao ingrediente que, por seu significado, rege os demais elementos da unidade. É o caso de ligeiramente na colocação bater ligeiramente, geralmente utilizada com o subtantivo ovos - bata ligeiramente os ovos ou ovos ligeiramente batidos. Algumas dessas unidades são: sal e pimenta-do-reino preta moída grosseiramente a gosto (18); tempere levemente com sal (12); separe (somente) as folhas e pique-as finamente (10); incorpore delicadamente as claras (batidas) em (ponto de) neve (10); até obter uma calda levemente encorpada (8); bata levemente o ovo com a água e o sal (7).

Como em inglês, identificamos unidades que contém categorias semânticas em sua formação. Aquelas encontradas em português, a partir dos advérbios, são: [INGREDIENTE], [RECIPIENTE], [ADICIONAR INGREDIENTE], [APLICAR CALOR], [INSTRUMENTO], [PROPÓSITO], [RESULTADO], [MISTURA], [MISTURA LÍQUIDA] e [PIMENTA]. Junto com palavras lexicais e gramaticais, formam fraseologias maiores que incluem os advérbios. Em português, é também difícil estabelecer um único padrão que possa englobar todas essas categorias, que compartilham outros elementos como unidade de tempo e unidade de medida. Vale destacar as fraseologias abaixo, agrupadas de acordo com suas características semânticas:

[APLICAR CALOR] + UNID TEMP + ou até dourar levemente [APLICAR CALOR] até/para que ([INGREDIENTE]) FICAR/ESTAR levemente DOURADO [APLICAR CALOR] (até) corar levemente [APLICAR CALOR] + ([INGREDIENTE]) (+ UNID TEMP ou) até dourar ligeiramente ligeiramente DOURADO

coloque + [INGREDIENTE] em [RECIPIENTE] e bata levemente coloque $+($ [RECIPIENTE] $)+$ (bastante/abundante $)$ água para ferver e salgue levemente

[ADICIONAR INGREDIENTE] + e misture delicadamente

[ADICIONAR INGREDIENTE] e mexa delicadamente incorpore delicadamente + ([INGREDIENTE]) (à/ao [MISTURA])

misture delicadamente até [RESULTADO]

[PIMENTA] + moída grosseiramente a gosto

pique grosseiramente $+($ [INGREDIENTE])

pique finamente + [INGREDIENTE] 


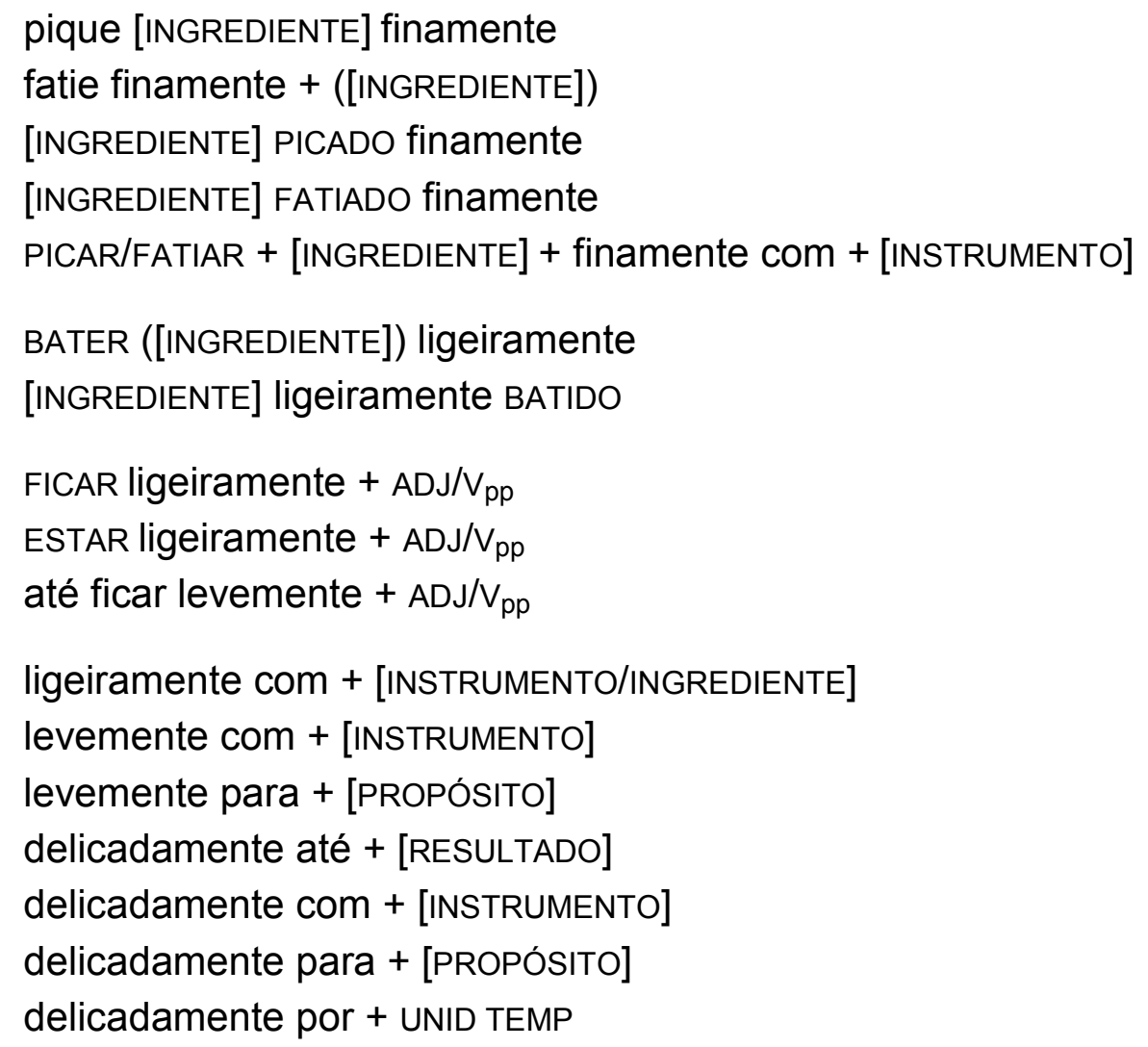

As duas últimas sequências de dados foram agrupadas a partir de características morfossintáticas e/ou devido à associação com palavras gramaticais que introduzem categorias semânticas.

Em geral, observamos que há advérbios que apresentam preferência semântica, como é o caso de levemente e ligeiramente (associam-se a palavras que se referem a aplicar calor), delicadamente (palavras que se referem a adicionar ingredientes e misturar), finamente e grosseiramente (palavras que se referem a formas de cortar).

Com menor frequência, observamos a recorrência de orações inteiras, que também representam uma única unidade de significado, com uso específico, como é o caso de Bata levemente o ovo com a água e o sal e adicione à mistura de farinha (5) e Bata ligeiramente os ovos para o recheio e acrescente o creme de leite (5), ambas no Modo de Fazer das receitas.

Sintaticamente, observamos um fenômeno semelhante nas duas línguas, o que consideramos ser típico de textos instrucionais. Quando tínhamos um verbo transitivo em colocação com o advérbio, as receitas apresentaram seu objeto subentendido, que pode ter sido, inclusive, mencionado em um período anterior. Ex.: Corte as pêras em laminas e pique grosseiramente. 
Analisando mais detalhadamente os verbos que integram as colocações levantadas, verificamos que geralmente encontram-se no imperativo (fatie finamente); na forma infinitiva (dourar levemente); no gerúndio (alguns casos mais pontuais, como misturando delicadamente e mexendo delicadamente); ou no particícipio passado (grosseiramente picado), na maioria das vezes com função adjetiva. Nos três primeiros casos, a ocorrência do advérbio depois do verbo é significativamente maior. Quando o particípio passado é utilizado, a anteposição do advérbio é, em geral, mais frequente, mas a recorrência dependerá do verbo utilizado. É o caso, por exemplo, de grosseiramente PICADO, com 30 ocorrências (atente-se para a forma lematizada) que, apesar de frequente, é menos utilizada do que PICADO grosseiramente (108). Tal fato não foi observado com levemente DOURADO, que apresenta 78 ocorrências com o advérbio anteposto e nenhuma de DOURADO levemente. Já os adjetivos per se, tais como macio, cremoso e picante, são bem menos utilizados em colocações com advérbios, sendo significativamente maior o uso de verbos no particípio passado com função adjetiva, conforme apontado anteriormente. A partir desses dados, podemos observar que as formas imperativa e infinitiva são típicas de textos instrucionais em português, dentre os quais se incluem as receitas culinárias. Já em inglês, o uso dos verbos fica mais restrito ao imperativo.

Diferente da língua inglesa e devido aos traços morfossintáticos do português, tivemos que nos valer da forma lematizada para o levantamento de várias colocações. Quando necessário, apontávamos as diferenças entre as formas feminina/masculina e singular/plural, por exemplo, o que naturalmente já se atrelava ao uso com determinado substantivo, como observamos em água levemente salgada ou mesmo ovos ligeiramente batidos e pimenta-do-reino moída grosseiramente. Ainda quanto à co-ocorrência com classes gramaticais, observamos que, assim como em inglês, os advérbios analisados raramente co-ocorrem com outros advérbios (terminados ou não em -mente). Encontramos apenas o advérbio muito associado a delicadamente e a levemente, com 5 ocorrências cada - o que indica ser uma associação pouco comum. Exemplos:

Acrescente os camarões refogados e misture muito delicadamente.

Coloque abundante água para ferver e salgue muito levemente. 
Em termos pragmáticos, ao contrário do que ocorre em inglês, os advérbios em português são típicos do Modo de Fazer das receitas. Dentre os cinco advérbios analisados, apenas finamente apresenta ocorrência significativa na Lista de Ingredientes. Para exemplificar, são 58 ocorrências de [INGREDIENTE] PICADO finamente e 27 de [INGREDIENTE] finamente PICADO.

Diante desses resultados, podemos concluir que, na tipologia das receitas culinárias em português, o uso dos advérbios é claro e delimitado, como também observado em inglês. Apresentam significado próprio e sua função principal é especificar o modo como um ingrediente deve estar ou ser preparado, dependendo do contexto em que ocorrem. Obviamente, há diferenças entre as línguas estudadas, o que será apresentado na próxima seção.

3.1.3 Comparando resultados: os advérbios em receitas culinárias - inglês e português

Diferente do que ocorre com os advérbios em língua geral, observamos que o grupo aqui analisado, ou seja, aqueles terminados em -ly e -mente, deixa clara sua função modalizadora nas receitas culinárias. Observando essa linguagem especializada em uso, com foco específico nos advérbios de maior índice de chavicidade, chegamos às conclusões acima descritas, que envolvem tanto aspectos gramaticais quanto lexicais e semânticos.

Em inglês, devemos ressaltar o papel de and, utilizada para indicar processos executados na sequência, especialmente em nível sintagmático, caso de peeled and finely chopped e seeded and finely sliced, e de then, utilizada para indicar o próximo passo da receita, em nível oracional. Ainda nessa língua, são frequentes until, utilizada para introduzir o resultado de um dado processo, to, para apresentar um propósito, e for, que introduz as unidades de tempo. Em português, destacam-se até, para introduzir um resultado; para, um propósito; com, um instrumento ou ingrediente; e por, sempre seguida de uma unidade de tempo.

Outra questão são as categorias semânticas identificadas a partir dos advérbios. Definidas durante as análises no corpus em inglês, praticamente não houve acréscimos quando identificamos as fraseologias em português. Nesse aspecto, podemos dizer que, independente da língua, o que predomina são as 
características do tipo de texto. Com exceção de [MISTURA LÍQUIDA], identificada apenas nos dados em português, as categorias semânticas são: [INGREDIENTE], [PIMENTA], [RECIPIENTE], [MISTURA], [MISTURA LÍQUIDA] [MASSA], [FORMA], [TEMPERO], [RESULTADO], [MODO], [PROPÓSITO], [TEMPERATURA], [LOCAL], [INSTRUMENTO], [APLICAR CALOR], [ADICIONAR INGREDIENTE], [ALTERAR FORMA], [CAUSAR MOVIMENTO] e [CORTAR]. No entanto, não podemos deixar de ressaltar que essas categorias foram mais frequentes em inglês, onde conseguimos definir melhor os grupos semânticos. A nosso ver, tal fato deve-se ao número de ocorrências dos advérbios, de onde partimos para desenvolver as análises, muito maior em inglês. A categoria [APLICAR CALOR], por exemplo, e considerando-se apenas as fraseologias apresentadas nos comentários gerais dos itens 3.1.1 e 3.1.2, está incluída em 7 padrões em inglês, enquanto em português são apenas quatro. Esses dados são extremamente relevantes e deveriam estar disponíveis aos falantes de ambas as línguas como objeto de consulta, especialmente do tradutor, que necessita conhecer essas especificidades linguísticas para que seu texto flua mais naturalmente na língua para a qual está traduzindo.

Em âmbito mais geral e a partir dos dados coletados e analisados em cada língua, observamos que a frequência de uso dos advérbios terminados em -mente difere significativamente daqueles terminados em $-l y$. Em termos de ocorrências, são 22.762 advérbios terminados em -ly e 7.276 terminados em -mente, que representam $1,32 \%$ do corpus em inglês e $0,45 \%$ daquele em português. Esses números, no entanto, não revelam uma outra diferença, observada na variedade de advérbios (formas) encontrada. Proporcionalmente, a diversidade em português é maior do que em inglês. Enquanto temos 145 formas (types) para as 7.276 ocorrências (tokens) naquela língua - que representam 1,99\% do total, em inglês são 326 para 22.762 ocorrências, ou seja, 1,43\% desse total. Se cada advérbio tivesse o mesmo número de ocorrências em todo o corpus, cada um em português ocorreria 50 vezes, enquanto em inglês esse número subiria para praticamente 70 .

Trabalhando com corpora comparáveis, ou seja, textos originais em ambas as línguas, podemos ver claramente que em inglês os advérbios se repetem com mais frequência do que em português. Esse fato gera outro questionamento: como a função dos advérbios em inglês é veiculada nas receitas culinárias em português? $\mathrm{E}$ no caso de receitas traduzidas, como o tradutor lida com essa questão? Considerando-se os aspectos morfossintático, semântico e pragmático, como esses 
advérbios são (se é que isso acontece) representados em português, já que são significativamente mais frequentes naquela língua?

Apesar de apresentarem várias características em comum, como pudemos observar nas palavras gramaticais e categorias semânticas acima apresentadas, entrecruzar os dados resultantes da análise dos advérbios considerados neste estudo e estabelecer as formas equivalentes é tema para outra pesquisa. Inicialmente, podemos observar que os advérbios com maior índice de chavicidade em uma língua não representam necessariamente a forma equivalente daqueles encontrados na outra. A nosso ver, é impossível estabelecer qualquer tipo de equivalência fora do contexto de uso, ou seja, os advérbios analisados, por serem cognatos, poderiam ser considerados formas equivalentes por tradutores menos atentos. No entanto, o que dizer quando eles co-ocorrem com outras palavras e em contextos mais específicos? Delineia-se assim o seguinte raciocínio: se as formas são cognatas, poderiam ser equivalentes; a pesquisa em corpus, entretanto, pode revelar que essas formas ou não são encontradas ou o são em frequência muito menor, o que pode nos levar a concluir que não são equivalentes.

Apenas alinhar os cinco advérbios com maior índice de chavicidade em cada língua em nossos corpora e tentar identificar se há equivalência entre eles não nos diz muita coisa, como podemos observar abaixo:

\begin{tabular}{|c|c|}
\hline finely & levemente \\
\hline freshly & delicadamente \\
\hline gently & grosseiramente \\
\hline lightly & finamente \\
\hline thinly & ligeiramente \\
\hline
\end{tabular}

Será que lightly pode ser traduzido como ligeiramente? Ou seria o caso de usarmos delicadamente, dependendo do contexto? Ou ainda levemente? Mesmo fugindo ao escopo desta tese, decidimos abordar, com alguns exemplos, a questão da busca pelas formas equivalentes. 
3.1.4 A busca pela forma equivalente em receitas culinárias: alguns exemplos na direção inglês - português

Falar sobre equivalência ou mesmo tentar estabelecê-la entre duas línguas não é tarefa fácil. Segundo estudiosos da Tradução, essa é uma discussão que já dura mais de vinte anos (HALVERSON, 1997; RODRIGUES, 2000). Koller (1995) afirma que equivalência é um conceito relativo, conduzido por uma dicotomia: de um lado as condições histórico-culturais sob as quais um texto é produzido e recebido considere-se tanto a língua em que foi originalmente escrito e a língua para a qual foi traduzido -, e de outro uma gama de fatores linguístico-textuais e extralinguísticos que fazem parte desse processo, dentre os quais destacamos (KOLLER, 1995, p. 196-197):

- as propriedades estruturais de ambas as línguas (partida e chegada);

- a percepção de mundo daqueles que falam as línguas envolvidas no processo;

- as diferentes realidades e como são representadas linguisticamente;

- as propriedades linguísticas, estilísticas e estéticas do texto de partida e do texto de chegada em relação à própria língua;

- as características estruturais e particularidades do texto;

- as condições de recepção/compreensão do leitor na língua de chegada;

- essas mesmas condições com relação ao tradutor, além de seu conceito do que é tradução;

- a tradição do processo de tradução, em um âmbito geral;

- os princípios de tradução e interpretação do texto original, na concepção do autor da obra;

- as orientações e propósitos estabelecidos pelo solicitante da tradução;

- as condições sob as quais o tradutor irá trabalhar.

Como podemos observar, traduzir ou estabelecer formas equivalentes entre duas (ou mais) línguas é um trabalho árduo em que vários fatores, implícita ou explicitamente, são considerados. Em nossa investigação, adotaremos um conceito mais pragmático e funcional de equivalência. Nosso objetivo é identificar unidades de significado que "funcionem" no texto de chegada como o fazem no texto em que foram originalmente escritas (TAGNIN, 2007b). Assim, como colocam Tognini-Bonelli 
e Manca (2004, p. 299), acreditamos que a equivalência nem sempre pode ser estabelecida - ou mesmo deve sê-lo -, no nível da palavra. Deve-se buscar "unidades de significado funcionalmente completas", ou seja, através de uma análise sistemática do contexto e do co-texto em que dada palavra se insere, na língua de chegada, o tradutor irá ampliar sua noção de equivalência ao observar outras palavras com as quais co-ocorre com certa frequência. A partir da análise com corpus, o tradutor/pesquisador poderá visualizar essa equivalência funcional ao comparar prováveis unidades equivalentes. Considerando vários aspectos, dentre os quais citamos o morfossintático e o semântico, irá observar os padrões sintagmáticos e as associações paradigmáticas das duas (ou mais) línguas, cuja análise será primordial para a definição das formas equivalentes que busca. Um bom exemplo desse processo é a análise das palavras welcome (inglês) e benvenuto (italiano), em textos de agriturismo, apresentada por Tognini-Bonelli e Manca (2004). As autoras concluíram que, nessa área de especialidade (agriturismo), welcome e benvenuto, apesar de serem tidas como formas equivalentes de forma descontextualizada, não apresentam equivalência funcional.

Feitas essas considerações, e partindo para o lado prático da questão, tentaremos aqui apresentar as formas equivalentes de algumas das unidades identificadas na análise dos cinco advérbios em inglês. Para isso, seguimos os passos abaixo descritos, numa investigação conduzida em ambos os corpora (inglês e português), conforme necessário.

Primeiramente, e para que não houvesse dúvidas quanto à forma equivalente proposta para as colocações, buscamos a tradução considerada prima facie do advérbio em estudo com o objetivo de fazer uma análise mais geral das linhas de concordância e encontrar alguma equivalência, caso esse advérbio não fizesse parte do grupo de advérbios já analisados em português. Obviamente, a possibilidade de equivalência de uso entre um advérbio terminado em -ly e outro terminado em -mente em português não deveria ser totalmente descartada. Considerando-se os resultados dessa investigação, passamos à tradução e busca da palavra à qual o advérbio se referia na colocação. Como observamos em nossos dados que o advérbio co-ocorria com verbos e adjetivos, nosso primeiro passo foi buscar a tradução dessas palavras, numa tentativa de verificar com quais outras co-ocorriam e analisar seu contexto de uso. Considerando-se as unidades indentificadas na 
língua de partida (o inglês), outra classe gramatical também utilizada para iniciar a investigação foi o substantivo.

Para desenvolvermos essa investigação, levantamos algumas unidades a partir das análises dos cinco advérbios mais chave em inglês, anteriormente descritas. As unidades selecionadas estão abaixo elencadas, com comentários e seguidas das formas equivalentes encontradas. Foram selecionadas de forma aleatória, mas consideramos também as dificuldades que poderiam trazer ao tradutor.

\section{- FINELY:}

- finely chopped:

A primeira tradução encontrada no dicionário ${ }^{117}$ para finely foi finamente, que por sua vez faz parte dos cinco advérbios com maior índice de chavicidade analisados em português. Apesar de termos encontrado 58 ocorrências de PICADO finamente e 27 de finamente PICADO, considerando-se PICADO como a forma equivalente de chopped, decidimos continuar nossa investigação, buscando picad $^{* 118}$ no corpus para verificar com quais outras palavras que expressassem modo (de picar) ela poderia ocorrer. Nas 7.503 ocorrências de picad*, que apresenta as formas picada, picadas, picadinha, picadinhas, picadinho, picadinhos, picado, picados encontramos 103 ocorrências de bem picada, 67 de bem picado, 41 de bem picadas e 40 de bem picados, com grande frequência na lista de ingredientes, totalizando 251 colocações com o advérbio bem (bem PICADO). Interessante foi observar o uso de outro advérbio (não terminado em -mente) para expressar modalização. Como ocorre em inglês, a colocação é frequente com o substantivo cebola - daí a maior frequência na forma feminina. Identificamos também picadinha (154 oc., precedida de bem em 13 delas), picadinho (124 oc., precedida de bem em 8 delas), picadinhos (71 oc., precedida de bem em 6 delas) e picadinhas (33 oc.). Nesses casos, o modo é expresso pela forma diminutiva, precedida ou não do advérbio bem. Essas unidades refletem o sentido de finely chopped e são, como pudemos observar, muito mais frequentes do que as co-ocorrências com finamente.

\footnotetext{
${ }^{117}$ Nessas análises, buscamos a tradução prima facie em Houaiss (1982).

${ }^{118} \mathrm{O}$ asterisco indica que a expressão de busca pode apresentar quaisquer sequências de letras em sua formação, como podemos observar nas linhas de concordância geradas para picad*.
} 
Com isso, consideramos que são as formas funcionalmente equivalentes da colocação em inglês:

- finely chopped $=$ bem PICADO, (bem) PICADINHO ${ }^{119}$. Exemplos: Ingredientes: 6 batatas-doces (cerca de $1 \mathrm{~kg}$ ) 1 cebola grande bem picada; 1 pimentão vermelho picadinho 1 pimentão verde picadinho.

- peeled and finely chopped:

Nesse caso, e como já havíamos investigado a forma equivalente de finely chopped, decidimos primeiramente buscar a tradução de peeled, ou seja, descascad*. Nas 419 ocorrências retornadas, observamos a co-ocorrência com PICADO em 39 delas: descascadas e picadas (20); descascado e picado (8); descascada e picada (7); descascados e picados (4). Diante desses resultados, nossa sugestão de tradução é:

peeled and finely chopped = DESCASCADO e (bem) PICADO. Exemplos: Ingredientes: $1 \mathrm{~kg}$ de mandioca descascada e picada; 10 dentes de alho descascados e picados; 1/4 col. (chá) de gengibre, descascado e bem picado.

- seeded and finely chopped:

Ao buscarmos seeded no dicionário, vimos que a tradução apresentada, ou seja, semeado, descaroçado, não equivalia ao uso da colocação, principalmente devido aos ingredientes com os quais seeded and finely chopped co-ocorre - caso de tomato(es), chilli(es) e pepper(s), com frequência significativa na Lista de Ingredientes. Decidimos então buscar pela colocação sem semente* e verificar se haveria a co-ocorrência com PICADO e os ingredientes acima. Em co-ocorrência direta, ou seja, com uma palavra seguida da outra, obtivemos poucos resultados para PICADO (e) sem semente(s) (8), mas verificamos várias concordâncias em que PICADO fazia parte da associação, como em 4 tomates picados, sem pele e sem sementes. Ao analisarmos as ocorrências à direita de sem semente(s), verificamos que a frequência de PICADO é significativamente maior (136): sem sementes(,) picados (86); sem sementes(,) picado (23); sem sementes(,) picada(s) (6); sem semente(,) picados (10); sem semente(s) e PICADO (6); sem semente picadinhos; sem semente picado (4). É importante observar o uso da vírgula, presente na

\footnotetext{
119 Para apresentação do resultado da investigação, decidimos utilizar as formas lematizadas como default. Outras informações serão acrescentadas quando necessário.
} 
maioria das ocorrências de sem sementes(,) picados. Diante desses resultados, nossas sugestões de tradução são:

seeded and finely chopped = sem sementes, PICADO; PICADO (e) sem sementes. Exemplos: 2 tomates médios, sem pele e sem sementes, picados; 6 tomates picados sem sementes.

- onions, finely sliced:

Para refinar um pouco mais a pesquisa, iniciamos a busca em fatiada* e, nessas linhas de concordância, buscamos o substantivo cebola(s). Especificamente com fatiada(s), observamos o uso de finamente, o que pode não acontecer quando finely sliced se refere a outro ingrediente. São 3 ocorrências de cebola (média/pequena) fatiada finamente e 9 oc. de cebolas (graúdas/médias) fatiadas finamente. Diante desses resultados, a nosso ver pouco satisfatórios, decidimos buscar apenas o substantivo cebola*, para assim verificar outra possibilidade de tradução. Levantamos as unidades: cebola(s) em rodelas (finas) (62); cebola(s) cortada(s) em rodelas (finas) (41); cebola(s) em fatias (bem) (finas) (15); cebola(s) cortada(s) em fatias (finas) (13); cebola pequena cortada fininha/o (4); cebolas pequenas fatiadas fino. Sugerimos assim as seguintes opções de tradução, em ordem decrescente de uso:

- onions, finely sliced = cebolas (cortadas) em rodelas (bem) finas; cebolas (cortadas) em fatias (bem) finas; cebolas cortadas fino/fininho.

\section{- finely grated:}

Ao analisarmos as concordâncias de finamente, observamos apenas 3 ocorrências de finamente RALADO, resultado que nos levou a buscar ralad* e analisar sua co-ocorrência com alguma unidade modalizadora pertinente. Nas 3.022 ocorrências levantadas, a única co-ocorrência relacionada ao sentido de finely grated foi ralado fino (12) - as demais não apresentaram frequência maior do que cinco, como é o caso de ralada (bem) fina (3). Decidimos então verificar os substantivos com os quais RALADO co-ocorria, para analisar se seria o caso de um advérbio ou expressão modalizadora não ser utilizado em português. De fato, houve coincidências entre as línguas: em português, encontramos: (queijo) parmesão ralado (764); queijo ralado (392); coco (fresco) ralado (282); cebola ralada (218); gengibre ralado (155); casca ralada (53) (referindo-se a limão ou laranja na maioria 
das ocorrências); casca de limão ralada (109); noz-moscada ralada (76); mussarela ralada (58); casca de laranja ralada (47); (queijo) gruyère ralado (43); chocolate (meio-amargo) ralado (24); (queijo) provolone ralado (23); (queijo) emmenthal ralado (22); queijo prato ralado (21); (queijo) cheddar ralado (11); etc. - para nomear alguns dos substantivos encontrados -, muitos dos quais co-ocorrem com finely grated em inglês. Diante desses resultados, observamos que, em português, ralar fino esses ingredientes é o procedimento usual. Quando há necessidade de ralar grosso, isso é mencionado na receita, como já apontado por Tagnin (2007b). Encontramos, por exemplo, 118 ocorrências de RALADO grosso; 10 oc. de RALADO grosseiramente; 16 oc. de na parte grossa do ralador e 5 de no lado grosso do ralador (ambas precedidas do verbo RALAR), o que corrobora nossa ideia. Nessas ocorrências, as fraseologias referiam-se, em grande maioria, a queijos, destacando-se os do tipo Gruyère, mussarela e parmesão. Encontramos também, em menor frequência, legumes como cenoura e batata, frutas como maçã, laranja e coco, e chocolate. Diante desses resultados, sugerimos como opção de tradução:

- finely grated $=$ ralado .

\section{- FRESHLY}

\section{- freshly ground black pepper:}

Conforme já apontado por Teixeira (2008), a tradução mais adequada para essa colocação é pimenta-do-reino moída na hora. Como é uma colocação extremamente frequente em inglês - cremos que a mais recorrente em todos os dados levantados, com 2.447 ocorrências -, não poderíamos deixar de mencioná-la. Na forma traduzida, observamos que não temos um advérbio terminado em -mente, mas sim a expressão na hora como forma equivalente de freshly. No corpus em português, identificamos 3.782 ocorrências de pimenta-do-reino e, quando esse ingrediente deveria ser moído no momento do preparo, encontramos a expressão moída na hora, perfazendo um total de 250 ocorrências de pimenta-do-reino (branca/preta) moída na hora, subdivididas em: pimenta-do-reino moída na hora (215), pimenta-do-reino branca moída na hora (28) e pimenta-do-reino preta moída na hora (7). Desse modo, corroboramos a tradução de Teixeira (2008) e também sugerimos:

freshly ground black pepper = pimenta-do-reino moída na hora. 
- freshly grated nutmeg:

Considerando-se que na hora é a forma equivalente mais adequada para o advérbio freshly, como observamos na análise anterior, iniciamos nossa busca pelo ingrediente, ou seja, noz-moscada. Nos 724 resultados de noz moscada (não utilizamos o hífen, apesar de ser a forma mais usada, para recuperar também as ocorrências em que porventura não tenha sido utilizado), encontramos 75 ocorrências de noz(-)moscada ralada e, dentre essas, destacou-se a colocação noz(-)moscada ralada na hora, com 10 ocorrências, o que mais uma vez (como no caso de pimenta-do-reino), demonstra que a forma equivalente de freshly não é um advérbio terminado em -mente. Nossa sugestão de tradução é:

freshly grated nutmeg $=$ noz-moscada ralada na hora .

\section{- freshly chopped parsley:}

Decidimos analisar as 32 ocorrências dessa colocação para verificar se a tradução de freshly como na hora se manteria no campo das ervas, o que de fato se comprovou. Iniciamos a análise a partir do substantivo salsa. Encontramos 307 ocorrências de salsa picada, 44 de salsa picadinha, além de 9 de salsa bem picada. Em 4 linhas, observamos a presença do adjetivo fresca, formando a unidade salsa fresca picada. No caso analisado, no entanto, o advérbio refere-se ao processo, não ao substantivo, o que descarta essa colocação como forma equivalente. Fomos também buscar uma outra opção de tradução utilizada para parsley, ou seja, salsinha. Nas 1.992 linhas de concordância desse substantivo, identificamos as colocações salsinha picada (698), salsinha bem picada (8) e salsinha picadinha (6). Apesar de encontrarmos apenas uma única ocorrência, chamou-nos a atenção o agrupamento salsinha picada na hora de servir, mas seu uso irá depender do contexto. Apresentamos abaixo nossas sugestões.

- freshly chopped parsley = salsa/salsinha (bem) picada na hora; salsa/salsinha picadinha na hora. 


\section{- GENTLY}

\section{- cover and simmer gently:}

Em consulta ao dicionário Houaiss (1982), encontramos as seguintes opções de tradução para o advérbio gently: suavemente, mansamente, docemente, delicadamente; paulatinamente, meigamente, ternamente, brandamente, bondosamente. De forma descontextualizada, fica difícil para o produtor de textos optar por uma ou outra tradução, especialmente em uma área de linguagem especializada. Com isso, decidimos partir do verbo mais próximo ao advérbio, ou seja, simmer, que apresenta ferver ou cozinhar em fogo brando como opções de tradução. Ao buscarmos cozinh* (8.619 oc.), encontramos as seguintes colocações, que podem compor a forma equivalente da unidade acima: cozinh ${ }^{*}$ em fogo baixo (276); cozinh ${ }^{*}$ em fogo brando (135); cozinh ${ }^{*}$ lentamente (35); cozinh ${ }^{*}$ em fogo lento (12); cozinhe em fogo bem baixo (4) / brando / lento. Para traduzir o verbo cover, decidimos continuar a investigação nas ocorrências de cozinh ${ }^{*}$, uma vez que buscávamos uma unidade que contivesse as opções de tradução de simmer. Encontramos os verbos TAMPAR e COBRIR, que poderiam ser considerados como formas equivalentes. Ao observarmos as concordâncias de cover and simmer gently, no entanto, verificamos que a melhor opção seria TAMPAR, já que a colocação referia-se a um recipiente em todas as ocorrrências. Com isso, sugerimos as colocações abaixo, como formas equivalentes.

- cover and simmer gently = tampe (a panela) e cozinhe em fogo baixo; tampe (a panela) e cozinhe em fogo brando; tampe (a panela) e cozinhe lentamente; tampe (a panela) e cozinhe em fogo lento.

\section{- simmer gently for a few minutes:}

Nesse caso, utilizamos cozinh ${ }^{*}$ em fogo ${ }^{*}$ por $^{120}$ como nossa expressão de busca, que apresenta as diferentes formas do verbo cozinhar e quaisquer adjetivos que venham a ocorrer depois da palavra fogo. Nas 231 concordâncias geradas, temos: cozinh* em fogo baixo por (110); cozinh* em fogo brando por (44); cozinh* em fogo lento por, além da unidade por alguns minutos (4). Como já havíamos sugerido formas equivalentes para simmer gently, apenas acrescentamos a unidade

\footnotetext{
${ }^{120}$ Nesse caso, o segundo asterisco representa qualquer palavra que venha a ocorrer entre fogo e por.
} 
de tempo. Observamos, no entanto, que em português o tempo geralmente é mais definido (com um numeral), como em Despeje a mistura em uma panela e cozinhe em fogo baixo por 5 minutos, até encorpar.

simmer gently for a few minutes = cozinhe em fogo baixo por alguns minutos; cozinhe em fogo brando por alguns minutos; cozinhe lentamente por alguns minutos; cozinhe em fogo lento por alguns minutos.

\section{- over a pan of gently simmering water:}

Partindo das 9.379 linhas de concordância geradas para água, encontramos 754 ocorrências de água fervente, colocação que, em um primeiro momento, poderia ser considerada como parte integrante (equivalente de simmering water) de uma unidade maior. No entanto, decidimos reavaliar essa possibilidade ao retomarmos nossa análise da colocação em inglês e observarmos sua frequente co-ocorrência com o substantivo chocolate na mesma oração. Decidimos então buscar essa palavra, no corpus em português, para analisar sua co-ocorrência com água ou formas de cozimento em que seu uso estivesse implícito. Chegamos à conclusão que, no preparo de chocolate (2.079 oc. em português), a colocação em banhomaria é a mais utilizada quando esse ingrediente é preparado em um outro recipiente colocado em água fervente - são 57 ocorrências de chocolate em banhomaria, precedidas do verbo DERRETER ou DISSOLVER. Com isso, utilizaríamos a unidade em banho-maria como forma funcionalmente equivalente para a tradução da colocação acima:

- over a pan of gently simmering water = em banho-maria (refere-se ao preparo de um ingrediente, como o chocolate, em um outro recipiente, que deve ser colocado em água fervente). Exemplos: Derreta o chocolate em banho-maria e o adicione à mistura, batendo bem.; Dissolva o chocolate em banho-maria, acrescente a glucose de milho e misture bem até formar uma pasta.

\section{- heat gently until melted:}

Nesse caso, decidimos iniciar nossa investigação com duas sugestões de tradução para until melted, ou seja, até dissolver (127) e até derreter (88). Nosso objetivo era verificar uma provável co-ocorrência com o verbo AQUECER e uma expressão modalizadora que equivalesse ao advérbio gently. Chamaram nossa atenção os agrupamentos aqueça em fogo baixo, mexendo sempre, até dissolver 
(7), leve ao fogo até dissolver (4); fogo baixo até derreter (4), leve ao fogo até derreter (3). Na sequência, partimos para as linhas de concordância de aqueça (2.052) e aquecer (355), numa tentativa de verificar a co-ocorrência com os verbos derreter e dissolver. Além desses verbos, frequentemente relacionados a AQUECER, identificamos os agrupamentos aqueça em fogo baixo (15); aqueça levemente (5); aqueça ligeiramente (5); LEVAR ao fogo para aquecer (27); aquecer levemente (5); aquecer ligeiramente. Verificamos a presença dos ingredientes manteiga, açúcar e chocolate, também relacionados aos verbos da colocação analisada em inglês. Diante desses resultados, sugerimos as formas equivalentes abaixo - interessante observar que um advérbio terminado em -mente pode ser utilizado, mas que não é necessariamente um equivalente prima facie de gently:

- heat gently until melted = aqueça em fogo baixo até dissolver/derreter; aqueça ligeiramente/levemente até dissolver/derreter

- gently fry:

Utilizamos a expressão frit* para levantar as ocorrências de fritar e frite, juntamente com alguma expressão que apresentasse o sentido de gently, ou seja, de modo rápido. Devido ao grande número de ocorrências (frit ${ }^{\star}=2.062$ oc.), optamos por levantar apenas as formas frite (1.165) e fritar (359). Nesses resultados, observamos, como em inglês, a co-ocorrência com os ingredientes alho e cebola. Para análise, consideramos as unidades frite ligeiramente (12); frite levemente (6); frite rapidamente (6); fritar levemente (4); fritar ligeiramente. Nas concordâncias de fritada (49), chamou-nos a atenção a expressão dê uma ligeira fritada, mesmo com apenas uma ocorrência. A nosso ver, ela reflete o significado da colocação em inglês e poderia ser considerada uma de suas formas equivalentes.

Além de modalizar o verbo, acreditamos que gently está relacionado ao tempo de fritura, que pode ser breve, como no caso do preparo do alho e da cebola para que outros ingredientes sejam acrescentados na sequência.

Uma outra forma equivalente para fry, especialmente em co-ocorrência com alho e cebola (e pode-se dizer com temperos em geral), é o verbo REFOGAR. Nos resultados de refogar (314) e refogue (1.720), observamos a frequência de coocorrência com alho e cebola - refogue a(s) cebola(s) (236); refogue o alho (65); refogar a cebola (50); refogar o alho (18). Quanto à co-ocorrência com um advérbio que contenha o sentido de gently, temos: refogue rapidamente (32); refogue 
levemente (4); refogar rapidamente (4); refogue ligeiramente (2); refogar ligeiramente. Considerando-se a frequência do verbo, podemos observar que a associação a um advérbio não é tão frequente, uma vez que ele mesmo já contém a ideia de que, quando associado aos ingredientes alho e cebola, por exemplo, o processo pode ser rápido. O que observamos, nas ocorrências do verbo em geral (entenda-se com outros ingredientes), são unidades de tempo como por alguns minutos e por + NUM + minutos.

Diante das considerações acima, nossas sugestões de formas equivalentes são:

gently fry = fritar/frite ligeiramente/levemente/rapidamente; dê uma ligeira fritada; refogar/refogue rapidamente/levemente/ligeiramente.

\section{- gently bring to the boil:}

Iniciamos nossa pesquisa analisando as seis concordâncias da colocação em inglês. Diante de nossas observações, consideramos, em português, as expressões até ferver e até levantar fervura para uma primeira busca. Nesses dados, as ocorrências que chamaram nossa atenção são: leve ao fogo até ferver (38); cozinhe até ferver (9); leve ao fogo até levantar fervura (4); deixe no fogo até levantar fervura (2); leve ao fogo baixo até ferver (2); cozinhe em fogo baixo até ferver. Com esses resultados, observamos que o sentido de gently é veiculado através da colocação fogo baixo, diferente do uso do advérbio na colocação anteriormente analisada, o que reforça nossas sugestões de formas equivalentes apresentadas abaixo:

- gently bring to the boil = cozinhe em fogo baixo até ferver/levantar fervura; leve ao fogo baixo até ferver/levantar fervura.

\section{- LIGHTLY}

- lightly floured surface:

Inicialmente, levantamos as ocorrências da palavra superfície (848), com o objetivo de observar as co-ocorrências com enfarinhada. Foram encontradas 117 ocorrências de superfície enfarinhada, que se associa aos advérbios levemente e ligeiramente, formando as colocações superfície levemente enfarinhada (5) e superfície ligeiramente enfarinhada (4). Ainda nos dados da palavra superfície, encontramos superfície polvilhada com farinha (27), o que nos leva a sugerir as 
formas equivalentes abaixo para a colocação lightly floured surface. Interessante observar que, nesse caso, um advérbio terminado em -mente deve ser utilizado em português.

- lightly floured surface = superfície levemente/ligeiramente polvilhada com farinha; superfície levemente/ligeiramente enfarinhada.

- until lightly browned:

Nossa primeira opção de busca foi a expressão até dourar. Encontramos frequência de co-ocorrência com dois advérbios, formando as unidades até dourar levemente (28) e até dourar ligeiramente (24). No entanto, resolvemos investigar apenas o verbo dourar, no sentido de buscarmos uma outra opção de tradução. Alinhando os dados à esquerda do verbo (1.545 oc.), surpreendemo-nos com sua associação ao verbo começar, que apresenta 175 ocorrências de COMEÇAR a dourar. Dentre elas, interessam-nos: até ([INGREDIENTE]) começar a dourar (55); até começarem a dourar (14); até que comece a dourar (11); até que comecem a dourar (9). Nesse caso, o verbo começar (associado a até) carrega, nas associações acima, o sentido de lightly, qual seja, o de brevidade, pouco, o que inclui essas unidades como opções de formas equivalentes.

Diante dessas observações, sugerimos até começar a dourar e até que comece a dourar como opções mais adequadas. No entanto, são também viáveis as unidades formadas com os advérbios levemente e ligeiramente. Em ordem decrescrente de uso, sugerimos:

- until lightly browned = até começar a dourar; até que comece a dourar; até dourar levemente/ligeiramente.

- lightly oiled bowl:

Partindo da tradução de bowl como tigela, geramos as linhas de concordância e chegamos a tigela untada com óleo (4) / manteiga (3) / azeite (2). Decidimos então levantar as ocorrências de untad* ${ }^{*} \mathrm{com}$, a fim de verificar suas associações à palavra óleo. Nesses dados, buscamos também quaisquer advérbios terminados em -mente que porventura pudessem estar relacionados à expressão de busca, mas nada foi encontrado. No entanto, chamou nossa atenção o agrupamento UNTADO com um pouco de/da + substantivo (ingredientes como manteiga, óleo e margarina), o que 
nos levou a concluir que pouco seria a palavra mais adequada para transmitir o sentido do advérbio lightly, em inglês, gerando a forma equivalente abaixo:

- lightly oiled bowl = tigela untada com um pouco de óleo.

\section{- THINLY}

- thinly sliced:

A partir das linhas de concordância de fatiad $^{*}$, identificamos as ocorrências FATIADO finamente (29); FATIADO (bem) FINO (8); fatiada bem fininha. Nas 337 ocorrências de finamente, observamos a frequência do verbo fatiar, com fatie finamente (34) e finamente FATIADO (5), além do verbo cortar, que apresentou 8 ocorrências CORTADO finamente. Decidimos também verificar as ocorrências de fatias, no sentido de buscar alguma referência à forma de ser cortada. Das 2.925 concordâncias encontradas, ativemo-nos à análise de em fatias (790oc.), que compõe as seguintes associações: CORTADO em fatias finas (62); CORTADO em fatias bem finas (5); CORTAR em fatias finas (29); cortar ([INGREDIENTE]) em fatias bem finas (16). Considerando-se o contexto e a frequência de uso dos dados analisados, nossa sugestão de tradução é:

- thinly sliced $=$ CORTADO em fatias $($ bem) finas.

- peeled and thinly sliced:

Depois de verificarmos as ocorrências da colocação em inglês, decidimos iniciar a busca com a expressão descascad* $e$, com o objetivo de verificar a quais outras palavras ela estaria relacionada. Nos resultados, havia 9 ocorrências de DESCASCADO e CORTADO em fatias, seguido de (bem) finas em 4 delas. Ainda em busca de uma opção com maior frequência de uso, buscamos apenas descas* $e$, para observar o verbo descascar em suas várias conjugações. No entanto, não houve resultados que alterassem nossas observações. Levando em conta a análise anterior da colocação thinly sliced, sugerimos a seguinte forma equivalente:

- peeled and thinly sliced = DESCASCADO e CORTADO em fatias (bem) finas.

\section{- thinly spread:}

Iniciamos nossa investigação buscando o verbo espalhar no corpus em português, com a expressão espal ${ }^{*}$. Os resultados apresentaram ocorrências de 
espalhar e espalhe. Nelas, encontramos espalhar uma camada de (5) e espalhe uma camada de (2), ambas seguidas de algum ingrediente. Com apenas 2 ocorrências, identificamos espalhe uma fina camada de (seguida de ingrediente). Apesar de pouco frequentes, assim como a colocação em inglês, com 5 ocorrências, consideramos essas associações ao apresentarmos nossa sugestão de equivalência:

thinly spread = espalhe uma camada fina de (seguido de ingrediente).

Numa tentativa de identificar, em português, formas equivalentes para algumas das colocações levantadas em inglês, pudemos observar que a equivalência entre um advérbio terminado em -ly e outro terminado em -mente nem sempre é a opção mais adequada na tipologia das receitas culinárias. Em vários casos, o sentido do advérbio é transferido para outra palavra da colocação, que pode pertencer a outra classe gramatical. É o caso, por exemplo, de thinly spread: enquanto em inglês temos o advérbio thinly para expressar o modo como o ingrediente deve ser espalhado, em português a melhor opção é utilizar camada fina. As análises acima estão recheadas de exemplos que podem melhor ilustrar essas considerações.

$\mathrm{Na}$ sequência, decidimos investigar as colocações e formas equivalentes acima identificadas nos corpora de língua geral, numa tentativa de classificá-las como típicas das receitas culinárias.

3.1.5 As fraseologias analisadas em receitas culinárias e suas formas equivalentes nos corpora de língua geral

Listamos abaixo todas as fraseologias e formas equivalentes analisadas na seção anterior. Dentre elas, selecionamos aquelas em negrito para investigação no BNC, em inglês, e no Banco de Português. Caso necessário, consultaremos também o COCA, para o inglês. Nesta parte da pesquisa, nosso objetivo é verificar se elas ocorrem nos corpora de referência e, quando isso acontece, se podemos identificálas como pertencentes à tipologia das receitas culinárias. 


\begin{tabular}{|c|c|}
\hline FRASEOLOGIA EM INGLÊS & FORMA(S) EQUIVALENTE(S) EM PORTUGUÊS \\
\hline finely chopped & bem PICADO, (bem) PICADINHO \\
\hline peeled and finely chopped & DESCASCADO e (bem) PICADO \\
\hline seeded and finely chopped & sem sementes, PICADO; PICADO (e) sem sementes \\
\hline onions, finely sliced & $\begin{array}{l}\text { cebolas (cortadas) em rodelas (bem) finas; cebolas } \\
\text { (cortadas) em fatias (bem) finas; cebolas cortadas } \\
\text { fino/fininho }\end{array}$ \\
\hline finely grated & ralado \\
\hline freshly ground black pepper & pimenta-do-reino moída na hora \\
\hline freshly grated nutmeg & noz-moscada ralada na hora \\
\hline freshly chopped parsley & $\begin{array}{l}\text { salsa/salsinha (bem) picada na hora; salsa/salsinha } \\
\text { picadinha na hora }\end{array}$ \\
\hline cover and simmer gently & $\begin{array}{l}\text { tampe (a panela) e cozinhe em fogo baixo; tampe } \\
\text { (a panela) e cozinhe em fogo brando; tampe (a } \\
\text { panela) e cozinhe lentamente; tampe (a panela) e } \\
\text { cozinhe em fogo lento }\end{array}$ \\
\hline simmer gently for a few minutes & $\begin{array}{l}\text { cozinhe em fogo baixo por alguns minutos; cozinhe } \\
\text { em fogo brando por alguns minutos; cozinhe } \\
\text { lentamente por alguns minutos; cozinhe em fogo } \\
\text { lento por alguns minutos }\end{array}$ \\
\hline over a pan of gently simmering water & em banho-maria \\
\hline heat gently until melted & $\begin{array}{l}\text { aqueça em fogo baixo até dissolver/derreter; } \\
\text { aqueça ligeiramente/levemente até dissolver/ } \\
\text { derreter }\end{array}$ \\
\hline gently fry & $\begin{array}{l}\text { fritar/frite ligeiramente/levemente/rapidamente; dê } \\
\text { uma ligeira fritada; refogar/refogue rapidamente/ } \\
\text { levemente/ligeiramente }\end{array}$ \\
\hline gently bring to the boil & $\begin{array}{l}\text { cozinhe em fogo baixo até ferver/levantar fervura; } \\
\text { leve ao fogo baixo até ferver/levantar fervura }\end{array}$ \\
\hline lightly floured surface & $\begin{array}{l}\text { superfície levemente/ligeiramente polvilhada com } \\
\text { farinha; superfície levemente/ligeiramente } \\
\text { enfarinhada }\end{array}$ \\
\hline until lightly browned & $\begin{array}{l}\text { até começar a dourar; até que comece a dourar; } \\
\text { até dourar levemente/ligeiramente }\end{array}$ \\
\hline lightly oiled bowl & tigela untada com um pouco de óleo \\
\hline thinly sliced & CORTADO em fatias (bem) finas \\
\hline peeled and thinly sliced & DESCASCADO e CORTADO em fatias (bem) finas \\
\hline thinly spread & $\begin{array}{l}\text { espalhe uma camada fina de (seguido de } \\
\text { ingrediente) }\end{array}$ \\
\hline
\end{tabular}

Quadro 8 - Algumas fraseologias em inglês e suas formas equivalentes em português (Culinária)

Apresentamos abaixo os resultados de nossa investigação: 
- finely chopped:

Em todas as 108 ocorrências do BNC, finely chopped fazia parte de receitas culinárias. Na busca no COCA, o mesmo foi observado nas 100 ocorrências coletadas por amostragem a partir das 1.543 linhas de concordância apresentadas.

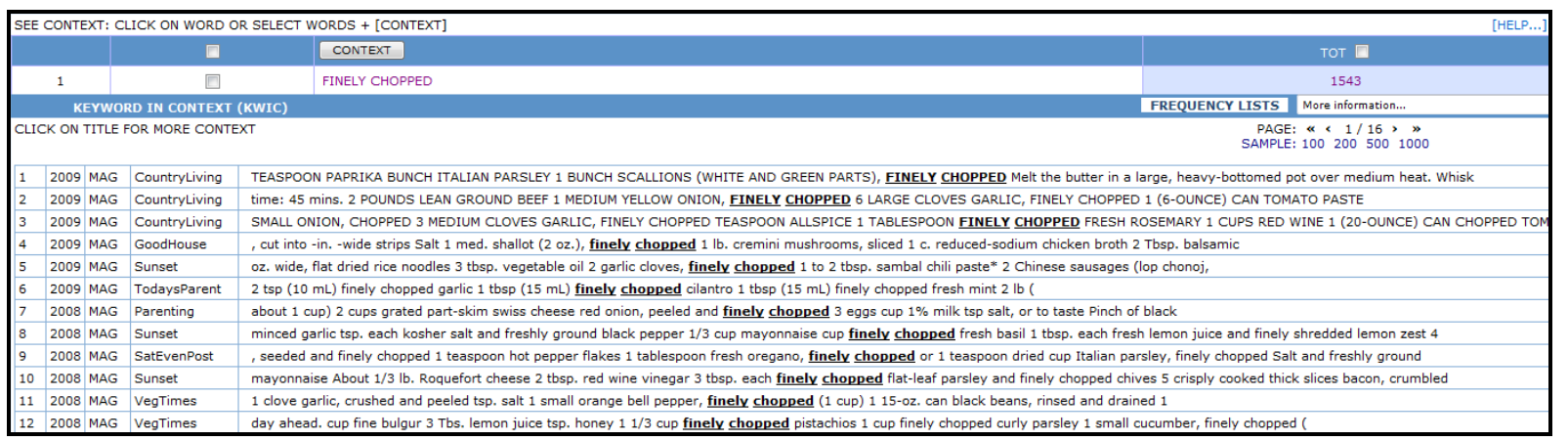

Figura 25 - Alguns resultados de finely chopped no COCA

- bem picado:

Todas as 35 ocorrências de bem picado registradas no Banco de Português ${ }^{121}$ encontram-se em receitas culinárias.

- freshly grated nutmeg:

Nas 5 ocorrências encontradas no BNC, apenas uma não era em receita, mas em um texto da área da Culinária. No COCA, apenas algumas das 38 ocorrências não eram em receitas, mas em todas elas o contexto referia-se a alimentos, como em: She called two days later to tell me that she added cream to the leftover pasta, heated it slowly in a saucepan, added a touch of freshly grated Parmesan and a touch of freshly grated nutmeg. Apesar de a fonte apresentada indicar tratar-se de um texto jornalístico, na realidade temos uma receita inserida em um texto narrativo.

- noz-moscada ralada na hora:

As quatro ocorrências apresentadas encontram-se em receitas culinárias.

- cover and simmer gently:

Todas as ocorrências no BNC (6) e no COCA (13) eram em receitas culinárias.

121 Todos os dados do Banco de Português apresentados nesta seção foram levantados com o programa WordSmith Tools (versão 5), considerando-se o corpus na íntegra. 
- tampe (a panela) e cozinhe em fogo baixo:

Nesse caso, fizemos a busca considerando tampe e cozinhe em fogo baixo. Foram encontradas 5 ocorrências e todas elas estavam em receitas culinárias.

- until lightly browned:

Todas as ocorrências no BNC (7) e as 100 levantadas por amostragem no COCA (total de 344 ocorrências) eram em receitas culinárias, mais especificamente no Modo de Fazer.

- até começar a dourar:

Foram encontradas apenas 4 ocorrências, todas em receitas culinárias.

- thinly sliced:

Das 25 ocorrências apresentadas no BNC, apenas 6 não eram em receitas, mas se referiam a alimentos em todos os casos. No COCA, todas as 100 linhas de concordância selecionadas por amostragem (são 1.438 ocorrências no total) apresentaram a colocação em receitas culinárias.

- cortado em fatias (bem) finas:

Optamos por fazer a busca sem o advérbio bem, considerando a expressão cortad $^{*}$ em fatias finas. Nas 19 linhas de concordância geradas, observamos que a expressão não se encontrava em receitas em apenas 3 delas. No entanto, relacionavam-se ao preparo de alimentos em todas elas.

Diante desses resultados, podemos afirmar que as unidades levantadas em inglês, bem como as formas equivalentes apresentadas a partir de uma investigação no corpus de receitas culinárias em português, pertencem à tipologia das receitas.

Na próxima seção, passaremos à análise dos advérbios na área do Direito, mais especificamente, na tipologia dos contratos. 


\subsection{Os advérbios no Direito}

A) Os advérbios nos contratos em inglês

Passaremos agora à análise dos cinco primeiros advérbios com maior índice de chavicidade em inglês, na área do Direito, mais especificamente do Direito Contratual. São eles: promptly, reasonably, expressly, duly e collectively.

Devido ao tamanho dos corpora, há de se observar que o número de dados para análise é significativamente menor, mas sempre mantendo o balanceamento entre as línguas. Em cada uma delas, temos 140 textos que englobam 28 tipos diferentes de contratos. Nesse caso, poderemos tecer comentários mais precisos nessa área de especialidade quanto à dispersão de cada advérbio nos arquivos, uma vez que cada um deles compreende um texto diferente, o que não ocorreu na área da Culinária. Decidimos elencar as unidades encontradas a partir da palavra com a qual o advérbio se relaciona, seguidas de análise, bem como reduzir o número de corte para quatro ocorrências.

- PROMPTLY

\begin{tabular}{|c|c|c|c|c|c|c|}
\hline$N$ & adv-chave & freq. CE & $\%$ CE & freq. CR & $\%$ CR & chav. \\
\hline 146 & promptly & 275 & 0,04 & 948 & & $1.480,30$ \\
\hline
\end{tabular}

Dispersão nos arquivos:

CE: $70(50 \%)$

CR: $592(14,60 \%)$

Normalização das frequências:

CE: 0,42 ocorrência em cada mil palavras

CR: resultado inexpressivo $(0,00097$ ocorrência em cada mil palavras)

O advérbio promptly encabeça a lista, com 275 ocorrências no CE. É encontrado em 50\% dos textos (cada texto representa um arquivo), índice significativamente menor no CR, onde o advérbio é encontrado em $14,6 \%$ dos arquivos. Quanto à normalização das frequências, promptly é encontrado uma vez em aproximadamente cada duas mil palavras no CE. Apresentamos abaixo a análise das linhas de concordância desse advérbio. 


\section{$>0$ advérbio promptly e os modais shall e will}

Nos dados analisados, observamos que shall e will são frequentemente utilizados para modalizar, junto com promptly, o verbo que se segue. São 88 ocorrências de shall promptly e 24 de will promptly, ambos seguidos de verbo (não necessariamente como primeira ocorrência após o advérbio). Exemplos:

Supplier shall promptly replace or correct, at Purchaser's option, returned Products or other Products not conforming to the warranty in Section.

Each party will promptly execute and deliver or cause to be executed and delivered all such other and further instruments, documents or assurances [...].

Há 4 ocorrências em que will aparece abreviado como 'll, sempre precedido de you, anteposto ao advérbio: You'll promptly and continuously comply, at your sole expense, with all provisions of, and additions/deletions/changes to, the Manuals.

Em 6 ocorrências, shall ocorre entre o advérbio e o verbo: When any of these governing documents are modified or changed, you promptly shall provide copies to us. Com will, identificamos apenas uma ocorrência: Upon Lessor's request, Lessee promptly will notify Lessor in writing of the location of any Equipment as of the date of such notification.

\section{$>0$ advérbio promptly e o uso da voz passiva}

Identificamos 11 ocorrências de be promptly $+v_{p p}$, precedida de shall na maior parte das ocorrências: Charges for taxes, penalties and interest shall be promptly paid by Lessee.

\section{$>0$ advérbio promptly e o verbo notify}

A co-ocorrência lexical mais frequente de promptly é com o verbo notify, formando a colocação promptly notify. A primeira busca foi com a expressão promptly notif*, que apresentou 30 ocorrências com as variações notify (23), notifies (6) e notified. Em 29 delas, a colocação é seguida da categoria semântica [RECEPTOR] e, na maior parte das ocorrências, precedida de um verbo modal - shall (o mais frequente) e will (não necessariamente como primeira palavra à esquerda da 
colocação). As unidades de sentido maiores, identificadas a partir da expressão de busca acima, são:

- [EMISSOR] + shall promptly notify + [RECEPTOR] (12):

[EMISSOR] e [RECEPTOR] representam as partes envolvidas no acordo.

Exemplos:

The Agent shall promptly notify the Lender of such notice and specify the Drawdown Date.

Each party shall promptly notify the other upon discovery of any unauthorized use or disclosure of the Confidential Information.

- promptly NOTIFY + [RECEPTOR] + in writing (11):

The Borrower shall promptly notify the Agent in writing of the occurrence of any event which might materially adversely affect the Borrower [...].

Supplier shall promptly notify Purchaser in writing if an item of such Property requires replacement or major repair [...].

- [EMISSOR] + promptly notifies + [RECEPTOR] (6):

[...] provided that TiVo (A) promptly notifies DIRECTV, in writing, of all such Claims [...].

[...] provided that Licensee promptly notifies Institution in writing of any claim.

- [EMISSOR] + will promptly notify + [RECEPTOR] (4):

[...] the insurers will promptly notify Landlord and the Note Purchaser and any such lapse, cancellation, termination or change [...].

[...] the Depository will promptly notify the Secretary and the Shipowner.

Em todas as linhas de concordância, observamos que há sempre uma das partes notificando a outra envolvida, acima representadas por categorias semânticas mais gerais. Essas partes ou são identificadas pelo nome da empresa ou por termos como lender (6), purchaser (5), seller (2), supplier (2), company, warrantholder, borrower, agent e buyer (os dois primeiros são mais frequentes à direita da colocação). 


\section{$>0$ advérbio promptly associado a outros verbos}

- promptly pay (15):

É precedido de shall em 12 ocorrências: The paying party shall promptly pay or reimburse all federal, state, and local Taxes [...]. Quando o que deve ser pago é citado, essa informação vem logo após a colocação (objeto direto). Quando a fonte recebedora é mencionada na sequência, é introduzida pela partícula to: [...] Customer shall promptly pay to Cisco the appropriate licensee fee for the additional computers or users.

- pay promptly (6):

A posposição do advérbio é menos frequente: Franchisee shall pay promptly when due all taxes, accounts, liabilities and indebtedness of any kind incurred by Franchisee in the conduct of its business.

- promptly reimburse (8), precedida de shall em quatro delas:

Supplier shall promptly reimburse Purchaser for the cost of any reworking of the Products.

- promptly execute (8):

É precedida de will em quatro ocorrências. Considerando-se as 8 linhas de concordância, identificamos o binômio execute and deliver, que forma uma unidade maior ao co-ocorrer com o advérbio - promptly execute and deliver (6): Each party will promptly execute and deliver or cause to be executed and delivered all such other and further instruments, documents or assurances [...].

- promptly make + SN (7): The Depository shall promptly make payment in accordance with the terms of a Request approved by the Secretary.

- promptly furnish (7): Upon request, the Company shall promptly furnish the Owner evidence of timely payment of such premium.

- promptly return (7), seguido de to em quatro delas: [...] Center and Institution shall promptly return to the other Party all Confidential Information of the other [...].

- promptly review (5), precedida de shall em todas as ocorrências: Purchaser shall promptly review any Additional Approved Sublease Documents [...]. 
- promptly comply (with [NORMA]) (5): Such Borrower shall promptly comply with all laws, orders and ordinances affecting the Properties [...].

- promptly remove (4): Seller shall also be obligated to (i) promptly remove such truck turnaround and restore the access road [...].

- promptly deliver (4): Such predecessor shall promptly deliver to such successor Depository all Financial Assets held in any Securities Account pursuant hereto [...].

- promptly provide (4): Borrowers shall promptly provide Lender with written notice of any litigation in which [...].

$>0$ advérbio promptly em associações com palavras gramaticais e outras classes de palavras

- SV + promptly after + SV/SN (17):

A co-ocorrência entre promptly e after indica, além da sequência das ações (vide exemplo), o imediatismo com que devem ser executadas:

Promptly after receiving a written request for release of funds under this subsection and prior to any such release, the Escrow Agent shall provide written notice to the Company [...].

Lessor shall notify Lessee promptly after the transfer by any Participant of its interest in this Lease and the related documents.

$-v+$ to promptly $+\vee(17)$

No primeiro verbo, destacam-se 8 ocorrências de $A G R E E$, formando a unidade AGREE to promptly, seguida de um outro verbo: Each party agrees to promptly give the other party notice of any claim for which indemnification might be sought.

- promptly and (14):

Nesse caso, chamou-nos a atenção a co-ocorrência com a conjunção and, indício da formação de uma unidade maior. Observamos que promptly and é seguida de um outro advérbio em 10 ocorrências, formando o padrão promptly and + ADV. São eles: promptly and fully (4); promptly and diligently (2); promptly and continuously; promptly and directly; promptly and duly; promptly and fairly. Exemplos: 
Lessee shall promptly and fully notify Lessor in writing if any item of Equipment shall be or become worn out, lost, stolen, destroyed, irreparably damaged in the reasonable determination of Lessee [...].

In addition, you shall promptly and diligently perform all necessary maintenance, repairs and replacements to your Rubio's Store [...].

- promptly upon + SUBST (13)

Os substantivos que apresentaram duas ocorrências cada são: demand, expiration, receipt e request. Exemplos:

Borrowers will reimburse Lender for all premiums paid by Lender, together with interest thereon from the date paid at the Default Rate, promptly upon demand by Lender.

Company will, promptly upon request, provide to Agent all information and evidence it may reasonably request [...].

- as promptly as + (ADV) + ADJ (4):

Em duas ocorrências, temos o adjetivo possible e, nas outras duas, practicable. Interessante observar a presença de advérbio antes do adjetivo, no exemplo abaixo:

[...] and to consummate and make effective as promptly as reasonably possible the transactions contemplated by this Warrant Agreement.

[...] use their reasonable best efforts to cooperate with one another in [...] (C) as promptly as practicable, responding to any request for information from such Governmental Entities.

Nas concordâncias em geral, observamos a frequência de alguns substantivos que delimitam o papel das partes no contrato, delimitando a categoria semântica [PARTES]. São eles: Borrower(s) (8); supplier (7); franchisee (7); Company (6); Depository (5); seller (5). Eles atuam como agentes na unidade SUBST + shall promptly + v. Exemplos:

The Borrower shall promptly notify the Agent in writing of the occurrence of any event which might materially adversely affect the Borrower [...].

Supplier shall promptly repair or replace any defective Products (or parts) or reperform any services, at its own expense. 
Em linhas gerais, pudemos observar que o advérbio promptly apresenta algumas peculiaridades quanto às classes gramaticais com as quais co-ocorre, sendo mais frequente a associação a verbos. Nessas co-ocorrências, podemos ressaltar as preposições after e upon, e a conjunção and, que integram unidades maiores; a fraseologia as promptly as, que apresenta o advérbio em estrutura utilizada para indicar imediatismo; a associação de promptly a um binômio, como verificamos em promptly execute and deliver; e a co-ocorrência com outro advérbio, como é o caso de promptly and fully. Além disso, a co-ocorrência com os modais shall e will é significativa.

- REASONABLY

\begin{tabular}{|c|c|c|c|c|c|c|}
\hline$N$ & adv-chave & freq. $C E$ & $\%$ CE & freq. CR & $\%$ CR & chav. \\
\hline 163 & reasonably & 344 & 0,05 & 3.027 & & $1.284,59$ \\
\hline
\end{tabular}

Dispersão nos arquivos:

CE: $74(52,86 \%)$

CR: $1.281(31,60 \%)$

Normalização das frequências:

CE: 0,53 ocorrência em cada mil palavras

CR: resultado inexpressivo $(0,0031$ ocorrência em cada mil palavras)

Como podemos observar nos dados acima, reasonably apresenta grande dispersão nos arquivos do CE, sendo encontrado em mais de $50 \%$ deles. Essa observação também é válida para o $C R$, que registra 0 advérbio em aproximadamente $30 \%$ de seus arquivos. Podemos melhor verificar sua presença significativa na área do Direito Contratual quando observamos a normalização das frequências: reasonably ocorre uma vez a cada duas mil palavras. Já no CR, os resultados não são expressivos.

Apesar de ser o segundo advérbio quanto ao índice de chavicidade, reasonably é o mais frequente em nosso corpus de estudo. Apresentamos abaixo os resultados da análise das 344 linhas de concordância onde foi encontrado, enfatizando as co-ocorrências mais frequentes.

Como em análises anteriores, levantamos os padrões desse advérbio baseados na frequência, desde associações que envolvem apenas classes 
gramaticais, até aquelas mais fixas, caso da colocação reasonably request. Incluiremos também a co-ocorrência com palavras gramaticais, caso a frequência seja acima de quatro.

Ao analisarmos as linhas de concordância e ordená-las na sequência $1^{a}$ palavra à esquerda, seguida da $1^{\mathrm{a}}$ e $2^{\mathrm{a}}$ à direita do nódulo, chamou-nos a atenção a unidade may reasonably $+\mathrm{v}(49)$. Diferente de promptly, reasonably é mais frequentemente precedido de um outro modal, ou seja, may, tendo request e require como verbos mais recorrentes na sequência. Ex: [...] such other documents and instruments as Lender may reasonably require. Shall também é usado, mas em um número menor de ocorrências (13), e seguido de verbos diversos. Ex.: Seller shall reasonably cooperate with Purchaser to transfer in an electronic format usable to Purchaser [...]. Encontramos também co-coorrências com CAN (8): Purchaser shall have no obligation for work done after the notice or for work done that Supplier could reasonably have avoided. Assim como may, o verbo BE é bastante frequente, formando a unidade $B E$ reasonably $+A D J / V_{p p}$, que implica também o uso de voz passiva (48 ocorrências no total): [...] the estimated cost to remediate such environmental condition is reasonably estimated by Purchaser's consultant [...]. $\mathrm{O}$ verbo BE também ocorre depois do advérbio, quando este é precedido de modal. Nesse caso, temos MODAL + reasonably + BE + ADJ $/ \mathrm{V}_{\mathrm{pp}}$, como este exemplo que apresenta a voz passiva: If the alleged default cannot reasonably be corrected within such ten (10) day period, the party alleged [...].

Outros agrupamentos recorrentes são:

- as reasonably $+\mathrm{ADJ} / \mathrm{V}_{\mathrm{pp}}(21)$, destacando-se a unidade as soon as reasonably possible/practicable (5):

[...] so long as that party uses all reasonable efforts to correct the default as soon as reasonably possible during that twenty (20) day period.

[...] Deposit Materials shall be provided in sufficient detail and quantity as reasonably necessary to enable ACLA or its contract manufacturer to [...].

- (other customary closing) documents reasonably + ADJ $/ \mathrm{V}_{\mathrm{pp}}(9)$ :

[...] and (viii) any other closing documents reasonably requested by Title Company. 
$\mathrm{Na}$ sequência, apresentaremos as demais unidades encontradas, encabeçadas por uma colocação de duas palavras.

\section{$>$ advérbio reasonably e o verbo request}

São 31 ocorrências de reasonably request, sendo precedida do modal may em 25 delas. Junto com o advérbio, may modaliza o significado do verbo. Exemplos:

Evidence of such insurance coverage shall be furnished to Lessor no later than the Acceptance Date set forth in the Equipment Schedule(s) and, from time to time, thereafter as Lessor may reasonably request.

The Pledge Holder shall execute and deliver [...] to Pledgors all such proxies and other instruments as Pledgors may reasonably request for the purpose of enabling them to exercise the voting and other rights [...].

[...] such additional information regarding the Equipment or financial condition of Lessee as Lessor shall from time to time reasonably request.

Observamos também a frequência constante da fraseologia from time to time na oração, associada a reasonably request em 6 ocorrências. Temos:

- from time to time, [...] Lessor may reasonably request

- Lessor/Lender from time to time may reasonably request_(2)

- [PARTES]+ may from time to time reasonably request (2)

- Lessor shall from time to time reasonably request

Exemplo: Lessee will promptly execute and deliver to Lessor such further documents, instruments and assurances and take such further action as Lessor from time to time may reasonably request [...].

Encontramos também 17 ocorrências de reasonably requested by + [PARTES], o que denota o uso de voz passiva e a necessidade de mencionar seu agente: Lessee shall, if at any time reasonably requested by Lessor, affix in a prominent position on each item of Equipment plates [...]. 


\section{O advérbio reasonably e o adjetivo necessary}

As colocações encontradas foram:

- reasonably necessary (29):

[...] they will take those actions reasonably necessary to carry out the matters contemplated by this Agreement or any of its provisions.

- BE reasonably necessary (10):

[...] and agree to execute such documentation as is reasonably necessary to effectuate such designation.

- reasonably necessary to $+\mathrm{V}(9)$ :

[...] inspections shall occur at reasonable times and during normal business hours, to the extent reasonably necessary to determine whether the conditions of this Article are being satisfied.

- reasonably necessary or + ADJ (5) - 3 ocorrências de appropriate e 2 de desirable: Employee agrees to travel on business to the extent reasonably necessary or appropriate for the performance of his duties [...].

- DEEM reasonably necessary (4):

You shall purchase any additional equipment and smallwares as we deem reasonably necessary in connection with new menu items.

\section{> $\mathrm{O}$ advérbio reasonably e o adjetivo satisfactory}

- reasonably satisfactory (29): Borrowers shall provide Lender with evidence of such completion reasonably satisfactory to Lender.

- reasonably satisfactory to + [PARTES] (24). A categoria [PARTES] apresenta 10 ocorrências de company. Ex.: [...] including the delivery of investment representation letters and legal opinions reasonably satisfactory to the Company [...].

- (upon receipt of) evidence reasonably satisfactory to + [PARTES] (4): The Company covenants to the Warrant Holder that, upon receipt of evidence reasonably satisfactory to the Company of the loss, theft, destruction or [...]. 


\section{O advérbio reasonably e o adjetivo acceptable}

- reasonably acceptable (to) (26): [...] in an amount reasonably acceptable to Seller and Purchaser.

- (in a/the) form reasonably acceptable to (7): [...] and a detailed marketing plan in the form reasonably acceptable to Lender.

- in form and substance reasonably acceptable to (4): [...] shall furnish the Company with written agreements, documents, and opinions, in form and substance reasonably acceptable to the Company and its counsel [...].

\section{O advérbio reasonably e o verbo require}

As colocações mais frequentes são reasonably required (17) e reasonably require (13), inclusas nas unidades abaixo descritas:

- may reasonably require (12): The Title Policy shall contain such endorsements as Lender may reasonably require.

- reasonably required by + [PARTES] (6): [...] together with such site information as may be reasonably required by Franchisor to evaluate the proposed site.

\section{O advérbio reasonably e outras associações}

- reasonably BELIEVE (11): [...] if Century reasonably believes your access codes have been or may be obtained or [...].

- reasonably DETERMINE (10): If Lender reasonably determines that any Work is not being performed in a workmanlike or timely manner [...].

- reasonably possible (8): [...] that party uses all reasonable efforts to correct the default as soon as reasonably possible during that twenty (20) day period.

- reasonably incurred (8): The Company may indemnify against all expenses, including legal fees, and against all judgments, fines and amounts paid in settlement and reasonably incurred in connection with legal, administrative or investigative proceedings [...].

- expenses reasonably incurred (4): [...] any expenses reasonably incurred by Tryon and Personnel in the performance of Services hereunder [...]. 
- reasonably practicable (6): The parties agree to complete such arbitration as expeditiously as reasonably practicable.

- reasonably cooperate (with [PARTES]) (5): Seller shall reasonably cooperate with Purchaser to transfer in an electronic format usable to Purchaser [...].

- COOPERATE reasonably (with [PARTES]) (4): TWTI agrees to cooperate reasonably with ACLA regarding the formalities of shipment [...].

- reasonably likely (to) (5): [...] in such Borrower's opinion, are reasonably likely to result in a material adverse effect on any Property [...].

- reasonably approved by [PARTES] (5): [...] all other customary closing documents reasonably approved by Seller and Purchaser in connection with the consummation [...].

- reasonably expected (4): [...] the Leverage Ratio is not reasonably expected to exceed 2.0, or $3.0[\ldots]$.

Semanticamente, observamos que reasonably é utilizado, em contratos, para atenuar questões relacionadas às partes envolvidas, que por sua vez são sempre mencionadas nos papéis de administrative agent, buyer, purchaser, seller, lessor, etc. Isso também se reflete na grande co-ocorrência com o modal may, como pudemos observar nas análises acima.

Em resumo, reasonably apresenta grande frequência de co-ocorrência com o modal may, associa-se a adjetivos e verbos (em geral no particípio passado), tendo reasonably request, reasonably necessary e reasonably satisfactory como as colocações mais frequentes. Além disso, integra unidades maiores de significado, como é o caso de in form and substance reasonably acceptable to.

\section{- EXPRESSLY}

\begin{tabular}{|c|c|c|c|c|c|c|}
\hline$N$ & adv-chave & freq. CE & $\%$ CE & freq. CR & $\%$ CR & chav. \\
\hline 189 & expressly & 198 & 0,03 & 600 & & $1.109,19$ \\
\hline
\end{tabular}

Dispersão nos arquivos:

CE: $71(50,71 \%)$

CR: $222(5,48 \%)$ 
Normalização das frequências:

CE: 0,30 ocorrência em cada mil palavras

CR: resultado inexpressivo $(0,00061$ ocorrência em cada mil palavras)

Expressly apresenta ótima dispersão nos arquivos do CE, ocorrendo em aproximadamente $50 \%$ dos textos. No CR, no entanto, isso não ocorre, uma vez que o advérbio é encontrado em pouco mais de $5 \%$ dos arquivos. Quanto à normalização de frequências, o resultado é significativamente mais expressivo no CE do que no CR: enquanto no primeiro há uma ocorrência em aproximadamente cada 3 mil palavras, no segundo o resultado é praticamente nulo.

Considerado o terceiro advérbio com maior índice de chavicidade em nosso corpus de estudo, expressly apresenta 198 ocorrências no total. Abaixo, apresentamos o levantamento e análise dos padrões linguísticos encontrados.

Nas linhas de concordância, a co-ocorrência mais frequente é com a palavra gramatical as, formando as expressly (36 ocorrências) que, isoladamente, não consideramos uma unidade de sentido. Ao analisarmos as ocorrências, observamos que as expressly é precedida da palavra except em 30 delas, e sempre seguida de verbo - a maioria no particípio passado, o que a integra a vários dos padrões abaixo descritos. Dessa forma, temos except as expressly + v (30). Exemplos:

Except as expressly stated herein, this Agreement does not grant you any intellectual property rights [...].

Neither party will use any Confidential Information of the disclosing party except as expressly permitted in or required by this Agreement or as expressly authorized in writing by the disclosing party.

Observamos que expressly apresenta co-ocorrência com outros advérbios, também utilizados em situações mais formais, como é o caso dos contratos. Essas ocorrências constituem unidades maiores, que serão mencionadas no decorrer desta análise. São elas: hereby expressly (13); otherwise expressly (12) e not expressly (12). Exemplos:

The LLC is hereby expressly prohibited from merging with, or converting into, a forprofit entity. 
Except as otherwise expressly provided herein, the Seal when affixed to any written instrument [...].

[...] this Agreement does not grant you any intellectual property rights in the Software and all rights not expressly granted are reserved by [...].

Expressly é também precedido do verbo $B E$ e seguido de verbo no particípio passado em 26 ocorrências, o que denota uso frequente da voz passiva, característica da língua escrita e, em especial, de textos mais formais. Exemplo: It is expressly understood and agreed between Ritek and Image that Image must use Loan funds for the sole and exclusive purpose of [...].

A seguir, apresentamos as unidades encontradas a partir de colocações formadas por duas palavras, que encabeçam cada item.

\section{$>0$ advérbio expressly e o verbo provide}

- expressly provided (33):

Except for those regulations expressly provided in this agreement [...].

- except as expressly provided in/herein (14):

Except as expressly provided herein, nothing in this Agreement or in any Schedule [...].

- except as otherwise expressly provided in/herein (6):

Except as otherwise expressly provided herein, the Seal when affixed to any written instrument shall [...].

- except as/unless otherwise expressly provided in this agreement (6):

In addition, unless otherwise expressly provided in this Agreement, the arbitral tribunal shall have no authority [...].

\section{$>0$ advérbio expressly e o verbo authorize}

- expressly authorized (by) [PARTES] (13): You'll use the Marks only as expressly authorized by us.

- except as expressly authorized (by) [PARTES] (5): [...] shall be maintained in confidentiality by the Translator and, except as expressly authorized by the Client in writing, shall [...]. 


\section{$>0$ advérbio expressly e o verbo set forth}

- expressly set forth in/herein (15): Other than the express representations and warranties of Seller expressly set forth herein, Purchaser [...].

- except as expressly set forth in/herein (5): [...] and the Lessee shall have no right, title or interest therein or thereto except as expressly set forth in this Lease.

\section{$>$ advérbio expressly e outros verbos}

- expressly AGREE (20). Em quatro ocorrências, expressly é precedido do substantivo parties. Exemplos:

[...] it is expressly agreed that Consultant may serve as a consultant, manager, investor $[\ldots]$.

A Contract referencing these terms is governed only by these terms and by no others, except where both parties expressly agree in writing.

- expressly WAIVE (12): Seller hereby expressly waives, relinquishes and releases any right or remedy available to it at law [...].

- expressly DISCLAIM (9): Purchaser expressly disclaims any intent to rely on any such materials provided to it by [...].

- expressly permitted (8): Except as expressly permitted in writing by Lender, such Borrower shall not initiate, join in [...].

- expressly granted (7), precedida de not em cinco ocorrências: The Products are licensed, not sold, to the User for use only under the terms of this Agreement, and the Company reserves all rights not expressly granted to the User.

- expressly understood (6): It is expressly understood, however, that the Agent need not devote its entire time to such business [...].

Em linhas gerais, expressly ocorre em colocações com verbos e visa intensificar e esclarecer o significado dessa palavra, como é o caso de expressly provided e expressly authorized. Observamos também que várias colocações são precedidas de palavras que expressam exceção, como é o caso de except, unless e otherwise. Em todos os casos, o papel de expressly é sempre o mesmo: não deixar quaisquer dúvidas sobre a ação a que se refere. 
- DULY

\begin{tabular}{|c|c|c|c|c|c|c|}
\hline$N$ & adv-chave & freq. CE & $\%$ CE & freq. CR & $\%$ CR & chav. \\
\hline 216 & duly & 206 & 0,03 & 961 & & $1.000,87$ \\
\hline
\end{tabular}

Dispersão nos arquivos:

CE: $61(43,57 \%)$

CR: 569 (14,04\%)

Normalização das frequências:

CE: 0,31 ocorrência em cada mil palavras

CR: resultado inexpressivo (0,00099 ocorrência em cada mil palavras)

Conforme observado nas análises anteriores, duly também apresenta boa dispersão entre os arquivos no CE, sendo encontrado em 43\% deles. Já no CR, a porcentagem não é tão significativa - duly está presente em $14 \%$ dos arquivos. Quanto à normalização de frequências, há uma ocorrência do advérbio em aproximadamente cada 3 mil palavras no CE.

Apresentamos abaixo os padrões formados a partir da investigação do advérbio, destacando as fraseologias mais frequentes.

\section{O advérbio duly e o verbo authorize}

Duly authorized (62) / authorised (4) é a colocação mais frequente. Nas 62 ocorrências, encontramos outras unidades maiores. São elas:

- duly authorized representative(s) (15):

A claimant or duly authorized representative shall request a review by filing a written application [...].

- (respective) duly authorized officer(s) (11):

[...] the parties hereto have duly executed this Agreement by their respective $\underline{d u l y}$ authorized officers.

- duly authorized to + $\mathrm{v}(11)$. No verbo, destaca-se certify, com 4 ocorrências:

[...] a certificate of analysis signed and dated by an ACLA employee qualified and duly authorized to certify that the results [...].

- duly authorized, executed and delivered (10). Nesta unidade, observamos que o advérbio enfatiza a legalidade dos três verbos que o seguem: 
[...] The Documents have been duly authorized, executed and delivered by Lessor and constitute valid, legal and binding agreements [...].

- duly authorized by all necessary (corporate) action (6):

The execution and delivery of this Agreement by Seller [...] has been duly authorized by all necessary corporate action and no other corporate proceedings [...].

\section{$>0$ advérbio duly e o verbo execute}

A colocação duly executed apresentou 43 ocorrências. A partir dela, identificamos as unidades abaixo descritas.

- duly executed by + [PARTES] (10):

This Agreement may be amended only by written agreement duly executed by all the parties hereto.

- the parties (hereto) have duly executed this (settlement) agreement (5):

[...] the parties hereto have duly executed this Agreement by their respective duly authorized officers.

- duly executed and delivered (7):

This Warrant Agreement has been duly executed and delivered and constitutes a valid and binding obligation [...].

\section{$>0$ advérbio duly e outras associações}

- duly and + ADV (13), formando um binômio. Nessas ocorrências, destaca-se duly and validly $+\mathrm{V}_{\mathrm{pp}}(10)$ :

[...] the Shareholder has duly and validly executed and delivered this Agreement [...].

- duly organized and validly existing (under the laws of) (9):

It is duly organized and validly existing under the laws of its state of incorporation [...].

- [PARTES] (is) duly organized, validly existing and in good standing under the laws of (7):

TiVo is a corporation duly organized, validly existing and in good standing under the laws of the state of Delaware [...].

- duly given (8). Essa colocação co-ocorre com palavras que denotam entrega e recebimento, como em duly given when/if delivered by hand (3) ou duly given upon receipt (2): 
All such notices and communications shall be deemed to have been duly given when delivered by hand, if personally delivered [...].

- duly constituted (7). Em todas as ocorrências, essa colocação refere-se a meeting:

A meeting of members is duly constituted if, at the commencement of the meeting, there are present in person [...].

- duly completed and executed (5):

[...] with the Notice of Exercise attached hereto as Exhibit A-2 duly completed and executed on behalf of Holder [...].

- duly qualified to [PROPÓsITO] (5):

TiVo is duly qualified to transact business and is in good standing in each jurisdiction $[\ldots]$.

Em geral, observamos que o advérbio duly é utilizado para reforçar o rigor com que uma dada ação é executada, intensificando seu significado, como evidenciamos no binômio duly and validly, nas ocorrências de duly authorized e duly executed. Outra observação é o uso frequente do present perfect nas orações. Nas concordâncias analisadas, 35 delas apresentaram esse tempo verbal, como podemos observar em The Lease has been duly authorized, executed and delivered by the Lessee [...]. Deve-se também observar a formação de unidades maiores, como é o caso de duly authorized, executed and delivered e duly organized and validly existing (under the laws of).

- COLLECTIVELY

\begin{tabular}{|c|c|c|c|c|c|c|}
\hline$N$ & adv-chave & freq. CE & $\%$ CE & freq. CR & $\%$ CR & chav. \\
\hline 252 & collectively & 155 & 0,02 & 538 & & 832,5 \\
\hline
\end{tabular}

Dispersão nos arquivos:

CE: $51(36,43 \%)$

CR: $362(8,93 \%)$

Normalização das frequências:

CE: 0,23 ocorrência em cada mil palavras

CR: resultado inexpressivo (0,00055 ocorrência em cada mil palavras) 
Apesar de apresentar uma dispersão menor do que os advérbios anteriormente analisados, collectively é encontrado em $36 \%$ dos arquivos do CE, resultado significativamente melhor do que o observado no $\mathrm{CR}$. O mesmo ocorre quando da normalização das frequências, visto que uma ocorrência de collectively é encontrada a aproximadamente cada quatro mil palavras em nosso corpus de estudo. Apresentamos abaixo as co-ocorrências mais frequentes deste advérbio.

\section{$>0$ advérbio collectively e o verbo refer}

Nas 155 linhas de concordância, chama-nos a atenção a frequente coocorrência com referred. São 36 ocorrências de collectively referred, encontradas em:

- collectively referred to as + SN (32):

Personal Property and the Woodside Personal Property are collectively referred to as the "Personal Property."

- collectively referred to herein as $+S N(4)$ :

THIS AGREEMENT is made by and between $X$ and $X$, the EMBRYO DONOR COUPLE, (also referred to herein as "DONORS"), and $X$ and $X$ the EMBRYO DONOR RECIPIENTS, (also referred to herein as "INTENDED PARENTS" and/or "RECIPIENTS") (all of the above are collectively referred to herein as the "Parties" or "Party").

- hereinafter collectively referred to as + SN (18):

[...] referred to as "RECIPIENT", and MONTANA STATE UNIVERSITY, hereinafter collectively referred to as "OWNER".

É também frequente a sequência collectively(,) SN (iniciando com the 56 vezes), ou seja, o advérbio collectively seguido de sintagma nominal, geralmente entre parênteses (89 ocorrências no total). Ao analisá-las, verificamos que a colocação referred to as estava implícita, como podemos observar nos exemplos abaixo:

All trademarks, service marks, [...] and brand names used in connection with any of the Publications identified on Schedule 3.11 (collectively, the "Intellectual Property") and the goodwill related thereto.

THIS SETTLEMENT AGREEMENT ("Agreement") is executed this 17th day of December, 2002, by and between Varitek Industries, Inc., a Texas Corporation 
("Varitek"), and Technetics, Inc., a California corporation, doing business as SMTEK San Diego (collectively, the "Parties").

Ao alinharmos as ocorrências à esquerda da expressão de busca, identificamos novamente o verbo referred, não necessariamente como primeira palavra, em 6 ocorrências: Hereinafter, Dell and InterVideo shall be referred to collectively as the "Parties." Ainda nessa disposição dos dados, observamos que individually (8) e each (5) são utilizados para contrastar com collectively, unidos pela conjunção and. Exemplo: [...] are individually referred to as a "Property" and collectively referred to as the "Properties."

\section{$>0$ advérbio collectively e outras associações}

Nas ocorrências abaixo, o sentido de collectively é o mesmo observado nas análises acima:

- MEAN(,) collectively(,) (9):

"Hazardous Materials" means, collectively, any material defined as, or considered to be, a "hazardous waste," "hazardous substance," [...].

- collectively called (4):

[...] all such debts, obligations and liabilities of Company being collectively called the "Secured Obligations".

Observamos que collectively geralmente co-ocorre com verbos no particípio passado e é utilizado para expressar o modo como as partes envolvidas ou mesmo algum trecho específico do contrato são, ou devem ser, reconhecidos. Nas fraseologias levantadas, destacamos collectively referred to as.

\subsubsection{Os advérbios em inglês nos contratos: algumas considerações}

Com os dados analisados, observamos que o uso dos advérbios na tipologia dos contratos, em inglês, é bem delimitado. Como em receitas culinárias, ele também se define de forma precisa nessa tipologia textual. É importante lembrar a grande frequência dos advérbios terminados em -ly em nosso corpus de estudo, 
visto que eles representam $27,55 \%$ do número total de advérbios no material investigado (para mais detalhes, vide capítulo II, item 2.6).

Considerando-se os cinco advérbios terminados em -ly com maior índice de chavicidade, quais sejam promptly, reasonably, expressly, duly e collectively, verificamos que todos apresentam boa dispersão nos textos, dois deles em mais de $50 \%$ do total. Em geral, esses advérbios co-ocorrem com adjetivos e verbos (a maioria no particípio passado), integrando também unidades maiores de significado, como em duly organized, validly existing and in good standing under the laws of. A partir dos advérbios, conseguimos identificar apenas algumas categorias semânticas - [EMISSOR], [RECEPTOR], [NORMA], [PARTES] e [PROPÓSITO], que não consideramos fundamentais para a definição das fraseologias levantadas.

Todos os advérbios analisados desempenham alguma função nas unidades que compõem: podem modalizar, como é o caso de collectively em collectively called; podem intensificar e melhor delimitar o sentido das palavras com as quais coocorrem, como por exemplo expressly em expressly authorized; podem indicar imediatismo na ação, caso de promptly; indicar exatidão, acentuando a legalidade, como duly em duly authorized, executed and delivered; ou mesmo podem apenas ser utilizados para cumprir o que Mellinkoff (1963, p. 190) classifica como padding, ou seja, estar ali sem qualquer carga semântica e com o fim único de inflar o discurso, como é o caso de reasonably em reasonably necessary ou reasonably possible - afinal, o que é razoavelmente necessário ou razoavelmente possível, valendo-nos de uma tradução palavra-por-palavra? Nesse último caso, fica clara a irrelevância semântica do uso do advérbio, fato que não o isenta, no entanto, de desempenhar uma função discursiva e mesmo cultural, como veremos em seguida.

O desenvolvimento da linguagem jurídica em inglês tem raízes históricas, conforme apontam Mellinkoff (1963) e Carvalho Fonseca (2007), e várias de suas características perpetuam-se ao longo dos tempos, desde antes do nascimento de Cristo - destacando-se a invasão celta às ilhas britânicas (MELLINKOFF, 1963, p. 36), passando pelos períodos do Old English, Middle English e Modern English -, até os dias atuais ${ }^{122}$. Considerando-se o uso dos advérbios nesse universo tão peculiar e específico - e atendo-nos apenas aos cinco mais frequentes terminados em $-l y-$, pudemos observar que o uso dessa classe gramatical não foge à regra do

${ }^{122}$ Para mais detalhes, vide Mellinkoff (1963, p. 33-282) 
que encontramos nessa tipologia textual em um âmbito geral: a verborragia. Em vários casos, eliminar o advérbio não traria quaisquer prejuízos semânticos para a oração. No próximo item, apresentaremos algumas informações que consideramos relevantes para que se compreenda melhor o papel do advérbio no discurso jurídico. Por ora, apresentamos algumas características sintagmáticas comuns aos cinco advérbios analisados neste estudo. São elas:

- grande frequência de co-ocorrência com modais, destacando-se shall, will, may e can;

- co-ocorrência com palavras gramaticais, que induzem a formação de unidades maiores (ex: hereinafter collectively referred to as $+\mathrm{SN}$ );

- formação de binômios, como promptly and fully e duly and validly;

- co-ocorrência com outros advérbios, como é o caso de herein, hereafter e hereto. Apesar de não terem relação semântica com o advérbio terminado em -ly, é interessante observá-los na formação de unidades maiores.

\subsubsection{O discurso jurídico: breves comentários}

A partir das características apresentadas acima, vale comentar alguns aspectos que, a nosso ver, devem ser considerados quando da análise de quaisquer palavras ou classes gramaticais que compõem a linguagem jurídica, numa tentativa de ampliar os conhecimentos do pesquisador. Na obra intitulada The language of the law, Mellinkoff (1963) apresenta um panorama desse discurso. Colocamos abaixo a divisão das partes e capítulos dessa obra, que já demonstra a complexidade do tema:

\section{PARTE UM: O QUE É A LINGUAGEM JURÍDICA?}

Capítulo I: Uma definição expandida da linguagem jurídica

Capítulo II: Características da linguagem jurídica

Capítulo III: Maneirismos da linguagem jurídica

PARTE DOIS: A HISTÓRIA DA LINGUAGEM JURÍDICA

Capítulo IV: Escopo da história

Capítulo V: Antes dos normandos 


\author{
Capítulo VI: A conquista normanda \\ Capítulo VII: A Lei e o latim \\ Capítulo VIII: Algumas características do período Middle English \\ Capítulo IX: $O$ auge e a queda da linguagem jurídica francesa \\ Capítulo X: Três séculos de Modern English \\ Capítulo XI: A linguagem jurídica na América \\ PARTE TRÊS: USANDO A LINGUAGEM JURÍDICA \\ Capítulo XII: Razões atribuídas e observadas \\ Capítulo XIII: Mais precisa \\ Capítulo XIV: Mais concisa \\ Capítulo XV: Mais inteligível \\ Capítulo XVI: Mais durável ${ }^{123}$
}

Nessa distribuição, interessa-nos comentar a parte três (MELLINKOFF, 1963, p. 281-454), quando o autor analisa a linguagem jurídica sob os aspectos da precisão, concisão, inteligibilidade e durabilidade, comparando-a à linguagem comum. Segundo ele, o sentido de precisão, no Direito, não se atém apenas ao conceito de exato. Pelo contrário, nessa linguagem a palavra precisão remete ao que Mellinkoff (1963, p. 296) descreve como exactly-the-same-way, ou seja, exatamente do mesmo modo, o que reforça o aspecto da repetição facilmente observável nesse discurso. Exatamente-do-mesmo-modo não implica, no entanto, que haja um significado específico ou mesmo qualquer significado em si. A palavra precisão remete à tradição, à forma como as coisas eram ditas desde muito antigamente, e consequentemente ao que é necessário e requerido pela legislação. Em busca dessa precisão, o discurso jurídico é tido como verborrágico (CARVALHO FONSECA, 2007, p. 22; MELLINKOFF, 1963, p. 25), com peculiaridades que se mantém ao longo dos tempos e que foram minuciosamente detalhadas por Mellinkoff (1963): o uso de duas palavras para expressar um único significado (exemplo: cease

\footnotetext{
${ }^{123}$ PART ONE: What IS THE LANGUAGE OF THE LAW? / Chapter I: An expanded definition of the language of the law / Chapter II: Characteristics of the language of the law / Chapter III: Mannerisms of the language of the law / PART TWO: HISTORY OF THE LANGUAGE OF THE LAW / Chapter IV: Scope of the history / Chapter V: Before the Normans / Chapter VI: The Norman conquest / Chapter VII: The Law and Latin / Chapter VIII: Some characteristics of the Middle English period / Chapter IX: The rise and fall of law French / Chapter X: Three centuries of Modern English / Chapter XI: Law language in America / PART THREE: UsING THE LANGUAGE OF THE LAW / Chapter XII: Reasons given and real / Chapter XIII: More precise / Chapter XIV: Shorter / Chapter XV: More intelligible / Chapter XVI: More durable.
} 
and desist); a preferência pelo ritmo (advinda da linguagem oral, como em rack and ruin), que também implica duplicações desnecessárias; a mistura do inglês com outras línguas, o que reforça o uso de sinônimos (fit and proper); o uso de orações longas - aspectos que sobrecarregam o Direito com uma linguagem tida como desnecessária e confusa (MELLINKOFF, 1963, p. 399). Além dessas características, temos também o padding (MELLINKOFF, 1963, p. 190), que nada mais é do que inflar o discurso com palavras que não implicam qualquer carga semântica e são, portanto, desnecessárias. Essas especificidades deram origem, em certa época, aos chamados bookforms, que traduziríamos como manuais contendo "formulários" que prescreviam como um determinado tipo de contrato, por exemplo, deveria ser escrito, substitutindo-se apenas as partes envolvidas. O objetivo era facilitar as negociações, impressionar os leigos e advogados iniciantes - se esses objetivos foram ou não alcançados, já é uma outra questão. Aos estudiosos da língua, fica claro que a formulaicidade característica desse discurso já era observada desde muito tempo.

Durante a análise da obra de Mellinkoff (1963), observamos várias referências ao uso dos advérbios, principalmente àqueles terminados em -ly, que corroboram a verborragia acima descrita. Ao comentar as palavras que apresentam certa flexibilidade semântica quando empregadas - muitas vezes até sendo vazias de sentido -, por exemplo, apresenta vários deles: apparently, approximately, clearly erroneous (seria uma colocação?), lately, promptly, shortly after e temporarily (MELLINKOFF, 1963, p. 21-22). Há vários outros quando descreve o aspecto pomposo do discurso, que se vale também dos advérbios para expressar isso: clearly expressed, clearly pointed out, clearly results, irrevocably concluded by previous decisions (MELLINKOFF, 1963, p. 28). Como já observamos, esse grupo de advérbios pode ser utilizado apenas para inflar o texto (padding), como é evidente em totally null and void ou mesmo em inhabitant actually resident. Ao comentar o que deve fazer parte da linguagem jurídica, mesmo considerando sua verborragia, o seguinte trecho chamou-nos a atenção, justamente por referir-se a um dos advérbios-chave de nossa pesquisa: 
There is even included the reasonably uncertain reasonable certainty. A related monstrosity of imprecision - reasonably possible - occurs in the required language of a standard insurance policy. (MELLINKOFF, 1963, p. 386) $)^{124}$

Como apenas abordamos um lado mais crítico da obra de Mellinkoff (1963), devemos deixar claro que apontamos aqui apenas aspectos relevantes para nossa pesquisa - o autor apresenta todo um panorama histórico, justifica e exemplifica todos os aspectos levantados e os critica quando julga necessário. É uma obra bastante esclarecedora do discurso jurídico e que merece especial atenção quando o assunto é estudado. Uma análise mais aprofundada, no entanto, foge ao escopo desta pesquisa.

Um aspecto formulaico da linguagem jurídica que vale ser citado é a formação de binômios, muito bem retratada por Carvalho Fonseca (2007) em sua dissertação de Mestrado intitulada $A$ tradução de binômios nos contratos de common law à luz da linguística de corpus. Ao enfocar as classes gramaticais que compõem os binômios, a autora elenca vários deles formados por advérbios terminados em -ly e que são frequentes na tipologia dos contratos, como é o caso de directly or indirectly, jointly and severally, wholly or partially, materially and adverselly, solely and exclusively, duly and validly, expressly and specifically e irrevocably and unconditionally. ${ }^{125}$

Como podemos observar, os advérbios terminados em -ly instigam pesquisas na área do discurso jurídico. Nossa investigação procura focá-los de forma mais incisiva numa tentativa de delimitar seu papel nessa linguagem especializada, contrastando-o com o português.

Apresentamos abaixo a análise dos cinco advérbios terminados em -mente (a contrapartida de $-l y$, em inglês) com os maiores índices de chavicidade em nosso corpus de estudo, em português.

\footnotetext{
${ }^{124}$ Nesse caso, preferimos colocar nossa sugestão de tradução em nota de rodapé, justamente pela estranheza que a tradução literal de reasonably causa neste contexto: "Inclui-se ainda a razoavelmente incerta certeza razoável. Uma outra monstruosidade da imprecisão - razoavelmente possível - ocorre na linguagem requerida em uma apólice de seguros padrão."

${ }^{125}$ Para mais detalhes, vide a dissertação na íntegra, disponível em: http://www.fflch.usp.br/dlm/comet
} 
B) Os advérbios nos contratos em português

Apresentaremos aqui a análise do último grupo de advérbios considerados para esta pesquisa, ou seja, os cinco advérbios terminados em -mente com maior índice de chavicidade em nosso corpus de estudo do Direito, em português. São eles: expressamente, devidamente, simplesmente, automaticamente e independentemente.

Apesar de significativamente frequentes no CE quando comparados com sua frequência no $\mathrm{CR}$, observamos que, nessa língua, todos apresentam chavicidade abaixo de 1.000. Passemos a análise de cada um desses advérbios, bem como ao levantamento das colocações mais frequentes.

- EXPRESSAMENTE

\begin{tabular}{|c|c|c|c|c|c|c|}
\hline$N$ & adv-chave & freq. CE & $\%$ CE & freq. CR & $\%$ CR & chav. \\
\hline 98 & expressamente & 120 & 0,04 & 1.867 & & 971,52 \\
\hline
\end{tabular}

Dispersão nos arquivos:

CE: $49(35 \%)$

CR: $1.345(1,07 \%)$

Normalização das frequências:

CE: 0,42 ocorrência em cada mil palavras

CR: resultado inexpressivo $(0,0026$ ocorrência em cada mil palavras)

Expressamente apresenta boa dispersão nos arquivos, ou seja, encontra-se em $35 \%$ dos textos que compõem nosso CE. No CR, entretanto, sua dispersão é significativamente menor, pois concentra-se em $1 \%$ dos arquivos. Quanto à normalização das frequências, expressamente ocorre uma vez em pouco mais de cada duas mil palavras em nosso corpus de estudo. Apresentamos abaixo os padrões linguísticos identificados a partir das 120 linhas de concordância desse advérbio.

Primeiramente, levantamos unidades que apresentam padrões gramaticais nos quais o advérbio se inclui. São elas: 
- FICAR expressamente $+\mathrm{V}_{\mathrm{pp}}$ (11). Na posição do verbo, temos: VEDADO (6), convencionado, consignado, estabelecido, prevista, proibida. Exemplo:

Fica expressamente estabelecido que não há vínculo empregatício entre os empregados [...].

- ESTAR expressamente $+V_{p p}$ (7). Na posição do verbo, temos: excluídos (5), classificada, previsto. Exemplo:

SINISTRO É a ocorrência de um evento danoso, que, desde que esteja expressamente previsto no contrato de seguro [...].

- ADV + e expressamente (4), nas formas prévia e expressamente (2); imediata e expressamente; formal e expressamente. Em português, quando temos a coocorrência de dois advérbios unidos pela conjunção e, apenas o segundo leva o sufixo. Exemplos:

As PARTES apenas votarão as matérias [...] se elas houverem sido aprovadas prévia e expressamente pela BNDESPAR e AES BRASIL em Reunião Prévia.

A DEPOSITÁRIA comunicará imediata e expressamente à Superintendência Regional da DEPOSITANTE qualquer problema e/ou condição anômala nos produtos elou embalagens [...].

Na sequência, apresentamos as colocações formadas por palavras lexicais:

- SER/FICAR expressamente VEDADO à/ao [PARTES] (17):

É expressamente vedado ao LOCATÁRIO sublocar os BENS locados no todo ou em parte $[\ldots]$.

Fica expressamente vedada ao CONTRATADO a apresentação de guias de atendimento médico em branco aos beneficiários [...].

- [PARTES] DECLARAR expressamente (12):

O locatário declara expressamente que o ramo de negócio que irá explorar no imóvel objeto desta locação [...].

- expressamente PREVISTO (8):

Considerar-se-á dissolvida a sociedade, além dos casos expressamente previstos em lei, nas seguintes hipóteses [...].

- RENUNCIAR expressamente (7). Encontramos fiadores como sujeitos da renúncia e foro (de uma dada comarca) como objeto:

Os fiadores renunciam expressamente os benefícios contidos nos artigos [...]. 
As partes elegem para seu domicílio o foro da Capital do Estado de São Paulo, [...] renunciando expressamente qualquer outro por mais privilegiado que seja.

- estão expressamente excluídos da garantia/cobertura (5). Essa fraseologia encontra-se especificamente em apólices de seguro. Exemplo:

Além dos riscos excluídos nas alíneas no subitem anterior, estão expressamente excluídos da cobertura de Morte Acidental e Invalidez Permanente [...].

- (que desde já) ACEITAR expressamente (5):

O imóvel entregue na data da assinatura deste contrato [...], possui as características contidas no auto de vistoria anexo, que desde já aceitam expressamente.

- AUTORIZA expressamente (5):

[...] o Associado autoriza expressamente o débito em sua conta corrente [...].

- expressamente AUTORIZADO (4):

[...] divulgando-as tão somente quando expressamente autorizada pela CONTRATANTE [...].

Em linhas gerais, observamos que expressamente associa-se basicamente a verbos, que se encontram tanto no particípio passado quanto no presente do indicativo. Os verbos ser, estar e ficar atuam como auxiliares em algumas unidades, como é o caso de é expressamente vedado. O advérbio atua como intensificador da palavra com a qual co-ocorre, reforçando seu significado. No entanto, cremos que não haveria comprometimento se fosse omitido, levando a cabo, de qualquer forma, a ação determinada.

- DEVIDAMENTE

\begin{tabular}{|c|c|c|c|c|c|c|}
\hline$N$ & adv-chave & freq. CE & $\%$ CE & freq. CR & $\%$ CR & chav. \\
\hline 119 & devidamente & 154 & 0,06 & 10.070 & & 818,11 \\
\hline
\end{tabular}

Dispersão nos arquivos:

CE: $61(43,57 \%)$

CR: $6.888(5,5 \%)$

Normalização das frequências:

CE: 0,55 ocorrência em cada mil palavras

CR: resultado inexpressivo $(0,014$ ocorrência em cada mil palavras) 
As 154 ocorrências de devidamente apresentam boa dispersão nos textos do CE, uma vez que se encontram em aproximadamente $44 \%$ deles. Já no $C R$, o número não é significativo, visto que o advérbio é encontrado em apenas $5,5 \%$ dos arquivos. Devidamente ocorre uma vez em aproximadamente cada duas mil palavras no corpus de estudo, sendo inexpressivo o resultado no corpus de referência.

Apresentamos abaixo a análise e os padrões linguísticos desse advérbio, o segundo com maior índice de chavicidade em nossos dados.

Inicialmente, observamos o uso de verbos auxiliares antes de expressamente, compondo as unidades SER devidamente $+v_{p p}(12)$ e ESTAR devidamente $+v_{p p}(6)$. Exemplos:

O valor parcelado será devidamente reajustado de acordo com o IGP-M [...].

Com base na comunicação e comprovantes do sinistro e estando devidamente caracterizada a incapacidade temporária nos termos [...].

Quanto a associações lexicais, foram identificadas as colocações abaixo descritas, com exemplos.

- devidamente representada (10). Todas as ocorrências estão no feminino singular. Em 4 delas, encontramos uma unidade maior, ou seja, devidamente representada neste ato por [PARTES]. Exemplos:

[...] autorizada pelo Conselho Monetário Nacional, devidamente representada neste ato por ( $x x x)$ (qualificá-lo) [...].

[...] inscrita no CNPJ/MF sob o $n^{\circ} x x x$, devidamente representada na forma de seu estatuto social [...].

- devidamente AUTORIZADO (9). Em 3 ocorrências, temos salvo/exceto se devidamente autorizado por escrito:

O aluguel será cobrado no próprio imóvel ora locado, por pessoa devidamente autorizada ou onde a locadora expressamente indicar [...].

[...] bem como para evitar e prevenir revelação a terceiros, exceto se devidamente autorizado por escrito pela PARTE REVELADORA.

- devidamente COMPROVADO (9):

[...] respeitada a periodicidade mínima de um ano, desde que devidamente comprovada a variação dos custos deste instrumento [...]. 
- devidamente PREENCHIDO (9):

Integram o presente Instrumento, os dados constantes da "Ficha Cadastral" devidamente preenchida pelo CLIENTE.

- devidamente REGISTRADO (8), sendo duas ocorrências de firma devidamente registrada:

O FRANQUEADO deverá manter sua firma devidamente registrada nos órgãos competentes [...].

Certidão de Óbito ou Declaração Judicial de Morte Presumida devidamente registrada no Cartório do Registro Público competente [...].

- devidamente ATUALIZADO (7). Esta colocação é geralmente utilizada para referir-se a dados:

O CONTRATANTE se obriga a manter os seus dados cadastrais devidamente atualizados.

- devidamente QUITADO (7). Esta colocação é geralmente utilizada para referir-se a despesas e parcelas. Foram encontradas 3 ocorrências de comprovantes de todas as despesas do imóvel devidamente quitadas. Exemplos:

Emitir-se-á tal recibo, desde que haja a apresentação pelo LOCATÁRIO, dos comprovantes de todas as despesas do imóvel devidamente quitadas.

Fotocópia da GPS, devidamente quitada e autenticada [...] referente a todos os empregados [...].

- devidamente ASSINADO (por/pelo/pelas [PARTES]) (6):

Integra e complementa este instrumento contratual, para todos os fins e de direito, devidamente assinados pelas partes [...].

- devidamente HABILITADO (5). Neste grupo, foram encontradas 3 ocorrências de laudo subscrito por médico devidamente habilitado na sua especialização. Exemplos:

A constatação [...] se fará através de laudo subscrito por médico devidamente habilitado na sua especialização, e/ou por declaração da Previdência Social.

[...] contratado ou empregado que esteja devidamente habilitado e capacitado a exercer suas funções [...].

- devidamente CORRIGIDO (5):

[...] qualquer diferença que venha a ser apurada, devidamente corrigida pelo índice de variação de correção [...]. 
- devidamente identificados (5). Nesse caso, todas as ocorrências foram no masculino plural:

O atendimento aos beneficiários devidamente identificados será realizado de acordo com as coberturas [...].

- devidamente INFORMADO (5):

A REPRESENTANTE deverá manter a REPRESENTADA devidamente informada $[\ldots]$.

- devidamente JUSTIFICADO (5). Em três dessas ocorrências, JUSTIFICADO é seguido da conjunção $e+v_{p p}$. Exemplo:

[...] salvo serviços já iniciados ou por motivo de força maior, os quais serão devidamente justificados e comprovados [...].

- devidamente caracterizada (4):

[...] exceto se a mora for devidamente caracterizada como de responsabilidade do CONTRATANTE.

Em linhas gerais, não observamos co-ocorrências com classes gramaticais diferentes daquelas já registradas em análises anteriores. Nesse caso, o advérbio é sempre seguido de verbo no particípio passado e, quando necessário, utiliza os verbos ser e estar como auxiliares. Semanticamente, podemos dizer que devidamente enfatiza a palavra que se segue, expressando rigor na ação. Mesmo com essa função, no entanto, cremos que sua omissão não comprometeria o significado do trecho em que se insere. A nosso ver, seu uso caracteriza o que Melinkoff (1963, p. 296) chama de exactly-the-same-way (exatamente-do-mesmomodo) - o uso frequente do advérbio foi incorporado ao discurso e, dessa forma, é assim repetido. Cremos não haver alteração de significado ao dizer que uma diferença será devidamente corrigida ou que uma diferença será corrigida. Foram também encontradas poucas unidades maiores de significado, como é o caso de laudo subscrito por médico devidamente habilitado na sua especialização. 
- SIMPLESMENTE

\begin{tabular}{|c|c|c|c|c|c|c|}
\hline$N$ & adv-chave & freq. $C E$ & $\% C E$ & freq. $C R$ & $\% C R$ & chav. \\
\hline 265 & simplesmente & 132 & 0,05 & 31.599 & & 378,58 \\
\hline
\end{tabular}

Dispersão nos arquivos:

CE: $50(35,71 \%)$

CR: $13.428(10,72 \%)$

Normalização das frequências:

CE: 0,47 ocorrência em cada mil palavras

CR: resultado inexpressivo $(0,045$ ocorrência em cada mil palavras)

O advérbio simplesmente apresenta boa dispersão nos arquivos do CE, sendo encontrado em aproximadamente $36 \%$ dos textos. No CR, no entanto, suas ocorrências concentram-se em apenas 11\% deles. Quanto à normalização das frequências, simplesmente ocorre uma vez em aproximadamente cada duas mil palavras em nosso corpus de estudo, registrando resultados inexpressivos no corpus de referência.

Ao analisarmos as 132 linhas de concordância desse advérbio, levantamos os padrões abaixo descritos.

- doravante denominada simplesmente (61). A partir dessa colocação, identificamos outras unidades maiores. São elas:

- neste ato representada na forma de seus atos constitutivos, doravante denominada simplesmente (22)

- neste ato representada na forma de seu estatuto social, doravante denominada simplesmente (19)

Exemplos:

[...] neste ato por seus representantes legais infra-assinados, doravante denominada simplesmente CONTRATADA [...].

[...] simplesmente HOLEMAKER, e do outro XXXX doravante denomindada simplesmente LOCATARIA [...].

Identificamos também 22 ocorrências de denominado(s) simplesmente (atente-se para o particípio passado no masculino singular), em menor número de ocorrências que se subdividem em unidades maiores, como podemos observar abaixo: 
- doravante denominado simplesmente (14):

Compreende o "Cartão Plástico", doravante denominado simplesmente "Cartão", emitido ao Associado Titular [...].

- de ora em diante denominado simplesmente (7):

O primeiro dos acima qualificados, de ora em diante denominado simplesmente VENDEDOR, [...].

- DESIGNADO simplesmente (30), com 25 ocorrências de designada, 4 de designado e uma de designados:

Caixa Beneficente dos Funcionários do Banco do Estado de São Paulo [...], neste ato designada simplesmente CABESP.

- doravante designada simplesmente (13):

[...] com sede na Rua da Ajuda $n^{\circ} 05-8^{\circ}$ andar, nesta cidade, doravante designada simplesmente CONTRATANTE [...]

- daqui por diante designada simplesmente (5):

[...] a empresa [...], daqui por diante designada simplesmente CONTRATADA, têm, entre si, justo e avençado, e celebram [...].

- representada na forma (preconizada em) de seu Estatuto/Contrato Social, doravante designada simplesmente (5):

[...] legalmente representada na forma de seu Estatuto Social, doravante designada simplesmente VENDEDORA [...].

- (doravante) designado(s) simplesmente (5):

[...] por si e/ou por seus assistentes, representantes legais ou procuradores, designados simplesmente "Representantes" [...].

- em sequência(,) designada simplesmente (4):

[...] do Exmo. Sr. Procurador-Chefe da PRR $5^{a}$ Região e, em seqüência, designada simplesmente CONTRATANTE e, de outro lado, a empresa [...].

Nas orações que contém as colocações acima, nomeiam-se as partes do contrato, em sequência, como é o caso de contratada (10), contratante (9), COMPRADOR (5) e VENDEDOR (4). Como podemos observar, simplesmente apresenta uso bastante específico nessa tipologia textual, formando colocações com basicamente dois verbos, quais sejam denominar e designar, sempre no particípio passado. Essas colocações despersonalizam as partes envolvidas, atribuindo-lhes papeis a serem desempenhados no contrato, conforme acima exposto. Novamente, 
observamos que a omissão desse advérbio não comprometeria o sentido do sintagma que integra.

- AUTOMATICAMENTE

\begin{tabular}{|c|c|c|c|c|c|c|}
\hline$N$ & adv-chave & freq. $C E$ & $\%$ CE & freq. CR & $\%$ CR & chav. \\
\hline 297 & automaticamente & 72 & 0,03 & 6.473 & & 338,35 \\
\hline
\end{tabular}

Dispersão nos arquivos:

CE: $40(28,57 \%)$

CR: $4.395(3,51 \%)$

Normalização das frequências:

$\mathrm{CE}: 0,25$ ocorrência em cada mil palavras

CR: resultado inexpressivo (0,0093 ocorrência em cada mil palavras)

Como podemos observar, automaticamente apresenta boa dispersão entre os textos de nosso CE, ou seja, encontra-se em aproximadamente $28 \%$ deles. Já no $\mathrm{CR}$, a dispersão entre os arquivos é baixa, em torno de 3,5\%. Quanto à normalização das frequências, o advérbio ocorre uma vez em cada quatro mil palavras no $C E$, enquanto no $C R$ os resultados são novamente inexpressivos, o que reflete a significância de sua ocorrência nos dados em estudo.

Analisamos as 72 linhas de concordância e apresentamos abaixo as unidades encontradas.

- SER automaticamente $+\mathrm{V}_{\mathrm{pp}}(11)$ :

Havendo infração de qualquer uma das cláusulas deste contrato, o mesmo será automaticamente rescindido.

- FICAR automaticamente $+\mathrm{V}_{\mathrm{pp}}(10)$ :

As ações vendidas publicamente, de forma pulverizada, ficarão automaticamente desvinculadas deste Acordo de Acionistas.

- automaticamente prorrogado(s) (5):

[...] os prazos dos limites de crédito concedidos serão considerados automaticamente prorrogados por períodos idênticos aos iniciais [...]. 
- automaticamente renovado (5):

[...] por um período inicial de 10 (dez) anos contados a partir desta data, sendo automaticamente renovado por períodos sucessivos de 10 (dez) anos [...].

- SER renovado(,) automaticamente (5):

O prazo deste contrato é por tempo indeterminado, sendo renovado automaticamente pelo mesmo período anterior [...].

- automaticamente CANCELADO (4):

[...] os beneficiários perderão o direito a qualquer serviço e o seguro ficará automaticamente cancelado nos seguintes casos [...].

- automaticamente rescindido (4):

O presente contrato ficará automaticamente rescindido de pleno direito de qualquer das partes se [...].

- CONSIDERAR automaticamente $+\mathrm{V}_{\mathrm{pp}}(4)$ :

[...] a REPRESENTADA poderá, a seu critério: (a) considerar automaticamente resolvido este contrato, independentemente de qualquer aviso [...].

- ESTAR automaticamente + V (4):

[...] o Usuário estará automaticamente aceitando todos os termos e condições do presente instrumento.

Observamos que as palavras com as quais automaticamente co-ocorre pertencem, em geral, a um mesmo grupo semântico, ou seja, ao de cancelamento, renovação e prorrogação de um contrato de serviços como seguro, locação, etc., o que caracteriza o papel desse advérbio nesta tipologia textual, qual seja o de indicar o modo como a ação será realizada. No caso de uma renovação de contrato, por exemplo, esta irá ocorrer independente da comunicação entre as partes envolvidas, pois tal fato é esperado e ocorrerá naturalmente. Outra observação é quanto ao uso de verbos auxiliares (ser, ficar e estar), que inclusive apresentam ocorrências no futuro, como podemos observar nos exemplos acima. 
- INDEPENDENTEMENTE

\begin{tabular}{|c|c|c|c|c|c|c|}
\hline$N$ & adv-chave & freq. CE & $\%$ CE & freq. CR & $\%$ CR & chav. \\
\hline 319 & independentemente & 104 & 0,04 & 23.220 & & 311,38 \\
\hline
\end{tabular}

Dispersão nos arquivos:

CE: $54(38,57 \%)$

CR: $13.722(10,96 \%)$

Normalização das frequências:

CE: 0,37 ocorrência em cada mil palavras

CR: resultado inexpressivo $(0,033$ ocorrência em cada mil palavras)

O advérbio independentemente apresenta boa dispersão, sendo encontrado em cerca de $38 \%$ dos contratos. No $C R$, os resultados não são tão significativos, com a ocorrência concentrada em aproximadamente $11 \%$ dos arquivos. Novamente, a normalização das frequências apresenta resultados positivos apenas no $\mathrm{CE}$, onde independentemente ocorre uma vez em aproximadamente cada três mil palavras.

Apresentamos abaixo os padrões linguísticos encontrados, observando seu uso também restrito (como advérbios anteriormente analisados) nesta tipologia textual.

A co-ocorrência mais frequente é com a preposição de, associada ou não a artigo definido. Temos: independentemente de (69), independentemente do(s) (17) e independentemente $d a(s)$ (14), distribuídos nas ocorrências abaixo descritas.

- independentemente de transcrição (13). Nas ocorrências, observamos a unidade farão parte do contrato, independentemente de transcrição (2) que, apesar de apenas duas ocorrências, apresenta variações em sua composição que refletem o mesmo significado, como neste exemplo: [...] que faz parte integrante deste Contrato, independentemente de transcrição.

- independentemente de aviso (10):

O emissor efetuará ainda o cancelamento do cartão, independentemente de aviso, nas seguintes hipóteses [...].

- independentemente de qualquer aviso (ou notificação judicial ou extrajudicial) (7):

[...] considerar rescindido de pleno direito o presente Contrato, independentemente de qualquer aviso ou notificação judicial ou extrajudicial, [...]. 
- independentemente de notificação (ou interpelação) judicial ou extrajudicial (6):

[...] Contrato de Depósito poderá ser rescindido de pleno direito, a qualquer tempo, independentemente de notificação ou interpelação judicial ou extrajudicial, [...].

- independentemente de aviso prévio (4):

[...] cancelamento do CARTÃO ou E-CARD, a qualquer tempo, independentemente de aviso prévio ou qualquer comunicação escrita [...].

- independentemente de aviso ou qualquer outra medida judicial ou extrajudicial (4):

[...] efetivando-se com a entrega das chaves, independentemente de aviso ou qualquer outra medida judicial ou extrajudicial.

- RESCINDIR/ANULAR + de pleno direito, + independentemente de + SUBST (4):

Este contrato poderá ser rescindido, de pleno direito, independentemente de notificação ou interpelação judicial ou extrajudicial, [...].

- independentemente de/da PRÉVIO + SUBST (4). Os substantivos apresentam um mesmo campo semântico: aviso (2), autorização e notificação:

Não obstante, a COMPRADORA e a VENDEDORA poderão, independentemente da prévia autorização, ceder os direitos e obrigações [...].

- a qualquer tempo, independentemente de + SUBST (4):

Esse critério poderá ser alterado a qualquer tempo, independentemente de comunicação prévia por qualquer das Partes, [...].

É interessante observar como esse advérbio não é utilizado para modalizar ou intensificar um verbo ou adjetivo. Nesse caso, entendemos que ele forma uma única unidade com a preposição de (independentemente de $+\mathrm{SN}$ ), com significado próprio que não se atrela a uma outra palavra para completar seu sentido. Independentemente de tem a função de relacionar duas ações, enfatizando que a primeira ocorrerá de qualquer forma, não estando vinculada à execução da segunda. Com isso, e em se tratando da tipologia textual de contratos, o léxico que co-ocorre com esse advérbio fica bastante limitado, restringindo-se a palavras que indicam comunicação, como é o caso de aviso (prévio), notificação e comunicação. 
3.2.2 Os advérbios em português nos contratos: algumas considerações

Nos dados analisados no capítulo II (item 2.6), pudemos observar que os advérbios terminados em -mente representam, de forma significativa, a classe dos advérbios em contratos, com $30,09 \%$ do número total de advérbios levantados com o uso de etiquetas.

Terminada a análise dos cinco advérbios com maior índice de chavicidade, quais sejam expressamente, devidamente, simplesmente, automaticamente e independentemente, observamos que eles apresentam função bastante específica em contratos. Apesar de termos trabalhado com um corpus de estudo bem menor nessa tipologia textual - comparado com nosso corpus de receitas culinárias -, não acreditamos que aumentar o número de textos compilados alteraria os resultados obtidos. Obviamente, registraríamos maior frequência de ocorrência de algumas unidades, mas a grosso modo isso não comprometeria nossas observações quanto ao uso dos advérbios analisados, visto que a linguagem do direito é essencialmente repetitiva.

Os advérbios analisados apresentam boa dispersão entre os textos, quase todos chegando a ocorrer em mais de 35\% deles. Em geral, co-ocorrem com verbos no particípio passado, o que revela o uso frequente da voz passiva, sendo pouco significativa a co-ocorrência com adjetivos. O presente do indicativo também é usado, como observado nas concordâncias de expressamente. Quanto ao tempo verbal da oração, há predominância do presente, mas verificamos também várias ocorrências no futuro, como em [...] o contrato ou aditamento a ele referente ficará automaticamente e de pleno direito cancelado, independentemente de qualquer interpelação judicial ou extrajudicial [...].

Como em inglês, observamos a formação de unidades maiores de significado, fato típico de contratos que, muitas vezes, assemelham-se a formulários onde são apenas acrescentadas as informações das partes envolvidas. Em alguns casos, verificamos pequena variação no léxico ou mesmo alteração na ordem das palavras na frase, como é o caso de [...] que faz parte integrante deste Contrato, independentemente de transcrição, [...] comparada com [...] fica fazendo parte integrante do presente Instrumento, independentemente de transcrição, [...].

Em linhas gerais, observamos as seguintes características nos cinco advérbios analisados: 
- é comum o uso de verbos auxiliares, como é o caso de ser e estar, utilizados para a formação da voz passiva;

- cada advérbio apresenta sua preferência semântica, como é o caso de independentemente, que ocorre basicamente com palavras que indicam comunicação, caso de aviso (prévio), notificação e comunicação;

- a formação de binômios não é significativa nesta língua: apenas expressamente apresentou algumas poucas ocorrências.

Semanticamente, cada advérbio desempenha um determinado papel dentro da unidade em que ocorre, e sua função passa a ser definida justamente pelo cotexto e contexto:

- expressamente: intensificador;

- devidamente: modalizador, expressando rigor na ação em questão;

- simplesmente: junto com a palavra com a qual co-ocorre - DENOMINADO ou DESIGNADO em praticamente todas as ocorrências, forma uma unidade de significado que despersonaliza as partes envolvidas, atribuindo-lhes papeis a serem desempenhados no contrato, conforme exposto na análise anteriormente apresentada;

- automaticamente: indica o modo como a ação será realizada, deixando clara a não necessidade de comunicação entre as partes para que a ação ocorra;

- independentemente: é o único advérbio que não co-ocorre com um verbo, colocando com a preposição de e um sintagma nominal, geralmente representado por um substantivo (aviso, notificação, comunicação, etc.).

Apesar de todos esses advérbios apresentarem alguma carga semântica, acreditamos que a omissão de expressamente, devidamente e simplesmente nos contratos não comprometeria o significado do trecho em que estão inseridos, o que mais uma vez demonstra a verborragia dessa tipologia textual.

A seguir, apresentamos uma comparação do uso de advérbios terminados em -ly, em inglês, e -mente, em português, na tipologia dos contratos. 
3.2.3 Comparando resultados: os advérbios em contratos - inglês e português

Como podemos observar, os advérbios terminados em -ly/-mente, diferentemente da concepção que temos da classe gramatical dos advérbios em língua geral, são utilizados de forma bem definida e desempenham funções específicas nas colocações e unidades maiores de significado em que ocorrem nos contratos. Os corpora de Direito Contratual apresentaram resultados equilibrados quanto ao uso dos advérbios. Nessa área, temos 4.929 advérbios terminados em -ly, em inglês, e 2.212 terminados em -mente, em português, o que equivale a $27,55 \%$ e $30,09 \%$ de todos os advérbios identificados em cada corpus e em cada língua, respectivamente. Considerando-se o número total de ocorrências em cada corpus, ou seja, 648.648 ocorrências em inglês e 279.923 ocorrências em português, os advérbios terminados em $-l y$ representam $0,75 \%$ desse total e, os terminados em -mente, $0,79 \%$, refletindo também, proporcionalmente, o equilíbrio no número de ocorrências nos dados investigados. No entanto, apesar de a diferença não ser discrepante, observamos que o mesmo não ocorre quando analisamos o número de formas, comparado ao número de ocorrências. Enquanto em inglês temos 261 advérbios diferentes que formam as 4.929 ocorrências, em português são 193 para as 2.212 ocorrências. Se considerássemos que cada um desses advérbios ocorre com a mesma frequência, o que é pouco provável, poderíamos dizer que, em inglês, cada um ocorre aproximadamente 19 vezes e, em português, esse número cai para 11, o que indica maior variedade lexical nessa língua. Trabalhando com corpora comparáveis, observamos que um mesmo advérbio se repete com maior frequência na língua inglesa. Em português, no entanto, há outras questões envolvidas, como o emprego de locuções adverbiais ou a eliminação do sufixo do primeiro advérbio quando dois deles, terminados em -mente, ocorrem em sequência, caso de formal e expressamente.

Como é de conhecimento geral, a linguagem do Direito é extremamente formulaica, como aponta Carvalho Fonseca (2007), o que pudemos observar ao manipularmos os dados nos contratos, em ambas as línguas. Em linhas gerais, os advérbios apresentam, tanto em inglês quanto em português, várias características morfossintáticas e estruturais em comum: co-ocorrem com verbos, especialmente aqueles no particípio passado, como primeira palavra à direita; co-ocorrem, com pouca frequência, com adjetivos que não são deverbais (como é o caso de 
necessary e possible); co-ocorrem com os mesmos verbos auxiliares; ocorrem, com maior frequência, em orações no presente, sendo também observadas ocorrências no futuro. Ambas as línguas apresentam unidades maiores de significado, como é o caso de in form and substance reasonably acceptable to e duly organized, validly existing and in good standing under the laws of, em inglês, e neste ato representada na forma de seus atos constitutivos, doravante denominada simplesmente e independentemente de qualquer aviso ou notificação judicial ou extrajudicial, em português. Quanto às diferenças entre as línguas em nossos dados, observamos: os índices de chavicidade dos advérbios são significativamente mais altos em inglês, o que sinaliza serem mais típicos dessa tipologia textual; a formação de binômios em inglês é mais frequente; em inglês, os padrões levantados são mais variados, ou seja, há mais padrões com menor frequência, enquanto em português o mesmo padrão ocorre mais vezes; em português, um dos advérbios analisados co-ocorre, em praticamente todas as linhas de concordância, com uma preposição: é a partir de independentemente de que são identificadas outras colocações, fato não observado em inglês.

Apesar dos pontos convergentes em termos morfossintáticos e estruturais, devemos refletir sobre o uso e o significado desses advérbios em contexto, principalmente quando buscamos sua forma equivalente em outra língua. Embora o número de ocorrências de advérbios terminados em -ly e -mente seja equilibrado na tipologia dos contratos, eles não ocorrem isoladamente, como pudemos observar nas colocações e unidades maiores de significado levantadas durante as análises. É sabido que, no processo tradutório, devemos considerar todo o contexto em que dada palavra ocorre. Mesmo sendo essa linguagem especializada repetitiva, cada língua apresenta fórmulas e padrões de uso que não incluem necessariamente a tradução literal (e isolada) das palavras que os compõem. Será que collectively coocorre com as mesmas palavras que coletivamente, em português? Será que razoavelmente, por exemplo, é a opção de tradução mais adequada para reasonably? E o que dizer quando deparamos com o fato de que há 344 ocorrências de reasonably e apenas 3 de razoavelmente em nossos dados? Isso corrobora a nossa tese de que a língua deve ser analisada em contexto, considerando-se todos os seus aspectos: sintático, morfológico, pragmático, semântico, cultural, etc. No caso específico de reasonably, vale mencionar que seu uso é muito marcado culturalmente: em inglês, e devido a vários aspectos históricos que remontam à 
origem da linguagem jurídica, o conceito de reasonable $\operatorname{man}^{126}$ (homem médio) é sempre explicitado, enquanto em português tal aspecto é tratado como presunção jurídica, visto que o direito é feito para o homem médio e não há necessidade de mencioná-lo nos documentos (CARVALHO FONSECA, 2010). Estamos aqui diante de uma questão a ser considerada no processo tradutório, inclusive quanto ao uso (ou mesmo à omissão) do advérbio reasonably em várias colocações. Além disso, é importante lembrar a verborragia do discurso jurídico, também observada no uso dos advérbios terminados em -ly e -mente, que deve ser considerada na busca pela equivalência.

No quadro abaixo, apresentamos os advérbios com maior índice de chavicidade em nosso corpus de estudo de Direito. Como ocorreu nas receitas culinárias, apenas alinhá-los não nos diz muita coisa.

\begin{tabular}{|l|l|}
\hline promptly & expressamente \\
\hline reasonably & devidamente \\
\hline expressly & simplesmente \\
\hline duly & automaticamente \\
\hline collectively & independentemente \\
\hline
\end{tabular}

À primeira vista, e ao compararmos esses advérbios, podemos pensar que a tradução de expressly por expressamente é óbvia, ou mesmo que o equivalente de duly é devidamente. Mas seriam realmente essas as melhores opções de tradução para os advérbios nos contratos? É o que verificaremos na próxima seção, quando trataremos do processo tradutório de vários padrões levantados durante nossas análises.

3.2.4 A busca pela forma equivalente em contratos: alguns exemplos na direção inglês - português

Considerando-se os advérbios analisados nesta pesquisa e apresentados ao final da seção anterior, levantamos algumas fraseologias que, a nosso ver, poderiam causar problemas ao serem traduzidas na direção inglês - português. Essa escolha

\footnotetext{
${ }^{126}$ Mellinkoff (1963, p. 19) aponta essa colocação como jargão na linguagem jurídica.
} 
foi, de certa forma, aleatória, considerando-se que não temos formação na área do Direito ou mesmo experiência na tradução dessa tipologia textual. Como na área da Culinária, apresentaremos sugestões de formas equivalentes, levantadas a partir de nosso corpus de estudo em português. Adotaremos a mesma metodologia de investigação anteriormente utilizada: primeiro buscaremos a tradução literal do advérbio, uma vez que essa equivalência não deve ser totalmente descartada. Em seguida, e a partir da tradução das palavras com as quais o advérbio co-ocorre, em inglês, investigaremos seu contexto de uso em português, em busca de formas equivalentes. A pesquisa será, majoritariamente, direcionada pelos dados. A partir de cada advérbio, apresentamos abaixo os resultados de nossa investigação. A forma lematizada dos substantivos, adjetivos e verbos foi adotada como default, o que implica que a palavra pode ocorrer tanto no masculino quanto no feminino, no singular e no plural, e em diferentes flexões e tempos do verbo. Caso necessário, alguma observação será feita durante a análise.

\section{- PROMPTLY:}

- promptly notify:

Nossa primeira busca foi com o advérbio prontamente, apresentado como opção de tradução em Houaiss (1982). Dentre as seis ocorrências encontradas, temos uma de prontamente notificadas e duas de comunicar prontamente:

[...] e que suas alterações sejam prontamente notificadas ao CONTRATADO.

A EMPRESA obriga-se a comunicar, prontamente, às PARTES, quaisquer atos, fatos ou omissões, que possam importar [...].

Devido ao número baixo de ocorrências, decidimos buscar a expressão notif*, que apresentou 165 ocorrências subdivididas em: notificação (99), notificações (15), notificada (10), notificadas, notificado (11), notificados, notificar (20), notificará (6) e notifique. Ao analisarmos essas ocorrências, chamou nossa atenção a expressão de imediato, com as duas ocorrências abaixo:

[...] a parte afetada deverá, de imediato, notificar a outra, para conhecimento desse fato, restabelecendo a situação [...]. 
A parte que for afetada por caso fortuito ou força maior, deverá notificar à outra, de imediato, da extensão do fato e do prazo estimado durante [...].

Nosso próximo passo foi gerar as linhas de concordância de de imediato. Nas 32 ocorrências, encontramos três outros verbos que pertencem ao mesmo campo semântico de notificar. São eles: comunicar (5), informar (2) e notificar (2). Exemplos:

O titular obriga-se a comunicar à ITAUCARD, de imediato e por escrito, qualquer alteração no seu endereço.

Quando o impedimento for devido a transferência para outra Patrocinadora ou Unidade, deverá o participante de imediato informar à FIPECq, [...].

A partir desses resultados, fomos também analisar as concordâncias de comunicar e informar. Com a expressão de busca comuni*, encontramos: COMUNICAR (SN) imediatamente (16); comunicação imediata (2); cOMUNICADO de imediato (2); e de imediato, deverão comunicar (2). Apenas 2 ocorrências de comunicar prontamente foram encontradas. Com a expressão de busca inform*, temos: informar (SN) imediatamente (3); imediatamente informada; imediatamente informar; informar de imediato; de imediato informar. Exemplos:

A ARRENDATÁRIA se compromete a comunicar imediatamente todas e quaisquer formas de ameaça realizadas por terceiros [...].

O TITULAR deverá informar de imediato ao BANCO DO BRASIL a mudança de seu endereço.

Diante desses resultados, concluímos que prontamente não é o advérbio mais adequado a ser utilizado na tradução da colocação promptly notify. Nossas sugestões de formas equivalentes são:

- promptly notify = COMUNICAR imediatamente; NOTIFICAR imediatamente; COMUNICAR de imediato; NOTIFICAR de imediato.

- promptly NOTIFY + SN + in writing:

Nesse caso, e como já havíamos levantado sugestões de formas equivalentes para a colocação promptly notify, decidimos iniciar nossa investigação pela colocação por escrito (in writing). Nas 222 ocorrências, encontramos algumas poucas co-ocorrências com imediato e imediatamente, abaixo apresentadas. Não 
identificamos quaisquer outras palavras que contivessem o sentido de promptly nessas linhas de concordância.

[...] impossibilitada de cumprir a sua obrigação deverá dar conhecimento à outra, por escrito e imediatamente, da ocorrência e suas conseqüências.

O titular obriga-se a comunicar à ITAUCARD, de imediato e por escrito, qualquer alteração no seu endereço.

[...] e b) comunicar imediatamente à Seguradora, por escrito, a efetivação posterior de outros seguros de vida.

Desse modo, concluímos que, em português, o imediatismo da notificação ou comunicação é, em geral, subentendido. Quando expresso, pode sê-lo com as associações por escrito e imediatamente, de imediato e por escrito, ou mesmo imediatamente, por escrito. Com isso, resumimos abaixo nossas sugestões de formas equivalentes:

- promptly NOTIFY + SN + in writing = COMUNICAR (à/aO SN) por escrito e

imediatamente; COMUNICAR (à/ao SN), de imediato e por escrito;

COMUNICAR imediatamente (à/ao SN), por escrito.

Ao invés de COMUNICAR, o verbo NOTIFICAR também pode ser utilizado.

\section{- promptly execute and deliver:}

Como a colocação acima é formada pelo binômio execute and deliver e não temos conhecimento adequado na área de Direito Contratual para apresentarmos, de imediato, uma sugestão de tradução, decidimos analisar as 54 linhas de concordância apenas do binômio, em busca de alguma outra palavra que não oferecesse grandes problemas de tradução. Devemos observar que ambos os verbos que constituem essa colocação estão no presente, fato que observamos diferenciá-lo da forma executed and delivered. Nas 54 ocorrências de execute and deliver, verificamos referência à documentação que deve ser apresentada a uma das partes envolvidas no contrato, mediante solicitação, representada por palavras como documentation, letter, document(s), instrument(s), agreement(s) e statement(s). Exemplos:

Upon receipt of notice of any such assignment, Lessee agrees to execute and deliver to Lessor such documentation as Assignee or any successor assignee may reasonably require [...]. 
From time to time, without further consideration, the Buyer will, at the expense of Seller, execute and deliver such documents as the Seller may reasonably request in order more effectively to consummate the transactions contemplated hereby.

Within thirty (30) days after receipt by you of said notice and franchise agreement, you shall execute and deliver two (2) executed copies of the franchise agreement and payment of the Renewal Fee [...].

Decidimos então traduzir e buscar algumas dessas palavras em nosso corpus em português, inciando com documentação. Nas 54 concordâncias, identificamos entrega da documentação (8) e apresentação da documentação (3). Nas concordâncias de documento(s) (310), encontramos apresentou os documentos (4) e, em várias ocorrências, a mesma referência, como em Arquivar os documentos derivados do presente contrato e apresentá-los quando exigidos por quem de direito.

Diante dessas observações, e também considerando-se que lemos todas as linhas de concordância da colocação em inglês, chegamos à conclusão que a forma equivalente mais adequada para execute and deliver é fornecer/apresentar/entregar (um documento) mediante solicitação de uma das partes (ou de seu representante) envolvidas no contrato. Como a co-ocorrência com o advérbio promptly não é tão frequente, em inglês (6 oc.), optamos pela sugestão das seguintes formas equivalentes:

- promptly execute and deliver = APRESENTAR/FORNECER (de imediato).

- as promptly as + (ADV) + ADJ:

Apesar da baixa frequência (4 ocorrências), decidimos verificar como poderíamos sugerir uma forma equivalente para esse agrupamento. Como possible ocorreu duas vezes na posição de adjetivo, iniciamos nossa busca por possível, em português. Nas 32 concordâncias apresentadas, identificamos as associações na medida do possível (3), quando possível (3) e tanto quanto possível (3). Como as outras duas ocorrências da colocação em inglês eram com practicable, buscamos viável e exeqüível para outras possibilidades, mas nenhum resultado foi encontrado. Decidimos então buscar a expressão assim que, numa tentativa de verificar se ela co-ocorria com possível, fato que não ocorreu em nenhuma das 6 linhas apresentadas. Voltando a analisar as ocorrências de possível, não identificamos quaisquer advérbios, como podemos verificar nos exemplos abaixo: 
Os substitutos deverão providenciar, quando possível, a reversão da decisão adotada em desconformidade com as instruções das PARTES [...].

[...] no sentido de que atuem de maneira a, tanto quanto possível, desfazerem-se os atos praticados em razão dos votos proferidos pelo representante substituído.

Considerando-se a investigação acima e devido ao significado da associação, optamos pela seguinte sugestão de forma equivalente:

as promptly as $+(A D V)+A D J=$ quando + ADJ. Ex.: quando possível.

\section{- REASONABLY:}

\section{- may reasonably request:}

Conforme já comentado anteriormente, o corpus em português apresenta apenas 3 ocorrências de razoavelmente, o que já sinaliza que esse advérbio provavelmente não é utilizado como forma equivalente nas colocações que porventura sejam formadas por reasonably, em inglês. No caso de may reasonably request, partimos do verbo, considerando solicitar nossa primeira opção de busca. A partir da expressão solicit*, levantamos as seguintes co-ocorrências: quando SOLICITADO (14); sempre que SOLICITADO (11); quando assim for solicitado (2); sempre que (Ihe) for SOLICITADO (2). A partir dessas associações, que consideramos apresentar o mesmo sentido veiculado na colocação em inglês, observamos a não ocorrência com quaisquer advérbios ou expressões de modo. Com isso, podemos dizer que, em português, ou utilizamos outras palavras para expressar a mesma ideia ou tal referência é omitida. Vejamos alguns exemplos:

Os resultados das avaliações de desempenho serão comunicados ao longo da execução contratual e consolidados através de atestado de execução de serviço ao final do CONTRATO, quando solicitados.

A CONTRATADA deverá apresentar, sempre que solicitada, a documentação relativa à comprovação do adimplemento de suas obrigações trabalhistas, [...].

No entanto, e como podemos observar em inglês, o verbo encontra-se na voz ativa. Decidimos voltar às linhas de concordância em português e analisar as ocorrências do verbo na forma infinitiva (solicitar) e verificar se haveria alguma expressão modalizadora que apresentasse equivalência nesse contexto. Encontramos 18 ocorrências de PODER solicitar, sendo que 16 delas estavam no 
futuro. O contexto de uso se encaixa àquele observado em inglês, como podemos comparar abaixo:

[...] you agree to provide Company with copies of such tax returns, W-2's or other documentation as Company may reasonably request in writing from time to time so as to calculate the amount of any offsets available to it hereunder and to promptly notify Company of any employment [...].

O Associado poderá solicitar, por escrito ou por meio da Internet no site www.bradesco.com.br do Emissor, a segunda via de documentos tais como: cópias de demonstrativos mensais [...].

Numa tentativa de encontrar outras opções, buscamos o verbo requerer, com a expressão requer*. Nas 42 linhas apresentadas, não identificamos quaisquer unidades que pudessem ser associadas ao sentido de may reasonably request. Com isso, sugerimos como forma equivalente:

- may reasonably request = poderá/poderão solicitar; sempre que (for) SOLICITADO.

O uso na voz passiva irá depender do contexto na língua de chegada.

\section{- reasonably necessary:}

Antes de iniciarmos a investigação, que a priori teria como única opção a palavra NECESSÁRIO (nas formas feminina, masculina, singular e plural), decidimos verificar com quais outras palavras a colocação co-ocorria, em inglês, numa tentativa de buscar seus pares nas 286 ocorrências geradas para NECESSÁRIO e assim chegarmos a uma conclusão sobre seu uso. Nos dados em inglês, levantamos: reasonably necessary action(s) (3); deem reasonably necessary (4); reasonably necessary or appropriate (3); reasonably necessary or desirable (2); to the extent reasonably necessary (3).

Geramos as concordâncias e analisamos o contexto de NECESSÁRIO observando, logo de início, que são raras as co-ocorrências com um advérbio terminado em -mente - comprovadamente necessária foi a única ocorrência identificada. Ainda nessas linhas de concordância e considerando-se os agrupamentos acima mencionados, em inglês, levantamos as seguintes ocorrências em português: que se fizerem necessários/as (16); quando NECESSÁRIO (13); medidas necessárias (13); sempre que necessário (9); JULGAR NECESSÁRIO (8); providências necessárias (8); atos necessários (6); que for necessário (5); julgados/as necessários/as (4). Exemplos: 
[...] para tanto nomeando e constituindo o BRADESCO na condição de seu procurador, considerando-o investido dos poderes indispensáveis para a prática dos atos que se fizerem necessários, podendo, ainda, assinar os documentos que the forem exigidos.

[...] autorizar, quando necessário, a saída do equipamento a ser reparado na sede da contratada, ou empresa por ela autorizada.

Analisados esses dados, concluímos que, ao traduzir a colocação reasonably necessary, o advérbio deverá ser eliminado, visto que nada que a ele se refira foi utilizado, em português. Isso posto, sugerimos como forma equivalente:

- reasonably necessary $=$ (que se fizer) NECESSÁRIO.

\section{- reasonably acceptable:}

Nas 26 ocorrências em inglês, já havíamos observado as unidades (in a/the) form reasonably acceptable to (7) e in form and substance reasonably acceptable to (4), que poderiam ser úteis na busca de outras palavras do contexto. Em português, primeiramente buscamos a expressão aceitáve*, que apresentou uma única ocorrência. Partimos então para uma outra opção de tradução para acceptable, buscando a palavra satisfatório (expressão de busca: satisfatóri*), que gerou apenas 5 linhas de concordância - nenhuma delas apresentou quaisquer semelhanças com o uso da colocação em inglês. Diante disso, fomos verificar em que parte dos contratos reasonably acceptable ocorria, em inglês, numa tentativa de buscar a equivalência pelo contexto. Observamos que a colocação ocorre no meio do contrato, não exatamente em uma cláusula específica. Em geral, refere-se a documentos e registros, garantia estabelecida entre as partes envolvidas, termos e condições acordadas, etc., o que nos levou a observar que ela é utilizada para retratar algo que deve ser feito de comum acordo entre as partes, ou melhor, que seja aceito por elas. Partindo dessa ideia, ocorreu-nos buscar as expressões de comum acordo e anuência. Analisamos as linhas de concordância geradas e chegamos às seguintes observações, incluindo a formação de algumas unidades:

- comum acordo (35): de comum acordo (27); de comum acordo entre (as partes) (9); RESOLVER(,) de comum acordo (6); as partes (não necessariamente como primeira ocorrência à esquerda do nódulo de busca) de comum acordo (6). 
- anuência (30): anuência de/da/do + SN (21), sendo que o SN é representado por uma das partes envolvidas no contrato; (prévia e) expressa anuência (7); anuência expressa (4).

Diante dessas análises, concluímos que um advérbio terminado em -mente não deve ser utilizado ao traduzirmos reasonably acceptable, e nem mesmo é o caso de utilizarmos aceitável como tradução de acceptable. Como podemos observar, a colocação simplesmente desaparece na língua de chegada. Baseados nos contextos acima analisados, sugerimos como formas equivalentes:

- reasonably acceptable = de comum acordo (entre/com); com a anuência de + SN.

\section{- reasonably BELIEVE:}

Nosso primeiro passo foi voltar às linhas de concordância da colocação para verificarmos o contexto em que ocorria. Nas 11 linhas, observamos que reasonably believe não é utilizada em uma cláusula específica, geralmente rementendo à ideia de alguma condição considerada por uma das partes, que porventura tenha sido estabelecida e pode (ou não) ser (ou ter sido) alterada ou rompida, como observamos nos exemplos abaixo:

If, at any time, the Pledgee reasonably believes that the Pledged Collateral is insufficient to guarantee payment of unpaid principal and interest of the Note, Pledgee in its discretion may demand the pledge of additional collateral by Pledgors and failure by the Pledgors to deliver such additional collateral within fifteen (15) days from such demand shall be an Event of Default.

Notwithstanding any provision to the contrary, the Bank shall be entitled to suspend the performance of any of its duties hereunder if it reasonably believes that compliance therewith may violate the provisions of any applicable law, rule, regulation, order, or regulatory directive.

Em português, iniciamos nossa pesquisa com a expressão consider*, uma vez que utilizamos considerar como nossa opção de tradução para o verbo believe. Apresentamos abaixo alguns exemplos das 267 linhas de concordância analisadas:

No caso da <parte> </parte> considerar a Contratada como não hábil para esta coordenação, a Contratada deverá reembolsar a <parte> </parte> no valor do saldo a pagar do gerenciamento indicado em sua Proposta Final, na data da notificação. 
Para efeitos do reajuste anual da TABELA DE PREÇOS do ANEXO I mencionada no item anterior, a TELEMAR considerará como referência o índice IGP-DI ou substituto a este.

Fica facultado à LOCADORA considerar rescindido o presente contrato na ocorrência de qualquer um dos seguintes eventos [...].

Em geral, observamos que o verbo considerar é também utilizado em contextos que remetem àquele observado para a colocação em inglês: fatos e condições a serem considerados caso alguma cláusula estabelecida no contrato seja alterada ou rompida. Diante dessas observações e de acordo como o contexto, observamos que não seria adequado utilizar um advérbio na forma equivalente de reasonably believe. Com isso, sugerimos:

reasonably believe $=$ CONSIDERAR.

\section{- EXPRESSLY:}

\section{- expressly provided:}

Nesse caso, e considerando-se que expressamente é o advérbio com maior índice de chavicidade terminado em -mente, em português, decidimos reanalisar as 120 ocorrências apresentadas, numa tentativa de encontrar alguma equivalência de uso entre expressamente e expressly na colocação acima. Como nenhuma coocorrência chamou-nos a atenção, decidimos voltar para as concordâncias em inglês, que apresentaram unidades maiores com as palavras except e otherwise na maioria das ocorrências. São elas: except as expressly provided in/herein (14) e except as otherwise expressly provided in/herein (6). Exemplos:

Except as expressly provided herein, neither this Agreement nor any interest hereunder will be assignable, nor any other obligation delegable, by a Party without the prior written consent of the other Party [...].

Except as otherwise expressly provided in Exhibit A, Unistar acknowledges and agrees that the payment to Executone for the Services hereunder are intended to compensate Executone at least for its costs, including, without limitation, out-ofpocket costs, expenses and disbursements [...].

Partindo da tradução da palavra as por conforme, chegamos a disposto, cujo significado corresponde, a nosso ver, ao sentido de provided na colocação em inglês. Nas 170 ocorrências de disposto, não identificamos quaisquer co-ocorrências 
com advérbios terminados em -mente ou mesmo expressões de modo. Considerando-se a ideia veiculada por expressly provided e pelas unidades maiores acima mencionadas, levantamos alguns agrupamentos nas concordâncias de disposto. São eles: conforme disposto (14); sem prejuízo do (acima) disposto (11); observado o disposto (14); em/de conformidade com o disposto (8); conforme o disposto (8); ressalvado o disposto (3). Todas essas unidades são sempre seguidas de onde a informação se encontra: no contrato, na cláusula $x x$, no item xx, no artigo xx, etc., o que nos leva a concluir que disposto pode ser considerado uma tradução adequada para provided. Diante disso, apresentamos as seguintes sugestões de formas equivalentes:

- expressly provided $=$ (conforme) disposto.

- except as expressly provided in/herein = ressalvando o disposto no/na; sem prejuízo do disposto no/na.

- except as otherwise expressly provided in/herein = ressalvando o disposto no/na; sem prejuízo do disposto no/na.

\section{- expressly AGREE:}

Considerando-se as 20 linhas de concordância em inglês, observamos que a colocação co-ocorre com a palavra parties em quatro delas. Decidimos assim iniciar nossa investigação usando a palavra partes como nódulo de busca e, como palavra de contexto, as expressões concord* e acord*, em dois levantamentos separados, no sentido de identificar as concordâncias em que partes co-ocorresse com os verbos concordar e acordar, opções de formas equivalentes para agree. Essa busca pode ser feita com a ferramenta Concord, no programa WordSmith Tools.

Nas 26 concordâncias de partes/concord*, não encontramos quaisquer advérbios terminados em -mente ou expressão que modalizasse ou intensificasse o sentido do verbo, como podemos observar na figura abaixo: 


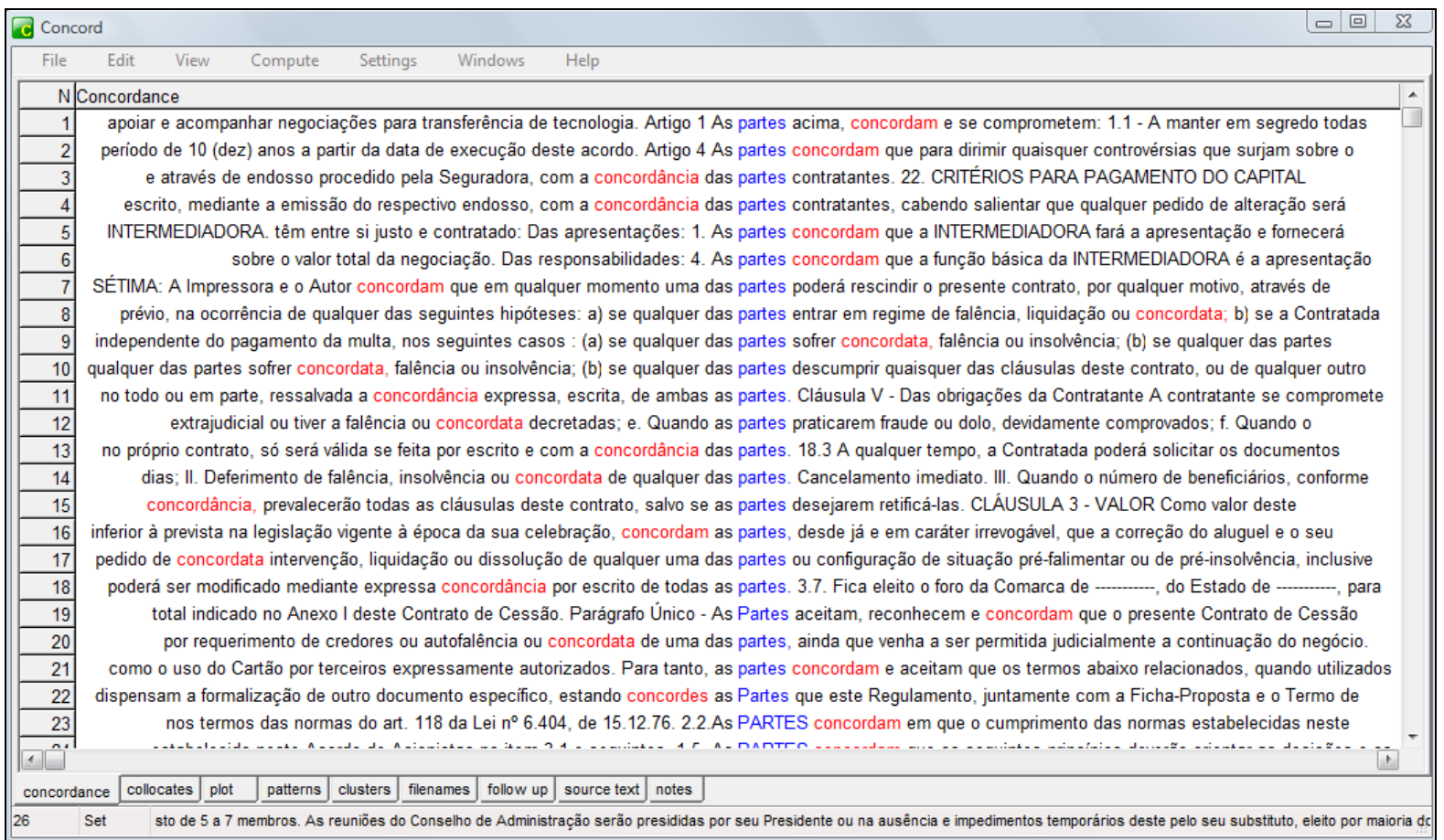

Figura 26 - Resultado parcial da busca da palavra partes e de concord $^{*}$, como palavra de contexto

Outrossim, identificamos 7 ocorrências de as partes concordam, como em:

As PARTES concordam em que o cumprimento das normas estabelecidas neste ACORDO DE ACIONISTAS é de alto interesse para a EMPRESA, quer sob o ponto de vista operacional, quer visando aos seus objetivos sociais.

Nas 101 linhas de partes/acord*, encontramos 3 ocorrências de as partes acordam e, finalmente, algumas co-ocorrências com advérbios terminados em -mente. São elas: desde que expressamente acordada entre as partes (3) e previamente acordado/a entre as partes (2). Exemplos:

[...] o início de vigência da cobertura será a data de aceitação da proposta de adesão ou outra data distinta, desde que expressamente acordada entre as partes e indicada nas Condições Particulares da Apólice [...].

A incorporação de novos procedimentos propedêuticos e/ou terapêuticos, próteses, órteses, materiais, medicamentos, equipamentos e taxas, deverá ser previamente acordada entre as partes, mediante solicitação do CONTRATADO [...].

Outras co-ocorrências: (comum) acordo entre as partes (24); acordado/a entre/pelas as partes (12).

Ao reanalisarmos as ocorrências de expressly agree, verificamos que a colocação não é utilizada em uma parte específica do contrato. Em linhas gerais, é 
usada para certificar, deixar claro que ambas as partes concordam com algum aspecto estabelecido no contrato, como observamos nos exemplos abaixo:

It is expressly agreed that the ownership of all of the El Pollo Loco Marks and the Confidential Information is and shall remain vested solely in the Company.

Notwithstanding the place where this Agreement may be executed by any of the parties hereto, the parties expressly agree that all terms and provisions hereof shall be construed and enforced in accordance with the laws of the Commonwealth of Virginia.

Diante desses resultados, observamos que, em português, o verbo quase nunca co-ocorre com um advérbio - essa co-ocorrência foi identificada apenas em uma associação maior, ou seja, desde que expressamente acordada entre as partes. Dessa forma, acreditamos que seu uso, em geral, não se faz necessário nos contextos analisados. Ao consultarmos uma especialista na área, a advogada, tradutora e pesquisadora Luciana Carvalho Fonseca sugeriu que investigássemos as ocorrências de as partes obrigam-se a e as partes convencionam. Ao analisarmos as linhas de concordância - três para a primeira unidade e duas para a segunda -, observamos que os contextos de uso equivalem àquele apresentado para a colocação em inglês, como podemos observar nos exemplos abaixo:

As PARTES obrigam-se a não firmar nenhum outro acordo de acionistas ou qualquer outro instrumento com qualquer terceiro [...].

As partes convencionam que o AUTOR nomeia e constitui a EDITORA como sua única procuradora, com poderes irrevogáveis [...].

Com isso, ampliamos nosso leque e sugerimos, como formas equivalentes: expressly agree = CONCORDAR; ACORDAR; FICAR acordado (entre as partes); as partes obrigam-se a; as partes convencionam.

\section{- DULY:}

- duly authorized (62)

Nossa primeira opção de busca foi a tradução prima facie de duly ou seja, devidamente, segundo advérbio terminado em -mente com maior índice de chavicidade em português. Nas 154 linhas de concordância, encontramos 9 ocorrências de devidamente AUTORIZADO, o que sinaliza equivalência entre a 
tradução literal das palavras que compõem a colocação em inglês. Decidimos então analisar o contexto, para verificar se essa equivalência se confirmava.

Em português, devidamente AUTORIZADO é utilizada para referir-se a alguma autorização concedida por uma das partes, mediante o acordado, que pode incluir a representação de uma dessas partes por outra pessoa. Exemplo:

Os representantes da Acionista que assinam este Acordo de Acionistas estão devidamente autorizados para assim proceder em nome da Acionista.

Em inglês, observamos que o uso mais frequente da colocação é também para esclarecer que as pessoas (representando as partes) estão autorizadas a firmar o contrato em questão, o que geralmente ocorre na parte final do documento. Observamos também que, dependendo das palavras com as quais duly authorized co-ocorre, sua forma equivalente pode variar - o que prevalece é a convencionalidade dessa tipologia textual em cada língua. As unidades duly authorized officers e duly authorized representatives não oferecem grandes dificuldades de tradução, partindo-se do princípio de que podemos nos valer de devidamente autorizados. No entanto, quando duly authorized faz parte de outras unidades, essa equivalência pode não ocorrer, como verificaremos nas colocações analisadas a seguir. Considerando o uso acima descrito, sugerimos como forma equivalente:

- duly authorized = devidamente AUTORIZADO.

- duly authorized, executed and delivered:

Segundo Carvalho Fonseca (2007, p. 97), executed and delivered é considerado um binômio na tipologia dos contratos, com 40 linhas de concordância em nosso corpus de estudo. Ao analisarmos suas ocorrências, observamos que geralmente apresenta a palavra agreement no co-texto, tanto à direita quanto à esquerda do nódulo de busca, além das partes envolvidas no contrato. A partir dessa informação, voltamos ao corpus em português e buscamos a palavra contrato, inserindo também, nessa mesma busca, partes como palavra de contexto. Especificamos que isso ocorresse em uma janela de 10 palavras à esquerda e 10 palavras à direita de contrato.

Como resultado, obtivemos 187 linhas de concordância e três co-ocorrências chamaram nossa atenção, quais sejam com os verbos firmar, assinar e celebrar. 
Voltamos ao corpus em inglês e decidimos analisar as 6.116 ocorrências de agreement, em busca de um ou mais verbos que transmitissem o sentido daqueles acima mencionados. Chegamos assim a execution of this agreement (62), EXECUTE this agreement (50), this agreement may be executed (29), execution and delivery of this agreement (28), agreement to be executed (13), this agreement to be executed (11), execute and deliver this agreement (7) e executed and delivered this agreement (2) em geral ao final do contrato, como também observado com os verbos assinar e firmar, em português. Antes de voltarmos ao corpus em português, decidimos levantar, novamente, as ocorrências de agreement, mas desta vez refinando a pesquisa e inserindo executed and delivered como palavra de contexto (janela de 10 ocorrências para cada lado). Nas 22 linhas de concordância apresentadas observamos que, mesmo quando a colocação não se encontrava na cláusula de fechamento do contrato, iniciada por in witness whereof em 3 ocorrências, ela referia-se ao ato de assinar/firmar o documento, como podemos verificar nos exemplos abaixo:

This Agreement (and, with respect to the Parent, the Indemnification Agreement) has been duly and validly executed and delivered by the Seller, MTI and the Parent and, [...].

(ii) the Shareholder has duly and validly executed and delivered this $\underline{\text { Agreement, }}$ and this Agreement constitutes a legal, valid and binding obligation of the Shareholder, $[\ldots]$.

Voltamos ao corpus em português, colocamos contrato como expressão de busca e, como palavra de contexto, os verbos firmar, assinar e celebrar, em pesquisas separadas. Os resultados foram:

- contrato/firm $^{*} \rightarrow 44$ ocorrências:

E por estarem assim justas e contratadas, as PARTES firmam o presente contrato em conjunto com os INTERVENIENTES ANUENTES [...].

- contrato/assin $^{*} \rightarrow 148$ ocorrências:

$E$, por estarem assim justos e contratados, assinam o presente contrato com 2 (duas) vias de igual teor e forma, na presença das testemunhas [...].

- contrato/celebr* $\rightarrow 64$ ocorrências:

Resolvem as partes, de comum acordo, celebrar o presente contrato, nos termos e condições seguintes: CLÁUSULA PRIMEIRA [...]. 
Analisados esses resultados e comparando seu uso em contexto, chegamos à conclusão que as formas equivalentes mais adequadas de executed and delivered são os verbos firmar ou assinar, em português. O verbo celebrar seria uma terceira opção.

Voltando à colocação duly authorized, executed and delivered, que apresenta 10 ocorrências e é utilizada nos mesmos contextos de executed and delivered (salvo as cláusulas de encerramento do contrato), decidimos buscar devidamente e, como palavra de contexto, colocamos autoriz*. A única ocorrência relacionada ao contexto da unidade em inglês é: Os representantes da Acionista que assinam este Acordo de Acionistas estão devidamente autorizados para assim proceder em nome da Acionista.

Diante desses resultados, decidimos buscar autoriz* e as expressões assin * firm $^{*}$, separadamente, como palavras de contexto. Nas 13 ocorrências de autoriz*assin*, identificamos novamente o exemplo acima mencionado.

Com isso, concluímos que, em português, não é usual dizermos que um documento, mais especificamente um contrato, foi devidamente autorizado e assinado pelas partes. A nosso ver, há redundância na colocação em inglês, já observada e apontada por Carvalho Fonseca (2007 p. 112). Quanto ao uso do advérbio, pode-se dizer que é possível, mas pouco provável ou frequente. Na busca de devidamente e assin*, como palavra de contexto, encontramos 6 ocorrências de devidamente ASSINADO, referindo-se a documentos diversos (não necessariamente a contrato), como em [...] mediante comunicação por escrito à Seguradora, devidamente assinada e protocolada pela Seguradora [...].

Depois de conduzirmos essa investigação direcionada pelos dados que foram gradativamente levantados no corpus, nossa sugestão de forma equivalente para a colocação em estudo é:

- duly authorized, executed and delivered = (devidamente) ASSINADO; (devidamente) FIRMADO (entre as partes).

- duly and validly:

Nas 10 ocorrências do binômio duly and validly, temos: duly and validly authorized (3) e duly and validly executed and delivered (3). Observamos que todas as concordâncias encontram-se, nos contratos, no item que esclarece o papel das partes e confirma sua autoridade para assinar o documento. Exemplo: 
The Shareholder represents and warrants as follows: (i) the Shareholder has the capacity to execute and deliver this Agreement and to consummate the transactions contemplated hereby and (ii) the Shareholder has duly and validly executed and delivered this Agreement [...].

Em português, fomos investigar as ocorrências dos dois advérbios, separadamente. Validamente apresentou apenas uma ocorrência, não relacionada ao contexto estudado. Devidamente apresentou 154 linhas de concordância, onde identificamos: devidamente AUTORIZADO (9); devidamente ASSINADO (6) e devidamente FIRMADO (3). Nesse levantamento, a colocação mais frequente foi devidamente representada, com 10 ocorrências.

Analisando esses resultados, podemos dizer que a forma equivalente para o binômio, em inglês, seria representada por apenas um advérbio em português, ou seja, devidamente ${ }^{127}$. Colocando-o em contexto, observamos que sua co-ocorrência com AUTORIZADO é um pouco mais frequente do que com ASSINADO e FIRMADO. Daí sugerirmos duas formas equivalentes, sendo opcional o uso do advérbio na segunda sugestão:

- duly and validly authorized = devidamente AUTORIZADO.

- duly and validly executed and delivered = (devidamente) ASSINADO; (devidamente) FIRMADO.

\section{- COLLECTIVELY:}

- collectively referred to as $+\mathrm{SN}$ :

Nossa primeira busca deu-se com o advérbio coletivamente que, como já prevíamos, não apresentou quaisquer ocorrências no corpus em português. Voltamos às 32 ocorrências de collectively referred to as e decidimos reiniciar a pesquisa a partir da tradução de uma palavra anteposta a essa associação em 18 ocorrências, ou seja, hereinafter collectively referred to as. Nas 194 ocorrências de doravante, palavra que consideramos como forma equivalente de hereinafter, observamos que a tradução mais adequada para o verbo refer (que a priori

\footnotetext{
${ }^{127}$ O binômio duly and validly é um bom exemplo do que Mellinkoff (1963) apresenta como uma das características da linguagem jurídica em inglês, ou seja, o uso de duas palavras para expressar um único significado (vide item 3.2.1.1 para mais detalhes).
} 
conduziria nossa próxima busca) seria designado ou denominado. Nessas linhas de concordância, levantamos as seguintes associações:

- doravante denominada (29);

- doravante denominada simplesmente (61);

- doravante denominado (27);

- doravante denominado simplesmente (15);

- doravante designada (10);

- doravante designada simplesmente (13);

- doravante designado (7);

- doravante designado simplesmente (3)

A partir desse levantamento, decidimos comparar o contexto de uso, em ambas as línguas, exemplificado no quadro abaixo:

\begin{tabular}{|l|l|}
\hline \multicolumn{1}{|c|}{ inglês } & \multicolumn{1}{|c|}{ português } \\
\hline $\begin{array}{l}\text { the Bay Oaks Premises and the Woodside } \\
\text { Premises are collectively referred to as the } \\
\text { "Premises." }\end{array}$ & $\begin{array}{l}\text { neste ato representada na forma de seu } \\
\text { estatuto social, doravante denominada } \\
\text { simplesmente LOGESTIC }\end{array}$ \\
\hline $\begin{array}{l}\text { Upon the closing (settlement) of each } \\
\text { transaction which Franchisee has handled } \\
\text { for either a buyer or seller (hereinafter } \\
\text { collectively referred to as "client") }\end{array}$ & $\begin{array}{l}\text { neste ato legalmente representada na forma } \\
\text { de seu Estatuto Social, doravante designada } \\
\text { simplesmente VENDEDORA }\end{array}$ \\
\hline
\end{tabular}

Diante dessas observações, concluimos que, em português, utilizamos um outro advérbio terminado em -mente nos contratos quando consideramos a unidade collectively referred to as $+\mathrm{SN}$. Portanto, nossas sugestões de formas equivalentes são:

- collectively referred to as $=$ (doravante) DENOMINADO simplesmente; (doravante) DESIGNADO simplesmente.

- collectively called:

Analisamos as 4 ocorrências de collectively called e observamos que seu uso equivale àquele apresentado para collectively referred to as, como podemos observar nas linhas abaixo:

[...] for the operation of multiple licensed real estate brokerages upon the terms and conditions set forth in this Agreement (hereinafter collectively called the "Franchise"). 
The parcel of land described on Exhibit $A$, together with the buildings and other improvements thereon, and the rights, interests, fixtures, personal property, and other properties described above, is collectively called the "Premises."

Desse modo, sugerimos como formas equivalentes:

collectively called = DENOMINADO simplesmente; DESIGNADO simplesmente.

Concluída esta parte da pesquisa, onde procuramos sugerir formas equivalentes para algumas das unidades levantadas em inglês, investigaremos como elas se apresentam nos corpora de língua geral, numa tentativa de apontar se suas ocorrências são (ou não) típicas da tipologia dos contratos.

3.2.5 As fraseologias analisadas em contratos e suas formas equivalentes nos corpora de língua geral

Depois da análise desenvolvida na seção anterior, objetivamos investigar, por amostragem e de forma aleatória, se as fraseologias e formas equivalentes analisadas a partir de nosso corpus de estudo em Direito Contratual ocorrem nos corpora de referência definidos para esta pesquisa, quais sejam, o BNC, em inglês, e o Banco de Português. Consultaremos também o COCA, em inglês. Além da ocorrência, pretendemos observar se, quando ocorrem, essas fraseologias e formas equivalentes pertencem (ou não) à tipologia dos contratos. Listamos abaixo todas as unidades - aquelas em negrito foram selecionadas para esta investigação.

\begin{tabular}{|l|l|}
\hline \multicolumn{1}{|c|}{ FRASEOLOGIA EM INGLÊS } & \multicolumn{1}{|c|}{ FORMA(S) EQUIVALENTE(S) EM PORTUGUÊS } \\
\hline promptly notify & $\begin{array}{l}\text { COMUNICAR imediatamente; NOTIFICAR imediatamente; } \\
\text { COMUNICAR de imediato; NOTIFICAR de imediato }\end{array}$ \\
\hline promptly NOTIFY + SN + in writing & $\begin{array}{l}\text { COMUNICAR (à/ao SN) por escrito e imediatamente; } \\
\text { COMUNICAR (à/ao SN), de imediato e por escrito; } \\
\text { COMUNICAR imediatamente (à/ao SN), por escrito. Ao } \\
\text { invés de COMUNICAR, o verbo NOTIFICAR também pode } \\
\text { ser utilizado. }\end{array}$ \\
\hline promptly execute and deliver & APRESENTAR/FORNECER (de imediato) \\
\hline as promptly as + (ADV) + ADJ & quando + ADJ. Ex.: quando possível. \\
\hline
\end{tabular}




\begin{tabular}{|c|c|}
\hline may reasonably request & $\begin{array}{l}\text { poderá/poderão solicitar; sempre que (for) SOLICITADo. } \\
\text { O uso da voz passiva irá depender do contexto na } \\
\text { língua de chegada. }\end{array}$ \\
\hline reasonably necessary & (que se fizer) NECESSÁRIO \\
\hline reasonably acceptable & $\begin{array}{l}\text { de comum acordo (entre/com); } \\
\text { com a anuência de + SN }\end{array}$ \\
\hline reasonably believe & CONSIDERAR \\
\hline expressly provided & (conforme) disposto \\
\hline $\begin{array}{l}\text { except as expressly provided } \\
\text { in/herein }\end{array}$ & $\begin{array}{l}\text { ressalvando o disposto no/na; } \\
\text { sem prejuízo do disposto no/na }\end{array}$ \\
\hline $\begin{array}{l}\text { except as otherwise expressly } \\
\text { provided in/herein }\end{array}$ & $\begin{array}{l}\text { ressalvando o disposto no/na; } \\
\text { sem prejuízo do disposto no/na }\end{array}$ \\
\hline expressly agree & $\begin{array}{l}\text { CONCORDAR; ACORDAR; FICAR acordado (entre as } \\
\text { partes); as partes obrigam-se a; as partes } \\
\text { convencionam }\end{array}$ \\
\hline duly authorized & devidamente AUTORIZADO \\
\hline $\begin{array}{l}\text { duly authorized, executed and } \\
\text { delivered }\end{array}$ & $\begin{array}{l}\text { (devidamente) ASSINADO; } \\
\text { (devidamente) FIRMADO (entre as partes) }\end{array}$ \\
\hline duly and validly authorized & devidamente AUTORIZADO \\
\hline $\begin{array}{l}\text { duly and validly executed and } \\
\text { delivered }\end{array}$ & $\begin{array}{l}\text { (devidamente) ASSINADO; } \\
\text { (devidamente) FIRMADO }\end{array}$ \\
\hline collectively referred to as & $\begin{array}{l}\text { (doravante) DENOMINADO simplesmente; } \\
\text { (doravante) DESIGNADO simplesmente }\end{array}$ \\
\hline collectively called & $\begin{array}{l}\text { DENOMINADO simplesmente; } \\
\text { DESIGNADO simplesmente }\end{array}$ \\
\hline
\end{tabular}

Quadro 9 - Algumas fraseologias em inglês e suas formas equivalentes em português (Direito)

- promptly notify:

No BNC, encontramos apenas uma ocorrência, justamente na área do Direito, como podemos observar abaixo:

On receiving notice from the buyer that the tender or documents do not comply, LCH may promptly notify the selling member to similar effect. Delivery and payment Although LCH is a principal party, buying as such from the selling member. ${ }^{128}$

No COCA, foram 4 ocorrências, e apenas uma delas não se referia diretamente ao Direito:

They resigned because their failure to promptly notify the government once they learned of the trading violations [...]. (extraída do Jornal Washington Post, 1991)

\footnotetext{
${ }^{128}$ Referência apresentada pelo BNC: Futures trading law and regulation. Ottino, Peter. Harlow: Longman Group UK Ltd, 1993, pp. 104-114. 159 s-units.
} 
- notificar imediatamente:

Nesse caso, decidimos investigar a forma infinitiva. O BP retornou 6 ocorrências de notificar imediatamente. Três foram em textos jornalísticos e as demais em textos acadêmicos, mas apresentam referências à area do Direito, inclusive com vocabulário mais formal. Exemplo:

[...] a Justiça Eleitoral, à vista do pedido, deverá notificar imediatamente o responsável pela emissora que realizou o programa para que entregue em vinte e quatro horas, sob as penas do artigo 347 da Lei no 4.737, de 15 de julho de 1965 Código Eleitoral, cópia da fita da transmissão [...].

- may reasonably request:

No BNC, duas das três ocorrências registradas são na área de administração (um mesmo manual) e, a outra, em locação comercial. Todas as três apresentam cunho contratual, como observamos na terceira ocorrência:

The latter part of the clause should therefore be amended as follows: and in addition to the foregoing such other risks as the Landlord from time to time in its reasonable discretion may think fit to insure against or against which the Tenant may reasonably request the Landlord to insure $\left[\ldots . .{ }^{129}\right.$

Nenhuma ocorrência foi encontrada no COCA, o que reforça o fato de que may reasonably request pertence à tipologia dos contratos.

- sempre que (for) solicitado:

Nossa opção de busca no BP foi sempre que solicitado, que retornou 24 ocorrências. Nessas, nenhuma foi observada especificamente na área do Direito. De acordo com a divisão do corpus, suas ocorrências foram nos seguintes registros:

- escrito/acadêmico/tese - 10 ocorrências;

- falado/congresso - 6 ocorrências;

- escrito/jornalístico/jornal - 5 ocorrências;

- escrito/acadêmico/artigo - 3 ocorrências.

Exemplo:

[...] apresentar relatório ao FNDE sempre que solicitado e formalizar denúncia no caso de irregularidades. (escrito/acadêmico/tese)

129 Referência apresentada pelo BNC: Commercial leases: tenants' amendments. Sweet, Robert. Harlow: Longman Group UK Ltd, 1993, pp. 1-127. 1047 s-units. 
Com essas ocorrências, apesar de serem apenas 24 em um corpus com aproximadamente 700 milhões de palavras, podemos observar que sempre que solicitado pode também ocorrer em outras áreas. No entanto, ainda consideramos a expressão significativa nos contratos.

\section{- expressly provided:}

Das 13 ocorrências de expressly provided apresentadas pelo BNC, 11 encontram-se em textos da área jurídica, fato que pode ser observado na identificação dos arquivos que aparece ao lado das linhas de concordância, como mostra a figura abaixo:

\begin{tabular}{|l|l|l|l|l|}
\hline 1 & AHY & W_newsp_brdsht_nat_science & job first. Schoolchildren are entitled to special equipment, but only if it is expressly provided for in their formal stateme \\
\hline 2 & FDW & W_ac_polit_law_edu & provides, so far as is relevant: "If, in any case not expressly provided for by this Act, a liability to any duty, or any aut \\
\hline 3 & FE2 & W_ac_polit_law_edu & it . Take for example a man who obtains land by deception. Save as otherwise expressly provided, the definitions in se \\
\hline 4 & EDL & W_ac_polit_law_edu & the Cayman Islands). To ensure the simplicity of the system, it is expressly provided in Article 2 that no intervening ag \\
\hline 5 & FAU & W_ac_polit_law_edu & makes important changes to the Treaty of Rome. The Act formalizes certain procedures not expressly provided for in th \\
\hline 6 & FBY & W_ac_polit_law_edu & a pupil and to lay down the admissions policy of the school. This is expressly provided by article 5 of the articles of gov \\
\hline 7 & FC2 & W_ac_polit_law_edu & step which was not part of the cause of action and that, save as expressly provided by section $10(4)$ for summary proc \\
\hline 8 & FCD & W_ac_polit_law_edu & statutory definition of "company" is only its prima facie meaning, since it is expressly provided in section 735(4) of the \\
\hline 9 & FCj & W_ac_polit_law_edu & of establishment through the setting up of agencies, branches or subsidiaries, as is expressly provided for in the secong \\
\hline 10 & GVG & W_ac_polit_law_edu & taking of possession by the debentureholder and (v) the happening of an event expressly provided for in the debenture \\
\hline 11 & J6R & W_ac_polit_law_edu & of the premium be paid by the headtenant to the landlord. If this is expressly provided for in the lease the parties will $n$ \\
\hline 12 & J6R & W_ac_polit_law_edu & have not only required a step to be taken within a specified time but have expressly provided for the consequences in \\
\hline 13 & CCU & W_commerce & copy, modification, or merged portion, in whole or in part, except as expressly provided for in this license. Distribute co \\
\hline
\end{tabular}

Figura 27 - Resultados da busca de expressly provided no BNC

Analisando esses resultados no contexto expandido - possível quando clicamos em qualquer uma das três colunas à esquerda das linhas de concordância - verificamos que, apesar de não pertencerem especificamente à tipologia dos contratos, as onze ocorrências faziam parte de publicações na área jurídica, tais como: The Weekly Law Reports (1992), onde tivemos a maioria das ocorrências, International judicial assistance (1992) e Principles of modern company law (1992). Exemplo:

The express statutory definition of "company" is only its prima facie meaning, since it is expressly provided in section 735(4) of the Act of 1985 that the defined meaning may be displaced where a contrary intention appears.

No COCA, foram registradas 7 ocorrências, sendo que apenas uma delas pertencia à área jurídica: 
Section 41 of the Manual states that " the voice of the majority decides. For the lex majoris partis is the law of all councils, elections, \&c.; where not otherwise expressly provided. "

As demais encontravam-se na área acadêmica e ficção.

Diante desses resultados, concluímos que expressly provided é típica de textos jurídicos, não necessariamente de contratos.

- (conforme) disposto:

Nas 98 ocorrências de conforme disposto apresentadas pelo Banco de Português, pudemos observar que, apesar de não serem registros no domínio jurídico, os textos referiam-se a leis e questões dessa área, como podemos observar na figura abaixo:

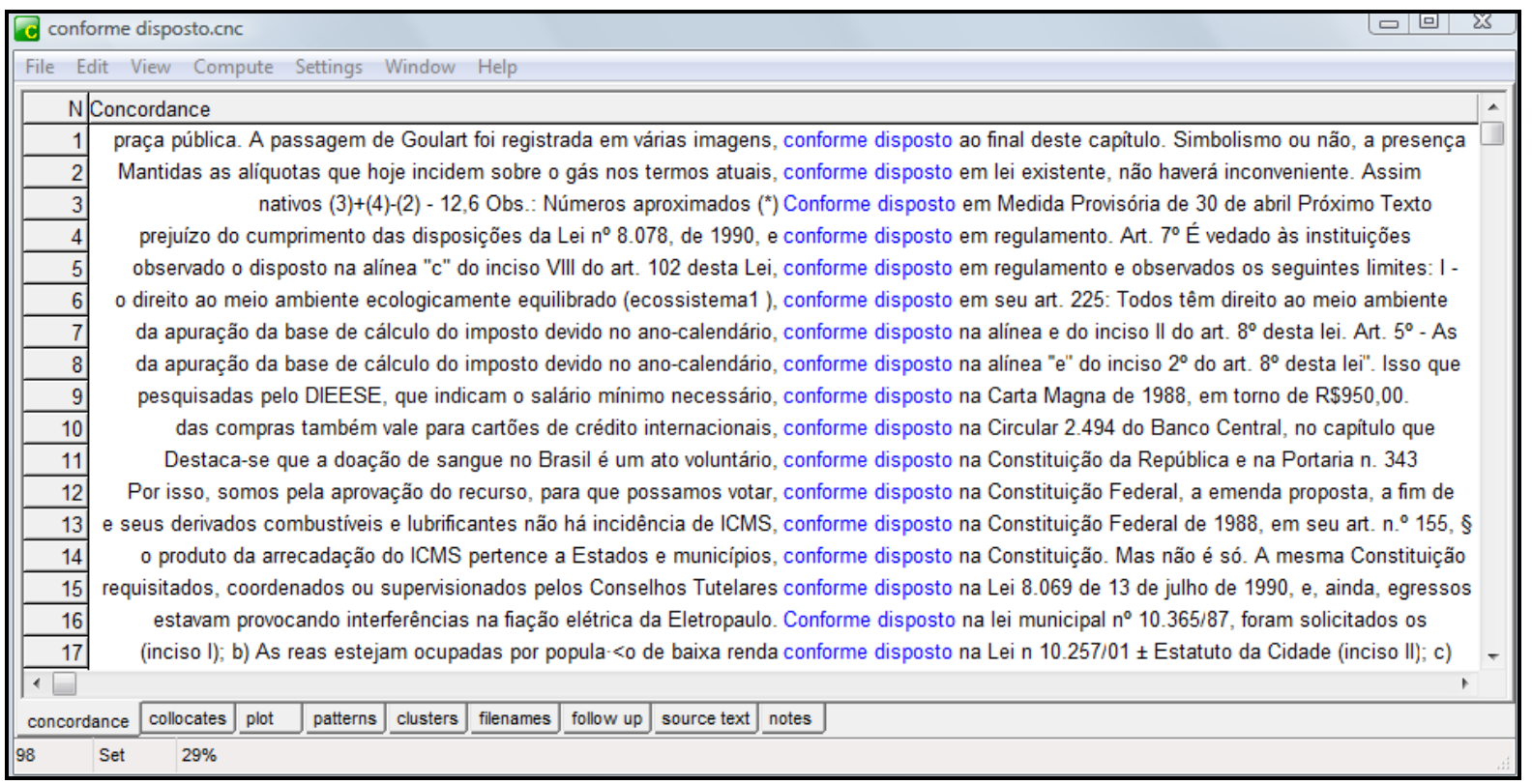

Figura 28 - Linhas de concordância para conforme disposto (BP)

Em 95 das ocorrências, conforme disposto é seguido da preposição em (e associações com artigos e pronomes), o que indica referência a alguma lei, artigo, etc. de conhecimento comum. Apenas para mencionar algumas co-ocorrências apresentadas, temos: no art. (28); na lei (7); neste artigo (6) e no artigo (6). Exemplo: Conforme disposto no art. 240 da Lei de Registros Públicos (Lei 6.015/73), o registro da penhora faz prova quanto à fraude de qualquer transação posterior. (texto acadêmico/tese) 
No total, a colocação aparece em 83 textos diferentes, nos seguintes registros: falado/congresso (28); acadêmico/tese (27); acadêmico/artigo (12); jornalístico/jornal (11); legal/legislação (4); negócios/variado (1).

Diante dessas observações, podemos dizer que, apesar de conforme disposto não ser especificamente da tipologia dos contratos, é uma colocação frequentemente utilizada quando questões legais são mencionadas no texto.

\section{- duly authorized, executed and delivered:}

Nenhuma ocorrência foi encontrada em ambos os corpora de referência, o que sinaliza ser a colocação característica da tipologia dos contratos.

\section{- (devidamente) assinado:}

O BP apresentou 35 ocorrências de devidamente assinado, identificadas em 32 textos nos seguintes registros: acadêmico/artigo (9); falado/congresso (8); jornalístico/jornal (8); acadêmico/tese (6); legal/legislação (1). Apesar de serem áreas diferentes, em todas as ocorrências a colocação referia-se à assinatura de documentos, como podemos observar nos exemplos abaixo:

X - apresentação de Contrato de Utilização do Patrimônio Genético e de Repartição de Benefícios devidamente assinado pelas partes, quando se tratar de acesso ao patrimônio genético ou ao conhecimento tradicional associado com potencial de uso econômico, como ocorre nas atividades de bioprospecção e desenvolvimento tecnológico. (acadêmico/tese)

[...] o edital só será fornecido com uma solicitação por escrito, em papel timbrado e devidamente assinado, feita pelo requerente. (jornalístico/jornal)

A partir dessas observações, podemos dizer que devidamente assinado não é uma colocação típica de contratos, mas é utilizada em questões legais.

\section{- collectively referred to as:}

Nas 5 linhas de concordância apresentadas pelo BNC, uma era na área político-filosófica, como podemos verificar abaixo:

Power is centralized within a handful of institutions --; sometimes collectively referred to as "the state" --; and those with economic and political power [...]. 
As demais eram duas na área das Ciências e as outras no que o corpus classifica como miscellaneous, ou seja, textos de origem diversa.

O COCA apresentou 19 ocorrências, das quais 17 eram em textos acadêmicos, em áreas de estudo diversas. Nenhuma era especificamente na área jurídica. Exemplo:

Reaction time and speed of information-processing paradigms -- collectively referred to as "chronometric methods or measures" [...]. (extraído de um texto acadêmico na área da Psicologia).

Com isso, podemos concluir que collectively referred to as não se restringe a textos jurídicos ou, mais especificamente, a contratos.

- (doravante) denominado simplesmente:

Observamos que 4 das 6 ocorrências de doravante denominad* simplesmente apresentadas pelo BP, apesar de não estarem registradas em textos da área jurídica, faziam parte de trechos de contratos e termos de compromisso, como no exemplo abaixo:

Que entre si fazem, de um lado o Sr. .... brasileiro, casado, agricultor, residente e domiciliado na Linha ..... - no município de .... - PR, portador da Cédula de Identidade-RG $n .^{\circ} \quad \ldots$. e CPF $n .^{\circ} \quad \ldots .$. doravante denominado simplesmente VENDEDOR e do outro lado a empresa ..... pessoa jurídica de direito privado [...].

Considerando-se a baixa frequência em um corpus de 700 milhões de palavras e que 4 delas relacionavam-se à área especializada em estudo, podemos dizer que doravante DENOMINADO simplesmente é uma colocação típica da tipologia dos contratos.

3.3 Os advérbios em receitas culinárias e contratos: comparações importantes

Ao final do capítulo II, mais precisamente no item 2.6.1, elencamos quatro listas com os advérbios terminados em -ly e -mente que apresentaram chavicidade igual ou superior a 100 quando comparamos nossos corpora de estudo aos corpora de referência, em ambas as línguas. Somando-se as formas (types) de advérbios listados nas duas línguas, temos: 
- em inglês: 28 advérbios diferentes na tipologia das receitas e 24 nos contratos;

- em português: 17 advérbios diferentes na tipologia das receitas e 15 nos contratos.

Em um primeiro momento, observamos certo equilíbrio entre esses números: 28/24 em inglês e 17/15 em português. Tal fato, no entanto, revela-se ilusório ao compararmos os dados apresentados nessas listas. Além da frequência, que certamente não pode ser comparada devido à diferença de tamanho dos corpora ${ }^{130}$, o que também se reflete no índice de chavicidade, observamos que o único advérbio em comum entre as áreas em inglês é immediately. Em português, são dois: imediatamente e juntamente. Pressupondo que seus contextos de uso sejam diferentes - afinal são duas áreas de especialidade bastante diversas -, decidimos levantar as fraseologias das quais esses advérbios fazem parte, bem como observar outros aspectos direcionados pelo corpus. Apresentamos abaixo os resultados das seis análises desses três advérbios - immediately nos dois corpora em inglês e imediatamente e juntamente, naqueles em português. Em um segundo momento, introduziremos um panorama mais geral quanto ao uso dos advérbios terminados em -ly e-mente em receitas culinárias e contratos.

\subsubsection{Immediately nas receitas culinárias}

O advérbio immediately apresenta 686 ocorrências no corpus de receitas culinárias, ocupando a $680^{a}$ posição na lista de palavras-chave de todo o corpus. Seu índice de chavicidade é de 826,91, sendo o $13^{\circ}$ advérbio na lista daqueles terminados em -ly e com chavicidade acima de 100. Como observado em análises anteriores, as unidades formadas por duas palavras são mais frequentes, algumas inclusive integrando agrupamentos maiores. Todas as ocorrências do advérbio encontram-se no Modo de Fazer das receitas. Em 26 linhas de concordância, immediately foi identificado em início de oração, anteposto ao verbo em 24 dessas ocorrências, como em Immediately remove cakes from pan or tins and place on rack

\footnotetext{
${ }^{130}$ Para isso, necessitaríamos fazer a normalização das frequências, conforme explicado no capítulo II, item 2.6.
} 
for cooling. Apresentamos abaixo todas as unidades encontradas com esse advérbio em receitas culinárias, em nosso corpus de estudo, seguidas de comentários.

\section{O advérbio immediately e o verbo serve}

- serve immediately (514):

Considerando-se as 514 ocorrências apresentadas pela ferramenta Concord, a colocação serve immediately foi encontrada 349 vezes ao final de cada receita, no último passo e terminando uma oração - precedida de and em 143 ocorrências e de then 5 vezes -, ou compondo uma oração isolada (198 oc.), separada por pontos finais. Exemplos:

Spoon a little toffee sauce around the puddings and serve immediately.

5. Pour the soup into individual soup bowls. 6. Serve immediately.

Stir in plenty of chopped parsley and then serve immediately.

Essa concentração do uso do advérbio ao final da receita torna-se ainda mais evidente quando observamos as ocorrências de immediately com o recurso plot (um daqueles apresentados na ferramenta Concord, programa WST) ${ }^{131}$, representadas pelos traços em vermelho na figura abaixo:

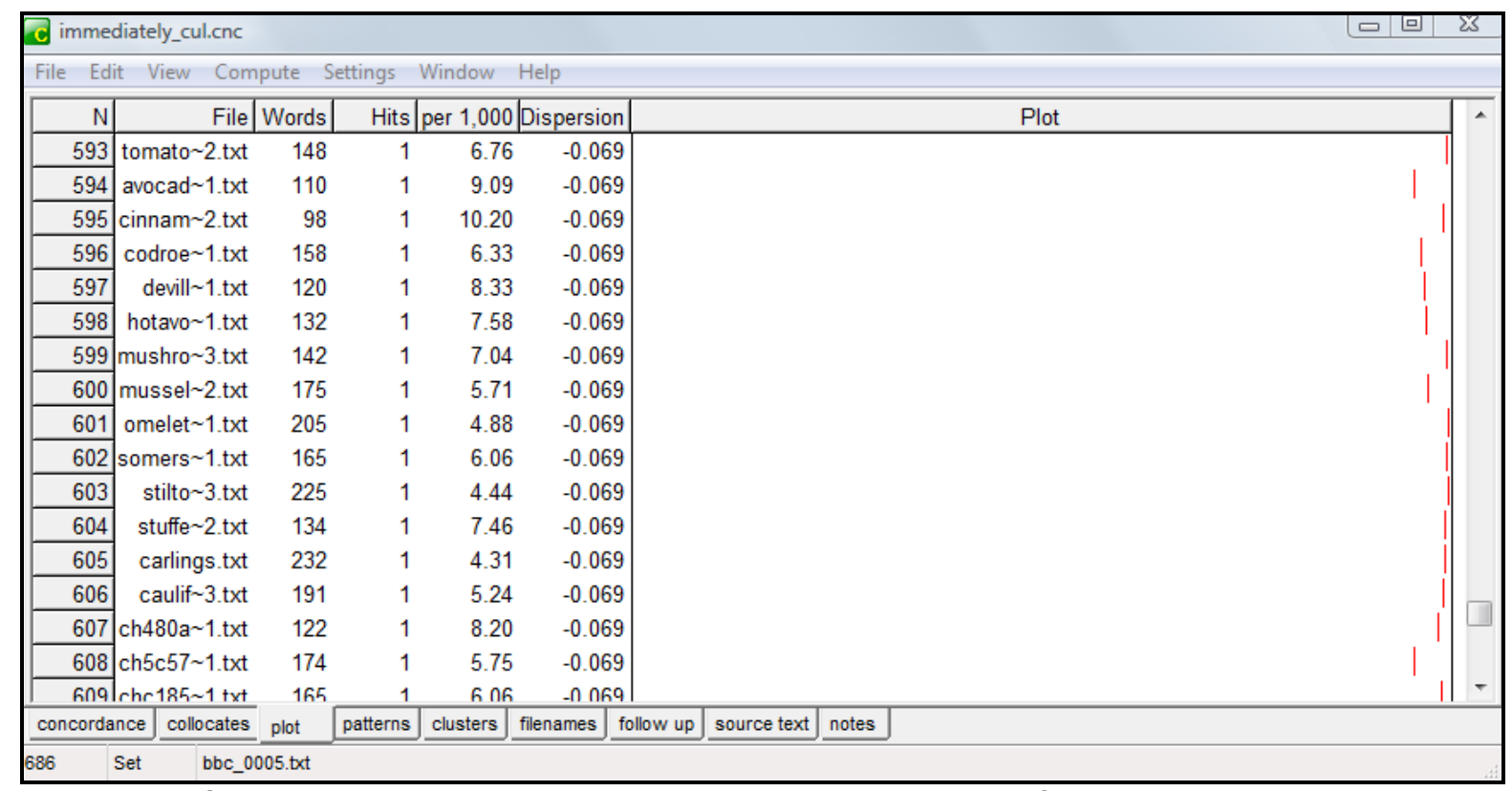

Figura 29 - O advérbio immediately nas receitas apresentado com a ferramenta plot do programa WST

\footnotetext{
${ }^{131}$ Para mais detalhes, vide capítulo II, item 2.5
} 
Conforme apontado, 349 das 514 ocorrências de serve immediately finalizam a receita. As demais 165 ocorrências, apesar de não serem as últimas palavras do texto, também encontram-se nas instruções que finalizam a preparação do prato.

Durante a análise, e conforme já mencionado anteriormente, observamos que há unidades menores que integram outras maiores. À medida em que mais elementos são agregados, maior a probabilidade dessa unidade ser composta pela associação entre itens lexicais e classes gramaticais e/ou sintagmas. É o caso da colocação serve immediately, que integra as unidades maiores de significado abaixo elencadas:

- sV + and serve immediately (194):

Scatter croutons over the top and serve immediately.

- serve (+[INGREDIENTE]) immediately with + [INGREDIENTE] (94):

Serve immediately with a little fresh coriander and lemon or lime wedges.

$-V+$ with + [INGREDIENTE] + and serve immediately ( 59):

- sprinkle with + [INGREDIENTE] + and serve immediately (19):

Sprinkle with chopped thyme and serve immediately.

- garnish with + [INGREDIENTE] + and serve immediately (13):

Garnish with lemon zest and serve immediately.

- drizzle with + [INGREDIENTE] + and serve immediately (4):

Drizzle with maple syrup and serve immediately.

- decorate (4) / top (3) / dust (3) / brush / glaze / coat / finish with + [INGREDIENTE] + and serve immediately:

Decorate with sprigs of mint and serve immediately.

Top with the salad and serve immediately.

Cover fruit with crushed biscuits and dust with icing sugar and serve immediately with hot custard.

- season with salt and pepper and serve immediately (7):

Sprinkle with the chopped parsley, season with salt and pepper and serve immediately.

$\mathrm{Na}$ categoria semântica [INGREDIENTE] nas fraseologias acima, destacam-se os temperos pepper (8), parsley (7) e coriander (leaves) (6).

- Season to taste and serve immediately (6):

Remove from the heat and fold in the shredded basil. Season to taste and serve immediately. 
Analisando atentamente o contexto de serve immediately, observamos a ocorrência das palavras golden (11), golden brown (10) e browned (2) ao final da oração anterior, o que indica a finalização do processo e o momento em que o prato está quase pronto, como podemos observar nos exemplos abaixo:

Gas 6 and cook for a further 15 minutes or until the top is golden. Serve immediately with garlic bread.

Cover it with the grated parmesan and grill until the cheese is golden brown. Serve immediately.

Transfer to the uppermost rack and bake for 5 more minutes until browned. Serve immediately!

Outra palavra que chamou nossa atenção nessa posição foi minute(s) (16). Uma vez seguida de serve immediately, indica também o processo de finalização do prato: Place on top of the pork, cover and cook for 15 minutes. Serve immediately.

Além dessas ocorrências, identificamos ingredientes que indicam a finalização do preparo, uma vez que geralmente são acrescentados pouco antes de servir. É o caso de sauce (6) e pepper (4):

Drain and toss in the pasta sauce. Serve immediately with a sprinkling of chopped basil leaves.

Stir in the roughly torn basil leaves and some freshly ground black pepper. Serve immediately.

- sV + bowl(s)/plate(s) and serve immediately (11). Nesse caso, a associação indica colocar o alimento preparado em um recipiente e servi-lo na sequência, outra característica da finalização do processo:

Remove from the oven, place on a serving plate and serve immediately.

- serve immediately or + sv (7):

Serve immediately or turn the oven low and keep warm for up to 30 minutes.

- serve immediately(,) garnished with + [INGREDIENTE] (7):

Serve immediately garnished with freshly chopped parsley.

- [ADICIONAR INGREDIENTE] + on/over (the) top and serve immediately (7):

Spread the fruit filling over the top and serve immediately. 
- serve immediately while $+\mathrm{sv}^{132}(6)$ :

Serve immediately while the pancakes are warm.

- [MISTURAR] + well and serve immediately (5):

Drain the pasta and add to the sauce - mix well and serve immediately.

\section{$>0$ advérbio immediately e o verbo cover}

- cover immediately (9): Pour into jars while hot and cover immediately.

- cover immediately with airtight and vinegar-proof tops/lids (7):

Spoon the chutney into prepared jars and cover immediately with airtight and vinegarproof tops.

\section{$>0$ advérbio immediately e outros verbos}

- use/be used immediately (or + Sv) (9):

Place in a bowl and use immediately.

The liquid caught in the bowl or pot is your vegetable broth it can be used immediately or stored for later use.

- Use immediately or refrigerate until required. (3) - a própria oração já constitui uma unidade maior de significado.

- immediately add + [INGREDIENTE] (7):

Immediately add the chicken, stirring vigorously to prevent it from sticking.

- immediately remove (7):

Add the red wine and bring to the boil then immediately remove from the heat and allow to cool.

- immediately reduce $(6)$ :

Immediately reduce to a very gentle simmer and be careful not to boil.

- eat immediately (6):

To serve warm, toss in a large bowl with the remaining ingredients and eat immediately.

\footnotetext{
${ }^{132}$ Deve-se observar que o SV inclui a conjunção while. Colocamos dessa forma para facilitar a visualização do padrão.
} 


\section{> $\mathrm{O}$ advérbio immediately e outras associações morfossintáticas}

- then immediately $+v(7)$. Essa unidade indica uma sequência de ações:

Bring to the boil quickly, then immediately reduce the heat, cover the pot and simmer for an hour.

- $v+$ immediately in/into + [RECIPIENTE] (11):

Pour the mixture in and place immediately in the oven.

Como podemos observar, o advérbio immediately apresenta um papel bem definido na tipologia das receitas: geralmente ocorre no Modo de Fazer, com verbos na forma imperativa e ao final da receita, sendo sua co-ocorrência mais frequente com o verbo serve. A colocação serve immediately integra vários agrupamentos maiores. Semanticamente, ele indica que a ação expressa pelo verbo deve ser realizada em um curto período.

$\mathrm{Na}$ sequência, apresentamos a análise desse mesmo advérbio na área do Direito.

\subsubsection{Immediately nos contratos}

O advérbio immediately apresenta 330 ocorrências no corpus de instrumentos contratuais e ocupa a $372^{\mathrm{a}}$ posição na lista que inclui todas as palavras-chave levantadas naquele corpus ${ }^{133}$. Seu índice de chavicidade é de 526,2 , sendo o sexto advérbio entre os terminados em -ly que apresentaram índice igual ou superior a 100.

Considerando-se a dispersão de immediately nas receitas culinárias, a primeira tela que fomos observar ao iniciarmos esta investigação foi a do recurso plot, na ferramenta Concord. Como podemos verificar na figura abaixo, a dispersão de immediately pelos contratos é totalmente diferente da anterior, não havendo grande concentração de ocorrências em quaisquer de suas partes. Pode-se dizer que, diferente das receitas, são raras as vezes em que o advérbio é utilizado ao final do texto.

\footnotetext{
${ }^{133}$ Vide Anexo H para consultar as 100 primeiras palavras-chave do corpus total.
} 


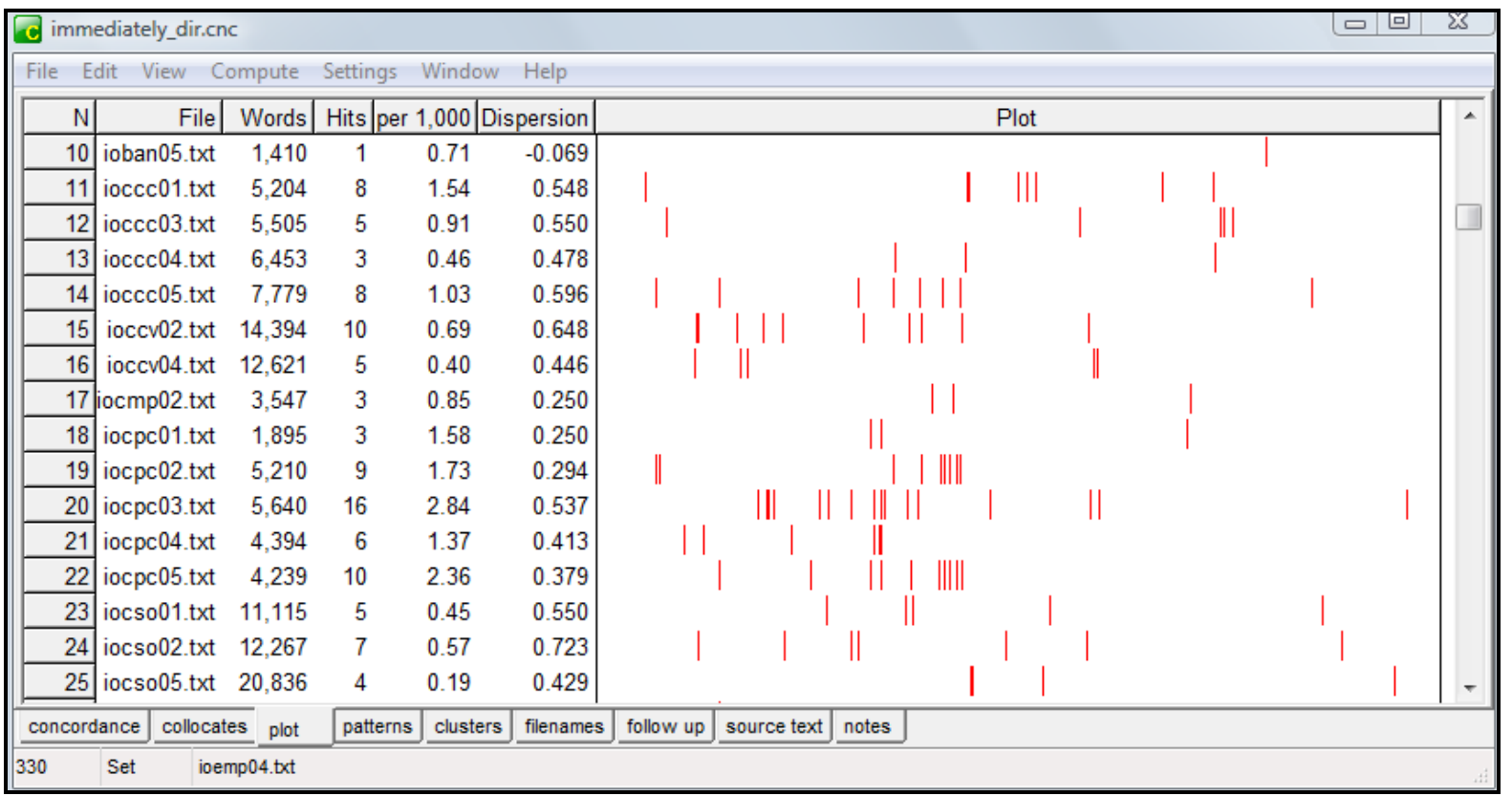

Figura 30 - O advérbio immediately nos contratos, apresentado com a ferramenta plot do programa WST

Esse é apenas um breve comentário sobre um fato que salta aos olhos do pesquisador - deixamos uma comparação mais detalhada sobre o advérbio nas duas áreas estudadas para a próxima seção. Por ora, vamos nos ater ao levantamento de seu uso no corpus de instrumentos contratuais.

No recurso patterns, definimos que a ferramenta Concord apresentasse clusters formados entre duas e sete palavras, com frequência igual ou superior a 5 . Apresentamos abaixo todas as unidades identificadas.

Nos contratos, observamos que immediately co-ocorre com várias palavras ou expressões que, em geral, são classificadas como funcionais, como é o caso de after, following e before (MACMILLAN, 2002). Inclusive, nesse contexto, consideramos também prior to, preceding e upon unidades funcionais, como podemos observar nas fraseologias apresentadas na sequência. Essas unidades totalizam 146 linhas de concordância $(44,24 \%)$, ou seja, quase metade das ocorrências de immediately.

- immediately prior (55):

As sete unidades de immediately prior que não foram seguidas da preposição to apresentaram 3 ocorrências de calendar year - nesse caso prior seria classificado como um adjetivo -, todas em um único texto, e três de thereto, com duas em um mesmo texto. Abaixo, exemplos dessa fraseologia: 
[...] Offices (whether operating under this Agreement or any other franchise or membership agreement with a subsidiary of Cendant) for the calendar year immediately preceding the immediately prior calendar year minus (ii) the Gross Revenue of all Offices closed pursuant to this clause [...].

[...] had such rights been exercised immediately prior thereto, and in any such case appropriate provision shall be made with respect to the rights and interests of the Holder to the end that the provisions hereof [...].

- immediately prior to + SN (47):

Nesse caso, é interessante observar que o SN é introduzido pelo artigo definido the em 23 ocorrências, demonstrando que a questão em pauta já foi mencionada anteriormente, como podemos observar no exemplo:

[...] none of the foregoing shall constitute a "Business Combination Transaction" if the beneficial ownership of the capital stock of the Company or the surviving entity (following a merger in which the Company ceases to exist) immediately after the consummation of the transaction is substantially the same as the beneficial ownership of the capital stock of the Company immediately prior to the transaction.

- immediately prior to such + SUBST (23):

Como observado com o artigo definido the, a palavra such é utilizada com o mesmo objetivo, ou seja, é um determinante:

[...] and the denominator of which shall be the unpaid principal balance of the Note immediately prior to such payment or prepayment.

- SN + in effect immediately prior to (6):

[...] then the Stock Purchase Price in effect immediately prior to such action shall then be adjusted in accordance with the formula [...].

- SN + outstanding immediately prior to + SN (5):

Nas cinco ocorrências, o primeiro SN inclui o substantivo share(s) ou stock:

[...] the number of shares outstanding immediately prior to the issuance of such additional shares.

- immediately preceding (29):

Nos contratos, classificamos preceding como palavra funcional, subdividindo seu uso em 17 ocorrências como preposição e em 12 como adjetivo. É interessante observar a co-ocorrência entre duas classes gramaticais que, em geral, não são associadas pelas gramáticas tradicionais, caso de advérbios e preposições. Tal fato 
também é observado com outras palavras funcionais, como veremos na sequência. Exemplos:

[...] where the employee has been performing work at a higher level for a continuous period of at least twelve months immediately preceding the date on which he or she is given Notice of Termination [...].

Except as set forth in the immediately preceding sentence, neither this Agreement nor any right or obligation hereunder may otherwise be assigned without the prior written consent [...].

- immediately preceding the date (5):

[...] begun on the Wednesday following the last Tuesday in the December immediately preceding the date hereof.

- the immediately preceding + SN (9):

[...] and a balance sheet for the Properties for the immediately preceding fiscal year $[\ldots]$.

- immediately after + SN (28):

Em 8 das ocorrências, o SN inicia com o determinante such, indicando que a questão representada pelo substantivo que se segue já foi mencionada. Exemplos:

[...] whenever any such issuance is made, and shall become effective immediately after such issuance.

[...] any shareholder who is present in person or by proxy and who objects to the result announced by the chairman of the meeting may, immediately after the declaration of the result, demand that the votes be counted [...].

- shall become effective immediately after + SN (6):

[...] the adjustment shall become effective immediately after the effective date of such corporate action.

- unless the directors determine that immediately after + SN (6):

Nesse caso, as seis ocorrências estão em dois contratos de um mesmo tipo, ou seja, ambos são Contratos Sociais. Exemplo:

No dividend shall be declared and paid unless the directors determine that immediately after the payment of the dividend the Company will be able to satisfy [...].

- shares/stock outstanding immediately after + SN (5):

[...] be the total number of all shares of the Company's Preferred Stock outstanding immediately after such dividend or distribution. 
- immediately upon + SN (18):

[...] therefore shall be entitled in such event to obtain an injunction against such breach from any court of competent jurisdiction immediately upon request.

- immediately following + SN (8):

Assim como apresentado no dicionário Macmillan (2002), consideramos following uma palavra funcional nesse contexto de uso. Novamente, temos uma preposição que co-ocorre com um advérbio:

Immediately following the execution of this Agreement, the Parties shall file with the United States District Court [...].

- immediately before + SN (8):

[...] be paid to the holder of the share immediately before such sale.

Em linhas gerais, observamos que as fraseologias acima elencadas deixam clara a relação temporal que estabelecem em seus contextos de uso. Além da conotação imediatista expressa pelo advérbio para a realização de dada ação, reforçada por palavras funcionais como prior to, following, preceding, before, after e upon, observamos que immediately exerce também um papel intensificador, evidente na redundância de sua co-ocorrência com preceding. Segundo o dicionário Macmillan (2002, p. 1087), essa palavra quer dizer "existing or coming immediately before someone or something else" (grifo nosso). Em geral, a relação temporal é reforçada por substantivos como calendar, month e year, frequentes nas linhas de concordância analisadas.

\section{> $\mathrm{O}$ advérbio immediately em associações com classes gramaticais diversas}

Apresentamos abaixo a co-ocorrência de immediately com verbos, adjetivos e outros advérbios; observamos, inclusive, a formação de binômios.

- will/shall immediately notify + SN (14):

[...] Franchisee will immediately notify the Company by the fastest means available.

- notify + SN + immediately (6):

You agree to notify us immediately if you do not receive a monthly statement.

- effective immediately (14): 
With reasonable cause, either party may terminate this Agreement effective immediately by giving written notice of termination for cause.

- immediately due and payable (14):

Upon default, we may declare the entire unpaid balance immediately due and payable, and you agree to pay that amount plus [...].

- immediately terminate (+SN) (12):

[...] in any such event all obligations of Company hereunder shall immediately terminate, except for the Company's obligations to pay you [...].

- (may) immediately terminate this agreement (8):

[...] Donee may immediately terminate this Agreement upon written notice to Donor $[\cdots]$.

- shall be immediately + V/ADJ (12):

[...] such transaction distributed with respect to the Morton Junior Shares shall be immediately subject to the Transfer Restrictions, [...].

- shall be immediately returned to purchaser (5):

[...] the Infrastructure Deposit and all Option Deposits shall be immediately returned to Purchaser, [...].

- immediately available funds (10):

The balance of the Purchase Price shall be paid to Seller at the Closing in immediately available funds.

- wire transfer of immediately available funds to + SN (6):

[...] for the account of the Company, by check, wire transfer of immediately available funds to a bank account specified by the Company or [...].

- immediately pay (7):

Master Franchisee shall immediately pay all sums owing to Franchisor under this Agreement [...].

Deparamos com associações cuja frequência é abaixo de 5, mas que parecem caracterizar fraseologias nessa tipologia. São elas:

- immediately and permanently (3):

Immediately and permanently discontinue all advertising as a CENTURY 21 franchisee, including, but not limited to, the immediate removal of all signs [...]. 
- immediately and without notice (2):

Termination shall be effective immediately and without notice, however, upon the occurrence of any or [...].

Em linhas gerais, o advérbio immediately apresenta um papel bem definido nos contratos. Sua co-ocorrência mais frequente é com palavras funcionais, principalmente preposições, como podemos observar nas fraseologias formadas com prior to, after, before e upon, além de co-ocorrer com verbos e adjetivos. Em nível textual, immediately não se identifica com uma posição específica nos contratos, mas pode-se dizer que suas ocorrências são mais frequentes no início e no meio do texto, fato observado com o recurso plot. Morfossintaticamente considerado um advérbio de tempo, immediately apresenta também função intensificadora. Nessa tipologia textual, sempre tivemos que ampliar as linhas de concordância ou mesmo consultar o contrato na íntegra para análise, o que inclusive possibilitou levantar fraseologias maiores.

$\mathrm{Na}$ próxima seção, teceremos alguns comentários sobre immediately nas duas tipologias estudadas.

\subsubsection{Immediately nas receitas e nos contratos: comparando as análises}

No início das análises acima, apresentamos os dados do advérbio immediately em nossos corpora de estudo. Para melhor observá-los, concentramos esses números no quadro abaixo e apresentamos nossos comentários na sequência.

\begin{tabular}{|l|c|c|}
\hline & Culinária - receitas & Direito - contratos \\
\hline posição lista pal-chave geral & 680 & 372 \\
\hline posição lista pal-chave advs & 13 & 6 \\
\hline índice chavicidade & 826,91 & 526,2 \\
\hline no. oc. no corpus de estudo & 686 & 330 \\
\hline oc. em cada mil palavras & 0,39 & 0,50 \\
\hline
\end{tabular}

Quadro 10 - Dados do advérbio immediately nas receitas e nos contratos 
Como já colocado no capítulo II, nossos corpora de estudo, considerando-se as duas tipologias textuais, são significativamente diferentes no número de palavras, fato que dificulta uma comparação mais adequada entre os dados acima. Observamos que immediately apresenta alto índice de chavicidade em ambas as tipologias e se encontra entre os 15 advérbios terminados em -ly considerados mais chave nas receitas culinárias e nos contratos. Apesar de esse índice ser maior nas receitas culinárias, o advérbio ocupa a sexta posição dentre os mais chave nos contratos. Inclusive, é interessante observar que, enquanto nas receitas immediately ocorre a cada 2.500 palavras, nos contratos isso acontece a aproximadamente cada duas mil palavras.

Quanto à formação de fraseologias, immediately integra unidades que iniciam com duas palavras e chegam a incluir, em alguns casos, mais de sete palavras, que tanto podem ser itens lexicais (palavras fixas) quanto palavras ou classes gramaticais. Evidenciado em ambas as tipologias, tal fato parece ser um dos poucos pontos em comum quanto ao uso do advérbio em receitas culinárias e contratos. $A$ primeira diferença que salta aos olhos ocorre ao observarmos os resultados do recurso plot: enquanto as ocorrências concentram-se ao final das receitas, mais especificamente nas últimas linhas do Modo de Fazer, nos contratos elas espalhamse e ocorrem poucas vezes ao final do texto.

Analisando as fraseologias mais detalhadamente, aquelas formadas por duas palavras são mais frequentes nas receitas, onde geralmente o advérbio ocorre posposto a um verbo no imperativo, caso de serve immediately. Já nos contratos, a maior parte das unidades são compostas por palavras funcionais, sendo a associação a verbos e adjetivos menos frequente.

Outra diferença refere-se à análise do contexto: enquanto nas receitas muitas vezes a colocação serve immediately constituía uma oração, nos contratos necessitávamos consultar o texto na íntegra para melhor compreender o papel do advérbio. Semanticamente, a relação temporal manteve-se nas duas áreas de estudo, mas observamos que nos contratos o advérbio exerce também um papel intensificador.

Para concluir, podemos dizer que immediately apresenta fraseologias específicas para cada área e significado diferenciado, informações extremamente relevantes para o produtor de textos e apenas observáveis em seu contexto de uso. 
Nas próximas seções, analisaremos os dois advérbios em português encontrados tanto nas receitas culinárias quanto nos contratos, quais sejam, imediatamente - coincidentemente a tradução prima facie de immediately -, e juntamente.

\subsubsection{Imediatamente e juntamente nas receitas culinárias}

Apresentamos abaixo os resultados do levantamento feito no corpus de Culinária, onde investigamos os advérbios imediatamente e juntamente em seus contextos de uso.

\section{IMEDIATAMENTE:}

O advérbio imediatamente apresenta 416 ocorrências e ocupa a $732^{\mathrm{a}}$ posição na lista de palavras-chave do corpus de receitas culinárias (português). É o nono considerando-se apenas os advérbios terminados em -mente, com um índice de chavicidade de 863,22. Apresentamos abaixo as fraseologias encontradas, bem como outros detalhes quanto ao seu uso em contexto.

\section{O advérbio imediatamente e o verbo servir}

- sirva imediatamente (282):

A associação com o verbo servir no imperativo é a mais frequente, abrangendo quase $70 \%$ das ocorrências de imediatamente. Como sua contrapartida em inglês, suas ocorrências concentram-se ao final das receitas, no Modo de Fazer, fato que pode ser observado com o recurso plot. Integra também unidades maiores, como podemos observar abaixo.

- Sirva imediatamente. (107): uma oração completa, entre pontos finais. Dessas, 26 são a última oração do texto. Anteposto a essas ocorrências, observamos a repetição de palavras que indicam a finalização do prato. São elas:

- DOURAR/DOURADO. Sirva imediatamente (16):

[...] até que esteja crocante e dourada. Sirva imediatamente. 
- NUM + minutos. Sirva imediatamente (10):

Frite os filés durante 10 minutos. Sirva imediatamente.

- molho. Sirva imediatamente (9):

Escorra bem a massa e misture ao molho. Sirva imediatamente ou leve ao forno para gratinar por 10 minutos.

- (bem) quente(s). Sirva imediatamente (6):

[...] e junte o molho de salmão bem quente. Sirva imediatamente, decorado com salsinha.

- retire do fogo. Sirva imediatamente (5):

[...] misture e retire do fogo. Sirva imediatamente.

- sV + e sirva imediatamente (132): essa unidade concentra-se ao final das receitas, e é utilizada para finalizar o processo de elaboração de um prato. Em geral, é seguida de ponto final (111 oc.). Em 21 linhas de concordância, são as últimas palavras do texto.

Dobre a omelete ao meio sobre o recheio e sirva imediatamente em um prato aquecido.

Acerte o sal e a pimenta e sirva imediatamente.

- misture (ADV) e sirva imediatamente (17):

Junte o molho, misture bem e sirva imediatamente.

- polvilhe (COm + [INGREDIENTE]) e sirva imediatamente (15):

Retire os aspargos da assadeira, polvilhe com o parmesão e sirva imediatamente.

- retire ([PRATO]) do fogo/forno e sirva imediatamente (9):

Retire o bolo do forno e sirva imediatamente, com a calda de amora para acompanhar.

- decore (com + [INGREDIENTE]) e sirva imediatamente (9):

Decore com rodelas de limão e sirva imediatamente.

- salpique (com+ [INGREDIENTE]) e sirva imediatamente (5):

Salpique com as lascas de gorgonzola e sirva imediatamente.

- regue ([INGREDIENTE]) com azeite e sirva imediatamente (5):

Regue o pirão com azeite e sirva imediatamente acompanhado de arroz branco. 
Na categoria semântica [INGREDIENTE] das unidades com polvilhe, decore e salpique geralmente temos queijo (parmesão) (ralado), salsa, salsinha, sálvia e tomilho.

- sirva imediatamente(,) com + [INGREDIENTE] (16): Sirva imediatamente com galhos de alecrim.

- sirva ([PRATO]) imediatamente(,) acompanhado(s) de + [INGREDIENTE] (14):

Sirva imediatamente acompanhado de fatias de pão.

- sirva imediatamente em + [RECIPIENTE] (5):

Volte ao fogo para ferver e sirva imediatamente em canequinhas ou copinhos pequenos.

- servir imediatamente (11): Misturar o arroz e o camarão e servir imediatamente.

\section{$>0$ advérbio imediatamente e outros verbos}

- acrescente imediatamente + [INGREDIENTE] (5):

Retire do fogo e acrescente imediatamente o chocolate meio amargo, essência de baunilha e a manteiga.

- escorra imediatamente (+ [INGREDIENTE]) (6):

Escorra imediatamente o macarrão.

- retire imediatamente (do fogo) (8):

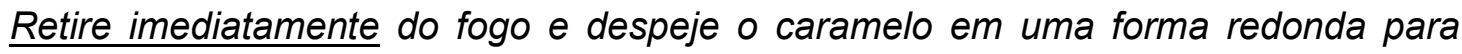
bolo [...].

\section{$>$ O advérbio imediatamente e outras associações}

- SV + imediatamente com + [INGREDIENTE/INSTRUMENTO] (25). No sV, a maior parte das ocorrências é com o verbo servir, como apontado anteriormente. Exemplos:

Sirva imediatamente com arroz branco ou macarrão chinês cozido.

Corte imediatamente com uma tesoura em tamanhos uniformes.

Em linhas gerais, a unidade mais frequente é sirva imediatamente, que inclusive integra unidades maiores de significado. Semanticamente, o advérbio 
relaciona-se a tempo, expressando o imediatismo com que a ação deve ser feita sua co-ocorrência é sempre com verbos e ao final do Modo de Fazer.

\section{JUNTAMENTE:}

O outro advérbio que as tipologias apresentam em comum nos dados analisados é juntamente. Nas receitas culinárias, foram identificadas 195 ocorrências e o advérbio ocupa a posição 1.301 na lista de palavras-chave do corpus. É o $14^{\circ}$ considerando-se os advérbios terminados em -mente, com um índice de chavicidade de 250,06. Apresentamos abaixo as unidades em que juntamente foi identificado.

- juntamente com + [INGREDIENTE] (193):

Em praticamente todas as linhas de concordância, o advérbio co-ocorre com a preposição com e é seguido da categoria semântica [INGREDIENTE]. Em geral, essa fraseologia é utilizada para indicar o acréscimo de determinado ingrediente para dar prosseguimento ao preparo do prato.

Nas unidades abaixo, o que varia é o recipiente onde os ingredientes são colocados. Esses ingredientes podem estar subentendidos nas fraseologias. Em geral, os verbos mais comuns na categoria semântica [ADICIONAR INGREDIENTE] são BATER, COLOCAR e DESPEJAR, no imperativo.

- [ADICIONAR INGREDIENTE] na/numa/em uma panela juntamente com + [INGREDIENTE] (19):

Coloque a manteiga ou margarina numa panela juntamente com a cebola e deixe que ela doure.

- [ADICIONAR INGREDIENTE] no liquidificador juntamente com + [INGREDIENTE] (13):

Bata o restante dos morangos no liquidificador juntamente com o limão.

- [ADICIONAR INGREDIENTE] ao/no/em um processador juntamente com + [INGREDIENTE] (8):

Coloque o queijo no processador juntamente com a mistura de cogumelos e a pimenta-do-reino.

- [AdICIONAR INGREDIENTE]) na/em uma tigela juntamente com + [INGREDIENTE] (7):

Coloque em uma tigela juntamente com o sal e o açúcar. 
- coloque em uma frigideira juntamente com o azeite (5):

Fatie os dentes de alho e coloque em uma frigideira juntamente com o azeite.

Em resumo, a fraseologia maior é: ([ADICIONAR INGREDIENTE]) + [RECIPIENTE/INSTRUMENTO] + juntamente com [INGREDIENTE]:

Coloque a beterraba triturada na tigela juntamente com a cebola, pepinos e alcaparras, misture todos os outros ingredientes [...].

Os ingredientes mais comuns depois do advérbio são: manteiga (9); açúcar (9); cebola(s) (8); azeite (7); água (6); maisena (6); creme de leite (6); leite (6); sal (6).

Outros verbos menos frequentes nas mesmas linhas de concordância, mas que também chamaram nossa atenção foram PENEIRAR e REFOGAR:

Peneire a farinha de trigo juntamente com o fermento e o sal e acrescente a mistura de manteiga.

Na mesma frigideira, refogue os cogumelos, juntamente com o alho.

Para concluir, o uso do advérbio juntamente em receitas culinárias é muito bem definido: co-ocorre com a preposição com em praticamente todas as linhas de concordância, integrando a unidade maior acima descrita. Em nível textual, encontra-se no Modo de Fazer.

\subsubsection{Imediatamente e juntamente nos contratos}

Nesta seção, analisaremos os advérbios imediatamente e juntamente em nosso corpus de estudo do Direito, apresentando todas as fraseologias observadas.

\section{IMEDIATAMENTE:}

Nos contratos, imediatamente encontra-se na posição 344 na lista de palavras-chave do corpus - é o $6^{\circ}$ advérbio terminado em -mente. Seu índice de chavicidade é de 280,41 , com 104 ocorrências. Semanticamente, além da relação temporal, observamos que atua muito mais como um intensificador de verbos e adjetivos. 
- COMUNICAR ([MENSAGEM]) ([PARTES]) imediatamente ([MENSAGEM]) ([PARTES]) (17). As categorias ([MENSAGEM]) ([PARTES]) podem ocorrer antes ou depois do advérbio.

[...] o Titular ou o Adicional deverá comunicar imediatamente o fato ao Emissor, fornecendo elementos esclarecedores [...].

[...] caso em que a Contratada deverá comunicar imediatamente à <parte> a exigência judicial, para que esta possa tomar [...].

- DEVER + [COMUNICAR] + imediatamente (14). A categoria [COMUNICAR] apresenta verbos como comunicar, informar e reportar:

A Contratada deverá reportar imediatamente à <parte> quaisquer casos de acidente de trabalho [...].

- imediatamente $+\mathrm{v}_{\mathrm{pp}}(9)$ :

[...] os recursos da conta Corrente Especial serão imediatamente transferidos para a Conta Corrente da VENDEDORA.

- SV + imediatamente após + SN (7):

[...] no Período de Teste terão sua contagem iniciada imediatamente após o registro da Conta de Usuário.

- imediatamente anterior (7). Em todas as ocorrências, anterior é um adjetivo:

A ltaucard informará, também na fatura imediatamente anterior ao evento, [...].

- devolver imediatamente (6):

[...] uma vez rescindido o Contrato, ficará obrigado a devolver imediatamente os bens ao PROMITENTE VENDEDOR [...].

- dia útil imediatamente anterior/posterior/subsequente (5):

[...] para que o novo vencimento ocorra no dia útil imediatamente subseqüente.

\section{JUNTAMENTE:}

Juntamente encontra-se na posição 632 na lista de palavras-chave de nosso corpus de instrumentos contratuais e é o $13^{\circ}$ advérbio terminado em -mente. Seu índice de chavicidade é de 143,35 e apresenta 63 ocorrências. É seguido da preposição com em todas as ocorrências, formando as unidades abaixo apresentadas.

- juntamente com + [PARTES] (63). Em geral, essa fraseologia é precedida de verbo não necessariamente como primeira palavra à sua esquerda. A categoria 
semântica [PARTES] apresenta o substantivo testemunha(s) em 28 ocorrências. Exemplos:

[...] valor que será pago juntamente com as primeiras 12 (doze) parcelas.

[...] adotar, em caso de sinistro, juntamente com a seguradora, todas as providências necessárias [...].

[...] o presente instrumento em .... vias de igual teor, juntamente com duas testemunhas idôneas abaixo nomeadas, [...].

- firmam/assinam o presente instrumento, em + NUM + vias de igual teor, juntamente com duas/as testemunhas (12). Essa fraseologia encontra-se ao final do contrato, na cláusula de encerramento. Devemos ressaltar que ela inclui a fraseologia anterior, sendo praticamente a única unidade maior de significado identificada nos dados investigados. Exemplo:

Por estarem assim justos e contratados, firmam o presente instrumento, em duas vias de igual teor, juntamente com 2 (duas) testemunhas.

Semanticamente, o advérbio é utilizado para indicar acréscimo, agregação de algo ou alguém a um dado processo, como é o caso de pagamentos ou da assinatura de um contrato. Há simultaneidade para a realização da ação, transmitindo a ideia de companhia, como em "resguardando a este, ainda, o direito de sacar, juntamente com o outorgante, quaisquer valores provenientes cujo objeto é ação".

Como podemos observar, juntamente apresenta um papel bem definido na tipologia dos contratos, limitando-se a um uso específico, como apontado nos exemplos acima.

3.3.6 Imediatamente e juntamente nas receitas e nos contratos: comparando as análises

Primeiramente, compararemos os números encontrados para o advérbio imediatamente nas duas tipologias estudadas, retomados no quadro abaixo: 


\begin{tabular}{|l|c|c|}
\hline \multicolumn{1}{|c|}{ IMEDIATAMENTE } & Culinária - receitas & Direito - contratos \\
\hline posição lista pal-chave geral & 732 & 344 \\
\hline posição lista pal-chave advs & 9 & 6 \\
\hline índice chavicidade & 863,22 & 280,41 \\
\hline no. oc. no corpus de estudo & 416 & 104 \\
\hline oc. em cada mil palavras & 0,26 & 0,37 \\
\hline
\end{tabular}

Quadro 11 - Dados do advérbio imediatamente nas receitas e nos contratos

Como podemos observar, o índice de chavicidade nas receitas é significativamente maior, mas imediatamente é mais chave nos contratos, onde ocupa a sexta posição considerando-se os advérbios terminados em -mente. É também um pouco mais frequente, ocorrendo uma vez em aproximadamente cada 2.800 palavras, comparadas às quase 4.000 necessárias para o advérbio nas receitas.

Seu uso apresentou-se bastante diverso nas duas tipologias. A primeira diferença é semântica: enquanto nas receitas expressa o imediatismo com que uma ação deve ser realizada durante a finalização de um determinado prato, relacionando-se basicamente a tempo, nos contratos é também evidente seu papel intensificador. Ainda nessa tipologia, observamos a formação de um campo semântico, o da comunicação, retratado por verbos como comunicar, informar e reportar. Morfossintaticamente, sua co-ocorrência nas receitas é sempre com verbos, geralmente no imperativo, destacando-se servir. Já nos contratos, co-ocorre com verbos (mais frequente), adjetivos e também com a preposição após. Sob uma visão textual, seu uso é bem mais definido nas receitas: ocorre sempre ao final do Modo de Fazer. Já nos contratos, espalha-se ao longo do texto, sendo menos frequente nas cláusulas finais. Quanto às fraseologias, nos contratos há maior diversidade, ou seja, há mais unidades diferentes. Nas receitas, mais de $50 \%$ das linhas de concordância apresentam a colocação sirva imediatamente.

Em resumo, e como ocorre com immediately em inglês, estamos diante de duas realizações de um mesmo advérbio: imediatamente nas receitas e imediatamente nos contratos. Apresentando padrões de uso diversos, ele se ajusta às especificidades de cada novo contexto. 
O segundo advérbio em comum entre as tipologias estudadas é juntamente, cujos dados retomamos abaixo:

\begin{tabular}{|l|c|c|}
\hline \multicolumn{1}{|c|}{ JUNTAMENTE } & Culinária - receitas & Direito - contratos \\
\hline posição lista pal-chave geral & 1.301 & 632 \\
\hline posição lista pal-chave advs & 14 & 13 \\
\hline índice chavicidade & 250,06 & 143,35 \\
\hline no. oc. no corpus de estudo & 195 & 63 \\
\hline oc. em cada mil palavras & 0,12 & 0,22 \\
\hline
\end{tabular}

Quadro 12 - Dados do advérbio juntamente nas receitas e nos contratos

Mesmo com um índice de chavicidade menor, juntamente encontra-se entre os 15 advérbios terminados em -mente mais chave de nossos corpora de estudo em português. Na Culinária, ocupa a $14^{\mathrm{a}}$ posição; no Direito, a $13^{\mathrm{a}}$. Nos contratos, juntamente é pouco mais frequente em cada mil palavras.

Ao compararmos as análises nas duas tipologias, observamos três pontos em comum: o primeiro é a co-ocorrência entre juntamente e a preposição com em praticamente todas as linhas de concordância. O segundo refere-se ao significado: juntamente é utilizado para indicar adição, acréscimo, agregação. Morfossintaticamente, em ambos os casos, relaciona-se a verbos, que frequentemente estão à sua esquerda. As diferenças, no entanto, começam a surgir quando passamos ao seu uso em contexto. Nas receitas, o advérbio é utilizado para referir-se ao acréscimo de ingredientes durante o preparo de um prato, enquanto na tipologia dos contratos pode referir-se à reunião de documentos, por exemplo, ou mesmo de testemunhas para a assinatura de um contrato. Quando passamos às fraseologias, a diferença de uso é evidente: são extremamente específicas às áreas em estudo. Nas receitas, destaca-se a unidade ([ADICIONAR INGREDIENTE]) + [RECIPIENTE/INSTRUMENTO] + juntamente com [INGREDIENTE], que associa itens lexicais e categorias semânticas bem delimitadas. Nos contratos, a fraseologia firmam/assinam o presente instrumento, em + NUM + vias de igual teor, juntamente com duas/as testemunhas, a associação é praticamente entre itens lexicais, demonstrando maior fixidez em sua composição. Textualmente, o advérbio sempre ocorre no Modo de Fazer das receitas, enquanto nos contratos é mais frequente nas cláusulas finais do documento. 
Para concluir, tanto as análises em inglês (immediately) quanto em português (imediatamente e juntamente), nas tipologias investigadas, demonstram que os advérbios se "acomodam" ao contexto de uso, apresentando características e formando unidades próprias àquela área de pesquisa, como se houvesse um "desdobramento" da palavra, observação que confirma a necessidade de análise do contexto de uso.

\subsubsection{Um panorama dos "-lys" e "-mentes" sob a ótica das tipologias}

Neste segundo momento, procuraremos tecer algumas observações mais pontuais que tragam alguma luz sobre o uso dos advérbios terminados em -ly e -mente nas linguagens especializadas em estudo. Primeiramente, compararemos os resultados obtidos em inglês, considerando os aspectos levantados durante as análises.

- frequência:

Tanto nas receitas quanto nos contratos, observamos que os advérbios terminados em -ly são bastante frequentes, visto que representam, considerando-se o número total de advérbios, $75,57 \%$ nas receitas e $27,55 \%$ nos contratos. Apesar de ambos serem resultados significativos, é patente a presença maciça desse grupo de advérbios nas receitas culinárias.

- aspectos morfossintáticos:

Em ambas as tipologias, há uma padronização quanto às palavras com as quais os advérbios co-ocorrem: geralmente associam-se a verbos e adjetivos. No caso de adjetivos, a associação com os não deverbais, caso de necessário, possível e satisfatório, é pouco encontrada. Quanto aos verbos, é frequente a co-ocorrência com aqueles no particípio passado, muitas vezes em função adjetiva. Nas receitas, é típica também a co-ocorrência com verbos no imperativo (mais frequente) e no infinitivo. Já nos contratos, o uso é mais frequente no infinitivo e no futuro do presente, destacando-se a co-ocorrência com verbos modais como shall, will, may e can. Notamos também a co-ocorrência com palavras funcionais, nos contratos. 
A associação com palavras gramaticais é observada em ambas as áreas, mas as receitas apresentam maior diversidade nos padrões encontrados. Quanto a co-ocorrerem com outros advérbios, o único que encontramos, e com poucas ocorrências, foi very, nas receitas. Nos contratos, levantamos unidades que continham também herein, hereafter e hereto, mas não se relacionavam ao advérbio em estudo. Outra característica é a formação de unidades maiores de significado (incluindo advérbios), que chegam a representar uma oração inteira, principalmente nos contratos.

Quando tínhamos um verbo transitivo em colocação com o advérbio, apenas as receitas apresentaram seu objeto subentendido, que pode ser sido, inclusive, mencionado em um período anterior.

\section{- aspectos semânticos e pragmáticos:}

Pragmaticamente, os advérbios exercem papéis diferentes nas duas tipologias. Enquanto nas receitas são utilizados para intensificar e principalmente indicar o modo como determinada ação deve ser realizada, estabelecendo categorias semânticas em suas associações, nos contratos isso não ocorre da mesma forma. Neles, observamos que a função do advérbio varia, sendo em alguns casos mais relevante do que em outros. É o que observamos, por exemplo, ao analisarmos expressly e reasonably. Enquanto o primeiro intensifica a palavra seguinte e apresenta sentido próprio, isso não ocorre com reasonably, que poderia ser facilmente descartado sem prejuízo para o significado. Esse caso retrata a redundância presente em textos jurídicos, apontada por vários autores, como citado, e também observado por Carvalho Fonseca (2007) durante a análise dos dados de sua pesquisa. Podemos dizer que essas observações se estendem ao uso dos advérbios terminados em $-l y$, como verificamos em nossas análises.

Nos contratos, alguns advérbios se associam a binômios e/ou multinômios de uso frequente nessa tipologia, como é o caso de promptly execute and deliver e duly authorized, executed and delivered. Nas receitas, esse tipo de co-ocorrência não foi observada.

Em termos discursivos, nas receitas é possível identificar em que parte do texto os advérbios mais ocorrem, seja no Modo de Fazer ou na Lista de Ingredientes. Já nos contratos, não houve o que chamaríamos de "identificação textual", ou seja, nenhum advérbio ocorreu de forma mais significativa nesta ou 
naquela cláusula (observe-se que estamos nos referindo aos advérbios em si, não às colocações das quais fazem parte).

Em termos práticos, diríamos que, semântica e pragmaticamente, se o advérbio fosse eliminado das receitas haveria comprometimento do sentido, o que não ocorreria nos contratos, em inglês.

\section{- aspectos culturais:}

Considerando-se os advérbios, pudemos observar marcas culturais nessa classe gramatical, principalmente nos contratos. É o caso de reasonably, o segundo advérbio com maior índice de chavicidade dentre os analisados. Conforme já explicitado, seu uso tem raízes históricas e culturais, atrelando-se ao conceito de reasonable man (homem médio), sempre empregado no discurso jurídico. Já nas receitas culinárias, nenhum advérbio revelou características de forma explícita. $O$ que de fato chamou nossa atenção foi sua predominância nessa tipologia: podemos dizer que o falante de língua inglesa tem maior necessidade de descrever minuciosamente todos os passos para melhor orientar o usuário de suas receitas.

Passaremos agora à comparação dos dados em português. Novamente, utilizaremos os aspectos levantados durante as análises como ponto de partida.

\section{- frequência:}

Apesar de frequentes em ambas as tipologias, em português, os advérbios terminados em -mente são mais recorrentes nos contratos do que nas receitas culinárias. Nos contratos, representam $30,09 \%$ de todos os advérbios identificados no corpus, enquanto nas receitas somam $17,38 \%$ deles.

\section{- aspectos morfossintáticos:}

Como em inglês, observamos certa padronização com relação às palavras com as quais os advérbios co-ocorrem, em ambas as tipologias, geralmente associando-se a verbos e adjetivos. Novamente, a presença de adjetivos não deverbais é pouco frequente. Quanto aos verbos, a frequência é maior no particípio passado, como registrado em inglês, o que revela a presença da voz passiva em muitas ocorrências, reforçada pelo uso comum dos verbos auxiliares ser e estar, tanto nas receitas quanto nos contratos, sendo mais incisivo nesses últimos. Devido 
à tipologia, o uso do presente e de várias ocorrências no futuro se mantém nos contratos. Nas receitas, no entanto, observamos que, além do particípio passado, do imperativo e do infinitivo, há um número maior de co-ocorrências com verbos no gerúndio, quando comparados com o inglês. Devemos ressaltar que o imperativo e o infinitivo são característicos de textos instrucionais em português.

A associação com palavras gramaticais ocorre em ambas as tipologias, onde também encontramos a formação de unidades maiores. Nos contratos, é comum encontrarmos orações muito semelhantes, com variação de uma ou outra palavra apenas, que lembram o preenchimento de um formulário. Outro ponto a destacar nessa tipologia é a associação do advérbio independentemente à preposição de. É a partir dessa associação que outros padrões maiores são identificados.

Pudemos observar, principalmente nas receitas, a formação de padrões em nível estrutural, que associam determinados itens lexicais a classes gramaticais, como é o caso de até ficar levemente + ADJ, onde o que é específico é a classe gramatical.

Quanto a outros grupos de advérbios que possam ter co-ocorrido com aqueles terminados em -mente, o único registrado foi muito, com cinco ocorrências de muito delicadamente e outras cinco de muito levemente, o que não consideramos relevante nas receitas.

Sintaticamente, registramos também o objeto subentendido quando tínhamos um verbo transitivo direto em colocação com um advérbio, como observado nas receitas em inglês.

No caso do português, tivemos que nos valer da forma lematizada de várias palavras com as quais os advérbios co-ocorreram, o que tornou a pesquisa mais trabalhosa.

\section{- aspectos semânticos e pragmáticos:}

Em termos pragmáticos e semânticos, os advérbios apresentam uso diferenciado também em português. Apesar de co-ocorrerem basicamente com as mesmas classes gramaticais, a função dos advérbios nas receitas é mais específica - eles expressam modo e formam unidades coesas de significado, sendo sua escolha também influenciada por outras palavras do sintagma, como é o caso de utilizarmos levemente (e não outro advérbio) em água levemente salgada. Já nos contratos, observamos que, apesar de a maioria exercer função modalizadora - isso 
quando o advérbio apresenta significado -, há maior variação no uso. Ainda nos contratos, observamos a preferência semântica de determinados advérbios, como é o caso de simplesmente, que co-ocorre basicamente com denominado e designado.

Assim como em inglês, observamos o exagero e a redundância do uso dos advérbios nos contratos - algo peculiar ao discurso jurídico, independente da língua -, que geralmente permeiam todo o texto e não são típicos de uma determinada parte. Nas receitas, ao contrário, são significativamente frequentes no Modo de Fazer, diferindo inclusive do que observamos em inglês, onde eles distribuem-se de forma mais balanceada entre o Modo de Fazer e a Lista dos Ingredientes.

Em nenhuma das tipologias, identificamos co-ocorrência significativa com binômios.

\section{- aspectos culturais:}

Em português, não identificamos quaisquer aspectos culturais implícitos no uso dos advérbios, em ambas as tipologias analisadas.

Para finalizar, podemos dizer que, em português, observamos o mesmo fato apontado em inglês: se o advérbio fosse eliminado das receitas haveria comprometimento do sentido, o que não ocorreria nos contratos.

Com isso, concluímos nossas observações quanto ao uso dos advérbios terminados em -ly e -mente: nos itens 3.1 .3 e 3.2.3, comparamos os advérbios na mesma tipologia, em línguas diferentes. Nesta seção, consideramos cada língua separadamente, tecendo comentários relativos à tipologia textual. $\mathrm{Na}$ próxima, trabalharemos com as fraseologias levantadas e suas formas equivalentes.

\subsection{As fraseologias e suas formas equivalentes: breves comentários}

Nesta seção, gostaríamos de comentar as unidades identificadas juntamente com suas formas equivalentes, nas duas tipologias investigadas. Apresentamos abaixo um quadro que deverá facilitar a comparação dos dados: 


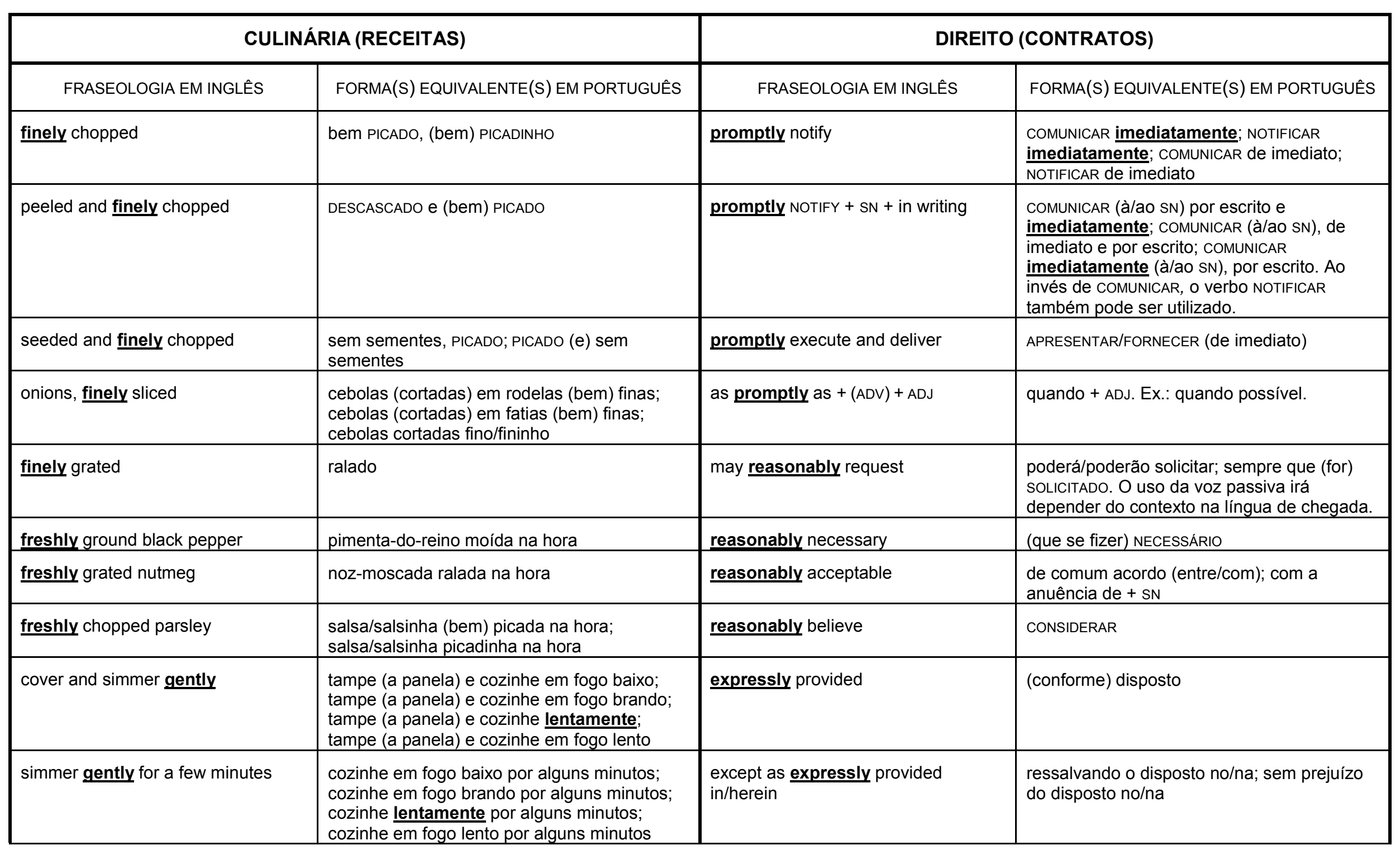




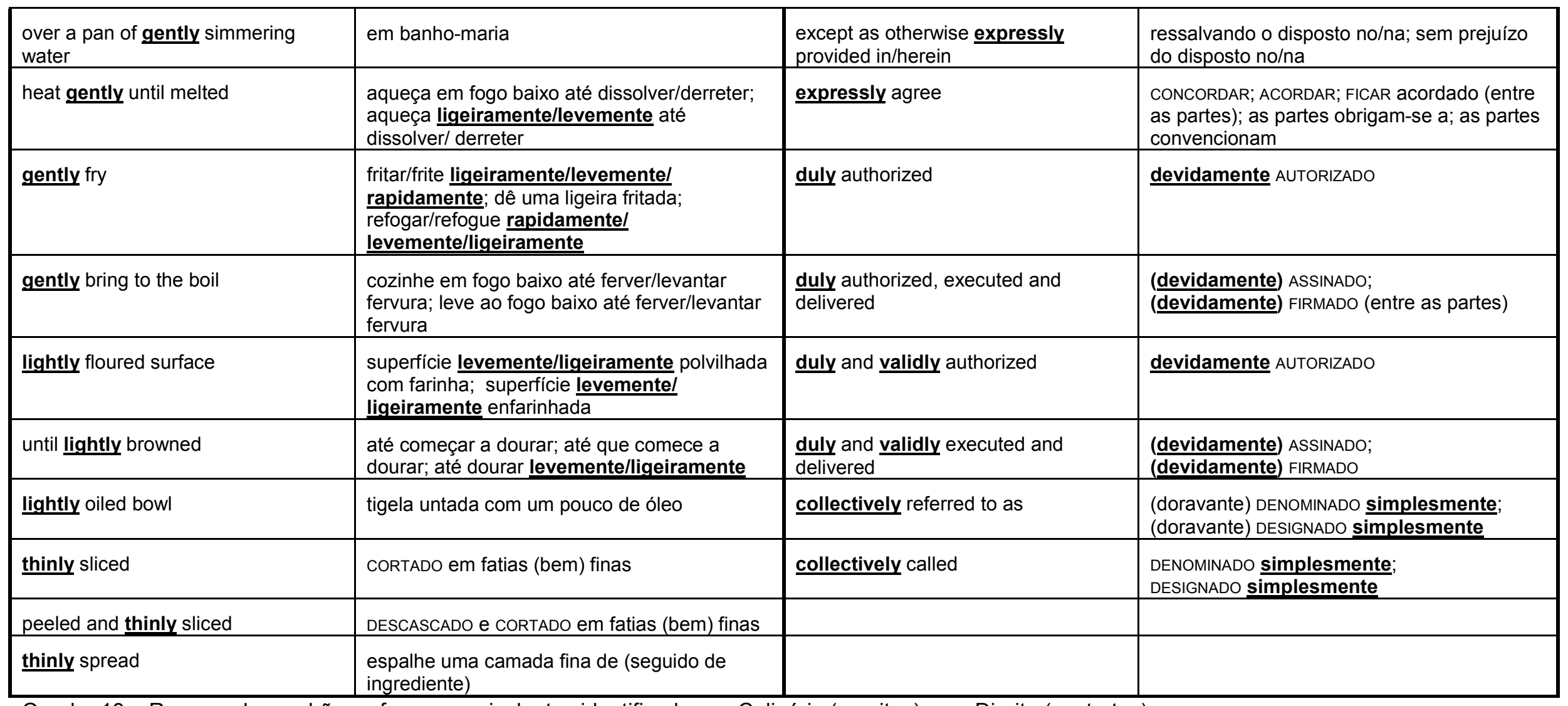

Quadro 13 - Resumo dos padrões e formas equivalentes identificados na Culinária (receitas) e no Direito (contratos) 
Antes de comentarmos o quadro, devemos esclarecer que os dados foram assim dispostos para facilitar a visualização, uma vez que cada área apresenta suas peculiaridades quanto ao uso dos advérbios, principalmente no que tange as formas equivalentes encontradas. Nesse formato, o leitor consegue observar o que é mais usado em uma ou outra tipologia, em ambas as línguas. Em negrito e sublinhado, colocamos todos os advérbios terminados em -ly e -mente. Obviamente, todas as fraseologias em inglês apresentam o advérbio, uma vez que foi essa nossa língua de partida. Nesse caso, é interessante comparar como os advérbios se apresentam nas formas equivalentes. Na tipologia das receitas, temos vinte fraseologias que apresentam advérbios terminados em -mente em apenas seis das formas equivalentes. Essas, por sua vez, podem também apresentar outras fraseologias (sem o advérbio terminado em -mente) como opção de tradução. Um mesmo advérbio em inglês pode apresentar equivalentes diferentes em -mente, como é o caso de gently, que tem lentamente, ligeiramente ou levemente nas fraseologias equivalentes. $O$ inverso também ocorre: um mesmo advérbio em português pode equivaler a mais de um advérbio em inglês - ligeiramente é tido como a contrapartida de gently e lightly. Nos contratos, das dezoito fraseologias em inglês apenas oito apresentam o advérbio em -mente em suas formas equivalentes, podendo inclusive ser omitido em alguns casos. Além disso, há outros que não são considerados a tradução prima facie, como é o caso de simplesmente na fraseologia denominado simplesmente (em inglês, temos collectively called).

Analisando os dados de forma mais detalhada, observamos que as receitas apresentam opções de formas equivalentes variadas em sua composição, que vão além de um advérbio terminado em -mente ou mesmo de sua eliminação na língua de chegada. É frequente o uso do advérbio bem, utilizado como intensificador, e do diminutivo, como em bem picado e bem picadinho. Há casos em que um sintagma preposicionado equivale à colocação formada por verbo + advérbio, em inglês, usando um adjetivo para expressar o significado do advérbio, como em cebolas em rodelas finas. Outros exemplos de sintagmas preposicionados que equivalem a advérbios terminados em -ly e modalizam o sentido da unidade em que ocorrem são: na hora, com um pouco de óleo, em fogo baixo/brando. Obviamente, há casos em que temos a equivalência morfológica, como em gently fry, que pode ser traduzida por frite ligeiramente, mas que também apresenta dê uma ligeira fritada como sugestão de equivalência. Nas receitas, o único caso em que não há 
necessidade de uma expressão modalizadora na forma equivalente é finely grated. Apenas a palavra ralado é suficiente, visto que, em português, seu uso em receitas implica que o ingrediente deve ser ralado fino (esse é o usual). Com isso, o uso da palavra fino é desnecessário.

Já nos contratos, observamos uma linguagem mais formulaica, com uso excessivo de advérbios em inglês que, em português, podem não ocorrer - caso do verbo considerar, utilizado como forma equivalente de reasonably believe, ou mesmo de ressalvando o disposto no/na, que apresentamos como equivalência para except as otherwise expressly provided in/herein. A única ocorrência de sintagma preposicionado que registramos foi de imediato, opção de tradução para promptly. Há várias ocorrências em que outro advérbio terminado em -mente é utilizado ao estabelecermos a equivalência, como é o caso de collectively, acima comentado.

Para concluir, podemos dizer que as linguagens especializadas em análise apresentaram uso bem definido dos advérbios terminados em -ly e -mente quando tratadas separadamente, ou seja, quando investigamos os dados em português e em inglês. Através da língua em uso conseguimos demonstrar que esse grupo de advérbios apresenta características específicas, apontando, inclusive, padrões linguísticos dos quais fazem parte, em ambas as línguas, deixando claro seu papel na tipologia das receitas e dos contratos. Ao tentarmos estabelecer as formas equivalentes, no entanto, o cenário modificou-se totalmente, como pudemos observar nos comentários acima. Esses resultados instigaram-nos a buscar, em dicionários especializados monolíngues e bilíngues, como as unidades levantadas em inglês são abordadas.

3.5 As fraseologias em inglês em dicionários especializados: são contempladas?

Identificadas as formas equivalentes para algumas unidades em inglês, em ambas as tipologias estudadas, interessou-nos consultar obras e dicionários especializados monolíngues e bilíngues para verificar se essas unidades eram abordadas, o que dificilmente acreditávamos fosse ocorrer. Percorrendo o caminho inverso do tradutor, que geralmente vale-se dos dicionários ao iniciar uma tradução, resolvemos partir dos resultados obtidos através de uma pesquisa baseada e direcionada por corpus para, posteriormente, verificar o que o tradutor encontraria 
em sua busca inicial numa das principais ferramentas para desenvolver seu trabalho, caso deparasse com as unidades que levantamos.

Considerando-se a tipologia das receitas culinárias, a primeira obra consultada foi Vocabulário para Culinária inglês/português, de Teixeira e Tagnin (2008). Decidimos iniciar por essa fonte de pesquisa justamente por se tratar de uma obra baseada em corpus, que vem ao encontro de nossa investigação e está disponível para o tradutor no mercado editorial. O primeiro diferencial é que ela apresenta os cinco advérbios em estudo como verbetes, o que geralmente não observamos em dicionários, especialmente naqueles que enfocam as linguagens especializadas. Pesquisamos as vinte unidades em inglês selecionadas para a busca da forma equivalente e praticamente todas foram encontradas, às vezes em mais de um verbete, como podemos observar abaixo:

\begin{tabular}{|c|c|}
\hline FRASEOLOGIA EM INGLÊS & RESULTADOS DA BUSCA EM TEIXEIRA E TAGNIN (2008) \\
\hline finely chopped & nos verbetes de finely e chopped, como subverbete \\
\hline peeled and finely chopped & no verbete de peeled, como subverbete \\
\hline seeded and finely chopped & $\begin{array}{l}\text { no verbete de seeded, encontramos seeded and chopped nos } \\
\text { exemplos, sem o advérbio }\end{array}$ \\
\hline onions, finely sliced & $\begin{array}{l}\text { finely sliced, como subverbete em finely. A co-ocorrência com onion foi } \\
\text { identificada nos exemplos }\end{array}$ \\
\hline finely grated & nos verbetes de finely e grated, como subverbete \\
\hline freshly ground black pepper & nos verbetes de freshly, pepper e ground, como subverbete \\
\hline freshly grated nutmeg & $\begin{array}{l}\text { encontramos apenas a colocação freshly grated no verbete de grated e } \\
\text { em um dos exemplos de freshly. A co-ocorrência com nutmeg não foi } \\
\text { encontrada. }\end{array}$ \\
\hline freshly chopped parsley & $\begin{array}{l}\text { encontramos apenas a colocação freshly chopped no verbete de } \\
\text { chopped. A co-ocorrência com parsley não foi encontrada. }\end{array}$ \\
\hline cover and simmer gently & no verbete de simmer, como exemplo para o subverbete simmer gently \\
\hline simmer gently for a few minutes & no verbete de simmer, encontramos simmer for, sem o advérbio \\
\hline over a pan of gently simmering water & $\begin{array}{l}\text { no verbete de water, a unidade inteira foi encontrada em um } \\
\text { subverbete }\end{array}$ \\
\hline heat gently until melted & apenas heat gently, como subverbete de heat \\
\hline gently fry & nos exemplos do verbete de gently \\
\hline gently bring to the boil & $\begin{array}{l}\text { apenas a colocação bring to the boil, como subverbete em boil, sem o } \\
\text { advérbio }\end{array}$ \\
\hline lightly floured surface & no verbete de ligthly, como subverbete \\
\hline until lightly browned & como subverbete em lightly \\
\hline lightly oiled bowl & $\begin{array}{l}\text { a colocação lightly oiled é um dos subverbetes de lightly e apresenta a } \\
\text { unidade inteira no exemplo }\end{array}$ \\
\hline thinly sliced & como subverbete em thinly e slice \\
\hline
\end{tabular}




\begin{tabular}{|l|l|}
\hline peeled and thinly sliced & apenas a colocação thinly sliced. Vide acima. \\
\hline thinly spread & não encontrada \\
\hline
\end{tabular}

Quadro 14 - Resultados da busca de unidades identificadas em receitas culinárias (inglês) em Teixeira e Tagnin (2008)

Como as próprias autoras comentam na introdução, elas tiveram que fazer um recorte nos dados analisados e trabalhar com as primeiras 300 palavras-chave do inglês, o que certamente limitou o número de verbetes apresentados. Enfatizam que este Vocabulário para Culinária não pretende ser exaustivo, mas sim privilegiar termos e fraseologias mais frequentemente encontrados em textos da área, partindo de substantivos, verbos, adjetivos e advérbios (TEIXEIRA; TAGNIN, 2008). Além de ser rico em exemplos - o contexto de uso é extremamente importante para o tradutor - a obra apresenta também figuras, notas explicativas e observações relevantes, que incluem diferenças culturais geralmente postas de lado em obras do gênero.

Para fins de comparação, consultamos outra obra bilíngue conhecida e utilizada por tradutores da área, que não é baseada em corpus, intitulada Glossário de Gastronomia (KLIE, 2006). Segundo a autora, esse glossário - nas direções português/inglês e inglês/português -, procura ser útil a profissionais das áreas de gastronomia, hotelaria e turismo, estudantes e professores de inglês, bem como a todos aqueles interessados por essa área. Abarca questões como homofonia, uso de palavras estrangeiras, falsos cognatos, expressões idiomáticas, metáforas, ditos e provérbios. Considerando-se essas informações, fomos buscar as fraseologias listadas no quadro acima, na direção inglês-português. Apresentamos abaixo os resultados obtidos.

\begin{tabular}{|l|l|}
\hline \multicolumn{1}{|c|}{ FRASEOLOGIA EM INGLÊS } & \multicolumn{1}{|c|}{ RESULTADOS DA BUSCA EM KLIE (2006) } \\
\hline finely chopped & $\begin{array}{l}\text { não encontrada. Encontramos apenas o verbo chop, como verbete e } \\
\text { no infinitivo }\end{array}$ \\
\hline peeled and finely chopped & $\begin{array}{l}\text { não encontrada. Dessa fraseologia, encontramos apenas o verbo } \\
\text { peel, como verbete e no infinitivo. }\end{array}$ \\
\hline seeded and finely chopped & $\begin{array}{l}\text { não encontrada. Como verbetes, encontramos o subst. seed, a forma } \\
\text { infinitiva (to seed) e o particípio passado (seeded). }\end{array}$ \\
\hline onions, finely sliced & $\begin{array}{l}\text { não encontrada. Encontramos o subst. slice e o verbo, no infinitivo, } \\
\text { como verbetes, além do subst. onion. }\end{array}$ \\
\hline finely grated & $\begin{array}{l}\text { não encontrada. Encontramos apenas o verbo grate, no infinitivo, } \\
\text { como verbete. }\end{array}$ \\
\hline não encontrada. Como verbetes, encontramos a colocação black \\
\hline
\end{tabular}




\begin{tabular}{|c|c|}
\hline & pepper e o verbo grind, no infinitivo, separadamente. \\
\hline freshly grated nutmeg & $\begin{array}{l}\text { não encontrada. Como entradas separadas, apenas o verbo grate e o } \\
\text { subst. nutmeg. }\end{array}$ \\
\hline freshly chopped parsley & $\begin{array}{l}\text { não encontrada. Além de chop como verbete, encontramos o subst. } \\
\text { parsley. }\end{array}$ \\
\hline cover and simmer gently & não encontrada. Como verbetes, apenas os dois verbos no infinitivo. \\
\hline simmer gently for a few minutes & não encontrada. Vide cover and simmer gently. \\
\hline over a pan of gently simmering water & $\begin{array}{l}\text { não encontrada. Encontramos separadamente os verbetes (to be) } \\
\text { simmering (não faz referência a water), water e pan. }\end{array}$ \\
\hline heat gently until melted & $\begin{array}{l}\text { não encontrada. Encontramos como verbetes separados os verbos } \\
\text { heat e melt, ambos no infinitivo. }\end{array}$ \\
\hline gently fry & não encontrada. Apenas o verbete de fry, no infinitivo. \\
\hline gently bring to the boil & não encontrada. Apenas o verbete de boil, no infinitivo. \\
\hline lightly floured surface & $\begin{array}{l}\text { não encontrada. Como verbetes, o verbo flour (infinitivo) e o subst } \\
\text { surface. }\end{array}$ \\
\hline until lightly browned & não encontrada. Apenas o verbete do verbo brown, no infinitivo. \\
\hline lightly oiled bowl & não encontrada. Apenas o verbete do subst. bowl. \\
\hline thinly sliced & $\begin{array}{l}\text { não encontrada. Apenas slice, em verbetes como subst. e verbo no } \\
\text { infinitivo. }\end{array}$ \\
\hline peeled and thinly sliced & $\begin{array}{l}\text { não encontrada. Dessa fraseologia, apenas o verbo peel, como } \\
\text { verbete e no infinitivo. }\end{array}$ \\
\hline thinly spread & $\begin{array}{l}\text { não encontrada. Apenas spread, em verbetes como subst. e verbo no } \\
\text { infinitivo. }\end{array}$ \\
\hline
\end{tabular}

Como podemos observar, nenhuma das unidades foi encontrada nesse glossário - nem mesmo os advérbios constam -, o que aponta ser mais produtiva, para o produtor de textos no par de línguas inglês-português, a busca em uma obra baseada em corpus.

A terceira obra bilíngue analisada intitula-se Not Just Hamburgers! (KLIE, 2003) e é da mesma autora que publicou a obra anterior. Nesse caso, não se trata especificamente de um glossário, mas sim de um livro que apresenta receitas em ambas as línguas, juntamente com informações históricas e culturais, observações técnicas, inclusive com sugestões para a substituição de ingredientes não encontrados no Brasil, dicas sobre a Culinária norte-americana, tabelas de conversão, etc. Nosso interesse atém-se justamente à última seção, intitulada Glossário e Gramática na Cozinha (KLIE, 2003, p. 165-190), subdividida em informações sobre palavras compostas e cognatas, expressões idiomáticas com alguma relação com comida e culinária, e um mini-glossário propriamente dito. Nessa seção, conduzimos nossa busca pelas fraseologias apresentadas no quadro 
acima e nenhuma delas foi encontrada. Identificamos apenas alguns verbos e substantivos, como acima, em verbetes separados. Verificamos todos os verbetes do glossário e encontramos apenas uma colocação formada por verbo + advérbio, ou seja, press lightly, cuja sugestão de tradução era levemente espremer. Diante desses resultados pouco satisfatórios para a busca de fraseologias, fomos investigar uma quarta fonte de pesquisa.

A quarta obra analisada é multilíngue e intitula-se Dicionário Tradutor de Gastronomia em Seis Línguas (SALDANHA, 2007). Trabalha com os seguintes idiomas: português, inglês, francês, alemão, italiano e espanhol. A autora agrupa os verbetes de acordo com ingredientes e temas afins, tais como Aves e Caças, Condimentos e Sementes, Leites e logurtes, Massas, Saladas, Comendo Fora, Termos Culinários, Utensílios de Cozinha, etc., de modo que nos valemos do índice remissivo em inglês ${ }^{134}$ ao final da obra para buscar as fraseologias em análise, principalmente porque as entradas são em português e nossa direção de busca é inversa.

\begin{tabular}{|l|l|}
\hline \multicolumn{1}{|c|}{ FRASEOLOGIA EM INGLÊS } & \multicolumn{1}{|c|}{ RESULTADOS DA BUSCA EM SALDANHA (2007) } \\
\hline finely chopped & não encontrada - apenas o verbo chop/chopped, em picar/picado \\
\hline peeled and finely chopped & $\begin{array}{l}\text { não encontrada - apenas o verbo no particípio passado (peeled), no } \\
\text { verbete de pelado }\end{array}$ \\
\hline seeded and finely chopped & nada encontrado \\
\hline onions, finely sliced & $\begin{array}{l}\text { não encontrada - apenas slice (verbo e subst.) e sliced (fatiar, fatia, } \\
\text { fatiado) }\end{array}$ \\
\hline finely grated & não encontrada - apenas grate/grated (ralar/ralado) \\
\hline freshly ground black pepper & $\begin{array}{l}\text { não encontrada - apenas black pepper (em pimenta-preta) e ground } \\
\text { (moído) }\end{array}$ \\
\hline freshly grated nutmeg & $\begin{array}{l}\text { não encontrada - apenas grate/grated (ralar/ralado) e nutmeg (noz- } \\
\text { moscada) }\end{array}$ \\
\hline freshly chopped parsley & não encontrada - apenas chop/chopped (picar/picado) \\
\hline cover and simmer gently & não encontrada - apenas cover (cobrir) e simmer (cozinhar em fogo \\
baixo, sem ferver)
\end{tabular}

\footnotetext{
${ }^{134}$ A autora apresenta o índice remissivo agrupado por línguas, facilitando a consulta.
} 


\begin{tabular}{|l|l|}
\hline lightly floured surface & não encontrada - apenas floured (enfarinhado) \\
\hline until lightly browned & não encontrada - apenas browned (corado) \\
\hline lightly oiled bowl & não encontrada - apenas bowl (tigela) \\
\hline thinly sliced & $\begin{array}{l}\text { não encontrada - apenas slice (verbo e subst.) e sliced (fatiar, fatia, } \\
\text { fatiado) }\end{array}$ \\
\hline peeled and thinly sliced & $\begin{array}{l}\text { não encontrada - apenas slice, sliced e peeled, separadamente, } \\
\text { conforme já apontado }\end{array}$ \\
\hline thinly spread & não encontrada - apenas spread (polvilhar, salpicar com) \\
\hline $\begin{array}{l}\text { Quadro 16 - Resultados da busca de unidades identificadas em receitas culinárias (inglês) em } \\
\text { Saldanha (2007) }\end{array}$
\end{tabular}

Diante desse quadro, podemos observar que as fraseologias levantadas em nossa pesquisa também não se encontram nessa obra.

Como tínhamos em mãos um dicionário monolíngue em português, o Pequeno Dicionário de Gastronomia (GOMENSORO, 1999), decidimos buscar algumas unidades levantadas quando analisamos os advérbios levemente, delicadamente, grosseiramente, finamente e ligeiramente, em português. Apenas para satisfazer nossa curiosidade de pesquisadora, buscamos as unidades de maior frequência na análise feita para cada um desses advérbios, quais sejam bater levemente, misturar delicadamente, picar grosseiramente, picar finamente e dourar ligeiramente, numa tentativa de verificar se essas colocações eram abordadas em um dicionário especializado em português. Como havíamos suposto, encontramos verbetes apenas para os verbos, com exceção de dourar. Nas acepções, os advérbios acima nem sequer foram mencionados.

Nossa tentativa seguinte foi no Dicionário Prático de Culinária (JONES, 1996), uma tradução de Cooking and kitchen skills, lançado por Briget Jones em 1991. Mesmo sendo uma obra traduzida, achamos interessante investigá-la no sentido de analisar mais um dentre os poucos recursos que o tradutor dessa linguagem especializada tem à sua disposição no mercado editorial. Apesar de ser um livro rico em informações e instruções sobre como selecionar, manipular e preparar determinados alimentos, e apresentar diversas receitas e conselhos sobre uma alimentação saudável, o que objetivamente interessa ao tradutor é o pequeno glossário que encontramos ao final da obra (JONES, 1996, p. 287-297). Nenhuma das colocações em português acima elencadas foi encontrada como verbete localizamos apenas três dos quatro verbos apresentados, quais sejam bater, misturar e picar. Na definição de picar, encontramos uma das colocações: 
Picar - cortar em pedaços pequenos e uniformes. Picar fino significa que os pedaços devem ficar bem miúdos. Picar grosseiramente significa que os pedaços não precisam ser miúdos e podem ter tamanhos variados. (JONES, 1996, p. 295) (grifo nosso)

Analisadas seis obras disponíveis para o tradutor na área da Culinária, quais sejam Vocabulário para Culinária inglês/português (TEIXEIRA; TAGNIN, 2008), Glossário de Gastronomia (KLIE, 2006), Not Just Hamburgers! (KLIE, 2003), Dicionário Tradutor de Gastronomia em Seis Línguas (SALDANHA, 2007), Pequeno Dicionário de Gastronomia (GOMENSORO, 1999) e Dicionário Prático de Culinária (JONES, 1996), concluímos que apenas aquela baseada em corpus (a primeira investigada) apresenta praticamente todas as fraseologias apontadas em nossa pesquisa - unidades que, quando traduzidas de acordo com seu uso na língua de chegada, certamente emprestam maior fluência e naturalidade ao texto traduzido. Com isso, observamos que fontes de pesquisa baseadas e direcionadas por corpus são de extrema valia e contribuem significativamente para o trabalho do produtor de textos, incluindo as receitas culinárias.

Nosso próximo passo foi conduzir o mesmo tipo de investigação na área jurídica, resultados que apresentamos na sequência.

Para os contratos, não localizamos quaisquer obras de referência baseadas em corpus. Nesse caso, decidimos consultar um dicionário jurídico monolíngue em inglês, dois bilíngues - inglês-português/português-inglês, e um tesouro, também em inglês, numa tentativa de verificar se as unidades levantadas em nossa pesquisa eram contempladas. Como sabemos, o tradutor também vale-se de obras monolíngues em busca de informações que possam auxiliá-lo no processo tradutório, principalmente de exemplos que privilegiem a contextualização de sua palavra ou expressão de busca.

O dicionário monolíngue intitulado Black's Law Dictionary (GARNER, 1999) é bastante elucidativo - para o advogado que domina o idioma. Esclarece algumas peculiaridades do discurso jurídico, como é o caso do conceito de reasonable man, mas não exatamente para o leigo na área, como pode ser o tradutor. Inclusive, não menciona que esse é um aspecto de raízes históricas típico do sistema jurídico dos falantes de língua inglesa, o que não se aplica, por exemplo, ao Brasil. Quanto às unidades levantadas em nossa pesquisa, nenhuma foi encontrada. Como podemos 
observar no quadro abaixo, nem mesmo unidades típicas do discurso jurídico são apontadas, como é o caso do binômio executed and delivered, e muito menos o uso de advérbios terminados em -ly:

\begin{tabular}{|c|c|}
\hline FRASEOLOGIA EM INGLÊS & RESULTADOS DA BUSCA EM GARNER (1999) \\
\hline promptly notify & não encontrada - apenas o verbo notify \\
\hline promptly NOTIFY + SN + in writing & não encontrada - apenas o verbo notify \\
\hline promptly execute and deliver & $\begin{array}{l}\text { nada encontrado - nem mesmo a colocação execute and deliver, } \\
\text { apenas o verbo execute }\end{array}$ \\
\hline as promptly as $+(A D V)+A D J$ & nada encontrado \\
\hline may reasonably request & não encontrada - apenas reasonably prudent person, como verbete \\
\hline reasonably necessary & não encontrada - apenas o adjetivo necessary \\
\hline reasonably acceptable & nada encontrado - nem mesmo o adjetivo acceptable \\
\hline reasonably believe & nada encontrado - nem mesmo o verbo believe \\
\hline expressly provided & não encontrada - apenas provided \\
\hline $\begin{array}{l}\text { except as expressly provided } \\
\text { in/herein }\end{array}$ & não encontrada - apenas provided \\
\hline $\begin{array}{l}\text { except as otherwise expressly } \\
\text { provided in/herein }\end{array}$ & não encontrada - apenas provided \\
\hline expressly agree & nada encontrado - nem mesmo o verbo agree \\
\hline duly authorized & $\begin{array}{l}\text { não encontrada - apenas authorize, mas nenhuma colocação com o } \\
\text { advérbio duly. Encontramos também o advérbio como verbete, mas } \\
\text { nenhuma colocação é apontada. }\end{array}$ \\
\hline $\begin{array}{l}\text { duly authorized, executed and } \\
\text { delivered }\end{array}$ & não encontrada - vide acima \\
\hline duly and validly authorized & não encontrada - apenas o adjetivo valid, vide acima \\
\hline $\begin{array}{l}\text { duly and validly executed and } \\
\text { delivered }\end{array}$ & não encontrada - vide acima \\
\hline collectively referred to as & nada encontrado - nem mesmo o verbo refer \\
\hline collectively called & não encontrada - apenas o verbo call \\
\hline
\end{tabular}

Quadro 17 - Resultados da busca de unidades identificadas em contratos (inglês) em Garner (1999)

Atendo-nos aos advérbios terminados em -ly, pudemos observar que nem mesmo uma obra monolíngue procura apontar fraseologias que possam conter essa classe gramatical. Inclusive, o único advérbio encontrado como verbete foi duly - e mesmo assim sem qualquer exemplo de uso ou colocação da qual faça parte.

A primeira obra bilíngue (inglês-português/português-inglês) investigada foi o Dicionário Jurídico Noronha (NORONHA GOYOS JR., 2003). Pelo que pudemos observar ao buscar as unidades mencionadas no quadro acima, esse dicionário deixa a desejar no que tange a apresentação de padrões linguísticos. $O$ levantamento dessas unidades, bem como a apresentação de suas respectivas 
formas equivalentes, muito auxiliariam o trabalho do tradutor. Além disso, observamos que os verbetes não trazem exemplos, o que descontextualiza a palavra ou expressão de busca. A esse respeito, o autor comenta:

Como este é um dicionário jurídico bilíngüe, o autor não se esforçou, por via de regra, em explicar todos os preceitos jurídicos envolvidos, mas somente fornecer a opção de tradução mais precisa possível para a outra língua. [...] O leitor que se interessar a respeito de particularidades adicionais daqueles preceitos deve, então, pesquisar a fonte jurídica apropriada na sua jurisdição. (NORONHA GOYOS JR., 2003, p. xxxiv-Xxxv)

Em resumo, nenhuma das unidades levantadas em nossa pesquisa foi encontrada nesta obra. Assim como no dicionário monolíngue, o único advérbio encontrado foi duly, como verbete, trazendo as opções de tradução (descontextualizadas) e a colocação duly sworn. Os resultados foram parecidos àqueles da obra anteriormente analisada: em alguns casos, nem mesmo os verbos ou adjetivos foram encontrados.

A terceira obra consultada foi o Dicionário Jurídico português-inglês/inglêsportuguês de Maria Chaves de Mello (2006). Na introdução, a autora chama nossa atenção quando tece comentários sobre os obstáculos enfrentados pelo tradutor e/ou intérprete da linguagem jurídica, o que sugere pensarmos numa abordagem diferenciada:

As agruras e aflições enfrentadas pelos intérpretes e tradutores de textos jurídicos parecem dar razão ao filósofo Jean-Paul Sartre, o qual dizia 'que o inferno são os outros'. Em nosso caso, a linguagem jurídica do outro. Mormente quando a comunidade lingüística jurídica desse Outro apresenta um vocabulário limitado oriundo de uma tradição jurídica diferente, gerada por uma língua de matrice também diferente. (MELLO, 2006, p. 13)

No entanto, nada acrescenta ao que foi observado nas obras analisadas anteriormente, ao menos no que tange os dados investigados. Inclusive, apresenta formas equivalentes descontextualizadas, como verificamos no verbete de execute: "Execute, to - Executar; Completar; Aperfeiçoar; Desempenhar; Assinar; Terminar; Satisfazer." (MELLO, 2006, p. 680). Como saber qual delas utilizar? O tradutor de um texto jurídico não necessariamente tem formação nesta área de especialidade - 
como então traduzir, por exemplo, a colocação duly and validly executed and delivered, que contém dois binômios em sua composição?

Em Mello (2006), o único advérbio encontrado (e como verbete) foi duly, mas apenas acompanhado de formas equivalentes descontextualizadas. Em resumo, os advérbios terminados em -ly e as colocacões das quais fazem parte não são contemplados nesta fonte de pesquisa do tradutor.

Diante desses resultados, decidimos investigar uma obra de referência que também pode auxiliar esse profissional, no caso um tesouro em língua inglesa (BURTON, 2006). Segundo dizeres na própria capa, a obra traz expressões encontradas no discurso jurídico: "8,000 terms, synonyms, definitions, and parts of speech related specifically to the legal profession" (grifo nosso). Iniciamos nossa busca com o verbo notify e não encontramos quaisquer associações com advérbios no verbete, o mesmo ocorrendo com execute, próximo verbo na sequência das fraseologias pesquisadas. Quando pertinente, o autor coloca uma subentrada intitulada associated concepts (conceitos afins), como observamos no verbete de execute. No entanto, não traz as colocações execute and deliver e/ou executed and delivered. Continuamos nossa busca com as palavras deliver, request, reasonable, necessary, acceptable, believe, provide, express, except, herein, otherwise, agree, authorize, due, duly, valid, refer, collective e call, numa tentativa de encontrar as unidades com os advérbios de nossa pesquisa. Apresentamos abaixo algumas observações relevantes:

- no verbete do verbo deliver, encontramos a colocação executed and delivered nos associated concepts (conceitos afins);

- advérbios como herein e otherwise apresentam-se como entrada. Dentre o grupo de advérbios terminados em -ly sob análise, os únicos encontrados foram duly e collectively. Apesar de não incluir as unidades levantadas em nossa investigação, vale ressaltar que o verbete de duly apresenta várias outras colocações em associated concepts, como é o caso de duly executed e duly entered into.

Com esta breve análise de algumas fontes de pesquisa tanto na área da Culinária quanto no Direito, esperamos ter deixado clara a ausência de obras de referência que abarquem o uso de advérbios, classe gramatical que integra várias fraseologias encontradas tanto nas receitas culinárias quanto nos contratos. 
Evidenciamos também que uma obra baseada em corpus, como é o caso do Vocabulário para Culinária (TEIXEIRA; TAGNIN, 2008), é indiscutivelmente uma excelente fonte de consulta para o tradutor, que necessita buscar padrões formados por várias classes de palavras, além de observações, notas explicativas e contextos de uso. Conforme apontado, a obra privilegia as 300 primeiras palavras-chave do corpus de estudo em inglês - dentre as quais figuram os cinco advérbios analisados nesta pesquisa - enfatizando o papel relevante dos advérbios terminados em -ly nessa tipologia textual. Concluindo, esta breve investigação em diferentes fontes de pesquisa demonstra que obras baseadas em corpus podem contribuir, decisivamente, para o trabalho do tradutor. Além de apresentar palavras e unidades maiores de significado levantadas a partir da língua em uso, esse tipo de obra oferece um dado extremamente valioso: a contextualização, pouco comum em dicionários bilíngues de linguagens especializadas.

Na próxima seção, apresentaremos um panorama geral de todos os capítulos da tese e a conclusão de nossa pesquisa. 


\section{Considerações finais}

Descrever o uso de uma classe gramatical tida como confusa e imprecisa não é tarefa fácil, especialmente em se tratando de duas tipologias textuais tão distintas, quais sejam, a das receitas culinárias e dos instrumentos contratuais. Para tecermos nossas considerações finais sobre esta pesquisa, primeiramente necessitamos retomar as duas hipóteses apresentadas na Introdução:

3- A função dos advérbios - ou de fraseologias com advérbios - varia de acordo com o domínio em que ocorre.

4- A tradução dos advérbios pode ser um problema para o tradutor, uma vez que as formas cognatas nem sempre satisfazem suas necessidades.

Em linhas gerais, acreditamos ter respondido a essas duas questões. Quanto à primeira, podemos dizer que sim, os advérbios apresentam fraseologias distintas, além de desempenharem funções específicas em cada área, conforme retomado nos comentários que se seguem. A segunda questão liga-se à primeira: por meio das fraseologias identificadas, pudemos comprovar que a tradução dos advérbios por suas formas cognatas, de forma descontextualizada, pode trazer problemas para o tradutor, uma vez que não são a melhor opção nas áreas investigadas.

Ao final desta pesquisa - e devemos ressaltar que trabalhamos com textos originalmente escritos nas duas línguas estudadas, ou seja, não consideramos textos traduzidos - podemos afirmar que os padrões linguísticos extraídos de nossos corpora de estudo a partir de advérbios terminados em -ly e -mente pertencem, definitivamente, à tipologia das receitas culinárias e dos instrumentos contratuais. Tal fato, inclusive, evidenciou-se quando buscamos várias dessas fraseologias nos corpora de língua geral. Com este estudo, comprovamos que esse grupo de advérbios - e não apenas esse - deve ser estudado e considerado em seus respectivos contextos de uso, que por sua vez irão delimitar seu papel e contribuir para sua descrição em dada área de especialidade. Nesse contexto, cada advérbio adquire um sentido, associa-se a diferentes palavras e compõe estruturas 
sintagmáticas que, ao se repetirem, passam a caracterizar seu uso naquele discurso.

É sabido que os advérbios terminados em -ly e -mente co-ocorrem com verbos, adjetivos ou outros advérbios. Com esta pesquisa, descobrimos coocorrências com outras classes gramaticais, como apontado nos contratos ao analisarmos immediately e depararmos com fraseologias como immediately prior to $+\mathrm{SN}$ (immediately prior to the transaction); immediately preceding (immediately preceding the date on which [...]); e immediately after + SN (immediately after the declaration of the result). Observamos também funções semânticas, pragmáticas e culturais, como o uso de reasonably nos contratos. Com nossos achados, procuramos contribuir para a descrição da classe dos advérbios, em um âmbito mais geral. Devemos ressaltar, inclusive, que seria útil incluir essas informações em obras de referência que tratam da descrição dos advérbios. A necessidade do produtor de textos vai além das informações disponíveis em gramáticas e dicionários - ter acesso a padrões lexicais e/ou gramaticais recorrentes em determinada área de estudos certamente facilitaria seu trabalho e emprestaria maior fluência e naturalidade a seu texto, principalmente em se tratando de áreas especializadas. Delimitado o objeto de nosso estudo, ou seja, os advérbios terminados em -ly e -mente nas receitas e nos contratos, partimos inicialmente para um panorama de como são apresentados em algumas obras de referência no mercado editorial. No primeiro capítulo da tese, apresentamos os resultados dessa investigação.

Em português, consultamos uma obra totalmente dedicada aos advérbios (BOMFIM, 1988), dois dicionários baseados em corpus (BORBA, 2002, 2004) e três obras voltadas para o estudo da gramática, também com uma abordagem baseada em corpus (NEVES, 2000, 2003, 2006). Em linhas gerais, observamos que há certa movimentação, por parte dos estudiosos, para que se privilegie a língua em uso. Dentre as obras analisadas, vale destacar a Gramática de usos do português (NEVES, 2000), que dispensa atenção especial à classe dos advérbios e dedica por volta de 100 páginas a esse tópico, diferente das gramáticas tradicionais comumente encontradas no mercado. Apesar do detalhamento da investigação, a autora não aborda a questão da padronização linguística, pelo menos no que tange o uso dos advérbios. Não se preocupa em apresentar fraseologias encontradas em língua geral, muito menos relacioná-las a tipologias específicas, como é o caso daquelas investigadas nesta tese. Também não menciona aspectos discursivos, tampouco 
detalhes relacionados a questões culturais. Resumindo, observamos que as obras analisadas, apesar de baseadas em corpus, não vão muito além da utilização do material como fonte para exemplificação de teorias pré-existentes.

Em inglês, analisamos duas gramáticas baseadas em corpus: a Longman Student Grammar of Spoken and Written English (SGSWE) (BIBER; CONRAD; LEECH, 2002) e a Cambridge Grammar of English (CARTER; McCARTHY, 2006), que dedicam uma parte significativa da obra à descrição dos advérbios. Mesmo considerando que essa é uma classe gramatical imprecisa, deixam claro como essa imprecisão pode ocorrer apresentando levantamentos que envolvem frequência e contexto de uso. Logo de início, notamos que ambas apresentam uma abordagem diversa daquela observada em português, uma vez que preparam o consulente para uma abordagem baseada e direcionada pelo corpus - apresentam o que é e qual sua importância para o estudo da língua. Ambas trabalham com a língua falada e escrita, mas a SGSWE dá um enfoque maior ao discurso, situando o uso da língua e a frequência em quatro grandes registros por meio de gráficos em barras e termos como frequentemente, raramente, comum ou incomum, referindo-se às ocorrências. São gramáticas descritivas que trabalham com a probabilidade de ocorrências, enfocando os aspectos morfológico, sintático, semântico, pragmático e discursivo das diversas classes de palavras. Quanto à padronização linguística, mais especificamente referindo-nos ao uso dos advérbios terminados em -ly, observamos que nenhuma das duas gramáticas menciona fraseologias em que esse grupo pode ser encontrado, nem mesmo em língua geral. Além disso, não relacionam o uso de advérbios a tipologias textuais ou sequer abordam questões culturais, aspectos que consideramos importantes em obras de referência como essas.

Fechando nossas análises em obras de referência em inglês e em português, concluímos que todas aquelas investigadas deixam a desejar quanto à descrição e contextualização de fraseologias que contemplem os advérbios, tanto em língua geral quanto em linguagens especializadas - um dos motivos que nos levaram a prosseguir com nossa pesquisa.

Para fundamentar nossa investigação apresentamos, ainda no primeiro capítulo, um apanhado histórico sobre Linguística de Corpus e seus principais conceitos, com enfoque na padronização linguística e na léxico-gramática, relacionando-as à convencionalidade do discurso. Explicamos e exemplificamos o que é colocação, coligação, prosódia semântica, preferência semântica e unidades 
maiores de significado, deixando claro que nosso objetivo é investigar a língua em uso e dela extrair esses padrões, não necessariamente nos atendo à nomenclatura utilizada pelos pesquisadores, que observamos ainda ser pouco precisa para a definição das associações lexicais e gramaticais.

Iniciamos o segundo capítulo apresentando nossos corpora de estudo, quais sejam, o corpus de receitas culinárias, com um total de 1.716.496 palavras em inglês e 1.590.969 em português, cedido pela pesquisadora Elisa Duarte Teixeira, e o corpus de instrumentos contratuais, com 648.648 palavras em inglês e 279.923 em português, compilado por Luciana Carvalho Fonseca. Introduzimos também nossos corpora de referência - o British National Corpus (BNC) e o COCA para o inglês e o Banco de Português (BP) -, que, além de serem utilizados para o levantamento dos advérbios-chave de nosso estudo, foram consultados para verificarmos o uso de determinadas fraseologias compostas por advérbios terminados em -ly e -mente que comprovamos serem típicas, em praticamente todos os casos, das áreas da Culinária e do Direito. Apresentamos o processo de etiquetagem de parte de nossos corpora de estudo (parte já estava etiquetada), necessária para que pudéssemos observar a relevância do grupo de advérbios em estudo nos dados investigados. Com isso, observamos que $75,57 \%$ dos advérbios do corpus de Culinária em inglês consistia de advérbios terminados em -ly e 17,38\% daqueles em português, em -mente. No Direito, observamos também como esse grupo de advérbios é relevante, com resultados mais balanceados entre as línguas: $27,55 \%$ dos advérbios identificados terminavam em -ly e 30,09\% daqueles no corpus em português terminavam em -mente. Para a extração desses e dos demais dados de nossa pesquisa, utilizamos o programa WordSmith Tools, cujas ferramentas foram detalhadas e seu uso exemplificado também no segundo capítulo. Dentre elas, devemos destacar: Wordlist (lista de palavras), Concord (linhas de concordância) e Keyword (lista de palavras-chave). Ao final do capítulo, detalhamos todo o processo para o levantamento e apresentamos todos os advérbios terminados em -ly e -mente com índice de chavicidade acima de 100, extraídos das listas de palavraschave em ambas as tipologias e línguas. Desses, consideramos para uma análise detalhada no capítulo seguinte os cinco primeiros em cada tipologia e língua. São eles:

- na Culinária (inglês): finely, freshly, gently, lightly e thinly; 
- na Culinária (português): levemente, delicadamente, grosseiramente, finamente e ligeiramente;

- no Direito (inglês): promptly, reasonably, expressly, duly e collectively;

- no Direito (português): expressamente, devidamente, simplesmente, automaticamente e independentemente.

No terceiro e último capítulo de nossa tese, nosso primeiro passo foi buscar, nos dicionários baseados em corpus apresentados no primeiro capítulo, os advérbios em português, numa tentativa de verificar como eram abordados - e se realmente o seriam - nessas obras. Diante de resultados pouco satisfatórios, passamos para a extração e análise das fraseologias que continham esse grupo de advérbios em nossos corpora de estudo. Ao final da análise de cada grupo, ou seja, quatro grupos subdivididos por tipologia e língua, apresentamos as observações mais relevantes que caracterizavam o uso do advérbio naquele contexto. Considerando cada uma das tipologias, comparamos também o papel do advérbio nas línguas investigadas. Observamos, por exemplo, que os advérbios terminados em -ly são muito mais frequentes na tipologia das receitas em inglês do que aqueles terminados em -mente, em português. Essa frequência, no entanto, não reflete a maior diversidade observada nessa língua. No Direito, tal discrepância não procede. Ao contrário da Culinária, a frequência manteve-se similar nas duas línguas, inclusive com uma porcentagem um pouco maior em português. Quanto à diversidade de advérbios, no entanto, o português apresenta maior número de formas, como o observado nas receitas. Em geral, verificamos que ambas as tipologias apresentam peculiaridades quanto ao uso dos advérbios, gerando fraseologias típicas de cada área. Durante essas análises, pudemos destacar a formação de unidades menores que propiciaram a extração de padrões maiores, mais especificamente na Culinária, como por exemplo o levantamento das associações entre finely e CHOP, que propiciou identificarmos fraseologias como [INGREDIENTE] + peeled and finely chopped e drain + ([INGREDIENTE]) + (well) and chop finely. Tal fato também ficou evidente nas co-ocorrências entre freshly e grind, quando pudemos identificar freshly ground black pepper, a fraseologia mais frequente em nossos dados, e salt and freshly ground [PIMENTA]. No Direito, mesmo iniciando com colocações de duas palavras, como por exemplo a co-ocorrência entre reasonably e satisfactory, a busca foi mais direcionada por padrões maiores - 
podemos exemplificar com (upon receipt of) evidence reasonably satisfactory to + [PARTES] -, muitas vezes com itens lexicais bastante fixos, o que caracteriza a formulaicidade do discurso jurídico. Eis alguns outros exemplos: in form and substance reasonably acceptable to; except as/unless otherwise expressly provided in this agreement; [PARTES] (is) duly organized, validly existing and in good standing under the laws of; neste ato representada na forma de seus atos constitutivos, doravante denominada simplesmente; representada na forma (preconizada em) de seu Estatuto/Contrato Social, doravante designada simplesmente; independentemente de aviso ou qualquer outra medida judicial ou extrajudicial. Menos frequente do que na Culinária, observamos também a associação entre itens lexicais e classes gramaticais, como em: as promptly as + (ADV) + ADJ; duly authorized to $+v$; FICAR expressamente $+v_{p p}$; SER automaticamente $+v_{p p}$.

Depois de extrairmos as fraseologias em ambas as tipologias, selecionamos algumas em inglês para detalhar e exemplificar o processo de busca de formas equivalentes na direção inglês-português. A partir dos dados levantados no corpus de receitas culinárias, selecionamos vinte fraseologias que continham advérbios terminados em -ly. Dentre as formas equivalentes definidas com a investigação no corpus em português, contabilizamos apenas seis que apresentavam advérbios terminados em -mente em sua formação. Em alguns casos, um mesmo advérbio em inglês apresentou mais de um advérbio terminado em -mente como forma equivalente, caso de gently fry, que apresentou ligeiramente, levemente e rapidamente como equivalente do advérbio nas opções de tradução. Houve ainda casos em que diferentes advérbios em inglês apresentaram as mesmas opções de tradução em português, como gently e lightly, que incluíram ligeiramente e levemente nas fraseologias que equivaliam àquelas em inglês. Exemplos: gently fry = fritar/frite ligeiramente/levemente/rapidamente; lightly floured surface = superfície levemente/ligeiramente polvilhada com farinha. Observamos também o uso de sintagmas preposicionados: em fogo brando e em fogo baixo foram utilizados nas fraseologias tampe (a panela) e cozinhe em fogo baixo/em fogo brando (cover and simmer gently); e até mesmo adjetivos, caso de finas em cebolas cortadas em rodelas (bem) finas (onions, finely sliced). Nos contratos, das dezoito fraseologias em inglês, apenas oito apresentaram o advérbio em -mente em suas formas equivalentes. Na realidade, a omissão do advérbio na língua de chegada foi a característica mais marcante nessa tipologia: muitos advérbios simplesmente 
desapareceram. Para exemplificar, podemos citar: reasonably believe = CONSIDERAR; expressly provided = (conforme) disposto; promptly execute and deliver = APRESENTAR/FORNECER (de imediato). Houve também casos em que um advérbio que não é considerado a tradução prima facie foi utilizado: na forma equivalente de collectively called, por exemplo, temos DENOMINADO simplesmente. Como pudemos observar, nem todos os "-lys" correspondem a "-mentes".

Para nos certificarmos de que essas fraseologias realmente eram típicas das receitas e dos contratos, selecionamos cinco em cada área (e uma de suas respectivas formas equivalentes) e as investigamos nos corpora de língua geral. Muitas não foram encontradas e, quando o foram, referiam-se às áreas em estudo em sua grande maioria. Dessa forma, comprovamos que se tratavam de padrões típicos da Culinária e do Direito.

Ainda nesse capítulo, decidimos comparar as listas dos 100 advérbios terminados em -ly e -mente mais chave de nossos dados, com o objetivo de verificar se as tipologias apresentavam algum advérbio em comum. Nos corpora em inglês (receitas e contratos), identificamos o advérbio immediately; naqueles em português, imediatamente e juntamente. Analisamos cada um desses advérbios em suas respectivas tipologias e levantamos as fraseologias, exatamente como fizemos com os cinco primeiros advérbios das listas de advérbios mais chave. Em todos os casos, concluímos que o mesmo advérbio, em cada uma das tipologias, apresenta características de uso e fraseologias próprias que os definem naquele contexto. Em linhas gerais, o advérbio adquire seu significado de acordo com o contexto e forma diferentes padrões, dependendo da tipologia em que se insere. Partindo desse pressuposto, inclusive, pode-se dizer que estamos diante de outra palavra.

Para concluir nossas análises nos corpora, fizemos um apanhado geral das observações quanto ao uso dos advérbios terminados em -ly e -mente a partir de cada língua, comparando os dados nas tipologias investigadas. Os tópicos abordados foram: frequência, aspectos morfossintáticos, semânticos, pragmáticos e culturais. Novamente, observamos que os advérbios apresentam fraseologias que são típicas de cada área, com padrões e usos distintos em ambas as línguas.

Por fim, e numa tentativa de verificar se constavam em obras hoje disponíveis no mercado, retomamos as vinte fraseologias para as quais estabelecemos as formas equivalentes nas receitas culinárias e as dezoito levantadas nos contratos e fomos buscá-las em dicionários especializados. Em mais essa fonte de pesquisa, 
comprovamos que nem os advérbios, muito menos as fraseologias das quais fazem parte, são contemplados. Exceção seja feita ao Vocabulário para Culinária (TEIXEIRA; TAGNIN, 2008), única obra baseada em corpus que, coincidentemente ou não, é a única que apresenta todos os advérbios como verbetes e a maior parte das fraseologias investigadas.

Para concluir, acreditamos ter atingido o objetivo proposto para esta pesquisa, ou seja, o de contribuir para a descrição e uso dos advérbios terminados em -ly e -mente nas áreas especializadas abordadas, partindo de textos escritos originalmente em inglês e em português. Dessa forma, esperamos ter apresentado dados úteis para o produtor de textos em ambas as línguas. Comprovamos que esses advérbios integram padrões linguísticos específicos que os caracterizam em um determinado discurso; demonstramos também a importância da inclusão dos resultados obtidos em obras de referência especializadas. Esta investigação não pretende ser exaustiva: procuramos contribuir para o estudo dos advérbios em linguagens especializadas e, quem sabe, inspirar estudos que tragam "outras luzes" e novos olhares sobre esse tema. 


\section{Referências bibliográficas}

ALVES, leda Maria. A renovação lexical nos domínios de especialidade. Ciência e Cultura, São Paulo, v. 58, n. 2, 2006. Disponível em: <http://cienciaecultura.bvs.br/ scielo.php?pid=S0009-67252006000200013\&script=sci_arttext>. Acesso em: 13 set. 2009.

ALVES, leda Maria. A delimitação da unidade lexical nas línguas de especialidade. Palavra/Departamento de Letras da PUC-Rio, Rio de Janeiro, v. 1, n. 5, p. 69-80, 1999.

AUBERT, Francis $H$. Introdução à metodologia da pesquisa terminológica bilíngüe. 2. ed. São Paulo: Humanitas/FFLCH-USP, 2001.

BAKER, Mona. Corpora in Translation Studies: an overview and some suggestions for future research. Target, Amsterdam/Philadelphia, v. 7, n. 2, p. 223-243, 1995.

BAKER, Mona. Corpus Linguistics and Translation Studies: implications and applications. In: BAKER, Mona et al (Eds.). Text and Technology: in honour of John Sinclair. Amsterdam/Philadelphia: John Benjamins Publishing Company, 1993. p. 233-250.

BAKER, Mona. In other words: a coursebook on translation. London and New York: Routledge, 1992.

BECHARA, Evanildo. O que muda com o novo acordo ortográfico. Rio de Janeiro: Nova Fronteira, 2008.

BECHARA, Evanildo. Moderna gramática portuguesa. 37. ed. rev. e aum. Rio de Janeiro: Editora Lucerna, 2001.

BECHARA, Evanildo. Moderna gramática portuguesa. 37. ed. rev. e ampl. Rio de Janeiro: Lucerna, 1999.

BENSON, Morton. Lexical Combinability. Papers in Linguistics, [S.I.], v. 18, n. 1, p. 3-15, 1985. 
BENSON, Morton; BENSON, Evelyn; ILSON, Robert. The BBI dictionary of English word combinations. 2nd ed. rev. Amsterdam/Philadelphia: John Benjamins Publishing Company, 1997.

BENSON, Morton; BENSON, Evelyn; ILSON, Robert. The BBI combinatory dictionary of English: a guide to word combinations. Amsterdam: John Benjamins Publishing Company, 1986.

BERBER SARDINHA, Antonio P. Corpora eletrônicos na pesquisa em tradução. In: TAGNIN, Stella Esther Ortweiler (Org.). Cadernos de Tradução, Florianópolis, n. 9, 2002/1, p. 15-59, 2002.

BERBER SARDINHA, Antonio P. Lingüística de Corpus: histórico e problemática. D.E.L.T.A., São Paulo, v. 16, n. 2, p. 323-367, 2000.

BERBER SARDINHA, Tony. Metaphor probabilities in corpora. In: ZANOTTO, Mara Sophia; CAMERON, Lynne; CAVALCANTI, Marilda C. (Eds.). Confronting metaphor in use: an applied linguistic approach. Amsterdam/Philadelphia: John Benjamins, 2008. p.127-148.

BERBER SARDINHA, Tony. Lingüística de Corpus. Barueri: Manole, 2004.

BERBER SARDINHA, Tony. Análise de gênero e Lingüística de Corpus: identificação das unidades internas do gênero por meio da padronização lexical. Direct Papers 51, São Paulo, 2003a. Disponível em: <http://lael.pucsp.br/direct>. Acesso em: 15 nov. 2008.

BERBER SARDINHA, Tony. The Bank of Portuguese. Direct Papers 50, São Paulo, 2003b. Disponível em: <http://lael.pucsp.br/direct>. Acesso em: 26 dez. 2009.

BERBER SARDINHA, Tony. Using keywords in text analysis: practical aspects. Direct Papers 42, São Paulo, 1999. Disponível em: <http://lael.pucsp.br/direct>. Acesso em: 10 jul. 2009.

BERBER SARDINHA, Tony; ALMEIDA, Gladis Maria de Barcellos. A Linguística de Corpus no Brasil. In: TAGNIN, Stellla E. O.; VALE, Otto Araújo (Orgs.). Avanços da Linguística de Corpus no Brasil. São Paulo: Humanitas, 2008. p. 17-40. 
BEVILACQUA, Cleci Regina. Fraseologia: perspectiva da língua comum e da língua especializada. Rev. Língua e Literatura, Frederico Westphalen, v. 6 e 7, n. 10/11, p. 73-86, 2004/2005.

BEVILACQUA, Cleci Regina. Terminologia mono/bi/multilíngüe: algumas propostas e reflexões referentes às unidades fraseológicas especializadas. TradTerm, São Paulo, v. 8, p. 135-147, 2002.

BEVILACQUA, Cleci Regina. Unidades Fraseológicas especializadas: novas perspectivas para sua identificação e tratamento. In: KRIEGER, Maria da Graça; MACIEL, Ana Maria Becker (Orgs.). Temas de Terminologia. Porto Alegre/São Paulo: Ed. Universidade/UFRGS/Humanitas/USP, 2001a. p. 106-117.

BEVILACQUA, Cleci Regina. Do domínio jurídico-ambiental: proposta de critérios para seleção e tratamento de unidades fraseológicas. In: KRIEGER, Maria da Graça; MACIEL, Ana Maria Becker (Orgs.). Temas de Terminologia. Porto Alegre/São Paulo: Ed. Universidade/UFRGS/Humanitas/USP, 2001b. p. 98-105.

BEVILACQUA, Cleci Regina. A fraseologia jurídico-ambiental. 1996. $148 \mathrm{f}$. Dissertação (Mestrado em Letras) - Instituto de Letras, Universidade Federal do Rio Grande do Sul, Porto Alegre, 1996.

BIBER, Douglas. Investigating language use through corpus-based analyses of association patterns. International Journal of Corpus Linguistics, Amsterdam/Philadelphia, v. 1, n. 2, p. 171-197, 1996.

BIBER, Douglas; CONRAD, Susan; LEECH, Geoffrey. Longman student grammar of spoken and written English. Edinburgh/Harlow/Essex: Longman, 2002.

BIBER, Douglas et al. Longman Grammar of Spoken and Written English. Essex: Longman, 1999.

BIBER, Douglas; CONRAD, Susan; REPPEN, Randi. Corpus linguistics: investigating language structure and use. Cambridge: Cambridge University Press, 1998.

BIDERMAN, Maria Tereza Camargo. Conceito lingüístico de palavra. Palavra/ Departamento de Letras da PUC-Rio, Rio de Janeiro, v. 1, n. 5, p. 69-80, 1999.

BOLINGER, Dwight. Degree Words. The Hague/Paris: Mouton, 1972. 
BOMFIM, Eneida. Advérbios. São Paulo: Ática, 1988.

BORBA, Francisco S. (Org.). Dicionário UNESP do português contemporâneo. São Paulo: UNESP, 2004.

BORBA, Francisco S. Dicionário de usos do Português do Brasil. São Paulo: Ática, 2002.

BOWKER, Lynne; PEARSON, Jeniffer. Working with specialized language: a practical guide to using corpora. London/New York: Routledge, 2002.

BURTON, William C. Burton's legal thesaurus. 4th ed. New York: McGraw-Hill, 2006.

BUYSSCHAERT, J. Criteria for the classification of English adverbials. Brussels: Koninklijke Academie, 1982.

CAMARGO, Diva Cardoso de. Metodologia de pesquisa em tradução e lingüística de corpus. São Paulo: Cultura Acadêmica; São José do Rio Preto: Laboratório Editorial do IBILCE/UNESP, 2007.

CARTER, Ronald; McCARTHY, Michael. Cambridge grammar of English: a comprehensive guide - spoken and written English grammar usage. Cambridge: Cambridge University Press, 2006.

CARVALHO, Luciana. Translating contracts and agreements: a Corpus Linguistics perspective. In: TAGNIN, Stella E. O.; VALE, Oto A. (Orgs.). Avanços da Linguística de Corpus no Brasil. São Paulo: Humanitas, 2008. p. 333-350.

CARVALHO, Luciana. Os dicionários jurídicos bilíngues e o tradutor - dois em direito contratual. TradTerm, São Paulo, v. 12, p. 309-347, 2006.

CARVALHO FONSECA, Luciana. O que é reasonable é razoável? Migalhas, São Paulo, 2010. Disponível em: <http://www.migalhas.com.br/mig_law_english.aspx> . Acesso em 15 jun. 2010. 
CARVALHO FONSECA, Luciana. A tradução de binômios nos contratos de common law à luz da lingüística de corpus. 2007. 2 v. 425 f. Dissertação (Mestrado em Letras) - Faculdade de Filosofia, Letras e Ciências Humanas, Universidade de São Paulo, São Paulo, 2007.

CASTILHO, Ataliba Teixeira de (Org.). Gramática do português falado. 3. ed. Campinas: Editora da UNICAMP, 1996. v. 1, p. 65-141.

CECHIN, Salete Moncay; CONTINI, Daviane Zottis; FINATTO, Maria José B. Advérbios terminados em -mente (L2) e em -ly (L1): um estudo sobre condições de tradução de manuais de química. In: FÓRUM INTERNACIONAL DE ENSINO DE LÍNGUAS ESTRANGEIRAS - FILE III, 2004, Pelotas. Anais... Pelotas: UCPEL/ UFPel, 2004. 1 CD-ROM.

CELCE-MURCIA, Marianne The elaboration of sociolinguistic competence: implications for teacher education. In: ALATIS, James et al (Eds.). Linguistics and the education of second language teachers: ethnolinguistic, psycholinguistic, and sociolinguistic aspects. GEORGETOWN UNIVERSITY ROUND TABLE OF LANGUAGES AND LINGUISTICS, 1995, Washington, DC. Washington, DC: Georgetown University Press, 1995. p. 699-710.

CHAFE, Wallace L. Discourse, consciousness, and time: the flow and displacement of conscious experience in speaking and writing. Chicago: University of Chicago Press, 1994.

COWIE, Anthony P. (Ed.). Phraseology: theory, analysis, applications. Oxford: The Claredon Press, 1998.

CUNHA, Celso; CINTRA, Lindley. Nova gramática do português contemporâneo. 2. ed. Rio de Janeiro: Nova Fronteira, 1997.

CUNHA, Celso; CINTRA, Lindley. Nova gramática do português contemporâneo. Rio de Janeiro: Nova Fronteira, 1985.

DANIELSSON, Pernilla. What constitutes a unit of analysis in language? Linguistik online, v. 31, n. 2, p. 17-24, 2007. Disponível em: <http://www.linguistikonline.com/31_07/danielsson.pdf>. Acesso em: 28 jun. 2010.

DAVIES, Mark. The Corpus of Contemporary American English (COCA): 400+ million words, 1990-present. 2008. Disponível em: <http://www.americancorpus.org>. 
DAVIES, Mark. BYU-BNC: The British National Corpus. [S.I.], 2004. Disponível em: $<$ http://corpus.byu.edu/bnc>.

FERREIRA, Aurélio Buarque de Holanda. Novo Dicionário Eletrônico Aurélio Versão 5.11a, [S.I.]: Positivo Informática Ltda., 2004. 1 CD-ROM.

FERREIRA, Aurélio Buarque de Holanda. Dicionário Aurélio eletrônico: Século XXI. Versão 3.0, [S.I.]: Lexicon Informática Ltda., 1999. 1 CD-ROM.

FERREIRA, Aurélio Buarque de Holanda. Novo dicionário da língua portuguesa. 2. ed. rev. e aum. Rio de Janeiro: Nova Fronteira, 1986.

FILLMORE, Charles J. Corpus linguistics or computer-aided armchair linguistics. In: SVARTVIK, Jan. (Ed.). Directions in Corpus Linguistics. Berlin: Mouton de Gruyter, 1992. p. 35-60.

FILLMORE, Charles J. Frame Semantics. In: The Linguistic Society of Korea (Ed.). Linguistics in the Morning Calm. Seoul: Hanshin Publishing Co., 1982. p. 111-138.

FIRTH, John Rupert. Linguistic analysis and translation. In: HALLE, M. et al. Festschrift for Roman Jackobson. The Hague: Mouton, 1956. p. 133-139.

FLOWERDEW, Lynne J. Corpus Linguistics in ESP: a genre-based perspective. LANG Conference Papers, [S.I.], p. 21-41, 1999. Disponível em: <http://repository.ust.hk/dspace/bitstream/1783.1/1047/1/LynneFlowerdew.pdf>. Acesso em: 25 set. 2007.

FRAMENET. Disponível em: <http://framenet.icsi.berkeley.edu>. Acesso em: 30 out. 2010.

GARNER, Bryan A. (Ed.). Black's Law dictionary. 7th ed. St. Paul: West Publishing Company, 1999.

GELLERSTAM, Martin. Translationese in Swedish novels translated from English. In: WOLLIN, Lars; LINDQUIST, Hans. (Eds.). Translation Studies in Scandinavia. Lund: CWK Gleerup, 1986. p. 88-95.

GOMENSORO, Maria Lúcia. Pequeno dicionário de Gastronomia. Rio de Janeiro: Editora Objetiva Ltda., 1999. 
GRANGER, Sylviane; MEUNIER, Fanny. Phraseology. Amsterdam/Philadelphia: John Benjamins Publishing Company, 2008.

GREENBAUM, Sidney; QUIRK, Randolph. A student's grammar of the English language. London: Longman, 1990.

GREENBAUM, Sidney. Verb-intensifier collocations in English. The Hague and Paris: Mouton, 1970.

GREENBAUM, Sidney. Studies in English adverbial usage. London: Longman, 1969.

GRIES, Stephan Th. Phraseology and linguistic theory: a brief survey. In: GRANGER, Sylviane; MEUNIER, Fanny (Eds.). Phraseology: an interdisciplinary perspective. Amsterdam/Philadelphia: John Benjamins, 2008. p. 3-25. Disponível em: <http://www.linguistics.ucsb.edu/faculty/stgries/research/Phraseology.pdf>. Acesso em: 25 jan. 2008.

GRIES, Stephan Th. Some proposals towards a more rigorous Corpus Linguistics. Special issue of Zeitschrift für Anglistik und Amerikanistik, Würzburg, v. 54 n .2, p. 191-202, 2006. Disponível em: <http://www.linguistics.ucsb.edu/faculty/stgries/ research/MoreRigCorpLing_ZAA.pdf>. Acesso em: 20 jan. 2009.

GRIES, Stephan Th.; HAMPE, Beate; SCHÖNEFELD, Doris. Converging evidence: bringing together experimental and corpus data on the association of verbs and constructions. Cognitive Linguistics, [S.I.], v. 16, n. 4, p. 635-676, 2005.

HALLIDAY, Michael A. K. Corpus Studies and probabilistic grammar. In: AIJMER, Karin; ALTENBERG, Bengt (Eds.). English Corpus Linguistics: studies in honour of Jan Svartvik. London/New York: Longman, 1991. p. 30-43.

HALVERSON, Sandra. The concept of equivalence in Translation Studies. Target, Amsterdam/Philadelphia, v. 9, n. 2, p. 207-233, 1997.

HANKS, Patrick. The lexicographical legacy of John Sinclair. International Journal of Lexicography, Oxford, v. 21, n. 3, p. 219-229, 2008. Special Issue: The Legacy of John Sinclair. Advance Access published on August 6, 2008.

HATIM, Basil; MUNDAY, Jeremy. Translation: an advanced resource book. London and New York: Routledge, 2004. 
HOEY, Michael; O'DONNELL, Matthew Brook. Lexicography, grammar and textual position. International Journal of Lexicography, Oxford, v. 21, n. 3, p. 293-309, 2008. Special Issue: The Legacy of John Sinclair. Advance Access published on August 4, 2008.

HOEY, Michael. Lexical priming: a new theory of words and language. London/New York: Routledge, 2005.

HOEY, Michael What's in a word? English Teaching professional, West Sussex, issue 27, p. 5-8, Apr. 2003.

HOEY, Michael. From concordance to text structure: new uses for computer corpora. In: LEWANDOWSKA-TOMASZCZYK, Barbara; MELIA, Patrick James (Eds.). International conference on practical applications in language corpora. Lódz: Lódz University Press, 1997. p. 2-23.

HOEY. Michael. Patterns of lexis in text. Oxford: Oxford University Press, 1991.

HOUAISS, Antonio. Dicionário eletrônico Houaiss da língua portuguesa. Versão 1.0, [S.I.]: Editora Objetiva Ltda., 2001. 1 CD-ROM.

HOUAISS, Antonio (Ed.). Webster's dicionário inglês-português. Rio de Janeiro: Record, 1982.

HUDDLESTON, Rodney D. Introduction to the grammar of English. Cambridge: Cambridge University Press, 1984.

HUNSTON, Susan. Corpora in Applied Linguistics. Cambridge: Cambridge University Press, 2002.

HUNSTON, Susan. Word patterns. English Teaching professional, West Sussex, issue 19, p. 39-41, Apr. 2001.

HUNSTON, Susan; FRANCIS, Gill. Pattern Grammar: a corpus-driven approach to the lexical grammar of English. Amsterdam/Philadelphia: John Benjamins Publishing Co., 2000. 
ILARI, Rodolfo et al. Considerações sobre a posição dos advérbios. In: CASTILHO, Ataliba Teixeira de (Org.). Gramática do português falado. 3. ed. Campinas:

Editora da UNICAMP, 1996. v. 1, p. 65-141.

JONES, Bridget. Dicionário prático de Culinária. Tradução Maria Emília de Oliveira. São Paulo: Companhia Melhoramentos, 1996.

KLIE, Virginia. Glossário de Gastronomia: português-inglês/inglês-português. São Paulo: Disal, 2006. Série Easy Way.

KLIE, Virginia. Not just hamburgers! Aprenda inglês com as melhores receitas da cozinha americana. São Paulo: Disal, 2003. Edição bilíngue.

KOLLER, Werner. The concept of equivalence and the object of Translation Studies. Target, Amsterdam/Philadelphia, v. 7, n. 2, p. 191-222,1995.

KRISHNAMURTHY, Ramesh. Corpus-driven lexicography. International Journal of Lexicography, Oxford, v. 21, n. 3, p. 231-242, 2008. Special Issue: The Legacy of John Sinclair. Advance Access published on July 5, 2008.

L'HOMME, Marie-Claude. A lexico-semantic approach to the structuring of Terminology. In: COMPUTERM 2004 - 3rd INTERNATIONAL WORKSHOP ON COMPUTATIONAL TERMINOLOGY, 2004, Geneva. Proceedings... Geneva: Coling, 2004. Disponível em: <http://www.ling.umontreal.ca/lhomme/docs/ Computerm_2004.pdf>. Acesso em: 14 set. 2009.

L'HOMME, Marie-Claude; BERTRAND, Claudine. Specialized lexical combinations: should they be described as collocations or in terms of selectional restrictions? In: HEID, Ulrich et al. (Eds.). Proceedings of the Ninth EURALEX International Congress, EURALEX 2000, Stuttgart. Proceedings... Stuttgart: Universität Stuttgart, 2000. p. 497-506. Disponível em: <http://www.olst.umontreal.ca/pdf/berlhom.pdf>. Acesso em: 22 dez. 2008.

LÁCIO-WEB (LW). Compilação de Córpus do Português do Brasil e Implementação de Ferramentas para Análises Lingüísticas. Disponível em: <http://www. nilc.icmc.usp.br/lacioweb/index.htm>. Acesso em: jul. 2007.

LAVIOSA, Sara. Corpus-based translation studies: where does it come from? Where is it going? TradTerm, São Paulo, v. 10, p. 29-57, 2004. 
LAVIOSA, Sara. Corpus-based translation studies: theory, findings, applications. Amsterdam/New York: Rodopi, 2002.

LEECH, Geoffrey. Corpora and theories of linguistic performance. In: SVARTVIK, Jan. (Ed.). Directions in Corpus Linguistics. Berlin: Mouton de Gruyter, 1992. p. 105-122.

LEECH, Geoffrey; SVARTVIK, Jan. A Communicative Grammar of English. Essex: Longman, 1975.

McENERY, Tony; WILSON, Andrew. Corpus Linguistics: an introduction. 2nd ed. Edinburgh: Edinburgh University Press, 2001.

McENERY, Tony; WILSON, Andrew. Corpus Linguistics. Edinburgh: Edinburgh University Press, 1997.

McENERY, Tony; XIAO, Richard; TONO, Yukio. Corpus-based language studies. London/New York: Routledge, 2006.

MELLINKOFF, David. The language of the law. Eugene: Resource Publications, 1963.

MELLO, Maria Chaves de. Dicionário jurídico: português-inglês/inglês-português. 8. ed. rev., atual. e ampl. São Paulo: Método, 2006.

MEUNIER, Fanny; GRANGER, Sylviane. Phraseology in foreign language learning and teaching. Amsterdam/Philadelphia: John Benjamins Publishing Company, 2008.

MOON, Rosamund. Sinclair, Phraseology, and Lexicography. International Journal of Lexicography, Oxford, v. 21, n. 3, p. 243-254, 2008. Special Issue: The Legacy of John Sinclair. Advance Access published on July 3, 2008.

MOON, Rosamund. Frequencies and forms of phrasal lexemes in English. In: COWIE, Anthony P. (Ed.). Phraseology: theory, analysis, applications. Oxford: The Claredon Press, 1998. p. 79-100. 
MORAES, Helmara F. R. de. Os advérbios em -ly e -mente: a busca pela equivalência na culinária e no direito. In: TAGNIN, Stella E. O.; VALE, Oto A. (Orgs.). Avanços da Lingüística de Corpus no Brasil. São Paulo: Humanitas, 2008. p. 315-332.

MORAES, Helmara F. Real de. Os advérbios em -ly e -mente: a busca pela equivalência na Culinária e no Direito. In: VI ENCONTRO DE LINGÜÍSTICA DE CORPUS, 2007, São Paulo. Anais eletrônicos..., São Paulo: USP, 2008. Disponível em: <http://www.nilc.icmc.usp.br/viencontro/anais.htm>. Acesso em: 15 jan. 2009.

MORAES, Helmara F. Real de. O tradutor pode estar redondamente enganado: um estudo contrastivo de colocações adverbiais (inglês-português) sob o enfoque da Lingüística de Corpus. 2005. 207 f. Dissertação (Mestrado em Letras) - Faculdade de Filosofia, Letras e Ciências Humanas, Universidade de São Paulo, São Paulo, 2005.

MORÉ, Zoila Carneado; TRISTÁ, Antonia M. Estudios de fraseologia. La Habana: Academia de Ciencias de Cuba, 1983.

MOSBACK, Gerald P. Adverb-adjective combinations: technical terms, idioms and clichés. Forum, [S.I]., v. 28, n. 2, p. 43-45, 1990.

NASCIMENTO, Solange. Os verdadeiros advérbios: modo, tempo e lugar. Caderno Seminal Digital, Rio de Janeiro, v. 10, n. 10, p. 322-339, jul./dez. 2008. Disponível em: <http://www.dialogarts.uerj.br/arquivos/Seminal_10.pdf>. Acesso em: 29 set. 2009.

NATTINGER, James R.; DeCARRICO, Jeanette S. Lexical phrases and language teaching. Oxford: Oxford University Press, 1992.

NEVES, Maria Helena de Moura. Texto e gramática. São Paulo: Contexto, 2006.

NEVES, Maria Helena de Moura. Guia de uso do português: confrontando regras e usos. São Paulo: Editora UNESP, 2003.

NEVES, Maria Helena de Moura. Gramática de usos do português. São Paulo: Editora UNESP, 2000. 
NORONHA GOYOS JR., Durval de. Dicionário Jurídico Noronha. 5. ed. São Paulo: Observador Legal Editora, 2003.

OXFORD COLLOCATIONS dictionary for students of English. Oxford: Oxford University Press, 2002.

PALUMBO, Giuseppe. The use of phraseology for training and research in translation of LSP texts. In: MAIA, Belinda et al (Eds.). Training the language services provider for the new millenium: Proceedings of the III Encontros de Tradução de Astra-FLUP, Porto. Proceedings... Porto: Faculdade de Letras Universidade do Porto, 2003. p. 199-211.

PAWLEY, Andrew; SYDER, Frances Hodgetts. Two puzzles for linguistic theory: nativelike selection and nativelike fluency. In: RICHARDS, Jack C.; SCHMIDT, Richard W. (Eds.). Language and Communication. London/New York: Longman, 1983. p. 191-226.

PEARSON, Jeniffer. Terms in context. Amsterdam/Philadelphia: John Benjamins, 1998.

POULSEN, Sonja. Collocations as a language resource - A functional and cognitive study in English phraseology. 2005. 298 f. Ph.D. Dissertation - Institute of Language and Communication, University of Southern Denmark, Odense, 2005. Disponível em: <http://www.humaniora.sdu.dk/phd/dokumenter/filer/Afhandlinger48.pdf>. Acesso em: 14 maio 2007.

PRODROMOU, Luke. Idiomaticity. English Teaching professional, West Sussex, issue 27, p. 10-12, Apr. 2003.

PROJETO COMET. Disponível em: <http://www.fflch.usp.br/dlm/comet>.

QUIRK, Randolph et al. A Comprehensive Grammar of the English Language. Harlow: Longman, 1985.

QUIRK, Randolph; GREENBAUM, Sidney. A University Grammar of English. London: Longman, 1974 [1973].

RAJAGOPALAN, Kanavillil. A Linguística de Corpus no tempo e no espaço: visão reflexiva. In: GERBER, Márcia Regina; VASILÉVSKI, Vera (Orgs.). Um percurso para pesquisas com base em corpus. Florianópolis: Ed. da UFSC, 2007. p. 23-44. 
RAMÓN, Noelia; LABRADOR, Belén. Translation of '-ly' adverbs of degree in an English-Spanish Parallel Corpus. Target, Amsterdam/Philadelphia, v. 20, n. 2, p. 275-296, 2008.

ROCHA LIMA, Carlos Henrique. Gramática normativa da língua portuguesa. 35. ed. ret. e enriq. Rio de Janeiro: J. Olympio, 1998.

ROCHA, Marco. Métodos estatísticos comuns em Linguística de Corpus: visão geral. In: GERBER, Márcia Regina; VASILÉVSKI, Vera (Orgs.) Um percurso para pesquisas com base em corpus. Florianópolis: Ed. da UFSC, 2007. p.194-221.

RODRIGUES, Cristina Carneiro. Tradução e diferença. São Paulo: Editora UNESP, 2000.

RUNDELL, Michael (Ed.). Macmillan English dictionary for advanced learners of American English. 2nd ed. Oxford: Macmillan, 2007. Inclui 1 CD-ROM.

RUNDELL, Michael (Ed.). Macmillan English dictionary for advanced learners of American English. Oxford: Macmillan, 2002. Inclui 1 CD-ROM.

SALDANHA, Roberta Malta. Dicionário tradutor de Gastronomia em seis línguas. São Paulo: Antonio Bellini Editora \& Cultura, 2007.

SAMPSON, Geoffrey. Empirical Linguistics. London/ New York: Continuum, 2001.

SANTORINI, Beatrice. Part-of-speech tagging guidelines for the Penn Treebank Project. 1991. Disponível em: <http://www.ims.uni-stuttgart.de/projekte/corplex/ TreeTagger/Penn-Treebank-Tagset.pdf>. Acesso em: 31 dez. 2009.

SANTOS, Diana. On grammatical translationese. In: KOSKENNIEMI, Kimmo (Ed.). SHORT PAPERS PRESENTED AT THE TENTH SCANDINAVIAN CONFERENCE ON COMPUTATIONAL LINGUISTICS, 1995, Helsinki. Proceedings... Helsinki: [s.n.], 1995. p. 59-66. Disponível em: <http://www.linguateca.pt/Diana/download/ SantosNodalida96.pdf>. Acesso em 13 jun. 2010.

SCOTT, Mike. WordSmith Tools. Versão 5.0. Oxford: Oxford University Press, 2007. Disponível em: <http://www.lexically.net/wordsmith/>. Acesso em: 20 ago. 2008. 
SCOTT, Mike. WordSmith Tools. Versão 3.0. Oxford: Oxford University Press, 1999. Disponível em: <http://www.lexically.net/wordsmith/>. Acesso em: 24 set. 2005.

SINCLAIR, John. Trust the text: language, corpus and discourse. London/New York: Routledge, 2004.

SINCLAIR, John. Reading concordances: an introduction. Harlow/London: Pearson Longman, 2003.

SINCLAIR, John. The search for units of meaning. In: CICLE DE CONFERÈNCIES 94-95: LĖXIC, CORPUS I DICCIONARIS, 1996, Barcelona. Barcelona: Universitat Pompeu Fabra. 1996a. Não paginado.

SINCLAIR, John. The search for units of meaning. Textus IX, [S.I.], v. 1, p. 75-106, $1996 b$.

SINCLAIR, John. Corpus, concordance, collocation. Oxford: Oxford University Press, 1991.

SINCLAIR, John et al (Eds.). COLLINS COBUILD English language dictionary. London: Collins Publishers, 1987.

STEFANOWITSCH, Anatol; GRIES Stephan Th. Collostructions: investigating the interaction of words and constructions. International Journal of Corpus Linguistics, Amsterdam/Philadelphia, v. 8, n. 2, p. 209-243, 2003. Disponível em: <http://www.linguistics.ucsb.edu/faculty/stgries/research/Collostructions_IJCL.pdf>. Acesso em: 25 jan. 2008.

STUBBS, Michael. Words and phrases: corpus studies of lexical semantics. Oxford: Blackwell Publishers, 2001.

STUBBS, Michael. Text and corpus anlysis: computer-assisted studies of language and culture. Oxford: Blackwell, 1996.

STUBBS, Michael. British traditions in text analysis. In: BAKER, Mona; FRANCIS, Gill; TOGNINI-BONELLI, Elena (Eds.). Text and Technology: in honour of John Sinclair. Amsterdam/Philadelphia: John Benjamins Publishing Co., 1993. p. 1-33. 
TAGNIN, Stella Esther Ortweiler. Lingüística de Corpus aplicada a áreas afins: projeto COMET. In: GERBER, Márcia Regina; VASILÉVSKI, Vera (Orgs.). Um percurso para pesquisas com base em corpus. Florianópolis: Ed. da UFSC, 2007a. p. $160-173$.

TAGNIN. Stella E. O. A identificação de equivalentes tradutórios em corpora comparáveis. In: I CONGRESSO INTERNACIONAL DA ABRAPUI, 2007, Belo Horizonte. Anais... Belo Horizonte: [s.n.], 2007b. Disponível em:

<http://www.fflch.usp.br/dlm/comet/>. Acesso em: 21 jun. 2010.

TAGNIN, Stella Esther Ortweiler. 0 jeito que a gente diz: expressões convencionais e idiomáticas. São Paulo: Disal, 2005.

TAGNIN, Stella Esther Ortweiler. Corpora and the innocent translator: In: LEWANDOWSKA-TOMASZCZYK, Barbara; THELEN, Marcel (Eds.). Proceedings of the Lódz Session of the $3^{\text {rd }}$ International Maastricht-Lódz Duo Colloquium on "Translation and Meaning", pt 6, Poland. Proceedings... Poland: Universitaire Pers Maastricht, 2002a. p. 489-496.

TAGNIN, Stella Esther Ortweiler. Os Corpora: instrumentos de auto-ajuda para o tradutor. In: TAGNIN, Stella Esther Ortweiler (Org.). Cadernos de Tradução, Florianópolis, n. 9, p. 15-59, 2002b.

TAGNIN, Stella Esther Ortweiler. Convencionalidade e produção de texto: um dicionário de colocações verbais inglês/português português/inglês. 1998. 102 f. Tese (Livre Docência em Língua Inglesa) - Faculdade de Filosofia, Letras e Ciências Humanas, Universidade de São Paulo, São Paulo, 1998.

TAGNIN, Stella Esther Ortweiler; TEIXEIRA, Elisa Duarte. Lingüística de Corpus e Tradução Técnica - relato da montagem de um corpus multivarietal de culinária. TradTerm, São Paulo, v. 10, p. 313-358, 2004.

TAGNIN, Stella Esther Ortweiler; VALE, Oto Araújo (Orgs.). Avanços da Lingüística de Corpus no Brasil. São Paulo: Humanitas, 2008.

TEIXEIRA, Elisa Duarte. A Lingüística de Corpus a serviço do tradutor: proposta de um dicionário de Culinária voltado para a produção textual. 2008. 400 f. Tese (Doutorado em Letras) - Faculdade de Filosofia, Letras e Ciências Humanas, Universidade de São Paulo, São Paulo, 2008. 
TEIXEIRA, Elisa Duarte. Etiquetagem em Lingüística de Corpus: possibilidades de aplicação. In: GERBER, Márcia Regina; VASILÉVSKI, Vera (Orgs.) Um percurso para pesquisas com base em corpus. Florianópolis: Ed. da UFSC, 2007. p. 116148.

TEIXEIRA, Elisa Duarte. Receita qualquer um traduz - Será? - A Culinária como área técnica de tradução. 2004. 2 v. Dissertação (Mestrado em Letras) Faculdade de Filosofia, Letras e Ciências Humanas, Universidade de São Paulo, São Paulo, 2004.

TEIXEIRA, Elisa Duarte; TAGNIN, Stella E. O. Vocabulário para Culinária: inglês/português. São Paulo: Special Book Services Livraria, 2008. (Série Mil \& Um Termos).

THE BRITISH NATIONAL CORPUS. Version 3 (BNC XML Edition). [S.I.]: Oxford University Computing Services, 2007. Disponível em: <http://www.natcorp.ox.ac.uk>

TOGNINI-BONELLI, Elena. Between Phraseology and Terminology in the language of Economics. In: NUCCORINI, Stefania. (Ed.). Phrases and Phraseology: data and descriptions, Bern: Peter Lang, 2002. p. 65-83.

TOGNINI-BONELLI, Elena. Corpus Linguistics at work. Amsterdam/ Philadelphia: John Benjamins, 2001.

TOGNINI-BONELLI, Elena; MANCA, Elena. Welcoming children, pets and guests: towards functional equivalence in the languages of 'Agriturismo' and 'Farmhouse Holidays'. TradTerm, São Paulo, v. 10, p. 295-312, 2004.

VASILÉVSKI, Vera. Aspectos histórico-teóricos da Linguística de Corpus:

surgimento, abandono, levante e uso. In: GERBER, Márcia Regina; VASILÉVSKI, Vera (Orgs.). Um percurso para pesquisas com base em corpus. Florianópolis: Ed. da UFSC, 2007. p. 45-62.

WRAY, Alison. Formulaic language: pushing the boundaries. Oxford: Oxford University Press, 2008.

WRAY, Alison. Formulaic language and the lexicon. Cambridge: Cambridge University Press, 2002. 
WYNNE, Martin (Ed.). Developing Linguistic Corpora: a guide to good practice. Oxford: Oxbow Books, 2005. Disponível em: <http://ahds.ac.uk/linguistic-corpora>. Acesso em: 15 jan. 2009. 
ANEXO A

Corpus de Culinária (inglês)

\begin{tabular}{|c|c|c|c|c|c|}
\hline subcorpora & no. de arquivos/pastas & $\begin{array}{l}\text { no. de } \\
\text { receitas }\end{array}$ & $\begin{array}{c}\text { itens } \\
\text { (tokens) }\end{array}$ & $\begin{array}{l}\text { formas } \\
\text { (types) }\end{array}$ & $\begin{array}{l}\text { razão forma/item } \\
\text { (type/token ratio) }\end{array}$ \\
\hline Palc_IOB & $\begin{array}{l}\text { - aco: side dishes (10 receitas) } \\
\text { - ent: appetizers (10 receitas) } \\
\text { - sal: salads (10 receitas) } \\
\text { - ppm: entrées - pasta (10 receitas) } \\
\text { - ppa: entrées - poultry (10 receitas) } \\
\text { - ppc: entrées - meat (10 receitas) } \\
\text { - ppp: entrées - fish and shellfish (10 receitas) } \\
\text { - sop: soups (10 receitas) } \\
\text { - sbr: desserts (10 receitas) } \\
\text { - pao: bread (10 receitas) } \\
\text { - teb: pies, tarts and cakes (10 receitas) }\end{array}$ & 110 & 27.974 & 2.513 & 8,98 \\
\hline
\end{tabular}




\begin{tabular}{|c|c|c|c|c|c|}
\hline HelenIOB & $\begin{array}{l}13 \text { arquivos com várias receitas cada, nas categorias: } \\
\text { - starters (starts, snacks and suppers); } \\
\text { - soups (soups, stocks, soup accompaniments); } \\
\text { - meat (beef and veal; poultry; lamb and mutton; pork, gammon, ham } \\
\text { and bacon; game; offal; mixed meat/other meat dishes); } \\
\text { - fish; } \\
\text { - vegetarian; } \\
\text { - vegetables and accompaniments; } \\
\text { - salads; } \\
\text { - savoury sauces; } \\
\text { - desserts; } \\
\text { - confectinery; } \\
\text { - drinks; } \\
\text { - baking (cakes; biscuits, bars and slices; breads; scones; pastry } \\
\text { - preserves (chutneys; jams, jellies and marmalades preserves) }\end{array}$ & 1.465 & 261.852 & 6.272 & 2,40 \\
\hline BBC_recs & 1 arquivo com 5.180 receitas em categorias variadas & 5.180 & 1.146 .241 & 9.259 & 0,81 \\
\hline fishSoup & 1 arquivo com receitas variadas de peixes e frutos do mar & 181 & 42.387 & 3.227 & 7,61 \\
\hline Total & & cerca de 7.400 & 1.578 .125 & 14.619 & 0,93 \\
\hline
\end{tabular}


Espec_1O: receitas coletadas em 2001 por alunos do Curso de Especialização em Tradução na USP, ministrado por Teixeira.

$10=$ Inglês Original.

Palc_IOB: receitas provenientes do Corpus Multivarietal PALC, coletado pela autora (Teixeira 2004).

IOB = Inglês Original Britânico.

Palc_IOA: receitas provenientes do Corpus Multivarietal PALC, coletado pela autora (Teixeira 2004).

$\mathrm{IOA}=$ Inglês Original Americano.

HelenIOB: cópia integral do site The Great British Kitchen, editado por Helen Watson.

IOB = Inglês Original Britânico

BBC_recs: receitas da seção Food do site da BBC, British Broadcast Corporation.

fishSoup: receitas de sopas com peixes e frutos do mar coletadas por alunos do curso de "Linguística de Corpus e Tradução" ministrado por Teixeira em 2006 no Unibero. 


\section{Corpus de Culinária (português)}

\begin{tabular}{|c|c|c|c|c|c|}
\hline subcorpora & no. de arquivos/pastas & $\begin{array}{l}\text { no. de } \\
\text { receitas }\end{array}$ & $\begin{array}{c}\text { itens } \\
\text { (tokens) }\end{array}$ & $\begin{array}{l}\text { formas } \\
\text { (types) }\end{array}$ & $\begin{array}{l}\text { razão forma/item } \\
\text { (type/token ratio) }\end{array}$ \\
\hline CD_Rec & $\begin{array}{l}\text { - aco: acompanhamentos (40 receitas) } \\
\text { - ave: aves ( } 80 \text { receitas) } \\
\text { - bol: bolos (38 receitas) } \\
\text { - car: carnes ( } 64 \text { receitas) } \\
\text { - chu: churrasco (54 receitas) } \\
\text { - drk: drinks (50 receitas) } \\
\text { - fnd: fondues, musses e souflês (56 receitas) } \\
\text { - mss: massas ( } 82 \text { receitas) } \\
\text { - pao: pães (55 receitas) } \\
\text { - ptp: típicos ( } 28 \text { receitas) } \\
\text { - pxs: peixes (49 receitas) } \\
\text { - sal: saladas (92 receitas) }\end{array}$ & 1.015 & 133.340 & 3.809 & 2,86 \\
\hline
\end{tabular}




\begin{tabular}{|c|c|c|c|c|c|}
\hline & $\begin{array}{l}\text { - snd: sanduíches e salgados (148 receitas) } \\
\text { - sob: sobremesas e doces (68 receitas) } \\
\text { - sop: sopas (40 receitas) } \\
\text { - srv: sorvetes ( } 28 \text { receitas) } \\
\text { - tor: tortas (43 receitas) }\end{array}$ & & & & \\
\hline Palc_POB & $\begin{array}{l}\text { - aco: acompanhamentos (10 receitas) } \\
\text { - ent: entradas (10 receitas) } \\
\text { - sal: saladas (10 receitas) } \\
\text { - ppm: pratos principais - massas (10 receitas) } \\
\text { - ppa: pratos principais - aves (10 receitas) } \\
\text { - ppc: pratos principais - carnes (10 receitas) } \\
\text { - ppp: pratos principais - peixes e frutos do mar (10 receitas) } \\
\text { - sop: sopas (10 receitas) } \\
\text { - sbr: sobremesas (10 receitas) } \\
\text { - pao: pães (10 receitas) } \\
\text { - teb: tortas e bolos (10 receitas) }\end{array}$ & 110 & 24.816 & 2.066 & 8,33 \\
\hline Basilico & $\begin{array}{l}\text { "Receitas com..." (430 receitas) } \\
\text { "Menu Basilico" + "Receitas do dia" + "Famosos na cozinha" + } \\
\text { "À mesa com Mari ( } 81 \text { arquivos - em média } 3 \text { receitas por arq.) }\end{array}$ & cerca de 700 & 193.442 & 6.376 & 3,30 \\
\hline JPAN & receitas variadas (1 arquivo) & 243 & 41.164 & 3.355 & 8,15 \\
\hline
\end{tabular}




\begin{tabular}{|c|c|c|c|c|c|}
\hline GRGula & receitas variadas (1 arquivo) & cerca de 45 & 14.046 & 1.626 & 11,58 \\
\hline Espec_PO & receitas variadas (23 arquivos, com várias receitas cada) & cerca de 600 & 102.833 & 3.907 & 3,80 \\
\hline Terra & $\begin{array}{l}\text { receitas variadas - acompanhamentos, aves, bebidas, carnes, } \\
\text { frutos do mar, grãos e massas, lanches, molhos, saladas, } \\
\text { sobremesas: bolos, sobremesas: tortas, sobremesas: doces, } \\
\text { sopas, tortas, pizzas e pães (1 arquivo) }\end{array}$ & 5.024 & 939.653 & 8.500 & 1,0 \\
\hline
\end{tabular}

CDCC: $\quad$ proveniente do CD "Grandes Receitas Cláudia Cozinha" (editora Abril), com 6 edições especiais de receitas da Revista Claudia Cozinha (sem data de publicação).

CD_Rec: retirado do CD "1001 Receitas Práticas", da Editora Escala (sem data de publicação).

Palc_POB: receitas provenientes do Corpus Multivarietal PALC, coletado pela autora em sua dissertação de Mestrado (Teixeira 2004). $\mathrm{POB}=$ Português Original Brasileiro.

Basilico: $\quad$ receitas do site Basilico - a gastronomia na web.

JPAN: $\quad$ coletado do site da rádio Jovem Pan em agosto de 2006 usando o offline browser HTTrack.

GRGula: receitas publicadas na Revista Gula (coletadas por Teixeira em 2002).

Espec_PO: receitas coletadas em 2001 por alunos do Curso de Especialização em Tradução na USP, ministrado por Teixeira. $\mathrm{PO}=$ Português Original.

Terra: $\quad$ coletado da seção de Culinária do portal Terra em junho de 2005, com o offline browser HTTrack. 


\section{ANEXO B \\ Advérbios terminados em -ly: corpus de Culinária}

Todos os advérbios terminados em -ly derivados de adjetivos encontrados no corpus de Culinária (inglês) estão identificados na tabela abaixo. Na sequência, aqueles descartados para esta pesquisa.

\section{Observações:}

$\mathbf{N}=\quad$ posição em que o advérbio ocorreu em uma lista de frequência com todas as palavras do corpus de estudo

Word $=$ advérbio a que os dados se referem

Freq. = frequência do advérbio no corpus de estudo, em ordem decrescente

$\%=\quad$ porcentagem que representa a frequência do advérbio no corpus de estudo, considerado em sua totalidade

Texts $=$ número de textos em que o advérbio ocorreu no corpus de estudo

$\%=\quad$ porcentagem que representa a frequência de textos em que o advérbio ocorreu, considerando-se o corpus de estudo em sua totalidade

\begin{tabular}{|c|l|r|r|r|r|}
\hline $\mathbf{N}$ & \multicolumn{1}{|c|}{ Word } & \multicolumn{1}{c|}{ Freq. } & \multicolumn{1}{c|}{$\%$} & \multicolumn{1}{c|}{ Texts } & \multicolumn{1}{c|}{$\%$} \\
\hline 73 & FINELY & 3261 & 0.19 & 1,962 & 25.31 \\
\hline 74 & FRESHLY & 3248 & 0.19 & 2,546 & 32.84 \\
\hline 100 & GENTLY & 2543 & 0.15 & 1,945 & 25.09 \\
\hline 164 & LIGHTLY & 1634 & 0.10 & 1,181 & 15.23 \\
\hline 293 & SLIGHTLY & 803 & 0.05 & 692 & 8.93 \\
\hline 311 & ROUGHLY & 750 & 0.04 & 588 & 7.58 \\
\hline 326 & THINLY & 701 & 0.04 & 553 & 7.13 \\
\hline 337 & IMMEDIATELY & 686 & 0.04 & 662 & 8.54 \\
\hline 345 & CAREFULLY & 550 & 0.04 & 582 & 7.51 \\
\hline 394 & FRIENDLY & 501 & 0.03 & 550 & 7.09 \\
\hline 418 & GRADUALLY & 494 & 0.03 & 436 & 6.08 \\
\hline 422 & THOROUGHLY & 423 & 0.02 & 389 & 5.62 \\
\hline 481 & OCCASIONALLY & 405 & 0.02 & 372 & 4.02 \\
\hline 499 & SLOWLY & 335 & 0.02 & 301 & 3.88 \\
\hline 583 & EVENLY & 332 & 0.02 & 284 & 3.66 \\
\hline 586 & APPROXIMATELY & 327 & 0.02 & 285 & 3.68 \\
\hline 592 & QUICKLY & 308 & 0.02 & 278 & 3.59 \\
\hline 618 & COMPLETELY & 230 & 0.01 & 181 & 2.33 \\
\hline 756 & COARSELY & 198 & 0.01 & 191 & 2.46 \\
\hline 835 & CONTINUOUSLY & 190 & 0.01 & 182 & 2.35 \\
\hline 855 & FREQUENTLY & 183 & 0.01 & 177 & 2.28 \\
\hline 874 & FINALLY & 170 & & 157 & 2.03 \\
\hline 929 & PREFERABLY & 160 & & 141 & 1.82 \\
\hline 959 & CONSTANTLY & 160 & & 145 & 1.87 \\
\hline 964 & REALLY & 136 & & 140 & 1.81 \\
\hline 1,007 & TIGHTLY & & 122 & 1.57 \\
\hline 1,072 & FAIRLY & & & \\
\hline
\end{tabular}




\begin{tabular}{|c|c|c|c|c|}
\hline 1,084 & GENEROUSLY & 134 & 129 & 1.66 \\
\hline 1,113 & EASILY & 126 & 119 & 1.53 \\
\hline 1,152 & BRIEFLY & 119 & 110 & 1.42 \\
\hline 1,199 & LOVELY & 110 & 109 & 1.41 \\
\hline 1,233 & NICELY & 104 & 96 & 1.24 \\
\hline 1,235 & SIMPLY & 104 & 96 & 1.24 \\
\hline 1,299 & SEPARATELY & 94 & 88 & 1.14 \\
\hline 1,334 & ALTERNATIVELY & 89 & 86 & 1.11 \\
\hline 1,363 & FIRMLY & 86 & 76 & 0.98 \\
\hline 1,371 & THICKLY & 86 & 81 & 1.04 \\
\hline 1,402 & HORIZONTALLY & 82 & 81 & 1.04 \\
\hline 1,423 & LOOSELY & 80 & 78 & 1.01 \\
\hline 1,426 & RAPIDLY & 80 & 77 & 0.99 \\
\hline 1,514 & ORIGINALLY & 71 & 71 & 0.92 \\
\hline 1,553 & VIGOROUSLY & 68 & 64 & 0.83 \\
\hline 1,629 & USUALLY & 61 & 45 & 0.58 \\
\hline 1,650 & DIAGONALLY & 59 & 58 & 0.75 \\
\hline 1,717 & EQUALLY & 55 & 54 & 0.70 \\
\hline 1,861 & IDEALLY & 47 & 46 & 0.59 \\
\hline 1,868 & SOFTLY & 47 & 45 & 0.58 \\
\hline 1,898 & NEARLY & 45 & 43 & 0.55 \\
\hline 1,943 & REGULARLY & 43 & 38 & 0.49 \\
\hline 1,985 & PROBABLY & 41 & 38 & 0.49 \\
\hline 2,003 & ESPECIALLY & 40 & 36 & 0.46 \\
\hline 2,038 & NEATLY & 39 & 36 & 0.46 \\
\hline 2,070 & PARTICULARLY & 38 & 38 & 0.49 \\
\hline 2,128 & TRADITIONALLY & 36 & 36 & 0.46 \\
\hline 2,142 & LIBERALLY & 35 & 35 & 0.45 \\
\hline 2,163 & BRISKLY & 34 & 34 & 0.44 \\
\hline 2,170 & FULLY & 34 & 32 & 0.41 \\
\hline 2,179 & PROPERLY & 34 & 30 & 0.39 \\
\hline 2,236 & PERFECTLY & 32 & 31 & 0.40 \\
\hline 2,299 & MODERATELY & 30 & 26 & 0.34 \\
\hline 2,319 & BARELY & 29 & 28 & 0.36 \\
\hline 2,334 & EXTREMELY & 29 & 25 & 0.32 \\
\hline 2,418 & DIRECTLY & 27 & 27 & 0.35 \\
\hline 2,468 & ALTERNATELY & 26 & 23 & 0.30 \\
\hline 2,505 & SECURELY & 26 & 24 & 0.31 \\
\hline 2,586 & STIFFLY & 24 & 23 & 0.30 \\
\hline 2,619 & PARTIALLY & 23 & 22 & 0.28 \\
\hline 2,837 & EXACTLY & 19 & 19 & 0.25 \\
\hline 2,920 & LASTLY & 18 & 18 & 0.23 \\
\hline 2,976 & BEAUTIFULLY & 17 & 17 & 0.22 \\
\hline 2,991 & DELICIOUSLY & 17 & 17 & 0.22 \\
\hline 3,057 & ABSOLUTELY & 16 & 16 & 0.21 \\
\hline 3,141 & TOTALLY & 16 & 16 & 0.21 \\
\hline 3,150 & WIDELY & 16 & 15 & 0.19 \\
\hline 3,180 & GENERALLY & 15 & 14 & 0.18 \\
\hline 3,304 & SUFFICIENTLY & 14 & 14 & 0.18 \\
\hline 3,369 & HEAVILY & 13 & 13 & 0.17 \\
\hline 3,404 & RICHLY & 13 & 13 & 0.17 \\
\hline 3,434 & ACCORDINGLY & 12 & 11 & 0.14 \\
\hline
\end{tabular}




\begin{tabular}{|c|c|c|c|c|}
\hline 3,465 & DELICATELY & 12 & 12 & 0.15 \\
\hline 3,478 & FREELY & 12 & 12 & 0.15 \\
\hline 3,489 & HIGHLY & 12 & 12 & 0.15 \\
\hline 3,577 & ACTUALLY & 11 & 9 & 0.12 \\
\hline 3,609 & COMMONLY & 11 & 7 & 0.09 \\
\hline 3,666 & MOSTLY & 11 & 9 & 0.12 \\
\hline 3,674 & PARTLY & 11 & 11 & 0.14 \\
\hline 3,699 & SHORTLY & 11 & 11 & 0.14 \\
\hline 3,709 & STEADILY & 11 & 11 & 0.14 \\
\hline 3,829 & PREVIOUSLY & 10 & 9 & 0.12 \\
\hline 3,910 & CLEANLY & 9 & 9 & 0.12 \\
\hline 3,913 & COMFORTABLY & 9 & 9 & 0.12 \\
\hline 3,929 & ELDERLY & 9 & 9 & 0.12 \\
\hline 3,963 & INDIVIDUALLY & 9 & 9 & 0.12 \\
\hline 4,007 & READILY & 9 & 7 & 0.09 \\
\hline 4,039 & SURPRISINGLY & 9 & 9 & 0.12 \\
\hline 4,056 & VIRTUALLY & 9 & 9 & 0.12 \\
\hline 4,061 & WONDERFULLY & 9 & 9 & 0.12 \\
\hline 4,070 & ATTRACTIVELY & 8 & 8 & 0.10 \\
\hline 4,101 & CLOSELY & 8 & 8 & 0.10 \\
\hline 4,253 & SNUGLY & 8 & 8 & 0.10 \\
\hline 4,356 & DECORATIVELY & 7 & 7 & 0.09 \\
\hline 4,368 & ENTIRELY & 7 & 7 & 0.09 \\
\hline 4,446 & NATURALLY & 7 & 7 & 0.09 \\
\hline 4,485 & REASONABLY & 7 & 6 & 0.08 \\
\hline 4,488 & RELATIVELY & 7 & 7 & 0.09 \\
\hline 4,674 & DEEPLY & 6 & 6 & 0.08 \\
\hline 4,787 & MELTINGLY & 6 & 6 & 0.08 \\
\hline 4,801 & NORMALLY & 6 & 6 & 0.08 \\
\hline 4,873 & SHARPLY & 6 & 6 & 0.08 \\
\hline 4,890 & SPARINGLY & 6 & 6 & 0.08 \\
\hline 4,907 & STRONGLY & 6 & 6 & 0.08 \\
\hline 4,937 & TYPICALLY & 6 & 4 & 0.05 \\
\hline 4,947 & VERTICALLY & 6 & 6 & 0.08 \\
\hline 5,200 & LOCALLY & 5 & 5 & 0.06 \\
\hline 5,205 & MAINLY & 5 & 5 & 0.06 \\
\hline 5,244 & OCCASSIONALLY & 5 & 4 & 0.05 \\
\hline 5,296 & RARELY & 5 & 5 & 0.06 \\
\hline 5,353 & SPECIALLY & 5 & 5 & 0.06 \\
\hline 5,366 & SUCCESSFULLY & 5 & 5 & 0.06 \\
\hline 5,370 & SUITABLY & 5 & 5 & 0.06 \\
\hline 5,378 & SWIFTLY & 5 & 5 & 0.06 \\
\hline 5,442 & ACCURATELY & 4 & 4 & 0.05 \\
\hline 5,465 & APPARENTLY & 4 & 2 & 0.03 \\
\hline 5,581 & COMMERCIALLY & 4 & 4 & 0.05 \\
\hline 5,585 & CONSIDERABLY & 4 & 4 & 0.05 \\
\hline 5,586 & CONSISTENTLY & 4 & 4 & 0.05 \\
\hline 5,645 & DRAMATICALLY & 4 & 4 & 0.05 \\
\hline 5,671 & ESSENTIALLY & 4 & 4 & 0.05 \\
\hline 5,673 & EVENTUALLY & 4 & 4 & 0.05 \\
\hline 5,681 & EXTENSIVELY & 4 & 4 & 0.05 \\
\hline 5,725 & FURIOUSLY & 4 & 4 & 0.05 \\
\hline
\end{tabular}




\begin{tabular}{|c|c|c|c|c|}
\hline 5,760 & HARDLY & 4 & 4 & 0.05 \\
\hline 5,806 & LAVISHLY & 4 & 4 & 0.05 \\
\hline 5,918 & PERIODICALLY & 4 & 4 & 0.05 \\
\hline 5,919 & PERSONALLY & 4 & 4 & 0.05 \\
\hline 5,940 & PRACTICALLY & 4 & 4 & 0.05 \\
\hline 6,103 & TRULY & 4 & 4 & 0.05 \\
\hline 6,112 & UNFORTUNATELY & 4 & 4 & 0.05 \\
\hline 6,272 & CAUTIOUSLY & 3 & 2 & 0.03 \\
\hline 6,277 & CERTAINLY & 3 & 3 & 0.04 \\
\hline 6,290 & CLEARLY & 3 & 3 & 0.04 \\
\hline 6,311 & CONTINUALLY & 3 & 3 & 0.04 \\
\hline 6,362 & DEFINITELY & 3 & 3 & 0.04 \\
\hline 6,365 & DELIGHTFULLY & 3 & 3 & 0.04 \\
\hline 6,375 & DIFFERENTLY & 3 & 3 & 0.04 \\
\hline 6,422 & EXCEPTIONALLY & 3 & 3 & 0.04 \\
\hline 6,423 & EXCLUSIVELY & 3 & 3 & 0.04 \\
\hline 6,481 & FRSHLY & 3 & 3 & 0.04 \\
\hline 6,513 & GREATLY & 3 & 3 & 0.04 \\
\hline 6,571 & INCREDIBLY & 3 & 3 & 0.04 \\
\hline 6,573 & INDEFINITELY & 3 & 3 & 0.04 \\
\hline 6,579 & INITIALLY & 3 & 3 & 0.04 \\
\hline 6,583 & INSTANTLY & 3 & 3 & 0.04 \\
\hline 6,648 & LITERALLY & 3 & 3 & 0.04 \\
\hline 6,794 & PLAINLY & 3 & 3 & 0.04 \\
\hline 6,918 & SEPERATELY & 3 & 3 & 0.04 \\
\hline 6,954 & SMOOTHLY & 3 & 2 & 0.03 \\
\hline 6,990 & STRICTLY & 3 & 3 & 0.04 \\
\hline 7,142 & ACCIDENTALLY & 2 & 2 & 0.03 \\
\hline 7,143 & ACCIDENTLY & 2 & 2 & 0.03 \\
\hline 7,259 & BASICALLY & 2 & 1 & 0.01 \\
\hline 7,445 & CLEVERLY & 2 & 2 & 0.03 \\
\hline 7,517 & CRISPLY & 2 & 2 & 0.03 \\
\hline 7,526 & CRUDELY & 2 & 2 & 0.03 \\
\hline 7,575 & DELIBERATELY & 2 & 2 & 0.03 \\
\hline 7,654 & EASILLY & 2 & 2 & 0.03 \\
\hline 7,711 & EXCEEDINGLY & 2 & 2 & 0.03 \\
\hline 7,726 & FAINTLY & 2 & 2 & 0.03 \\
\hline 7,744 & FESHLY & 2 & 2 & 0.03 \\
\hline 7,793 & FORMERLY & 2 & 2 & 0.03 \\
\hline 7,919 & HASTILY & 2 & 2 & 0.03 \\
\hline 7,985 & IMPORTANTLY & 2 & 2 & 0.03 \\
\hline 7,990 & INCIDENTALLY & 2 & 2 & 0.03 \\
\hline 8,005 & INTENSELY & 2 & 2 & 0.03 \\
\hline 8,134 & LIVELY & 2 & 2 & 0.03 \\
\hline 8,145 & LOVINGLY & 2 & 2 & 0.03 \\
\hline 8,149 & LUCKILY & 2 & 2 & 0.03 \\
\hline 8,224 & MERELY & 2 & 2 & 0.03 \\
\hline 8,346 & OCCATIONALLY & 2 & 2 & 0.03 \\
\hline 8,351 & OFFICIALLY & 2 & 2 & 0.03 \\
\hline 8,454 & PLEASANTLY & 2 & 2 & 0.03 \\
\hline 8,464 & POLITELY & 2 & 2 & 0.03 \\
\hline 8,472 & POSSIBLY & 2 & 2 & 0.03 \\
\hline
\end{tabular}




\begin{tabular}{|c|c|c|c|c|}
\hline 8,486 & PRETTILY & 2 & 2 & 0.03 \\
\hline 8,487 & PRIMARILY & 2 & 2 & 0.03 \\
\hline 8,498 & PROMPTLY & 2 & 2 & 0.03 \\
\hline 8,538 & RANDOMLY & 2 & 2 & 0.03 \\
\hline 8,549 & RECENTLY & 2 & 2 & 0.03 \\
\hline 8,574 & REPEATEDLY & 2 & 2 & 0.03 \\
\hline 8,657 & SCRUPULOUSLY & 2 & 2 & 0.03 \\
\hline 8,665 & SEEMINGLY & 2 & 2 & 0.03 \\
\hline 8,703 & SIMULTANEOUSLY & 2 & 2 & 0.03 \\
\hline 8,757 & SPECIFICALLY & 2 & 2 & 0.03 \\
\hline 8,764 & SPOTLESSLY & 2 & 2 & 0.03 \\
\hline 8,831 & SUPPOSEDLY & 2 & 2 & 0.03 \\
\hline 8,949 & UNIFORMLY & 2 & 2 & 0.03 \\
\hline 8,968 & UTTERLY & 2 & 2 & 0.03 \\
\hline 9,093 & ABUNDANTLY & 1 & 1 & 0.01 \\
\hline 9,111 & ADDITIONALLY & 1 & 1 & 0.01 \\
\hline 9,117 & ADMIRABLY & 1 & 1 & 0.01 \\
\hline 9,159 & ALIGHTLY & 1 & 1 & 0.01 \\
\hline 9,217 & ANNUALLY & 1 & 1 & 0.01 \\
\hline 9,230 & ANXIOUSLY & 1 & 1 & 0.01 \\
\hline 9,246 & APPRIMATELY & 1 & 1 & 0.01 \\
\hline 9,248 & APPROPRIATELY & 1 & 1 & 0.01 \\
\hline 9,543 & BRIGHTLY & 1 & 1 & 0.01 \\
\hline 9,545 & BRILLIANTLY & 1 & 1 & 0.01 \\
\hline 9,676 & CAREFULLLY & 1 & 1 & 0.01 \\
\hline 9,677 & CAREFUULY & 1 & 1 & 0.01 \\
\hline 9,729 & CENTRALLY & 1 & 1 & 0.01 \\
\hline 9,745 & CHARACTERISTICALLY & 1 & 1 & 0.01 \\
\hline 9,831 & CHUNKILY & 1 & 1 & 0.01 \\
\hline 9,902 & COARSLY & 1 & 1 & 0.01 \\
\hline 9,961 & COMPLETLY & 1 & 1 & 0.01 \\
\hline 9,995 & CONSEQUENTLY & 1 & 1 & 0.01 \\
\hline 10,02 & CONVENTIONALLY & 1 & 1 & 0.01 \\
\hline 10,045 & CORRECTLY & 1 & 1 & 0.01 \\
\hline 10,090 & CREAMILY & 1 & 1 & 0.01 \\
\hline 10,137 & CUNNINGLY & 1 & 1 & 0.01 \\
\hline 10,144 & CURIOUSLY & 1 & 1 & 0.01 \\
\hline 10,167 & DARKLY & 1 & 1 & 0.01 \\
\hline 10,176 & DECADENTLY & 1 & 1 & 0.01 \\
\hline 10,197 & DEFINATELY & 1 & 1 & 0.01 \\
\hline 10,201 & DEFTLY & 1 & 1 & 0.01 \\
\hline 10,206 & DELECTABLY & 1 & 1 & 0.01 \\
\hline 10,282 & DISASTROUSLY & 1 & 1 & 0.01 \\
\hline 10,342 & DORSALLY & 1 & 1 & 0.01 \\
\hline 10,406 & ECONOMICALLY & 1 & 1 & 0.01 \\
\hline 10,420 & EFFECTIVELY & 1 & 1 & 0.01 \\
\hline 10,434 & ELABORATELY & 1 & 1 & 0.01 \\
\hline 10,440 & ELEGANTLY & 1 & 1 & 0.01 \\
\hline 10,456 & EMPHATICALLY & 1 & 1 & 0.01 \\
\hline 10,474 & ENERGETICALLY & 1 & 1 & 0.01 \\
\hline 10,484 & ENORMOUSLY & 1 & 1 & 0.01 \\
\hline 10,531 & EVIDENTLY & 1 & 1 & 0.01 \\
\hline
\end{tabular}




\begin{tabular}{|c|c|c|c|c|}
\hline 10,543 & EXCESSIVELY & 1 & 1 & 0.01 \\
\hline 10,594 & FANTASTICALLY & 1 & 1 & 0.01 \\
\hline 10,611 & FEASHLY & 1 & 1 & 0.01 \\
\hline 10,626 & FERSHLY & 1 & 1 & 0.01 \\
\hline 10,634 & FIERCELY & 1 & 1 & 0.01 \\
\hline 10,656 & FIRMILY & 1 & 1 & 0.01 \\
\hline 10,676 & FLAMBOYANTLY & 1 & 1 & 0.01 \\
\hline 10,758 & FRANKLY & 1 & 1 & 0.01 \\
\hline 10,772 & FRESHELY & 1 & 1 & 0.01 \\
\hline 10,792 & FRSEHLY & 1 & 1 & 0.01 \\
\hline 10,881 & GINGERLY & 1 & 1 & 0.01 \\
\hline 10,935 & GRAMMATICALLY & 1 & 1 & 0.01 \\
\hline 10,976 & GROSSLY & 1 & 1 & 0.01 \\
\hline 11,016 & HANDSOMELY & 1 & 1 & 0.01 \\
\hline 11,021 & HAPHAZARDLY & 1 & 1 & 0.01 \\
\hline 11,023 & HAPPILY & 1 & 1 & 0.01 \\
\hline 11,059 & HEAVENLY & 1 & 1 & 0.01 \\
\hline 11,143 & HUMANELY & 1 & 1 & 0.01 \\
\hline 11,174 & IMMENSELY & 1 & 1 & 0.01 \\
\hline 11,181 & IMPERCEPTIBLY & 1 & 1 & 0.01 \\
\hline 11,208 & INEVITABLY & 1 & 1 & 0.01 \\
\hline 11,225 & INORDINATELY & 1 & 1 & 0.01 \\
\hline 11,240 & INTERCHANGEABLY & 1 & 1 & 0.01 \\
\hline 11,244 & INTERMITTENTLY & 1 & 1 & 0.01 \\
\hline 11,254 & INTRIGUINGLY & 1 & 1 & 0.01 \\
\hline 11,260 & INVARIABLY & 1 & 1 & 0.01 \\
\hline 11,268 & IRONICALLY & 1 & 1 & 0.01 \\
\hline 11,344 & JUSTLY & 1 & 1 & 0.01 \\
\hline 11,359 & KEENLY & 1 & 1 & 0.01 \\
\hline 11,384 & KINDLY & 1 & 1 & 0.01 \\
\hline 11,442 & LARGELY & 1 & 1 & 0.01 \\
\hline 11,455 & LAZILY & 1 & 1 & 0.01 \\
\hline 11,474 & LEISURELY & 1 & 1 & 0.01 \\
\hline 11,503 & LIGHLY & 1 & 1 & 0.01 \\
\hline 11,508 & LIGTLY & 1 & 1 & 0.01 \\
\hline 11,734 & METICULOUSLY & 1 & 1 & 0.01 \\
\hline 11,771 & MINUTELY & 1 & 1 & 0.01 \\
\hline 11,914 & NECCESSARILY & 1 & 1 & 0.01 \\
\hline 11,928 & NERALY & 1 & 1 & 0.01 \\
\hline 11,936 & NEWLY & 1 & 1 & 0.01 \\
\hline 11,993 & OBVIOUSLY & 1 & 1 & 0.01 \\
\hline 11,994 & OCCAIONALLY & 1 & 1 & 0.01 \\
\hline 11,995 & OCCAISIONALLY & 1 & 1 & 0.01 \\
\hline 11,997 & OCCASSIONALY & 1 & 1 & 0.01 \\
\hline 12,031 & OPTIONALLY & 1 & 1 & 0.01 \\
\hline 12,039 & ORGANICALLY & 1 & 1 & 0.01 \\
\hline 12,073 & OVERLY & 1 & 1 & 0.01 \\
\hline 12,100 & PAINLESSLY & 1 & 1 & 0.01 \\
\hline 12,155 & PATIENTLY & 1 & 1 & 0.01 \\
\hline 12,202 & PERFERABLY & 1 & 1 & 0.01 \\
\hline 12,359 & PREFERRABLY & 1 & 1 & 0.01 \\
\hline 12,362 & PREFFERABLY & 1 & 1 & 0.01 \\
\hline
\end{tabular}




\begin{tabular}{|c|c|c|c|c|}
\hline 12,381 & PRESUMABLY & 1 & 1 & 0.01 \\
\hline 12,411 & PROPORTIONATELY & 1 & 1 & 0.01 \\
\hline 12,479 & QUIETLY & 1 & 1 & 0.01 \\
\hline 12,568 & RELENTLESSLY & 1 & 1 & 0.01 \\
\hline 12,572 & RELUCTANTLY & 1 & 1 & 0.01 \\
\hline 12,575 & REMARKABLY & 1 & 1 & 0.01 \\
\hline 12,612 & RESPECTIVELY & 1 & 1 & 0.01 \\
\hline 12,670 & ROBUSTLY & 1 & 1 & 0.01 \\
\hline 12,709 & ROUGLY & 1 & 1 & 0.01 \\
\hline 12,711 & ROUTINELY & 1 & 1 & 0.01 \\
\hline 12,800 & SCANTILY & 1 & 1 & 0.01 \\
\hline 12,918 & SHOCKINGLY & 1 & 1 & 0.01 \\
\hline 12,937 & SICKLY & 1 & 1 & 0.01 \\
\hline 12,941 & SIGNIFICANTLY & 1 & 1 & 0.01 \\
\hline 12,952 & SIMULATNEOUSLY & 1 & 1 & 0.01 \\
\hline 12,954 & SINFULLY & 1 & 1 & 0.01 \\
\hline 12,957 & SINGLY & 1 & 1 & 0.01 \\
\hline 12,989 & SLIGHLY & 1 & 1 & 0.01 \\
\hline 13,031 & SOLELY & 1 & 1 & 0.01 \\
\hline 13,170 & STRANGELY & 1 & 1 & 0.01 \\
\hline 13,188 & SUBSEQUENTLY & 1 & 1 & 0.01 \\
\hline 13,193 & SUBTLY & 1 & 1 & 0.01 \\
\hline 13,244 & SWEETLY & 1 & 1 & 0.01 \\
\hline 13,311 & TECHNICALLY & 1 & 1 & 0.01 \\
\hline 13,377 & THOUROUGHLY & 1 & 1 & 0.01 \\
\hline 13,422 & TOLERABLY & 1 & 1 & 0.01 \\
\hline 13,483 & TREMENDOUSLY & 1 & 1 & 0.01 \\
\hline 13,500 & TRUELY & 1 & 1 & 0.01 \\
\hline 13,518 & TWIRLY & 1 & 1 & 0.01 \\
\hline 13,524 & UASUALLY & 1 & 1 & 0.01 \\
\hline 13,531 & ULTIMATELY & 1 & 1 & 0.01 \\
\hline 13,538 & UNACCOUNTABLY & 1 & 1 & 0.01 \\
\hline 13,551 & UNCOMFORTABLY & 1 & 1 & 0.01 \\
\hline 13,562 & UNDOUBTEDLY & 1 & 1 & 0.01 \\
\hline 13,579 & UNPLEASANTLY & 1 & 1 & 0.01 \\
\hline 13,642 & VENTRALLY & 1 & 1 & 0.01 \\
\hline 13,674 & VISUALLY & 1 & 1 & 0.01 \\
\hline 13,697 & WARMLY & 1 & 1 & 0.01 \\
\hline 13,764 & WHOLLY & 1 & 1 & 0.01 \\
\hline
\end{tabular}

Total de ocorrências (tokens): 22.762

Total de formas (types): 326 
Advérbios descartados ${ }^{135}$ :

Os advérbios abaixo listados ou derivam de outras classes gramaticais ou apresentam dúvidas quanto ao uso, podendo também ser classificados como adjetivos. Antes do descarte, observamos vários deles em contexto.

\begin{tabular}{|c|l|r|r|r|r|}
\hline $\mathbf{N}$ & Word & Freq. & \multicolumn{1}{c|}{$\%$} & \multicolumn{1}{c|}{ Texts } & \multicolumn{1}{c|}{$\%$} \\
\hline 180 & ONLY & 1494 & 0.09 & 1,25 & 16.12 \\
\hline 2,25 & EARLY & 31 & & 31 & 0.40 \\
\hline 3,083 & DAILY & 16 & & 12 & 0.15 \\
\hline 3,355 & FIRSTLY & 13 & & 13 & 0.17 \\
\hline 4,775 & LIKELY & 6 & & 5 & 0.06 \\
\hline 7,114 & WEEKLY & 3 & & 3 & 0.04 \\
\hline 7,965 & HOURLY & 2 & & 2 & 0.03 \\
\hline 13,409 & TIMELY & 1 & & 1 & 0.01 \\
\hline 11,898 & NAMELY & 1 & & 1 & 0.01 \\
\hline
\end{tabular}

Total de ocorrências (tokens) descartadas: 1.567

Total de formas (types) descartadas: 9

135 Ao analisar as listas com os advérbios terminados em -ly e -mente apresentadas em anexo, o leitor irá observar que vários deles, por desatenção em sua digitação nos textos dos corpora, estão grafados incorretamente. Apesar desses erros, decidimos mantê-los em nossos dados, uma vez que tal fato foi observado em estágio avançado da pesquisa e não influenciaria nossos resultados. Os advérbios grafados incorretamente só foram eliminados no Anexo E (Advérbios terminados em -mente: corpus de Direito). 


\section{ANEXO C \\ Advérbios terminados em -mente: corpus de Culinária}

Todos os advérbios terminados em -mente derivados de adjetivos encontrados no corpus de Culinária (português) estão identificados na tabela abaixo. Durante o levantamento, foram descartados os vocábulos que definitivamente não eram advérbios, como é o caso de semente, aumente, experimente, apimente, etc.

\section{Observações:}

$\mathbf{N}=\quad$ posição em que o advérbio ocorreu em uma lista de frequência com todas as palavras do corpus de estudo

Word $=$ advérbio a que os dados se referem

Freq. = frequência do advérbio no corpus de estudo, em ordem decrescente

$\%=\quad$ porcentagem que representa a frequência do advérbio no corpus de estudo, considerado em sua totalidade

Texts $=$ número de textos em que o advérbio ocorreu no corpus de estudo

$\%=\quad$ porcentagem que representa a frequência de textos em que o advérbio ocorreu, considerando-se o corpus de estudo em sua totalidade

\begin{tabular}{|c|l|r|r|r|r|}
\hline $\mathbf{N}$ & \multicolumn{1}{|c|}{ Word } & \multicolumn{1}{c|}{ Freq. } & \multicolumn{1}{c|}{$\%$} & \multicolumn{1}{c|}{ Texts } & \multicolumn{1}{c|}{$\%$} \\
\hline 229 & LEVEMENTE & 943 & 0.06 & 745 & 10.75 \\
\hline 250 & NOVAMENTE & 851 & 0.05 & 606 & 8.74 \\
\hline 259 & APROXIMADAMENTE & 802 & 0.05 & 541 & 7.80 \\
\hline 390 & DELICADAMENTE & 513 & 0.03 & 439 & 6.33 \\
\hline 398 & LIGEIRAMENTE & 495 & 0.03 & 321 & 4.63 \\
\hline 447 & IMEDIATAMENTE & 416 & 0.03 & 329 & 4.75 \\
\hline 456 & GROSSEIRAMENTE & 410 & 0.03 & 369 & 5.32 \\
\hline 516 & RAPIDAMENTE & 347 & 0.02 & 283 & 4.08 \\
\hline 527 & FINAMENTE & 337 & 0.02 & 296 & 4.27 \\
\hline 720 & COMPLETAMENTE & 213 & 0.01 & 185 & 2.67 \\
\hline 732 & CUIDADOSAMENTE & 207 & 0.01 & 184 & 2.65 \\
\hline 761 & JUNTAMENTE & 195 & 0.01 & 179 & 2.58 \\
\hline 887 & SOMENTE & 149 & & 139 & 2.00 \\
\hline 940 & LENTAMENTE & 135 & & 123 & 1.77 \\
\hline 985 & TOTALMENTE & 124 & & 120 & 1.73 \\
\hline 1,036 & PREVIAMENTE & 112 & & 98 & 1.41 \\
\hline 1,257 & SEPARADAMENTE & 79 & & 69 & 1.00 \\
\hline 1,500 & VIGOROSAMENTE & 57 & & 53 & 0.76 \\
\hline 1,627 & UNIFORMEMENTE & 48 & & 44 & 0.63 \\
\hline 1,676 & PRINCIPALMENTE & 45 & & 44 & 0.63 \\
\hline 1,683 & ALTERNADAMENTE & 44 & & 40 & 0.58 \\
\hline 1,726 & PARCIALMENTE & 42 & & 41 & 0.59 \\
\hline 1,730 & REGULARMENTE & 42 & & 38 & 0.55 \\
\hline 1,801 & DIRETAMENTE & 38 & & 36 & 0.52 \\
\hline 1,825 & CONSTANTEMENTE & 37 & & 35 & 0.50 \\
\hline 1,857 & FACILMENTE & 36 & & 33 & 0.48 \\
\hline & & & & & \\
\hline
\end{tabular}




\begin{tabular}{|c|c|c|c|c|}
\hline 2,032 & FINALMENTE & 30 & 22 & 0.32 \\
\hline 2,128 & SUAVEMENTE & 28 & 28 & 0.40 \\
\hline 2,153 & GENTILMENTE & 27 & 27 & 0.39 \\
\hline 2,334 & PREFERENCIALMENTE & 23 & 22 & 0.32 \\
\hline 2,492 & HERMETICAMENTE & 20 & 19 & 0.27 \\
\hline 2,623 & GERALMENTE & 18 & 15 & 0.22 \\
\hline 2,624 & GRADUALMENTE & 18 & 18 & 0.26 \\
\hline 2,771 & NORMALMENTE & 16 & 15 & 0.22 \\
\hline 3,101 & VAGAROSAMENTE & 13 & 13 & 0.19 \\
\hline 3,149 & ENERGICAMENTE & 12 & 12 & 0.17 \\
\hline 3,158 & FORTEMENTE & 12 & 12 & 0.17 \\
\hline 3,203 & PRATICAMENTE & 12 & 12 & 0.17 \\
\hline 3,218 & SUCESSIVAMENTE & 12 & 10 & 0.14 \\
\hline 3,347 & SIMPLESMENTE & 11 & 11 & 0.16 \\
\hline 3,368 & ANTERIORMENTE & 10 & 9 & 0.13 \\
\hline 3,441 & GENEROSAMENTE & 10 & 10 & 0.14 \\
\hline 3,611 & FIRMEMENTE & 9 & 8 & 0.12 \\
\hline 3,622 & IGUALMENTE & 9 & 9 & 0.13 \\
\hline 3,654 & OCASIONALMENTE & 9 & 7 & 0.10 \\
\hline 3,666 & PRIMEIRAMENTE & 9 & 9 & 0.13 \\
\hline 3,669 & PROVAVELMENTE & 9 & 9 & 0.13 \\
\hline 3,765 & CONTINUAMENTE & 8 & 8 & 0.12 \\
\hline 3,798 & FARTAMENTE & 8 & 7 & 0.10 \\
\hline 3,904 & TRADICIONALMENTE & 8 & 8 & 0.12 \\
\hline 4,021 & ESPECIALMENTE & 7 & 7 & 0.10 \\
\hline 4,042 & FREQÜENTEMENTE & 7 & 7 & 0.10 \\
\hline 4,200 & ATUALMENTE & 6 & 6 & 0.09 \\
\hline 4,345 & INDIVIDUALMENTE & 6 & 6 & 0.09 \\
\hline 4,346 & INICIALMENTE & 6 & 6 & 0.09 \\
\hline 4,551 & BASICAMENTE & 5 & 5 & 0.07 \\
\hline 4,640 & DEVIDAMENTE & 5 & 5 & 0.07 \\
\hline 4,680 & EXTERNAMENTE & 5 & 4 & 0.06 \\
\hline 4,737 & HORIZONTALMENTE & 5 & 5 & 0.07 \\
\hline 4,806 & NATURALMENTE & 5 & 5 & 0.07 \\
\hline 4,819 & ORIGINALMENTE & 5 & 5 & 0.07 \\
\hline 4,870 & RÁPIDAMENTE & 5 & 5 & 0.07 \\
\hline 4,873 & REALMENTE & 5 & 4 & 0.06 \\
\hline 4,892 & SEGUIDAMENTE & 5 & 3 & 0.04 \\
\hline 4,917 & TIPICAMENTE & 5 & 5 & 0.07 \\
\hline 4,980 & ANTIGAMENTE & 4 & 4 & 0.06 \\
\hline 5,330 & INTERNAMENTE & 4 & 4 & 0.06 \\
\hline 5,349 & LARGAMENTE & 4 & 4 & 0.06 \\
\hline 5,665 & ABSOLUTAMENTE & 3 & 3 & 0.04 \\
\hline 5,714 & ANTECIPADAMENTE & 3 & 3 & 0.04 \\
\hline 5,784 & BRANDAMENTE & 3 & 2 & 0.03 \\
\hline 5,921 & DEMASIADAMENTE & 3 & 3 & 0.04 \\
\hline 6,046 & EXTREMAMENTE & 3 & 3 & 0.04 \\
\hline 6,154 & HARMONIOSAMENTE & 3 & 3 & 0.04 \\
\hline 6,188 & INTEIRAMENTE & 3 & 3 & 0.04 \\
\hline 6,375 & PERFEITAMENTE & 3 & 3 & 0.04 \\
\hline 6,453 & RAZOAVELMENTE & 3 & 3 & 0.04 \\
\hline 6,470 & RELATIVAMENTE & 3 & 2 & 0.03 \\
\hline
\end{tabular}




\begin{tabular}{|c|c|c|c|c|}
\hline 6,560 & SÓMENTE & 3 & 3 & 0.04 \\
\hline 6,575 & SUFICIENTEMENTE & 3 & 3 & 0.04 \\
\hline 6,682 & ABUNDANTEMENTE & 2 & 2 & 0.03 \\
\hline 6,756 & ALTAMENTE & 2 & 2 & 0.03 \\
\hline 7,032 & CERTAMENTE & 2 & 2 & 0.03 \\
\hline 7,142 & CORRETAMENTE & 2 & 2 & 0.03 \\
\hline 7,192 & DECORATIVAMENTE & 2 & 2 & 0.03 \\
\hline 7,204 & DELICIOSAMENTE & 2 & 2 & 0.03 \\
\hline 7,260 & DIARIAMENTE & 2 & 2 & 0.03 \\
\hline 7,384 & ESSENCIALMENTE & 2 & 2 & 0.03 \\
\hline 7,403 & EXCLUSIVAMENTE & 2 & 2 & 0.03 \\
\hline 7,459 & FOLGADAMENTE & 2 & 2 & 0.03 \\
\hline 7,483 & FREQUENTEMENTE & 2 & 1 & 0.01 \\
\hline 7,519 & GENUINAMENTE & 2 & 1 & 0.01 \\
\hline 7,539 & GRADATIVAMENTE & 2 & 2 & 0.03 \\
\hline 7,612 & ININTERRUPTAMENTE & 2 & 2 & 0.03 \\
\hline 7,713 & LONGITUDINALMENTE & 2 & 2 & 0.03 \\
\hline 7,741 & MANUALMENTE & 2 & 2 & 0.03 \\
\hline 7,899 & OPCIONALMENTE & 2 & 2 & 0.03 \\
\hline 7,948 & PERIODICAMENTE & 2 & 2 & 0.03 \\
\hline 7,999 & POPULARMENTE & 2 & 2 & 0.03 \\
\hline 8,025 & PREFERIVELMENTE & 2 & 2 & 0.03 \\
\hline 8,046 & PROPRIAMENTE & 2 & 1 & 0.01 \\
\hline 8,353 & TRANSVERSALMENTE & 2 & 2 & 0.03 \\
\hline 8,407 & VELOZMENTE & 2 & 2 & 0.03 \\
\hline 8,702 & ALINHADAMENTE & 1 & 1 & 0.01 \\
\hline 8,860 & APROPRIADAMENTE & 1 & 1 & 0.01 \\
\hline 8,866 & APROXIDAMENTE & 1 & 1 & 0.01 \\
\hline 8,913 & ARTIFICIALMENTE & 1 & 1 & 0.01 \\
\hline 8,931 & ASSELIGEIRAMENTE & 1 & 1 & 0.01 \\
\hline 9,391 & CARINHOSAMENTE & 1 & 1 & 0.01 \\
\hline 9,595 & CLASSICAMENTE & 1 & 1 & 0.01 \\
\hline 9,701 & COMUMENTE & 1 & 1 & 0.01 \\
\hline 9,734 & CONJUNTAMENTE & 1 & 1 & 0.01 \\
\hline 9,741 & CONSEQUENTEMENTE & 1 & 1 & 0.01 \\
\hline 9,793 & CORRENTEMENTE & 1 & 1 & 0.01 \\
\hline 9,889 & CUIDOSAMENTE & 1 & 1 & 0.01 \\
\hline 9,983 & DELICAMENTE & 1 & 1 & 0.01 \\
\hline 10,127 & DIAGONALMENTE & 1 & 1 & 0.01 \\
\hline 10,144 & DIFICILMENTE & 1 & 1 & 0.01 \\
\hline 10,349 & ENERGETICAMENTE & 1 & 1 & 0.01 \\
\hline 10,351 & ENÉRGIVAMENTE & 1 & 1 & 0.01 \\
\hline 10,371 & ENGROSSARLIGEIRAMENTE & 1 & 1 & 0.01 \\
\hline 10,375 & ENORMEMENTE & 1 & 1 & 0.01 \\
\hline 10,494 & ESPONTANEAMENTE & 1 & 1 & 0.01 \\
\hline 10,573 & EXATAMENTE & 1 & 1 & 0.01 \\
\hline 11,025 & GROSSAMENTE & 1 & 1 & 0.01 \\
\hline 11,153 & IMEDIATMENTE & 1 & 1 & 0.01 \\
\hline 11,175 & INACREDITAVELMENTE & 1 & 1 & 0.01 \\
\hline 11,211 & INDISCUTIVELMENTE & 1 & 1 & 0.01 \\
\hline 11,220 & INEVITAVELMENTE & 1 & 1 & 0.01 \\
\hline 11,260 & INTENSAMENTE & 1 & 1 & 0.01 \\
\hline
\end{tabular}




\begin{tabular}{|l|l|r|r|r|r|}
\hline 11,295 & IRREMEDIAVELMENTE & 1 & 1 & 0.01 \\
\hline 11,359 & JUSTAMENTE & 1 & & 1 & 0.01 \\
\hline 12,474 & POSTERIORMENTE & 1 & & 1 & 0.01 \\
\hline 12,564 & PROPORCIONALMENTE & 1 & & 1 & 0.01 \\
\hline 12,701 & RECENTEMENTE & 1 & 1 & 0.01 \\
\hline 12,828 & RESPECTIVAMENTE & 1 & 1 & 0.01 \\
\hline 12,889 & RIGOROSAMENTE & 1 & & 1 & 0.01 \\
\hline 12,993 & SAMENTE & 1 & & 1 & 0.01 \\
\hline 13,075 & SEPADARAMENTE & 1 & & 1 & 0.01 \\
\hline 13,130 & SIMPLISMENTE & 1 & & 1 & 0.01 \\
\hline 13,131 & SIMULTANEAMENTE & 1 & & 1 & 0.01 \\
\hline 13,132 & SIMULTÂNEAMENTE & 1 & & 1 & 0.01 \\
\hline 13,261 & SUPOSTAMENTE & 1 & & 1 & 0.01 \\
\hline 13,462 & TRANQÜILAMENTE & 1 & & 1 & 0.01 \\
\hline 13,633 & VERTICALMENTE & 1 & & 1 & 0.01 \\
\hline
\end{tabular}

Total de ocorrências (tokens): 7.276

Total de formas (types): 145 


\section{ANEXO D \\ Advérbios terminados em -ly: corpus de Direito}

Todos os advérbios terminados em -ly derivados de adjetivos encontrados no corpus de Direito (inglês) estão identificados na tabela abaixo. Na sequência, aqueles descartados para esta pesquisa.

\section{Observações:}

$\mathbf{N}=\quad$ posição em que o advérbio ocorreu em uma lista de frequência com todas as palavras do corpus de estudo

Word $=$ advérbio a que os dados se referem

Freq. = frequência do advérbio no corpus de estudo, em ordem decrescente

$\%=\quad$ porcentagem que representa a frequência do advérbio no corpus de estudo, considerado em sua totalidade

Texts $=$ número de textos em que o advérbio ocorreu no corpus de estudo

$\%=\quad$ porcentagem que representa a frequência de textos em que $o$ advérbio ocorreu, considerando-se o corpus de estudo em sua totalidade

\begin{tabular}{|c|l|r|r|r|r|}
\hline $\mathbf{N}$ & \multicolumn{1}{|c|}{ Word } & Freq. & \multicolumn{1}{c|}{$\%$} & \multicolumn{1}{c|}{ Texts } & \multicolumn{1}{c|}{$\%$} \\
\hline 252 & REASONABLY & 344 & 0.05 & 74 & 52.86 \\
\hline 267 & IMMEDIATELY & 330 & 0.05 & 78 & 55.71 \\
\hline 318 & PROMPTLY & 275 & 0.04 & 70 & 50.00 \\
\hline 438 & DULY & 206 & 0.03 & 61 & 43.57 \\
\hline 452 & EXPRESSLY & 198 & 0.03 & 71 & 50.71 \\
\hline 468 & DIRECTLY & 192 & 0.03 & 71 & 50.71 \\
\hline 518 & FULLY & 175 & 0.03 & 67 & 47.86 \\
\hline 584 & COLLECTIVELY & 151 & 0.02 & 51 & 36.43 \\
\hline 595 & SOLELY & 141 & 0.02 & 53 & 37.86 \\
\hline 630 & SUBSTANTIALLY & 126 & 0.02 & 58 & 41.43 \\
\hline 689 & SPECIFICALLY & 107 & 0.02 & 45 & 42.14 \\
\hline 786 & INDIRECTLY & 94 & 0.01 & 44 & 31.43 \\
\hline 868 & GENERALLY & 79 & 0.01 & 35 & 25.00 \\
\hline 973 & CURRENTLY & 76 & 0.01 & 36 & 25.71 \\
\hline 1,004 & MUTUALLY & 73 & 0.01 & 29 & 20.71 \\
\hline 1,042 & UNREASONABLY & 72 & 0.01 & 36 & 25.71 \\
\hline 1,053 & PROPERLY & 67 & 0.01 & 38 & 27.14 \\
\hline 1,117 & PREVIOUSLY & 66 & 0.01 & 35 & 25.00 \\
\hline 1,125 & MATERIALLY & 62 & & 31 & 22.14 \\
\hline 1,168 & ACTUALLY & 61 & & 38 & 27.14 \\
\hline 1,194 & PERSONALLY & 58 & & 31 & 22.14 \\
\hline 1,215 & ACCORDINGLY & 53 & & 31 & 22.14 \\
\hline 1,301 & LEGALLY & 50 & & 28 & 20.00 \\
\hline 1,344 & JOINTLY & 42 & & 31 & 22.14 \\
\hline 1,515 & AUTOMATICALLY & 39 & & 19 & 13.57 \\
\hline 1,600 & ADVERSELY & & 21 & 15.00 \\
\hline 1,609 & EXCLUSIVELY & 23 & 16.43 \\
\hline 1,688 & VALIDLY & & & \\
\hline & & & & & \\
\hline
\end{tabular}




\begin{tabular}{|c|c|c|c|c|}
\hline 1,698 & COMMERCIALLY & 36 & 17 & 12.14 \\
\hline 1,744 & IRREVOCABLY & 35 & 19 & 13.57 \\
\hline 1,756 & SEPARATELY & 35 & 24 & 17.14 \\
\hline 1,784 & PUBLICLY & 34 & 19 & 13.57 \\
\hline 1,957 & RESPECTIVELY & 29 & 21 & 15.00 \\
\hline 1,963 & WHOLLY & 29 & 23 & 16.43 \\
\hline 1,972 & DILIGENTLY & 28 & 13 & 9.29 \\
\hline 1,994 & PRESENTLY & 28 & 16 & 11.43 \\
\hline 2,010 & APPROXIMATELY & 27 & 8 & 5.71 \\
\hline 2,045 & SUBSEQUENTLY & 27 & 21 & 15.00 \\
\hline 2,066 & CONCURRENTLY & 26 & 18 & 12.86 \\
\hline 2,080 & INDIVIDUALLY & 26 & 16 & 11.43 \\
\hline 2,119 & INDEPENDENTLY & 25 & 21 & 15.00 \\
\hline 2,127 & ORIGINALLY & 25 & 15 & 10.71 \\
\hline 2,155 & ANNUALLY & 24 & 18 & 12.86 \\
\hline 2,193 & LAWFULLY & 24 & 18 & 12.86 \\
\hline 2,263 & VOLUNTARILY & 23 & 16 & 11.43 \\
\hline 2,291 & FINALLY & 22 & 17 & 12.14 \\
\hline 2,332 & CLEARLY & 21 & 14 & 10.00 \\
\hline 2,397 & EARLY & 20 & 10 & 7.14 \\
\hline 2,407 & INITIALLY & 20 & 14 & 10.00 \\
\hline 2,435 & STRICTLY & 20 & 14 & 10.00 \\
\hline 2,444 & BENEFICIALLY & 19 & 8 & 5.71 \\
\hline 2,459 & EQUALLY & 19 & 16 & 11.43 \\
\hline 2,482 & PARTICULARLY & 19 & 10 & 7.14 \\
\hline 2,493 & UNCONDITIONALLY & 19 & 14 & 10.00 \\
\hline 2,563 & SUCCESSFULLY & 18 & 5 & 3.57 \\
\hline 2,686 & EFFECTIVELY & 16 & 13 & 9.29 \\
\hline 2,690 & ELECTRONICALLY & 16 & 10 & 7.14 \\
\hline 2,753 & COMPLETELY & 15 & 11 & 7.86 \\
\hline 2,756 & CONTINUOUSLY & 15 & 7 & 5.00 \\
\hline 2,790 & ORALLY & 15 & 14 & 10.00 \\
\hline 2,805 & SEVERALLY & 15 & 12 & 8.57 \\
\hline 2,806 & SIMILARLY & 15 & 14 & 10.00 \\
\hline 2,826 & ADDITIONALLY & 14 & 12 & 8.57 \\
\hline 2,836 & BODILY & 14 & 11 & 7.86 \\
\hline 2,841 & CAREFULLY & 14 & 11 & 7.86 \\
\hline 2,843 & COMMONLY & 14 & 8 & 5.71 \\
\hline 2,847 & CUSTOMARILY & 14 & 8 & 5.71 \\
\hline 2,859 & ENTIRELY & 14 & 11 & 7.86 \\
\hline 2,901 & PROPORTIONATELY & 14 & 7 & 5.00 \\
\hline 2,928 & TEMPORARILY & 14 & 6 & 4.29 \\
\hline 2,941 & ACTIVELY & 13 & 10 & 7.14 \\
\hline 2,953 & CONTEMPORANEOUSLY & 13 & 10 & 7.14 \\
\hline 3,057 & ACCURATELY & 12 & 11 & 7.86 \\
\hline 3,111 & HONESTLY & 12 & 4 & 2.86 \\
\hline 3,119 & MEDICALLY & 12 & 4 & 2.86 \\
\hline 3,148 & SIMULTANEOUSLY & 12 & 9 & 6.43 \\
\hline 3,168 & ADEQUATELY & 11 & 6 & 4.29 \\
\hline 3,210 & FAIRLY & 11 & 8 & 5.71 \\
\hline 3,230 & KNOWINGLY & 11 & 9 & 6.43 \\
\hline 3,245 & NEWLY & 11 & 7 & 5.00 \\
\hline
\end{tabular}




\begin{tabular}{|c|c|c|c|c|}
\hline 3,319 & CONSISTENTLY & 10 & 5 & 3.57 \\
\hline 3,354 & FREELY & 10 & 6 & 4.29 \\
\hline 3,356 & FREQUENTLY & 10 & 4 & 2.86 \\
\hline 3,381 & NECESSARILY & 10 & 10 & 7.14 \\
\hline 3,403 & REGULARLY & 10 & 8 & 5.71 \\
\hline 3,411 & RIGHTFULLY & 10 & 7 & 5.00 \\
\hline 3,483 & CONSPICUOUSLY & 9 & 8 & 5.71 \\
\hline 3,554 & INTENTIONALLY & 9 & 8 & 5.71 \\
\hline 3,576 & NATIONALLY & 9 & 8 & 5.71 \\
\hline 3,593 & PERMANENTLY & 9 & 6 & 4.29 \\
\hline 3,597 & PRIMARILY & 9 & 7 & 5.00 \\
\hline 3,627 & SUFFICIENTLY & 9 & 8 & 5.71 \\
\hline 3,732 & FAITHFULLY & 8 & 7 & 5.00 \\
\hline 3,765 & INTERNALLY & 8 & 5 & 3.57 \\
\hline 3,792 & NORMALLY & 8 & 5 & 3.57 \\
\hline 3,801 & PARTIALLY & 8 & 8 & 5.71 \\
\hline 3,805 & PERIODICALLY & 8 & 6 & 4.29 \\
\hline 3,838 & SPECIALLY & 8 & 6 & 4.29 \\
\hline 3,952 & FORMALLY & 7 & 6 & 4.29 \\
\hline 4,022 & POTENTIALLY & 7 & 5 & 3.57 \\
\hline 4,035 & RECENTLY & 7 & 7 & 5.00 \\
\hline 4,063 & SATISFACTORILY & 7 & 5 & 3.57 \\
\hline 4,092 & ULTIMATELY & 7 & 5 & 3.57 \\
\hline 4,122 & ALTERNATIVELY & 6 & 4 & 2.86 \\
\hline 4,186 & CONFUSINGLY & 6 & 4 & 2.86 \\
\hline 4,281 & INVOLUNTARILY & 6 & 4 & 2.86 \\
\hline 4,351 & PROFESSIONALLY & 6 & 2 & 1.43 \\
\hline 4,359 & QUICKLY & 6 & 6 & 4.29 \\
\hline 4,361 & READILY & 6 & 5 & 3.57 \\
\hline 4,419 & SUCCESSIVELY & 6 & 2 & 1.43 \\
\hline 4,457 & ABSOLUTELY & 5 & 3 & 2.14 \\
\hline 4,472 & AMICABLY & 5 & 3 & 2.14 \\
\hline 4,526 & CONCLUSIVELY & 5 & 4 & 2.86 \\
\hline 4,537 & CONTINUALLY & 5 & 5 & 3.57 \\
\hline 4,602 & EXPEDITIOUSLY & 5 & 5 & 3.57 \\
\hline 4,606 & EXPLICITLY & 5 & 5 & 3.57 \\
\hline 4,611 & FINANCIALLY & 5 & 3 & 2.14 \\
\hline 4,617 & FORMERLY & 5 & 5 & 3.57 \\
\hline 4,631 & GROSSLY & 5 & 4 & 2.86 \\
\hline 4,649 & INDEFINITELY & 5 & 5 & 3.57 \\
\hline 4,692 & NEARLY & 5 & 5 & 3.57 \\
\hline 4,705 & ORDERLY & 5 & 5 & 3.57 \\
\hline 4,793 & STRONGLY & 5 & 2 & 1.43 \\
\hline 4,831 & UNILATERALLY & 5 & 3 & 2.14 \\
\hline 4,837 & VERBALLY & 5 & 5 & 3.57 \\
\hline 4,873 & APPROPRIATELY & 4 & 4 & 2.86 \\
\hline 4,923 & COLLATERALLY & 4 & 3 & 2.14 \\
\hline 4,951 & CORRECTLY & 4 & 4 & 2.86 \\
\hline 5,032 & FAVORABLY & 4 & 4 & 2.86 \\
\hline 5,095 & INTERNATIONALLY & 4 & 2 & 1.43 \\
\hline 5,158 & NOTARIALLY & 4 & 3 & 2.14 \\
\hline 5,213 & PUNCTUALLY & 4 & 3 & 2.14 \\
\hline
\end{tabular}




\begin{tabular}{|c|c|c|c|c|}
\hline 5,316 & TOTALLY & 4 & 4 & 2.86 \\
\hline 5,385 & AFFIRMATIVELY & 3 & 2 & 1.43 \\
\hline 5,456 & BROADLY & 3 & 3 & 2.14 \\
\hline 5,486 & CLOSELY & 3 & 3 & 2.14 \\
\hline 5,507 & CONSEQUENTLY & 3 & 3 & 2.14 \\
\hline 5,538 & DEMONSTRABLY & 3 & 2 & 1.43 \\
\hline 5,553 & DIGITALLY & 3 & 2 & 1.43 \\
\hline 5,618 & EXTREMELY & 3 & 3 & 2.14 \\
\hline 5,624 & FEDERALLY & 3 & 3 & 2.14 \\
\hline 5,728 & LARGELY & 3 & 3 & 2.14 \\
\hline 5,770 & MERELY & 3 & 3 & 2.14 \\
\hline 5,792 & MORALLY & 3 & 2 & 1.43 \\
\hline 5,804 & NEGATIVELY & 3 & 3 & 2.14 \\
\hline 5,849 & PEACEABLY & 3 & 3 & 2.14 \\
\hline 5,862 & PHYSICALLY & 3 & 3 & 2.14 \\
\hline 5,900 & PROMINENTLY & 3 & 2 & 1.43 \\
\hline 5,973 & SAFELY & 3 & 3 & 2.14 \\
\hline 5,988 & SERIOUSLY & 3 & 1 & 0.71 \\
\hline 6,028 & STRUCTURALLY & 3 & 1 & 0.71 \\
\hline 6,081 & UNANIMOUSLY & 3 & 3 & 2.14 \\
\hline 6,086 & UNFAVORABLY & 3 & 3 & 2.14 \\
\hline 6,101 & USUALLY & 3 & 2 & 1.43 \\
\hline 6,127 & WILLFULLY & 3 & 1 & 0.71 \\
\hline 6,150 & ACCEPTABLY & 2 & 1 & 0.71 \\
\hline 6,191 & ALLEGEDLY & 2 & 2 & 1.43 \\
\hline 6,380 & CONSECUTIVELY & 2 & 1 & 0.71 \\
\hline 6,393 & COOPERATIVELY & 2 & 2 & 1.43 \\
\hline 6,408 & CRITICALLY & 2 & 1 & 0.71 \\
\hline 6,418 & DANGEROUSLY & 2 & 1 & 0.71 \\
\hline 6,496 & ECONOMICALLY & 2 & 2 & 1.43 \\
\hline 6,560 & EXTERNALLY & 2 & 1 & 0.71 \\
\hline 6,564 & FACTUALLY & 2 & 1 & 0.71 \\
\hline 6,601 & FRAUDULENTLY & 2 & 2 & 1.43 \\
\hline 6,620 & GLOBALLY & 2 & 2 & 1.43 \\
\hline 6,701 & INFORMALLY & 2 & 2 & 1.43 \\
\hline 6,753 & JUDICIALLY & 2 & 2 & 1.43 \\
\hline 6,776 & LEGIBLY & 2 & 2 & 1.43 \\
\hline 6,822 & MECHANICALLY & 2 & 2 & 1.43 \\
\hline 6,872 & NUMERICALLY & 2 & 1 & 0.71 \\
\hline 6,892 & ORDINARILY & 2 & 2 & 1.43 \\
\hline 6,992 & QUIETLY & 2 & 2 & 1.43 \\
\hline 7,039 & RELATIVELY & 2 & 1 & 0.71 \\
\hline 7,044 & RELIABLY & 2 & 1 & 0.71 \\
\hline 7,113 & SECURELY & 2 & 2 & 1.43 \\
\hline 7,138 & SIMPLY & 2 & 2 & 1.43 \\
\hline 7,140 & SINGLY & 2 & 2 & 1.43 \\
\hline 7,144 & SLIGHTLY & 2 & 1 & 0.71 \\
\hline 7,227 & THOROUGHLY & 2 & 2 & 1.43 \\
\hline 7,261 & TYPICALLY & 2 & 1 & 0.71 \\
\hline 7,309 & VIGOROUSLY & 2 & 2 & 1.43 \\
\hline 7,314 & VISUALLY & 2 & 2 & 1.43 \\
\hline 7,413 & ADMINISTRATIVELY & 1 & 1 & 0.71 \\
\hline
\end{tabular}




\begin{tabular}{|c|c|c|c|c|}
\hline 7,473 & ALTERNATELY & 1 & 1 & 0.71 \\
\hline 7,682 & BRIEFLY & 1 & 1 & 0.71 \\
\hline 7,761 & CERTAINLY & 1 & 1 & 0.71 \\
\hline 7,849 & COMPETENTLY & 1 & 1 & 0.71 \\
\hline 7,872 & CONDITIONALLY & 1 & 1 & 0.71 \\
\hline 7,891 & CONSTANTLY & 1 & 1 & 0.71 \\
\hline 7,894 & CONSTRUCTIVELY & 1 & 1 & 0.71 \\
\hline 7,909 & CONTRACTUALLY & 1 & 1 & 0.71 \\
\hline 7,917 & CONVENIENTLY & 1 & 1 & 0.71 \\
\hline 7,919 & CONVERSELY & 1 & 1 & 0.71 \\
\hline 7,935 & CORRESPONDINGLY & 1 & 1 & 0.71 \\
\hline 7,966 & CULPABLY & 1 & 1 & 0.71 \\
\hline 8,031 & DELIBERATELY & 1 & 1 & 0.71 \\
\hline 8,034 & DEMOCRATICALLY & 1 & 1 & 0.71 \\
\hline 8,069 & DETRIMENTALLY & 1 & 1 & 0.71 \\
\hline 8,090 & DIFFERENTLY & 1 & 1 & 0.71 \\
\hline 8,106 & DISASSEMBLY & 1 & 1 & 0.71 \\
\hline 8,121 & DISHONESTLY & 1 & 1 & 0.71 \\
\hline 8,194 & EASILY & 1 & 1 & 0.71 \\
\hline 8,209 & EFFECTUALLY & 1 & 1 & 0.71 \\
\hline 8,270 & ERRONEOUSLY & 1 & 1 & 0.71 \\
\hline 8,278 & ETHICALLY & 1 & 1 & 0.71 \\
\hline 8,281 & EXACTLY & 1 & 1 & 0.71 \\
\hline 8,382 & FLEXIBLY & 1 & 1 & 0.71 \\
\hline 8,426 & FRESHLY & 1 & 1 & 0.71 \\
\hline 8,429 & FRIENDLY & 1 & 1 & 0.71 \\
\hline 8,433 & FUNCTIONALLY & 1 & 1 & 0.71 \\
\hline 8,458 & GENETICALLY & 1 & 1 & 0.71 \\
\hline 8,550 & HIGHLY & 1 & 1 & 0.71 \\
\hline 8,604 & ILLEGALLY & 1 & 1 & 0.71 \\
\hline 8,629 & IMPROPERLY & 1 & 1 & 0.71 \\
\hline 8,633 & INADVERTENTLY & 1 & 1 & 0.71 \\
\hline 8,641 & INCONSISTENTLY & 1 & 1 & 0.71 \\
\hline 8,646 & INDEFEASIBLY & 1 & 1 & 0.71 \\
\hline 8,660 & INEVITABLY & 1 & 1 & 0.71 \\
\hline 8,682 & INNOVATIVELY & 1 & 1 & 0.71 \\
\hline 8,696 & INTENTIONALY & 1 & 1 & 0.71 \\
\hline 8,711 & INTRINSICALLY & 1 & 1 & 0.71 \\
\hline 8,730 & IRREPARABLY & 1 & 1 & 0.71 \\
\hline 8,756 & JUSTIFIABLY & 1 & 1 & 0.71 \\
\hline 8,809 & LEGITIMATELY & 1 & 1 & 0.71 \\
\hline 8,888 & MANDATORILY & 1 & 1 & 0.71 \\
\hline 8,891 & MANUALLY & 1 & 1 & 0.71 \\
\hline 8,925 & MEANINGFULLY & 1 & 1 & 0.71 \\
\hline 8,941 & MENTALLY & 1 & 1 & 0.71 \\
\hline 9,057 & NOMINALLY & 1 & 1 & 0.71 \\
\hline 9,109 & OCCASIONALLY & 1 & 1 & 0.71 \\
\hline 9,119 & OFFICIALLY & 1 & 1 & 0.71 \\
\hline 9,141 & OPTIONALLY & 1 & 1 & 0.71 \\
\hline 9,206 & PATENTLY & 1 & 1 & 0.71 \\
\hline 9,229 & PERPETUALLY & 1 & 1 & 0.71 \\
\hline 9,289 & POSITIVELY & 1 & 1 & 0.71 \\
\hline
\end{tabular}




\begin{tabular}{|c|l|r|r|r|r|}
\hline 9,310 & PREDOMINATELY & 1 & 1 & 0.71 \\
\hline 9,315 & PREMATURELY & 1 & 1 & 0.71 \\
\hline 9,336 & PROBABLY & 1 & 1 & 0.71 \\
\hline 9,367 & PURELY & 1 & 1 & 0.71 \\
\hline 9,398 & RAPIDLY & 1 & 1 & 0.71 \\
\hline 9,502 & REMOTELY & 1 & 1 & 1 & 0.71 \\
\hline 9,523 & REPEATEDLY & 1 & 1 & 0.71 \\
\hline 9,575 & RETROACTIVELY & 1 & 1 & 0.71 \\
\hline 9,608 & ROUGHLY & 1 & 1 & 0.71 \\
\hline 9,610 & ROUTINELY & 1 & 1 & 0.71 \\
\hline 9,655 & SEASONALLY & 1 & 1 & 0.71 \\
\hline 9,656 & SECONDARILY & 1 & 1 & 0.71 \\
\hline 9,666 & SELECTIVELY & 1 & 1 & 0.71 \\
\hline 9,674 & SEQUENTIALLY & 1 & 1 & 0.71 \\
\hline 9,677 & SERIALLY & 1 & 1 & 0.71 \\
\hline 9,679 & SERVICEABLY & 1 & 1 & 0.71 \\
\hline 9,713 & SINGULARLY & 1 & 1 & 0.71 \\
\hline 9,861 & SUITABLY & 1 & 1 & 0.71 \\
\hline 9,910 & TECHNICALLY & 1 & 1 & 0.71 \\
\hline 10,029 & TRULY & 1 & 1 & 0.71 \\
\hline 10,068 & UNDULY & 1 & 1 & 0.71 \\
\hline 10,084 & UNLAWFULLY & 1 & 1 & 0.71 \\
\hline 10,088 & UNNECESSARILY & 1 & 1 & 0.71 \\
\hline 10,105 & UNUSUALLY & 1 & 1 & 0.71 \\
\hline 10,157 & VIRTUALLY & & 1 & 0.71 \\
\hline
\end{tabular}

Total de ocorrências (tokens): 4.929

Total de formas (types): 261 
Advérbios descartados:

Os advérbios abaixo listados ou derivam de outras classes gramaticais ou apresentam dúvidas quanto ao uso, podendo também ser classificados como adjetivos. Antes do descarte, observamos vários deles em contexto.

\begin{tabular}{|r|l|r|r|r|r|}
\hline \multicolumn{1}{|c|}{ Word } & \multicolumn{1}{|c|}{ Freq. } & \multicolumn{1}{c|}{$\%$} & \multicolumn{1}{c|}{ Texts } & \multicolumn{1}{c|}{$\%$} \\
\hline 160 & ONLY & 494 & 0.08 & 110 & 78.57 \\
\hline 560 & MONTHLY & 162 & 0.02 & 35 & 25.00 \\
\hline 1,038 & TIMELY & 73 & 0.01 & 23 & 16.43 \\
\hline 1,173 & DAILY & 62 & & 15 & 10.71 \\
\hline 2,049 & WEEKLY & 27 & & 7 & 5.00 \\
\hline 2,425 & QUARTERLY & 20 & & 11 & 7.86 \\
\hline 2,880 & LIKELY & 14 & & 11 & 7.86 \\
\hline 3,353 & FORTNIGHTLY & 10 & & 1 & 0.71 \\
\hline 3,543 & HOURLY & 9 & & 4 & 2.86 \\
\hline 4,109 & YEARLY & 7 & & 1 & 0.71 \\
\hline 5,802 & NAMELY & 3 & & 2 & 1.43 \\
\hline 7,002 & RATABLY & 2 & & 2 & 1.43 \\
\hline 8,195 & EASTERLY & 1 & & 1 & 0.71 \\
\hline 8,370 & FIRSTLY & 1 & & 1 & 0.71 \\
\hline 9,080 & NORTHERLY & 1 & & 1 & 0.71 \\
\hline 9,202 & PARTLY & 1 & & 1 & 0.71 \\
\hline
\end{tabular}

Total de ocorrências (tokens) descartadas: 887

Total de formas (types) descartadas: 16 


\section{ANEXO E \\ Advérbios terminados em -mente: corpus de Direito}

Todos os advérbios terminados em -mente derivados de adjetivos encontrados no corpus de Direito (português) estão identificados na tabela abaixo. Na sequência, aqueles descartados para esta pesquisa.

\section{Observações:}

$\mathbf{N}=\quad$ posição em que o advérbio ocorreu em uma lista de frequência com todas as palavras do corpus de estudo

Word $=$ advérbio a que os dados se referem

Freq. = frequência do advérbio no corpus de estudo, em ordem decrescente

$\%=\quad$ porcentagem que representa a frequência do advérbio no corpus de estudo, considerado em sua totalidade

Texts $=$ número de textos em que o advérbio ocorreu no corpus de estudo

$\%=\quad$ porcentagem que representa a frequência de textos em que o advérbio ocorreu, considerando-se o corpus de estudo em sua totalidade

\begin{tabular}{|c|l|r|r|r|r|}
\hline $\mathbf{N}$ & \multicolumn{1}{|c|}{ Word } & Freq. & \multicolumn{1}{c|}{$\%$} & \multicolumn{1}{c|}{ Texts } & \multicolumn{1}{c|}{$\%$} \\
\hline 226 & DEVIDAMENTE & 154 & 0.06 & 61 & 43.57 \\
\hline 265 & SIMPLESMENTE & 132 & 0.05 & 50 & 35.71 \\
\hline 267 & SOMENTE & 131 & 0.05 & 58 & 41.43 \\
\hline 296 & EXPRESSAMENTE & 120 & 0.04 & 49 & 35.00 \\
\hline 356 & IMEDIATAMENTE & 104 & 0.04 & 50 & 35.71 \\
\hline 357 & INDEPENDENTEMENTE & 104 & 0.04 & 54 & 38.57 \\
\hline 437 & DIRETAMENTE & 86 & 0.03 & 44 & 31.43 \\
\hline 449 & EXCLUSIVAMENTE & 83 & 0.03 & 43 & 30.71 \\
\hline 531 & AUTOMATICAMENTE & 72 & 0.03 & 40 & 28.57 \\
\hline 604 & JUNTAMENTE & 63 & 0.02 & 53 & 37.86 \\
\hline 652 & PREVIAMENTE & 58 & 0.02 & 31 & 22.14 \\
\hline 747 & INDIRETAMENTE & 50 & 0.02 & 23 & 16.43 \\
\hline 804 & MENSALMENTE & 46 & 0.02 & 31 & 22.14 \\
\hline 913 & INTEGRALMENTE & 40 & 0.01 & 29 & 20.71 \\
\hline 1,011 & EVENTUALMENTE & 36 & 0.01 & 25 & 17.86 \\
\hline 1,019 & ANUALMENTE & 35 & 0.01 & 22 & 15.71 \\
\hline 1,029 & ESPECIALMENTE & 35 & 0.01 & 24 & 17.14 \\
\hline 1,084 & JUDICIALMENTE & 33 & 0.01 & 20 & 14.29 \\
\hline 1,164 & OBRIGATORIAMENTE & 30 & 0.01 & 18 & 12.86 \\
\hline 1,304 & LEGALMENTE & 26 & & 16 & 11.43 \\
\hline 1,499 & PARCIALMENTE & 22 & & 19 & 13.57 \\
\hline 1,575 & ANTERIORMENTE & 20 & & 14 & 10.00 \\
\hline 1,593 & EFETIVAMENTE & 20 & & 17 & 12.14 \\
\hline 1,602 & FORMALMENTE & 20 & & 15 & 10.71 \\
\hline 1,615 & ISOLADAMENTE & 20 & & 10 & 7.14 \\
\hline 1,629 & POSTERIORMENTE & 20 & & 15 & 10.71 \\
\hline 1,683 & MONETARIAMENTE & 19 & & 11 & 7.86 \\
\hline 1,702 & ANTECIPADAMENTE & 18 & & 12 & 8.57 \\
\hline
\end{tabular}




\begin{tabular}{|c|c|c|c|c|}
\hline 1,889 & PERIODICAMENTE & 16 & 14 & 10.00 \\
\hline 1,924 & COMPROVADAMENTE & 15 & 11 & 7.86 \\
\hline 2,022 & ESPECIFICAMENTE & 14 & 12 & 8.57 \\
\hline 2,045 & LIVREMENTE & 14 & 12 & 8.57 \\
\hline 2,068 & REGULARMENTE & 14 & 10 & 7.14 \\
\hline 2,147 & GRATUITAMENTE & 13 & 11 & 7.86 \\
\hline 2,204 & TOTALMENTE & 13 & 9 & 6.43 \\
\hline 2,315 & RELATIVAMENTE & 12 & 11 & 7.86 \\
\hline 2,321 & SEPARADAMENTE & 12 & 9 & 6.43 \\
\hline 2,418 & INDIVIDUALMENTE & 11 & 7 & 5.00 \\
\hline 2,440 & MUTUAMENTE & 11 & 10 & 7.14 \\
\hline 2,481 & RIGOROSAMENTE & 11 & 11 & 7.86 \\
\hline 2,488 & SOLIDARIAMENTE & 11 & 9 & 6.43 \\
\hline 2,578 & INTEIRAMENTE & 10 & 8 & 5.71 \\
\hline 2,611 & PESSOALMENTE & 10 & 10 & 7.14 \\
\hline 2,628 & RESPECTIVAMENTE & 10 & 9 & 6.43 \\
\hline 2,705 & CUMULATIVAMENTE & 9 & 7 & 5.00 \\
\hline 2,714 & DIARIAMENTE & 9 & 8 & 5.71 \\
\hline 2,735 & FIELMENTE & 9 & 9 & 6.43 \\
\hline 2,808 & SUCESSIVAMENTE & 9 & 9 & 6.43 \\
\hline 2,862 & CONJUNTAMENTE & 8 & 8 & 5.71 \\
\hline 2,932 & IGUALMENTE & 8 & 7 & 5.00 \\
\hline 2,941 & INDEVIDAMENTE & 8 & 7 & 5.00 \\
\hline 2,946 & INICIALMENTE & 8 & 8 & 5.71 \\
\hline 2,996 & PLENAMENTE & 8 & 7 & 5.00 \\
\hline 2,998 & PONTUALMENTE & 8 & 5 & 3.57 \\
\hline 3,155 & ELETRONICAMENTE & 7 & 6 & 4.29 \\
\hline 3,166 & ESTRITAMENTE & 7 & 6 & 4.29 \\
\hline 3,255 & PROPORCIONALMENTE & 7 & 4 & 2.86 \\
\hline 3,39 & CONTRATUALMENTE & 6 & 4 & 2.86 \\
\hline 3,589 & PRONTAMENTE & 6 & 6 & 4.29 \\
\hline 3,592 & QUINZENALMENTE & 6 & 4 & 2.86 \\
\hline 3,624 & SIMULTANEAMENTE & 6 & 5 & 3.57 \\
\hline 3,666 & ADEQUADAMENTE & 5 & 5 & 3.57 \\
\hline 3,676 & AMIGAVELMENTE & 5 & 3 & 2.14 \\
\hline 3,689 & ATUALMENTE & 5 & 5 & 3.57 \\
\hline 3,730 & CONCOMITANTEMENTE & 5 & 3 & 2.14 \\
\hline 3,751 & CONTRARIAMENTE & 5 & 3 & 2.14 \\
\hline 3,773 & DEFINITIVAMENTE & 5 & 5 & 3.57 \\
\hline 3,883 & IRREVOGAVELMENTE & 5 & 4 & 2.86 \\
\hline 3,896 & LEGITIMAMENTE & 5 & 5 & 3.57 \\
\hline 3,921 & NECESSARIAMENTE & 5 & 3 & 2.14 \\
\hline 3,924 & NORMALMENTE & 5 & 5 & 3.57 \\
\hline 3,925 & NOTADAMENTE & 5 & 5 & 3.57 \\
\hline 3,936 & ORIGINALMENTE & 5 & 3 & 2.14 \\
\hline 3,985 & RECIPROCAMENTE & 5 & 5 & 3.57 \\
\hline 4,018 & RESTRITIVAMENTE & 5 & 5 & 3.57 \\
\hline 4,030 & SEMESTRALMENTE & 5 & 4 & 2.86 \\
\hline 4,085 & VERBALMENTE & 5 & 5 & 3.57 \\
\hline 4,104 & ABSOLUTAMENTE & 4 & 3 & 2.14 \\
\hline 4,217 & CONFIDENCIALMENTE & 4 & 2 & 1.43 \\
\hline 4,330 & EXCEPCIONALMENTE & 4 & 4 & 2.86 \\
\hline
\end{tabular}




\begin{tabular}{|c|c|c|c|c|}
\hline 4,379 & GLOBALMENTE & 4 & 1 & 0.71 \\
\hline 4,388 & HABITUALMENTE & 4 & 4 & 2.86 \\
\hline 4,493 & NATURALMENTE & 4 & 3 & 2.14 \\
\hline 4,500 & NOVAMENTE & 4 & 3 & 2.14 \\
\hline 4,556 & PORMENORIZADAMENTE & 4 & 4 & 2.86 \\
\hline 4,571 & PREFERENCIALMENTE & 4 & 4 & 2.86 \\
\hline 4,580 & PRINCIPALMENTE & 4 & 4 & 2.86 \\
\hline 4,592 & PROVISORIAMENTE & 4 & 2 & 1.43 \\
\hline 4,679 & TEMPESTIVAMENTE & 4 & 3 & 2.14 \\
\hline 4,933 & CONSEQÜENTEMENTE & 3 & 3 & 2.14 \\
\hline 4,969 & CORRETAMENTE & 3 & 3 & 2.14 \\
\hline 4,987 & CRIMINALMENTE & 3 & 2 & 1.43 \\
\hline 5,127 & EXEMPLIFICATIVAMENTE & 3 & 3 & 2.14 \\
\hline 5,144 & EXTRAJUDICIALMENTE & 3 & 3 & 2.14 \\
\hline 5,145 & EXTRAORDINARIAMENTE & 3 & 2 & 1.43 \\
\hline 5,372 & PENALMENTE & 3 & 1 & 0.71 \\
\hline 5,379 & PERFEITAMENTE & 3 & 3 & 2.14 \\
\hline 5,383 & PERMANENTEMENTE & 3 & 3 & 2.14 \\
\hline 5,419 & PRIMEIRAMENTE & 3 & 3 & 2.14 \\
\hline 5,464 & RAZOAVELMENTE & 3 & 2 & 1.43 \\
\hline 5,538 & SATISFATORIAMENTE & 3 & 3 & 2.14 \\
\hline 5,589 & SUPLETIVAMENTE & 3 & 3 & 2.14 \\
\hline 5,599 & TECNICAMENTE & 3 & 3 & 2.14 \\
\hline 5,602 & TEMPORARIAMENTE & 3 & 3 & 2.14 \\
\hline 5,606 & TERMINANTEMENTE & 3 & 3 & 2.14 \\
\hline 5,634 & UNILATERALMENTE & 3 & 2 & 1.43 \\
\hline 5,718 & ADICIONALMENTE & 2 & 2 & 1.43 \\
\hline 6,006 & COMPLETAMENTE & 2 & 2 & 1.43 \\
\hline 6,064 & CONSIDERAVELMENTE & 2 & 1 & 0.71 \\
\hline 6,072 & CONSTANTEMENTE & 2 & 1 & 0.71 \\
\hline 6,138 & CUIDADOSAMENTE & 2 & 2 & 1.43 \\
\hline 6,345 & ERRONEAMENTE & 2 & 2 & 1.43 \\
\hline 6,576 & INADEQUADAMENTE & 2 & 2 & 1.43 \\
\hline 6,600 & INDISTINTAMENTE & 2 & 2 & 1.43 \\
\hline 6,624 & ININTERRUPTAMENTE & 2 & 2 & 1.43 \\
\hline 6,649 & INTENCIONALMENTE & 2 & 2 & 1.43 \\
\hline 6,700 & JURIDICAMENTE & 2 & 2 & 1.43 \\
\hline 6,774 & MERAMENTE & 2 & 2 & 1.43 \\
\hline 6,815 & NEGATIVAMENTE & 2 & 2 & 1.43 \\
\hline 6,856 & OPORTUNAMENTE & 2 & 2 & 1.43 \\
\hline 6,860 & ORDINARIAMENTE & 2 & 2 & 1.43 \\
\hline 6,892 & PASSIVAMENTE & 2 & 2 & 1.43 \\
\hline 6,969 & PRESUMIVELMENTE & 2 & 2 & 1.43 \\
\hline 7,038 & RADIOLOGICAMENTE & 2 & 2 & 1.43 \\
\hline 7,051 & REALMENTE & 2 & 2 & 1.43 \\
\hline 7,060 & RECONHECIDAMENTE & 2 & 2 & 1.43 \\
\hline 7,254 & SUBSIDIARIAMENTE & 2 & 2 & 1.43 \\
\hline 7,275 & TACITAMENTE & 2 & 2 & 1.43 \\
\hline 7,340 & UNICAMENTE & 2 & 2 & 1.43 \\
\hline 7,448 & ACIDENTALMENTE & 1 & 1 & 0.71 \\
\hline 7,497 & ADMINISTRATIVAMENTE & 1 & 1 & 0.71 \\
\hline 7,578 & ALTAMENTE & 1 & 1 & 0.71 \\
\hline
\end{tabular}




\begin{tabular}{|c|c|c|c|c|}
\hline 7,584 & ALTERNATIVAMENTE & 1 & 1 & 0.71 \\
\hline 7,609 & AMPLAMENTE & 1 & 1 & 0.71 \\
\hline 7,783 & ATIVAMENTE & 1 & 1 & 0.71 \\
\hline 7,903 & CABALMENTE & 1 & 1 & 0.71 \\
\hline 8,112 & COMERCIALMENTE & 1 & 1 & 0.71 \\
\hline 8,142 & COMPLEMENTARMENTE & 1 & 1 & 0.71 \\
\hline 8,143 & COMPLEMENTE & 1 & 1 & 0.71 \\
\hline 8,180 & COMUMENTE & 1 & 1 & 0.71 \\
\hline 8,255 & CONSCIENTEMENTE & 1 & 1 & 0.71 \\
\hline 8,256 & CONSECUTIVAMENTE & 1 & 1 & 0.71 \\
\hline 8,260 & CONSENSUALMENTE & 1 & 1 & 0.71 \\
\hline 8,312 & CONTEMPORANEAMENTE & 1 & 1 & 0.71 \\
\hline 8,392 & CREDENCIAMENTE & 1 & 1 & 0.71 \\
\hline 8,416 & CRONOLOGICAMENTE & 1 & 1 & 0.71 \\
\hline 8,591 & DESTACADAMENTE & 1 & 1 & 0.71 \\
\hline 8,603 & DETALHADAMENTE & 1 & 1 & 0.71 \\
\hline 8,608 & DETIDAMENTE & 1 & 1 & 0.71 \\
\hline 8,716 & DOCUMENTALMENTE & 1 & 1 & 0.71 \\
\hline 8,912 & ESPONTANEAMENTE & 1 & 1 & 0.71 \\
\hline 8,970 & EXATAMENTE & 1 & 1 & 0.71 \\
\hline 9,052 & FACILMENTE & 1 & 1 & 0.71 \\
\hline 9,107 & FINANCEIRAMENTE & 1 & 1 & 0.71 \\
\hline 9,205 & FUTURAMENTE & 1 & 1 & 0.71 \\
\hline 9,218 & GENERALIZADAMENTE & 1 & 1 & 0.71 \\
\hline 9,219 & GENERICAMENTE & 1 & 1 & 0.71 \\
\hline 9,22 & GENETICAMENTE & 1 & 1 & 0.71 \\
\hline 9,258 & GRAMATICALMENTE & 1 & 1 & 0.71 \\
\hline 9,355 & ILIMITADAMENTE & 1 & 1 & 0.71 \\
\hline 9,363 & IMOTIVADAMENTE & 1 & 1 & 0.71 \\
\hline 9,373 & IMPERFEITAMENTE & 1 & 1 & 0.71 \\
\hline 9,400 & IMPRETERIVELMENTE & 1 & 1 & 0.71 \\
\hline 9,439 & INCONDICIONALMENTE & 1 & 1 & 0.71 \\
\hline 9,450 & INCORRETAMENTE & 1 & 1 & 0.71 \\
\hline 9,477 & INDISPENSAVELMENTE & 1 & 1 & 0.71 \\
\hline 9,488 & INDUBITAVELMENTE & 1 & 1 & 0.71 \\
\hline 9,529 & INJUSTIFICADAMENTE & 1 & 1 & 0.71 \\
\hline 9,591 & INTERNACIONALMENTE & 1 & 1 & 0.71 \\
\hline 9,593 & INTERNAMENTE & 1 & 1 & 0.71 \\
\hline 9,648 & INVOLUNTARIAMENTE & 1 & 1 & 0.71 \\
\hline 9,662 & IRRESTRITAMENTE & 1 & 1 & 0.71 \\
\hline 9,973 & MUNDIALMENTE & 1 & 1 & 0.71 \\
\hline 10,038 & NOMEADAMENTE & 1 & 1 & 0.71 \\
\hline 10,064 & NUMERICAMENTE & 1 & 1 & 0.71 \\
\hline 10,108 & OFICIALMENTE & 1 & 1 & 0.71 \\
\hline 10,117 & ONEROSAMENTE & 1 & 1 & 0.71 \\
\hline 10,159 & ORIGINARIAMENTE & 1 & 1 & 0.71 \\
\hline 10,203 & PARCELADAMENTE & 1 & 1 & 0.71 \\
\hline 10,224 & PARTICULARMENTE & 1 & 1 & 0.71 \\
\hline 10,367 & PRATICAMENTE & 1 & 1 & 0.71 \\
\hline 10,379 & PRECISAMENTE & 1 & 1 & 0.71 \\
\hline 10,447 & PRIVATIVAMENTE & 1 & 1 & 0.71 \\
\hline 10,504 & PROPRIAMENTE & 1 & 1 & 0.71 \\
\hline
\end{tabular}




\begin{tabular}{|c|l|r|r|r|r|}
\hline 10,539 & PUBLICAMENTE & 1 & 1 & 0.71 \\
\hline 10,700 & REGRESSIVAMENTE & 1 & & 1 & 0.71 \\
\hline 10,83 & RESUMIDAMENTE & 1 & 1 & 0.71 \\
\hline 11,086 & SUBSTANCIALMENTE & 1 & & 1 & 0.71 \\
\hline 11,104 & SUPERVENIENTEMENTE & 1 & 1 & 0.71 \\
\hline 11,149 & TECNOLOGICAMENTE & 1 & & 1 & 0.71 \\
\hline 11,307 & UNIVERSALMENTE & 1 & 1 & 0.71 \\
\hline 11,318 & USUALMENTE & 1 & 1 & 0.71 \\
\hline 11,341 & VALIDAMENTE & 1 & & 1 & 0.71 \\
\hline
\end{tabular}

Total de ocorrências (tokens): 2.212

Total de formas (types): 193

Advérbios descartados:

Por estarem grafados incorretamente, os advérbios abaixo foram descartados $^{136}$ :

\begin{tabular}{|c|l|r|r|r|r|}
\hline $\mathbf{N}$ & \multicolumn{1}{|c|}{ Word } & \multicolumn{1}{c|}{ Freq. } & \multicolumn{1}{c|}{ \% } & \multicolumn{1}{c|}{ Texts } & \multicolumn{1}{c|}{$\%$} \\
\hline 6,06 & CONSEQUENTEMENTE & 2 & & 2 & 1.43 \\
\hline 6,618 & INGUALMENTE & 2 & & 1 & 0.71 \\
\hline 10,435 & PREVIALMENTE & 1 & & 1 & 0.71 \\
\hline 11,284 & TRIINESTRALMENTE & 1 & & 1 & 0.71 \\
\hline
\end{tabular}

Total de ocorrências (tokens) descartadas: 6

Total de formas (types) descartadas: 4

\footnotetext{
${ }^{136}$ É importante ressaltar que os corpora utilizados foram compilados antes do início do período de transição para a nova ortografia da língua portuguesa, qual seja, o ano de 2009. O Acordo Ortográfico da Língua Portuguesa foi aprovado em 1990, em Lisboa, pela Academia das Ciências de Lisboa, Academia Brasileira de Letras e delegações de Angola, Cabo Verde, Guiné-Bissau, Moçambique e São Tomé e Príncipe, com a adesão da delegação de observadores de Galiza (BECHARA, 2008, p. 7). Dessa forma, considerarmos como grafia incorreta a palavra consequentemente (sem o uso do trema), que antes do período de transição era grafada conseqüentemente.
} 


\section{ANEXO F \\ 100 primeiras palavras-chave do corpus de Culinária (inglês)}

De um total de 13.880 formas (types) do corpus de Culinária (inglês), apresentamos as 100 primeiras identificadas como palavras-chave quando comparadas com o BNC, corpus de referência para o inglês. Foram abaixo distribuídas em ordem decrescente de chavicidade.

\section{Observações:}

$\mathbf{N}=\quad$ posição da palavra na lista de palavras-chave, em ordem decrescente de chavicidade

Key word $=$ palavra-chave a que os dados se referem

Freq. $=\quad$ frequência da palavra no corpus de estudo

$\%=\quad$ porcentagem que representa a frequência da palavra no corpus de estudo, considerado em sua totalidade

RC. Freq. = frequência da palavra no corpus de referência

RC. $\%=$ porcentagem que representa a frequência da palavra no corpus de referência, considerado em sua totalidade

Keyness $=$ índice de chavicidade da palavra, em ordem decrescente

$\mathbf{P}=$ valor de $\mathrm{P}$

\begin{tabular}{|r|l|r|r|r|r|r|c|}
\hline $\mathbf{N}$ & \multicolumn{1}{|c|}{ Key word } & Freq. & \multicolumn{1}{c|}{$\%$} & RC. Freq. & RC. $\%$ & Keyness & P \\
\hline 1 & $\#$ & 219513 & 12,78843689 & 1604421 & 1,61304605 & 525899,875 & $0.0^{*}$ \\
\hline 2 & TBSP & 11259 & 0,655929267 & 569 & & 87326,48438 & \\
\hline 3 & MINS & 9261 & 0,539529383 & 575 & & 71195,13281 & \\
\hline 4 & OZ & 9633 & 0,561201453 & 1283 & & 70734,53125 & \\
\hline 5 & MINUTES & 13556 & 0,78974843 & 17662 & 0,017756946 & 68495,21094 & \\
\hline 6 & ADD & 11541 & 0,672358096 & 8162 & & 67718,97656 & \\
\hline 7 & CHOPPED & 8690 & 0,506263912 & 1037 & & 64328,43359 & \\
\hline 8 & PAN & 8586 & 0,50020504 & 1862 & & 60316,16406 & \\
\hline 9 & BUTTER & 8547 & 0,497933 & 2086 & & 59270,89844 & \\
\hline 10 & OIL & 10511 & 0,612352133 & 10158 & 0,010212608 & 57460,625 & \\
\hline 11 & PEPPER & 7202 & 0,419575691 & 951 & & 52908,8125 & \\
\hline 12 & INGREDIENTS & 7235 & 0,421498209 & 1242 & & 51997,95313 & \\
\hline 13 & HEAT & 8621 & 0,502244115 & 5794 & & 51103,83984 & \\
\hline 14 & TSP & 6491 & 0,378154099 & 394 & & 49941,17188 & \\
\hline 15 & SALT & 7606 & 0,443112016 & 2932 & & 49685,11719 & \\
\hline 16 & UNTIL & 13004 & 0,757589877 & 40128 & 0,04034372 & 48350,22266 & \\
\hline 17 & COOK & 7230 & 0,421206921 & 3543 & & 45452,01563 & \\
\hline 18 & COOKING & 6844 & 0,398719251 & 2592 & & 44821,87891 & \\
\hline
\end{tabular}




\begin{tabular}{|c|c|c|c|c|c|c|}
\hline 19 & SERVES & 6448 & 0,375649005 & 1728 & & 44221,64063 \\
\hline 20 & SUGAR & 7043 & 0,410312623 & 3678 & & 43789,03516 \\
\hline 21 & SAUCE & 5799 & 0,337839425 & 1387 & & 40296,99609 \\
\hline 22 & SERVE & 6748 & 0,393126458 & 5306 & & 38687,75781 \\
\hline 23 & METHOD & 7433 & 0,433033347 & 8955 & & 38363,02734 \\
\hline 24 & CREAM & 5884 & 0,342791349 & 3135 & & 36448,98438 \\
\hline 25 & FLOUR & 4922 & 0,286746949 & 1038 & & 34667,60547 \\
\hline 26 & STIR & 4938 & 0,287679076 & 1158 & & 34386,99219 \\
\hline 27 & GARLIC & 4737 & 0,275969177 & 784 & & 34150,07031 \\
\hline 28 & OVEN & 4936 & 0,287562579 & 1308 & & 33893,43359 \\
\hline 29 & OLIVE & 4535 & 0,264201015 & 895 & & 32156,63086 \\
\hline 30 & PREPARATION & 5248 & 0,305739135 & 3284 & & 31544,49219 \\
\hline 31 & ONION & 4023 & 0,23437281 & 671 & & 28981,07227 \\
\hline 32 & JUICE & 4175 & 0,243228063 & 1612 & & 27257,92383 \\
\hline 33 & LEMON & 3990 & 0,232450292 & 1203 & & 26960,08398 \\
\hline 34 & BOWL & 4054 & 0,236178815 & 2355 & & 24714,23438 \\
\hline 35 & MIXTURE & 4251 & 0,24765569 & 3206 & & 24588,66992 \\
\hline 36 & REMOVE & 4331 & 0,252316356 & 3920 & & 24038,5293 \\
\hline 37 & EGG & 3922 & 0,228488728 & 2442 & & 23594,28906 \\
\hline 38 & FRESH & 4709 & 0,274337947 & 6620 & & 23250,94531 \\
\hline 39 & FINELY & 3261 & 0,189980045 & 684 & & 22978,30273 \\
\hline 40 & FRESHLY & 3248 & 0,189222693 & 670 & & 22925,95313 \\
\hline 41 & CHICKEN & 3666 & 0,213574633 & 2009 & & 22589,89844 \\
\hline 42 & SLICED & 3110 & 0,181183055 & 658 & & 21894,38477 \\
\hline 43 & POUR & 3305 & 0,192543417 & 1228 & & 21698,80859 \\
\hline 44 & MIX & 3704 & 0,215788439 & 2677 & & 21619,04688 \\
\hline 45 & CHEESE & 3591 & 0,20920527 & 2530 & & 21071,50781 \\
\hline 46 & PEELED & 2783 & 0,162132621 & 310 & & 20691,53516 \\
\hline 47 & BOIL & 2979 & 0,173551232 & 776 & & 20493,87305 \\
\hline 48 & MILK & 3824 & 0,222779423 & 4740 & & 19574,26172 \\
\hline 49 & FRY & 2973 & 0,17320168 & 1103 & & 19522,75781 \\
\hline 50 & SIMMER & 2548 & 0,148441941 & 246 & & 19121,4668 \\
\hline 51 & PARSLEY & 2534 & 0,147626325 & 384 & & 18404,57617 \\
\hline 52 & PLACE & 6882 & 0,400933057 & 47914 & 0,048171576 & 16354,13672 \\
\hline 53 & WATER & 5980 & 0,348384142 & 34134 & 0,034317497 & 16157,14746 \\
\hline 54 & FRYING & 2211 & 0,128808916 & 321 & & 16115,24219 \\
\hline 55 & COOKED & 2550 & 0,148558453 & 1248 & & 16027,5791 \\
\hline 56 & TIME & 11562 & 0,673581541 & 154580 & 0,15541099 & 15675,01367 \\
\hline
\end{tabular}




\begin{tabular}{|c|c|c|c|c|c|c|}
\hline 57 & BAKE & 2231 & 0,129974082 & 495 & & 15626,61719 \\
\hline 58 & TOMATOES & 2321 & 0,135217324 & 745 & & 15552,09082 \\
\hline 59 & ONIONS & 2242 & 0,130614921 & 544 & & 15549,84668 \\
\hline 60 & INTO & 11548 & 0,672765911 & 157885 & 0,158733755 & 15276,49805 \\
\hline 61 & GROUND & 4372 & 0,254704922 & 15806 & 0,015890969 & 15104,01465 \\
\hline 62 & PREHEAT & 1923 & 0,112030558 & 132 & & 14705,29004 \\
\hline 63 & GRATED & 2069 & 0,120536253 & 424 & & 14612,4043 \\
\hline 64 & SLICES & 2099 & 0,122284003 & 594 & & 14294,71582 \\
\hline 65 & CHILLI & 1878 & 0,109408937 & 193 & & 14037,01172 \\
\hline 66 & LESS & 5750 & 0,33498475 & 38627 & 0,03883465 & 13996,90723 \\
\hline 67 & POTATOES & 2362 & 0,13760592 & 1599 & & 13972,64453 \\
\hline 68 & BAKING & 2042 & 0,118963286 & 591 & & 13867,4502 \\
\hline 69 & AND & 72375 & 4,21643877 & 2624341 & 2,638448954 & 13846,53711 \\
\hline 70 & SPOON & 2087 & 0,1215849 & 800 & & 13637,90723 \\
\hline 71 & PASTRY & 1964 & 0,11441914 & 490 & & 13578,2207 \\
\hline 72 & CUT & 4175 & 0,243228063 & 17122 & 0,017214045 & 13556,40234 \\
\hline 73 & DICED & 1695 & 0,098747678 & 83 & & 13153,51758 \\
\hline 74 & STOCK & 3208 & 0,18689236 & 8025 & & 12997,59277 \\
\hline 75 & SAUCEPAN & 1801 & 0,104923055 & 322 & & 12889,80859 \\
\hline 76 & TOMATO & 1956 & 0,113953076 & 720 & & 12858,01758 \\
\hline 77 & CORIANDER & 1666 & 0,097058192 & 119 & & 12714,60156 \\
\hline 78 & WINE & 2911 & 0,169589669 & 6057 & & 12641,11426 \\
\hline 79 & $\mathrm{DISH}$ & 2160 & 0,125837758 & 1586 & & 12563,17969 \\
\hline 80 & VINEGAR & 1776 & 0,1034666 & 404 & & 12405,78125 \\
\hline 81 & CHOCOLATE & 2223 & 0,129508018 & 1994 & & 12362,13184 \\
\hline 82 & GENTLY & 2543 & 0,148150653 & 3775 & & 12349,63477 \\
\hline 83 & PINT & 2032 & 0,118380703 & 1210 & & 12327,50488 \\
\hline 84 & VEGETABLE & 1891 & 0,110166289 & 957 & & 11816,4707 \\
\hline 85 & SPRINKLE & 1641 & 0,095601737 & 315 & & 11665,08594 \\
\hline 86 & HOT & 3044 & 0,177338019 & 8751 & & 11652,10449 \\
\hline 87 & MEDIUM & 2360 & 0,137489393 & 3452 & & 11512,12598 \\
\hline 88 & CASTER & 1541 & 0,089775912 & 183 & & 11405,04688 \\
\hline 89 & STEADY & 2234 & 0,130148858 & 2798 & & 11400,39941 \\
\hline 90 & GARNISH & 1553 & 0,090475015 & 207 & & 11395,73926 \\
\hline 91 & CLOVES & 1516 & 0,088319458 & 161 & & 11306,59082 \\
\hline 92 & EGGS & 2326 & 0,135508612 & 3651 & & 11102,67578 \\
\hline 93 & POTATO & 1736 & 0,101136267 & 858 & & 10892,21387 \\
\hline 94 & ZEST & 1457 & 0,084882222 & 181 & & 10748,10645 \\
\hline
\end{tabular}




\begin{tabular}{|c|l|r|r|r|r|r|l|}
\hline 95 & ML & 1922 & 0,111972295 & 1709 & & 10709,98145 & \\
\hline 96 & RICE & 1900 & 0,110690616 & 1637 & & 10665,48438 & \\
\hline 97 & SERVING & 2103 & 0,122517034 & 2769 & & 10580,79883 & \\
\hline 98 & LARGE & 4620 & 0,269152969 & 34282 & 0,034466293 & 10495,09766 & \\
\hline 99 & DRAIN & 1747 & 0,101777107 & 1141 & & 10409,00391 & \\
\hline 100 & GOLDEN & 2219 & 0,129274994 & 3760 & & 10336,46191 & \\
\hline
\end{tabular}

* O valor de $\mathrm{P}$, para todas as formas é, 0.0000000000 . Para uma melhor distribuição das colunas, decidimos colocar esta informação separadamente. 


\section{ANEXO G \\ 100 primeiras palavras-chave do corpus de Culinária (português)}

De um total de 13.765 formas (types) do corpus de Culinária (português), apresentamos as 100 primeiras identificadas como palavras-chave quando comparadas com o BP, corpus de referência para o português. Foram abaixo distribuídas em ordem decrescente de chavicidade.

\section{Observações:}

$\mathbf{N}=\quad$ posição da palavra na lista de palavras-chave, em ordem decrescente de chavicidade

Key word $=$ palavra-chave a que os dados se referem

Freq. $=\quad$ frequência da palavra no corpus de estudo

$\%=\quad$ porcentagem que representa a frequência da palavra no corpus de estudo, considerado em sua totalidade

RC. Freq. = frequência da palavra no corpus de referência

RC. $\%=$ porcentagem que representa a frequência da palavra no corpus de referência, considerado em sua totalidade

Keyness $=$ índice de chavicidade da palavra, em ordem decrescente

$\mathbf{P}=\quad$ valor de $P$

\begin{tabular}{|r|l|r|r|r|r|r|c|}
\hline \multicolumn{1}{|c|}{$\mathbf{N}$} & \multicolumn{1}{|c|}{ Key Word } & \multicolumn{1}{c|}{ Freq. } & \multicolumn{1}{c|}{$\%$} & RC. Freq. & RC. $\%$ & Keyness & P \\
\hline 1 & SOPA & 15820 & 0,994362533 & 9477 & & 159169,3438 & $0.0^{*}$ \\
\hline 2 & SAL & 13279 & 0,83464855 & 16138 & & 121204,1641 & \\
\hline 3 & UM & 9645 & 0,606234312 & 0 & & 117377,8047 & \\
\hline 4 & CHÁ & 11752 & 0,738669336 & 10133 & & 112862,0156 & \\
\hline 5 & COLHERES & 10192 & 0,64061588 & 4848 & & 105151,3125 & \\
\hline 6 & XÍCARA & 9461 & 0,594669044 & 4503 & & 97599,07813 & \\
\hline 7 & INGREDIENTES & 9811 & 0,616668224 & 8729 & & 93799,97656 & \\
\hline 8 & COLOQUE & 9196 & 0,578012526 & 7611 & & 88795,8125 & \\
\hline 9 & PREPARO & 10516 & 0,660980821 & 20849 & & 88065,63281 & \\
\hline 10 & COLHER & 9360 & 0,588320732 & 9734 & & 87489,40625 & \\
\hline 11 & MANTEIGA & 7487 & 0,470593721 & 5476 & & 73472,82031 & \\
\hline 12 & PIMENTA & 7516 & 0,47241649 & 13090 & & 64478,54688 & \\
\hline 13 & MINUTOS & 10601 & 0,666323483 & 88398 & 0,012718895 & 62027,42969 & \\
\hline 14 & DEIXE & 6917 & 0,434766471 & 9690 & & 61653,82813 & \\
\hline 15 & MISTURE & 5801 & 0,364620566 & 2560 & & 60293,73047 & \\
\hline 16 & FOGO & 8242 & 0,518049061 & 33124 & & 59134,33984 & \\
\hline 17 & RETIRE & 5814 & 0,365437657 & 3269 & & 58887,16797 & \\
\hline 18 & QUENTE & 4792 & 0,301200092 & 0 & & 58303,09766 & \\
\hline
\end{tabular}




\begin{tabular}{|c|c|c|c|c|c|c|}
\hline 19 & PANELA & 5803 & 0,364746273 & 3990 & & 57387,16406 \\
\hline 20 & MOLHO & 5945 & 0,373671651 & 6006 & & 55795,74609 \\
\hline 21 & JUNTE & 5147 & 0,323513538 & 2140 & & 53809,97656 \\
\hline 22 & AZEITE & 5411 & 0,340107203 & 3755 & & 53447,59766 \\
\hline 23 & FORNO & 5777 & 0,363112032 & 7628 & & 51998,81641 \\
\hline 24 & CEBOLA & 5254 & 0,330238998 & 5325 & & 49284,80078 \\
\hline 25 & FARINHA & 6137 & 0,385739774 & 15194 & & 49141,07031 \\
\hline 26 & CREME & 5191 & 0,326279134 & 5619 & & 48215,65234 \\
\hline 27 & LEVE & 6399 & 0,402207702 & 25456 & & 46019,36328 \\
\hline 28 & ALHO & 4888 & 0,307234138 & 4978 & & 45817,73438 \\
\hline 29 & AÇÚCAR & 6632 & 0,416852862 & 35072 & & 44320,41016 \\
\hline 30 & ACRESCENTE & 4555 & 0,28630349 & 3553 & & 44319,16797 \\
\hline 31 & LEITE & 7838 & 0,492655724 & 77329 & 0,011126263 & 43401,35938 \\
\hline 32 & $\mathrm{DE}$ & 132045 & 8,299658775 & 31575728 & 4,543183804 & 41873,52344 \\
\hline 33 & ÁGUA & 9374 & 0,589200675 & 196792 & 0,028314859 & 38712,55469 \\
\hline 34 & COZINHE & 3530 & 0,221877366 & 1269 & & 37407,45313 \\
\hline 35 & SIRVA & 3953 & 0,248464927 & 3840 & & 37308,86719 \\
\hline 36 & RESERVE & 3769 & 0,236899644 & 3960 & & 35162,19922 \\
\hline 37 & BATA & 3405 & 0,214020506 & 1776 & & 34771,53125 \\
\hline 38 & MASSA & 6553 & 0,411887348 & 76844 & 0,011056481 & 34171,34766 \\
\hline 39 & GOSTO & 5067 & 0,318485141 & 30386 & & 32700,44922 \\
\hline 40 & LIMÃO & 3575 & 0,22470583 & 4703 & & 32193,32031 \\
\hline 41 & DIFICULDADE & 5641 & 0,354563802 & 51979 & & 31944,55664 \\
\hline 42 & PICADA & 3239 & 0,203586623 & 3181 & & 30519,99609 \\
\hline 43 & ADICIONE & 2893 & 0,18183887 & 1115 & & 30460,69141 \\
\hline 44 & TEMPERATURA & 6133 & 0,385488331 & 82676 & 0,011895602 & 30383,55273 \\
\hline 45 & XÍCARAS & 2780 & 0,174736276 & 1599 & & 28079,27539 \\
\hline 46 & FATIAS & 2925 & 0,183850214 & 2810 & & 27649,06641 \\
\hline 47 & PORÇÕES & 3169 & 0,199186787 & 5070 & & 27597,27734 \\
\hline 48 & REINO & 4370 & 0,274675369 & 28419 & & 27553,35547 \\
\hline 49 & TIGELA & 2623 & 0,164868072 & 1168 & & 27232,74219 \\
\hline 50 & ATÉ & 11944 & 0,750737429 & 716486 & 0,103089556 & 26740,51758 \\
\hline 51 & CATEGORIA & 4994 & 0,313896745 & 56173 & & 26425,16797 \\
\hline 52 & MODO & 6762 & 0,425024003 & 162026 & 0,023312651 & 26257,35742 \\
\hline 53 & TRIGO & 3804 & 0,239099562 & 20571 & & 25261,13281 \\
\hline 54 & QUEIJO & 3159 & 0,198558241 & 8273 & & 24992,04102 \\
\hline 55 & COZINHA & 3461 & 0,217540383 & 14319 & & 24643,86914 \\
\hline 56 & CALDO & 2869 & 0,180330351 & 5244 & & 24385,43555 \\
\hline
\end{tabular}




\begin{tabular}{|c|c|c|c|c|c|c|}
\hline 57 & FÁCIL & 4520 & 0,284103572 & 48137 & & 24376,27734 \\
\hline 58 & OLIVA & 2579 & 0,162102461 & 3492 & & 23112,05469 \\
\hline 59 & SUCO & 3086 & 0,193969846 & 10568 & & 22997,7207 \\
\hline 60 & ÓLEO & 3726 & 0,234196901 & 27188 & & 22703,69141 \\
\hline 61 & CUBRA & 2190 & 0,137651965 & 1091 & & 22473,5 \\
\hline 62 & AQUEÇA & 2050 & 0,128852293 & 654 & & 21949,5 \\
\hline 63 & G & 7220 & 0,453811496 & 280505 & 0,040359665 & 21661,33594 \\
\hline 64 & MEXENDO & 2217 & 0,139349043 & 1723 & & 21578,08398 \\
\hline 65 & $E$ & 68013 & 4,274941921 & 16114721 & 2,31862092 & 21537,69531 \\
\hline 66 & RECHEIO & 2141 & 0,134572074 & 1338 & & 21415,67773 \\
\hline 67 & TEMPERE & 2011 & 0,126400948 & 819 & & 21062,44531 \\
\hline 68 & SALSINHA & 1991 & 0,125143856 & 1064 & & 20276,00977 \\
\hline 69 & RALADO & 1982 & 0,124578163 & 1041 & & 20222,83789 \\
\hline 70 & FRIGIDEIRA & 1951 & 0,122629665 & 953 & & 20062,48242 \\
\hline 71 & FRANGO & 2597 & 0,163233846 & 8973 & & 19312,51953 \\
\hline 72 & BEM & 7640 & 0,480210483 & 404030 & 0,058132708 & 18750,99805 \\
\hline 73 & PICADO & 1924 & 0,120932586 & 1576 & & 18595,20117 \\
\hline 74 & TOMATES & 1995 & 0,125395283 & 2143 & & 18547,77148 \\
\hline 75 & REFOGUE & 1720 & 0,108110212 & 579 & & 18331,23438 \\
\hline 76 & DESPEJE & 1754 & 0,110247277 & 826 & & 18105,66797 \\
\hline 77 & COM & 30185 & 1,897271395 & 5469020 & 0,786894381 & 17939,92969 \\
\hline 78 & OVos & 3005 & 0,188878596 & 23890 & & 17833,88672 \\
\hline 79 & FERVER & 1795 & 0,112824321 & 1250 & & 17718,46484 \\
\hline 80 & RENDIMENTO & 3331 & 0,209369257 & 37749 & & 17575,78516 \\
\hline 81 & ASSADEIRA & 1660 & 0,104338929 & 607 & & 17562,01172 \\
\hline 82 & VINHO & 2600 & 0,163422421 & 14450 & & 17134,96484 \\
\hline 83 & CARNE & 3224 & 0,202643797 & 37163 & & 16908,75 \\
\hline 84 & Xíc & 1357 & 0,085293934 & 1 & & 16490,93945 \\
\hline 85 & CHOCOLATE & 2078 & 0,130612224 & 5532 & & 16381,05469 \\
\hline 86 & DOURAR & 1545 & 0,097110629 & 576 & & 16316,33789 \\
\hline 87 & FERMENTO & 1707 & 0,107293099 & 1689 & & 16065,30176 \\
\hline 88 & ESFRIAR & 1676 & 0,105344601 & 1578 & & 15887,3623 \\
\hline 89 & ESCORRA & 1503 & 0,094470732 & 558 & & 15878,84961 \\
\hline 90 & LAVE & 1517 & 0,095350698 & 626 & & 15867,82129 \\
\hline 91 & TOMATE & 2089 & 0,131303623 & 7697 & & 15299,57129 \\
\hline 92 & NBSP & 1254 & 0,078819886 & 2 & & 15224,56836 \\
\hline 93 & PÓ & 2194 & 0,137903377 & 12321 & & 14417,34766 \\
\hline 94 & GELADEIRA & 1778 & 0,111755788 & 4240 & & 14343,16016 \\
\hline
\end{tabular}




\begin{tabular}{|r|l|r|r|r|r|r|l|}
\hline 95 & POLVILHE & 1309 & 0,082276903 & 352 & & 14209,24902 & \\
\hline 96 & REGUE & 1334 & 0,083848268 & 488 & & 14112,27148 & \\
\hline 97 & $\#$ & 117436 & 7,38141346 & 36005116 & 5,180493832 & 13911,32031 & \\
\hline 98 & GEMAS & 1727 & 0,108550198 & 4158 & & 13904,23145 & \\
\hline 99 & PEDAÇOS & 1843 & 0,115841351 & 6596 & & 13591,39844 & \\
\hline 100 & PARMESÃO & 1349 & 0,084791094 & 821 & & 13535,30078 & \\
\hline
\end{tabular}

* $O$ valor de $P$, para todas as formas é, 0.0000000000 . Para uma melhor distribuição das colunas, decidimos colocar esta informação separadamente. 


\section{ANEXO H \\ 100 primeiras palavras-chave do corpus de Direito (inglês)}

De um total de 10.243 formas (types) do corpus de Direito (inglês), apresentamos as 100 primeiras identificadas como palavras-chave quando comparadas com o BNC, corpus de referência para o inglês. Foram abaixo distribuídas em ordem decrescente de chavicidade.

\section{Observações:}

$\mathbf{N}=\quad$ posição da palavra na lista de palavras-chave, em ordem decrescente de chavicidade

Key word $=$ palavra-chave a que os dados se referem

Freq. = $\quad$ frequência da palavra no corpus de estudo

$\%=\quad$ porcentagem que representa a frequência da palavra no corpus de estudo, considerado em sua totalidade

RC. Freq. = frequência da palavra no corpus de referência

RC. $\%=$ porcentagem que representa a frequência da palavra no corpus de referência, considerado em sua totalidade

Keyness $=\quad$ índice de chavicidade da palavra, em ordem decrescente $\mathbf{P}=\quad$ valor de $P$

\begin{tabular}{|r|l|r|r|r|r|r|c|}
\hline $\mathbf{N}$ & Key Word & Freq. & $\mathbf{\%}$ & RC. Freq. & RC. $\%$ & Keyness & P \\
\hline 1 & SHALL & 8787 & 1,354663849 & 19817 & 0,019923532 & 53643,37109 & $0.0^{*}$ \\
\hline 2 & OR & 19341 & 2,981740475 & 370166 & 0,372155935 & 46328,03906 & \\
\hline 3 & AGREEMENT & 6116 & 0,942884266 & 13242 & 0,013313186 & 37717,21875 & \\
\hline 4 & ANY & 11025 & 1,69968915 & 122180 & 0,122836813 & 36809,73438 & \\
\hline 5 & SUCH & 6016 & 0,927467585 & 107326 & 0,107902959 & 15037,39648 & \\
\hline 6 & FRANCHISEE & 1448 & 0,223233551 & 46 & & 14186,47754 & \\
\hline 7 & COMPANY & 3024 & 0,466200471 & 35947 & 0,036140244 & 9689,033203 & \\
\hline 8 & HEREUNDER & 775 & 0,119479284 & 45 & & 7463,502441 & \\
\hline 9 & LENDER & 824 & 0,127033457 & 380 & & 6809,098145 & \\
\hline 10 & FRANCHISOR & 696 & 0,10730011 & 24 & & 6805,135742 & \\
\hline 11 & HEREOF & 700 & 0,107916772 & 35 & & 6774,625977 & \\
\hline 12 & PURCHASER & 1006 & 0,155091822 & 1676 & & 6613,243652 & \\
\hline 13 & SELLER & 999 & 0,15401265 & 1640 & & 6589,92041 & \\
\hline 14 & APPLICABLE & 946 & 0,145841807 & 1413 & & 6376,626465 & \\
\hline 15 & BORROWER & 742 & 0,114391781 & 280 & & 6282,437988 & \\
\hline 16 & DATE & 1758 & 0,27102527 & 17192 & 0,017284421 & 6238,036133 & \\
\hline 17 & NOTICE & 1422 & 0,219225213 & 9028 & & 6138,090332 & \\
\hline 18 & THEREOF & 757 & 0,116704285 & 466 & & 6010,709961 & \\
\hline
\end{tabular}




\begin{tabular}{|c|c|c|c|c|c|c|}
\hline 19 & PURSUANT & 746 & 0,115008451 & 434 & & 5972,592773 \\
\hline 20 & HEREIN & 633 & 0,0975876 & 100 & & 5797,420898 \\
\hline 21 & OTHER & 4172 & 0,643184006 & 153017 & 0,153839588 & 5538,526855 \\
\hline 22 & SECTION & 1623 & 0,250212759 & 18725 & 0,018825661 & 5282,903809 \\
\hline 23 & TERMINATION & 665 & 0,102520935 & 525 & & 5076,416016 \\
\hline 24 & LESSEE & 584 & 0,090033427 & 174 & & 5071,817383 \\
\hline 25 & PROPERTY & 1353 & 0,208587706 & 12485 & 0,012552117 & 4939,912598 \\
\hline 26 & ESCROW & 481 & 0,074154243 & 16 & & 4706,816406 \\
\hline 27 & BY & 8038 & 1,239192963 & 513444 & 0,516204178 & 4690,176758 \\
\hline 28 & OBLIGATIONS & 783 & 0,120712623 & 1902 & & 4675,672852 \\
\hline 29 & SHARES & 1136 & 0,175133511 & 8389 & & 4597,876953 \\
\hline 30 & HERETO & 495 & 0,076312579 & 67 & & 4579,36084 \\
\hline 31 & RIGHTS & 1289 & 0,198721036 & 12845 & 0,012914052 & 4529,928711 \\
\hline 32 & PRIOR & 948 & 0,146150142 & 4736 & & 4493,007324 \\
\hline 33 & LESSOR & 507 & 0,078162581 & 130 & & 4467,149414 \\
\hline 34 & PAYMENT & 976 & 0,150466815 & 5400 & & 4450,113281 \\
\hline 35 & HEREBY & 532 & 0,082016751 & 258 & & 4367,330078 \\
\hline 36 & AGREES & 642 & 0,0989751 & 938 & & 4348,550293 \\
\hline 37 & FORTH & 746 & 0,115008451 & 2201 & & 4213,308594 \\
\hline 38 & PROVIDED & 1348 & 0,207816869 & 16880 & 0,016970742 & 4192,355957 \\
\hline 39 & ACCORDANCE & 712 & 0,109766774 & 2092 & & 4026,212402 \\
\hline 40 & AGENT & 838 & 0,129191801 & 4139 & & 3988,32959 \\
\hline 41 & PARTIES & 1164 & 0,179450184 & 12581 & 0,012648633 & 3922,633301 \\
\hline 42 & RESPECT & 1073 & 0,165420994 & 10028 & 0,010081909 & 3892,924561 \\
\hline 43 & LEASE & 677 & 0,104370937 & 2208 & & 3708,643555 \\
\hline 44 & DEFAULT & 564 & 0,086950086 & 1018 & & 3636,919189 \\
\hline 45 & UNDER & 2124 & 0,327450335 & 61096 & 0,061424438 & 3614,599854 \\
\hline 46 & MAY & 3100 & 0,477917135 & 127748 & 0,128434747 & 3581,237793 \\
\hline 47 & DIRECTORS & 783 & 0,120712623 & 4334 & & 3569,322998 \\
\hline 48 & UPON & 1361 & 0,209821045 & 22806 & 0,022928599 & 3540,934814 \\
\hline 49 & RUBIO'S & 352 & 0,054266721 & 1 & & 3534,05127 \\
\hline 50 & EMPLOYEE & 689 & 0,106220938 & 2859 & & 3488,851318 \\
\hline 51 & PARTY & 1652 & 0,254683584 & 37720 & 0,037922774 & 3431,932617 \\
\hline 52 & WRITTEN & 1086 & 0,167425171 & 13472 & 0,013544423 & 3395,131836 \\
\hline 53 & $\#$ & 16867 & 2,600331783 & 1604421 & 1,61304605 & 3339,162598 \\
\hline 54 & PROVISIONS & 734 & 0,11315845 & 4195 & & 3304,348877 \\
\hline 55 & PROVIDER & 431 & 0,066445902 & 427 & & 3160,178223 \\
\hline 56 & OTHERWISE & 884 & 0,136283472 & 8651 & & 3134,612305 \\
\hline
\end{tabular}




\begin{tabular}{|c|c|c|c|c|c|c|}
\hline 57 & PURCHASE & 718 & 0,110691778 & 4449 & & 3129,506348 \\
\hline 58 & FRANCHISE & 467 & 0,071995907 & 765 & & 3081,747314 \\
\hline 59 & OF & 27987 & 4,314666748 & 3049564 & 3,065957785 & 3007,390869 \\
\hline 60 & INCLUDING & 1254 & 0,193325192 & 24007 & 0,024136057 & 2976,169922 \\
\hline 61 & CLOSING & 594 & 0,091575094 & 2608 & & 2949,306396 \\
\hline 62 & LICENSE & 383 & 0,059045892 & 335 & & 2872,436523 \\
\hline 63 & EVENT & 881 & 0,13582097 & 10299 & 0,010354365 & 2846,321289 \\
\hline 64 & WARRANT & 474 & 0,073075071 & 1144 & & 2835,288574 \\
\hline 65 & USBL & 275 & 0,042395875 & 0 & & 2771,661621 \\
\hline 66 & REASONABLE & 725 & 0,111770943 & 6165 & & 2751,883057 \\
\hline 67 & TRANSFER & 747 & 0,115162618 & 6917 & & 2722,134766 \\
\hline 68 & FRANCHISEE'S & 272 & 0,041933376 & 5 & & 2691,434082 \\
\hline 69 & DEEMED & 474 & 0,073075071 & 1407 & & 2672,054932 \\
\hline 70 & FEES & 563 & 0,086795919 & 2902 & & 2637,014893 \\
\hline 71 & TERM & 890 & 0,137208477 & 12344 & 0,012410359 & 2607,657471 \\
\hline 72 & CORPORATION & 577 & 0,088954255 & 3339 & & 2584,727295 \\
\hline 73 & FOREGOING & 330 & 0,050875049 & 286 & & 2478,926025 \\
\hline 74 & STOCK & 732 & 0,112850115 & 8025 & & 2447,958252 \\
\hline 75 & THIS & 6042 & 0,931475937 & 454419 & 0,456861854 & 2445,294434 \\
\hline 76 & BUSINESS & 1323 & 0,203962699 & 35127 & 0,035315834 & 2420,523682 \\
\hline 77 & LIMITATION & 399 & 0,06151256 & 924 & & 2413,620117 \\
\hline 78 & SECURITIES & 471 & 0,072612576 & 1921 & & 2398,93335 \\
\hline 79 & BE & 7809 & 1,203888655 & 651535 & 0,655037522 & 2385,48291 \\
\hline 80 & EXPENSES & 470 & 0,072458409 & 2000 & & 2359,174072 \\
\hline 81 & ASSIGNMENT & 407 & 0,062745899 & 1138 & & 2335,187744 \\
\hline 82 & AUTHORIZED & 336 & 0,051800054 & 443 & & 2327,074463 \\
\hline 83 & CONFIDENTIAL & 403 & 0,062129229 & 1104 & & 2326,013672 \\
\hline 84 & $B$ & 1118 & 0,172358513 & 25627 & 0,025764765 & 2314,672607 \\
\hline 85 & COLLATERAL & 295 & 0,045479212 & 213 & & 2285,070557 \\
\hline 86 & EXCEPT & 758 & 0,116858453 & 10144 & 0,010198532 & 2268,281738 \\
\hline 87 & CONSENT & 528 & 0,081400082 & 3551 & & 2224,421387 \\
\hline 88 & SERVICES & 1074 & 0,165575162 & 24866 & 0,024999674 & 2205,697998 \\
\hline 89 & RECEIPT & 405 & 0,062437564 & 1352 & & 2202,382568 \\
\hline 90 & REQUIRED & 896 & 0,138133466 & 16344 & 0,016431862 & 2199,999756 \\
\hline 91 & RITEK & 218 & 0,033608366 & 0 & & 2197,152588 \\
\hline 92 & EXPIRATION & 246 & 0,037925038 & 78 & & 2122,727783 \\
\hline 93 & CONNECTION & 568 & 0,087566756 & 4996 & & 2121,658936 \\
\hline 94 & $S$ & 1020 & 0,157250151 & 23425 & 0,023550928 & 2108,455566 \\
\hline
\end{tabular}




\begin{tabular}{|r|l|r|r|r|r|r|l|}
\hline 95 & AMOUNT & 834 & 0,128575131 & 15311 & 0,015393308 & 2038,555542 & \\
\hline 96 & EQUIPMENT & 665 & 0,102520935 & 8845 & & 1997,064209 & \\
\hline 97 & OSS & 220 & 0,033916701 & 43 & & 1983,575806 & \\
\hline 98 & GRANTOR & 208 & 0,032066699 & 24 & & 1942,35083 & \\
\hline 99 & TWTI & 192 & 0,02960003 & 0 & & 1935,099365 & \\
\hline 100 & TERMINATE & 284 & 0,043783378 & 407 & & 1931,745361 & \\
\hline
\end{tabular}

* O valor de $\mathrm{P}$, para todas as formas é, 0.0000000000 . Para uma melhor distribuição das colunas, decidimos colocar esta informação separadamente. 


\section{ANEXO I \\ 100 primeiras palavras-chave do corpus de Direito (português)}

De um total de 11.465 formas (types) do corpus de Direito (português), apresentamos aquelas identificadas como palavras-chave quando comparadas com o BP, corpus de referência para o português. Foram abaixo distribuídas em ordem decrescente de chavicidade.

\section{Observações:}

$\mathbf{N}=\quad$ posição da palavra na lista de palavras-chave, em ordem decrescente de chavicidade

Key word $=$ palavra-chave a que os dados se referem

Freq. = $\quad$ frequência da palavra no corpus de estudo

$\%=\quad$ porcentagem que representa a frequência da palavra no corpus de estudo, considerado em sua totalidade

RC. Freq. = frequência da palavra no corpus de referência

RC. $\%=$ porcentagem que representa a frequência da palavra no corpus de referência, considerado em sua totalidade

Keyness $=\quad$ índice de chavicidade da palavra, em ordem decrescente

$\mathbf{P}=\quad$ valor de $\mathrm{P}$

\begin{tabular}{|c|l|r|r|r|r|r|c|}
\hline $\mathbf{N}$ & Key word & Freq. & \% & RC. Freq. & RC. $\%$ & Keyness & P \\
\hline 1 & CLÁUSULA & 1520 & 0,54300648 & 4906 & & 16746,83594 & $0.0^{*}$ \\
\hline 2 & CONTRATO & 2017 & 0,720555305 & 52574 & & 14328,98047 & \\
\hline 3 & SUA & 666 & 0,237922564 & 0 & & 10414,59375 & \\
\hline 4 & CONTRATADA & 938 & 0,335092157 & 3682 & & 10009,59961 & \\
\hline 5 & UM & 532 & 0,190052271 & 0 & & 8318,910156 & \\
\hline 6 & CONTRATANTE & 638 & 0,227919817 & 851 & & 7943,745117 & \\
\hline 7 & OU & 4027 & 1,438609958 & 1691320 & 0,2434 & 7653,39502 & \\
\hline 8 & XXX & 493 & 0,176119864 & 1836 & & 5306,141113 & \\
\hline 9 & QUALQUER & 1353 & 0,483347207 & 218509 & 0,0314 & 4863,033203 & \\
\hline 10 & SEGURADO & 439 & 0,156828836 & 2117 & & 4521,579102 & \\
\hline 11 & PAGAMENTO & 835 & 0,298296303 & 63976 & & 4182,513672 & \\
\hline 12 & AES & 381 & 0,13610886 & 1462 & & 4080,3396 & \\
\hline 13 & USO & 257 & 0,091810964 & 0 & & 4018,468994 & \\
\hline 14 & UTILIZAÇÃO & 254 & 0,090739235 & 0 & & 3971,558105 & \\
\hline 15 & PARTES & 730 & 0,260785997 & 46651 & & 3911,861572 & \\
\hline 16 & PRESENTE & 984 & 0,351525247 & 160165 & 0,023 & 3521,25293 & \\
\hline 17 & PARÁGRAFO & 454 & 0,162187457 & 12921 & & 3145,265869 & \\
\hline 18 & QUAISQUER & 423 & 0,151112989 & 10251 & & 3062,487305 & \\
\hline
\end{tabular}




\begin{tabular}{|c|c|c|c|c|c|c|}
\hline 19 & CARTÃO & 477 & 0,170404002 & 18778 & & 3003,890381 \\
\hline 20 & BRASILIANA & 266 & 0,095026135 & 733 & & 3001,931641 \\
\hline 21 & ACIONISTAS & 377 & 0,134679899 & 6853 & & 2939,352783 \\
\hline 22 & TITULAR & 505 & 0,180406749 & 26138 & & 2911,926514 \\
\hline 23 & RIPASA & 213 & 0,076092355 & 114 & & 2907,670166 \\
\hline 24 & USUÁRIO & 178 & 0,063588917 & 0 & & 2783,169678 \\
\hline 25 & PRAZO & 651 & 0,232563958 & 96662 & 0,0139 & 2440,686768 \\
\hline 26 & OBRIGAÇÕES & 338 & 0,120747492 & 8697 & & 2407,678223 \\
\hline 27 & EMISSOR & 245 & 0,087524071 & 1585 & & 2391,173828 \\
\hline 28 & SEGURADORA & 248 & 0,088595793 & 2912 & & 2141,803467 \\
\hline 29 & LOCATÁRIO & 174 & 0,062159952 & 291 & & 2105,98877 \\
\hline 30 & PODERÁ & 543 & 0,193981916 & 76056 & 0,0109 & 2095,070557 \\
\hline 31 & SERVIÇOS & 698 & 0,249354288 & 163922 & 0,0236 & 2027,146973 \\
\hline 32 & INSTRUMENTO & 465 & 0,166117117 & 50774 & & 2013,110596 \\
\hline 33 & SEGURO & 413 & 0,147540569 & 33962 & & 2011,947144 \\
\hline 34 & DESTE & 781 & 0,279005289 & 225533 & 0,0325 & 1979,946899 \\
\hline 35 & BRADESCO & 283 & 0,10109923 & 8862 & & 1907,870605 \\
\hline 36 & CNPJ & 154 & 0,055015128 & 221 & & 1900,250244 \\
\hline 37 & $\mathrm{~N}^{\circ}$ & 569 & 0,203270182 & 105626 & 0,0152 & 1896,735962 \\
\hline 38 & RESCISÃO & 203 & 0,072519943 & 1661 & & 1892,162964 \\
\hline 39 & DEVERÁ & 473 & 0,16897504 & 62086 & & 1882,736572 \\
\hline 40 & VALOR & 762 & 0,272217721 & 235274 & 0,0339 & 1842,168213 \\
\hline 41 & CLÁUSULAS & 222 & 0,079307526 & 3417 & & 1801,982788 \\
\hline 42 & DORAVANTE & 194 & 0,069304772 & 1681 & & 1787,328857 \\
\hline 43 & FATURA & 210 & 0,075020634 & 3228 & & 1705,1073 \\
\hline 44 & MEDIANTE & 356 & 0,127177835 & 31428 & & 1685,694336 \\
\hline 45 & DÉCIMA & 194 & 0,069304772 & 2308 & & 1670,546509 \\
\hline 46 & REPRESENTADA & 273 & 0,097526819 & 12163 & & 1653,377319 \\
\hline 47 & VIGÊNCIA & 245 & 0,087524071 & 7744 & & 1647,212769 \\
\hline 48 & SERÁ & 799 & 0,285435647 & 303753 & 0,0437 & 1645,556763 \\
\hline 49 & FORO & 193 & 0,068947531 & 2822 & & 1585,630127 \\
\hline 50 & ASSINATURA & 267 & 0,095383376 & 15006 & & 1496,727417 \\
\hline 51 & DESPESAS & 307 & 0,109673016 & 27810 & & 1438,453369 \\
\hline 52 & SUBCLÁUSULA & 96 & 0,034295145 & 13 & & 1421,34729 \\
\hline 53 & OBJETO & 402 & 0,143610924 & 68320 & & 1405,545288 \\
\hline 54 & INSCRITA & 148 & 0,052871682 & 1263 & & 1367,76062 \\
\hline 55 & SERÃO & 481 & 0,171832964 & 117018 & 0,0168 & 1366,010254 \\
\hline 56 & CPF & 151 & 0,053943407 & 1470 & & 1357,893799 \\
\hline
\end{tabular}




\begin{tabular}{|l|l|r|r|r|r|r|l|}
\hline 57 & ITAUCARD & 94 & 0,033580665 & 27 & 1341,290527 & \\
\hline 58 & ACIONISTA & 167 & 0,059659265 & 2779 & & 1330,406982 & \\
\hline 59 & BNDESPAR & 129 & 0,046084102 & 661 & & 1314,287842 & \\
\hline 60 & ENCARGOS & 202 & 0,072162703 & 7140 & & 1314,189209 & \\
\hline 61 & CENTO & 218 & 0,077878557 & 9925 & & 1311,079224 & \\
\hline 62 & ITEM & 289 & 0,10324268 & 28925 & & 1298,961548 & \\
\hline 63 & ÚTIL & 83 & 0,02965101 & 0 & & 1297,741943 & \\
\hline 64 & DIREITO & 552 & 0,19719708 & 178484 & 0,0257 & 1289,771973 & \\
\hline 65 & DEPÓSITO & 222 & 0,079307526 & 11307 & & 1286,805542 & \\
\hline 66 & CASO & 774 & 0,276504606 & 384307 & 0,0553 & 1253,518433 & \\
\hline 67 & TERCEIROS & 186 & 0,066446841 & 6249 & & 1228,44043 & \\
\hline 68 & CONTRATADO & 193 & 0,068947531 & 7921 & & 1199,5979 & \\
\hline 69 & BENEFICIÁRIO & 139 & 0,049656514 & 1875 & & 1163,479614 & \\
\hline 70 & PARTICIPAÇÕES & 174 & 0,062159952 & 5785 & & 1152,717285 & \\
\hline 71 & AÇÕES & 486 & 0,173619181 & 154894 & 0,0223 & 1147,657349 & \\
\hline 72 & TIETE & 94 & 0,033580665 & 148 & & 1146,523071 & \\
\hline 73 & FRANQUEADOR & 126 & 0,045012377 & 1160 & & 1146,390137 & \\
\hline 74 & ÚTEIS & 73 & 0,0260786 & 0 & & 1141,384888 & \\
\hline 75 & CLIENTES & 287 & 0,102528192 & 38029 & & 1137,096558 & \\
\hline 76 & SINISTRO & 125 & 0,044655137 & 1172 & & 1132,972778 & \\
\hline 77 & LOCADOR & 99 & 0,03536687 & 252 & & 1130,511597 & \\
\hline 78 & CONTRATUAL & 146 & 0,052157201 & 2739 & & 1129,296265 & \\
\hline 79 & APÓLICE & 113 & 0,040368244 & 658 & & 1124,794922 & \\
\hline 80 & FRANQUEADA & 105 & 0,037510317 & 410 & & 1121,148682 & \\
\hline 81 & S & 813 & 0,290437013 & 472521 & 0,068 & 1116,249146 & \\
\hline 82 & UTILIZAR & 70 & 0,025006877 & 0 & & 1094,477905 & \\
\hline 83 & VENCIMENTO & 170 & 0,060730986 & 6603 & & 1074,829834 & \\
\hline 0 & & & & \\
\hline
\end{tabular}

* $\mathrm{O}$ valor de $\mathrm{P}$, para todas as formas é, 0.0000000000 . Para uma melhor distribuição das colunas, decidimos colocar esta informação separadamente. 